UNIVERSIDADE DE SÃO PAULO

INSTITUTO DE GEOCIÊNCIAS

\title{
GEOLOGIA E PETROLOGIA DE XENÓLITOS MANTÉLICOS DA PROVÍNCIA ÍGNEA DO ALTO PARANAÍBA, MINAS GERAIS
}

Felix Nannini

Orientador: Prof. Dr. Valdecir de Assis Janasi

\section{TESE DE DOUTORAMENTO}

\section{(VERSÃO CORRIGIDA)}

Programa de Pós-Graduação em Mineralogia e Petrologia

SÃO PAULO

2016 
Autorizo a reprodução e divulgação total ou parcial deste trabalho, por qualquer meio convencional ou eletrônico, para fins de estudo e pesquisa, desde que citada a fonte.

Nannini, Felix

Geologia e Petrologia de Xenólitos Mantélicos da Província Ígnea do Alto Paranaíba, Minas Gerais / Felix Nannini. - São Paulo, 2016.

285 p. : il + anexos

Tese (Doutorado) : IGc/USP

Orient.: Janasi, Valdecir de Assis

1. Manto da Terra 2. Petrologia 3. Kimberlito I. Título 


\section{SUMÁRIO}

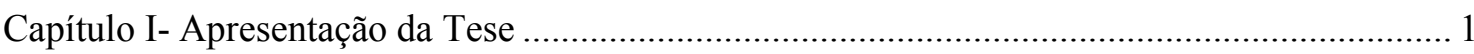

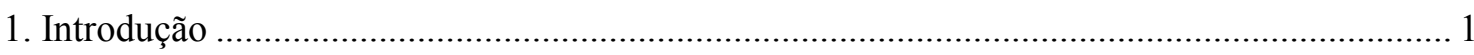

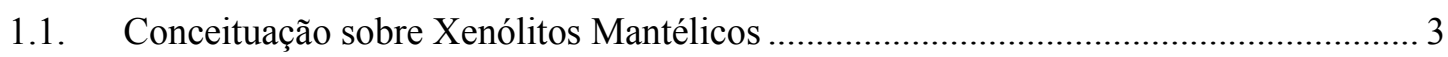

1.2. Distribuição de elementos incompatíveis em xenólitos do manto ................................. 7

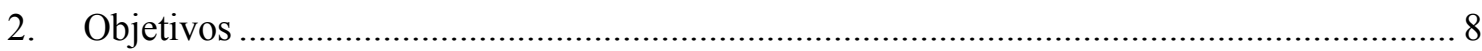

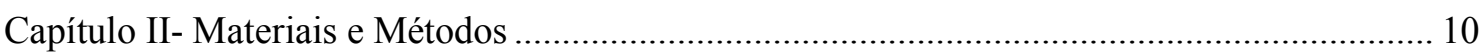

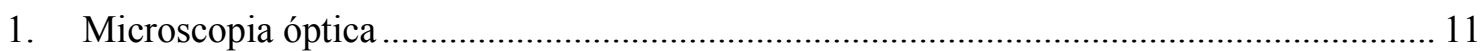

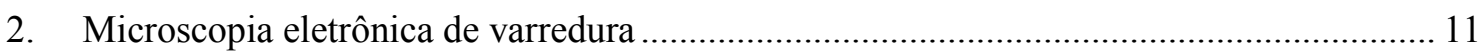

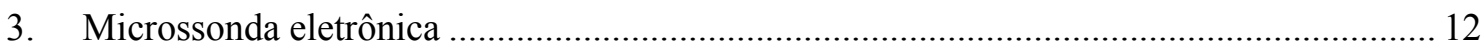

4. LA-Q-ICPMS: elementos traço in situ em minerais .......................................................... 13

5. LA-MC-ICPMS: isotopia de $\mathrm{Sr}$ in situ em clinopiroxênio.................................................... 14

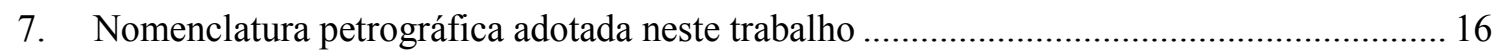

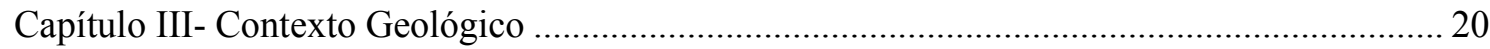

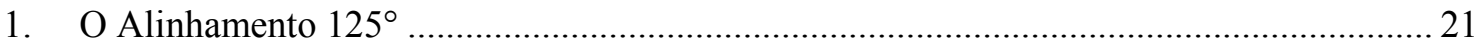

2. Assinatura isotópica do manto na APIP e implicações regionais.......................................... 22

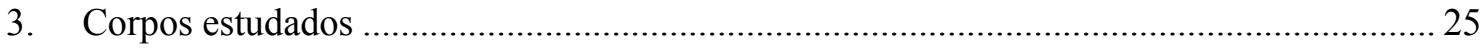

Capítulo IV- Petrografia e classificação das amostras ................................................................... 30

1. Petrografia, mineralogia e classificação das rochas magmáticas estudadas......................... 33

1.1. Nódulos esverdeados com carbonato, agregados e megacristais de carbonato em

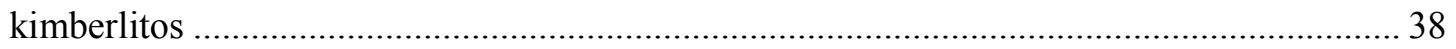

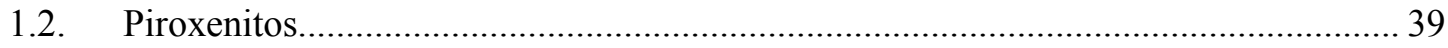

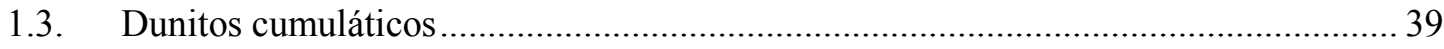

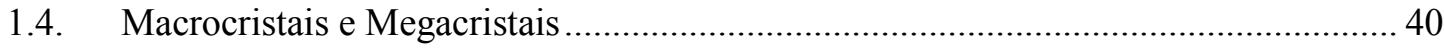

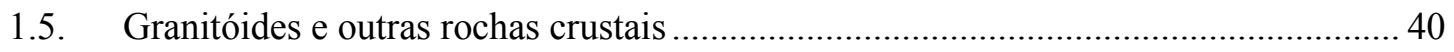

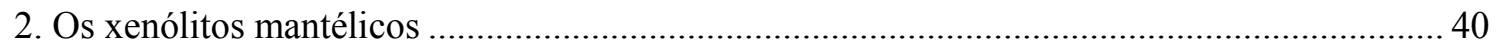

2.1. Lherzolitos e harzburgitos com espinélio vermelho.......................................................... 41

2.2. Harzburgitos e dunitos com espinélio castanho-escuro .................................................... 44

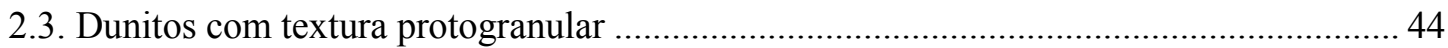

2.4. Dunitos e harzburgito com textura porfiroclástica com mosaico ....................................... 44

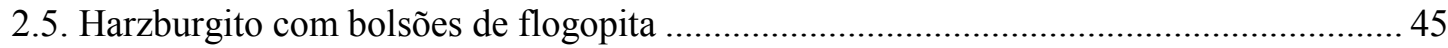

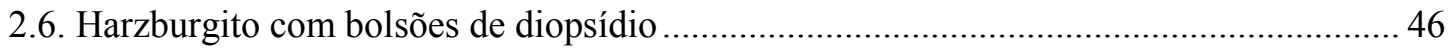

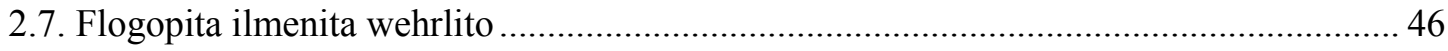

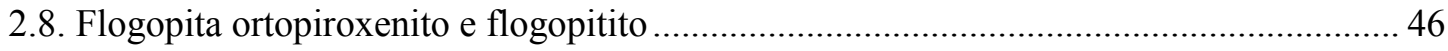

Capítulo V- Quimica Mineral de Elementos Maiores..................................................................... 47

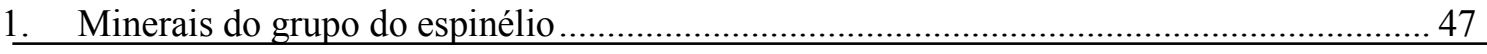




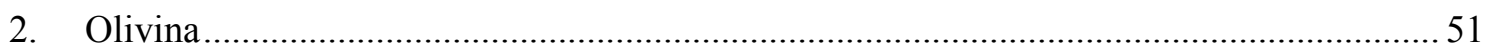

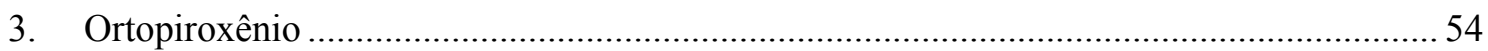

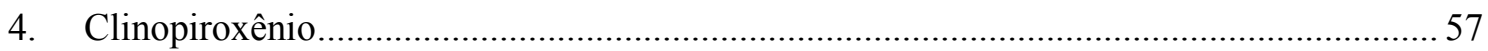

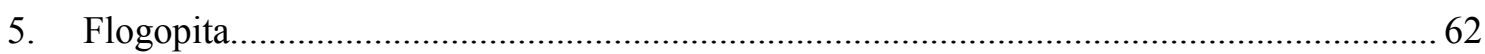

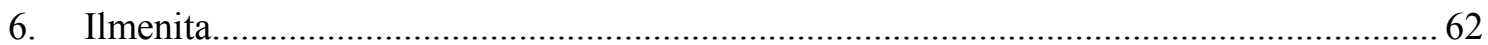

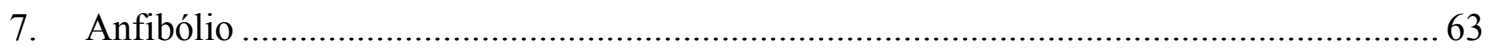

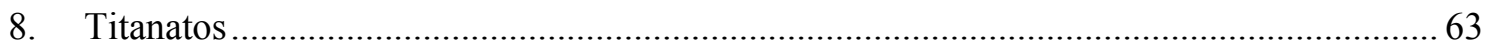

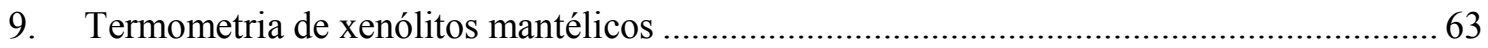

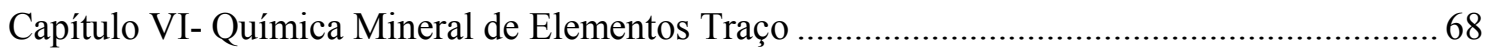

1. Metais de Transição e elementos de alta carga iônica (HFSE) ……………………........... 73

2. Elementos de alto raio atômico (LILE) e outros elementos ................................................ 75

3. Residência de Elementos Terras Raras (ETR) .................................................................. 76

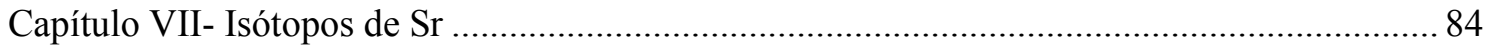

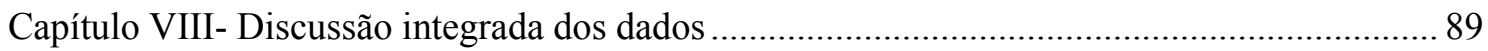

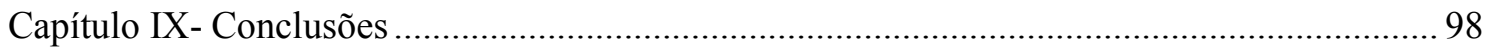

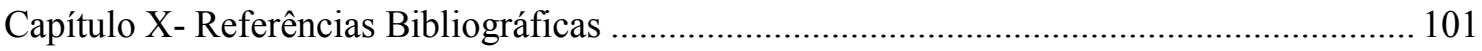

ANEXO A - TABELA COM A RELAÇÃO DAS AMOSTRAS ESTUDADAS E A CLASSIFICAÇÃO PETROGRÁFICA

ANEXO B - IMAGENS DAS AMOSTRAS E SEÇÕES POLIDAS ESTUDADAS

ANEXO C - TABELAS DE ANÁLISES DE ELEMENTOS MAIORES POR MICROSSONDA ELETRÔNICA

ANEXO D - TABELAS DE ANÁLISES DE ELEMENTOS TRAÇO POR LA-Q-ICP-MS 


\section{LISTA DE FIGURAS}

Figura 1- Mapa geológico com destaque para a compartimentação das unidades geotectônicas e a localização de kimberlitos, kamafugitos, lamproítos e complexos carbonatíticos........................ 28

Figura 2- Contexto geológico dos kimberlitos Indaiá 1, Limeira 1 e Forca 1.................................. 29 Figura 3- Fotos representativas das amostras analisadas e imagens de MEV mostrando a textura e mineralogia das rochas vulcânicas estudadas.

Figura 4- Composição de minerais das intrusões Indaiá 1, Limeira 1, Forca 1, Facão e Indaiá 2. . 34 Figura 5 - Classificação mineralógica dos xenólitos de peridotito dos kimberlitos Indaiá 1, Limeira 1 e Forca baseada no diagrama de Streckeisen (1976).

Figura 6- Imagens de micróscópio óptico dos principais tipos de xenólitos mantélicos das intrusões Limeira I e Indaiá 1.

Figura 7- Diagramas de variação química ilustrando a composição de minerais de xenólitos do manto da APIP..

Figura 8- Composição química de clinopiroxênio de xenólitos e megacristal das intrusões Indaiá 1, Limeira 1 e Forca 1.

Figura 9- Diagramas de variação química ilustrando a composição de minerais de xenólitos do manto da APIP.

Figura 10- Diagramas multielementares de clinopiroxênio e anfibólio normalizados pelo manto primitivo de Sun \& McDonough (1995)

Figura 11- Razões $Y_{N} v s$. $Y_{b_{N}}$ de cristais de clinopiroxênio projetadas em curvas geradas por modelamentos de fusão por Norman (1998)..

Figura 12- Projeção das razões de ${ }^{87} \mathrm{Rb} /{ }^{86} \mathrm{Sr}$ e ${ }^{87} \mathrm{Sr} /{ }^{86} \mathrm{Sr}$ obtidas por LA-MC-ICP-MS em cristais de clinopiroxênio.

Figura 13- Perfil hipotético sob a região do Alto Paranaíba, com base em perfil esquemático de Carvalho (1997)

Figura 14- Composição isotópica $\mathrm{Sr}^{87} / \mathrm{Sr}^{86} i$ vs. $\mathrm{Nd}^{143} / \mathrm{Nd}^{144}{ }_{i}$ de rochas máficas e ultramáficas, com destaque para os kamafugitos e lamproítos; e reservatórios mantélicos (Zindler \& Hart, 1986), com curvas de mistura de componentes mantélicos para a geração de kamafugitos segundo Guo et al. (2014). 


\section{LISTA DE TABELAS}

Tabela 1- Padrões químicos utilizados nas análises por microssonda eletrônica nos laboratórios do IGc-USP e na Universidade de St. Andrews.

Tabela 2- Limites de deteç̧ão médios (em ppm) e desvio padrão obtidos em análises em materiais de referência para elementos traço em LA-Q-ICP-MS.

Tabela 3- Razões isotópicas obtidas em coral moderno, médias e desvios padrão........................... 15

Tabela 4- Composição em peso dos óxidos (\%) das rochas vulcânicas abordadas neste trabalho comparadas com composições de porcentagens em peso de óxidos representativas em kimberlitos, orangeítos, lamproitos e kamafugitos de trabalhos da bibliografia

Tabela 5- Composições químicas representativas em espinélio, Cr-espinélio, cromita e

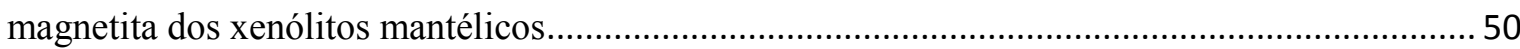

Tabela 6- Composições químicas representativas em olivina dos xenólitos mantélicos ................. 53

Tabela 7- Composições químicas representativas em ortopiroxênio dos xenólitos mantélicos ...... 56

Tabela 8- Composições químicas representativas em clinopiroxênio dos xenólitos mantélicos .... 59 Tabela 9- Coeficiente de partição de olivina/ortopiroxênio e ortopiroxênio/clinopiroxênio nos xenólitos mantélicos.

Tabela 10- Resultados dos geotermômetros calculados pelo programa PTEXL para amostras de xenólitos representativos baseados na troca entre $\mathrm{Fe}-\mathrm{Mg}$ entre clinopiroxênio e ortopiroxênio, e entre olivina e espinélio; e no conteúdo de $\mathrm{Ca}$ e $\mathrm{Al}$ em ortopiroxênio.

Tabela 11- Médias (em ppm) e desvios padrão relativos (em \%) das composições de elementos traços de olivina em amostras representativas.

Tabela 12- Médias (em ppm) e desvios padrão relativos (em \%) das composições de elementos traços de ortopiroxênio de amostras representativas.

Tabela 13- Médias (em ppm) e desvios padrão relativos (em \%) das composições de elementos traços de clinopiroxênio de amostras representativas

Tabela 14- Médias (em ppm) e desvios padrão relativos (em \%) das composições de elementos traços em espinélio, Cr-espinélio, cromita, ilmenita e titanatos de amostras representativas......... 71 Tabela 15- Médias (em ppm) e desvios padrão relativos (em \%) das composições de elementos traços de pargasita e flogopita de amostras representativas.

Tabela 16- Coeficientes de partição Ol/Opx e Opx/Cpx com base na média dos elementos traço em amostras representativas.

Tabela 17- Razões isotópicas de Sr nas amostras de peridotito com espinélio (In1-14), flogopita ilmenita wehrlito (In1-6) e harzburgito com clinopiroxênio secundário (In1-12). 


\section{Agradecimentos}

Agradeço ao meu orientador Valdecir de Assis Janasi, por sua dedicação e paciência. Sua paixão à Geologia é inspiradora.

Agradeço a minha mãe, meu pai, minhas irmãs Karina e Grá, vó e todas as pessoas da minha família por simplesmente existirem na minha vida.

À FAPESP, pelo apoio com o projeto Temático e à CNPq pelo apoio com o doutorado e com o Sandwich, e à CPRM que me apoiou na reta final deste doutorado.

For the people who kindly received me and my wife in Scotland: teachers, especially Colin Donaldson and Chris Hawkesworth, colleagues, lab workers, Connor, Nick and Pauline, and of course Boggiani and family.

A todas as pessoas da sala B9 desde 2009 até o presente, aos professores e funcionários do IGc: dos laboratórios, da diretoria, da biblioteca, xerox, gráfica e fotografia e outrso que não me lembrei.

Ao Prof. Darcy Svisero, pelo apoio irrestrito.

Aos amigos da CPRM, do Projeto Diamante Brasil, da GEREMI, e das festas e blocos carnavalescos de Recife.

Por fim, dedico esta tese a minha companheira de aventuras: “you'll never know dear how much I love you". 


\section{RESUMO}

Processos de fusão parcial e metassomatismo foram identificados em xenólitos mantélicos da Província Ígnea Alto Paranaíba (APIP), na região de Coromandel (Minas Gerais), pela combinação de técnicas de análise textural (petrografia, microscopia eletrônica de varredura), análises químicas minerais pontuais de elementos maiores (por Microssonda Eletrônica), traços (por LA-Q-ICPMS) e isótopos ( $\mathrm{Sr}$ em clinopiroxênio por LA-MC-ICPMS). Os xenólitos, oriundos dos kimberlitos Indaiá 1, Limeira 1 e Forca, foram divididos em três grupos exibindo texturas, mineralogia e química distintas: peridotitos com espinélio ou Cr- espinélio, interpretados como fragmentos de fácies espinélio no manto litosférico raso; xenólitos com flogopita e/ou clinopiroxênio secundário representando porções do manto litosférico que sofreram metassomatismo por interação com fluidos ou magmas; e dunitos e harzburgitos com textura mosaico porfiroclástica a fluidal compatíveis com porções que sofreram efeitos de um fluxo térmico maior, possivelmente associadas a astenosfera ou a zonas de maior permeabilidade na litosfera.

De modo geral os xenólitos mantélicos da Província Ígnea do Alto Paranaíba foram afetados por intensa fusão parcial, indicada especialmente pelo alto valor de mg\# em olivina e ortopiroxênio, e pelo empobrecimento de Al em clinopiroxênio e minerais do grupo do espinélio. Boa parte desses xenólitos foi modificada por metassomatismo modal e/ou críptico, que atingiu inclusive níveis rasos do manto litosférico (fácies espinélio).

Os harzburgitos e dunitos com textura porfiroclástica com mosaico têm baixos valores de mg\# em olivina e ortopiroxênio, e altas concentrações de de Ti, $\mathrm{Ca}$ e $\mathrm{Na}$ em relação aos demais grupos de amostras sugerindo um processo de metassomatismo críptico de alta temperatura (astenosfera, ou zonas permeáveis da litosfera).

Estimativas com base em razões $\mathrm{Y}_{\mathrm{N}}$ e $\mathrm{Yb}_{\mathrm{N}}$ (normalizadas por Manto PrimitivoPM) em clinopiroxênio, indicam que os peridotitos com Cr-espinélio sofreram uma porcentagem maior de fusão parcial (15-20\%), em relação aos peridotitos com espinélio (5-8\%), e preferencialmente fracionada. Em algumas amostras nos peridotitos com $\mathrm{Cr}$ espinélio ainda são encontrados padrões enriquecidos de $\mathrm{ETRL}_{\mathrm{N}}$, indicando processos de metassomatismo críptico.

Os cristais de clinopiroxênio das amostras de xenólitos metassomatisados têm padrão de distribuição de $\mathrm{ETR}_{\mathrm{N}}$ semelhantes entre si, com padrão de $\mathrm{ETRL}_{\mathrm{N}}$ convexo e enriquecido em relação aos $\operatorname{ETRP}_{\mathrm{N}}\left(\mathrm{La}_{\mathrm{N}}\right.$ e $\mathrm{Lu}_{\mathrm{N}}$, respectivamente 5-14xPM e 0,3-1xPM). Uma amostra de harzburgito com bolsões de clinopiroxênio (In1-12), tem o clinopiroxênio com as maiores razões de $\mathrm{ETR}_{\mathrm{N}}$ do conjunto, mantendo o padrão de ETRL $_{N}$ convexo e enriquecido em relação aos $\operatorname{ETRP}_{N}\left(\operatorname{La}_{\mathrm{N}}\right.$ e $\mathrm{Lu}_{\mathrm{N}}$, respectivamente 2543xPM e 1-2,5xPM) dos peridotitos metassomatisados. Razões $\mathrm{Sr}^{87} / \mathrm{Sr}^{86}$ de clinopiroxênio desta última amostra $(0,706-0,714)$ e de flogopita ilmenita wehrlito $(0,706-7,10)$ sugerem que o metassomatismo seria derivado de porção da astenosfera ou litosfera com material proveniente de subducção de crosta. Um valor mais baixo de razão $\mathrm{Sr}^{87} / \mathrm{Sr}^{86}$ para clinopiroxênio de peridotito com espinélio $(0,703)$,indica, juntamente com aspectos texturais e de química de maiores e traços, pouca ou nenhuma, influencia do metassomatismo nesta amostra.

Palavras-chave: xenólito do manto; metassomatismo do manto; kimberlito; Província Ígnea Alto Paranaíba. 


\begin{abstract}
Partial melting processes and metasomatism were identified in mantle xenoliths of the Alto Paranaíba Igneous Province (APIP), next Coromandel (Minas Gerais), by combining textural analysis techniques (petrography, scanning electron microscopy) and specific mineral chemical analyzes of major elements (for Electronic Microprobe), trace elements (LA-Q-ICPMS) and isotopes ( $\mathrm{Sr}$ in clinopyroxene by LA-MC-ICPMS). The xenoliths which are from Indaiá 1, Limeira 1 and Forca kimberlite were divided into three groups displaying different textures, mineralogy and chemistry: peridotites with spinel or Cr-spinel, were interpreted as fragments in the shallow lithospheric mantle; xenoliths with phlogopite and/or secondary clinopyroxene representing the lithospheric mantle portions that suffered metasomatism by interaction with fluids or magmas; and dunites and harzburgites with porphyroclastic texture with mosaic are compatible with portions that have suffered the effects of a higher heat flow, possibly associated with asthenosphere or zones of greater permeability in the lithosphere.

Mantle xenoliths from APIP were affected by intense partial melting, suitable for high-value $\mathrm{mg \#}$ of olivine and orthopyroxene, and the depletion of $\mathrm{Al}$ in clinopyroxene and spinel minerals from the group. Many of these xenoliths were modified by modal and/or cryptic metasomatism, which reached even shallow levels of the lithospheric mantle (facies spinel).

Harzburgites and dunites with prophyroclastic texture with mosaic have low values of $\mathrm{mg \#}$ and high concentrations of $\mathrm{Ti}, \mathrm{Ca}$ and $\mathrm{Na}$ in olivine and orthopyroxene compared to other groups of samples suggesting a cryptic metasomatism process of high temperature.

$\mathrm{Y}_{\mathrm{N}}$ and $\mathrm{Yb}_{\mathrm{N}}$ (normalized by Primitive Mantle-PM) ratios in clinopyroxene indicate that the peridotites with Cr-spinel suffered a higher percentage of partial melting (15-20\%) compared to the peridotites with spinel (5-8\%), and preferably fractional. Some samples in peridotites with Cr-spinel are still found $\mathrm{LREE}_{\mathrm{N}}$ enriched ratios patterns, indicating cryptic metasomatism processes.

The clinopyroxene crystals of metasomatized xenoliths samples have similar $\mathrm{REE}_{\mathrm{N}}$ ratios pattern, with convex $\mathrm{LREE}_{\mathrm{N}}$ pattern with higher ratios compared to $\mathrm{HREE}_{\mathrm{N}}$ ( $\mathrm{La}_{\mathrm{N}}: 5-14 \times \mathrm{PM}$ and $\mathrm{Lu}_{\mathrm{N}}$ 0,3-1xPM). A harzburgite with insterticial pockted clinopyroxene (In1-12), has the clinopyroxene with the highest $\mathrm{REE}_{\mathrm{N}}$ of the set, the convex and enriched $\mathrm{LREE}_{\mathrm{N}}$ pattern as well $\left(\mathrm{La}_{\mathrm{N}}\right.$ : $25-43 \times \mathrm{PM}$ and $\left.\mathrm{Lu}_{\mathrm{N}} 1-2.5 \mathrm{XPM}\right)$ of metasomatized peridotites. Clinopyroxene ${ }^{87} \mathrm{Sr} /{ }^{86} \mathrm{Sr}$ ratios of the latter sample $(0,706$ to $0,714)$ and from phlogopite wehrlite ilmenite sample $(0,706$ to 0,710$)$ suggest that metassomatism fluids from astenosphere or lithosphere were derivative from crust subduction processes. A lower value ratio ${ }^{87} \mathrm{Sr} /{ }^{86} \mathrm{Sr}$ for clinopyroxene in peridotite with spinel $(0,703)$, is in agreement with textural aspects, major and trace elements information, that this group of xenolith little or no influence of metasomatism.
\end{abstract}

Keywords: mantle xenolith; mantle metasomatism; kimberlite; Alto Paranaíba Igneous Province. 


\section{Capítulo I- Apresentação da Tese}

\section{Introdução}

Estimativas da composição dos magmas extraídos do manto terrestre são criticamente dependentes do conhecimento da distribuição dos elementos químicos nos minerais encontrados em xenólitos mantélicos. A residência dos elementos incompatíveis é particularmente complexa, dado que sua distribuição é muito afetada por processos de empobrecimento (geralmente por extração de líquidos) e enriquecimento (por diversos tipos de "metassomatismo mantélico"), que podem ser recorrentes no manto litosférico subcontinental (e.g., Zindler \& Jagoutz 1988). Em estudos de xenólitos do manto, este quadro é complicado por possíveis processos de interação com o magma hospedeiro, que frequentemente é rico em elementos incompatíveis (e.g., kimberlitos, lamprófiros, lamproítos etc; e.g., Ionov et al. 2006)

O manto litosférico subcontinental no sudeste brasileiro constitui fonte importante para o magmatismo basáltico e alcalino de idade cretácea-terciária (e.g., Picirillo et al. 1989, Gibson et al. 1995). São abundantes as evidências geoquímicas e isotópicas de que os principais reservatórios mantélicos amostrados por esses processos magmáticos tinham caráter enriquecido (Gibson et al. 1995, Peate et al. 1999), e que já eram assim quando da geração de magmas graníticos no neoproterozóico (e.g., Janasi et al. 1993, Wernick \& Menezes 2001).

Neste contexto, ganha especial importância a identificação da residência dos elementos incompatíveis (LIL e HFS) nas amostras de xenólitos do manto disponíveis. O presente projeto propõe obter dados texturais e químicos em amostras de xenólitos mantélicos encontrados em kimberlitos e rochas associadas da Província Ígnea do Alto Paranaíba (Indaiá 1, Limeira 1, Forca 1 e Facão) para identificar a assinatura geoquímica e isotópica associada a processos metassomáticos e distingui-la de efeitos secundários associados à interação com os magmas hospedeiros. Para tanto, foi utilizada a coleção de xenólitos disponibilizada pelo Prof. Darcy Pedro Svisero, reconhecido especialista no tema, que em parte já foi estudada por Almeida (2009) e pelo candidato em Nannini (2011).

Um conjunto de amostras representativas da diversidade encontrada foi objeto de estudos texturais-mineralógicos detalhados combinando petrografia ao microscópio óptico e microscopia eletrônica de varredura. As assinaturas geoquímicas dos xenólitos 
foram obtidas em minerais (principalmente clinopiroxênio ou, quando possível, em outras fases ricas em elementos incompatíveis) utilizando microssonda eletrônica, e espectrômetros, quadropolo (Q) e multicoletor (MC), com amostradores laser ablation acoplado: LA-Q-ICPMS (elementos maiores e traços) e LA-MC-ICPMS (isótopos de $\mathrm{Sr})$.

Os xenólitos do manto são os únicos materiais que amostram diretamente os reservatórios mais importantes dos quais são derivados os magmas que constituem a crosta terrestre. Embora informações sobre xenólitos da APIP tenham sido apresentadas em alguns trabalhos na literatura recente (e.g., Araujo et al. 2001, Carlson et al. 2007, Costa 2012), existe ainda uma carência crítica de estudos que focalizem a petrogênese das poucas amostras de xenólitos do manto do sudeste brasileiro. Em particular, dado o predomínio de magmas derivados do "manto enriquecido", são importantes a caracterização dos processos de enriquecimento do manto e sua clara distinção de processos de enriquecimento secundário, associados à interação com o magma hospedeiro dos xenólitos.

O presente projeto propõe contribuir para o conhecimento do manto superior do sudeste brasileiro através do estudo petrográfico, geoquímico e isotópico de detalhe de xenólitos do manto encontrados em intrusões subvulcânicas da região de Coromandel, MG: Indaiá 1 (previamente estudada pelo candidato), Limeira 1 (estudada por Almeida 2009), Forca e Facão.

Análises in situ em minerais de xenólitos mantélicos através de amostrador laserablation acoplado ao espectrômetro ICPMS quadrupolo instalado no Laboratório de ICP do Instituto de Geociências permitiram a determinação dos teores de elementos traço e de sua distribuição espacial nas fases minerais maiores. A resolução espacial do amostrador laser-ablation (normalmente até $20 \mu \mathrm{m}$ ) pode em alguns casos ser insuficiente para a quantificação isolada das fases minerais, mas estimativas bastante úteis podem ser obtidas com técnicas de amostragem alternativas (e.g., "raster" ao longo de linhas; extração do efeito químico do efeito da fase hospedeira em inclusões; cf. Heirich et al. 2003). Em particular, a combinação dos dados químicos com estudos petrográficos e de microscopia eletrônica de varredura, juntamente com os estudos de elementos traços permitiu caracterizar melhor processos de fusão parcial e de metassomatismo, que ocorreram no manto litosférico da região do Alto Paranaiba.

A determinação da composição isotópica de $\mathrm{Sr}$ em clinopiroxênio de algumas amostras através de técnica de análise pontual LA-MC-ICPMS permitiu, 
adicionalmente, obter dados importantes para a caracterização do manto no sudeste brasileiro. A resolução espacial possível nesse tipo de análise permite identificar as assinaturas isotópicas originais (distinguindo-as de processos de interação com o magma hospedeiro) e associá-las a diferentes gerações de minerais, eventualmente associadas a diferentes assinaturas geoquímicas (Class and le Roex 2011, Schmidberger et al. 2003). Não existem, até o momento, na literatura dados deste tipo para os xenólitos das rochas da Província Ígnea Alto Paranaíba, de modo que a sua obtenção deverá trazer subsídios fundamentais para a compreensão dos processos de enriquecimento do manto, entre eles a controversa origem da assinatura enriquecida (Dupal) presente nessas rochas (Toyoda et al., 1994).

\subsection{Conceituação sobre Xenólitos Mantélicos}

O conhecimento da composição e estrutura do manto superior é fundamental para diversas áreas das geociências, com implicações diretas para a geração de magmas de natureza a mais variada, sejam basálticos, alcalinos ou até mesmo graníticos, que embora geralmente dominados por componentes crustais, em muitos casos têm proporção importante de componentes mantélicos (e.g., Barbarin 1999, Patiño-Douce 1999).

Fragmentos do manto terrestre são freqüentemente transportados em magmas básicos e ultrabásicos, principalmente de natureza alcalina, como kimberlitos (Grupos I e II), lamproítos e lamprófiros (minettes, monchoquitos, alnoítos), membros da série dos basaltos alcalinos (basaltos alcalinos sensu stricto, basanitos, tefritos etc), nefelinitos e melilititos (e.g. Nixon 1987, Mitchell 1986).

Apesar de aflorarem em áreas restritas da crosta, as associações de rochas basálticas alcalinas e os conjuntos de corpos kimberlíticos ou lamproíticos estão amplamente distribuídos, de modo que em trabalhos recentes menciona-se a existência de xenólitos mantélicos em mais de 3500 localidades (Pearson et al. 2003).

$\mathrm{Na}$ literatura sobre xenólitos mantélicos destacam-se dois grupos principais de rochas, os eclogitos e os peridotitos. Os eclogitos consistem em agregados de clinopiroxênio da variedade onfacita e granada do grupo do piropo-almandina, com vários minerais acessórios entre os quais o mais comum é o rutilo.

Os peridotitos contêm abundante olivina e quantidades menores e variáveis de ortopiroxênio e clinopiroxênio, podendo apresentar fases aluminosas como plagioclásio, 
Capítulo I-Apresentação da Tese

espinélio ou granada, e representam o tipo de rocha mais abundante no manto (Pearson et al. 2003).

Com base no estudo dos xenólitos do manto transportados por associações de rochas distintas, localizadas em diferentes ambientes tectônicos, Pearson et al. (2003) destacaram as diferenças entre os xenólitos mantélicos encontrados em regiões cratônicas ou situadas ao redor dos crátons (“on craton”), que são comumente transportados por kimberlitos, daqueles que ocorrem em rochas alcalinas máficas (e.g. basaltos alcalinos sensu latu), lamprófiros etc, e estão localizadas em regiões afetadas por adelgaçamento da litosfera. Estas regiões, denominadas "não cratônicas" ("off craton"), podem ser tanto continentais como oceânicas, sendo a profundidade de xenólitos mantélicos amostrados inferior a $140 \mathrm{~km}$ e predominando peridotitos de fácies espinélio. Nas regiões "on-craton" a profundidade de amostragem de xenólitos mantélicos ultrapassa $200 \mathrm{~km}$, e ocorre predominância de xenólitos em fácies granada (Mitchel 1986).

Pearson et al. (2003) também apresentam informações detalhadas sobre peridotitos encontrados em kimberlitos, principalmente nos kimberlitos do Grupo I, são reconhecidos cinco tipos importantes, cujas características são resumidas a seguir:

Tipo I - peridotitos ricos em Mg. A maioria são harzburgitos e lherzolitos; peridotitos da fácies com espinélio são comuns, porém menos abundantes. São considerados de "baixa temperatura", com temperaturas de equilíbrio em torno de, ou menores que $1100^{\circ} \mathrm{C}$ (Boyd 1987, Pearson et al. 2003). Geralmente apresentam granulação grossa, com baixo grau de deformação.

Tipo II - peridotitos ricos em Fe (lherzolitos, websteritos, clinopiroxenitos, ortopiroxenitos), com temperatura de equilíbrio semelhante ao tipo anterior. Os minerais componentes possuem teores mais elevados de $\mathrm{Fe}, \mathrm{Ca}, \mathrm{Al}$ e $\mathrm{Na}$.

Tipo III - dunitos. Conhecem-se duas variedades, uma de granulação grossa a muito grossa, e outra, de granulação fina a média, com olivina mais rica em Fe e indícios de deformação e metassomatismo.

Tipo IV - peridotitos e piroxenitos vários, deformados (com texturas porfiroclásticas), com temperaturas de equilíbrio semelhantes às do tipo I. Estes xenólitos exibem características intermediárias entre as dos tipos I e V.

Tipo V - peridotitos geralmente com granulometria mais fina, altamente deformados, com granadas e piroxênios freqüentemente zonados. São os xenólitos de 
alta temperatura; as temperaturas de equilíbrio variam entre 1100 e $1500{ }^{\circ} \mathrm{C}$ (Boyd 1987, Pearson et al. 2003).

\subsubsection{Textura em peridotitos mantélicos}

Mercier \& Nicolas (1975) ilustraram e descreveram detalhadamente vários tipos de lherzolitos com espinélio encontrados em basaltos alcalinos da França, Alemanha, Península Ibérica e Hawaii e caracterizaram os principais tipos texturais, organizados segundo uma sequência que começa com a textura metamórfica protogranular e culmina com a textura equigranular.

Segundo estes autores a textura protogranular é observada principalmente nos lherzolitos. $\mathrm{O}$ aspecto geral é parecido ao de rochas magmáticas, com cristais maiores (até $4 \mathrm{~mm}$ ) de olivina e ortopiroxênio e grãos menores de clinopiroxênio e espinélio vermicular. Os contatos entre os grãos são irregulares (a curvilíneos), exceto localmente, quando podem ser encontradas estruturas de recristalização, evidenciadas pela retificação dos contornos dos grãos. Fracas evidências de deformação estão indicadas pelo achatamento de cristais maiores de olivina e a presença de kink bands esporádicas. $\mathrm{O}$ tamanho dos cristais é em média maior que $2 \mathrm{~mm}$.

A textura porfiroclástica exibe duas classes de cristais de olivina e enstatita: grãos grandes com evidências de deformação (porfiroclastos com kink bands) e grãos menores sem deformação, com contornos retos (neoblastos), junto com os pequenos grãos xenomórficos de outros minerais (clinopiroxênio e espinélio). Os neoblastos, se menores que $0,01 \mathrm{~mm}$ e com proporção maior que $90 \%$, conferem à textura da rocha o radical mosaico (-porfiroclástica), no entanto este tipo de textura foi descrita em pouquíssimas amostras estudadas por Mercier \& Nicolas (1975). Os porfiroclastos, comumente achatados, conferem foliação às rochas.

A textura equigranular, descrita por Mercier \& Nicolas (1975), é o resultado de uma recristalização completa. Apresenta minerais que em média são menores que $2 \mathrm{~mm}$, nas quais os diferentes minerais têm tamanho semelhantes, exceto pela ocasional presença de relictos de porfiroclastos. Os limites entre os grãos são retilíneos e convergem em pontos tríplices a $120^{\circ}$. É equivalente a textura denominada granoblástica definida por Harte (1977) para estas amostras, termo que apresenta 
contexto textural e genético mais adequado e portanto é o que será utilizado nas classificações.

O trabalho de Boulier \& Nicolas (1975) analisou as características de xenólitos de kimberlitos Sul-africanos e descreve texturas semelhantes ao trabalho de Mercer \& Nicolas (1975), com exceção da textura fluidal, que consiste em lentes compostas por grãos muito pequenos (em torno de $0,01 \mathrm{~mm}$ ), formando mosaicos geralmente de olivina, conectados com porfiroclastos da mesma espécie. Esta é uma variação da textura mosaico-porfiroclática, que ao contrário dos xenólitos de basaltos alcalinos (Mercier \& Nicolas 1975), são comuns nos kimberlitos sul-africanos. Segundo Harte (1977), esta característica textural tem conotação genética e está relacionada a processos de superplasticidade relacionadas a astenosfera, como indica a "inflexão de Lesotho" de Boyd (1987), que consiste em uma mudança da inclinação da geoterma entre os grupos de xenólitos granulares e cisalhados (porfiroclástico e porfiroclástico em mosaico), calculada por geotermobarometria.

No entanto, trabalhos mais recentes atribuem estas texturas ao metassomatismo na base da litosfera, pela identificação de bordas enriquecidas em Fe, Ti, Zr e empobrecidas em Cr em porfiroclastos de granada (Griffin et al. 1996, O’Reilly \& Griffin 2013). Gaillard et al. (2008) sugerem que zonas de baixa resistividade elétrica no manto superior provavelmente são causados pela presença de pequenos volumes de líquidos carbonatíticos, que por conta disso seriam altamente condutivas (1000 vezes mais que silicato fundido). Estes magmas também têm alta capacidade de percolação o que ajuda na formação de redes interconectadas entre os limites de grãos, gerando as texturas em mosaico.

Outro importante aspecto textural é o metassomatismo modal, que é comum nos xenólitos de kimberlitos no mundo inteiro (Dawson 1980, Erlank et al. 1987). Segundo Dawson (1980) o reconhecimento do metassomatismo modal envolve:

a) observações detalhadas das texturas dos xenólitos. Veios de tamanho e forma variáveis compostos por minerais resultantes de processos metassomáticos podem atravessar os grãos das rochas, ou se infiltrar ao longo das bordas dos cristais; pode haver também substituição de minerais do peridotito (e.g. conversão de piroxênios em K-richterita e flogopita);

b) estudo das espécies minerais no tocante ao tipo, forma e distribuição e, principalmente a sua composição química. (e.g. diferenças entre a composição das flogopitas metassomáticas e as do peridotito). 
A origem do metassomatismo é também complexa, assim como o são as relações

entre metassomatismo e subsequente magmatismo (Jones et al. 1982). O metassomatismo de infiltração provavelmente é o precursor necessário para a fusão parcial do manto superior e, particularmente para gerar magmas kimberlíticos e basálticos alcalinos (Jones et al. 1982). Por outro lado, as relações de fases experimentais sugerem fortemente que o metassomatismo de infiltração pode ser uma conseqüência do magmatismo kimberlítico (Jones et al. 1982).

O trabalho de Gregoire et al. (2002) sugere a partir de estudos de elementos traço e modelagem petrogenética que a existência de xenólitos metassomatisados tais como MARID (mica + anfibólio + rutilo + ilmenita + clinopiroxênio) e PIC (flogopita + ilmenita + clinopiroxênio) estariam intimamente ligados à geração de magmas kimberlíticos, respectivamente do tipo I e do tipo II (orangeítos).

1.2. Distribuição de elementos incompatíveis em xenólitos do manto

Os processos de geração de magmas no manto são frequentemente modelados a partir de sua composição modal e dos teores e razões entre elementos traço. Os elementos incompatíveis, em particular, são largamente utilizados para inferências sobre o tipo de fonte, grau de fusão parcial e ambiente tectônico, sendo amplamente aceita, por exemplo a correlação entre razões LILE/HFSE e ambientes associados ou não a subducção.

O estudo textural e mineralógico de xenólitos mantélicos ultramáficos tem mostrado, no entanto, que o comportamento dos elementos incompatíveis pode ser bastante complexo nessas rochas, refletindo múltiplos processos de enriquecimento e/ou empobrecimento. A possibilidade de alteração associada a interações com o magma hospedeiro adiciona complexidade ao quadro.

É bem estabelecido na literatura há algum tempo que elementos incompatíveis móveis $(\mathrm{Rb}, \mathrm{K}, \mathrm{Ba}, \mathrm{U})$ ocorrem em fases acessórias ao longo de limites de grãos em xenólitos do manto (Zindler \& Jagoutz 1988). Embora em alguns casos que elementos traço incompatíveis sejam residentes principalmente nas fases minerais sólidas principais de xenólitos de manto (Eggins et al. 1998), tem sido demonstrado em anos recentes que mesmo elementos incompatíveis menos móveis (e.g., ETR, Nb, Ta) podem não ser residentes nessas fases. 
A combinação de estudos texturais e químicos de detalhe utilizando técnicas analíticas modernas (e.g., microscopia eletrônica de varredura e LA-ICPMS) tem revelado que os elementos incompatíveis ocorrem com frequência em fases minerais de limites de grãos, inclusões fluidas ou líquidos aprisionados (Zindler and Jagoutz 1988, Bodinier et al. 1996, Condie et al. 2004). Mesmo nos casos mais comuns em que as dimensões dessas fases são muito pequenas para a sua identificação ou quantificação de sua composição química, tem sido possível identificar assinaturas geoquímicas características, que permitem associar a sua geração com processos de modificação do manto singulares e/ou com interação com o magma hospedeiro (e.g., Condie et al. 2004, Ionov et al. 2002)

\section{Objetivos}

Os principais objetivos deste trabalho foram:

- Estudo petrográfico de detalhe de um conjunto de 74 amostras de xenólitos do manto com caracterização textural, mineralógica e modal com a finalidade de identificar xenólitos mantélicos que sofreram metassomatismo modal (Dawson 1984), ou seja, com a presença de minerais diferentes daqueles comumente presentes em peridotitos (olivina+ortopiroxênio+clinopiroxênio+espinélio e/ou granada), e os xenólitos isentos deste tipo de processo. Embora o clinopiroxênio seja uma fase comum em xenólitos mantélicos, algumas vezes pode ocorrer clinopiroxênio com textura intersticial, na forma de bolsões, ou associado a flogopita caracterizando metassomatismo modal. Por isso, O'Reilly \& Griffin (2013) sugeriram o termo "stealth metasomatism" para este caso específico, no entanto para o presente trabalho, onde a textura do clinopiroxênio discrimina muito bem os dois tipos distintos, são usados somente os termos metassomatismo modal e metassomatismo críptico. Este último se refere a modificação química dos minerais sem a adição de uma nova fase mineral (Dawson 1984);

- Estudo textural e químico semi-quantitativo em microscópio eletrônico de varredura, para identificação de fases minerais acessórias, incluindo aquelas presentes em limites de grão e micro-fraturas, objetivando a caracterização de infiltração de magmas hospedeiros e diferenciar evetuais processos de metassomatismo in loco (no manto) e durante o transporte pelo magma hospedeiro;

- Determinação da composição química dos minerais constituintes em termos de elementos maiores e menores (por microssonda eletrônica), traços, incluindo os 
elementos terras raras (por LA-Q-ICPMS), e isótopos de Sr (por LA-MC-ICPMS), de modo a investigar as assinaturas químicas dos minerais caracterizados como de origem metassomática, como identificar minerais de amostras sem metassomatismo modal, mas com metassomatismo críptico, além de determinar as condições de formação dos xenólitos (geotermobarometria) e a residência dos elementos incompatíveis;

- Identificação dos processos petrológicos registrados nos xenólitos, e distinção entre esses processos e as eventuais modificações associadas à interação com os magmas hospedeiros. 


\section{Capítulo II- Materiais e Métodos}

Além de explorar os aspectos petrológicos de rochas máfica-ultramáficas alcalinas e de xenólitos mantélicos estudados, bem como o contexto geológico destas rochas na área da APIP existentes na bibliografia especializada, o presente trabalho obteve dados petrográficos e de química mineral (elementos maiores e traços) a partir de 74 seções delgadas de amostras previamente coletadas por Darcy P. Svisero e pelo candidato (Nannini 2011) em cinco ocorrências conhecidas. Segundo Gonzaga \& Tompkins (1991), empresas de prospecção fizeram inúmeras descobertas de kimberlitos e rochas afins nessa região, de modo que os nomes e as localizações dessas ocorrências não foram divulgadas, até 2003, quando a CPRM (Serviço Geológico do Brasil) adquiriu algumas informações a esse respeito. Paralelamente ao trabalho das empresas de prospecção na época, outros pesquisadores e técnicos independentes (e.g. Barbosa et al. 1970, Svisero et al. 1984, Gonzaga \& Tompkins 1991, entre outros) identificaram diversos kimberlitos e rochas semelhantes na região do Alto Paranaíba, nomeando-os à sua maneira. Estes acontecimentos fizeram com que um mesmo corpo pudesse apresentar dois (ou mais) nomes diferentes ou, em alguns casos, um mesmo nome pode ter sido atribuído a corpos distintos, provocando muita confusão entre os prospectores vinculados a empresas de prospecção e pesquisadores vinculados às Universidades. Esta discussão foi objeto de debate no $6^{\circ}$ Simpósio de Geologia do Diamante em Patos de Minas (2014). Embora não se tenha chegado a um consenso sobre os nomes a serem adotados, a sugestão com concordância unânime nesse debate foi a de localizar os corpos em UTM ou coordenadas geográficas em trabalhos futuros, para evitar maiores confusões. Os nomes das intrusões adotados nesta tese são os empregados pelo professor Darcy P. Svisero e sua correspondência com aqueles utilizados por empresas de exploração está explicitada no parágrafo seguinte, a partir de informações do banco de dados não publicados da CPRM.

Os nomes das intrusões estudadas e suas respectivas coordenadas geográficas são: Indaiá $1\left(-47,457717^{\circ},-18,571007^{\circ}\right)$, Indaiá $2\left(-47,456124^{\circ},-18,569510^{\circ}\right)$, Limeira $1 \quad\left(-47,466837^{\circ},-18,559824^{\circ}\right)$, Forca $1 \quad\left(-47,366252^{\circ},-18,559824^{\circ}\right)$ e Facão $(-$ $\left.47,366252^{\circ},-18,505729^{\circ}\right)$. As denominações Perdizes 3, Perdizes 4 e Presidente Olegário 9, atribuídas pelas empresas de exploração, correspondem respectivamente aos corpos Indaiá 1, Limeira 1 e Facão. O corpo Forca apresenta o mesmo nome (Forca 1). Já a intrusão Indaiá 2 não apresenta correspondência com os nomes dados pelas empresas. 
1. Microscopia óptica

Foram estudadas seções delgadas ao microscópio petrográfico de luz transmitida e refletida, a fim de caracterizar os minerais dos xenólitos e as relações texturais, orientando estudos de microscopia eletrônica de varredura e as interpretações sobre a evolução petrológica dos xenólitos. Foram estudados 6 exemplares da intrusão Forca, 30 exemplares da intrusão Limeira 1, 30 exemplares da intrusão Indaiá 1, 8 exemplares da Facão, além de uma amostra do corpo Indaiá 2. Estimativas modais foram feitas utilizando charriot e contador de pontos.

2. Microscopia eletrônica de varredura

Os estudos de microscopia óptica foram seguidos, em amostras selecionadas, por microscopia eletrônica de varredura, com obtenção de imagens de elétrons retroespalhados e análises semi-quantitativas por EDS. Em particular, serão estudados os minerais opacos, que podem apresentar heterogeneidades, em texturas que não são visíveis ao microscópio óptico, e a eventual presença de fases exóticas como titanatos (e.g., mathiasita, priderita, que já foram reportadas em xenólitos da região com evidências de metassomatismo; Almeida et al. 2014). Além disto, foram estudadas as texturas indicativas de interação com magmas ou fluidos, como apoio à identificação da residência dos elementos incompatíveis e sua associação com processos metassomáticos.

Nesses estudos, deverão ser utilizados o microscópio eletrônico de varredura Stereoscan S440 (Leo) com sistemas de microanálise INCA (EDS/WDS, marca Oxford) e de análises de imagens QWin Pro (Leica) do Laboratório de Caracterização Tecnológica do Departamento de Engenharia de Minas e de Petróleo da Escola Politécnica da USP e o microscópio LEO-440I com sistemas de microanálise INCA (EDS/WDS, marca Oxford) do Departamento de Geologia Sedimentar e Ambiental do Instituto de Geociências da USP. 


\section{Microssonda eletrônica}

Todas as amostras foram recobertas com carbono em vácuo. As análises foram efetuadas com um potencial de $15 \mathrm{kv}$ e uma corrente de cerca de $20 \eta \mathrm{A}$ e diâmetro de 5 $\mu \mathrm{m}$ para todos os minerais analisados em ambas microssondas eletrônicas de São Paulo e de Saint Andrews (Escócia). As análises químicas em fases minerais foram realizadas em Microssonda Eletrônica (EPMA) marca JEOL, modelo JXA-8600 composto por cinco espectrômetros, no IGc-USP; e modelo JCXA-733, composto por três espectrômetros, em Saint Andrews. Os espectrômetros têm dois cristais analisadores, com automação de fabricação NORAN e sistema Voyager 3.6.1. Correções de efeitos de matriz foram feitas com o procedimento PROZA (Bastin et al. 1984). Em Saint Andrews alguns minerais muito pequenos foram analisados por área e o vidro foi analisado com um feixe de $10 \mu \mathrm{m}$, para minimizar efeitos de volatilização. Os padrões utilizados nas análises feitas na microssonda do IGc-USP e em St Andrews estão contidos na Tabela 1.

Os dados obtidos foram tratados para o cálculo das fórmulas estruturais das fases minerais analisadas por meio do programa Microsoft Office Excel ${ }^{\circledR}$. A visualização destes dados pode ser feita por meio de tabelas representativas no texto (Tabelas 5-9), tabelas com os dados completos, no ANEXO C, juntamente com os dados de xenólitos obtidos em Nannini (2011), expressos com os códigos das amostras em negrito. A partir destes resultados e dados, foi possível analisar o comportamento químico, e suas implicações para a química do manto e a determinação das condições de pressão e temperatura com o auxílio do programa PTELX baixado gratuitamente no site: www.mineralogie.uni-frankfurt.de/petrologie-geochemie.

Tabela 1- Padrões químicos utilizados nas análises por microssonda eletrônica nos laboratórios do IGcUSP e na School of Geography and Geosciences da Universidade de St. Andrews, Escócia.

\section{Elemento}

Si

Ti

Al

Fe

Mn

Mg

Ca

$\mathrm{Na}$

K

$\mathrm{Cr}$

$\mathrm{Ni}$

\section{IGc- USP}

wollastonita

rutilo

anortita

olivina

olivina

diopsídio

wollastonita

albita

ortoclásio

óxido de $\mathrm{Cr}\left(\mathrm{Cr}_{2} \mathrm{O}_{3}\right)$

óxido de $\mathrm{Ni}(\mathrm{NiO})$
Universidade de St. Andrews

wollastonita

rutilo

Coríndon

óxido de $\mathrm{Fe}\left(\mathrm{Fe}_{2} \mathrm{O}_{3}\right)$

óxido de $\mathrm{Mn}(\mathrm{MnO})$

periclásio $(\mathrm{MgO})$

wollastonita

albita

Ortoclásio

óxido de $\mathrm{Cr}\left(\mathrm{Cr}_{2} \mathrm{O}_{3}\right)$

óxido de $\mathrm{Ni}(\mathrm{NiO})$ 
4. LA-Q-ICPMS: elementos traço in situ em minerais

Análises químicas de elementos traço (em concentração da ordem de ppm, ou ppb) em minerais constituem uma ferramenta fundamental no estudo de xenólitos do manto, e seu uso, inicialmente limitado a um pequeno número de laboratórios dotados de microssonda iônica (SIMS), tem ganhado grande impulso com a implantação de espectrômetros ICPMS dotados de amostradores por "laser ablation". O interesse pela análise de elementos traços reflete não apenas a possibilidade de determinar com precisão a composição de diversos elementos incompatíveis de grande significado na petrologia de magmas derivados do manto (e.g., ETR, Nb, Ta, Th, U etc), mas também a grande vantagem de identificar zoneamentos químicos que muitas vezes podem ser preservados devido aos baixos coeficientes de difusão desses elementos em algumas fases minerais. Dessa forma, ao lado de estimativas adicionais e/ou mais precisas de parâmetros físico-químicos como temperatura e pressão de cristalização, os dados obtidos por LA-ICPMS (ou SIMS) permitem estimar o controle de processos de fusão parcial e extração de fundidos sobre a composição do manto (e.g., Norman 1998).

O amostrador "laser ablation" de $216 \mathrm{~nm}$ marca New-Wave foi implantado em abril de 2006 no espectrômetro quadrupolo (Q) ICP-MS Perkin-Elmer modelo ELAN600 dotado de uma célula de reação dinâmica, em rotina no Laboratório de ICP do Instituto de Geociências desde o ano de 2004. As rotinas de análise implementadas permitem alcançar limites de detecção da ordem de sub-ppm para a maior parte dos elementos traço nos minerais de interesse (olivina, piroxênio), com resolução espacial da ordem de 5-10 $\mu \mathrm{m}$. O sinal produzido pelos íons amostrados é quantitativamente estimado a partir da calibração utilizando materiais de referência certificados, que incluem um padrão externo (tipicamente, vidros artificiais produzidos pelo NISTNational Institute of Stardards and Technology- EUA) e um padrão interno (um elemento químico interno, cuja concentração é conhecida de modo independente) (e.g., Jackson et al. 1992). A exatidão do método é avaliada pela análise de materiais de referência como amostra desconhecida (e.g., vidros de composição basáltica).

Foram analisados cristais de clinopiroxênio, ortopiroxênio, olivina,flogopita, anfibólio minerais do grupo do espinélio, ilmenita e titanato utilizando-se como padrões químicos a composição de vidros artificiais (NIST-610) e como controle de qualidade vidro de basalto (BCR). Os diâmetros dos spots utilizados nas análises variaram de 20 a $40 \mu \mathrm{m}$. Como padrões internos foram utilizados teores de $\mathrm{CaO}$, obtidos por microssonda 
eletrônica, para normalização das análises de clinopiroxênio e anfibólio; MgO para as de ortopiroxênio, olivina, flogopita e espinélio; $\mathrm{TiO}_{2}$ para ilmenita e titanato.

Os limites de detecção médios por elemento, juntamente com o desvio padrão, de análises em materiais de referência (NIST-612, BHVO-2 e BIR-1G) são mostrados na Tabela 2. Os valores dos limites de detecção obtidos nas análises dos minerais dos xenólitos foram por vezes menores em relação aos mostrados na Tabela 2 e mostraram variações entre os minerais como é mostrado no ANEXO D.

Tabela 2- Limites de detecção médios (em ppm) e desvio padrão obtidos em análises em materiais de referência para elementos traço em LA-Q-ICP-MS.

\begin{tabular}{|c|c|c|c|c|c|c|c|c|}
\hline elemento & $\begin{array}{l}\text { limite de } \\
\text { detecção }\end{array}$ & $\begin{array}{l}\text { desvio } \\
\text { padrão }\end{array}$ & elemento & $\begin{array}{l}\text { limite de } \\
\text { detecção }\end{array}$ & $\begin{array}{l}\text { desvio } \\
\text { padrão }\end{array}$ & Elemento & $\begin{array}{l}\text { limite de } \\
\text { detecção }\end{array}$ & $\begin{array}{l}\text { desvio } \\
\text { padrão }\end{array}$ \\
\hline${ }_{7} \mathrm{Li}$ & 0,35 & 0,270 & ${ }_{63} \mathrm{Cu}$ & 0,156 & 0,109 & ${ }_{151} \mathrm{Eu}$ & 0,025 & 0,018 \\
\hline${ }_{23} \mathrm{Na}$ & 0,54 & 0,408 & ${ }_{66} \mathrm{Zn}$ & 0,889 & 0,660 & ${ }_{157} \mathrm{Gd}$ & 0,074 & 0,051 \\
\hline${ }_{25} \mathrm{Mg}$ & 3,51 & 2,192 & ${ }_{85} \mathrm{Rb}$ & 0,046 & 0,034 & ${ }_{159} \mathrm{~Tb}$ & 0,013 & 0,008 \\
\hline${ }_{27} \mathrm{Al}$ & 1,01 & 0,701 & ${ }_{88} \mathrm{Sr}$ & 0,027 & 0,017 & ${ }_{163} \mathrm{Dy}$ & 0,076 & 0,055 \\
\hline${ }_{31} \mathrm{P}$ & 10,47 & 5,852 & ${ }_{89} \mathrm{Y}$ & 0,025 & 0,015 & ${ }_{165} \mathrm{Ho}$ & 0,015 & 0,010 \\
\hline${ }_{42} \mathrm{Ca}$ & 94,00 & 59,359 & ${ }_{90} \mathrm{Zr}$ & 0,052 & 0,035 & ${ }_{166} \mathrm{Er}$ & 0,042 & 0,025 \\
\hline${ }_{45} \mathrm{Sc}$ & 0,17 & 0,093 & ${ }_{93} \mathrm{Nb}$ & 0,029 & 0,019 & ${ }_{169} \mathrm{Tm}$ & 0,016 & 0,010 \\
\hline${ }_{49} \mathrm{Ti}$ & 2,00 & 1,514 & ${ }_{137} \mathrm{Ba}$ & 0,124 & 0,088 & ${ }_{173} \mathrm{Yb}$ & 0,071 & 0,045 \\
\hline${ }_{51} \mathrm{~V}$ & 0,13 & 0,089 & ${ }_{139} \mathrm{La}$ & 0,015 & 0,010 & ${ }_{175} \mathrm{Lu}$ & 0,018 & 0,011 \\
\hline${ }_{52} \mathrm{Cr}$ & 0,90 & 0,609 & ${ }_{140} \mathrm{Ce}$ & 0,014 & 0,009 & ${ }_{179} \mathrm{Hf}$ & 0,069 & 0,035 \\
\hline${ }_{55} \mathrm{Mn}$ & 0,31 & 0,226 & ${ }_{141} \mathrm{Pr}$ & 0,012 & 0,007 & ${ }_{181} \mathrm{Ta}$ & 0,019 & 0,012 \\
\hline${ }_{59} \mathrm{Co}$ & 0,07 & 0,055 & ${ }_{143} \mathrm{Nd}$ & 0,081 & 0,049 & ${ }_{208} \mathrm{~Pb}$ & 0,049 & 0,034 \\
\hline \multirow[t]{2}{*}{${ }_{60} \mathrm{Ni}$} & 3,21 & 3,098 & ${ }_{147} \mathrm{Sm}$ & 0,089 & 0,057 & ${ }_{232} \mathrm{Th}$ & 0,021 & 0,012 \\
\hline & & & & & & ${ }_{238} \mathrm{U}$ & 0,023 & 0,016 \\
\hline
\end{tabular}

\section{LA-MC-ICPMS: isotopia de Sr in situ em clinopiroxênio}

A assinatura isotópica do manto é informação importante para estudos de petrogênese, mas muitas vezes não pode ser obtida com confiança, dado o pequeno tamanho dos xenólitos disponíveis e as evidências petrográficas e geoquímicas de interação com o magma hospedeiro (e.g. Schmidberger et al. 2003). Deste modo, a possibilidade de obter análises isotópicas in situ de pequenos volumes de minerais onde os elementos incompatíveis de interesse se concentram (e.g., clinopiroxênio e perovskita) por técnicas como LA-MC-ICPMS e SIMS tem trazido grande impulso à identificação mais precisa das características isotópicas de xenólitos do manto, com implicações significativas para modelos de evolução do manto (Class and le Roex 2011, Paton et al. 2007).

Análises isotópicas de $\mathrm{Sr}$ foram obtidas em cristais de clinopiroxênio por LA-MCICPMS no CPGeo-USP, em cristais com diferentes assinaturas de elementos 
incompatíveis. O equipamento é um laser $193 \mathrm{~nm}$ Ar-F excimer acoplado a um espectrômetro de massa ThermoFinnigan NeptuneTM equipado com 9 colletores Faraday (com resistores de 10-11 $\Omega$ ).

Para monitorar o fracionamento de isótopos de $\mathrm{Sr}$, para cada dia de análise são feitas 8 a 9 medidas obtidas em um padrão de coral moderno (Bizzarro et al. 2003, Schmidberger et al. 2003). A ablação foi realizada em spots $126 \mu \mathrm{m}$ para as análises nos cristais de clinopiroxênio, pulso com a taxa de $6 \mathrm{~Hz}$ e energia de $6 \mathrm{~mJ}$ (resultando em uma densidade de energia de $4,29 \mathrm{~mJ} / \mathrm{cm} 2$ ).

As análises envolveram 60 ciclos de um segundo cada e após retiradas as interferências isobáricas advindas do branco ( $\mathrm{Kr}$ contido no gás Ar utilizado na ablação interfere sobre as massas 84,86 e $87 \mathrm{de} \mathrm{Sr}$ ) e de ${ }^{87} \mathrm{Rb}$ sobre ${ }^{87} \mathrm{Sr}$.

As médias e desvios padrão relativos em 7 determinações no coral intercaladas com as análises do clinopiroxênios dos xenólitos, são mostradas na Tabela 3. Os cálculos e procedimentos foram adotados de Segal et al. (2003).

Tabela 3- Razões isotópicas obtidas em coral moderno, com as médias e desvios padrão para todas as análises de referência.

\begin{tabular}{|c|c|c|c|c|c|c|}
\hline & ${ }^{87} \mathrm{Sr} /{ }^{86} \mathrm{Sr}$ & erro $2 \mathrm{~s}$ & ${ }^{84} \mathrm{Sr} /{ }^{86} \mathrm{Sr}$ & erro $2 \mathrm{~s}$ & ${ }^{84} \mathrm{Sr} /{ }^{88} \mathrm{Sr}$ & erro $2 \mathrm{~s}$ \\
\hline 1 & 0,70907 & 0,00003 & 0,05672 & 0,00004 & 0,00677 & 0,000005 \\
\hline 2 & 0,70914 & 0,00003 & 0,05666 & 0,00002 & 0,00676 & 0,000002 \\
\hline 3 & 0,70917 & 0,00002 & 0,05655 & 0,00001 & 0,00675 & 0,000001 \\
\hline 4 & 0,70918 & 0,00003 & 0,05631 & 0,00002 & 0,00672 & 0,000002 \\
\hline 5 & 0,70911 & 0,00003 & 0,05659 & 0,00002 & 0,00676 & 0,000002 \\
\hline 6 & 0,70916 & 0,00003 & 0,05641 & 0,00002 & 0,00674 & 0,000002 \\
\hline 7 & 0,70911 & 0,00003 & 0,05625 & 0,00002 & 0,00672 & 0,000003 \\
\hline média & 0,70913 & 0,00003 & 0,05650 & 0,00002 & 0,00675 & 0,000002 \\
\hline padrão & 0,00004 & 0,00000 & 0,00018 & 0,00001 & 0,00002 & 0,000001 \\
\hline
\end{tabular}

A qualidade dos dados foi ainda verificada através do monitoramento das razões invariantes 84/86 e 84/88, com valores aceitos próximos a 0,0565 e 0,00675, respectivamente.

6. Elementos maiores nas rochas dos corpos Indaiá 1 e Indaiá 2

Foram feitas análises químicas de rocha total em rochas das intrusões Indaiá 1 e Indaiá 2 no Laboratório de ICP do Instituto de Geociências da Universidade de São 
Paulo. A metodologia utilizada foi ICP-OES, após abertura e ionização por fusão alcalina, esta metodologia é descrita com detalhes em Janasi et al. (1995).

7. Nomenclatura petrográfica adotada neste trabalho

A classificação de rochas máficas/ultramáficas alcalinas é tema de grande discussão e divergências na literatura. A definição de kimberlitos, lamproítos, kamafugitos foi discutida no trabalho de Woolley et al. (1996) objetivando a classificação adequada destas rochas, que depende de critérios mineralógicos e químicos específicos. Lamprófiros ultramáficos como alnöitos, aillikitos e damtjernitos foram incorporados a classificação pelo trabalho de Tappe et al. (2005).

Katungitos, mafuritos e uganditos, que dão o radical ao termo kamafugito, são rochas vulcânicas que apresentam entre os principais minerais componentes, kalsilita $\left(\mathrm{KAlSi}_{2} \mathrm{O}_{6}\right)$ e/ou leucita $\left(\mathrm{KAlSiO}_{4}\right)$ e/ou melilita $\left[(\mathrm{Ca}, \mathrm{Na})_{2}(\mathrm{Mg}, \mathrm{Fe}, \mathrm{Al}, \mathrm{Si})_{3} \mathrm{O}_{7}\right]$. Se a melilita é o mineral mais abundante, a rocha é chamada de katungito, se a kalsilita é o mineral mais abundante a rocha é chamada de mafurito, já se a rocha tem leucita como mineral mais abundante e contém kasilita ou melilita, ela é chamada de ugandito segundo os critérios de Holmes (1950, in Sahama 1974), que efetuou um importante estudo em Uganda, a oeste do Rift Valley Africano, mais precisamente na região de Toro-Ankole, em pequenos vulcões de caráter explosivo, com abundantes rochas piroclásticas. No entanto, Woolley et al. (1996) excluem os uganditos da classificação de kamafugitos, devido ao fato destas rochas raramente apresentarem melilita ou kalsilita, as denominando simplesmente de olivina leucititos. Segundo Woolley et al. (1996), além de mafurito (olivina-piroxênio kalsilitito) e katungito (kalsilita-leucitaolivina melilitito), venanzito (kalsilita-flogopita-olivina-leucita melilitito) e coppaelito (kalsilita-flogopita melilitito) são outros nomes utilizados para kamafugitos.

Lamproítos se distinguem de kamafugitos por não possuirem nefelina, melilita, kalsilita, feldspato alcalino rico em $\mathrm{Na}$, plagioclásio, monticellita, granadas com $\mathrm{Ti}$ ou Zr e augita rica em Fe (Mitchell \& Bergman 1991). São rochas vulcânicas que podem ser reconhecidas por apresentar Ti-flogopita, olivina forsterítica, Ti-K-richterita, Titetraferriflogopita, leucita com pouco $\mathrm{Na}$ e Al, sanidina rica em $\mathrm{Fe}$, diopsídio pobre em $\mathrm{Al}$, titanatos de $\mathrm{K}$ e $\mathrm{Ba}$, e silicatos de $\mathrm{K}$ e $\mathrm{Zr}$ ou $\mathrm{Ti}$ (como wadeíta $-\mathrm{K}_{2} \mathrm{ZrSi}_{3} \mathrm{O}_{9}$ ) (Mitchell \& Bergman 1991). 
Quanto à composição química, os lamproítos têm as seguintes razões (entre \% em peso) particularidades: $\mathrm{K}_{2} \mathrm{O} / \mathrm{Na}_{2} \mathrm{O}>3$ (são rochas ultrapotássicas); $\mathrm{K}_{2} \mathrm{O} / \mathrm{Al}_{2} \mathrm{O}_{3}>$ 0,8; $\left(\mathrm{K}_{2} \mathrm{O}+\mathrm{Na}_{2} \mathrm{O}\right) / \mathrm{Al}_{2} \mathrm{O}_{3}>1$ (são peralcalinas); tipicamente possuem menos de $10 \% \mathrm{em}$ peso de $\mathrm{FeO}$, menos de $10 \%$ de $\mathrm{CaO}$ e entre 1 e $7 \%$ em peso de $\mathrm{TiO}_{2}$. Os teores de alguns elementos traços são: $\mathrm{Ba}>2000$ ppm, $\mathrm{Zr}>500$ ppm, $\mathrm{Sr}>1000$ ppm e La >200 ppm.

Os kimberlitos são rochas ultrabásicas, potássicas, de origem mantélica, ricas em voláteis $\left(\mathrm{CO}_{2}, \mathrm{H}_{2} \mathrm{O}\right)$ e enriquecidas em elementos compatíveis e incompatíveis. Apresentam textura inequigranular marcada pela presença de macrocristais (entre $0,5 \mathrm{e}$ $10 \mathrm{~mm}$ de diâmetro) e, às vezes, megacristais (com 1 a $20 \mathrm{~cm}$ de diâmetro), predominantemente de olivina com contornos xenomórficos, numa matriz fina que contém, além de olivina idiomórfica a subidiomórfica, alguns dos seguintes minerais: flogopita, carbonato (normalmente calcita), serpentina, clinopiroxênio (normalmente diopsídio), monticellita, apatita, espinélio, perovskita e ilmenita (Mitchell 1986).

Grande parte dos macrocristais de olivina magnesiana derivam da desagregação de xenólitos do manto. Além de olivina, podem ocorrer flogopita, picroilmenita, Crespinélio, granada magnesiana, clinopiroxênio (normalmente Cr-diopsídio) e ortopiroxênio (comumente enstatita). Tanto os macrocristais como os minerais da matriz podem aparecer alterados ou até totalmente substituídos por minerais secundários (carbonato, serpentina), resultantes de processos deutéricos (Mitchell 1986).

Os kimberlitos são divididos em dois grupos: kimberlitos do grupo I e kimberlitos do grupo II (denominados de orangeítos, por Mitchell 1995), que diferem na sua mineralogia, refletindo diferentes composições dos voláteis.

Os kimberlitos do grupo I apresentam minerais que remetem à origem em um ambiente rico em $\mathrm{CO}_{2}$ e possuem olivina, espinélios, monticellita, diopsídio, perovskita, flogopita, apatita, carbonatos, serpentina, e rara barita (Mitchell 1986).

Os kimberlitos do grupo II, ou orangeítos (antigamente denominados de kimberlitos micáceos), têm origem em magmas ricos em $\mathrm{H}_{2} \mathrm{O}$ e se caracterizam pela presença de flogopita como macrocristais, fenocristais e na matriz. Segundo Le Maitre et al. (2002), os estudos até agora realizados não permitem uma completa definição dessas rochas. Em suma, os minerais componentes incluem olivina, flogopita e tetraferriflogopita, poucos espinélios -em relação aos kimberlitos do Grupo I-, 
diopsídio, perovskita, apatita, carbonatos, serpentina, ilmenita com Mn, silicatos de zircônio, raras leucita e sanidina (Mitchell 1995).

Os lamprófiros ultramáficos foram classificados por Tappe et al. (2005), que eliminaram o termo melnoíto proposto por Mitchell et al. (1995). Alnöitos são considerados lamprófiros ultramáficos portadores de melilita, podendo conter macrocritais de olivina, flogopita e clinopiroxênio e/ou fenocristais e matriz composta por melilita, clinopiroxênio, flogopita, espinélio, ilmenita, perovskita, granada rica em $\mathrm{Ti}$, apatita e pouco carbonato primário. A monticellita pode ocorrer nesta rocha em casos raros. Aillikitos são constituídos por carbonatos, macrocristais de olivina e flogopita, fenocristais e matriz de carbonato primário, flogopita, espinélio, ilmenita, rutilo, perovskita, granada rica em Ti e apatita. O termo mela-aillikitos se refere a espécies mais melanocráticas (índice de cor $>90 \%$ ) como um resultado da presença de clinopiroxênio e/ou richterita na matriz juntamente com o carbonato. A monticellita pode ocorrer, porém não é comum. Damtjernitos são rochas com matriz composta por nefelina ou K-feldspato, com macrocristais de olivina, flogopita e clinopiroxênio, podendo ter fenocristais ou matriz contendo flogopita/biotita, clinopiroxênio, espinélio, ilmenita, rutilo, perovskita, granada rica em Ti, titanita, apatita e carbonato primário.

Tappe et al. (2005) e Woolley et al. (1996) apresentam critérios, utilizando as considerações de Le Maitre et al. (1989) e Le Bas \& Streckeisen (1991), descritas a seguir:

1. Se a rocha possui mais de $50 \%$ de carbonato, é recomendado ser chamada de carbonatito.

2. Se a rocha é ultramáfica, com índice de cor maior que $90 \%$, textura inequigranular contendo macrocristais e /ou fenocristais de olivina e flogopita:

a) se a rocha não contém carbonato primário, provavelmente é um lamproíto;

b) se contém melilita é um alnöito;

c) se contém nefelina e /ou feldspato alcalino, é um damtjernito;

d) se é rico em carbonato e contém melanita/schorlomita ou kimzeyita é um aillikito;

e) se a rocha contém carbonato, esta pode ser aillikito, orangeíto (kimberlito Grupo 2) ou kimberlito do tipo 1, as diferenças devem ser identificadas pela composição mineral a seguir: 
I. é aillikito se os cristais de espinélio formarem um "trend da titanomagnetita" e tiverem $\mathrm{Cr} \#<0,85, \mathrm{Al}-\mathrm{Ti}$ flogopita evoluindo para empobrecimento em $\mathrm{Al}$ em direção a tetraferriflogopita pobre em Ti;

II. é orangeíto se os cristais de espinélio formarem um "trend da titanomagnetita" e tiverem Cr\#>0,85, Ti-flogopita com composição de tetraferriflogopita em direção ao empobrecimento em Al, e se o clinopiroxênio for pobre em $\mathrm{Al}$ e $\mathrm{Ti}$;

III. é kimberlito se os cristais de espinélio formarem um "trend do ulvoespinélio magnesiano" e tiverem $\mathrm{Cr} \#>0,85$; Al-flogopita com composição de tetraferriflogopita em direção ao enriquecimento em Al e Ba (kinoshitalita), e se o clinopiroxênio for ausente na matriz.

3. Se a rocha possui mais de $10 \%$ de melilita na moda e apresenta índice de cor maior que $90 \%$, a recomendação é de ser chamada de melilitito.

4. Se a rocha contém kalsilita, mesmo que com mellilita, é sugerido o nome kalsilitito.

5. Se a rocha tem textura fina ou vítrea e há larnita normativa, a recomendação é de ser chamada de melilitito.

6. Se a rocha não apresentar leucita, for rica em olivina (35-55\%) e se monticellita, flogopita, carbonato, serpentina, ou diopsídio forem minerais dominantes na matriz, a rocha é denominada de kimberlito.

7. Nos casos em que a rocha contém flogopita rica em titânio e pobre em Al, seja como fenocristais ou grãos da matriz (ou ambos), junto com leucita rica em $\mathrm{Fe}$ e/ou forsterita, além de richterita rica em $\mathrm{K}$ e Ti, diopsídio pobre em $\mathrm{Al}$ e $\mathrm{Na}$, sanidina rica em $\mathrm{Fe}$, wadeíta $\left(\mathrm{K}_{2} \mathrm{Zr}\left(\mathrm{Si}_{3} \mathrm{O}_{9}\right)\right.$ e priderita $\left[(\mathrm{K}, \mathrm{Ba})\left(\mathrm{Ti}_{,} \mathrm{Fe}^{3+}\right)_{8} \mathrm{O}_{16}\right]$ como acessórios na matriz, a rocha deve ser denominada de lamproíto. 


\section{Capítulo III- Contexto Geológico}

Durante o período cretáceo ocorreram as maiores manifestações de magmatismo máfico/ultramáfico alcalino no Continente Sul-Americano. Centenas de corpos de natureza kimberlítica, kamafugítica, lampróitica ou lamprofírica; e pelo menos 6 complexos carbonatíticos desenvolveram-se na porção oeste de Minas Gerais, com continuidade para o leste de Goiás e nordeste de São Paulo, abrangendo uma área de aproximadamente $180.000 \mathrm{~km}^{2}$ (Gibson et al. 1995). Associada às intrusões ocorreu expressiva deposição de rochas piroclásticas do Grupo Mata da Corda (Leonardos \& Meyer 1991, Fernandes et al. 2013). Segundo Brod et al. (2000) a associação de carbonatitos e rochas ultrapotássicas ocorre em diversas outras partes do mundo, e existe uma forte relação genética entre os dois tipos de magmatismo, com processos de imiscibilidade explicando a separação dos magmas carbonatíticos dos magmas kamafugíticos.

A porção norte desta área é descrita na literatura como Província Ígnea do Alto Paranaíba (APIP), por estar situada próxima ao rio homônimo (Barbosa et al. 1970, Gibson et al. 1995, Leonardos \& Meyer 1991, entre outros); alguns autores a designam Província Alcalina do Alto Paranaíba (Araujo et al. 2001). Já ao sul, se aproximando do limite de estado com São Paulo ocorrem agrupamentos de corpos máficos-ultramáficos alcalinos próximos às intrusões Araxá-Tapira que ocorrem desde a região de Franca-SP. Nas proximidades da Serra da Canastra, agrupamento semelhante foi nomeado de Província Kimberlítica/Diamantífera da Serra da Canastra por Chaves et al. (2008). Este último é o único local do estado de Minas Gerais onde ocorre um corpo com teor econômico comprovado de diamantes, o Canastra-1 (Chaves et al. 2008).

Estas rochas alcalinas e carbonatíticas ocorrem intrusivas (diatremas ou diques) ou na forma de derrames (no caso dos kamafugitos), em três ambientes tectônicos distintos: Bacia do Paraná, Cráton do São Francisco e Faixa Brasília, sendo que a predominância de corpos ocorre na região da Faixa Brasília devido a um paleo-alto, que separou as bacias do Paraná e São Francisco (Dardenne \& Schobbenhaus 2001, Hasui \& Haralyi 1991, Campos \& Dardenne 1997). A porção sul da Faixa Brasília tem elementos estruturais como dobras e cavalgamentos resultantes da colisão entre as placas Paranapanema e Sanfranciscana de modo que o limite aflorante representa a frente de cavalgamento que sobrepõe as rochas da faixa de Dobramentos Brasília aos sedimentos cratônicos do Grupo Bambuí, conforme evidenciado pelos levantamentos gravimétricos 
realizados, e pela coleta de dados geológicos regionais (Dardenne \& Schobbenhaus 2001). Os dados de sísmica de reflexão, tomografia sísmica e gravimetria, assim como a geologia, também sugerem que o limite da placa Sanfranciscana ocorreria mais a W e boa parte das rochas da faixa Brasília estão sobrepostas ao craton, de modo que a localização de praticamente todas as ocorrências de kimberlitos estariam sobre litosfera cratônica, o que está de acordo com a grande quantidade de corpos na região com xenocristais e xenólitos constituídos por Cr-piropo, que indicam resgate de xenólitos de litosfera profunda, caracterizando região cratônica (Pereira 2007, Rocha 2008). Na Bacia do São Francisco os litotipos mais antigos são atribuídos ao neoproterozóico e correspondem ao Grupo Bambuí, constituído por calcários e siliciclásticas interpretados como de sedimentação marinha plataformal em bacia do tipo ante-país (Martins-Neto et al. 1997, Campos \& Dardenne 2007, Fragoso et al. 2011). Em discordância com este grupo ocorrem depósitos espessos de idade cretácica pertencentes aos grupos Areado e Mata da Corda. Estas unidades têm sua gênese relacionada ao estiramento crustal produzido após a abertura do Atlântico Sul sendo responsável pela formação de um conjunto de falhamentos normais, com reativação de estruturas mais antigas originando uma bacia em formato graben-horst, onde depositou-se o grupo Areado, constituído pelas formações Abaeté (conglomerados, brechas e arenitos), Quiricó (siltito, argilito, folhelho e arenito fino a grosso) e Três Barras (arenitos estratificados). Rochas vulcânicas, piroclásticas e epiclásticas do Grupo Mata da Corda evidenciam uma atividade magmática produzida durante o Cretáceo Superior (Gibson et al. 1995, Sgarbi et al. 2000).

\section{O Alinhamento $125^{\circ}$}

Os kimberlitos e rochas afins do W de Minas Gerais, e regiões adjacentes estão alinhados com os corpos kamafugiticos da Província Alcalina de Goiás (PAG; Junqueira- Brod 2002) e com os basaltos alcalinos de Poroxéu (Mato Grosso) ao longo de um "trend" estrutural chamado de alinhamento $125^{\circ}$, ou azimute $125^{\circ}$ (Bardet 1977). Os kimberlitos de Paranatinga (MT) e lamproítos e kimberlitos de Juína também ocorrem alinhados ao longo deste alinhamento. Todas as datações das rochas kimberlíticas, lamproíticas e kamafugíticas para este alinhamento têm idades entre $68 \mathrm{e}$ 99 Ma (Gibson et al. 1995, Sgarbi et al. 2004, Basei et al. 2003, Guarino et al. 2013, 
Costa 1996 e Felgate et al. 2014), com exceção dos kimberlitos de Paranatinga com datações de 123-126 Ma pelo método U/Pb em zircão (Heaman et al. 1998).

Com o avanço dos estudos de aeromagnetometria foi possível verificar a existência de diversos lineamentos magnéticos muito bem marcados, com direção NWSE, que coincidem com o alinhamento $125^{\circ}$ (Rocha et al. 2014). Estes lineamentos magnéticos podem ser observados desde a Província Alcalina de Goiás até o sul do Craton do São Francisco. Segundo Rocha et al. (2014) o alinhamento é composto por rochas com alta resposta ao magnetismo que não afloram na superfície em sua maior extensão. No entanto, alguns trechos contidos nestes lineamentos magnéticos têm diques aflorantes de olivina gabro e olivina diabásio, com idades que variam de 120-900 Ma. Rocha et al. (2014) considera que os lineamentos foram gerados durante o evento Brasiliano, resultante de tectônica transtensional que teria sido reativada durante a fragmentação do Gondwana e posteriormente durante a extrusão dos magmas alcalinos da APIP.

Algumas populações de kimberlitos são concentradas ao longo de conjuntos paralelos de corredores largamente distribuídos ao longo de boa parte do Sul da África, e episódios repetidos de magmatismo são observados dentro de muitos agrupamentos. Estes corredores são interpretados como a manifestação de descontinuidades no manto litosférico, identificados através de gradientes geofísicos e mudanças na composição do manto litosférico. $\mathrm{Na}$ crosta, estes corredores são expressos como limites de terrenos, riftes continentais incipientes, zonas de fraturas ou grandes enxames de diques (Jelsma et al. 2009).

2. Assinatura isotópica do manto na APIP e implicações regionais

A assinatura isotópica de kimberlitos do tipo 1 é similar aos basaltos de ilha oceânica, e, portanto, eles são considerados de origem astenosférica. No entanto, uma variedade de fontes tem sido proposta por pesquisadores para explicar a origem de kimberlitos do tipo 1 que, além de manto sublitosférico metassomatisado, poderia ser gerado por fontes do manto inferior, zona de transição e crosta oceânica reciclada no manto inferior (Ringwood et al. 1992, Tainton \& Mackenzie 1994, Nowell et al. 2004, Patton et al. 2007 e Tappe et al. 2013). 
Capitulo III-Contexto Geológico

A assinatura isotópica do manto na APIP tem sido inferida a partir de determinações nas diversas variedades de rochas vulcânicas e plutônicas que a constituem (Toyoda et al. 1994, Gibson et al. 1995, Araujo et al. 2001, Bizzi \& Araujo 2005) ou, mais raramente, diretamente em xenólitos do manto (Carlson et al. 2007).

Existem dados publicados para os principais sistemas de isótopos radiogênicos nas rochas da APIP. As razões iniciais ${ }^{87} \mathrm{Sr} /{ }^{86} \mathrm{Sr}$ variam em geral 0,705 e 0,706 , com ampla superposição entre os diferentes tipos de rocha. Os valores de $\varepsilon \mathrm{Nd}(\mathrm{t})$ são sempre negativos (-3.4 a -8.9), e tendem a ser menos radiogênicos (mais negativos) nas rochas kamafugíticas (lavas e corpos intrusivos) se comparadas aos kimberlitos, que em geral têm valores entre -5 e -6. Como consequência, as idades-modelo Sm-Nd (manto empobrecido) dos kimberlitos são um pouco mais baixas (830-910 Ma) que as dos kamafugitos (1000-1120 Ma). A assinatura isotópica de $\mathrm{Pb}$ também distingue os kimberlitos, que tendem a apresentar maiores razões iniciais ${ }^{206} \mathrm{~Pb} /{ }^{204} \mathrm{~Pb}(>18)$ se comparados às demais rochas alcalinas (17-18); os carbonatitos apresentam valores intermediários entre os dois grupos (Bizzi and Araujo 2005). A assinatura Re-Os distingue claramente os kimberlitos, com valores de $\gamma \mathrm{Os}$ negativos $\left(\begin{array}{lll}0 & \text { a } & -8\end{array}\right)$ dos kamafugitos, com valores em geral positivos (-1 a +15) (Araujo et al. 2001).

Os dados isotópicos têm permitido identificar que os magmas parentais da APIP derivaram diretamente do manto litosférico enriquecido ou interagiram extensivamente com este manto (e.g., Araujo et al. 2001, Bizzi and Araujo 2005). A similaridade com a assinatura isotópica dos basaltos adjacentes da Província Magmática Paraná-Etendeka (PMPE), formados cerca de 45 Ma antes (a 130-135 Ma), é evidência de que uma fonte mantélica comum, que se moveu juntamente com a Placa Sul-Americana ou, menos provavelmente, estava disponível para servir como fonte por distâncias muito grandes (Bizzi and Araujo 2005). Os isótopos de Os são também consistentes com a derivação dominantemente litosférica para as rochas da APIP (Carlson et al. 1996).

As diferenças observadas entre as assinaturas de kimberlitos e kamafugitos da APIP são compatíveis com o envolvimento de mais de uma fonte mantélica que, para (Bizzi \& Araujo 2005), corresponderiam a (1) manto peridotítico litosférico enriquecido, que domina a assinatura de elementos traço das rochas, e (2) manto mais profundo, que seria a fonte dos kimberlitos. A assinatura enriquecida é compatível com fontes do tipo EM1; os valores de ${ }^{207} \mathrm{~Pb} /{ }^{204} \mathrm{~Pb}$ e ${ }^{208} \mathrm{~Pb} /{ }^{204} \mathrm{~Pb}$, quando plotados contra ${ }^{206} \mathrm{~Pb} /{ }^{204} \mathrm{~Pb}$, são notavelmente enriquecidos com relação à tendência do hemisfério norte (NHRL), o que caracteriza a anomalia Dupal (Hart 1984). A dispersão para razões 
$\mathrm{Pb} / \mathrm{Pb}$ mais elevadas que EM1 pode ser atribuída a um componente HIMU (manto com alto $\mathrm{U} / \mathrm{Pb}$ ) (Bizzi \& Araujo 2005).

A anomalia Dupal tem sido comumente associada à influência da pluma de Tristan da Cunha; no entanto, a associação desta assinatura com o manto litosférico local implica que a anomalia Dupal não tem origem única no manto astenosférico, e pode também estar associada a fontes rasas (Peate et al. 1999) ou, alternativamente, que o manto litosférico local preservou assinatura vinculada à passagem prévia da pluma de Tristan da Cunha na região durante a geração dos basaltos da PMPE; (e.g., Toyoda et al. 1994, Turner et al. 1994). Outro indício desta teoria é a anomalia de ondas P e S, por tomografia sísmica, com forma cilíndrica compreendendo a região da borda $\mathrm{NE}$ da Bacia do Paraná e a região do Alto Paranaíba, identificada por Vandecar (1995). Foi proposto que o conduto permaneceu anômalo por um longo período de tempo sendo a fonte de calor que produziu magmatismo no Alto Paranaíba. Entretanto, estudos mais recentes indicam que a anomalia pode ser relacionada a composição do manto na região (Liu et al. 2003 e Rocha et al. 2011).

Gibson et al. 1995 e Thompson et al. 1998 observaram regionalmente a diminuição das idades de intrusão de corpos de NW para SE, com 90 Ma na província kamafugítica de Rio Verde-Iporá (PAG), 85-80 Ma na APIP e 60 Ma na província da Serra do Mar. A progressão da idade nesse modelo é também suportada por idades $\mathrm{U} / \mathrm{Pb}$ em perovskita em kamafugitos de RioVerde-Iporá e em kamafugitos do Alto Paranaíba (Sgarbi et al. 2004). Com base neste possível trend de idades, Gibson et al. (1995) e Thompson et al. (1998), propuseram modelo de reconstituição do movimento das placas associando o magmatismo da APIP à Pluma de Trindade/Martin Vaz. No entanto, a descoberta de rochas kimberlíticas na APIP (e.g. 95 Ma para o kimberlito Três Ranchos 4 por U/Pb em perovskita; Guarino et al. 2013) mais antigas que $90 \mathrm{Ma}$, identificados por Sgarbi et al. (2004) como a idade máxima dos kamafugitos da PAG, contraria esta hipótese.

Read et al. (2004) sugeriram que o magmatismo kimberlítico foi anterior (89$120 \mathrm{Ma}$ ) ao magmatismo kamafugitico (75-85 Ma) na região, a partir de informações de geocronologia disponibilizadas por empresas de prospecção que atuaram na APIP, e de geotermobarometria (pelo geotermômetro e geobarômetro de Nimis \& Taylor 2000) de macrocristais de clinopiroxênio (em fácies granada): de kimberlitos, e de kamafugitos, com registro de geotermas mais quentes para os kamafugitos (superior a $40 \mathrm{~mW} / \mathrm{m}^{2}$ ) do que nos kimberlitos (menor que $40 \mathrm{~mW} / \mathrm{m}^{2}$ ). Deste modo, estes autores defendem que o 
manto litosférico foi delaminado entre o intervalo de magmatismo kimberlítico e kamafugitico, gerando estes gradientes geotérmicos mais altos ao longo do tempo.

A fusão parcial do manto litosférico metassomatisado explicaria a ampla variação de tipos litológicos na província do Alto Paranaíba, com magmas kimberlíticos gerados a partir de peridotitos a profundidades de 150 kilometros e magmas kamafugíticos gerados de uma fonte a profundidades da ordem de $100 \mathrm{~km}$ (Guarino et al. 2013).

Felgate (2014) e Guarino et al. (2013) contestaram o modelo de aquecimento pela Pluma de Trindade/Martins Vaz pelo fato de que a distância entre os corpos kamafugiticos e kimberlíticos de mesma idade (90Ma) entre a PAG e APIP excedem $500 \mathrm{~km}$ em diâmetro, que representaria o tamanho da cabeça da pluma. De acordo com Felgate (2014) uma pluma deste tamanho provocaria o magmatismo em uma faixa com maior abrangência que a configuração atual das intrusões.

Embora as características isotópicas das rochas da APIP tenham em alguns sistemas isotópicos $(\mathrm{Sr}, \mathrm{Nd} \mathrm{e} \mathrm{Pb})$ indícios da associação com fonte em comum às rochas das ilhas oceânicas Trindade, Martin Vaz (para isótopos de Sr e Nd) e Tristão da Cunha (para isótopos de $\mathrm{Pb}$ ), dados de isótopos de Os sugerem fontes distintas destas rochas para a APIP (Carlson et al. 2007). Argumento análogo a este é utilizado por RochaJúnior et al. (2012), que compara a assinatura isotópica Re-Os da ilha de Tristão da Cunha com os derrames basálticos da Bacia do Paraná, e descarta a possibilidade do magmatismo basáltico da Bacia do Paraná estar relacionado à Pluma Tristão da Cunha.

Felgate (2014) defende que teria ocorrido de fusão parcial de um manto litosférico metassomatisado através de descompressão adiabática. Esse processo estaria ligado à uma possível distenção pós-abertura do Oceano Atlântico, gerando um mecanismo de perturbação que provocou fusão parcial em baixa porcentagem. Tal mecanismo seria capaz de explicar a localização das outras rochas alcalinas do Alto Paranaíba ao longo do alinhamento $125^{\circ}$ (zona de fraqueza reativada durante o Cretáceo).

\section{Corpos estudados}

Na Província Alcalina do Alto Paranaíba, a maioria das rochas potássicas são kamafugitos (Araujo et al. 2001), porém vários diatremas de kimberlitos têm sido reconhecidas e caracterizadas na literatura (Guarino et al. 2013 e Felgate 2014). Segundo Svisero et al. (1984) as diatremas têm tamanhos que variam entre 50 e $400 \mathrm{~m}$ e 
aparecem comumente alteradas e cobertas por solo de cor amarelo-avermelhado. Raramente aparecem rochas frescas, exceto em alguns casos como, por exemplo, nas intrusões Limeira, Indaiá, Facão e Forca. A classificação petrológica destas intrusões será discutida nos próximos itens.

Os Kimberlito Indaiá 1, Limeira 1 e Forca são intrusivos em xistos e granitos intercalados que ocorrem na região situada entre Monte Carmelo e Abadia dos Dourados, sendo o solo de alteração branco a cinza claro nos granitóides e rosa claro nas áreas de mica xistos (Figura 1 e 2). Estão localizados cerca de 60-70 km a oeste dos limites cratônicos definidos em Alkmim \& Martins-Neto (2001) e Leonardos \& Meyer (1991). O Lamproíto Facão localiza-se a leste deste limite, encaixado nos arenitos da Formação Areado, muito próximo aos afloramentos do Grupo Mata da Corda.

A intrusão Indaiá 1 tem $250 \mathrm{~m}$ de diâmetro e fica $20 \mathrm{~m}$ a SW de uma intrusão menor denominada Indaiá 2. O corpo é intrusivo em granitóides cataclasados da Suíte Monte Carmelo (Seer et al. 2010), intrusivos na Faixa de Dobramentos Brasília (Barbosa et al. 1970). O mapeamento geológico detalhado com o uso de magnetometria terrestre e gamaespectrometria indicou que o kimberlito possui formato piriforme e diâmetro principal de 220 m na direção N-S (Svisero \& Haralyi 1984).

O corpo Limeira I é um diatrema, localizado a $26 \mathrm{~km}$ a norte da cidade de Monte Carmelo (MG), que corta os granitos cataclasados da Suite Monte Carmelo, apresenta formato piriforme, com diâmetro de $200 \mathrm{~m}$ na direção NW-SE (Meyer et al. 1991). O corpo intrusivo tem solo argiloso avermelhado, o que destaca bem o contato com as rochas graníticas que apresentam um solo de alteração de cor cinza claro. Já a intrusão Limeira 2 é, segundo Meyer et al. (1991), uma rocha alcalina de granulação fina. Situa-se cerca de $100 \mathrm{~m}$ a norte, de Limeira 1, também com formato piriforme, e tem diâmetro de $90 \mathrm{~m}$ na direção N-S, apresenta-se como uma elevação de aproximadamente $5 \mathrm{~m}$, coberta por blocos de cerca de $30 \mathrm{~cm}$, semi-alterados (Svisero \& Ulbrich 1992). Segundo Meyer et al. (1991), o corpo Limeira 3, é uma brecha de composição semelhante à intrusão Limeira 2.

O corpo Forca ocorre em uma ravina encaixado em micaxistos do Grupo Araxá. A forma dos corpos é incerta devido à alta densidade da vegetação. As amostras foram coletadas pelo Prof. Darcy Svisero a cerca de 10 anos atrás; atualmente o afloramento é praticamente inexistente devido ao alto grau de intemperismo. Intrusões próximas como o kimberlito Forca têm granadas em abundância e alguns megacristais. 
Capitulo III-Contexto Geológico

Em especial na região próxima das cabeceiras dos rios Santo Inácio, Santo Antônio do Bonito, Dourados e Douradinho (Figura 2) são comuns nos corpos a presença de granada piropo em abundância - Read et al. 2004), além de megacristais de ilmenita, diopsídio superiores a $2 \mathrm{~cm}$. Além disto, diamantes de mais de $100 \mathrm{ct}$ foram relatados diversas vezes nos rios supracitados (Svisero et al. 1995), sugerindo que a presença e a frequência de megacristais de ilmenita, clinopiroxênio e granada pode ser um indício de diamantes grandes.

O corpo Facão ocorre encaixado em sedimentos do Grupo Areado, próximo aos derrames da Grupo Mata da Corda. Blocos de rocha frescos foram encontrados no interior da fazenda Facão, pouco destacados no relevo e escondidos pela vegetação. Ocorrem afloramentos em corte da estrada de terra adjacente à fazenda, porém com alto grau de alteração. 

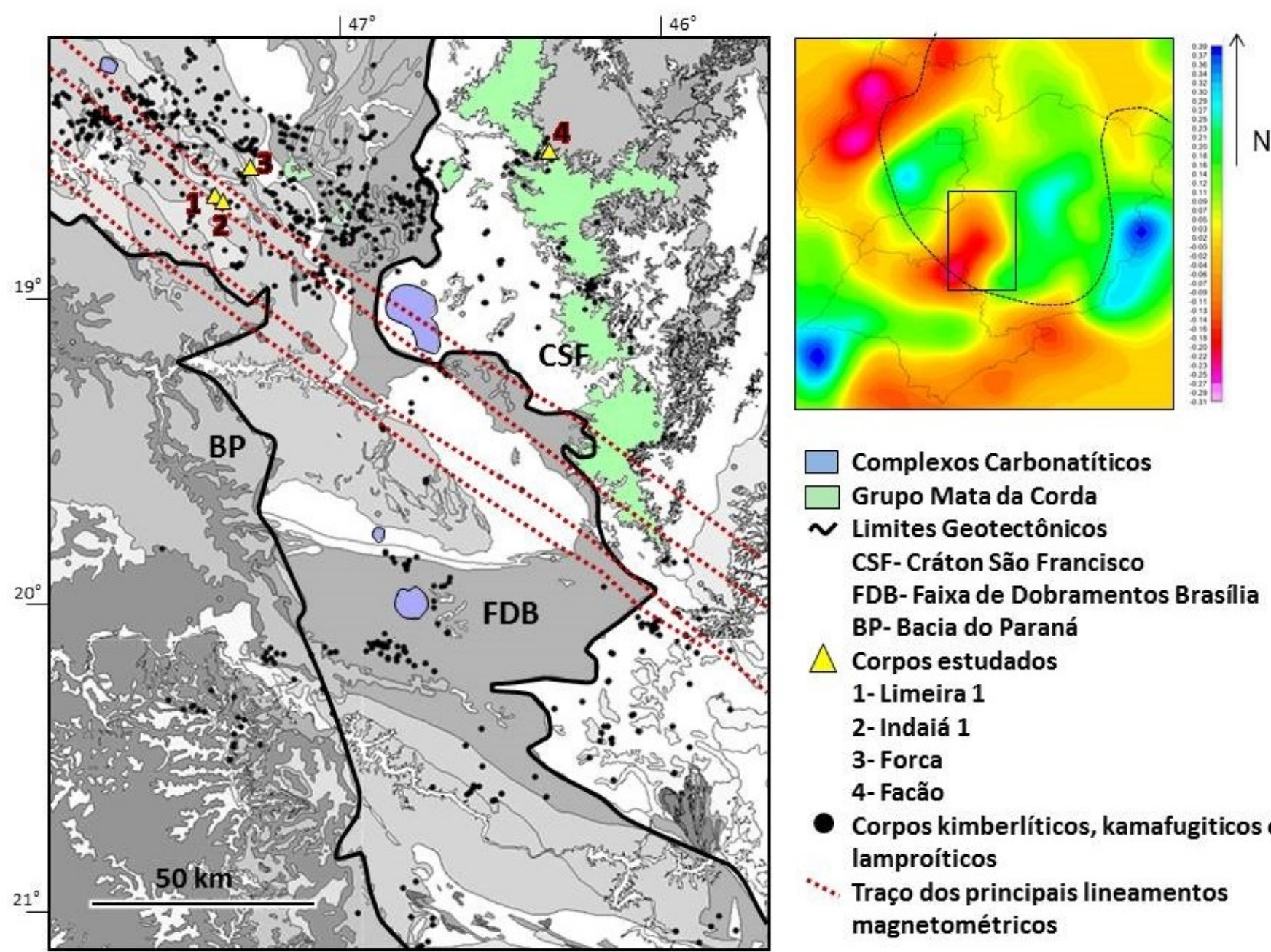

Complexos Carbonatíticos

Grupo Mata da Corda

Limites Geotectônicos

CSF- Cráton São Francisco

FDB- Faixa de Dobramentos Brasília

BP-Bacia do Paraná

$\triangle$ Corpos estudados

1-Limeira 1

2-Indaiá 1

3- Forca

4- Facão

- Corpos kimberlíticos, kamafugiticos e lamproíticos

**. Traço dos principais lineamentos magnetométricos

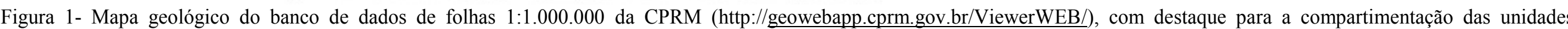

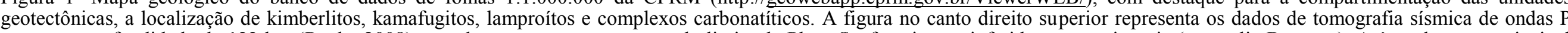

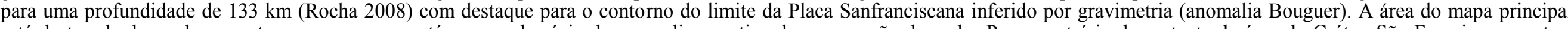

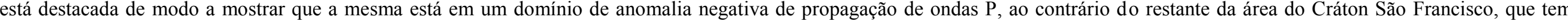
anomalias positivas. 


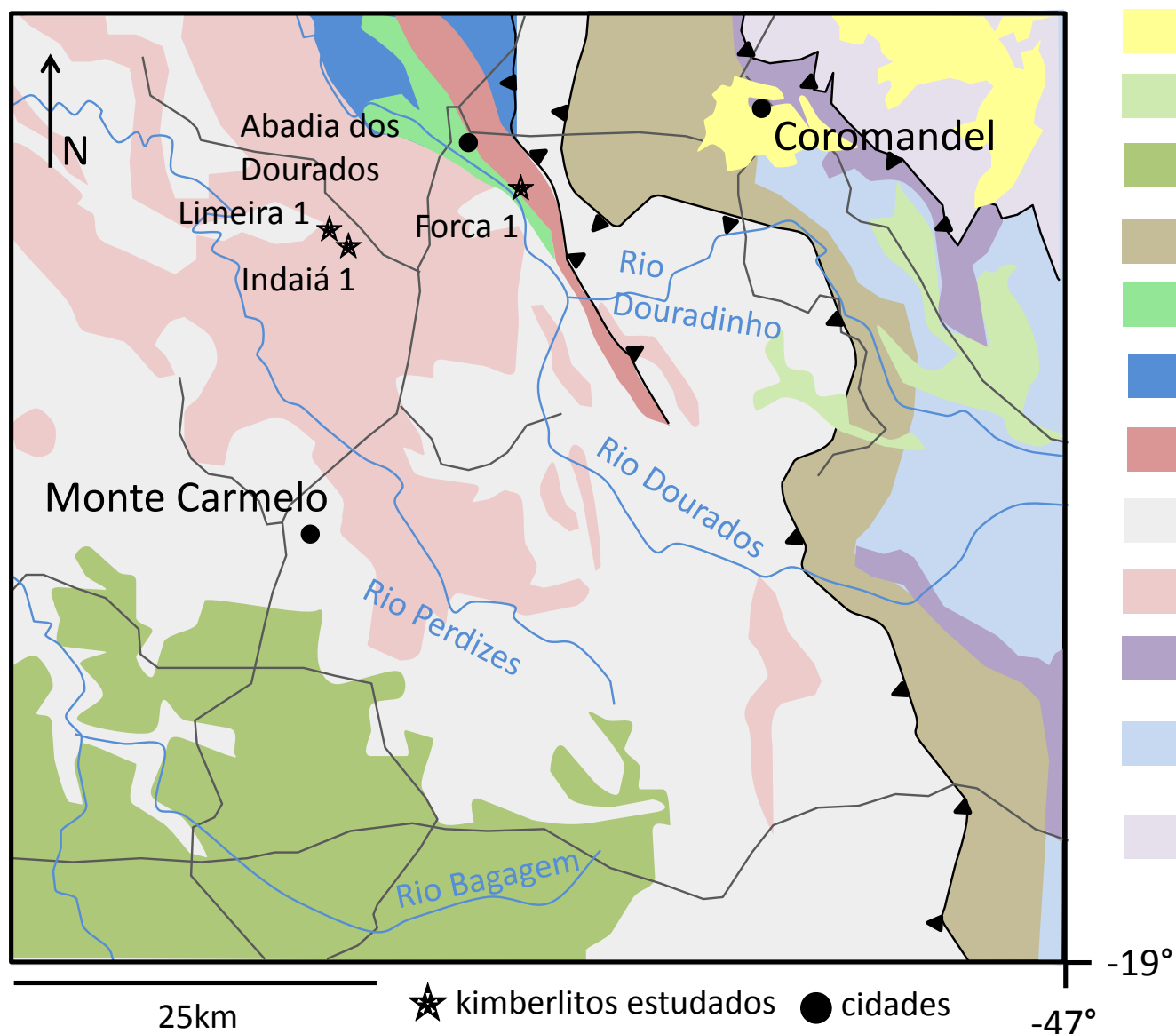

Coberturas detríticas e/ou lateríticas indiferenciadas

Grupo Mata da Corda: lavas piroclásticas e arenito cinerítico

Sedimentos da Bacia do Paraná: arenito , laminito arenoso e basalto com intercalação de arenitos e diques de diabásio

Grupo Ibiá: filito, quartzito, calcixisto, clorita e sericita xistos.

Complexo Abadia dos Dourados:

anfibolito

Complexo Abadia dos Dourados:

filito

Complexo Abadia dos Dourados:

metavulcânica ácida

Grupo Araxá: micaxisto

Suíte Monte Carmelo: granito porfirítico.

790Ma U -Pb

Grupo Canastra: quartzito, filito,

filito carbonoso, quartzito ferruginoso

Grupo Canastra: filito prateado e

quartzito

Grupo Vazante: siltito, argilito arenito e conglomerado

Zona de Cavalgamento

Principais estradas

Principais drenagens

Figura 2- Contexto geológico dos kimberlitos Indaiá 1, Limeira 1 e Forca 1 (Mapa Geológico Estadual de Minas Gerais, 2014- CPRM - disponível no site: http://geobank.sa.cprm.gov.br/pls/publico/geobank.download.downloadlayouts?p webmap=N) 


\section{Capítulo IV- Petrografia e classificação das amostras}

Segundo Araujo et al. (2001), cerca de 85\% das rochas máficas da APIP são kamafugitos, entre mafuritos (com kalsilita) e uganditos (com leucita) e apenas 15\% foram classificados como kimberlitos em estudo com cerca de 50 corpos, não sendo neste estudo identificados lamproítos. Gibson et al. (1995) por meio de análises químicas em rocha total identificou algumas intrusões lamproíticas. Byron (1999) também identificou lamproítos na APIP. Ulbrich \& Leonardos (1991) argumentaram que alguns corpos da Província Ígnea do Alto Paranaíba tem composição que projetam em campos composicionais de kamafugitos, ou no limite kamafugitos-lamproíto, no entanto a ausência de kalsilita e de melilita em algumas destas amostras, e a presença de minerais como wadeíta, K-richterita e priderita se faz um critério mais confiável de modo a classificar algumas rochas como lamproíto. Wadeíta e K-richterita foram encontrados em autólito da intrusão Facão, como mostra a Figura 3.

Segundo Meyer et al. (1991), a maioria das intrusões na região do Alto Paranaíba, incluindo carbonatitos, contém associações de minerais e assinaturas isotópicas semelhantes, mas elas diferem em características petrográficas. Felgate (2014) registra similaridades entre kamafugitos e kimberlitos da região do Alto Paranaíba e algumas diferenças entre os dois tipos. Os conteúdos de K, Rb, Cs e Ti são substancialmente maiores nos kamafugitos que nos kimberlitos, sugerindo que estes derivaram de fusão de uma fonte contendo uma maior proporção de flogopita. Gibson et al. (1995) observa que os kamafugitos têm alta concentração de $\mathrm{Al}$ e Ca comparados com os kimberlitos, indicando também uma maior contribuição de diopsídio na fonte mantélica. Já para os kimberlitos, o mais alto conteúdo de $\mathrm{Mg}$ está relacionado à composição do magma derivado de $1 \%$ de fusão parcial de uma fonte peridotitica carbonatada a cerca 5-6 GPa (Dalton e Presnall 1998).

A geoquímica de rocha total é utilizada para descriminar kimberlitos do tipo I, que são diferenciados de orangeítos, lamproítos e kamafugitos pela baixa porcentagem em peso de $\mathrm{SiO}_{2}$ (em média abaixo de 32\%), como mostra a Tabela 4. Já os lamproítos são as rochas que apresentam maior porcentagem em peso de $\mathrm{SiO}_{2}$ (em média acima de 40\%). Depois dos kimberlitos do tipo I, os orangeítos são as rochas que tem maior porcentagem em peso de $\mathrm{MgO}$ (em torno de $20 \%$ ), de modo a ser um parâmetro 
importante para se diferenciar de kamafugitos e lamproítos. Kamafugitos apresentam em média as porcentagens em peso mais altas de $\mathrm{CaO}$, embora alguns lamproítos tenham alta porcentagem em peso de $\mathrm{CaO}$ (e.g. 13,21\%; Tabela 4). A classificação de rochas segundo somente a geoquímica de rocha total se mostra insuficiente quando os valores de $\mathrm{SiO}_{2}$ situam-se entre 38 e $42 \%$, sendo fundamental a identificação dos minerais presentes e suas composições.

Composições das rochas das intrusões estudadas são apresentadas na Tabela 4. As intrusões Indaiá 1, Limeira 1 (dados de Melluso et al. 2008) e Forca 1 (Nishijima 2013) enquadram-se geoquímicamente como kimberlitos do tipo 1, com baixo $\mathrm{SiO}_{2}$ $\mathrm{Al}_{2} \mathrm{O}_{3}$ e alto $\mathrm{MgO}$ (\% em peso), apesar de Indaiá 1 e Limeira 1 apresentarem uma quantidade maior de $\mathrm{CaO}$ (\% em peso). Já as intrusões Indaiá 2 e Facão (Guarino et al. 2013) tem composições comuns a lamproítos e kamafugitos, com $\mathrm{SiO}_{2}, \mathrm{TiO}_{2}, \mathrm{Al}_{2} \mathrm{O}_{3} \mathrm{e}$ $\mathrm{K}_{2} \mathrm{O}$ em maior quantidade que nas demais intrusões. Algumas características mineralógicas permitem distingir melhor os tipos litológicos das intrusões Indaiá 2 e Facão.

Tabela 4- Composição em peso dos óxidos (\%) das rochas vulcânicas abordadas neste trabalho comparadas com composições de porcentagens em peso de óxidos representativas em kimberlitos, orangeítos, lamproitos e kamafugitos de trabalhos da bibliografia.

\begin{tabular}{|c|c|c|c|c|c|c|c|c|c|}
\hline & Indaiá 1 & Indaiá 2 & Limeira 1 & Forca & Facão & $\begin{array}{l}\text { Kimberlitos } \\
\text { sulafricanos }\end{array}$ & $\begin{array}{l}\text { Orangeítos } \\
\text { sulafricanos }\end{array}$ & $\begin{array}{c}\text { Lamproítos } \\
\text { australianos } \\
\text { e da } \\
\text { Antartida }\end{array}$ & $\begin{array}{c}\text { Kamafugitos } \\
\text { chineses }\end{array}$ \\
\hline Fonte & $\begin{array}{c}\text { este } \\
\text { trabalho }\end{array}$ & $\begin{array}{c}\text { este } \\
\text { trabalho }\end{array}$ & $\begin{array}{l}\text { Meluso et } \\
\text { al. (2008) }\end{array}$ & $\begin{array}{l}\text { Nishijima } \\
\text { (2013) }\end{array}$ & $\begin{array}{c}\text { Guarino } \\
\text { et al. } \\
(2013)\end{array}$ & $\begin{array}{l}\text { Mitchell } \\
\text { (1986) }\end{array}$ & $\begin{array}{c}\text { Mitchell \& } \\
\text { Bergman (1991) }\end{array}$ & $\begin{array}{c}\text { Jaques et al. } \\
\text { (1986), } \\
\text { Murphy et al. } \\
\text { (2002) }\end{array}$ & $\begin{array}{l}\text { Guo et al. } \\
\text { (2014) }\end{array}$ \\
\hline $\mathrm{SiO}_{2}$ & 28,04 & 38,83 & 27,9 & 31,03 & 38,4 & $30,42-32,53$ & $36,12-38,9$ & $42,84-51,16$ & $38,8-39,9$ \\
\hline $\mathrm{TiO}_{2}$ & 2,68 & 3,40 & 2,0 & 2,01 & 3,7 & $1,38-2,95$ & $1,45-1,67$ & $1,04-7,53$ & $3,27-4,26$ \\
\hline $\mathrm{Al}_{2} \mathrm{O}_{3}$ & 1,65 & 5,91 & 2,2 & 1,48 & 4,9 & $2,12-3,09$ & $3,97-4,38$ & $5,45-17,5$ & $7,71-9,64$ \\
\hline $\mathrm{Fe}_{2} \mathrm{O}_{3}$ & 11,69 & 10,93 & 11,6 & 10,42 & 12,3 & $8,88-11,36$ & $8,57-9,48$ & $7,78-12,06$ & $11,0-12,5$ \\
\hline $\mathrm{MnO}$ & 0,21 & 0,19 & 0,2 & 0,18 & 0,2 & $0,15-0,18$ & $0,15-0,22$ & $0,09-0,18$ & $0,14-0,17$ \\
\hline $\mathrm{MgO}$ & 28,56 & 15,07 & 27,8 & 29,56 & 20,4 & $25,14-31,35$ & $19,92-22,82$ & $5,29-11,24$ & $8,91-16,8$ \\
\hline $\mathrm{CaO}$ & 13,15 & 13,95 & 12,5 & 9,40 & 9,7 & $7,59-9,72$ & $7,06-8,33$ & $3,98-13,21$ & $12,8-13,3$ \\
\hline $\mathrm{Na}_{2} \mathrm{O}$ & --- & 1,21 & 0,2 & 0,26 & 0,4 & $0,05-0,08$ & $0,28-0,29$ & $0,46-2,8$ & $1,79-3,44$ \\
\hline $\mathrm{K}_{2} \mathrm{O}$ & 0,81 & 2,71 & 1,4 & 1,10 & 1,2 & $1,63-2,15$ & $4,68-5,04$ & $0,02-7,37$ & $1,05-3,31$ \\
\hline $\mathrm{P}_{2} \mathrm{O}_{5}$ & 3,00 & 1,90 & 2,4 & 1,34 & 0,5 & $0,54-1,17$ & $1,34-1,46$ & $0,26-2,02$ & $1,12-1,45$ \\
\hline P.F. & 8,89 & 3,85 & 10,4 & 11,78 & 5,4 & $12,09-12,56$ & $9,97-11,39$ & ------ & $3,11-4,87$ \\
\hline Total & 98,69 & 97,95 & 98,8 & 99,8 & 97,0 & $98,60-98,91$ & $98,24-99,56$ & 100,83 & $99,6-99,7$ \\
\hline
\end{tabular}



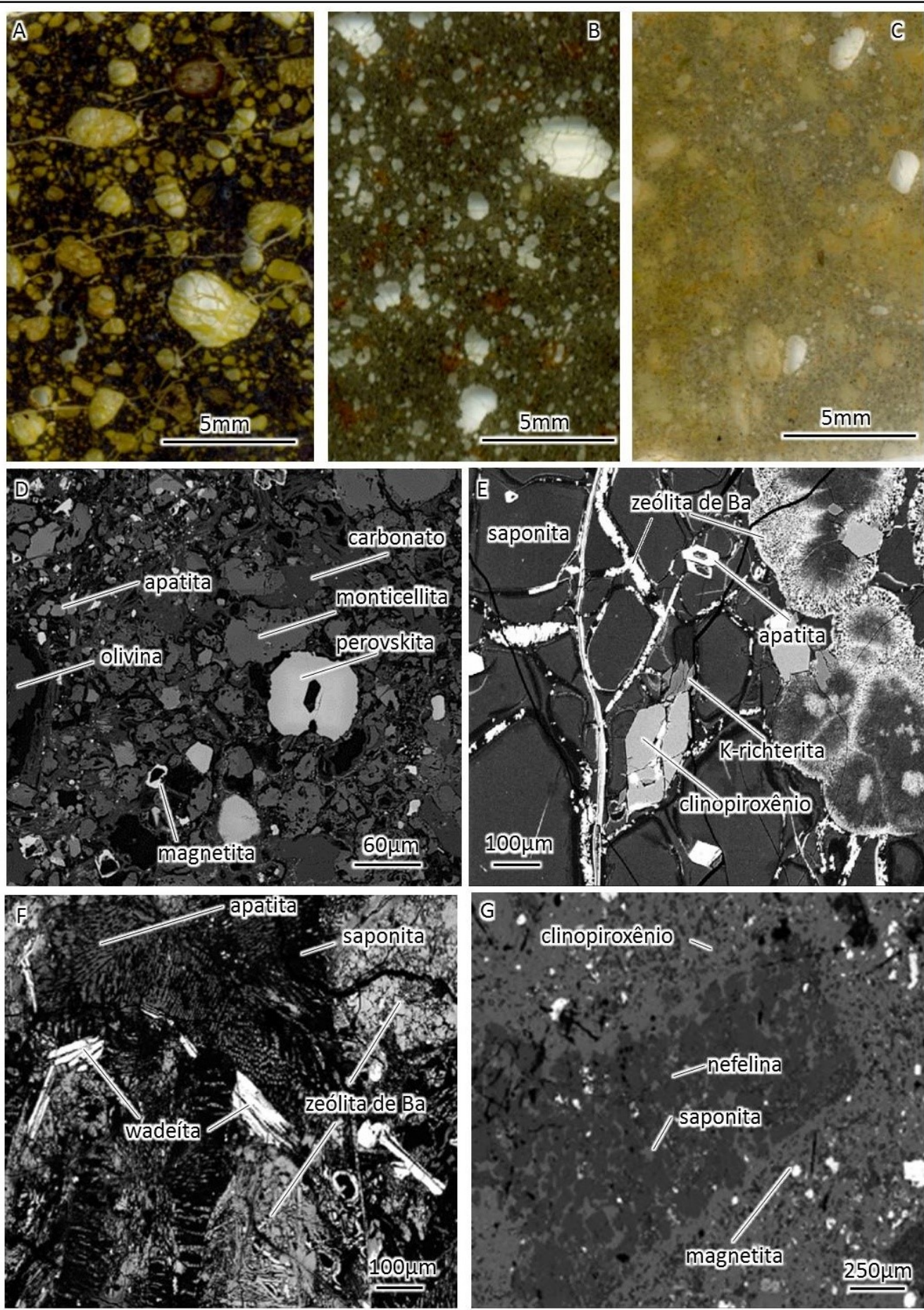

Figura 3- Fotos representativas das amostras analisadas e imagens de MEV mostrando a textura e mineralogia das rochas vulcânicas estudadas. A- Fotomicrografia do kimberlito Forca 1, mostrando venulações de carbonato, e pseudomorfos de granada arredondada; B- Fotomicrografia do corpo Facão, com destaque para os abundantes macrocristais de olivina; C- Fotomicrografia do corpo Indaiá 2, com coloração amarelada e proporção menor de olivina; imagens de MEV:D- imagem de MEV da matriz do kimberlito Indaiá 1 e seus principais minerais da matriz; E-autólito devitrificado da intrusão Facão; Ftextura de desequilíbrio em autólito da intrusão Facão; G- xenólito de nefelinito em matriz do corpo Indaiá 2. 
Análises de microssonda foram realizadas em minerais da matriz e macrocristais dos corpos estudados. A composição dos principais minerais, e sua fórmula estrutural estão no ANEXO C. Um breve resumo dos principais parâmetros de química mineral é apresentado na Figura 4 para auxiliar na classificação destas rochas no próximo item.

As intrusões Indaiá 1, Limeira 1 e Forca 1 tem características químicas dos minerais da matriz que permitem denomina-los de kimberlito segundo Tappe et al. (2005), cristais do grupo do espinélio seguindo o "trend do ulvoespinélio magnesiano", predominância de ilmenita magnesiana, olivina com mg\# superior a 0,92 e macrocritais de flogopita com baixo $\mathrm{TiO}_{2}$ e alto $\mathrm{Al}_{2} \mathrm{O}_{3}$ corroboram a classificação de kimberlitos para estas intrusões (Figura 4). Já as intrusões Facão e Indaiá 2 apresentam minerais do grupo do espinélio com trend da titanomagnetita no campo de lamproítos,orangeítos e lamprófiros, a composição da flogopita projeta em campos kamafugíticos em trend de lamproíto (Figura 4). No entanto a ilmenita somente esta presente no corpo Facão, com composição não kimberlítica (Figura 4), este mineral não ocorre em kamafugitos.

A partir destes parâmetros químicos conclui-se que as intrusões Indaiá 1, Limeira 1 e Forca 1 apresentam minerais com composição compatível com kimberlitos do tipo I, com mica com composição transicional entre kimberlitos e orangeítos (Figura 4A). Já nos corpos Facão e Indaiá 2 exibem características transicionais entre lamproítos e kamafugitos nos minerais analisados.

1. Petrografia, mineralogia e classificação das rochas magmáticas estudadas

O Kimberlito Indaiá 1 apresenta em sua composição uma matriz muito fina com perovskita, magnetita, barita, serpentina, carbonato, apatita e monticellita. Há grande quantidade de macrocristais, sendo olivina, ilmenita e flogopita os principais em ordem de abundância, conferindo textura inequigranular à rocha (Silva 2008 e Meyer \& Svisero 1991). Frequentemente com perovskita nas bordas, a ilmenita ocorre geralmente na forma de macrocristais anédricos de contornos arredondados.

Clastos de carbonato, na forma de cristais individuais ou agregados, de cor cinza claro a branco de até $5 \mathrm{~cm}$, ocorrem frequentemente apresentando halo esverdeado no contato com a rocha kimberlítica. Ocorrem também nódulos esverdeados de até $10 \mathrm{~cm}$, de formato variado (tabular anguloso, ameboide com reentrâncias, ou subcircular) com textura inequigranular, dada pela matriz fina composta por serpentina e clorita fina, 

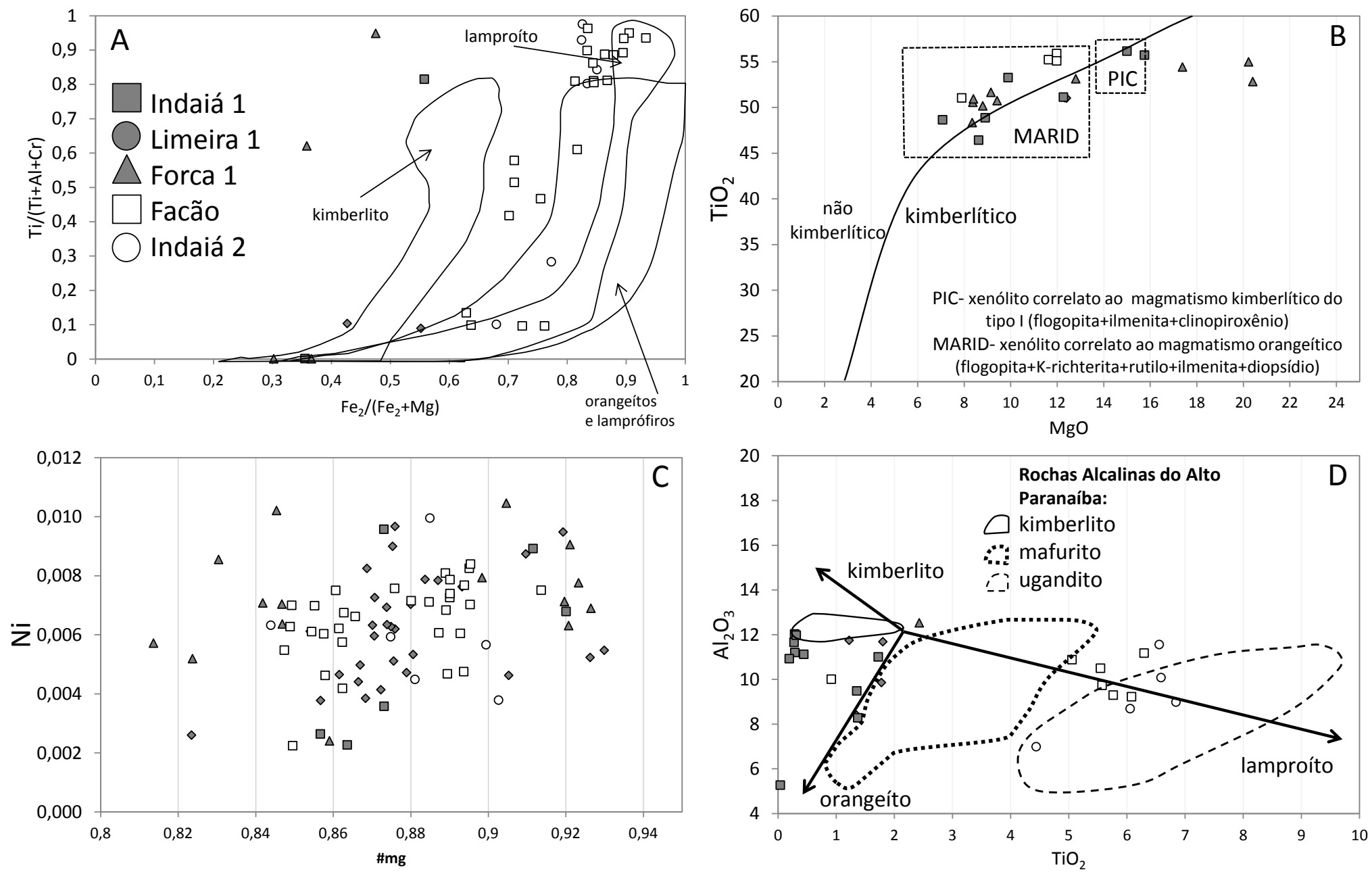

Figura 4- Composição de minerais das intrusões Indaiá 1, Limeira 1, Forca 1, Facão e Indaiá 2. A-Fe2/Fe2+Mg vs. Ti/(Ti+Al+Cr) em minerais do grupo do espinélio com os campos discriminates de Mitchel (1995); $\mathrm{B}-\mathrm{MgO}_{\text {v }}$. $\mathrm{TiO}_{2}$ em ilmenita com os campos discrimitantes de Wyatt et al. (2004) e Gregoire et al. (2002); C- mg\# vs. Ni (apfu) em olivina; $\mathrm{D}-\mathrm{TiO}_{2}$ vs. $\mathrm{Al}_{2} \mathrm{O}_{3}$ em flogopita com trends discriminates de Mitchell (1995) e campos definidos para as rochas da APIP (Araujo et al. 2001). 
macrocristais de olivina (de até $20 \mathrm{~mm}$ ) e clastos de carbonato arredondados (de até 30 $\mathrm{mm})$.

Xenólitos graníticos são comuns, e apresentam halo de alteração amarelado no contato com o kimberlito.

Xenólitos peridotíticos ocorrem em grande número, com tamanhos que variam de 0,5 a $10 \mathrm{~cm}$ de diâmetro. Em ordem decrescente de abundância ocorrem harzburgitos, lherzolitos e dunitos, podendo conter minerais produzidos por metassomatismo (i.e., flogopita, clinopiroxênio secundário, ilmenita, cromita e pargasita) ou não. Ocorrem ainda flogopititos, xenólito polimítico e de piroxenito. Megacristais de olivina são frequentes.

Análises de química mineral e de rocha total do Kimberlito Indaiá 1 foram feitas por Meyer \& Svisero (1991), Gibson et al. (1995) e Guarino et al. (2013). Estes trabalhos classificaram a rocha como um kimberlito do tipo I, o que está de acordo com as informações de química de rocha total e de química mineral obtidos no presente trabalho.

O Kimberlito Limeira 1 é uma rocha muito semelhante ao Kimberlito Indaiá 1. Também exibe textura inequigranular fina apresentando serpentina, carbonato, apatita, monticellita, perovskita, magnetita e barita, com abundantes macrocristais de olivina e ilmenita. Clastos contendo material esverdeado e pequenos fragmentos de carbonato também são frequentes, assim como xenólitos graníticos. Os xenólitos mantélicos também são peridotíticos, porém entre as amostras estudadas predominam os dunitos e harzburgitos metassomatisados (com flogopita, clinopiroxênio secundário, cromita, ilmenita e titanatos raros). Foi encontrado um xenólito de piroxenito, porém com alto grau de alteração.

Meyer \& Svisero (1991), Gibson et al. (1995), Guarino et al. (2013) e Almeida et al. (2014) classificaram a rocha como um kimberlito do tipo I, corroborando com as informações de química de rocha total e de química mineral obtidos no presente trabalho.

O Kimberlito Forca apresenta coloração cinza esverdeada e textura inequigranular dada pela matriz fina, e apresenta macrocristais de olivina e ilmenita, como nas intrusões Limeira 1 e Indaiá 1. Porém, as intensas venulações de carbonato e a presença de macrocristais de granada de até $0,5 \mathrm{~cm}$ e ortopiroxênio com borda kelifítica indicam uma diferença petrográfica importante. Foram encontrados: um xenólito crustal de rocha metabásica, xenólitos peridotíticos como espinélio lherzolito e de dunito com 
flogopita, e um megacristal de clinopiroxênio. A matriz desta rocha é composta principalmente por carbonato, apatita, perovskita e magnetita. Os macrocristais de ilmenita, de até $0,5 \mathrm{~cm}$ e formas anédricas arredondadas, mostram reação com o magma, representada por espessas bordas de perovskita. Nas intrusões Limeira 1 e Indaiá 1 bordas de perovskita também são comuns, mas a sua espessura é bem menor que no caso da intrusão Forca. Não foi observada monticellita, porém ocorre mica rica em Ba na matriz, característica de kimberlitos (Figura 3).

A Intrusão Facão apresenta foliação de fluxo magmático visível, com textura inequigranular, dada pela presença de macrocristais abundantes de olivina em meio a uma matriz composta por clinopiroxênio fino idiomórfico, Ti-flogopita alaranjada poiquilítica, perovskita, serpentina, zeólita de $\mathrm{Ba}$ (harmotoma) e material esverdeado com baixa birrefringência (Figura 3). As análises químicas representadas por dados de análise WDS são apresentados no ANEXO C. Macrocristais de cromita com borda de Ti-magnetita ocorrem com frequência; macrocristais de ilmenita são mais raros, e têm borda de perovskita.

Ocorrem alguns nódulos de formato subarredondado a arredondado (de até 1,2 cm) compostos por material fino devitrificado (saponita), apresentando pequenos cristais esparsos e idiomórficos de até $250 \mu \mathrm{m}$ de clinopiroxênio e K-richterita isolados no centro do nódulo e diversos cristais espiculares na borda. Associadas à saponita ocorrem fraturas concêntricas, com aspecto perlítico, contendo harmotoma. Ocorrem outros nódulos com aspecto similar, mas com mais harmotoma apresentando zircão, baddeleyita e wadeíta $\left(\mathrm{K}_{2} \mathrm{ZrSi}_{3} \mathrm{O}_{9}\right)$. Tais nódulos foram considerados neste trabalho como autólitos, por apresentarem matriz muito fina com microcristais de clinopiroxênio e K-richterita, além de fraturas concêntricas semelhante a rocha afanítica vulcânica máfica ultrapotássica.

O autólito da amostra Fac-1 tem forma irregular, com borda arredondada pela reação com o magma. Esta reação aparentemente gerou cristais aciculares de clinopiroxênio nas bordas do autólito, bem como alguns cristais de K-richterita. No centro do autólito, dentro da massa de saponita ocorrem poucos cristais euédricos de clinopiroxênio e K-richterita. Ocorrem também fraturas concêntricas onde aparece zeólita branca de bário (harmotoma).

A amostra Fac-4 é composta por saponita, harmotoma e apatita; apresenta forma arredondada pela reação com o magma, formando espículas de clinopiroxênio ao redor do fragmento. Ocorrem nesta amostra zircão com cerca de 0,2 mm associado a 
wadeíta (mineral característico de lamproítos; Mitchell \& Bergman 1991) e pirita intercrescida com calcopirita, com cerca de $0,5 \mathrm{~mm}$.

A identificação dos minerais dos autólitos foi auxiliada pela química mineral, apresentada no Anexo C. A amostra Fac-6 apresenta grande quantidade de clinopiroxênio anédrico corroído em meio à matriz composta por harmotoma, apatita, saponita (com clinopiroxênio e K-richterita finos e idiomórficos); o clinopiroxênio é manteado por Ti-flogopita poiquilítica com inclusões de apatita e perovskita.

Guarino et al. (2013) classificam o corpo Facão como kamafugito por ter composição química de rocha total compatível com este tipo litológico. No entanto a presença de minerais como ilmenita, encontrada em macrocristais e em inclusôes em olivina; além de wadeíta e K-richterita, identificada em autólitos sugere que estas rochas sejam transicionais entre lamproítos e kamafugitos. Para efeitos de classificação, o critério mineralógico se faz mais confiável já que o critério químico segundo os critérios de Tappe et al. (2005), portanto é classificado neste trabalho como lamproíto.

Ocorrem xenólitos de peridotitos duníticos e wehrlíticos, com textura cumulática, e clinopiroxenito com inflitração de minerais da matriz do lamproíto. A olivina apresenta composições muito próximas entre macrocristais e xenólitos, onde mg\#=0,85-0,90, indicando juntamente com as texturas cumuláticas em algumas amostras, que as olivinas provém do próprio magma. Além disso, o valor de mg\# na olivina não chega aos valores mais altos (mg\#=0,90-095), registrados em alguns xenólitos dos kimberlitos estudados, como será apresentado no Capítulo X- Química Mineral.

A Intrusão Indaiá 2 apresenta rocha de coloração cinza escuro, com textura fanerítica muito fina inequigranular. Sua matriz é composta por clinopiroxênio, Timagnetita, flogopita rica em Ti, zeólita e sulfetos, com macrocristais de olivina. Cristais milimétricos de cromita ocorrem em meio à matriz, apresentando zoneamento para Timagnetita.

Ocorrem xenólitos angulosos de até $1,5 \mathrm{~mm}$ de nefelinito com nefelina euédrica abundante com clinopiroxênio e saponita intersticiais (amostra In2-1). A nefelina ocorre apenas no xenólito, e não na matriz do magma hospedeiro. São descritos xenólitos com estas características em textura schilieren por Meyer et al. (1991).

Xenólitos "graníticos" transportados pelo magma ocorrem muito alterados, sendo muito difícil a identificação da sua composição original. Somente são observados cristais alterados de feldspato potássico. O restante da mineralogia do xenólito é 
composto por minerais de alteração e minerais do magma hospedeiro infiltrados, como clinopiroxênio, K-richterita, flogopita e magnetita. Ocorre material de alteração intersticial semelhante ao descrito na intrusão Facão (saponita), com fraturas concêntricas preenchidas por zeólita, apatita, barita e magnetita. A borda do xenólito é rica em Ti-flogopita poiquilítica, com inclusões de clinopiroxênio e Ti-magnetita, provavelmente resultante da mobilização de K a partir do K-feldspato do granito para a porção ao seu redor.

A menor quantidade de olivina em relação às demais intrusões estudadas, a química mineral compatível com kamafugitos, e a ausência de minerais tais como wadeíta, K-richterita e ilmenita faz com que esta rocha seja descartada da classificação de lamproítos. Portanto este trabalho vai de acordo com a classificação de Gibson et al. (1995) e Meyer et al. (1991) e classifica esta rocha como kamafugito.

1.1. Nódulos esverdeados com carbonato, agregados e megacristais de carbonato em kimberlitos

Ocorrem nódulos de coloração verde a bege com formas variadas, de angulosas a arredondadas, com diversos cristais de carbonato de tamanhos e formatos variados (0,1 a $2 \mathrm{~mm}$, anguloso, amebóide ou esférico), com macrocristais de olivina parcialmente ou totalmente substituída por serpentina em matriz composta por carbonato, clinopiroxênio, clorita, apatita, monticellita, perovskita, magnetita e sulfetos. O óxido mais abundante é a perovskita, que ocorre dispersa na matriz, ao redor de pseudomorfos de olivina, ou em cristais de até $1 \mathrm{~mm}$ com textura poiquilítica, intercrescida com flogopita.

Grande parte dos clastos de carbonato, brancos no kimberlito Indaiá 1 e róseos no kimberlito Limeira 1, apresentam borda de reação com o kimberlito. Estas bordas possuem textura, mineralogia e cor muito semelhante aos nódulos de coloração verde descritos acima. Em uma primeira aproximação, estes nódulos foram interpretados como autólitos (Nannini 2011), porém as características texturais e grau de alteração das amostras sugere que estes materiais foram resultado de intensa reação com o magma kimberlítico. 


\subsection{Piroxenitos}

Foram reconhecidas 3 amostras de piroxenito, uma no corpo Facão e 2 no corpo Limeira 1.

A amostra Fac-5, com cerca de $2 \mathrm{~cm}$ de diâmetro, apresenta cristais de clinopiroxênio de 0,5 a $2 \mathrm{~mm}$, com forma subidiomórfica e alguns cristais de ilmenita isolados entre eles. Em meio aos cristais de clinopiroxênio ocorrem bolsões de flogopita, associada a clorita com agregados de perovskita em forma de gota. Ainda ocorre harmotoma intersticial entre os cristais de clinopiroxênio. A textura indica que a formação da flogopita e da perovskita é devida a reação com o magma, pois as características ópticas da flogopita (forte pleocroísmo, que varia de laranja claro a avermelhado) são muito semelhantes às observadas na matriz do lamproíto Facão.

Os piroxenitos do corpo Limeira 1 são arredondados, apresentando reação com o magma nas bordas e entre os cristais subidiomórficos de clinopiroxênio (augita), com a formação de carbonato, monticellita e magnetita. Os clinopiroxênios são melhor identificados na amostra Lm1-14b, que se apresenta menos alterada. Na amostra Lm140 o grau de alteração deixa a rocha com coloração mais amarronzada; nas bordas ocorrem apatita e barita como produtos de reação com o magma.

\subsection{Dunitos cumuláticos}

Dunitos cumuláticos ocorrem no lamproíto Facão, com forma circular ou tabular. As olivinas nestas amostras são idiomórficas, com tamanhos de 0,3 a 2,5 mm. A amostra Fac-2 contém olivinas maiores (até $5 \mathrm{~mm}$ ) subidiomórficas com kink-bands em contato com cristais de olivina idiomórfica. Na amostra Fac-8, os cristais de olivina têm até $1 \mathrm{~mm}$, e contato marcado pela presença de clorita verde escuro. Há maior quantidade de material secundário intersticial entre os cristais de olivina euédricos desta amostra. $\mathrm{O}$ mesmo ocorre para a amostra Fac-7, porém com clinopiroxênio e clorita intersticial em meio aos cristais de olivina, que ocorre com tamanhos mais diversificados (0,1 a $2 \mathrm{~mm})$. Nos cristais de olivina ocorrem inclusões de ilmenita idiomórfica subarredondada (50$100 \mu \mathrm{m})$, por vezes com lamelas de cromita. 


\subsection{Macrocristais e Megacristais}

No presente trabalho foram observados diversos macrocristais e megacristais de olivina, flogopita, ilmenita e piroxênios. Os megacristais variam de 1 a $5 \mathrm{~cm}$, e apresentam formas variadas, desde idiomórficas a xenomórficas. São representados por: clinopiroxênio na amostra Fo-3, olivina nas amostras In1-18, In1-20, Lm1-41, e um cristal de contornos arredondados de flogopita com inclusões de ilmenita na amostra In1-36.

\subsection{Granitóides e outras rochas crustais}

Rochas crustais ocorrem nas intrusões Limeira 1 (amostra Lm1-27), Indaiá 2 (In2/1), Indaiá 1 (In1-20d), Facão e Forca. Apresentam-se extremamente alterados, com borda de reação intensa e gradual com cerca de $0,5 \mathrm{~cm}$ em todas as amostras. Os minerais constituintes ocorrem com aspecto fosco. Os xenólitos graníticos ocorrem extremamente alterados com poucos cristais apresentando a mineralogia original, representados por biotita, feldspato potássico, plagioclásio, quartzo e zircão que somam menos de $20 \%$ do volume nos nódulos graníticos estudados. As substituições minerais e os materiais de alteração são amplamente controlados pela composição dos magmas hospedeiros, sendo carbonato, clorita, serpentina, clinopiroxênio e apatita os minerais predominantes nos xenólitos "graníticos" carregados por kimberlito (Indaiá 1).

$\mathrm{Na}$ intrusão Forca, um xenólito esférico marrom avermelhado, extremamente alterado (amostra Fo-4) corresponde a um granito, tendo como minerais residuais feldspato potássico, plagioclásio, anfibólio, biotita, ilmenita e titanita, além de clorita e material de alteração avermelhado.

\section{Os xenólitos mantélicos}

A intrusões Indaiá 1, Limeira 1 e Forca têm xenólitos mantélicos com composição, mineralogia, textura e química mineral variadas. A proporção de olivina, ortopiroxênio e clinopiroxênio nos xenólitos estudados está representada na Figura 5, onde é observado que as amostras têm composição predominantemente harzburgítica e 
dunítica. As amostras dos xenólitos do kimberlito Forca apresentam maior teor de clinopiroxênio.

A variedade textural e mineralógica dos xenólitos estudados, ilustrada nas Figuras 5 e 6, apresenta características comuns que permitem agrupá-los em três grupos notadamente distintos:

a) Peridotitos portadores de espinélio- lherzolitos e harzburgitos com textura protogranular, harzburgitos e dunitos com textura transicional a granoblástica com espinélio escuro podendo conter anfibólio idiomórfico a subidiomórfico.

b) Peridotitos com flogopita (ou clinopiroxênio secundário)- dunitos e harzburgitos com textura protogranular com quantidades variadas de flogopita e clinopiroxênio na forma de bolsões intersticiais comumente associados a cromita, ilmenita e/ou titanatos, wehrlito polimítico com ilmenita e zircão, harzburgito protogranular com bolsão de clinopiroxênio. Ocorrem também flogopititos, que provavelmente provêm de porções maiores de natureza similar aos bolsões supracitados.

c) Peridotitos sem espinélio- dunitos com textura protogranular e harzburgitos e dunitos com textura mosaico porfiroclática.

Em relação ao número total de xenólitos mantélicos por intrusão, a proporção de xenólitos de peridotitos com espinélio é de 51\% para a intrusão Indaiá 1, 36\% para Limeira 1, e 60\% para Forca. Já para os xenólitos com flogopita ou clinopiroxênio secundário, as proporções são de 37\% para Indaiá 1, 43\% para Limeira 1 e $40 \%$ para Forca. Para dunitos e harzburgitos sem espinélio e sem minerais de origem metassomática esta proporção é de $10 \%$ para o Indaiá 1, 14\% para o Limeira 1 e nenhuma amostra para o kimberlito Forca.

\subsection{Lherzolitos e harzburgitos com espinélio vermelho}

Representados pelas amostras Fo-2, Lm1-17, In1-4, In1-9 e In1-14a, os lherzolitos e harzburgitos com espinélio avermelhado ocorrem na forma de xenólitos arredondados ou de forma tabular, com dimensões variando de 0,5 a $9 \mathrm{~cm}$.

A maioria das amostras apresenta textura protogranular dada por cristais anédricos maiores de olivina e ortopiroxênio, que variam de 1 a $4 \mathrm{~mm}$ (chegando a 10 
cm na amostra In1-9), exceto pela amostra Fo-2, que apresenta cristais menores (até 1 $\mathrm{mm})$.

Apresentam espinélio anédrico, por vezes com textura vermicular, associado a cristais de clinopiroxênio ou ortopiroxênio. Por vezes ocorrem inclusões de pequenas placas de espinélio dentro do ortopiroxênio.

Algumas diferenças texturais são particulares de cada amostra. A amostra Fo-2 apresenta a granulação mais fina (textura granoblástica) e seu espinélio é o único que registrou heterogeneidade química, sendo mais rico em Fe nas bordas, fraturas e reentrâncias (ANEXO B). Este espinélio está em contato com kimberlito e tem borda composta por magnetita. A textura granoblástica indica passagem para ambiente com maior recristalização (Mercier \& Nicolas 1975). As demais amostras apresentam textura tipicamente mais grossa (transicional, entre porfiroclástica e protogranular).

O espinélio da amostra Lm1-17 (Figura 6-A) é associado com ortopiroxênio e clinopiroxênio, de modo a formar uma estrutura esferoidal em meio aos cristais de olivina. 


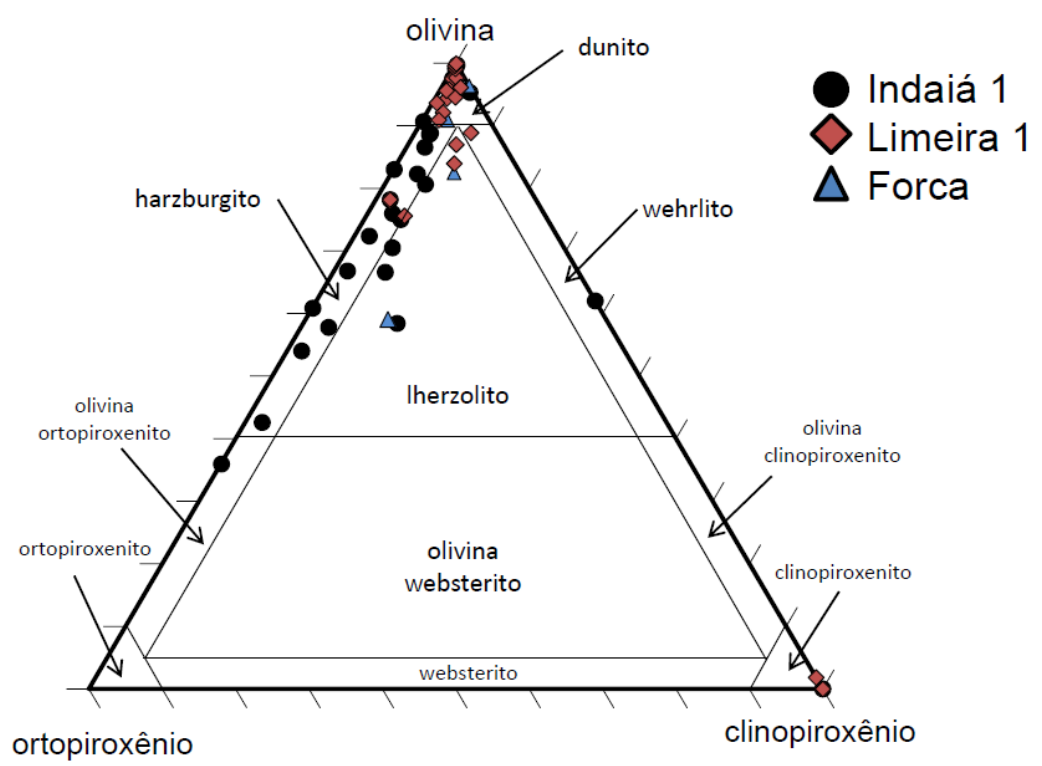

Figura 5 - Classificação mineralógica dos xenólitos de peridotito dos kimberlitos Indaiá 1, Limeira 1 e Forca baseada no diagrama de Streckeisen (1976).
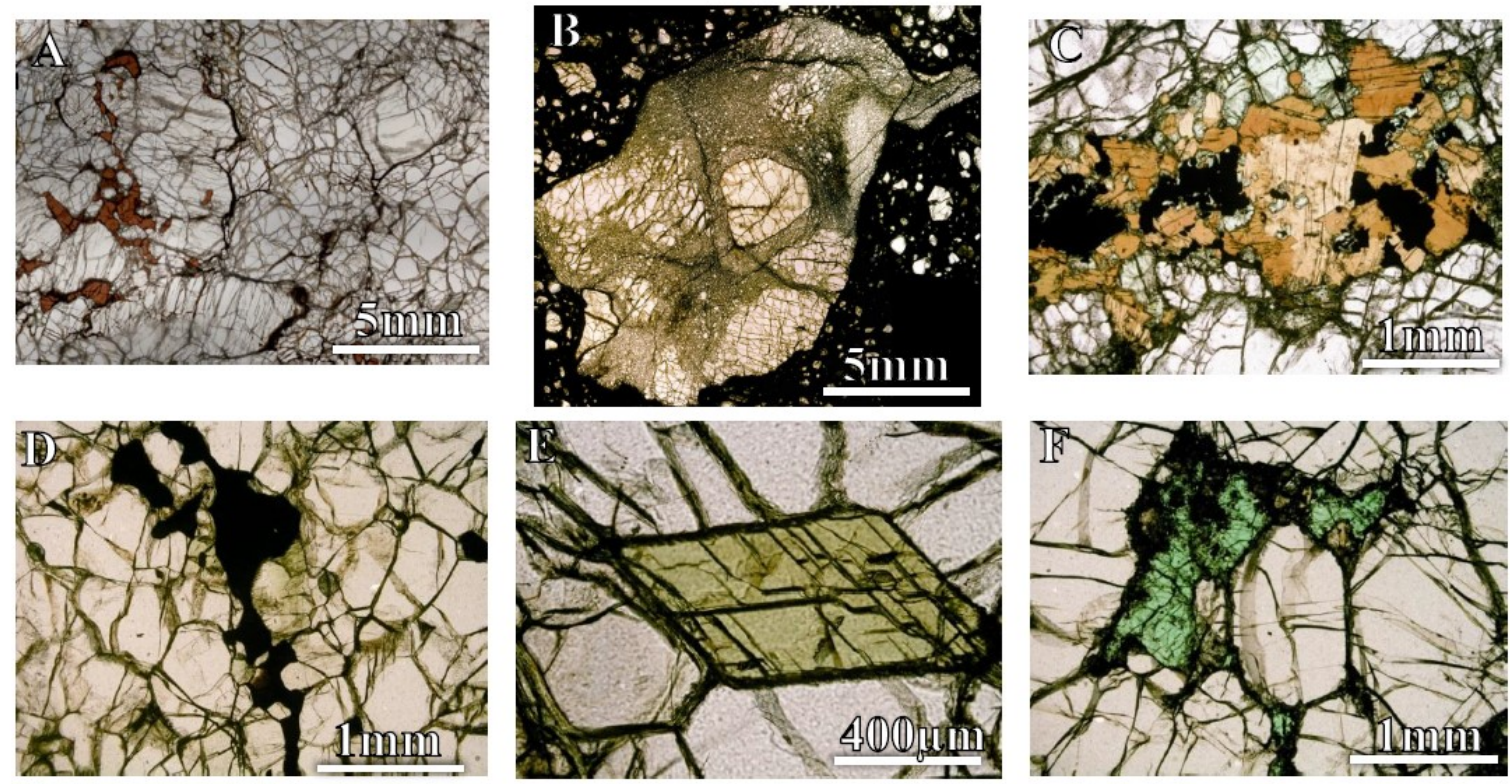

Figura 6- Imagens de micróscópio óptico dos principais tipos de xenólitos mantélicos das intrusões Limeira I e Indaiá 1. A- lherzolito com espinélio vermelho intercresciido com ortopiroxênio e clinopiroxênio; B-harzburgito com textura mosaico porfiroclástica em meio a matriz kimberlítica; Cbolsão composto por flogopita, cromita e clinopiroxênio em harzburgito protogranular; D- Cr-espinélio escuro em textura holy-leaf, com cristais menores de clinopiroxênio associados em harzburgito com textura porfiroclástica; E- cristal euédrico de pargasita em contato com cristais de olivina em dunito granoblástico com Cr-espinélio; F- detalhe de bolsão em harzburgito protogranular contendo diopsídio com coloração verde intensa e pequenos cristais de flogopita associados. 
2.2. Harzburgitos e dunitos com espinélio castanho-escuro

Os kimberlitos Indaiá 1 e Limeira 1 contêm harzburgitos e dunitos com $\mathrm{Cr}$ espinélio (de coloração marrom-escuro) que apresentam textura predominantemente granoblástica, com Cr-espinélio idiomórfico ou formato de holy-leaf, representados pelas amostras Lm1-20, Lm1-30 e In1-3 (Figura 6-D).

Anfibólio de composição pargasítica pode ocorrer neste tipo de xenólito, com formato idiomórfico a subidiomórfico com cerca de $0,5 \mathrm{~cm}$. Cromita harzburgito com pargasita e cromita dunito com pargasita ocorrem apenas na intrusão Indaiá 1, também contendo Cr-espinélio em textura holy-leaf ou idiomórfica. As amostras In1-20 e In124a (Figura 6-E) são dunitos com cromita e pargasita e as amostras In1-34 e In1-50 são harzburgitos com cromita, clinopiroxênio e pargasita.

\subsection{Dunitos com textura protogranular}

Xenólitos de dunitos com textura protogranular ocorrem na intrusão Limeira 1. São compostos por cristais de olivina de 1 a $3 \mathrm{~mm}$ com extinção ondulosa, e podem conter perovskita, monticellita e sulfetos (pirita e pentlandita) junto às fraturas e interstícios, juntamente com serpentina. Ocorrem nas amostras Lm1-14a e Lm1-29, sendo que na amostra Lm1-29 ocorre maior faturamento e a coloração do xenólito tem tom amarelo, mais intenso que a amostra Lm1-14a, provavelmente devido a maior interação com fluidos metassomáticos. As características e diferenças destas amostras voltarão a serem discutidas no Capítulo V. A amostra Lm1-14 apresenta pequenos cristais de cromita entre os cristais de olivina (vide Capítulo V), de modo que a ausência de clinopiroxênio e a baixa quantidade de ortopiroxênio indica um importante processo de fusão parcial nesta amostra. É dada atenção especial a presença da cromita nesta amostra, que não contém minerais secundários como clinopiroxênio e flogopita, pois isto indica que este mineral pode ser formado por fusão parcial.

\subsection{Dunitos e harzburgito com textura porfiroclástica com mosaico}

Xenólitos de dunitos e harzburgitos com textura porfiroclástica em mosaico foram identificados nas intrusões Indaiá 1 e Limeira 1. Estes xenólitos apresentam contornos que podem ser tabular subarredondado (Lm1-32), tabular anguloso (In1-25a), ou irregular com cúspides (In1-33/Figura 6-B). As amostras apresentam até 17\% de 
ortopiroxênio (>1 mm), olivina em cristais maiores $(6 \mathrm{~mm})$ com forma anedral, e outra geração de olivina muito pequena $(\sim 100 \mu \mathrm{m})$, com formato poligonal em algumas porções da rocha. A amostra In1-25a deve representar um estágio inicial de recristalização e as amostras Lm1-32 e In1-33, com maior quantidade de cristais em mosaico, seriam estágios mais avançados da deformação.

Um xenólito de harzburgito de granulação grossa (até $5 \mathrm{~mm}$ ), rico em ortopiroxênio (39\%) apresenta pequenos cristais de olivina recristalizada $(100 \mu \mathrm{m})$ nas bordas dos cristais anédricos maiores (In1-1). Entre os cristais e associados às porções mais finas ocorre flogopita intersticial, sugerindo um processo inicial de metassomatismo, com geração de pequeno volume de mica resultante da maior percolação de fluidos ou magmas em porções de cristais de olivina em mosaico.

\subsection{Harzburgito com bolsões de flogopita}

Essas rochas são frequentes nos kimberlitos Limeira 1, Indaiá 1 e Forca. Podem apresentam textura protogranular dada pelos cristais abundantes anédricos de olivina e ortopiroxênio (1 a $6 \mathrm{~mm})$ que por vezes apresentam kink- bands ou extinção ondulante (Mercier \& Nicolas 1975), Algumas amostras, no entanto, apresentam textura transicional de protogranular para porfiroclástica, como Lm1-1, onde ocorrem cristais de olivina em mosaico com cerca de $120 \mu \mathrm{m}$ nas bordas dos cristais anédricos de olivina e ortopiroxênio com tamanho variando de 1 a $2 \mathrm{~mm}$. Na amostra Lm1-28 também há cristais de olivina em mosaico $(100 \mu \mathrm{m})$, mas a maior parte é anédrica com 1 a $3 \mathrm{~mm}$, podendo chegar a $10 \mathrm{~mm}$.

Ocorrem ainda bolsões contendo flogopita, minerais opacos (cromita, ilmenita ou titanatos raros) e clinopiroxênio subordinado. As amostras Lm1-15, Lm1-26, Lm128, In1-2 (Figura 6-C), In1-20b e Fo-5 têm cromita no centro destes bolsões, podendo ser anedral, esqueletal ou granular subarredondada, com 0,5 a $2 \mathrm{~mm}$ (e que na amostra Fo-5 chegam a $5 \mathrm{~mm}$ ). Na amostra In1-2 ocorre ilmenita intercrescida com cromita, podendo ter bordas de magnetita. Ocorrem ainda titanatos raros (mathiasita e priderita) em alguns desses bolsões. Na amostra Lm1-1 titanato da série loverengita-mathiasita aparece envolvendo cristal de cromita. Já cristais de priderita ocorrem também em bolsões flogopíticos ou em macrocristais do kimberlito, apresentando núcleo de rutilo, como descrito em xenólito da mesma intrusão por Almeida et al. (2014). 
2.6. Harzburgito com bolsões de diopsídio

Os peridotitos com bolsões de clinopiroxênio secundário são representados pelas amostras In1-12 (Figura 6-F), Lm1-22 e Lm1-36. Estas amostras apresentam desequilíbrio textural entre os minerais peridotíticos e textura protogranular (2 a $7 \mathrm{~mm})$, com extinção kink-bands. Os cristais de olivina (1 a $10 \mathrm{~mm}$ ) e ortopiroxênio (1 a $3 \mathrm{~mm}$ ) são anedrais. Alguns cristais de ortopiroxênio são manteados por clinopiroxênio. Os cristais de clinopiroxênio secundários têm coloração verde-água intensa e disposição intersticial; ocorre cromita dentro dos bolsões de clinopiroxênio.

\subsection{Flogopita ilmenita wehrlito}

A amostra In1-6 é um flogopita-ilmenita wehrlito com diopsídio de coloração amarelada em seção delgada. Olivina e diopsídio têm tamanhos variados (olivina com 0,3 a $2 \mathrm{~mm}$; clinopiroxênio com 1 a $4 \mathrm{~mm}$ ). Ocorre textura de intercrescimento entre clinopiroxênio e ilmenita (1 a $3 \mathrm{~mm}$ ), bem como entre olivina e ilmenita. Veios posteriores, com $2 \mathrm{~mm}$ de largura, com flogopita e ilmenita, também são observados. Junto a um cristal de ilmenita foi encontrado zircão de cerca de $1 \mathrm{~mm}$, euédrico, parcialmente manteado por pequenos cristais de baddeleyita. Nesta amostra ainda há um bolsão com agregados de carbonato apresentando cristais euédricos de estroncianita identificados por EDS (38\% de Sr, 10\% de Ca e 1,3\% de Ba em proporção atômica).

\subsection{Flogopita ortopiroxenito e flogopitito}

Estas rochas são pouco frequentes e de difícil reconhecimento nas amostras de mão, pois os minerais são escuros e finos, e a olho nú não são distinguiveis da matriz do kimberlito. Foram apenas identificadas no Kimberlito Indaiá 1 (In1-24b e In1-31). A característica em comum das amostras é a grande quantidade de flogopita e ilmenita (Nannini 2011). As amostras In1-24b e In1-31 correspondem respectivamente aos flogopitito e flogopita ortopiroxenito, e têm de forma esferoidal e tabular arredondadas, compostos por flogopita, ilmenita e ortopiroxênio. Nestas rochas pode ocorrer magnetita, perovskita e/ou schorlomita nas bordas dos cristais de ilmenita (Nannini 2011). 


\section{Capítulo V- Quimica Mineral de Elementos Maiores}

Este capítulo apresenta as principais características químicas dos minerais dos xenólitos estudados, com análises representativas das amostras de peridotitos com espinélio, peridotitos sem espinélio e xenólitos com minerais secundários, além de discutir algumas implicações nas variações composicionais dentro das amostras e entre as amostras. As tabelas de análises completas de todos os xenólitos se encontram no ANEXO C desta tese, com os dados das amostras analisadas em Nannini (2011) marcadas em negrito. Os símbolos mg\#, fe\# e cr\# correspondem respectivamente às razões de proporções por fórmula unitária $\mathrm{Mg} / \mathrm{Mg}+\mathrm{Fe}_{\text {total }}, \mathrm{Fe}^{2} / \mathrm{Fe}^{2}+\mathrm{Mg}$ e $\mathrm{Cr} / \mathrm{Cr}+\mathrm{Al}$.

1. Minerais do grupo do espinélio

Minerais do grupo do espinélio são presentes em quase todas as amostras estudadas apresentando uma grande variação composicional (Tabela 5) correspondendo a espinélio, Cr-espinélio, cromita e magnetita (da solução sólida magnetitaulvoespinélio). As proporções catiônicas de $\mathrm{Fe}^{3+}$ foram calculadas segundo o procedimento de Carmichael (1967).

O espinélio vermelho dos lherzolitos e harzburgitos protogranulares tem altas proporções de $\mathrm{Al}$ (1,73-1,76 apfu) e Mg (0,769-0,778 apfu) (Tabela 5; Figura 7). O espinélio castanho-escuro de harzburgitos e dunitos com texturas granoblásticas tem $\mathrm{Cr}$ (0,460-0,755 apfu) e $\mathrm{Fe}^{2+}(0,299-0,346$ apfu) maiores que em espinélios vermelhos $\left(\mathrm{Cr}=0,172-0,0,212\right.$ apfu; $\left.\quad \mathrm{Fe}^{2+}=0,213-0,223\right)$ e correspondem a Cr-espinélios $(\mathrm{Cr} /(\mathrm{Cr}+\mathrm{Al})>0,25$; Deer 1992). Os espinélios das amostras com anfibólio têm a mesma composição dos presentes nos demais harzburgitos e dunitos com textura granoblástica e também podem ser denominados de Cr-espinélio. Todos os peridotitos com espinélio e Cr-espinélio têm baixos valores de $\mathrm{Fe}^{3+}(0-0,131$ apfu) e Ti (0-0,005 apfu) nos cristais de espinélio. Uma análise da borda de Cr-espinélio da amostra Lm1-20, no entanto, tem altos $\mathrm{Fe}^{2+}, \mathrm{Fe}^{3+}$ e Ti $(0,404-0,557 ; 1,269-1,382 ; 0,088-0,248$ apfu) apresentando $\mathrm{Fe}^{3+}+\mathrm{Fe}^{2+}>1$ no sitio $\mathrm{A}$ e $\mathrm{Fe}^{3+}>\mathrm{Fe}^{2+}$ sendo classificada como magnetita (Deer et al. 1992), e deve ser produto de reação com o magma kimberlítico.

Xenólitos portadores de flogopita podem conter minerais nas quais a proporção $\mathrm{Cr} /(\mathrm{Cr}+\mathrm{Al})$ ultrapassa 0,5 podendo ser chamados de cromita (alto $\mathrm{Cr} \#$ and $\mathrm{Fe}^{2+}$; Tabela 
5; Deer et al. 1992), com quantidades moderadas de $\mathrm{Ti}$ e $\mathrm{Fe}^{3+}(0,017-0,178 ; 0,111-$ 0,366). A amostra Lm1-15 destaca-se por apresentar o mais alto valor de $\operatorname{Cr}$ (1,368apfu) de todo o conjunto, importante característica para a geração de titanatos ricos em $\mathrm{Cr}$ em suas bordas. Cristais de magnetita também estão presentes em xenólitos com alta proporção modal de flogopita ou clinopiroxênio secundário. Este último está claramente relacionado a zonas de reação com o magma hospedeiro, ocorrendo por vezes em associação com perovskita. Além de $\mathrm{Fe}^{3+}+\mathrm{Fe}^{2+}>1$ no sitio $\mathrm{A}$ e $\mathrm{Fe}^{3+}>\mathrm{Fe}^{2+}$ (característico de magnetita), os cristais de magnetita neste contexto textural têm altos teores de Ti (0,340-0,479 apfu) e Mg (0,509-0,512 apfu) em um trend de solução sólida com Mgulvoespinélio. Este trend é uma das feições mais características em espinélios para distinguir magmas kimberlíticos de magmas orangeíticos e lamproíticos (Mitchell et al. 1986), o que reforça a interação destas amostras com magma kimberlítico.

Magnetita e cromita também podem ser encontradas em dunitos protogranulares (Figura 7-E e F). A presença de cromita em xenólitos sem clinopiroxênio e sem minerais metassomáticos sugere que a rocha (Lm1-14) sofreu intensa fusão parcial, maior que nos peridotitos com Cr-espinélio descritos, e que não foi afetado por metassomatismo posterior. A presença de magnetita em fraturas nesta amostra sugere percolação tardia de material kimberlítico. 


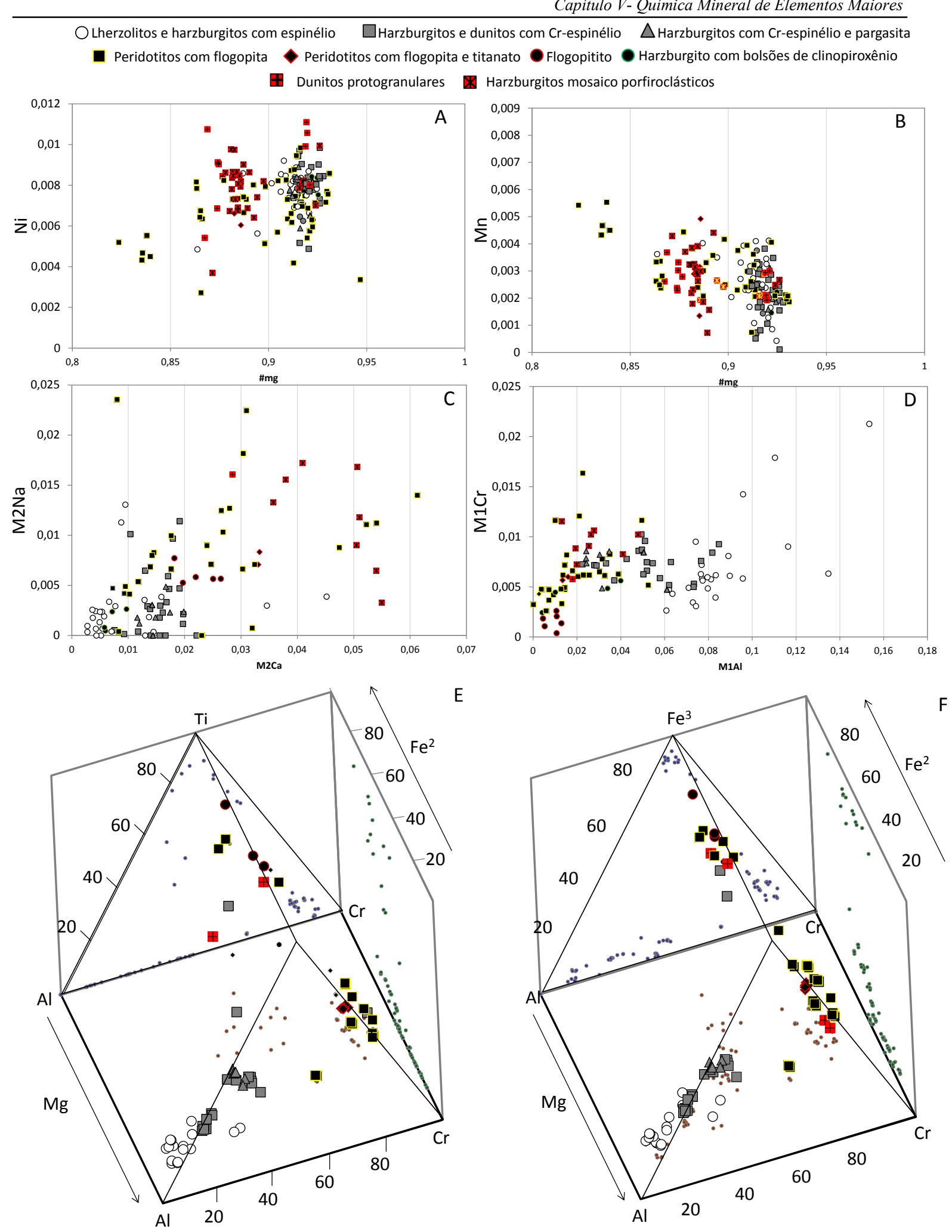

Figura 7- Diagramas de variação química ilustrando a composição de minerais de xenólitos do manto da APIP. A) mg \# vs. Ni em olivina; B) mg \# vs. Mn em olivina; C) Ca vs. Na no sítio octaédrico M2 em ortopiroxênio; D) Al vs. Cr no sítio octaédrico M1 em ortopiroxênio; E) composição de minerais do grupo do espinélio considerando as proporções atômicas de Ti, as projeções em planos auxiliares permitem a visualização das parcelas no espaço; F) composição de minerais do grupo do espinélio considerando proporções atômicas de $\mathrm{Fe}^{3+}$. 
Capitulo V-Quimica Mineral de Elementos Maiores

Tabela 5- Composições químicas representativas de espinélio, Cr-espinélio, cromita e magnetita dos xenólitos mantélicos

\begin{tabular}{|c|c|c|c|c|c|c|c|c|c|c|c|c|}
\hline \multicolumn{8}{|c|}{ peridotitos com espinélio } & \multicolumn{5}{|c|}{ xenólitos com minerais minerais secundários } \\
\hline natureza & $\begin{array}{l}\text { Therzolito com } \\
\text { espinélio com } \\
\text { textura } \\
\text { protogranular }\end{array}$ & $\begin{array}{l}\text { lherzolito com } \\
\text { espinélio com } \\
\text { textura } \\
\text { protogranular }\end{array}$ & $\begin{array}{l}\text { harzburgito } \\
\text { com Cr- } \\
\text { espinélio com } \\
\text { textura } \\
\text { granoblástica }\end{array}$ & $\begin{array}{l}\text { harzburgito } \\
\text { com Cr- } \\
\text { espinélio com } \\
\text { textura } \\
\text { granoblástica }\end{array}$ & $\begin{array}{l}\text { harzburgito } \\
\text { com Cr- } \\
\text { espinélio com } \\
\text { textura } \\
\text { granoblástica } \\
\text { com pargasita }\end{array}$ & $\begin{array}{l}\text { harzburgito } \\
\text { com Cr- } \\
\text { espinélio com } \\
\text { textura } \\
\text { granoblástica } \\
\text { com pargasita }\end{array}$ & $\begin{array}{l}\text { dunito } \\
\text { protogranular }\end{array}$ & $\begin{array}{l}\text { harzburgito com } \\
\text { bolsão de } \\
\text { flogopita com } \\
\text { clinopiroxênio e } \\
\text { cromita }\end{array}$ & $\begin{array}{l}\text { harzburgito } \\
\text { com bolsão } \\
\text { de flogopita } \\
\text { com cromita }\end{array}$ & $\begin{array}{l}\text { harzburgito com } \\
\text { bolsão de } \\
\text { flogopita com } \\
\text { clinopiroxênio, } \\
\text { cromita e } \\
\text { titanato } \\
\text { associado }\end{array}$ & $\begin{array}{l}\text { flogopita } \\
\text { ilmenita } \\
\text { wehrlito }\end{array}$ & $\begin{array}{c}\text { flogopita } \\
\text { ortopiroxenito }\end{array}$ \\
\hline $\begin{array}{l}\text { código da } \\
\text { amostra }\end{array}$ & In1-4-2 & Lm1-17-8 & In1-3-2 & Lm1-20a-12 & In1-24a-3 & In1-50-17 & Lm1-14-4b & Lm1-15-7 & In1-20b-2 & Lm1-1-5 & In1-6-1 & In1-24b-1 \\
\hline $\mathrm{SiO}_{2}$ & 0,00 & 0,00 & 0,03 & 0,17 & 0,02 & 0,00 & 0,00 & 0,47 & 0,08 & 0,00 & 0,04 & 0,41 \\
\hline $\mathrm{TiO}_{2}$ & 0,01 & 0,02 & 0,09 & 0,07 & 0,19 & 0,13 & 2,90 & 0,54 & 1,31 & 4,84 & 18,04 & 12,75 \\
\hline $\mathrm{Al}_{2} \mathrm{O}_{3}$ & 55,44 & 53,37 & 25,81 & 39,92 & 26,10 & 24,50 & 3,89 & 2,84 & 11,97 & 3,06 & 0,77 & 0,15 \\
\hline $\mathrm{Cr}_{2} \mathrm{O}_{3}$ & 12,06 & 14,60 & 41,12 & 28,38 & 42,80 & 43,93 & 58,98 & 62,65 & 54,02 & 50,91 & 1,15 & 3,58 \\
\hline $\mathrm{FeO}$ & 6,25 & 6,07 & 16,21 & 10,03 & 17,85 & 14,25 & 14,89 & 14,39 & 12,35 & 18,11 & 31,92 & 27,14 \\
\hline $\mathrm{Fe}_{2} \mathrm{O}_{3}$ & 7,17 & 6,09 & 2,10 & 5,48 & 1,60 & 6,00 & 6,82 & 7,36 & 3,87 & 12,12 & 36,80 & 45,25 \\
\hline $\mathrm{MnO}$ & 0,07 & 0,10 & 0,20 & 0,11 & 0,18 & 0,15 & 0,07 & 0,22 & 0,09 & 0,19 & 0,81 & 0,78 \\
\hline $\mathrm{MgO}$ & 19,10 & 18,93 & 12,47 & 15,09 & 12,03 & 11,18 & 11,76 & 11,04 & 14,47 & 9,89 & 9,72 & 9,65 \\
\hline $\mathrm{CaO}$ & 0,00 & 0,00 & 0,00 & 0,03 & 0,00 & 0,01 & 0,05 & 0,05 & 0,03 & 0,02 & 0,07 & 0,73 \\
\hline $\mathrm{K}_{2} \mathrm{O}$ & 0,00 & 0,00 & n.a. & 0,00 & n.a. & 0,00 & 0,04 & 0,32 & n.a. & 0,00 & n.a. & n.a. \\
\hline $\mathrm{Na}_{2} \mathrm{O}$ & 0,00 & 0,00 & 0,00 & 0,05 & 0,00 & 0,04 & 0,18 & 0,25 & 0,00 & 0,73 & n.a. & n.a. \\
\hline $\mathrm{NiO}$ & 0,32 & 0,32 & 0,03 & 0,08 & 0,07 & 0,05 & 0,20 & 0,02 & 0,18 & 0,10 & 0,25 & 0,14 \\
\hline Total & 100,42 & 99,50 & 98,06 & 99,40 & 100,84 & 100,25 & 99,77 & 100,16 & 98,38 & 99,97 & 99,56 & 100,58 \\
\hline \multicolumn{13}{|c|}{ Fórmula estrutural calculada com base em 4 oxigênios } \\
\hline AAl & 1,764 & 1,734 & 1,060 & 1,447 & 1,051 & 1,013 & 0,187 & 0,138 & 0,538 & 0,145 & 0,032 & 0,006 \\
\hline $\mathrm{AFe}^{3}$ & 0,064 & 0,053 & 0,055 & 0,086 & 0,041 & 0,158 & 0,209 & 0,229 & 0,111 & 0,366 & 0,978 & 1,205 \\
\hline $\mathrm{ACr}$ & 0,172 & 0,212 & 0,755 & 0,460 & 0,771 & 0,813 & 1,267 & 1,368 & 1,085 & 1,077 & 0,021 & 0,067 \\
\hline ATi & 0,000 & 0,000 & 0,002 & 0,002 & 0,005 & 0,004 & 0,089 & 0,017 & 0,038 & 0,146 & 0,479 & 0,340 \\
\hline $\mathrm{ASi}$ & 0,000 & 0,000 & 0,001 & 0,005 & 0,001 & 0,000 & 0,000 & 0,020 & 0,003 & 0,000 & 0,001 & 0,014 \\
\hline $\mathrm{AFe}^{2}$ & 0,000 & 0,000 & 0,127 & 0,000 & 0,131 & 0,012 & 0,249 & 0,228 & 0,225 & 0,267 & 0,488 & 0,368 \\
\hline Atotal & 2,000 & 2,000 & 2,000 & 2,000 & 2,000 & 2,000 & 2,000 & 2,000 & 2,000 & 2,000 & 2,000 & 2,000 \\
\hline $\mathrm{BFe}^{2}$ & 0,223 & 0,213 & 0,346 & 0,299 & 0,380 & 0,406 & 0,259 & 0,270 & 0,168 & 0,341 & 0,454 & 0,435 \\
\hline $\mathrm{BMg}$ & 0,769 & 0,778 & 0,648 & 0,692 & 0,613 & 0,585 & 0,714 & 0,682 & 0,822 & 0,592 & 0,512 & 0,509 \\
\hline BMn & 0,001 & 0,002 & 0,006 & 0,003 & 0,005 & 0,005 & 0,002 & 0,008 & 0,003 & 0,006 & 0,024 & 0,023 \\
\hline BK & 0,000 & 0,000 & 0,000 & 0,000 & 0,000 & 0,000 & 0,002 & 0,017 & 0,000 & 0,000 & 0,000 & 0,000 \\
\hline $\mathrm{BNa}$ & 0,000 & 0,000 & 0,000 & 0,003 & 0,000 & 0,003 & 0,014 & 0,020 & 0,000 & 0,057 & 0,000 & 0,000 \\
\hline $\mathrm{BCa}$ & 0,000 & 0,000 & 0,000 & 0,001 & 0,000 & 0,000 & 0,002 & 0,002 & 0,001 & 0,001 & 0,003 & 0,028 \\
\hline $\mathrm{BNi}$ & 0,007 & 0,007 & 0,001 & 0,002 & 0,002 & 0,002 & 0,007 & 0,001 & 0,006 & 0,003 & 0,007 & 0,004 \\
\hline Btotal & 1,000 & 1,000 & 1,000 & 1,000 & 1,000 & 1,000 & 1,000 & 1,000 & 1,000 & 1,000 & 1,000 & 1,000 \\
\hline Cr\# & 0,089 & 0,109 & 0,416 & 0,241 & 0,423 & 0,445 & 0,871 & 0,908 & 0,669 & 0,881 & 0,401 & 0,913 \\
\hline $\mathrm{Fe} 2 \#$ & 0,225 & 0,215 & 0,422 & 0,302 & 0,454 & 0,417 & 0,415 & 0,422 & 0,324 & 0,507 & 0,648 & 0,612 \\
\hline Mg\# & 0,84 & 0,85 & 0,58 & 0,73 & 0,55 & 0,58 & 0,58 & 0,58 & 0,68 & 0,49 & 0,35 & 0,39 \\
\hline
\end{tabular}




\section{Olivina}

A olivina é o mineral mais abundante em praticamente todos os xenólitos (exceto flogopititos). As principais variações químicas estão nas razões mg\# e nos conteúdos de Ni e Mn (apfu), como mostra a Tabela 6. O conjunto de xenólitos tem correlação positiva entre mg\# e Ni e correlação inversa entre mg\# e Mn, como ilustra a Figura 7 (A e B).

O mg\# de olivinas varia no intervalo $0,90-0,93$ em peridotitos com espinélio ou Cr-espinélio, sendo que as maiores razões se concentram em harzburgitos e dunitos com Cr-espinélio (0,92-0,93). O aumento no mg\# da olivina, acompanhado aumento do cr\# no espinélio nestes xenólitos, sustenta a hipótese de que eles correspondem a resíduos de fusão parcial.

Um intervalo maior é observado nas olivinas de xenólitos com flogopita e clinopiroxênio secundário $(\mathrm{mg} \#=0,86-0,95)$, provavelmente refletindo a presença tanto de cristais residuais como de cristais secundários. Em xenólitos em que estão presentes minerais secundários como ilmenita ou titanatos, o mg\# de olivinas é sempre baixo $(0,86-0,89)$; nas amostras com flogopita nas quais esses minerais estão ausentes o mg\# se estende ao longo de todo o intervalo $(0,86-0,95)$. O menor mg\# é observado em olivina de um wehrlito polimítico com flogopita e ilmenita (amostra In1-6; 0,83-0,84).

Em um harzburgito protogranular com clinopiroxênio secundário (amostra In1-12), o mg\# da olivina é 0,90-0,92.

Em dunitos e harzburgitos sem espinélio o mg\# da olivina varia no intervalo 0,87-0,93, que é a mesma ampla variação observada nas amostras de dunitos protogranulares (Lm1-14a e Lm1-29). A olivina da amostra Lm1-14a tem o maior mg\# e a amostra Lm1-29, com padrão de fraturas mais forte e coloração amarelada tem mg\# mais baixos. As amostras de dunitos e harzburgitos com textura mosaico-porfiroclástica têm duas modas de mg\#, na qual a maioria dos cristais analisados (cristais muito finos em mosaico e porfiroclastos) tem mg\# de 0,87-0,89 e centros de porfiroclastos têm mg\# alto $(0,92-0,93)$ preservado. Um harzburgito com textura mosaico-porfiroclástica com flogopita intersticial (In1-1) também apresenta o mesmo comportamento, com mg\# maior $(0,92)$ no centro dos cristais de olivina maiores enquanto na borda dos cristais maiores, nos cristais em mosaico e nas porções amareladas do xenólito o mg\# é menor.

Considerando que as análises de megacristais e macrocristais de olivina, abordadas anteriormente no Capítulo IV (Figura 4 e no ANEXO C), que apresentam 
distribuição ampla de mg\# (0,82-0,92), e representam fragmentos dos xenólitos mantélicos, já que se espalham por intervalos ocupados por xenólitos de composição conhecida. A borda de alguns macrocristais de olivina é enriquecida em $\mathrm{Fe}$, como mostram imagens obtidas por MEV (cf. ANEXO C). Nestes casos é possível que o magma kimberlitico tenha alterado a composição original. Na maioria dos xenólitos, microcristais e megacristais as alterações de borda em olivinas não são significativas, levando à conclusão de que nos kimberlitos estudados a grande maioria dos macrocristais e megacristais de olivina não foram gerados a partir do magma kimberlítico. Esta conclusão está de acordo com o trabalho de Arndt et al. (2010) que a partir de estudos de química mineral de aspectos texturais defende que em kimberlitos a maior parte dos macrocristais é de origem xenolítica. Deste modo, assim como a olivina, é esperado que boa parte dos macrocristais e megacristais de outros minerais (flogopita, clinopiroxênio, minerais do grupo do espinélio, ilmenita e titanatos) sejam provenientes de xenólitos mantélicos nos kimberlitos estudados.

Coeficientes de partição olivina/ortopiroxênio exibidos na Tabela 9, mostram que $\mathrm{NiO}$ é mais compatível em olivina que em ortopiroxênio (2-27); $\mathrm{MnO}$ tem concentrações que se equivalem nos dois minerais. No entanto $\mathrm{Al}_{2} \mathrm{O}_{3}, \mathrm{CaO}, \mathrm{Na}_{2} \mathrm{O}$ e $\mathrm{TiO}_{2}$ são amplamente predominantes em ortopiroxênio, com coeficientes muito inferiores a $1(0,001-0,20)$. Isto ocorre, pois o sítio octaédrico M1 da olivina, onde poderiam ser hospedados estes elementos, hospeda relativamente mais $\mathrm{Mg}, \mathrm{Fe}, \mathrm{Ni}$ e $\mathrm{Mn}$ que preenchem quase que totalmente este sítio. Apesar das diferenças estruturais destes dois minerais, o parâmetro mg\# tem valores similares em olivina e ortopiroxênio de uma mesma amostra, como será discutido no próximo item. 
Capitulo V-Quimica Mineral de Elementos Maiores

Tabela 6- Composições químicas representativas de olivina dos xenólitos mantélicos

peridotitos com espinélio

harzburgitos e dunitos sem espinélio

xenólitos com minerais minerais secundários

\begin{tabular}{|c|c|c|c|c|c|c|c|c|c|c|c|c|c|c|c|c|c|c|}
\hline \multirow{3}{*}{$\begin{array}{l}\text { natureza } \\
\text { código da } \\
\text { amostra }\end{array}$} & & & & & & & & & & \multirow{3}{*}{$\begin{array}{l}\text { harzburgito } \\
\text { com bolsão de } \\
\text { flogopita com } \\
\text { clinopiroxênio } \\
\text {, cromita e } \\
\text { titanato } \\
\text { associado } \\
\text { Lm1-1-1c }\end{array}$} & \multirow{2}{*}{\multicolumn{2}{|c|}{$\begin{array}{l}\text { flogopita dunito com } \\
\text { clinopiroxênio secundário }\end{array}$}} & \multirow{3}{*}{$\begin{array}{l}\text { flogopita } \\
\text { ilmenita } \\
\text { wehrlito } \\
\text { In1-6-4 }\end{array}$} \\
\hline & \multicolumn{2}{|c|}{$\begin{array}{l}\text { lherzolito com espinélio } \\
\text { com textura } \\
\text { protogranular }\end{array}$} & \multicolumn{2}{|c|}{$\begin{array}{l}\text { harzburgito com Cr- } \\
\text { espinélio com textura } \\
\text { granoblastica }\end{array}$} & \multicolumn{2}{|c|}{$\begin{array}{l}\text { harzburgito com Cr- } \\
\text { espinélio com textura } \\
\text { granoblástica com } \\
\text { pargasita }\end{array}$} & \multirow{2}{*}{$\begin{array}{c}\substack{\text { dunito } \\
\text { protogranula } \\
\mathrm{r}} \\
\mathrm{Lm} 1-14-2\end{array}$} & \multicolumn{2}{|c|}{$\begin{array}{l}\text { harzburgito } \\
\text { porfiroclástico com } \\
\text { mosaico }\end{array}$} & \multirow{2}{*}{$\begin{array}{l}\text { harzburgito } \\
\text { porfiroclástic } \\
\text { o com } \\
\text { mosaico } \\
\text { (cristal em } \\
\text { mosaico) } \\
\text { In1-33-11d }\end{array}$} & \multirow{2}{*}{$\begin{array}{c}\text { harzburgito } \\
\text { porfiroclasstic } \\
\text { o com } \\
\text { mosaico } \\
\text { (centro de } \\
\text { porfiroclato) } \\
\text { In1-33-11e }\end{array}$} & \multirow{2}{*}{$\begin{array}{l}\text { harzburgito } \\
\text { com bolsão de } \\
\text { flogopita com } \\
\text { clinopiroxêni } \\
\text { o e cromita } \\
\text { Lm1-15-18 }\end{array}$} & \multirow{2}{*}{$\begin{array}{c}\text { harzburgito } \\
\text { com bolsão } \\
\text { de } \\
\text { flogopita } \\
\text { com } \\
\text { cromita } \\
\text { In1-20b- } \\
5\end{array}$} & \multirow{2}{*}{$\begin{array}{c}\text { harzburgito } \\
\text { com } \\
\text { bolsões de } \\
\text { cpx }\end{array}$} & & & & \\
\hline & In1-4-2' & $\begin{array}{l}\text { Lm1-17- } \\
\quad 11\end{array}$ & In1-3-4 & $\begin{array}{l}\text { Lm1-20- } \\
\quad 14\end{array}$ & $\begin{array}{l}\text { In1-24a- } \\
5\end{array}$ & $\begin{array}{l}\text { In1-50- } \\
12\end{array}$ & & $\begin{array}{c}\text { In1-1- } \\
1 *\end{array}$ & In1-1-6 & & & & & & & Lm1-22-2 & Lm1-22-13 & \\
\hline $\mathrm{SiO}_{2}$ & 39,56 & 40,88 & 41,05 & 41,25 & 40,91 & 40,77 & 39,22 & 40,45 & 41,40 & 40,50 & 41,72 & 40,67 & 40,38 & 41,72 & 41,16 & 39,82 & 40,40 & 39,39 \\
\hline $\mathrm{TiO}_{2}$ & 0,00 & 0,00 & 0,00 & 0,01 & 0,00 & 0,02 & 0,01 & 0,04 & 0,01 & 0,08 & 0,00 & 0,00 & 0,04 & 0,05 & 0,00 & 0,00 & 0,02 & 0,00 \\
\hline $\mathrm{Al}_{2} \mathrm{O}_{3}$ & 0,07 & 0,00 & 0,01 & 0,00 & 0,00 & 0,00 & 0,00 & 0,03 & 0,06 & 0,02 & 0,06 & 0,00 & 0,02 & 0,00 & 0,03 & 0,06 & 0,15 & 0,04 \\
\hline $\mathrm{FeO}$ & 9,13 & 9,28 & 7,74 & 8,23 & 7,95 & 7,74 & 7,93 & 10,03 & 8,32 & 12,54 & 7,52 & 7,83 & 6,87 & 7,62 & 11,30 & 9,88 & 10,97 & 15,36 \\
\hline $\mathrm{MnO}$ & 0,13 & 0,12 & 0,14 & 0,04 & 0,10 & 0,10 & 0,09 & 0,12 & 0,10 & 0,21 & 0,12 & 0,14 & 0,10 & 0,12 & 0,07 & 0,20 & 0,10 & 0,12 \\
\hline $\mathrm{MgO}$ & 49,51 & 50,14 & 51,19 & 50,58 & 51,46 & 51,69 & 50,94 & 49,26 & 50,77 & 47,69 & $\begin{array}{l}51,26 \\
\text { S }\end{array}$ & 51,21 & 51,46 & $\begin{array}{l}51,64 \\
\end{array}$ & 48,95 & 48,79 & 48,44 & 44,58 \\
\hline $\mathrm{CaO}$ & 0,00 & 0,01 & 0,00 & 0,00 & 0,00 & 0,02 & 0,05 & 0,12 & 0,09 & 0,11 & 0,01 & 0,00 & 0,09 & 0,00 & 0,03 & 0,00 & 0,01 & 0,05 \\
\hline $\mathrm{Na}_{2} \mathrm{O}$ & & 0,00 & 0,02 & 0,01 & 0,00 & 0,00 & & 0,03 & 0,0 & 0 & 0,04 & 0,02 & 0,02 & 0,00 & 0,00 & 0,09 & 0,00 & 0,01 \\
\hline $\mathrm{K}_{2} \mathrm{O}$ & 0,01 & 0,00 & 0,00 & 0,00 & 0,00 & 0,00 & 0,00 & 0,00 & $0,0 c$ & 0,0 & 0,00 & 0,02 & 0,0 & 0,00 & 0,03 & 0,00 & 0,04 & 0,00 \\
\hline $\mathrm{Cr}_{2} \mathrm{O}_{3}$ & 0,01 & 0,00 & 0,03 & 0,00 & 0,00 & 0,02 & 0,04 & 0,10 & 0,1 & 0,0 & 0,00 & 0,08 & 0,05 & 0,05 & 0,00 & 0, & 0,07 & 0,00 \\
\hline $\mathrm{NiO}$ & 0,39 & 0,41 & 0,46 & 0,37 & 0,41 & 0,42 & 0,54 & 0,42 & 0,41 & 0,19 & 0,36 & 0,30 & 0,39 & 0,37 & 0,41 & 0,26 & 0,38 & 0,27 \\
\hline \multirow[t]{2}{*}{ Total } & 98,83 & 100,84 & 100,63 & 100,49 & 100,83 & 100,78 & 98,89 & 100,60 & 101,34 & 101,42 & 101,09 & 100,26 & 99,45 & 101,57 & 101,98 & 99,09 & 100,58 & 99,82 \\
\hline & \multicolumn{18}{|c|}{ 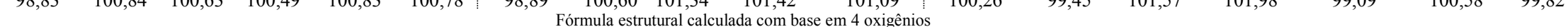 } \\
\hline $\mathrm{TSi}$ & 0,977 & 0,990 & 0,990 & 0,999 & 0,984 & 0,980 & 0,961 & 0,986 & 0,996 & 0,990 & 1,001 & 0,984 & 0,9 & 0,9 & 0,9 & 0,984 & 0,990 & 0,992 \\
\hline $\mathrm{TFe}^{3}$ & 0,023 & 0,010 & 0,010 & 0,001 & 0,016 & 0,020 & 0,039 & 0,014 & 0,003 & & 0000 & 1 & & 0,0 & 0,0 & 0,016 & $0, \mathrm{c}$ & 0,008 \\
\hline TAl & & 0,000 & & 0, & & 0,0 & 0, & & & & & & & 0,0 & 0,0 & 0,0 & & 0,000 \\
\hline Ttotal & 1,000 & 1,000 & 1,000 & 1,000 & 1,000 & 1,0 & 1,000 & 1,000 & 1,0 & $1, \mathrm{C}$ & 1,0 & 1,0 & 1,0 & 1,000 & 1,000 & 1,000 & 1,000 & 1,000 \\
\hline $\mathrm{M} 1 \mathrm{Fe}^{3}$ & 0,021 & 0,010 & & & & 0,0 & & & & & & & & 0,0 & & & & 0,007 \\
\hline M1Al & 0,002 & 0,000 & 0,000 & 0,000 & 0,000 & 0,000 & 0,000 & 0,001 & 0,001 & 0,0 & 0,0 & $0,0 c$ & $0,0 c$ & 0,000 & 0,0 & 0,002 & 0,004 & 0,001 \\
\hline M1Mg & 1,822 & 1,811 & 1,841 & & & & & & & & & & & & & 1,7 & & 1,674 \\
\hline $\mathrm{M} 1 \mathrm{Fe}^{2}$ & 0,144 & 0,169 & 0,137 & 0,164 & 0,129 & 0,118 & 0,082 & 0,181 & 0,1 & 0,2 & 0,1 & 0,1 & 0,104 & 0,149 & 0,218 & 0,169 & 0,210 & 0,308 \\
\hline M1K & 0,000 & 0,000 & 0,000 & 0,000 & & $0,0 c$ & 0,000 & & 0,0 & & & 0,0 & 0,001 & 0,000 & 0,0 & 0,000 & 0,001 & 0,000 \\
\hline M1Ni & 0,008 & 0,008 & 0,009 & 0,007 & 0, & 0,0 & 0,011 & 0,0 & 0,0 & 0, & & 0 & 0,0 & 0,0 & 0,0 & 0,005 & 0,0 & 0,006 \\
\hline $\mathrm{M} 1 \mathrm{Cr}$ & 0,000 & 0,000 & & 0,000 & & 0,0 & & & 0,0 & & & 0, & & 0,0 & & $0, \mathrm{C}$ & & 0,000 \\
\hline M1Mn & & 0,002 & & & & 0,0 & & & & & & & 0,0 & 0,0 & & 0,004 & 0,002 & 0,003 \\
\hline M1Ti & 0,000 & 0,000 & 0,000 & 0,000 & 0,000 & 0,000 & 0,000 & 0,001 & 0,000 & 0,0 & 0,0 & 0,000 & 0,001 & 0,001 & 0,000 & 0,000 & 0,000 & 0,000 \\
\hline $\mathrm{M} 1 \mathrm{Ca}$ & 0 , & 0,000 & 0,000 & 0,000 & 0,000 & 0,00 & 0,000 & & 0,002 & & 0,0 & 0,000 & 0,001 & 0,000 & 0,001 & 0,002 & 0,004 & 0,001 \\
\hline M1Total & 2 & 2,000 & 1,999 & 2,000 & 2,000 & 2,00 & & 1,996 & & & & & 1,997 & 2,000 & 2,000 & 1,998 & 2,004 & 1,999 \\
\hline Mg\# & 0,906 & 0,906 & 0,922 & 0,916 & 0,920 & 0,922 & 0,920 & 0,897 & 0,916 & 0,871 & 0,924 & 0,921 & 0,930 & 0,924 & 0,885 & 0,898 & 0,887 & 0,838 \\
\hline
\end{tabular}




\section{Ortopiroxênio}

O segundo mineral mais abundante nos xenólitos estudados é o ortopiroxênio. De acordo com a nomenclatura de Morimoto et al. (1988) corresponde a enstatita. A partir das analises de microssonda em ortopiroxênio, foi observado que além da razão mg\#, também as proporções de $\mathrm{Ca}, \mathrm{Na}, \mathrm{Al}$ e $\mathrm{Cr}$ apresentam variações importantes (Figura 7-C e D).

O mg\# de todos os ortopiroxênios analisados é alto, e varia no mesmo intervalo da olivina $(0,90$ a 0,93$)$ em peridotitos com espinélo ou Cr-espinélio. Para os xenólitos com fases secundárias a distribuição ampla dos valores de mg\# $(0,88-0,94)$ das análises observada nas olivinas é similar para o ortopiroxênio, provavelmente refletindo a presença de cristais residuais e de origem secundária. O menor valor de mg\# é observado em ortopiroxênio de flogopititos $(\mathrm{mg} \#=0,86-0,87)$.

Em um harzburgito com clinopiroxênio secundário (amostra In1-12) o ortopiroxênio tem $\mathrm{mg} \#=0,93$.

Em dunitos e harzburgitos sem espinélio o mg\# varia de 0,89 a 0,93 . Nos dunitos e harzburgitos protogranulares e nos dunitos e harzburgitos com textura mosaico-porfiroclástica, amostras com coloração amarelada, ou porções dentro de uma mesma amostra com porções mais amareladas assim como para o mg\# da olivina, o mg\# do ortopiroxênio é mais baixo $(0,89-0,90)$. Nos harzburgitos e dunitos com textura mosaico-porfiroclástica as porções em mosaico e as zonas adjacentes são susceptíveis a maior percolação de fluidos, e o ortopiroxênio ali presente tem mg\# mais baixo $(0,89$ 0,91), enquanto os núcleos de ortopiroxênio têm mg\# mais alto $(0,92-0,93)$.

$\mathrm{Ca}$ e $\mathrm{Na}$, que ocupam em ortopiroxênio o sítio octaédrico M2, somam menos de 0,06 apfu, para todas as amostras. Algumas variações podem simplesmente refletir imprecisões analíticas, já que estes valores estão próximos ao limite de detecção. Os menores conteúdos destes elementos estão em ortopiroxênio de peridotitos com espinélio e Cr-espinélio ( $\mathrm{Na}<0,05, \mathrm{Ca}<0,01 \mathrm{apfu}$ ), enquanto que um harzburgito com textura mosaico-porfiroclática (In1-33) tem o mais alto $\mathrm{Ca}(0,03-0,05 \mathrm{apfu})$ e $\mathrm{Na}$ (0,003-0,017 apfu) (Figura 7).

No sítio octaédrico $\mathrm{M} 1, \mathrm{Al}$ e $\mathrm{Cr}$ apresentam uma correlação positiva para todas as amostras. A quantidade de Al no ortopiroxênio discrimina dois grupos de xenólitos: os peridotitos com espinélio e Cr-espinélio ( $\mathrm{Al}>0,02 \mathrm{apfu})$, e xenólitos com minerais secundários $(\mathrm{Al}<0,04 \mathrm{apfu})$. O $\mathrm{Cr}$ varia de 0,003 a 0,010 apfu em peridotitos com 
espinélio ou Cr-espínélio. Algumas análises com $\mathrm{Cr}$ mais alto devem refletir as finas inclusões deste mineral em ortopiroxênio nestas amostras. $\mathrm{O}$ menor $\mathrm{Cr}$ ocorre em ortopiroxênio de flogopitito (In1-24b) e em harzburgito com clinopiroxênio secundário (In1-12). Em outros xenólitos, o Cr em ortopiroxênio varia de 0,001 a 0,016 apfu, sendo que o mais alto $\mathrm{Cr}$ é observado em harzburgitos com textura mosaico-porfiroclática (Tabela 7; Figura 7).

No sítio tetraédrico (T), Si varia de 1,9 a 2,0 apfu para todo o conjunto de amostras, apresentando muito pouco $\mathrm{Al} \mathrm{e} \mathrm{Fe}^{3+}$ neste sítio. A única exceção é um ortopiroxênio de xenólito da intrusão Forca $(\mathrm{TSi}=1,74 \mathrm{apfu})$; estes cristais ocorrem em contato com o kimberlito, e têm uma composição claramente secundária (Tabela 7).

A olivina e o ortopiroxênio dos xenólitos estudados tem variação na razão mg\# provavelmente causadas por processos distintos. Um deles é o processo de fusão parcial, resultando em alto mg\# em olivina e ortopiroxênio em harzburgitos e dunitos com Cr-espinélio, dunitos porfiroclásticos com traços de cromita (In1-14), além de núcleos de porfiroclastos de dunitos e harzburgitos porfiroclásticos. Xenólitos com minerais secundários registram baixo $\mathrm{Al}$ em ortopiroxênio de todas as amostras, além de preservarem mg\# alto em amostras com baixa proporção relativa de flogopita (In1-20b) e clinopiroxênio (In1-12). No entanto, amostras contendo ilmenita, ou com maior proporção de clinopiroxênio e flogopita tem olivina e ortopiroxênio com as menores razões de mg\# caracterizando o metassomatismo críptico em olivina e ortopiroxênio.

Outro processo provável é a reação do magma/fluidos kimberlítico(s) com os minerais preexistentes baixando o mg\#. A percolação de material kimberlítico pode ser observada em fraturas e interstícios de diversos xenólitos, com precipitação de minerais kimberlíticos como serpentina, magnetita, perovskita e monticellita. No entanto as evidências de reação com o magma kimberlítico são na maior parte das vezes inexpressivas na olivina. A ausência de ortopiroxênio na matriz dos kimberlitos estudados indica que este mineral seja mais reativo com o magma kimberlitico que a olivina. O trabalho de Russel et al. (2012) aponta que uma reação provável para a geração de $\quad \mathrm{CO}_{2}$ nos magmas kimberlíticos seja carbonato+ortopiroxênio $=$ clinopiroxênio $+\mathrm{CO}_{2}$, também além de discutir que assumindo que a grande maioria dos kimberlitos não exibe macrocristais de ortopiroxênio. 
Capitulo V- Quimica Mineral de Elementos Maiores

Tabela 7- Composições químicas representativas de ortopiroxênio dos xenólitos mantélicos

\begin{tabular}{|c|c|c|c|c|c|c|c|c|c|c|c|c|c|c|c|}
\hline \multirow[b]{2}{*}{ natureza } & \multicolumn{6}{|c|}{ peridotitos com espinélio } & \multicolumn{4}{|c|}{ harzburgitos e dunitos sem espinélio } & \multicolumn{5}{|c|}{ xenólitos com minerais minerais secundários } \\
\hline & $\begin{array}{l}\text { lherzolito } \\
\text { com espinélio } \\
\text { com textura } \\
\text { protogranular }\end{array}$ & $\begin{array}{l}\text { lherzolito } \\
\text { com espinélio } \\
\text { com textura } \\
\text { protogranular }\end{array}$ & $\begin{array}{l}\text { harzburgito } \\
\text { com Cr- } \\
\text { espinélio com } \\
\text { textura } \\
\text { granoblástica }\end{array}$ & $\begin{array}{l}\text { harzburgito } \\
\text { com Cr- } \\
\text { espinélio com } \\
\text { textura } \\
\text { granoblástica }\end{array}$ & $\begin{array}{l}\text { harzburgito } \\
\text { com Cr- } \\
\text { espinélio com } \\
\text { textura } \\
\text { granoblástica } \\
\text { com pargasita }\end{array}$ & $\begin{array}{l}\text { harzburgito } \\
\text { com Cr- } \\
\text { espinélio com } \\
\text { textura } \\
\text { granoblástica } \\
\text { com pargasita }\end{array}$ & $\begin{array}{c}\text { dunito } \\
\text { protogranular }\end{array}$ & $\begin{array}{l}\text { harzburgito } \\
\text { porfiroclástico } \\
\text { com mosaico } \\
\text { (cristal em } \\
\text { mosaico em } \\
\text { porção } \\
\text { amarelada) }\end{array}$ & $\begin{array}{l}\text { harzburgito } \\
\text { porfiroclástico } \\
\text { com mosaico }\end{array}$ & $\begin{array}{l}\text { harzburgito } \\
\text { porfiroclástico } \\
\text { com mosaico }\end{array}$ & $\begin{array}{l}\text { harzburgito } \\
\text { com bolsão de } \\
\text { flogopita com } \\
\text { clinopiroxênio } \\
\text { e cromita }\end{array}$ & $\begin{array}{c}\text { harzburgito } \\
\text { com bolsão } \\
\text { de flogopita } \\
\text { com } \\
\text { cromita }\end{array}$ & $\begin{array}{c}\text { harzburgito } \\
\text { com bolsões } \\
\text { de } \\
\text { clinopiroxênio }\end{array}$ & $\begin{array}{l}\text { harzburgito } \\
\text { com bolsão de } \\
\text { flogopita com } \\
\text { clinopiroxênio, } \\
\text { cromita e } \\
\text { titanato } \\
\text { associado }\end{array}$ & $\begin{array}{c}\text { flogopita } \\
\text { ortopiroxenito }\end{array}$ \\
\hline código da amostra & In1-4-3' & Lm1-17-6 & In1-3-5 & Lm1-20-8 & In1-24a-3 & In1-50-7 & Lm1-14-4a & In1-1-2* & In1-1-8 & In1-33-1 & Lm1-15-1 & In1-20b-3 & In1-12-1 & Lm1-1-9a & In1-24b-2 \\
\hline $\mathrm{SiO}_{2}$ & 54,34 & 54,98 & 56,93 & 56,33 & 57.67 & 56,26 & 57,32 & 56,79 & 57,82 & 56,12 & 57,98 & 57,48 & 57,88 & 56,46 & 57,68 \\
\hline $\mathrm{TiO}_{2}$ & 0,15 & 0,00 & 0,00 & 0,00 & 0,11 & 0,09 & 0,16 & 0,27 & 0,17 & 0,28 & 0,01 & 0,04 & 0,00 & 0,31 & 0,28 \\
\hline $\mathrm{Al}_{2} \mathrm{O}_{3}$ & 4,02 & 4,46 & 1,87 & 2,36 & 1,64 & 1,61 & 0,45 & 1,22 & 1,24 & 1,19 & 0,32 & 1,46 & 0,11 & 0,33 & 0,28 \\
\hline $\mathrm{MnO}$ & 0,14 & 0,09 & 0,14 & 0,05 & 0,13 & 0,14 & 0,17 & 0,15 & 0,11 & 0,10 & 0,16 & 0,08 & 0,14 & 0,11 & 0,23 \\
\hline $\mathrm{MgO}$ & 33,86 & 34,22 & 36,15 & 34,78 & 35,61 & 35,71 & 36,18 & 33,87 & 35,54 & 33,37 & 36,27 & 35,54 & 37,43 & 34,39 & 33,26 \\
\hline $\mathrm{CaO}$ & 0,26 & 0,45 & 0,32 & 0,35 & 0,46 & 0,39 & 0,78 & 1,47 & 0,66 & 1,36 & 0,40 & 0,48 & 0,27 & 0,89 & 0,72 \\
\hline $\mathrm{Na}_{2} \mathrm{O}$ & 0,20 & 0,00 & 0,01 & 0,10 & 0,07 & 0,00 & 0,24 & 0,17 & 0,14 & 0,13 & 0,13 & 0,10 & 0,04 & 0,11 & 0,09 \\
\hline $\mathrm{K}_{2} \mathrm{O}$ & 0,00 & 0,01 & 0,01 & 0,00 & 0,01 & 0,02 & 0,00 & 0,00 & 0,00 & 0,00 & 0,02 & 0,00 & 0,00 & 0,00 & 0,01 \\
\hline $\mathrm{Cr}_{2} \mathrm{O}_{3}$ & 0,50 & 0,54 & 0,48 & 0,32 & 0,48 & 0,26 & 0,32 & 0,67 & 0,46 & 0,56 & 0,27 & 0,36 & 0,14 & 0,31 & 0,02 \\
\hline $\mathrm{NiO}$ & 0,13 & 0,18 & n.a. & 0,01 & n.a. & 0,11 & 0,05 & n.a. & n.a. & 0,15 & 0,01 & n.a. & n.a. & 0,12 & n.a. \\
\hline Total & 100,35 & 100,70 & 100,88 & 100,00 & 101,29 & 100,28 & 100,42 & 101,09 & 100,87 & 100,30 & 100,41 & 99,68 & 100,78 & 99,79 & 101,61 \\
\hline & & & & & & Fórmula est & utural calculada & com base em 6 o & xigênios & & & & & & \\
\hline $\mathrm{TSi}$ & 1,866 & 1,878 & 1,931 & 1,934 & 1,954 & 1,923 & 1,951 & 1,946 & 1,966 & 1,942 & 1,974 & 1,971 & 1,956 & 1,955 & 1,980 \\
\hline $\mathrm{TFe}^{3}$ & 0,087 & 0,040 & 0,042 & 0,028 & 0,005 & 0,073 & 0,049 & 0,026 & 0,000 & 0,035 & 0,026 & 0,000 & 0,044 & 0,045 & 0,019 \\
\hline TAl & 0,046 & 0,082 & 0,027 & 0,038 & 0,041 & 0,004 & 0,000 & 0,028 & 0,034 & 0,022 & 0,000 & 0,029 & 0,000 & 0,000 & 0,001 \\
\hline M1Al & 0,116 & 0,098 & 0,048 & 0,058 & 0,024 & 0,061 & 0,018 & 0,021 & 0,015 & 0,026 & 0,013 & 0,030 & 0,004 & 0,013 & 0,011 \\
\hline $\mathrm{M} 1 \mathrm{Cr}$ & 0,009 & 0,010 & 0,009 & 0,006 & 0,009 & 0,005 & 0,006 & 0,012 & 0,008 & 0,010 & 0,005 & 0,006 & 0,002 & 0,006 & 0,000 \\
\hline $\mathrm{M} 1 \mathrm{Fe}^{3}$ & 0,000 & 0,000 & 0,000 & 0,000 & 0,000 & 0,000 & 0,025 & 0,000 & $\begin{array}{l}0,000 \\
0,000\end{array}$ & 0,000 & 0,009 & 0,000 & 0,036 & 0,008 & 0,000 \\
\hline M1Ti & 0,004 & 0,000 & 0,000 & 0,000 & 0,003 & 0,002 & 0,004 & 0,007 & 0,004 & 0,007 & 0,000 & 0,001 & 0,000 & 0,008 & 0,007 \\
\hline M1Ni & 0,004 & 0,005 & 0,000 & 0,000 & 0,000 & 0,003 & 0,001 & 0,000 & 0,000 & 0,004 & 0,000 & 0,000 & 0,000 & 0,003 & 0,000 \\
\hline${\mathrm{M} 1 \mathrm{Fe}^{2}}^{2}$ & 0,000 & 0,000 & 0,000 & 0,000 & 0,000 & 0,000 & 0,000 & 0,000 & 0,000 & 0,000 & 0,000 & 0,000 & 0,000 & 0,000 & 0,000 \\
\hline M1Mg & 0,867 & 0,888 & 0,943 & 0,936 & 0,964 & 0,929 & 0,946 & 0,960 & 0,972 & 0,952 & 0,972 & 0,962 & 0,957 & 0,961 & 0,982 \\
\hline M1Mn & 0,000 & 0,000 & 0,000 & 0,000 & 0,000 & 0,000 & 0,000 & 0,000 & 0,000 & 0,000 & 0,000 & 0,000 & 0,000 & 0,000 & 0,000 \\
\hline M1total & 1,000 & 1,000 & 1,000 & 1,000 & 1,000 & 1,000 & 1,000 & 1,000 & 1,000 & 1,000 & 1,000 & 1,000 & 1,000 & 1,000 & 1,000 \\
\hline $\mathrm{M} 2 \mathrm{Mg}$ & 0,867 & 0,855 & 0,885 & 0,844 & 0,834 & 0,891 & 0,890 & 0,770 & 0,829 & 0,770 & 0,869 & 0,855 & 0,929 & 0,814 & 0,720 \\
\hline $\mathrm{M}^{2} \mathrm{Fe}^{2}$ & 0,107 & 0,125 & 0,099 & 0,135 & 0,140 & 0,089 & 0,061 & 0,160 & 0,135 & 0,168 & 0,103 & 0,119 & 0,055 & 0,143 & 0,241 \\
\hline $\mathrm{M} 2 \mathrm{Mn}$ & 0,004 & 0,003 & 0,004 & 0,001 & 0,004 & 0,004 & 0,005 & 0,004 & 0,003 & 0,003 & 0,005 & 0,002 & 0,004 & 0,003 & 0,007 \\
\hline $\mathrm{M} 2 \mathrm{Ca}$ & 0,010 & 0,016 & 0,012 & 0,013 & 0,017 & 0,014 & 0,028 & 0,054 & 0,024 & 0,050 & 0,015 & 0,018 & 0,010 & 0,033 & 0,026 \\
\hline $\mathrm{M} 2 \mathrm{Na}$ & 0,013 & 0,000 & 0,000 & 0,006 & 0,005 & 0,000 & 0,016 & 0,011 & 0,009 & 0,009 & 0,008 & 0,007 & 0,003 & 0,007 & 0,006 \\
\hline M2total & 1,000 & 1,000 & 1,000 & 1,000 & 1,000 & 0,999 & 1,000 & 1,000 & 1,000 & 1,000 & 0,999 & 1,000 & 1,000 & 1,000 & 1,000 \\
\hline Mg\# & 0,899 & 0,914 & 0,928 & 0,916 & 0,926 & 0,918 & 0,931 & 0,903 & 0,930 & 0,894 & 0,930 & 0,939 & 0,933 & 0,900 & 0,867 \\
\hline
\end{tabular}




\section{Clinopiroxênio}

O clinopiroxênio é o terceiro mineral mais frequente nos xenólitos estudados. Os cristais apresentam importantes variações composicionais, como mostrado na Tabela $8 \mathrm{e}$ Figura 8. De acordo com a classificação de Morimoto et al. (1988), os cristais correspondem a diopsídio ou augita.

Nos peridotitos com espinélio ou Cr-espinélio uma das características químicas mais importantes no clinopiroxênio é seu alto Al (0,061-0,165 apfu); além disso, tem pequenas variações de $\mathrm{Cr}(0,018-0,020 \mathrm{apfu})$ e $\mathrm{mg \#}(0,93-0,95)$. O clinopiroxênio de lherzolitos com espinélio tem $\mathrm{Na}, \mathrm{Al}$, Ti mais altos $(0,092-0,117 ; 0,143-0,165 ; 0,002-$ 0,011 apfu) comparado àquele presente nas amostras com Cr-espinélio. $\mathrm{Na}$ amostra com anfibólio (In1-50) o clinopiroxênio tem maior quantidade de $\mathrm{Cr}$ (0,036 apfu) e mg\# $(0,95)$ (ANEXO C). Uma porção da borda de um cristal de clinopiroxênio de um lherzolito com espinélio da intrusão Forca tem mg\# $(0,88-0,91)$ menores, e deve corresponder a registro de processos de interação com o magma kimberlítico.

Os clinopiroxênios de peridotitos com flogopita têm baixo $\mathrm{Al}(<0,05 \mathrm{apfu}), \mathrm{Ca}$ (0,8-0,85 apfu) e Ti (0,01- 0,02 apfu). O mg\# varia de 0,86 a 0,92, com valores maiores para amostras com maior proporção de fases metassomaticas. Em diversas amostras, como por exemplo Lm1-1 e In1-12, ocorre uma variação significativa nos índices mg\# $(0,91-0,93)$ e cr\# $(0,51-0,72)$. Tais variações são identificadas em imagens de MEV em diversas amostras de xenólitos com minerais secundários, Figuras (86-1 e 94-3) do ANEXO B. Representam bordas de reações com minerais primários, principalmente ortopiroxênio, gradando de mais alto $\mathrm{mg} \#$ ao redor de cristais de ortopiroxênio, para mg\# mais baixo em direção ao centro dos cristais de clinopiroxênio.

Assim como na olivina e ortopiroxênio, o clinopiroxênio da amostra de harzburgito protogranular com clinopiroxênio secundário $(\operatorname{In} 1-12)$ tem alto mg\# $(0,93)$, maior que qualquer outra amostra com minerais secundários; o clinopiroxênio nesta amostra ainda tem alto $\mathrm{Na}$ e $\mathrm{Cr}(0,165 ; 0,056-0,076$ apfu) e baixo Ti e $\mathrm{Ca}(0-0,001$; $0,756-0,792)$.

O clinopiroxênio de uma amostra de harzburgito com textura mosaicoporfiroclástica (In1-33 e In1-1) tem o maior Ti (0,021-0,040 apfu) de todo o conjunto. O mg\# desta amostra é $0,86-0,87$. 
Capitulo V-Química Mineral de Elementos Maiores

Um megacristal de clinopiroxênio tem alto Ti comparado a todas as amostras de xenólitos; tem o mg\# mais baixo $(0,84)$ que os xenólitos e maior Al que nas amostras de xenólitos metassomatisados $(0,091 \mathrm{apfu})$.

Coeficiente de partição entre ortopiroxênio e clinopiroxênio (Tabela 9) permite estimar que $\mathrm{Ti}, \mathrm{Ca}$ e $\mathrm{Na}$ (razões próximas a 0 ) são mais compatíveis com clinopiroxênio, por estes elementos estarem ligados ao sítio octaédrico M2, o que não ocorre no sítio M2 do ortopiroxênio (ocupado por $\mathrm{Mg}$ e Fe).

O Al que está associado ao sítio octaédrico M1, assim como Cr e Ni, também se associa ao sítio T (tetraédrico). Nas amostras de harzburgitos porfiroclásticos (In1-1 e In1-33) o coeficiente de partição para $\mathrm{Al}_{2} \mathrm{O}_{3}$ é próximo de 4 , o que contrasta com o coeficiente de partição das demais amostras que é menor que 1. Isto pode ser explicado pela entrada de Al no sítio tetraédrico no ortopiroxênio destas amostras, que tem textura sugestiva de alta temperatura. 
Capitulo V- Quimica Mineral de Elementos Maiores

Tabela 8- Composições químicas representativas de clinopiroxênio dos xenólitos mantélicos

\begin{tabular}{|c|c|c|c|c|c|c|c|c|c|c|c|c|}
\hline \multirow[b]{2}{*}{ natureza } & \multicolumn{4}{|c|}{ peridotitos com espinélio } & \multicolumn{2}{|c|}{$\begin{array}{l}\text { harzburgitos e dunitos sem } \\
\text { espinélio }\end{array}$} & \multicolumn{5}{|c|}{ xenólitos com minerais secundários } & \multirow[t]{2}{*}{ megacrista } \\
\hline & $\begin{array}{l}\text { lherzolito com } \\
\text { espinélio com } \\
\text { textura } \\
\text { protogranular }\end{array}$ & $\begin{array}{l}\text { lherzolito com } \\
\text { espinélio com } \\
\text { textura } \\
\text { protogranular }\end{array}$ & $\begin{array}{l}\text { harzburgito com } \\
\text { Cr-espinélio com } \\
\text { textura } \\
\text { granoblástica }\end{array}$ & $\begin{array}{l}\text { harzburgito com } \\
\text { Cr-espinélio com } \\
\text { textura } \\
\text { granoblástica }\end{array}$ & $\begin{array}{c}\text { harzburgito } \\
\text { porfiroclástico } \\
\text { com mosaico } \\
\text { (cristal em } \\
\text { mosaico em } \\
\text { porção } \\
\text { amarelada) }\end{array}$ & $\begin{array}{l}\text { harzburgito } \\
\text { porfiroclático } \\
\text { com mosaico } \\
\text { (cristal em } \\
\text { mosaico) }\end{array}$ & \multicolumn{2}{|c|}{$\begin{array}{l}\text { harzburgito com } \\
\text { bolsões de cpx }\end{array}$} & \multicolumn{2}{|c|}{$\begin{array}{l}\text { harzburgito com bolsão } \\
\text { de flogopita com } \\
\text { clinopiroxênio, cromita } \\
\text { e titanato associado }\end{array}$} & $\begin{array}{l}\text { flogopita } \\
\text { ilmenita } \\
\text { wehrlito }\end{array}$ & \\
\hline cód. análise & In1-4-3 & L1-17a-12 & In1-3-6 & Lm1-20a-17 & In1-1-1 & In1-33-8b & In1-12-1 & In1-12-3 & Lm1-1-4c & Lm1-1-4d & In1-6-4 & Fo-3-5 \\
\hline $\mathrm{SiO}_{2}$ & 52,61 & 52,22 & 54,03 & 53,58 & 53,24 & 54,00 & 54,44 & 54,41 & 54,61 & 54,34 & 54,20 & 52,97 \\
\hline $\mathrm{TiO}_{2}$ & 0,40 & 0,07 & 0,00 & 0,00 & 1,46 & 0,76 & 0,04 & 0,00 & 0,34 & 0,31 & 0,05 & 0,63 \\
\hline $\mathrm{Al}_{2} \mathrm{O}_{3}$ & 6,46 & 5,52 & 2,13 & 3,52 & 0,30 & 0,31 & 1,08 & 0,68 & 0,80 & 0,79 & 0,28 & 2,14 \\
\hline $\mathrm{FeO}$ & 2,00 & 1,67 & 1,59 & 1,67 & 5,18 & 4,58 & 2,64 & 2,24 & 3,60 & 3,14 & 4,18 & 6,42 \\
\hline $\mathrm{MnO}$ & 0,11 & 0,15 & 0,02 & 0,09 & 0,13 & 0,11 & 0,12 & 0,04 & 0,05 & 0,03 & 0,14 & 0,24 \\
\hline $\mathrm{MgO}$ & 14,86 & 15,19 & 17,57 & 16,37 & 18,01 & 18,05 & 16,44 & 16,00 & 18,11 & 17,77 & 17,29 & 18,46 \\
\hline $\mathrm{CaO}$ & 21,94 & 22,32 & 23,34 & 22,85 & 20,57 & 20,34 & 19,28 & 20,19 & 20,78 & 20,57 & 22,14 & 17,34 \\
\hline $\mathrm{Na}_{2} \mathrm{O}$ & 1,69 & 1,30 & 0,75 & 1,28 & 0,80 & 0,89 & 2,32 & 2,33 & 1,45 & 1,44 & 0,74 & 1,40 \\
\hline $\mathrm{K}_{2} \mathrm{O}$ & 0,00 & 0,01 & 0,01 & 0,02 & 0,00 & 0,03 & 0,00 & 0,02 & 0,04 & 0,01 & 0,01 & 0,01 \\
\hline $\mathrm{Cr}_{2} \mathrm{O}_{3}$ & 1,01 & 0,92 & 0,96 & 1,06 & 0,10 & 0,68 & 2,88 & 3,91 & 1,85 & 1,87 & 0,48 & 0,41 \\
\hline $\mathrm{NiO}$ & n.a. & 0,02 & n.a. & 0,01 & n.a. & 0,08 & n.a. & n.a. & 0,13 & 0,09 & n.a. & 0,00 \\
\hline Total & 101,07 & 98,08 & 100,40 & 99,18 & 99,80 & 98,94 & 99,24 & 99,82 & 100,32 & 98,91 & 99,50 & 98,63 \\
\hline \multicolumn{13}{|c|}{ Fórmula estrutural calculada com base em 6 oxigênios } \\
\hline $\mathrm{TSi}$ & 1,883 & 1,901 & 1,946 & 1,928 & 1,943 & 1,968 & 1,994 & 1,993 & 1,949 & 1,966 & 1,982 & 1,916 \\
\hline $\mathrm{TFe}^{3}$ & 0,010 & 0,005 & 0,025 & 0,035 & 0,057 & 0,032 & 0,000 & 0,000 & 0,051 & 0,029 & 0,018 & 0,084 \\
\hline TAl & 0,107 & 0,094 & 0,029 & 0,037 & 0,000 & 0,000 & 0,006 & 0,007 & 0,000 & 0,004 & 0,000 & 0,000 \\
\hline T P & 0,000 & 0,000 & 0,000 & 0,000 & 0,000 & 0,000 & 0,000 & 0,000 & 0,000 & 0,000 & 0,000 & 0,000 \\
\hline $\mathrm{T}$ total & 2,000 & 2,000 & 2,000 & 2,000 & 2,000 & 2,000 & 2,000 & 2,000 & 2,000 & 2,000 & 2,000 & 2,000 \\
\hline M1Al & 0,165 & 0,143 & 0,061 & 0,112 & 0,013 & 0,013 & 0,040 & 0,022 & 0,033 & 0,029 & 0,012 & 0,091 \\
\hline $\mathrm{M} 1 \mathrm{Cr}$ & 0,019 & 0,018 & 0,018 & 0,020 & 0,002 & 0,013 & 0,056 & 0,076 & 0,035 & 0,036 & 0,009 & 0,008 \\
\hline $\mathrm{M} 1 \mathrm{Fe}^{3}$ & 0,000 & 0,000 & 0,000 & 0,000 & 0,016 & 0,008 & 0,000 & 0,000 & 0,014 & 0,000 & 0,032 & 0,037 \\
\hline M1Ti & 0,011 & 0,002 & 0,000 & 0,000 & 0,040 & 0,021 & 0,001 & 0,000 & 0,009 & 0,008 & 0,001 & 0,017 \\
\hline $\mathrm{M} 1 \mathrm{Ni}$ & 0,000 & 0,001 & 0,000 & 0,000 & 0,000 & 0,002 & 0,000 & 0,000 & 0,004 & 0,003 & 0,000 & 0,000 \\
\hline${\mathrm{M} 1 \mathrm{Fe}^{2}}^{2}$ & 0,012 & 0,012 & 0,000 & 0,000 & 0,000 & 0,000 & 0,006 & 0,028 & 0,000 & 0,000 & 0,000 & 0,000 \\
\hline M1Nb & 0,000 & 0,000 & 0,000 & 0,000 & 0,000 & 0,000 & 0,000 & 0,000 & 0,000 & 0,000 & 0,000 & 0,000 \\
\hline M1Mg & 0,793 & 0,825 & 0,897 & 0,858 & 0,930 & 0,942 & 0,898 & 0,874 & 0,905 & 0,925 & 0,943 & 0,847 \\
\hline M1Mn & 0,000 & 0,000 & 0,000 & 0,000 & 0,000 & 0,000 & 0,000 & 0,000 & 0,000 & 0,000 & 0,002 & 0,000 \\
\hline M1total & 1,000 & 1,000 & 1,000 & 1,000 & 1,000 & 1,000 & 1,000 & 1,000 & 1,000 & 1,000 & 1,000 & 1,000 \\
\hline M2Mg & 0,000 & 0,000 & 0,023 & 0,010 & 0,050 & 0,039 & 0,000 & 0,000 & 0,059 & 0,034 & 0,000 & 0,148 \\
\hline $\mathrm{M} 2 \mathrm{Fe}^{2}$ & 0,038 & 0,033 & 0,023 & 0,016 & 0,085 & 0,100 & 0,075 & 0,040 & 0,043 & 0,066 & 0,078 & 0,074 \\
\hline M2Mn & 0,003 & 0,005 & 0,001 & 0,003 & 0,004 & 0,003 & 0,004 & 0,001 & 0,002 & 0,001 & 0,002 & 0,007 \\
\hline $\mathrm{M} 2 \mathrm{Ca}$ & 0,841 & 0,870 & 0,901 & 0,881 & 0,804 & 0,794 & 0,756 & 0,792 & 0,795 & 0,798 & 0,868 & 0,672 \\
\hline $\mathrm{M} 2 \mathrm{Na}$ & 0,117 & 0,092 & 0,052 & 0,089 & 0,056 & 0,063 & 0,165 & 0,165 & 0,100 & 0,101 & 0,052 & 0,098 \\
\hline M2total & 1,000 & 1,000 & 1,000 & 0,999 & 1,000 & 0,999 & 1,000 & 0,999 & 0,998 & 0,999 & 1,000 & 0,999 \\
\hline Mg\# & 0,930 & 0,942 & 0,952 & 0,946 & 0,861 & 0,875 & 0,917 & 0,927 & 0,900 & 0,910 & 0,880 & 0,837 \\
\hline $\mathrm{Ca} / \mathrm{Al}+\mathrm{Ca}$ & 0,755 & 0,786 & 0,909 & 0,855 & 0,984 & 0,984 & 0,942 & 0,964 & 0,960 & 0,960 & 0,986 & 0,881 \\
\hline $\mathrm{Cr} \#$ & 0,065 & 0,069 & 0,168 & 0,119 & 0,126 & 0,498 & 0,543 & 0,720 & 0,510 & 0,515 & 0,438 & 0,080 \\
\hline
\end{tabular}


O Lherzolitos e harzburgitos com espinélio

Peridotitos com flogopita $\square$ Harzburgitos e dunitos com Cr-espinélio

Peridotitos com flogopita e titanato $\triangle$ Harzburgitos com $\mathrm{Cr}$-espinélio e pargasita Harzburgito com bolsões de clinopiroxênio

田 Dunitos protogranulares Harzburgitos mosaico porfiroclásticos Megacristal
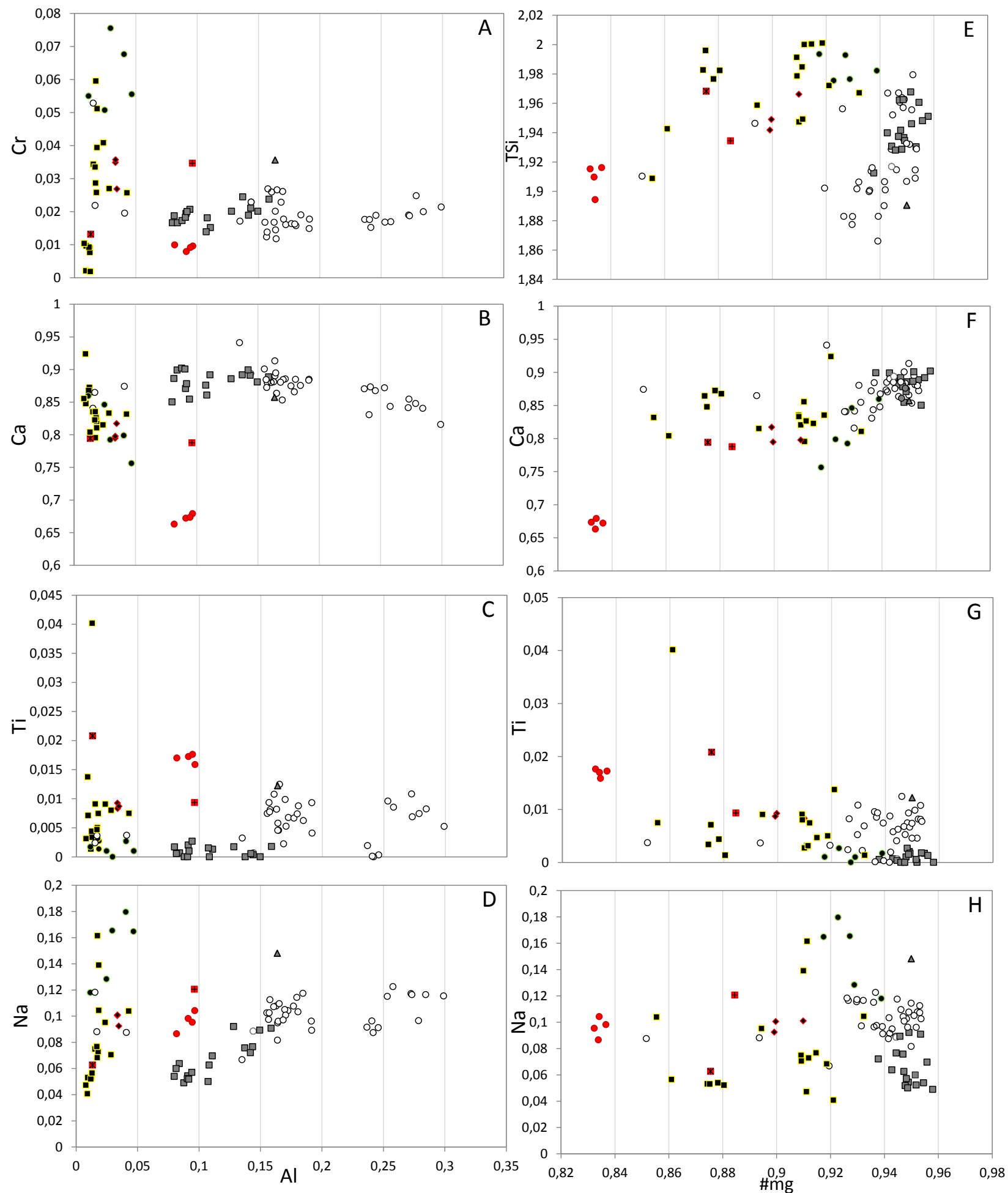

Figura 8- Composição química de clinopiroxênio de xenólitos e megacristal das intrusões Indaiá 1, Limeira 1 e Forca 1. A primeira coluna apresenta projeções de $\mathrm{Al}$ (apfu) vs. $\mathrm{Cr}$ (A), Ca (B) Ti (C) and In (D), e a segunda coluna mg\# $v$ s. $\mathrm{Si}(\mathrm{E}), \mathrm{Ca}(\mathrm{F}), \mathrm{Ti}(\mathrm{G})$ and $\mathrm{Na}(\mathrm{H})$. 
Capitulo V- Quimica Mineral de Elementos Maiores

Tabela 9- Coeficiente de partição de olivina/ortopiroxênio e ortopiroxênio/clinopiroxênio nos xenólitos mantélicos

$\mathrm{Ol} / \mathrm{Opx}$

peridotitos com espinélio

harzburgitos e dunitos sem espinélio

xenólitos com minerais minerais secundários

\begin{tabular}{|c|c|c|c|c|c|c|}
\hline $\begin{array}{l}\text { lherzolito } \\
\text { com } \\
\text { espinélio } \\
\text { com textura } \\
\text { protogranular }\end{array}$ & $\begin{array}{l}\text { lherzolito } \\
\text { com } \\
\text { espinélio } \\
\text { com textura } \\
\text { protogranular }\end{array}$ & $\begin{array}{l}\text { harzburgito } \\
\text { com Cr- } \\
\text { espinélio } \\
\text { com textura } \\
\text { granoblástica }\end{array}$ & $\begin{array}{l}\text { harzburgito } \\
\text { com Cr- } \\
\text { espinélio } \\
\text { com textura } \\
\text { granoblástica }\end{array}$ & $\begin{array}{l}\text { harzburgito } \\
\text { com Cr- } \\
\text { espinélio } \\
\text { com textura } \\
\text { granoblástica } \\
\text { com } \\
\text { pargasita }\end{array}$ & $\begin{array}{c}\text { harzburgito } \\
\text { com Cr- } \\
\text { espinélio } \\
\text { com textura } \\
\text { granoblástica } \\
\text { com } \\
\text { pargasita }\end{array}$ & $\begin{array}{c}\text { dunito } \\
\text { protogranular }\end{array}$ \\
\hline In1-4 & Lm1-17 & In1-3 & Lm1-20 & In1-24a & In1-50 & Lm1-14 \\
\hline 0,73 & 0,74 & 0,72 & 0,73 & 0,71 & 0,72 & 0,68 \\
\hline 0,02 & n.d. & n.d. & n.d. & 0,00 & 0,23 & 0,08 \\
\hline 0,02 & 0,00 & 0,00 & 0,00 & 0,00 & 0,00 & 0,00 \\
\hline 1,35 & 1,61 & 1,56 & 1,45 & 1,56 & 1,36 & 1,67 \\
\hline 0,92 & 1,33 & 0,99 & 0,80 & 0,74 & 0,68 & 0,54 \\
\hline 1,46 & 1,47 & 1,42 & 1,45 & 1,45 & 1,45 & 1,41 \\
\hline 0,00 & 0,01 & 0,00 & 0,00 & 0,00 & 0,04 & 0,07 \\
\hline 0,00 & n.d. & 2,83 & 0,10 & 0,00 & n.d. & 0,26 \\
\hline n.d. & 0,00 & 0,00 & n.d. & 0,00 & 0,00 & n.d. \\
\hline 0,02 & 0,00 & 0,06 & 0,00 & 0,00 & 0,07 & 0,11 \\
\hline 2,92 & 2,27 & n.d. & 26,59 & n.d. & 4,00 & 10,00 \\
\hline & & & & & & \\
\hline
\end{tabular}

harzburgito

porfiroclástico

harzburgito

porfiroclastico

porcão

amarelada)

In1-1
0,71
0,13
0,03
1,55
0,80
1,45
0,08
0,20
n.d.
0,14
n.d.
1,00

$\begin{array}{cc}\text { In1-1 } & \text { In } 1-33 \\ 0,72 & 0,72 \\ 0,07 & 0,29 \\ 0,05 & 0,02 \\ 1,75 & 1,78 \\ 0,91 & 2,11 \\ 1,43 & 1,43 \\ 0,14 & 0,08 \\ 0,18 & 0,38 \\ \text { n.d. } & \text { n.d. } \\ 0,32 & 0,05 \\ \text { n.d. } & 1,27 \\ 1,00 & 1,01\end{array}$

harzburgitos e dunitos sem espinélio

harzburgito harzburgito

harzburgito

com bolsão harzburgito com bolsão de

com mosaico flogopita com de com flogopita com

(centro de clinopiroxênio flogopita bolsões de cromita e

naturez

$\mathrm{Opx} / \mathrm{Cpx}$

\begin{tabular}{c|cccc} 
In1-33 & Lm1-15 & In1-20b & In1-12 & Lm1-1 \\
0,74 & 0,70 & 0,70 & 0,72 & 0,73 \\
0,00 & 0,00 & 0,97 & n.d. & 0,00 \\
0,05 & 0,01 & 0,02 & 0,00 & 0,08 \\
1,07 & 1,62 & 1,66 & 1,59 & 1,67 \\
1,25 & 0,87 & 1,25 & 0,83 & 0,61 \\
1,54 & 1,41 & 1,45 & 1,38 & 1,42 \\
0,01 & 0,00 & 0,19 & 0,00 & 0,04 \\
0,26 & 0,13 & 0,17 & 0,00 & 0,00 \\
n.d. & 1,43 & n.d. & n.d. & n.d. \\
0,00 & 0,29 & 0,15 & 0,35 & 0,00 \\
2,46 & 20,94 & n.d. & n.d. & 3,57 \\
1,01 & 1,00 & 1,00 & 1,01 & 1,02
\end{tabular}

peridotitos com espinélio

harzburgito com harzburgito porfiroclático com

harzburgito porfiroclático

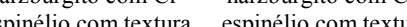
granoblástica
gálio com text-

granoblástica
Lm $1-20 a$

Lm1-20a
1,05
n.d.
0,67
3,40
0,55
2,13
0,02
0,08
0,00
0,31
1,01
1,01

porção amarelada)

In $1-3$
1,05
n.d.
0,88
3,13
6,41
2,06
0,01
0,01
0,86
0,50
n.a.
1,00

In1-1
1,07
0,18
4,04
1,25
1,11
1,88
0,07
0,21
n.d.
6,89
n.a.
1,01




\section{Flogopita}

A flogopita ocorre como fase secundária em bolsões dentro de harzburgitos e dunitos, em xenólito polimítico, flogopita ortopiroxenito e flogopitito. Os cristais apresentam intervalo amplo de mg\# $(0,85$ a 0,94$)$; a flogopita de xenólitos com ilmenita ( \pm titanatos) tem um intervalo menor $(0,88-0,91)$.

Em flogopita ortopiroxenito (In1-24b) o mg\# nas flogopitas $(0,87-0,89)$ está entre os menores de todas as amostras, sendo compatível também com o mg\# do ortopiroxênio desta amostra.

As Figuras 9A (mg\# vs. $\left.\mathrm{Al}_{2} \mathrm{O}_{3}\right)$ e 5B $\left(\mathrm{TiO}_{2}\right.$ vs. $\left.\mathrm{Cr}_{2} \mathrm{O}_{3}\right)$ ilustram as composições de xenólitos contendo flogopita projetadas nos diagramas discriminates de xenólitos MARID e PIC (Gregoire et al. 2002) e GP (peridotitos com granada), PP (peridotito com flogopita), PKP (peridotito com flogopita e K-richterita) e flogopitas com origem magmática (Erlank et al. 1987). Algumas amostras projetam no campo MARID (In1-6 e In1-2) e a maioria delas projeta muito próximo deste campo na Figura 9A, mas com mais $\mathrm{Al}_{2} \mathrm{O}_{3}$, já as amostras Lm1-15 e In1-20b encontram-se dentro ou muito próximas ao campo PIC. No diagrama da Figura 9B é possível verificar dois trends em direção ao campo de flogopitas magmáticas, os trends se iniciam com as amostras In1-6 (flogopita wherlito polimítico) e In1-24b (flogopita ortopiroxenito) no campo MARID.

\section{Ilmenita}

Cristais de ilmenita têm mg\# que varia de 0,36 a 0,43 . Os mais altos conteúdos de $\mathrm{Fe}^{2+}(0,541-0,592$ apfu) e os menores de $\mathrm{Cr}(0,018-0,026)$ são encontrados nas ilmenitas de flogopititos (In1-24b) e do flogopita ilmenita wehrlito (In1-6), enquanto os maiores conteúdos de $\mathrm{Mg}$ e $\mathrm{Cr}$ são encontrados em ilmenitas de dunito com bolsões de flogopita (In1-2). As ilmenitas das amostras estudadas, a exemplo de algumas flogopitas, projetam inteiramente no campo de xenólitos MARID de Gregoire et al. (2002) e no campo de ilmenita kimberlítica de Wyatt et al. (2004) no diagrama $\mathrm{TiO}_{2}$ vs. $\mathrm{MgO}$ da Figura 9C. 


\section{Anfibólio}

Cristais de anfibólio encontrados em harburgito e dunito com Cr-espinélio com textura granoblástica (In1-24a e In1-50) correspondem a pargasita de acordo com a nomenclatura de Hawtorne \& Oberti (2007); mg\# é 0,92-0.93. No sítio A, $\mathrm{Na}=0,76-$ 0,91(apfu) e $\mathrm{K}=0,17-0,23$ (apfu). No sítio $\mathrm{B}, \mathrm{Ca}=1,75-1,81$ (apfu) e no sítio $\mathrm{C}$, $\mathrm{Ti}=$ 0,21 to 0,24 (apfu). Si no sítio tetraédrico varia de 6,14 a 6,44 (apfu).

\section{Titanatos}

Cristais de titanatos da série da crinchtonita formando a solução sólida mathiasita-loverengita somente ocorrem na amostra Lm1-1 como bordas de reação em cromita. Os minerais desta série têm fórmula estrutural $\mathrm{AM}_{21} \mathrm{O}_{38}$, sendo que o sítio A hospeda $\mathrm{Ba}, \mathrm{K}, \mathrm{Sr}, \mathrm{Na}, \mathrm{Pb}, \mathrm{Ca}, \mathrm{U}$, e ETR, o sítio M hospeda Ti, Cr, Fe, Mg, Zr e Nb (Haggerty et al. 1983). Quando o sítio A é dominado por K o mineral é chamado de mathiasita, e quando o Ca é o principal elemento do sítio A ele é denominado loverengita. O Ti no sítio $\mathrm{M}$ corresponde a 12,7 to 14,3 apfu, Al varia de 0,21 to 0,30 , e Cr de 2,3 a 2,4 (apfu). Ca no sítio A varia de 0,47 a 0,53 apfu, e K de 0,35 a 3 apfu, deste modo foi classificado como mathiasita-loverengita por apresentar composições intermediárias entre estes end-members. O mg\# deste mineral varia de 0,88 a 0,91 , e é compatível com olivina e ortopiroxênio na amostra Lm1-1. Amostra muito semelhante foi descrita por Almeida et al. (2014) em outra amostra da intrusão Limeira 1.

\section{Termometria de xenólitos mantélicos}

Estimativas de temperatura podem ser feitas em xenólitos mantélicos, utilizando análises químicas em minerias em equilíbrio. Considerando que a passagem de espinélio a granada em peridotitos ocorre no sistema $\mathrm{CaO}-\mathrm{MgO}-\mathrm{Al}_{2} \mathrm{O}_{3}-\mathrm{SiO}_{2}$ perto de 15 kbar a $1200 \mathrm{~K}\left(926,85^{\circ} \mathrm{C}\right)$ e cerca de $20 \mathrm{kbar}$ para $1600 \mathrm{~K}\left(1326,85^{\circ} \mathrm{C}\right)(\mathrm{Jenkins} \&$ Newton 1979), a substituição de metade do $\mathrm{Al}_{2} \mathrm{O}_{3}$ por $\mathrm{Cr}_{2} \mathrm{O}_{3}$ aumenta a pressão em cerca de 16 kbar (MacGregor 1970), e a substituição total do $\mathrm{Al}_{2} \mathrm{O}_{3}$ resulta em um incremento de 28 kbar (O'Neill 1981), pode-se dizer que as cromitas, presentes em grande parte das amostras estudadas podem ser estáveis até 48 kbar. Em peridotitos mantélicos a estimativa da temperatura baseia-se em trocas catiônicas entre minerais que são pouco dependentes dos valores de pressão, de modo que foi assumida uma pressão arbritária de 20 kbar. Os geotermômetros mais utilizados baseiam-se: na troca 
de $\mathrm{Mg}$ e Fe entre ortopiroxênio e clinopiroxênio coexistentes (Brey \& Koehler 1990, Wells 1977, Bertrand \& Merrier 1985); no teor de Ca em ortopiroxênio (Brey \& Koehler 1990); na troca de Fe-Mg entre olivina e espinélio (podendo ser Cr-espinélio ou cromita) (Ballhaus 1991, O'Neill \& Wall 1987) e no teor de Al em ortopiroxênio (WittEickshen 1991). Já os geobarômetros somente têm calibrações adequadas para amostras contendo granada, e se baseiam: no conteúdo de Al em ortopiroxênio (MacGregor 1974, Nickel \& Green 1974, Brey \& Koehler 1990, Brey et al. 2008); na partição de Ca entre olivina e clinopiroxênio (Koehler \& Brey 1990); e nos teores de Al em olivina (Koehler \& Brey 1990), Cr em clinopiroxênio (Nimis \& Taylor 2000) e Cr em granada (Ryan et al. 1996). Como nenhum dos xenólitos estudados tem granada, somente será discutida neste capítulo a geotermometria.

As composições dos minerais foram inseridas em um programa que calcula temperaturas e pressões de rochas mantélicas a partir das composições dos minerais coexistentes em porcentagem em peso denominado PTEXL, desenvolvido por $\mathrm{T}$. Koehler e A.Girnis (baixado em http://www.mineralogie.uni-frankfurt.de). Este programa apresenta uma vasta gama de geotermobarômetros, porém como boa parte deles foram desenvolvidos para calibração de amostras portadoras de granada, diversas destas calibrações foram rejeitadas. As composições de cristais representativos, apresentadas nas tabelas de química mineral apresentadas neste capítulo foram utilizadas para os cálculos do programa, e os resultados se encontram na Tabela 10.

Os geotermômetros apresentados na Tabela 10 exibem ampla variação de temperatura entre as amostras, de 623 a $1325^{\circ} \mathrm{C}$.

Os termômetros baseados na troca $\mathrm{Mg}-\mathrm{Fe}$ em clinopiroxênio e ortopiroxênio e foram aplicados em peridotitos com espinélio, peridotitos com com Cr-espinélio, pois os cristais de clinopiroxênio presentes nestas amostras encontram-se em equilíbrio textural e químico. O mesmo não ocorre com clinopiroxênio das demais amostras, que são intersticiais ou associados a flogopita. Neste termômetro, a calibração de Wells (1977), apresenta em torno de $40-50^{\circ} \mathrm{C}$ mais alto que outras duas calibrações (Brey \& Koehler 1990; Bertrand \& Merrier 1975), estas últimas apresentam resultados similares entre si (Tabela 10). 

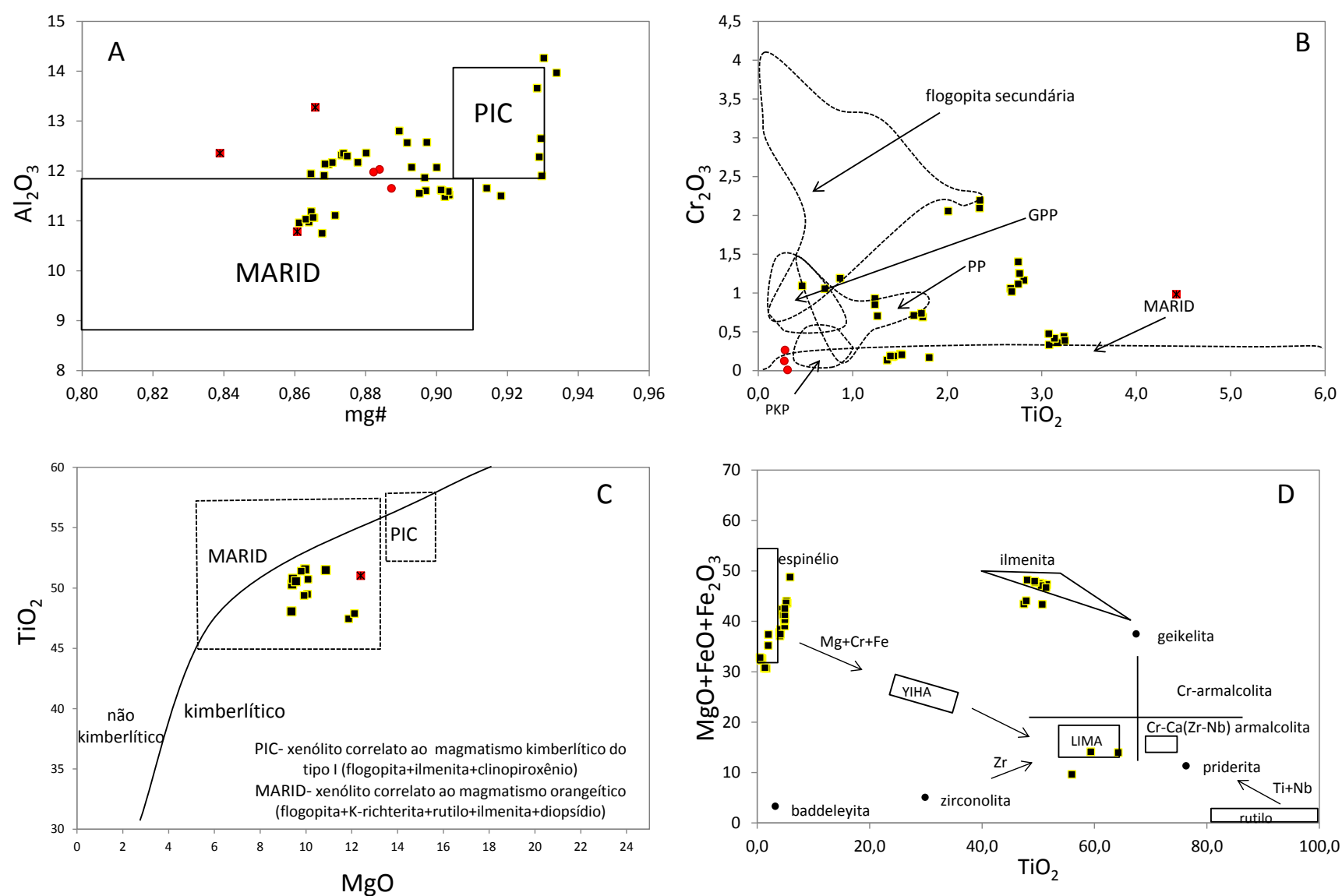

Figura 9- Diagramas de variação química ilustrando a composição de minerais de xenólitos do manto da APIP. A) mg \# vs. $\mathrm{Al}_{2} \mathrm{O}_{3}$ em flogopita, com os campos discriminantes de xenólitos do tipo MARID e PIC (Gregoire et al. 2002); B) $\mathrm{TiO}_{2} v s . \mathrm{Cr}_{2} \mathrm{O}_{3}$ em flogopita com campos discriminantes de flogopita de origem magmática, de peridotitos com granada (GP), peridotitos com flogopita (PP), peridotitos com flogopita e K-richterita (PKP), e de xenólitos MARID segundo Erlank et al. 1987; C) $\mathrm{MgO}$ vs. $\mathrm{TiO}_{2}$ em ilmenita e campos discriminantes de xenólitos MARID e PIC (Gregoire et al. 2002), e de ilmenitas kimberlíticas e não kimberlíticas; D) $\mathrm{TiO}_{2}$ vs. $\mathrm{MgO}+\mathrm{FeO}+\mathrm{Fe}_{2} \mathrm{O}_{3}$ em cromita, ilmenita e titanato da série loverengita-mathiasita e campos correspondentes a óxidos de origem metassomática (Haggerty 1995). 
Tabela 10- Resultados dos geotermômetros calculados pelo programa PTEXL para amostras de xenólitos representativos baseados na troca entre Fe-Mg entre clinopiroxênio e ortopiroxênio, e entre olivina e espinélio; e no conteúdo de $\mathrm{Ca}$ e $\mathrm{Al}$ em ortopiroxênio. As temperaturas são dadas em ${ }^{\circ} \mathrm{C}$.

\begin{tabular}{|c|c|c|c|c|c|c|c|c|c|c|c|c|}
\hline & \multicolumn{6}{|c|}{ peridotitos com espinélio } & \multicolumn{3}{|c|}{ harzburgitos e dunitos sem espinélio } & \multicolumn{3}{|c|}{ xenólitos com minerais minerais } \\
\hline & $\begin{array}{l}\text { lherzolito com } \\
\text { espinélio com } \\
\text { textura } \\
\text { protogranular }\end{array}$ & $\begin{array}{l}\text { lherzolito com } \\
\text { espinélio com } \\
\text { textura } \\
\text { protogranular }\end{array}$ & $\begin{array}{l}\text { harzburgito } \\
\text { com Cr- } \\
\text { espinélio com } \\
\text { textura } \\
\text { granoblástica }\end{array}$ & $\begin{array}{l}\text { harzburgito } \\
\text { com Cr- } \\
\text { espinélio com } \\
\text { textura } \\
\text { granoblástica }\end{array}$ & $\begin{array}{l}\text { harzburgito } \\
\text { com Cr- } \\
\text { espinélio com } \\
\text { textura } \\
\text { granoblástica } \\
\text { com pargasita }\end{array}$ & $\begin{array}{l}\text { harzburgito } \\
\text { com Cr- } \\
\text { espinélio com } \\
\text { textura } \\
\text { granoblástica } \\
\text { com pargasita }\end{array}$ & $\begin{array}{c}\text { dunito } \\
\text { protogranular }\end{array}$ & $\begin{array}{l}\text { harzburgito } \\
\text { porfiroclático } \\
\text { com mosaico } \\
\text { (cristal em } \\
\text { mosaico) }\end{array}$ & $\begin{array}{l}\text { harzburgito } \\
\text { porfiroclástco } \\
\text { com mosaico } \\
\text { (cristal em } \\
\text { mosaico) }\end{array}$ & $\begin{array}{c}\text { harzburgito } \\
\text { com bolsão } \\
\text { de flogopita } \\
\text { com } \\
\text { cromita }\end{array}$ & $\begin{array}{l}\text { harzburgito } \\
\text { com bolsão de } \\
\text { flogopita com } \\
\text { clinopiroxênio } \\
\text { e cromita }\end{array}$ & $\begin{array}{l}\text { harzburgito } \\
\text { com bolsão de } \\
\text { flogopita com } \\
\text { clinopiroxênio, } \\
\text { cromita e } \\
\text { titanato } \\
\text { associado }\end{array}$ \\
\hline & In1-4 & Lm1-17 & In1-3 & Lm1-20 & In1-24a & In1-50 & Lm1-14 & In1-1 & In1-33 & In1-20b & Lm1-15 & Lm1-1 \\
\hline \multicolumn{13}{|l|}{ Fe-Mg entre Cpx e Opx } \\
\hline Brey \& Koehler (1990) & 742,4 & 720,6 & 763,3 & 638,3 & n.d. & n.d. & n.d. & n.d. & n.d. & n.d. & n.d. & n.d. \\
\hline Wells (1977) & 786,0 & 775,8 & 835,3 & 734,6 & n.d. & n.d. & n.d. & n.d. & n.d. & n.d. & n.d. & n.d. \\
\hline Bertrand \& Merrier (1985) & 729,4 & 720,1 & 762,2 & 660,2 & n.d. & n.d. & n.d. & n.d. & n.d. & n.d. & n.d. & n.d. \\
\hline \multicolumn{13}{|l|}{ Ca em Opx } \\
\hline Brey \& Koehler (1990) & 799,0 & 896,3 & 831,6 & 849,6 & n.d. & n.d. & n.d. & 1187,5 & 1167,2 & 998,7 & n.d. & 1167,2 \\
\hline \multicolumn{13}{|l|}{ Al em Opx } \\
\hline Witt-Eickshen (1991) & 998,0 & 1022,0 & 889,7 & 860,9 & 877,3 & 795,2 & 780,4 & n.d. & n.d. & 834,3 & 756,7 & 756,5 \\
\hline \multicolumn{13}{|l|}{ Fe-Mg entre Ol e Sp } \\
\hline O’Neill \& Wall (1987) & 1208,5 & 1269,8 & 665,7 & 819,0 & 636,8 & 741,2 & 1067,0 & n.d. & n.d. & 1002,8 & 1033,0 & 1136,1 \\
\hline Ballhaus et al. (1991) & 1270,4 & 1325,4 & 652,7 & 828,1 & 623,2 & 725,4 & 1023,5 & n.d. & n.d. & 968,0 & 983,7 & 1096,2 \\
\hline
\end{tabular}


O termômetro de $\mathrm{Ca}$ em ortopiroxênio (Brey \& Koehler 1990) fornece temperaturas sistematicamente mais altas, em até $100^{\circ} \mathrm{C}$, em relação aos métodos baseados na troca $\mathrm{Mg}-\mathrm{Fe}$ entre clinopiroxênio e ortopiroxênio (e.g., 800-900 ${ }^{\circ} \mathrm{C}$ ) em peridotitos com espinélio ou Cr-espinélio. Este método (Brey \& Koehler 1990) foi aplicado as amostras de harzburgitos porfiroclásticos com mosaicos e em xenólitos metassomatisados, de modo que a temperatura obtida para estes $\left(1000^{\circ}-1200^{\circ} \mathrm{C}\right)$ é maior que a obtida em peridotitos com espinélio e Cr-espinélio.

Os resultados pela calibração de Witt-Eickshen (1991) em termômetro de conteúdo de $\mathrm{Al}$ em ortopiroxênio foram de pouca utilidade, uma vez que as amostras com maior teor de $\mathrm{Al}$ são calculadas como de maior temperatura $\left(1000^{\circ} \mathrm{C} \mathrm{em}\right.$ peridotitos com espinélio), este método não leva em conta os efeitos de diminuição de Al decorrentes de fusão parcial, que é registrada em grande parte das amostras de xenólito da APIP. Registra-se, no entanto que as menores temperaturas obtidas por este termômetro são dos xenólitos metassomatisados $\left(760-830^{\circ} \mathrm{C}\right)$, provavelmente decorrente de um maior grau de fusão parcial e empobrecimento em Al nestas amostras.

O geotermômetro baseado na troca em troca de $\mathrm{Mg}-\mathrm{Fe}$ entre olivina e espinélio (ou Cr-espinélio/cromita) fornece temperaturas muito elevadas $\left(1209-1325^{\circ} \mathrm{C}\right)$ para os dois peridotitos com espinélio se comparadas com as amostras com Cr-espinélio (623$828^{\circ} \mathrm{C}$ ). Estas altas temperaturas podem ser registros da cristalização de olivina e espinélio em condições de gradiente geotérmico muito mais altos que no Cretáceo, provavelmente no Arqueano se levadas em consideração as idades-modelo Re depletion superiores a 2,4 Ga para espinélio peridotitos obtidas por Carlson et al. (2007).

Estima-se que os dados geortermométricos obtidos em xenólitos metassomatisados pelo termômetro de Fe-Mg em núcleos de olivina e cromita sejam registro da temperatura das rochas antes do metassomatismo $\left(970-1130^{\circ} \mathrm{C}\right)$. A amostra de dunito protogranular Lm1-14 apresenta temperaturas semelhantes (em torno de $1050^{\circ} \mathrm{C}$ ). Esta amostra não contém clinopiroxênio, tem altos valores de mg\# em olivina e ortopiroxênio, e contém cromita, que fatores indicam elevada fusão parcial nesta amostra. Características químicas similares são encontradas na amostra In1-20b (harzburgito protogranular com bolsões de flogopita), indicando que olivina e cromita foram pouco afetadas pelo metassomatismo, de modo que o geotermômetro tenha aplicabilidade comprovada para esta amostra. 
Capitulo VI- Química Mineral de Elementos Traço

\section{Capítulo VI- Química Mineral de Elementos Traço}

Neste capítulo são discutidos os dados de elementos traços efetuados nos minerais de 15 amostras. Devido à grande quantidade de análises efetuadas serão apresentados neste capítulo os dados de elementos traço na forma de média e desvio padrão relativo (\%) em 8 amostras representativas (Tabela 11-16). As tabelas de dados completa que mostra os resultados de acordo com as amostras analisadas e minerais são mostrados no ANEXO D desta tese.

Tabela 11- Médias (em ppm) e desvios padrão relativos (em \%) das composições de elementos traços de olivina em amostras representativas. n.d.-elementos não analisado ou abaixo do limite de detecção.

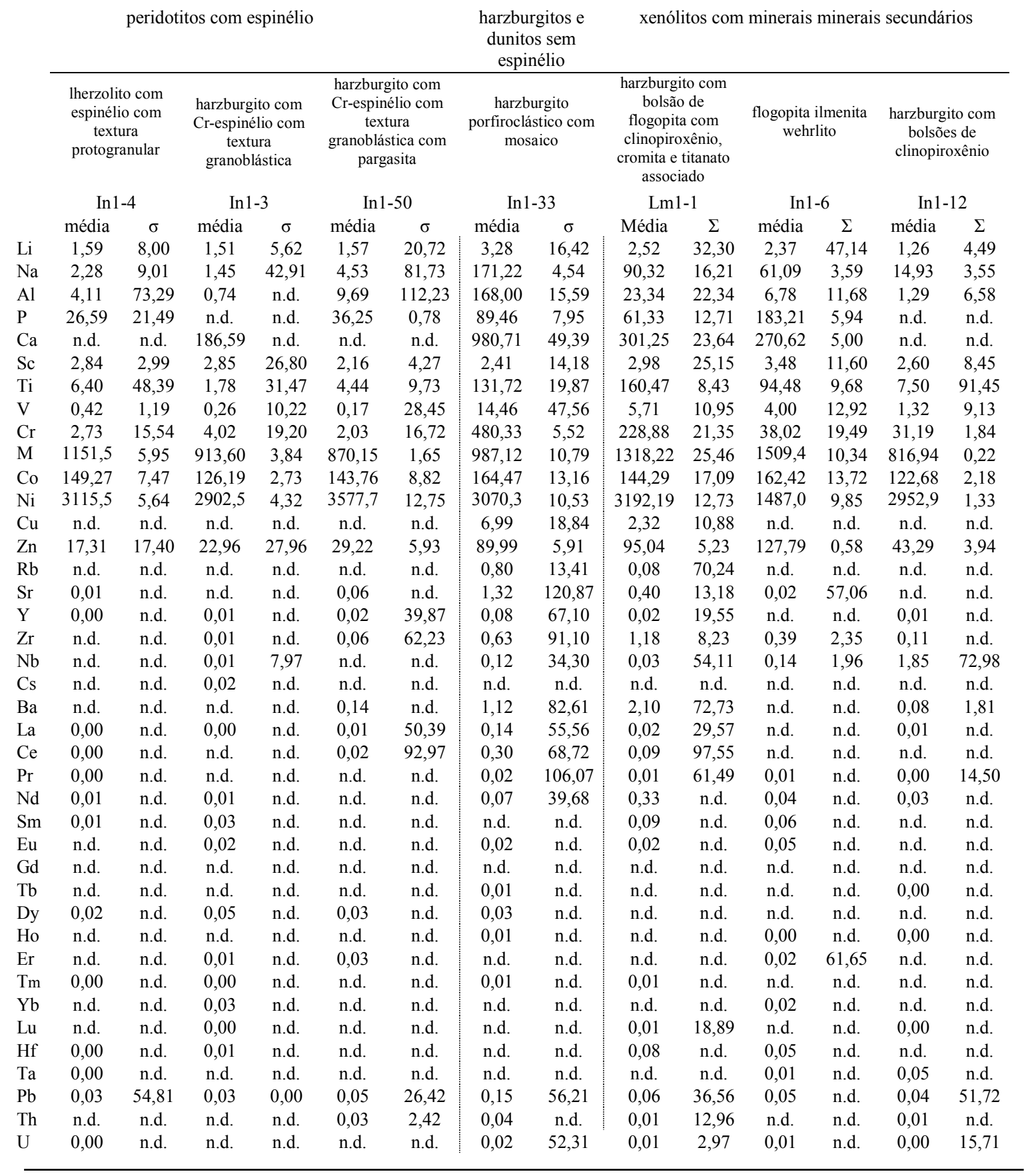


Capitulo VI- Química Mineral de Elementos Traço

Tabela 12- Médias (em ppm) e desvios padrão relativos (em \%) das composições de elementos traços de ortopiroxênio de amostras representativas. n.d.- elementos não analisados ou abaixo do limite de detecção.

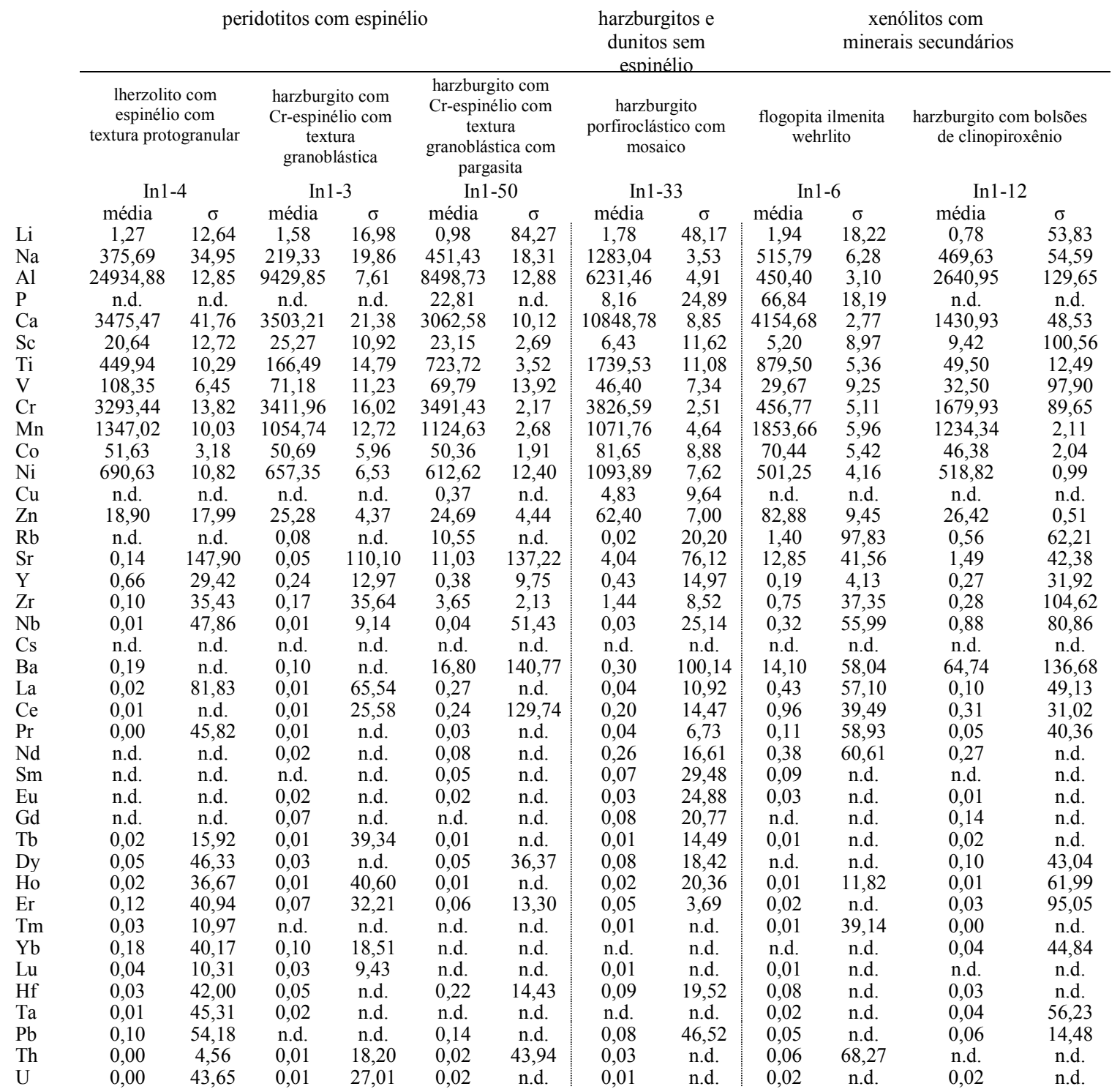


Capitulo VI- Quimica Mineral de Elementos Traço

Tabela 13- Médias (em ppm) e desvios padrão relativos (em \%) das composições de elementos traços de clinopiroxênio de amostras representativas. n.d.- elementos não analisados ou abaixo do limite de detecção.

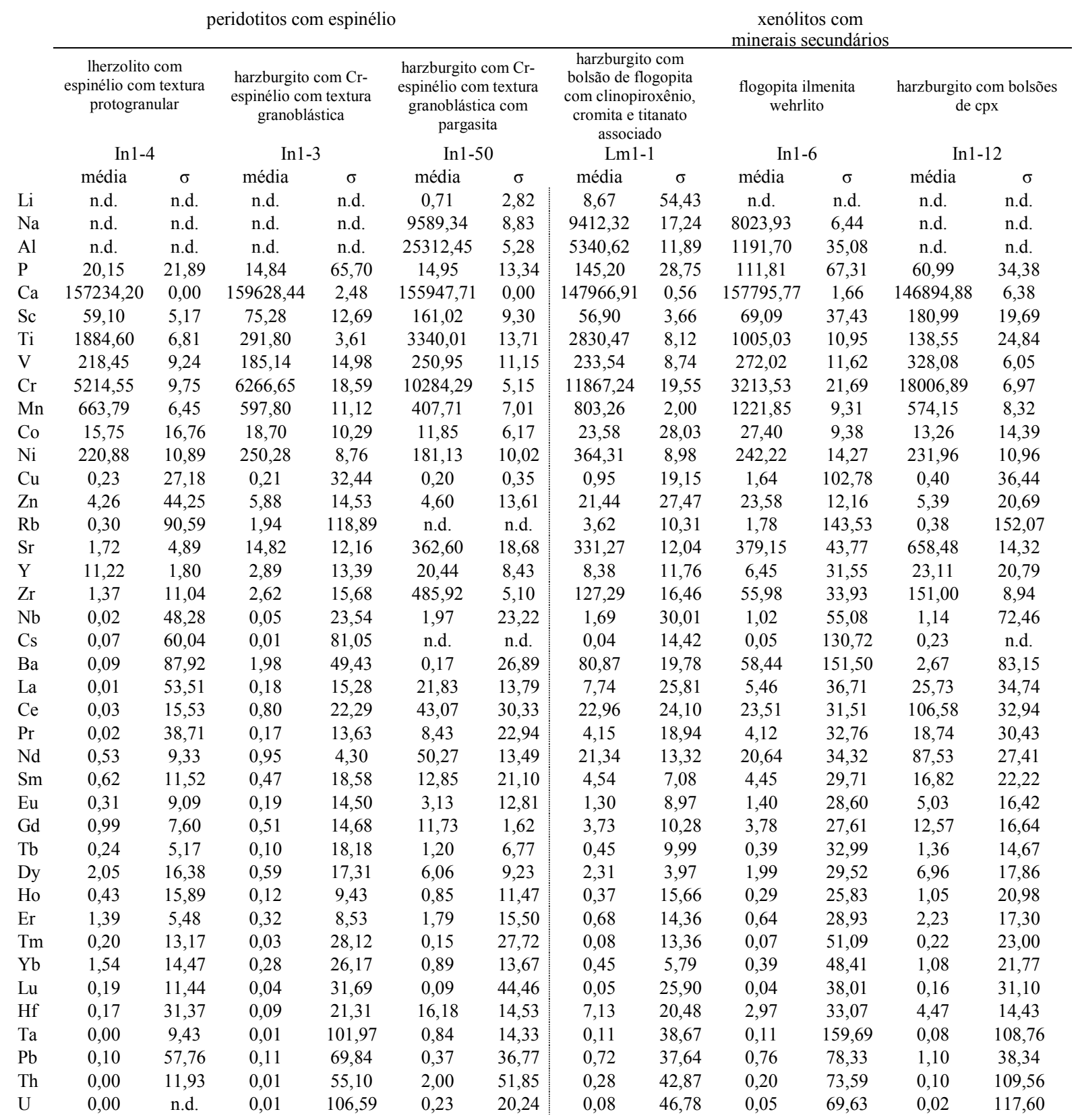


Capitulo VI- Química Mineral de Elementos Traço

Tabela 14- Médias (em ppm) e desvios padrão relativos (em \%) das composições de elementos traços em espinélio, Cr-espinélio, cromita, ilmenita e titanatos de amostras representativas. n.d.- elementos não analisados ou abaixo do limite de detecção.

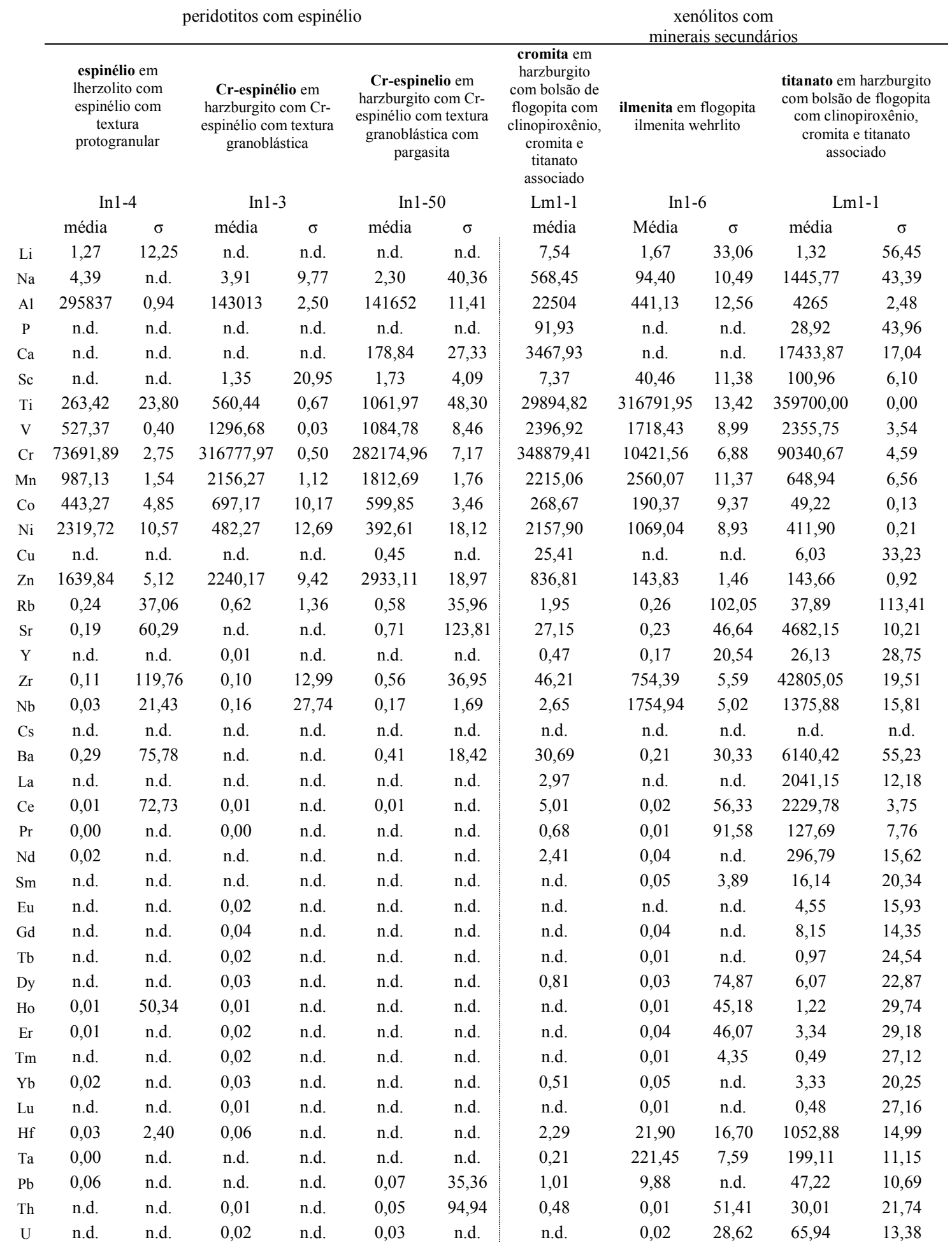


Capitulo VI- Química Mineral de Elementos Traço

Tabela 15- Médias (em ppm) e desvios padrão relativos (em \%) das composições de elementos traços de pargasita e flogopita de amostras representativas. n.d. -elementos não analisados ou abaixo do limite de detecção.

\begin{tabular}{|c|c|c|c|c|c|c|}
\hline \multirow{2}{*}{\multicolumn{3}{|c|}{$\begin{array}{c}\text { pargasita de peridotitos } \\
\text { com espinélio } \\
\text { harzburgito com Cr-espinélio } \\
\text { com textura granoblástica com } \\
\text { pargasita }\end{array}$}} & \multicolumn{4}{|c|}{$\begin{array}{l}\text { flogopita de xenólitos com } \\
\text { minerais secundários }\end{array}$} \\
\hline & & & \multicolumn{2}{|c|}{$\begin{array}{l}\text { harzburgito com bolsão de flogopita com } \\
\text { clinopiroxênio, cromita e titanato associado }\end{array}$} & \multicolumn{2}{|c|}{ flogopita ilmenita wehrlito } \\
\hline & \multicolumn{2}{|c|}{ In $1-50$} & \multicolumn{2}{|c|}{ Lm1-1 } & \multicolumn{2}{|c|}{ In1-6 } \\
\hline & média & $\sigma$ & média & $\sigma$ & Média & $\sigma$ \\
\hline $\mathrm{Li}$ & 9,38 & 59,65 & 13,06 & 24,64 & 28,64 & 24,92 \\
\hline $\mathrm{Na}$ & 19166,36 & 4,55 & 346,81 & 41,15 & 2432,61 & 31,40 \\
\hline $\mathrm{Al}$ & 72520 & 2,77 & 66706 & 29,09 & 62301 & 17,13 \\
\hline$P$ & 73,84 & 6,98 & n.d. & n.d. & n.d. & n.d. \\
\hline $\mathrm{Ca}$ & 81737,94 & 1,31 & 61,40 & n.d. & 1059,86 & n.d. \\
\hline $\mathrm{Sc}$ & 152,21 & 3,93 & 3,97 & 17,10 & 3,09 & 2,52 \\
\hline $\mathrm{Ti}$ & 15613,64 & 2,46 & 13454,20 & 31,85 & 11168,25 & 8,41 \\
\hline V & 377,93 & 4,50 & 128,44 & 27,36 & 147,63 & 9,25 \\
\hline $\mathrm{Cr}$ & 13221,07 & 12,09 & 6017,14 & 34,23 & 1588,34 & 6,39 \\
\hline $\mathrm{Mn}$ & 260,80 & 7,10 & 163,83 & 27,25 & 252,35 & 4,26 \\
\hline $\mathrm{Co}$ & 25,16 & 2,85 & 47,44 & 11,98 & 74,52 & 7,70 \\
\hline $\mathrm{Ni}$ & 615,58 & 0,79 & 1254,90 & 22,20 & 1157,01 & 6,00 \\
\hline $\mathrm{Cu}$ & 0,73 & 21,87 & 2,37 & 29,60 & n.d. & n.d. \\
\hline $\mathrm{Zn}$ & 8,16 & 19,68 & 33,28 & 27,43 & 56,50 & 1,10 \\
\hline $\mathrm{Rb}$ & 6,33 & 10,07 & 334,84 & 36,14 & 711,26 & 2,02 \\
\hline $\mathrm{Sr}$ & 533,42 & 43,13 & 9,71 & 40,05 & 4,27 & 33,45 \\
\hline Y & 23,93 & 9,30 & 0,09 & 17,17 & 0,09 & n.d. \\
\hline $\mathrm{Zr}$ & 396,30 & 9,49 & 80,12 & 39,47 & 8,01 & 6,89 \\
\hline $\mathrm{Nb}$ & 414,86 & 48,77 & 6,80 & 18,72 & 20,26 & 4,68 \\
\hline Cs & 0,01 & n.d. & n.d. & n.d. & 4,47 & 3,16 \\
\hline $\mathrm{Ba}$ & 260,11 & 9,07 & 469,12 & 40,53 & 182,95 & 32,92 \\
\hline $\mathrm{La}$ & 34,25 & 40,57 & 0,02 & n.d. & 0,08 & n.d. \\
\hline $\mathrm{Ce}$ & 67,86 & 45,50 & 0,02 & 31,59 & 0,15 & n.d. \\
\hline $\operatorname{Pr}$ & 10,78 & 50,49 & n.d. & n.d. & 0,01 & n.d. \\
\hline $\mathrm{Nd}$ & 56,99 & 52,37 & 0,11 & n.d. & n.d. & n.d. \\
\hline $\mathrm{Sm}$ & 13,63 & 41,12 & n.d. & n.d. & n.d. & n.d. \\
\hline $\mathrm{Eu}$ & 3,63 & 36,05 & n.d. & n.d. & n.d. & n.d. \\
\hline $\mathrm{Gd}$ & 10,88 & 29,76 & n.d. & n.d. & n.d. & n.d. \\
\hline $\mathrm{Tb}$ & 1,30 & 18,51 & n.d. & n.d. & n.d. & n.d. \\
\hline Dy & 6,75 & 10,37 & n.d. & n.d. & n.d. & n.d. \\
\hline Ho & 0,91 & 3,73 & n.d. & n.d. & n.d. & n.d. \\
\hline $\mathrm{Er}$ & 2,09 & 7,15 & n.d. & n.d. & 0,04 & n.d. \\
\hline $\mathrm{Tm}$ & 0,20 & 6,00 & n.d. & n.d. & n.d. & n.d. \\
\hline $\mathrm{Yb}$ & 1,10 & 5,34 & 0,15 & n.d. & n.d. & n.d. \\
\hline $\mathrm{Lu}$ & 0,15 & 14,94 & 0,01 & n.d. & n.d. & n.d. \\
\hline Hf & 12,20 & 22,24 & 1,06 & 39,54 & 0,27 & 20,05 \\
\hline $\mathrm{Ta}$ & 26,26 & 69,31 & 0,66 & 35,57 & 1,66 & 11,54 \\
\hline $\mathrm{Pb}$ & 0,72 & 9,42 & 0,19 & 22,64 & 0,22 & n.d. \\
\hline Th & 2,17 & 34,94 & n.d. & n.d. & 0,03 & n.d. \\
\hline $\mathrm{U}$ & 0,30 & 30,29 & 0,01 & n.d. & 0,02 & 17,40 \\
\hline
\end{tabular}


Capitulo VI- Química Mineral de Elementos Traço

Tabela 16- Coeficientes de partição Ol/Opx e Opx/Cpx com base na média dos elementos traço em amostras representativas. n.d. -elementos não analisado ou abaixo do limite de detecção.

\begin{tabular}{|c|c|c|c|c|c|c|c|c|c|c|c|}
\hline \multirow{2}{*}{\multicolumn{2}{|c|}{$\begin{array}{c}\text { lherzolito } \\
\text { com } \\
\text { espinélio } \\
\text { com textura } \\
\text { protogranular }\end{array}$}} & \multicolumn{5}{|c|}{ Ol/Opx } & \multicolumn{5}{|c|}{$\mathrm{Opx} / \mathrm{Cpx}$} \\
\hline & & $\begin{array}{l}\text { harzburgito } \\
\text { com Cr- } \\
\text { espinélio } \\
\text { com textura } \\
\text { granoblástica }\end{array}$ & $\begin{array}{l}\text { harzburgito } \\
\text { com Cr- } \\
\text { espinélio } \\
\text { com textura } \\
\text { granoblástica } \\
\text { com } \\
\text { pargasita }\end{array}$ & $\begin{array}{l}\text { harzburgito } \\
\text { porfiroclástico } \\
\text { com mosaico }\end{array}$ & $\begin{array}{l}\text { flogopita } \\
\text { ilmenita } \\
\text { wehrlito }\end{array}$ & $\begin{array}{l}\text { harzburgito com } \\
\text { bolsões de cpx }\end{array}$ & $\begin{array}{l}\text { lherzolito com } \\
\text { espinélio }\end{array}$ & $\begin{array}{c}\text { harzburgito } \\
\text { com Cr- } \\
\text { espinélio }\end{array}$ & $\begin{array}{l}\text { harzburgito } \\
\text { com Cr- } \\
\text { espinélio com } \\
\text { pargasita }\end{array}$ & $\begin{array}{c}\text { flogopita } \\
\text { ilmenita wehrlito }\end{array}$ & $\begin{array}{l}\text { harzburgito com } \\
\text { bolsões de cpx }\end{array}$ \\
\hline & In1-4 & In $1-3$ & In $1-50$ & In $1-33$ & In1-6 & In $1-12$ & In $1-4$ & In $1-3$ & In $1-50$ & In $1-6$ & In $1-12$ \\
\hline $\mathrm{Li}$ & 1,25 & 0,96 & 1,61 & 1,84 & 1,22 & 1,63 & n.d. & n.d. & 1,38 & n.d. & n.d. \\
\hline $\mathrm{Na}$ & 0,01 & 0,01 & 0,01 & 0,13 & 0,12 & 0,03 & n.d. & n.d. & 0,05 & 0,06 & n.d. \\
\hline $\mathrm{Al}$ & 0,00 & 0,00 & 0,00 & 0,03 & 0,02 & 0,00 & n.d. & n.d. & 0,34 & 0,38 & n.d. \\
\hline$P$ & n.d. & n.d. & 1,59 & 10,97 & 2,74 & n.d. & n.d. & n.d. & 1,53 & 0,60 & n.d. \\
\hline $\mathrm{Ca}$ & n.d. & 0,05 & n.d. & 0,09 & 0,07 & n.d. & 0,02 & 0,02 & 0,02 & 0,03 & 0,01 \\
\hline $\mathrm{Sc}$ & 0,14 & 0,11 & 0,09 & 0,38 & 0,67 & 0,28 & 0,35 & 0,34 & 0,14 & 0,08 & 0,05 \\
\hline $\mathrm{Ti}$ & 0,01 & 0,01 & 0,01 & 0,08 & 0,11 & 0,15 & 0,24 & 0,57 & 0,22 & 0,88 & 0,36 \\
\hline $\mathrm{V}$ & 0,00 & 0,00 & 0,00 & 0,31 & 0,13 & 0,04 & 0,50 & 0,38 & 0,28 & 0,11 & 0,10 \\
\hline $\mathrm{Cr}$ & 0,00 & 0,00 & 0,00 & 0,13 & 0,08 & 0,02 & 0,63 & 0,54 & 0,34 & 0,14 & 0,09 \\
\hline $\mathrm{Mn}$ & 0,85 & 0,87 & 0,77 & 0,92 & 0,81 & 0,66 & 2,03 & 1,76 & 2,76 & 1,52 & 2,15 \\
\hline Co & 2,89 & 2,49 & 2,85 & 2,01 & 2,31 & 2,65 & 3,28 & 2,71 & 4,25 & 2,57 & 3,50 \\
\hline $\mathrm{Ni}$ & 4,51 & 4,42 & 5,84 & 2,81 & 2,97 & 5,69 & 3,13 & 2,63 & 3,38 & 2,07 & 2,24 \\
\hline $\mathrm{Cu}$ & n.d. & n.d. & n.d. & 1,45 & n.d. & n.d. & n.d. & n.d. & 1,83 & n.d. & n.d. \\
\hline $\mathrm{Zn}$ & 0,92 & 0,91 & 1,18 & 1,44 & 1,54 & 1,64 & 4,44 & 4,30 & 5,36 & 3,51 & 4,90 \\
\hline $\mathrm{Rb}$ & n.d. & n.d. & n.d. & 38,57 & n.d. & n.d. & n.d. & 0,04 & n.d. & 0,78 & 1,45 \\
\hline $\mathrm{Sr}$ & 0,04 & n.d. & 0,01 & 0,33 & 0,00 & n.d. & 0,08 & 0,00 & 0,03 & 0,03 & 0,00 \\
\hline Y & 0,01 & 0,03 & 0,04 & 0,18 & n.d. & 0,04 & 0,06 & 0,08 & 0,02 & 0,03 & 0,01 \\
\hline $\mathrm{Zr}$ & n.d. & 0,04 & 0,02 & 0,44 & 0,52 & 0,39 & 0,07 & 0,07 & 0,01 & 0,01 & 0,00 \\
\hline $\mathrm{Nb}$ & n.d. & 0,54 & n.d. & 4,30 & 0,45 & 2,11 & 0,49 & 0,25 & 0,02 & 0,31 & 0,77 \\
\hline Cs & n.d. & n.d. & n.d. & n.d. & n.d. & n.d. & n.d. & n.d. & n.d. & n.d. & n.d. \\
\hline $\mathrm{Ba}$ & n.d. & n.d. & 0,01 & 3,75 & n.d. & 0,00 & 2,20 & 0,05 & 100,19 & 0,24 & 24,28 \\
\hline $\mathrm{La}$ & 0,10 & 0,34 & 0,03 & 3,73 & n.d. & 0,10 & 2,32 & 0,05 & 0,01 & 0,08 & 0,00 \\
\hline $\mathrm{Ce}$ & 0,46 & n.d. & 0,09 & 1,48 & n.d. & n.d. & 0,33 & 0,02 & 0,01 & 0,04 & 0,00 \\
\hline $\operatorname{Pr}$ & 0,21 & n.d. & n.d. & 0,56 & 0,05 & 0,08 & 0,14 & 0,04 & 0,00 & 0,03 & 0,00 \\
\hline $\mathrm{Nd}$ & n.d. & 0,57 & n.d. & 0,27 & 0,10 & 0,10 & n.d. & 0,02 & 0,00 & 0,02 & 0,00 \\
\hline $\mathrm{Sm}$ & n.d. & n.d. & n.d. & n.d. & 0,61 & n.d. & n.d. & n.d. & 0,00 & 0,02 & n.d. \\
\hline $\mathrm{Eu}$ & n.d. & 1,20 & n.d. & 0,79 & 1,93 & n.d. & n.d. & 0,11 & 0,00 & 0,02 & 0,00 \\
\hline $\mathrm{Gd}$ & n.d. & n.d. & n.d. & n.d. & n.d. & n.d. & n.d. & 0,13 & n.d. & n.d. & 0,01 \\
\hline $\mathrm{Tb}$ & n.d. & n.d. & n.d. & 1,09 & n.d. & 0,21 & 0,06 & 0,14 & 0,01 & 0,03 & 0,01 \\
\hline Dy & 0,35 & 1,84 & 0,51 & 0,43 & n.d. & n.d. & 0,03 & 0,04 & 0,01 & n.d. & 0,01 \\
\hline Ho & n.d. & n.d. & n.d. & 0,22 & 0,26 & 0,41 & 0,05 & 0,13 & 0,02 & 0,05 & 0,01 \\
\hline $\mathrm{Er}$ & n.d. & 0,13 & 0,51 & n.d. & 0,81 & n.d. & 0,09 & 0,22 & 0,03 & 0,04 & 0,01 \\
\hline $\mathrm{Tm}$ & 0,08 & n.d. & n.d. & 0,60 & n.d. & n.d. & 0,13 & n.d. & n.d. & 0,19 & 0,02 \\
\hline $\mathrm{Yb}$ & n.d. & 0,28 & n.d. & n.d. & n.d. & n.d. & 0,12 & 0,34 & n.d. & n.d. & 0,04 \\
\hline $\mathrm{Lu}$ & n.d. & 0,10 & n.d. & n.d. & n.d. & n.d. & 0,20 & 0,82 & n.d. & 0,13 & n.d. \\
\hline $\mathrm{Hf}$ & 0,12 & 0,21 & n.d. & n.d. & 0,66 & n.d. & 0,16 & 0,51 & 0,01 & 0,03 & 0,01 \\
\hline $\mathrm{Ta}$ & 0,09 & n.d. & n.d. & n.d. & 0,70 & 1,13 & 4,58 & 1,29 & n.d. & 0,19 & 0,51 \\
\hline $\mathrm{Pb}$ & 0,26 & n.d. & 0,32 & 1,98 & 0,96 & 0,68 & 1,04 & n.d. & 0,39 & 0,07 & 0,06 \\
\hline Th & n.d. & n.d. & 1,48 & 1,63 & n.d. & n.d. & 0,75 & 1,31 & 0,01 & 0,30 & n.d. \\
\hline $\mathrm{U}$ & 0,19 & n.d. & n.d. & 2,43 & 0,32 & 0,13 & 2,53 & 0,88 & 0,10 & 0,41 & 0,92 \\
\hline
\end{tabular}

1. Metais de Transição e elementos de alta carga iônica (HFSE)

Os metais de transição (Ti, Cr, Co, Zn, Ni, Mn, Sc e V) e os HFSE estudados (Zr, Hf, Nb, Ta, Y, U, Th e Pb) tem ampla variação nas concentrações nos minerais de cada grupo de amostras estudado. Os elementos terras raras pesados (ETRP), que se enquadram no grupo HFSE serão descritos do item 3. deste capítulo.

Em olivina os mais altos níveis de $\mathrm{Ti}, \mathrm{Zn}, \mathrm{V}$ e $\mathrm{Cr}$ estão em peridotitos com espinélio. As amostras com anfibólio têm maiores quantidades de $\mathrm{Ni}$ e $\mathrm{Zn}$ e menores valores de $\mathrm{Sc}, \mathrm{V}, \mathrm{Cr}$ e $\mathrm{Mn}$ entre os peridotitos com espinélio. A olivina de xenólitos 
com flogopita tem os maiores valores de Sc, Mn, e Zn, e Ti. A olivina amostra com titanato tem os maiores valores de Ti. A quantidade de Ni na olivina dos xenólitos é alta, exceto para a amostra com maior quantidade de clinopiroxênio (In1-6). As amostras com clinopiroxênio secundário apresentam a maior quantidade de $\mathrm{Nb} \mathrm{em}$ olivina, e contêm quantidades menores de Sc, Mn e Co. A amostra de harzburgito com textura porfiroclástica em mosaico (In1-33) tem as maiores concentrações de $\mathrm{V}, \mathrm{Cr}$ e Co, e Ti.

O ortopiroxênio em peridotitos com espinélio tem a maior quantidade de $\mathrm{Al}, \mathrm{Sc}$ e V. Entre os peridotitos de espinélio, aqueles com pargasita tem os mais altos valores de $\mathrm{Ti}, \mathrm{Zr}$ e $\mathrm{Nb}$. Os xenólitos metassomatisados tem as maiores quantidades de $\mathrm{Mn}$ e Zn e menores quantidades de Al, Sc e Y. Mas o harzburgito com textura protogranular e com clinopiroxênio secundário tem os maiores valores de $\mathrm{Nb}$ e mais baixo Ti e Co. As amostras com textura porfiroclástica em mosaico (In1-33 e In1-1) têm ortopiroxênio com as maiores quantidades de metais de transição de todo o conjunto de amostras (Ti, $\mathrm{Cr}, \mathrm{Co}$, $\mathrm{Ni}$ e $\mathrm{Cu})$.

Co e Ni são elementos que são preferencialmente de olivina a ortopiroxênio nos xenólitos mantélicos (Tabelas 11, 12 e 16), no entanto nas amostras com textura mosaico porfiroclástica e nas amostras com maior porcentagem de metassomatismo modal, que tem baixo mg\# em olivina e ortopiroxênio, tem os menores coeficientes de partição para Co, Ni. O Zn é outro elemento que tem coeficientes de partição ol/opx maiores que 1 , no entanto nas amostras que não sofreram metassomatismo críptico ou modal, as razões são pouco inferiores a $1(0,91-0,92)$, levando à conclusão de que o $\mathrm{Zn}$ é sensível ao metassomatismo mantélico em olivina e ortopiroxênio.

Entre os silicatos analisados, clinopiroxênio é a fase mais enriquecida em metais de transição, especialmente os minerais metassomáticos. Os peridotitos com espinélio têm os menores valores de $\mathrm{Cu}, \mathrm{Zn}$. No entanto, as amostras contendo anfibólio tem ortopiroxênio com maiores valores de $\mathrm{Sc}, \mathrm{Ti}, \mathrm{V}, \mathrm{Cr}, \mathrm{U}, \mathrm{Zr}, \mathrm{Nb}, \mathrm{Hf}$ e $\mathrm{Ta} . \mathrm{O}$ clinopiroxenio de xenólitos portadores de flogopita têm os maiores valores de $\mathrm{Mn}, \mathrm{Co}$, $\mathrm{Ni}, \mathrm{Cu}$ e $\mathrm{Zn}$ e os menores valores de Sc. O harzburgitos com clinopiroxênio secundário tem clinopiroxênio com maiores teores de $\mathrm{Sc}, \mathrm{Cr}$ e $\mathrm{Y}$, quantidades elevadas de $\mathrm{Nb}$ e $\mathrm{Zr}$, e os menores valores de Ti e V. O clinopiroxênio de megacristal (Fo-3), comparado com clinopiroxênio dos xenólitos, que têm maiores teores de $\mathrm{Co}, \mathrm{Zn}, \mathrm{Cu}$, e quantidades menores de Sc e V. 
Apesar de conter quantidades pequenas, o clinopiroxênio tem quantidade de $\mathrm{Pb}$, U e Th maior que em ortopiroxêno e em olivina, de modo que as maiores concentrações detes elementos ocorrem em clinopiroxênio nas amostras com flogopita e com anfibólio, estes minerais são os silicatos mais ricos nestes elementos. O anfibólio apresenta uma forte variação composicional do centro para a borda no conteúdo de Ta e $\mathrm{Nb}$, com razão $\mathrm{Ta}_{\mathrm{N}} / \mathrm{Nb}_{\mathrm{N}}>1$ no centro e $T a_{N} / \mathrm{Nb}_{\mathrm{N}}<1$ na borda. Esta variação (Tabela 15) resulta em desvios padrões relativos mais altos em ETRL em relação aos ETRP em pargasita. O clinopiroxênio da amostra In1-50, associado à borda de pargasita e com textura intersticial tem $\mathrm{Ta}_{\mathrm{N}} / \mathrm{Nb}_{\mathrm{N}}>1$, sendo considerado aqui como o principal possível responsável pela redistribuição na borda da pargasita de Nb, Ta e ETRL (Figura 10C). A concentração de ETR em anfibólio será discutida no item 3 deste capítulo.

Espinélio, Cr-espinélio e cromita têm metais de transição como componentes principais. Cristais de espinélio tem maiores teores de $\mathrm{Ti}, \mathrm{Zn}, \mathrm{Zr}$ e $\mathrm{Pb}$ e diminuição em Ni em relação ao Cr-espinélio. A cromita presente em amostras metassomatizada têm altos níveis de Ti, V, Mn, Y, Zr, Nb e menores níveis de Co e Zn em comparação com peridotitos com espinélio (Tabela 14).

Ilmenita e titanato têm concentrações muito elevadas de alguns metais de transição. A ilmenita tem os maiores valores de $\mathrm{Mn}, \mathrm{Co}, \mathrm{Ni}, \mathrm{Nb}$ e Ta, enquanto que o titanato tem o maior $\mathrm{Al}, \mathrm{Cr}, \mathrm{Zr}, \mathrm{Hf}, \mathrm{U}$ e $\mathrm{Pb}$ (Tabela 14).

2. Elementos de alto raio atômico (LILE) e outros elementos

Neste item serão apresentadas as concentrações de LILE ( $\mathrm{Rb}, \mathrm{Sr}, \mathrm{Cs}$ e $\mathrm{Ba})$ e discutidas as concentrações de elementos de baixa carga iônica como $\mathrm{Ca}, \mathrm{Na}$ em olivina e ortopiroxênio, que apesar de já terem sido discutidos no capítulo de química mineral, tem precisão analítica maior nos dados de LA-ICP-MS; e Li; além de P.

Olivina e ortopiroxênio são muito pobres em LILE (Tabelas 11 e 12), com excessão de alguns elementos terras raras leves em ortopiroxênio de poucas amostras, no entanto algumas análises acima do limite de detecção indicam pouco $\mathrm{Rb}$ em olivina de harzburgito com textura mosaico porfiroclático e $\mathrm{Sr}$ na amostra de harzburgito protogranular com clinopiroxênio secundário (In1-12). Os níveis mais elevados de Li em olivina são nas amostras com a textura porfiroclástica com mosaico e são menores na amostra com clinopiroxênio secundário. O ortopiroxenio do wehrlito polimítico tem 
o valor mais alto de $\mathrm{Sr}$ e o harzburgito com clinopiroxênio secundário tem o maior teor de Ba.

As amostras que contêm anfibólio e os harzburgitos com textura mosaicoporfiroclástica (In1-33) tem as maiores concentrações de $\mathrm{P}$ em olivina, enquanto que os maiores teores de $\mathrm{P}$ em ortopiroxênio são encontrados no wehrlito polimítico. Os valores de $\mathrm{P}$ são maiores em clinopiroxênio estão em peridotitos com flogopita, enquanto os valores mais baixos estão em peridotitos com espinélio sem anfibólio.

As amostras de harzburgito com textura mosaico porfiroclástica (In1-1 e In133) tem os mais altos valores de $\mathrm{Al}, \mathrm{Ca}$ e $\mathrm{Na}$ em olivina e $\mathrm{Ca}$ e $\mathrm{Na}$ ortopiroxênio, sugerindo percolação de fluido carbonatítico também nestas amostras, coerente com a diminuição de mg\# relatada no capítulo de química mineral.

Estimativas de coeficiente de partição de ol/opx mostram que, em todas as amostras, as concentrações de Li e P são maiores em olivinas (Tabelas 11 e 16).

Se comparado com olivina e ortopiroxênio, o clinopiroxênio têm maiores quantidades de LILE (Tabelas 13 e 16), ao passo que a maior teor de $\mathrm{Rb}$ e $\mathrm{Ba}$ nas amostras se encontram em xenólitos com flogopita, e conteúdos mais altos de $\mathrm{Cs}$ e $\mathrm{Sr}$ estão em harzburgito com clinopiroxênio secundário (In1-12).

Flogopita e pargasita são os silicatos com maiores teores de LILE (Tabela 15). Já entre os óxidos, o titanato da amostra Lm1-1 também possue alto teor destes elementos, diferentemente de minerais do grupo do espinélio e ilmenita.

Concentrações anômalas de LILE em minerais de uma mesma amostra, indicados pelo alto desvio padrão relativo (Tabelas 6-10), sugerem a presença de microinclusões de flogopita ou barita.

\section{Residência de Elementos Terras Raras (ETR)}

Os elementos terras raras são elementos traço e as mais importantes ferramentas no estudo de processos de fusão parcial e metassomatismo. Na literatura que trata sobre rochas mantélicas, a grande maioria dos trabalhos adota a normalização pelo manto primitivo (PM) de McDonough \& Sun (1995), que também será adotada neste trabalho, sendo $\mathrm{N}$ o símbolo adotado para se referir a um elemento normalizado (e.g. $\mathrm{La}_{\mathrm{N}}, \mathrm{Y}_{\mathrm{N}}$ ). 
O conteúdo de ETR em olivina é geralmente abaixo dos limites de detecção, mas os poucos resultados obtidos indicam padrões enriquecido em elementos terras raras pesados (ETRP) em relação aos leves (ETRL), com $\mathrm{La}_{\mathrm{N}} / \mathrm{Yb}_{\mathrm{N}}$ inferior a 0,1.

O ortopiroxênio também tem conteúdo de ETR baixo que, sendo em alguns casos inferiores ao limite de detecção (especialmente em Sm, Nd, Eu e Gd). Os padrões de ETR normalizados (PM) são variáveis com amostras com evidência de metasomatismo (In1-6 e In1-12) mostrando enriquecimento em ETRL, em contraste com um padrão aparente retilíneo em harzburgito com textura mosaico porfiroclástica (In1-1), e enriquecimento em ETRP nas amostras peridotíticos. No dunito granoblástico (In1-24a) o ortopiroxênio é empobrecido em ETR sendo ao redor ou inferior a 1x PM (La, Ce, Pr, e Nd, e Ho, Er, Yb e Lu).

O clinopiroxênio é o silicato que hospeda maior quantidade de ETR nos xenólitos estudados, com razões de ETRL 0,01-100x PM e ETRP 0,5-5x PM (Fig.10). Os padrões de ETR são fortemente variáveis, refletindo processos de fusão e metassomatismo, sendo que a maior diversidade de padrões de ETR está nos peridotitos com espinélio, evidenciando estes processos nestas amostras.

O padrão de razões de ETR em clinopiroxênio de lherzolito com espinélio da amostra In1-14a é praticamente plano, o conteúdo de ETRL e ETRP cerca de 10x o manto primitivo (Fig. 10A). O padrão de clinopiroxênio de lherzolito com espinélio In1-4 é semelhante à amostra In1-14a para ETRP, mas é drasticamente mais baixo em ETRL, atingindo valores abaixo de 0,1x o manto primitivo para La e Ce. $\mathrm{Na}$ amostra Lm1-17, também de lherzolito com espinélio, ETRP tem valores semelhantes à amostra In1-4, porém a partir do Dy ocorre uma queda na concentração dos ETR, em direção aos ETRL, mais acentuada. Padrões de baixo ETRL e alto ETRP não são esperados para clinopiroxênio de xenólitos de ambiente cratônico (Haggerty et al. 1995), porém são comuns em clinopiroxênio de xenólitos mantélicos abissais das dorsais meso-oceânicas (Bodinier \& Godard 2003). O padrão de ETR de clinopiroxênio no harzburgito granoblástico (In1-3) é plano, mas com concentrações mais baixas de ETRL e ETRP em comparação com lherzolito com espinélio In1-14a (com padrão de ETR plano).

Evidências concretas de metassomatismo mantélico críptico em clinopiroxênio de peridotitos com espinélio são encontradas nas amostras Lm1-20 e In1-50. No harzburgitos com Cr-espinélio (Lm1-20) as razões de ETRP são maiores que 1, no entanto ocorre uma diminuição na concentração de ETR até Eu e Sm não atingirem o limite de detecção $(0,1 \mathrm{x} \mathrm{PM})$, no entanto o $\mathrm{Nd}$ já apresenta teores acima do limite de 
detecção e ocorre um aumento na razão de ETRL com razão máxima em La (4x PM). Em clinopiroxênio da amostra In1-50 há um padrão enriquecido em ETRL em relação aos ETRP, além de tem maiores concentrações de ETRL em relação aos cristais de peridotitos com espinélio sem anfibólio. Este padrão sugere que o clinopiroxênio desta amostra foi produzido por metassomatismo mantélico e está de acordo com seu contexto textural instersticial, relacionado as bordas de pargasita, com conteúdo de ETR semelhantes.

Padrões enriquecidos em ETRL em relação a ETRP e razões $\mathrm{La}_{\mathrm{N}} / \mathrm{Ce}_{\mathrm{N}}<1$ são assinaturas características em todos os cristais de clinopiroxênio analisados em peridotitos com flogopita e clinopiroxênio secundários. No entanto, em relação ao clinopiroxênio de amostra de peridotito com Cr-espinélio e pargasita (In1-50), onde a proporção $\mathrm{La}_{\mathrm{N}} / \mathrm{Ce}_{\mathrm{N}}>1$, o clinopiroxênio das amostras com metassomatismo modal difere, muito provavelmente devido a presença de pargasita.

Dentro do grupo dos xenólitos com flogopita e clinopiroxênio secundário, a amostra mais enriquecida em ETR é o harzburgito com textura protogranular e clinopiroxênio secundário (In1-12), com mais de 50x o manto primitivo (PM) de ETRL e razão ao redor de 5x o manto primitivo para ETRP (Fig.6). Este padrão é muito semelhante ao clinopiroxênio da amostra de ilmenita-flogopita-clinopiroxenito Klxm3 com priderita do kimberlito Limeira 1 descrito por Almeida et al. (2014). O clinopiroxênio da amostra de flogopita ilmenita wehrlito polimítico In1-6 tem também padrões paralelos ao da amostra In1-12, mas com razões inferiores de ETRL e de ETRP, respectivamente 7-20x PM e em torno de 0,5-1x PM (Figura 10B). Estas duas amostras têm em comum a grande variação no teor de ETR, que pode ser observada na Tabela 8 observado pelo alto desvio padrão relativo. O padrão de enriquecimento em ETRL de clinopiroxênio também é verificado nas amostras de dunito com bolsões de flogopita contendo clinopiroxênio, cromita e titanato (ETRL 12xPM e ETRP 1XPM; Lm1-1), flogopita dunito com bolsões de flogopita com cromita e ilmenita (ETRL 8xPM e ETRP 0,5XPM;In1-2) (Figura 10B). As razões de ETR/PM da amostra Lm1-1 é praticamente idêntico ao da amostra de dunito com bolsões de flogopita com cromita e titanatos (amostra Klxm2) do kimberlito Limeira descrito por Almeida et al. (2014).

O megacristal de clinopiroxênio (amostra Fo-3) tem razões de ETRL maiores que os ETRP em padrão muito similar ao da amostra de flogopita ilmenita wehrlito polimítico (In1-6), sugerindo que esta amostra sofreu metassomatismo em condições similares aos xenólitos com flogopita e clinopiroxênio secundário estudados. 
Capitulo VI- Química Mineral de Elementos Traço

Nos diagramas com razões Clinopiroxênio/manto primitivo para multielementos, correspondentes às Figuras 10C e 10D, é possível observar certa uniformidade entre LILE e HFS em xenólitos metassomatizados em relação aos peridotitos com espinélio e Cr-espinélio. Além do enriquecimento relativo em ETRL, ocorrem anomalias negativas de $\mathrm{Nb}, \mathrm{Pb}, \mathrm{P}, \mathrm{Zr}$ e $\mathrm{Ti}$ em todas as amostras de peridotitos metassomatizados, no entanto na amostra In1-12 (harzburgito com clinopiroxênio secundário) destaca-se como tendo as mais altas razões de ETR e as menores razões de Ti. A amostra com titanato, também tem razões altas de ETR, porém menor que In1-12, e apresenta juntamente com a amostra de flogopita ilmenita wehrlito as maiores razões de $\mathrm{Rb}, \mathrm{Ba}, \mathrm{U}$ e Th. A amostra com titanato tem as maiores razões de Hf do conjunto, provavelmente devido a presença do titanato, que contribui para que Ti seja maior que em outras amostras metassomatizadas. $\mathrm{O}$ megacristal tem as maiores razões de $\mathrm{Ti}$ do conjunto e os menores valores de ETR.

A projeção dos dados de clinopiroxênio de todas as amostras estudadas em diagrama de razões $\mathrm{Ti} / \mathrm{Eu}$ vs. $\mathrm{La} / \mathrm{Yb}_{\mathrm{N}}$ proposto por Coltorti et al. (1999; Figura 10F) sugere que, exceto para peridotitos com espinélio sem anfibólios e megacristal (Fo-3), todo o clinopiroxênio estudados teriam origem por metassomatismo de carater dominantemente carbonatítico, com maior influência deste processo nas amostras que apresentam menor proporção de $\mathrm{Ti} / \mathrm{Eu}$, como harzburgito protogranular com clinopiroxênio secundário (In1-12). A amostra Lm1-20, ao contrário, mostra evidências de que a geração do clinopiroxênio passou por processo de metassomatismo silicático devido a baixa razão La/Yb e a altíssima razão Ti/Eu. Já o megacristal possivelmente seria resultante de um processo conjugado de metassomatismo com fontes carbonatíticas e silicáticas, a maior proporção de $\mathrm{Al}$ e de elementos de transição corroboram o processo de metassomatismo silicático.

Os ETR em pargasita tem padrão enriquecido em ETRL cerca de 30-80X PM. Nas análises da borda dos cristais de pargasita ocorre uma diminuição na concentração de ETRL em relação ao centro dos cristais nas duas amostras analisadas, para núcleo e borda a proporção de ETRP é similar variando de $10 x \mathrm{xM}$ para Gd e $\sim 1 \mathrm{xPM}$ para Lu (Figura 10E).

O titanato de série mathiasita-loverengita tem a maior concentração de terras raras nos minerais analisados nos xenólitos (> 100X PM). Apresenta um padrão ETRL enriquecido, e, portanto, pode desempenhar um papel importante nos processos de 
fracionamento no manto (Tabela 14). Já os dados de ETR em ilmenita têm conteúdo

abaixo do limite de detecção.

$\diamond \square \bigcirc$ Lherzolitos e harzburgitos com espinélio $\diamond \square$ Harzburgitos e dunitos com Cr-espinélio

Harzburgito com Cr-espinélio e pargasita

- $\Delta$ Peridotitos com flogopita
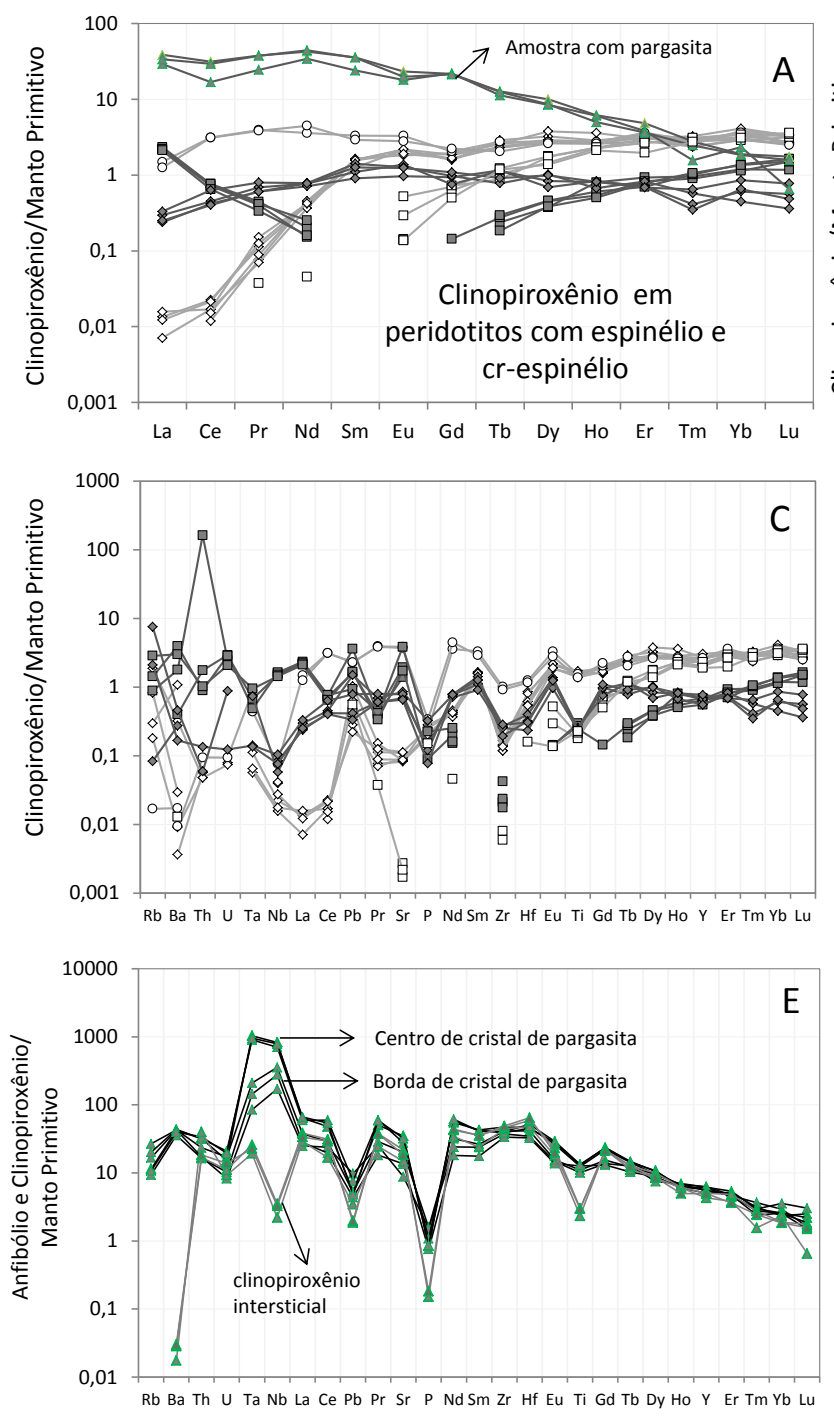

Harzburgito com bolsões de clinopiroxênio Megacristal
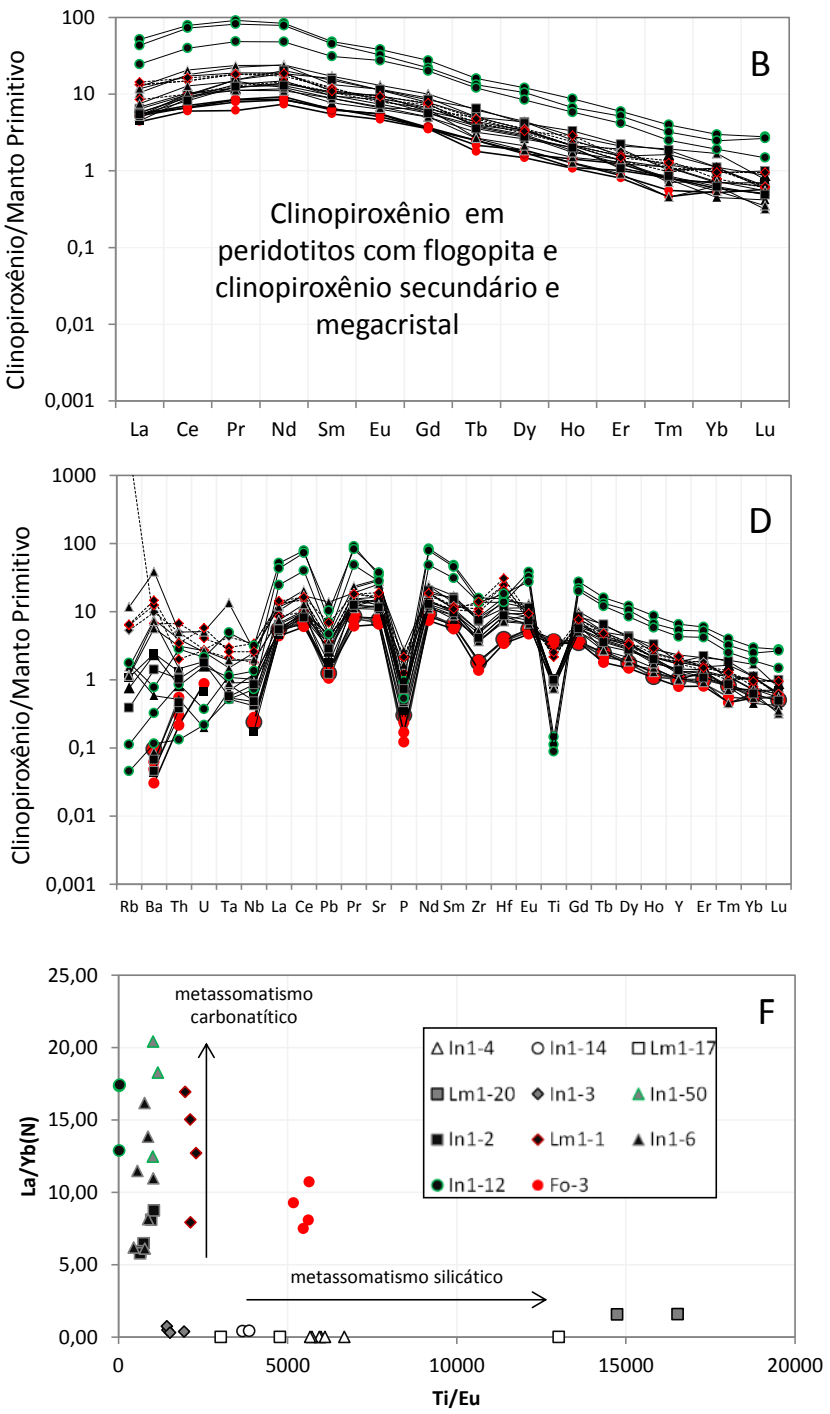

Figura 10- Diagramas representativos de elementos traço em clinopiroxênio e anfibólio de xenólitos mantélicos. Padrões de ETR em clinopiroxênio, normalizados pelo manto primitivo de Sun \& McDonough (1995): A- peridotitos com espinélio e Cr-espinélio; B- peridotitos metassomatisados. Padrões de LILE e HFS de clinopiroxênio (ou anfibólio) normalizados pelo manto primitivo de Sun \& McDonough (1995): C- peridotitos com espinélio e Cr-espinélio; D- peridotitos metassomatisados; e Eperidotitos com Cr-espinélio e anfibólio. F- composição de Ti/Eu vs. $\mathrm{La}_{\mathrm{N}} / \mathrm{Eu}_{\mathrm{N}}$ em clinopiroxênio projetadas em diagrama discriminante de metassomatismo carbonatítico e matassomatismo silicático de Coltorti et al. (1999), com as legendas dos códigos das amostras estudadas. 
3.1.Inferências sobre fusão parcial com base na composição do clinopiroxênio

Processos de enriquecimento metassomático e processos de empobrecimento por fusão parcial no manto superior podem ser estimados pela composição de elementos traço. Análises de rocha total podem dimensionar esses processos, porém análises in situ de minerais constituem uma ferramenta mais confiável, pois evita eventuais porções contaminadas relacionadas a limites entre grãos (Bianchinni et al. 2007). Para identificar os processos de fusão parcial e estimar suas condições de equilíbrio e graus de fusão, foram utilizadas as equações de Norman (1998), assumindo que o clinopiroxênio é o principal hospedeiro de elementos traço (principalmente ETR) na fase sólida residual.

As equações têm como base os seguintes parâmetros:

$\mathbf{C}_{\mathbf{c p x}}$ - concentração do elemento traço no diopsídio residual.

$\mathbf{C}_{0}$ - composição inicial da fonte $=3$ x condrito carbonáceo $C 1$ de Anders \& Grevesse (1989).

$\mathbf{X}_{\mathbf{c p x}}$ - fração molar de diopsídio na fonte (assume-se 0,2).

f- grau de fusão parcial.

$\mathbf{D}_{\text {cpx }}{ }^{-}$coeficiente de distribuição cristal/líquido do elemento traço no diopsídio.

Os elementos $\mathrm{Y}$ e Yb geralmente tem incompatibilidade com a composição de fluidos ou fundidos metassomáticos, portanto são amplamente utilizados para estimativas de fusão parcial (e.g. Norman 1998, Beard et al. 2007). Foram utlilizados os mesmos valores de Norman (1998) para $\mathrm{D}_{\mathrm{cpx}}$ para os elementos $\mathrm{Y}(0,42)$ e $\mathrm{Yb}(0,40)$.

As equações de Norman (1998) são:

$$
\begin{aligned}
& \left.\mathbf{C}_{\mathrm{cpx}}=\left(\mathbf{D}_{\mathrm{cpx}} * \mathbf{C}_{\mathbf{0}}\right) /\left(\mathbf{D}_{\mathrm{cpx}} * \mathbf{X}_{\mathrm{cpx}} * \mathbf{( 1}-\mathbf{f}\right)+\mathbf{f}\right) \quad \text { para fusão em equilíbrio } \\
& C_{\text {cpx }}=\left(C_{0} / X_{\text {cpx }}\right) *(1-f)\left[1 / D_{\text {cpx }}{ }^{*} X_{\text {cpx }}\right]-1 \quad \text { para fusão fracionada }
\end{aligned}
$$

A Figura 11 mostra os teores de $\mathrm{Y}$ e $\mathrm{Yb}$ normalizados por $3 \mathrm{X}$ o condrito de Anders \& Grevesse (1989) dos cristais de clinopiroxênio dos xenólitos analisados, seguindo as equações de Norman (1998) para fusão em equilíbrio e fusão fracionada. A projeção destes dados permite as seguintes observações: 
a) Os dados de clinopiroxênio em peridotitos com espinélio projetam pouco acima das curvas das equações determinadas por Norman (1998), sendo de 7$15 \%$ de fusão para o modelo em equilíbrio e 5-8\% para o modelo de fracionamento.

b) Para os peridotitos com Cr-espinélio sem anfibólio as composições de clinopiroxênio projetam na porção da curva que equivale a mais de $50 \%$ de fusão para o modelo em equilíbrio e 15-20\% para o modelo de fracionamento. Tais dados são consistentes com o caráter mais residual desses xenólitos.

c) No peridotito com anfibólio, os dados projetaram abaixo das curvas. Nas amostras de harzburgitos com clinopiroxênio secundário e no dunito com anfibólio a porcentagem de fusão é $<1$ a 3\% de fusão para ambos os modelos.

d) Nas demais amostras é de 15 a $>50 \%$ de fusão para o modelo em equilíbrio e 8 a $18 \%$ para o modelo de fracionamento.

Os dados de peridotitos com espinélio e Cr- espinélio situam-se acima da curva significa e, portanto, tem maior razão $\mathrm{Yb} / \mathrm{Y}$. Somente a amostra In1-3 tem razão Yb/Y mais baixa, e é projetada praticamente na curva de Norman (1998), mas de qualquer modo ela está próxima de Lm1-20 e tem $\mathrm{Yb} / \mathrm{Y}$ mais alto que as demais amostras do conjunto (com metassomatismo modal).

Os dados de clinopiroxênio em xenólitos metassomátizados e megacristal projetam abaixo da curva, ou seja, tem menor razão $\mathrm{Yb} / \mathrm{Y}$ em relação as amostras com espinélio. O grupo principal de amostras metassomatizadas (contendo flogopita), guardam composições do clinopiroxênio que indicam alto grau de fusão, sugerindo: 1que já existia um clinopiroxênio pretérito que teria sofrido fusão parcial antes do processo de metassomatismo; ou 2- que houve um processo de metassomatismo acompanhado por fusão parcial. Quanto ao clinopiroxênio das amostras de harzburgito com clinopiroxênio secundário (In1-12) e com pargasita (In1-50), a explicação seria que o alta razão de $\mathrm{Y}$ e, em menor proporção, de $\mathrm{Yb}$ seria devido ao enriquecimento secundário por metassomatismo carbonatítico.

É possível que um eventual processo de fusão parcial de uma rocha tal como o harzburgito com clinopiroxênio secundário (In1-12), gerasse um clinopiroxênio com composição semelhante ao clinopiroxênio dos outros xenólitos metassomatizados. Esta hipótese poderia explicar porque as razões de ETR são bem mais altos no clinopiroxênio secundário da amostra In1-12, em relação às outras amostras metassomatizadas. 
$\diamond \square \bigcirc$ Lherzolitos e harzburgitos com espinélio

$\diamond \square$ Harzburgitos e dunitos com Cr-espinélio

$\triangle$ Harzburgito com Cr-espinélio e pargasita

\} \Delta \text { Peridotitos com flogopita Peridotitos com flogopita e titanato Harzburgito com bolsões de clinopiroxênio Megacristal }
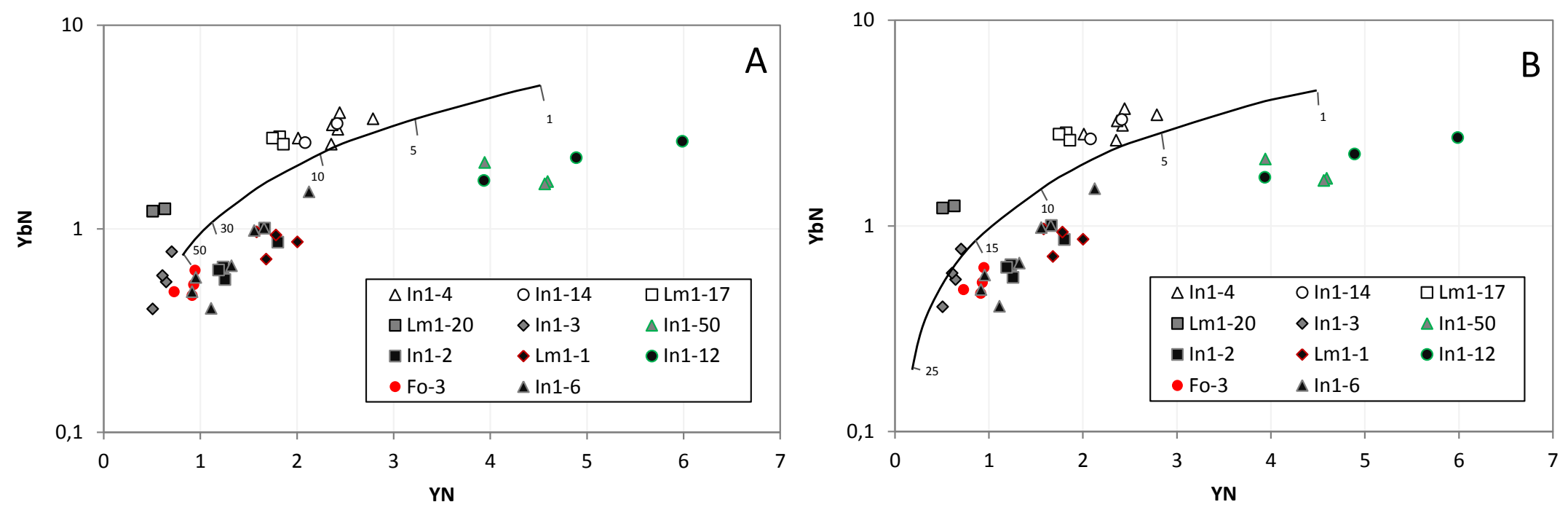

Figura 11- Razões $Y_{N} v s . ~ Y b_{N}$ de cristais de clinopiroxênio projetadas em curvas geradas por modelamentos de fusão em equilíbrio (A) e fracionada (B). Calibração de Norman (1998). Dados normalizados ao manto primitivo (3 x condrito de Anders \& Grevesse 1989). 


\section{Capítulo VII- Isótopos de Sr}

A composição química do clinopiroxênio, além de guardar informações importantes de petrogênese, como fusão parcial e metassomatismo, ainda pode ser usada para determinações isotópicas. Concentrações de $\mathrm{Sr}$ em clinopiroxênio (74-740 ppm) em peridotitos metassomatisados e em lherzolito com epinélio (In1-14a), são suficientes para a medição de razões isotópicas ${ }^{87} \mathrm{Sr} /{ }^{86} \mathrm{Sr}$ por LA-MC-ICPMS. Por outro lado, olivina, ortopiroxênio e minerais do grupo do espinélio têm quantidades de $\mathrm{Sr}$ muito baixas (0-22 ppm), que não permitem a análise da razão isotópica ${ }^{87} \mathrm{Sr} /{ }^{86} \mathrm{Sr}$ (Tabela 8- Capítulo VII).

Foram selecionadas as amostras de lherzolito protogranular com espinélio (In114a), o flogopita ilmenita wehrlito polimítico (In1-6) e o harzburgito protogranular com clinopiroxênio secundário (In1-12), todos da intrusão kimberlítica Indaiá 1. A Tabela 17 mostra as razões de $\mathrm{Sr}$ e seus erros calculados. Considerando que dados confiáveis tem $\mathrm{Rb} / \mathrm{Sr}$ menores que 0,02 (Segal et al. 2003), as análises G3, G3 2 e G2 TRY 2 na amostra In1-12 não foram consideradas. As análises G3 \#3 e G3 \#2 em cristais de clinopiroxênio da amostra de lherzolito com espinélio (In1-14) também não foram consideradas, pois estão com invariantes (razões ${ }^{84} \mathrm{Sr} /{ }^{86} \mathrm{Sr}$ e ${ }^{84} \mathrm{Sr} /{ }^{88} \mathrm{Sr}$ ) distintas do esperado, portanto não confiáveis.

As razões mais baixas de $\mathrm{Sr}$ se encontram na amostra de lherzolito com espinélio In1-14a, com 0,7029. As outras duas amostras, com evidências texturais e químicas de metassomatismo exibem razões ${ }^{87} \mathrm{Sr} /{ }^{86} \mathrm{Sr}$ mais radiogênicas, variando entre 0,7061 e 0,7102 no flogopita ilmenita wehrlito (In1-6) e entre 0,7064 e 0,7147 no harzburgito com clinopiroxênio secundário (In1-12).

A amostra In1-6 apresenta cristais de clinopiroxênio amarelados, com as razões mais baixas de ${ }^{87} \mathrm{Sr} /{ }^{86} \mathrm{Sr}$ da amostra, em torno de 0,7061-0,7064. Razões entre 0,7066 e 0,7079 ocorrem em cristais com coloração mais tonalidade mais clara (verde claro). Nesta mesma amostra a análise com a maior razão $(0,7102)$ ocorre em contato com flogopita. Aparentemente, os núcleos de G1 1 (0,7061-0,7064) são um pouco menos radiogênicos que G1 2 (0,7066-0,7073). Mas deve-se levar em conta variações de $\mathrm{Rb} / \mathrm{Sr}$ paralelas a aumentos de ${ }^{87} \mathrm{Sr} /{ }^{86} \mathrm{Sr}$. As demais análises mostram-se mais radiogênicas, $\left({ }^{87} \mathrm{Sr} /{ }^{86} \mathrm{Sr}=0,708-0,710\right)$. 
0,7091) se encontram em bordas e fraturas de clinopiroxênio, as demais análises estão em porções centrais dos cristais, entre 0,7103-0,7147.

Tabela 17- Razões isotópicas de Sr nas amostras de peridotito com espinélio (In1-14), xenólito polimítico (In1-6) e harzburgito com clinopiroxênio secundário (In1-12). A tabela apresenta os dados completos de todas as anáilises efetuadas de modo que as com cor cinza são foram rejeitadas neste trabalho, por não apresentarem boas invariantes ou por apresentarem alta razão Rb/Sr.

\begin{tabular}{|c|c|c|c|c|}
\hline \multicolumn{5}{|c|}{ In1-14 $^{a}$} \\
\hline $\begin{array}{l}\text { G3 \#3 } \\
\text { std error 2s } \\
\text { G3 \#2 } \\
\text { std error 2s } \\
\text { G3 \#1 } \\
\text { std error 2s }\end{array}$ & $\begin{array}{l}87 / 86 \\
0,703016 \\
0,000958 \\
0,703496 \\
0,000794 \\
\mathbf{0 , 7 0 2 9 6 4} \\
0,000856 \\
\text { In } 1\end{array}$ & $\begin{array}{l}84 / 86 \\
0,048349 \\
0,00077 \\
0,042954 \\
0,000637 \\
\mathbf{0 , 0 5 8 5 0 6} \\
0,001022\end{array}$ & $\begin{array}{l}84 / 88 \\
0,005773 \\
0,000700 \\
0,005129 \\
0,000076 \\
\mathbf{0 , 0 0 6 9 8 6} \\
0,000122\end{array}$ & $\begin{array}{l}\mathrm{Rb} / \mathrm{Sr} \\
0,0006 \\
0,0002 \\
0,0016 \\
0,0007 \\
0,0014 \\
0,0007\end{array}$ \\
\hline $\begin{array}{l}\text { G1 } 2 \text { centro } \\
\text { std error } 2 \mathrm{~s} \\
\text { G1 borda } \\
\text { std error } 2 \mathrm{~s} \\
\text { G3 com carbonato } \\
\text { std error } 2 \mathrm{~s} \\
\text { G3 } 2 \\
\text { std error } 2 \mathrm{~s} \\
\text { G3 1 } \\
\text { std error } 2 \mathrm{~s} \\
\text { G2 TRY5 (2) centro } \\
\text { std error } 2 \mathrm{~s} \\
\text { G2 TRY4 borda } \\
\text { std error } 2 \mathrm{~s} \\
\text { G2 TRY3 centro } \\
\text { std error } 2 \mathrm{~s} \\
\text { G2 TRY2 centro } \\
\text { std error } 2 \mathrm{~s} \\
\text { G2 borda } \\
\text { std error } 2 \mathrm{~s}\end{array}$ & $\begin{aligned} 87 / 86 \\
\mathbf{0 , 7 1 0 2 6 6} \\
0,000484 \\
\mathbf{0 , 7 0 8 6 2 8} \\
0,000231 \\
0,776327 \\
0,000566 \\
0,828184 \\
0,002684 \\
\mathbf{0 , 7 1 0 2 8 7} \\
0,000566 \\
\mathbf{0 , 7 1 4 7 3 4} \\
0,000912 \\
\mathbf{0 , 7 0 9 1 7 1} \\
0,000513 \\
\mathbf{0 , 7 1 0 5 5 2} \\
0,000700 \\
0,713506 \\
0,00139 \\
\mathbf{0 , 7 0 6 4 6 2} \\
0,000233 \\
\text { In }\end{aligned}$ & $\begin{array}{l}84 / 86 \\
\mathbf{0 , 0 5 5 9 1 0} \\
0,000078 \\
\mathbf{0 , 0 5 6 2 8 5} \\
0,000079 \\
0,055470 \\
0,000092 \\
0,055565 \\
0,000136 \\
\mathbf{0 , 0 5 5 0 8 1} \\
0,000072 \\
\mathbf{0 , 0 5 5 9 6 2} \\
0,000081 \\
\mathbf{0 , 0 5 6 2 1 5} \\
0,000048 \\
\mathbf{0 , 0 5 5 7 4 8} \\
0,000052 \\
0,056515 \\
0,000060 \\
\mathbf{0 , 0 5 5 8 2 1} \\
0,000036\end{array}$ & $\begin{array}{l}84 / 88 \\
\mathbf{0 , 0 0 6 6 7 6} \\
0,000009 \\
\mathbf{0 , 0 0 6 7 2 0} \\
0,000009 \\
0,006623 \\
0,000011 \\
0,006634 \\
0,000016 \\
\mathbf{0 , 0 0 6 5 7 7} \\
0,000009 \\
\mathbf{0 , 0 0 6 6 8 2} \\
0,000010 \\
\mathbf{0 , 0 0 6 7 1 2} \\
0,000006 \\
\mathbf{0 , 0 0 6 6 5 6} \\
0,000006 \\
0,006748 \\
0,000007 \\
\mathbf{0 , 0 0 6 6 6 5} \\
0,000004\end{array}$ & $\begin{array}{l}\mathrm{Rb} / \mathrm{Sr} \\
\mathbf{0 , 0 0 8 7} \\
0,0014 \\
\mathbf{0 , 0 0 6 6} \\
0,0005 \\
0,1145 \\
0,0174 \\
0,2781 \\
0,0362 \\
\mathbf{0 , 0 0 7 7} \\
0,0008 \\
\mathbf{0 , 0 1 4 8} \\
0,0019 \\
\mathbf{0 , 0 1 0 1} \\
0,0014 \\
\mathbf{0 , 0 1 1 6} \\
0,0013 \\
1,6440 \\
0,8359 \\
0,0027 \\
0,0004\end{array}$ \\
\hline $\begin{array}{l}\text { G1 } 23 \text { borda, próximo a flogopita } \\
\text { std error } 2 \text { s } \\
\text { G1 } 22 \text { centro } \\
\text { std error } 2 \text { s } \\
\text { G1 } 21 \text { centro } \\
\text { std error } 2 \text { s } \\
\text { G1 } 14 \text { contato com ilmenita } \\
\text { std error } 2 \text { s } \\
\text { G1 } 13 \text { borda de crital amarelado } \\
\text { std error } 2 \text { s } \\
\text { G1 } 12 \text { centro de cristal amarelado } \\
\text { std error } 2 \text { s } \\
\text { G1 } 1 \text { centro de cristal amarelado } \\
\text { std error } 2 \text { s }\end{array}$ & $\begin{array}{l}87 / 86 \\
\mathbf{0 , 7 1 0 1 5 9} \\
0,000262 \\
\mathbf{0 , 7 0 6 6 3 6} \\
0,000186 \\
\mathbf{0 , 7 0 7 3 4 7} \\
0,000491 \\
\mathbf{0 , 7 0 7 9 1 5} \\
0,000297 \\
\mathbf{0 , 7 0 6 1 7 0} \\
0,000250 \\
\mathbf{0 , 7 0 6 3 8 9} \\
0,000225 \\
\mathbf{0 , 7 0 6 0 9 0} \\
0,000158\end{array}$ & $\begin{array}{l}84 / 86 \\
\mathbf{0 , 0 5 5 7 0 8} \\
0,000127 \\
\mathbf{0 , 0 5 6 1 0 1} \\
0,000146 \\
\mathbf{0 , 0 5 5 4 8 7} \\
0,000282 \\
\mathbf{0 , 0 5 5 7 6 3} \\
0,000101 \\
\mathbf{0 , 0 5 4 0 2 7} \\
0,000179 \\
\mathbf{0 , 0 5 5 2 8 6} \\
0,000107 \\
\mathbf{0 , 0 5 4 4 5 2} \\
0,000148\end{array}$ & $\begin{array}{l}84 / 88 \\
\mathbf{0 , 0 0 6 6 5 2} \\
0,000015 \\
\mathbf{0 , 0 0 6 6 9 8} \\
0,000017 \\
\mathbf{0 , 0 0 6 6 2 5} \\
0,000034 \\
\mathbf{0 , 0 0 6 6 5 8} \\
0,000012 \\
\mathbf{0 , 0 0 6 4 5 1} \\
0,000021 \\
\mathbf{0 , 0 0 6 6 0 1} \\
0,000013 \\
\mathbf{0 , 0 0 6 5 0 2} \\
0,000018\end{array}$ & $\begin{array}{l}\mathrm{Rb} / \mathrm{Sr} \\
\mathbf{0 , 0 0 7 8} \\
0,0005 \\
\mathbf{0 , 0 0 1 7} \\
0,0002 \\
\mathbf{0 , 0 0 4 4} \\
0,0007 \\
\mathbf{0 , 0 0 4 3} \\
0,0007 \\
\mathbf{0 , 0 0 1 0} \\
0,0003 \\
\mathbf{0 , 0 0 1 3} \\
0,0002 \\
\mathbf{0 , 0 0 0 7} \\
0,0002\end{array}$ \\
\hline
\end{tabular}



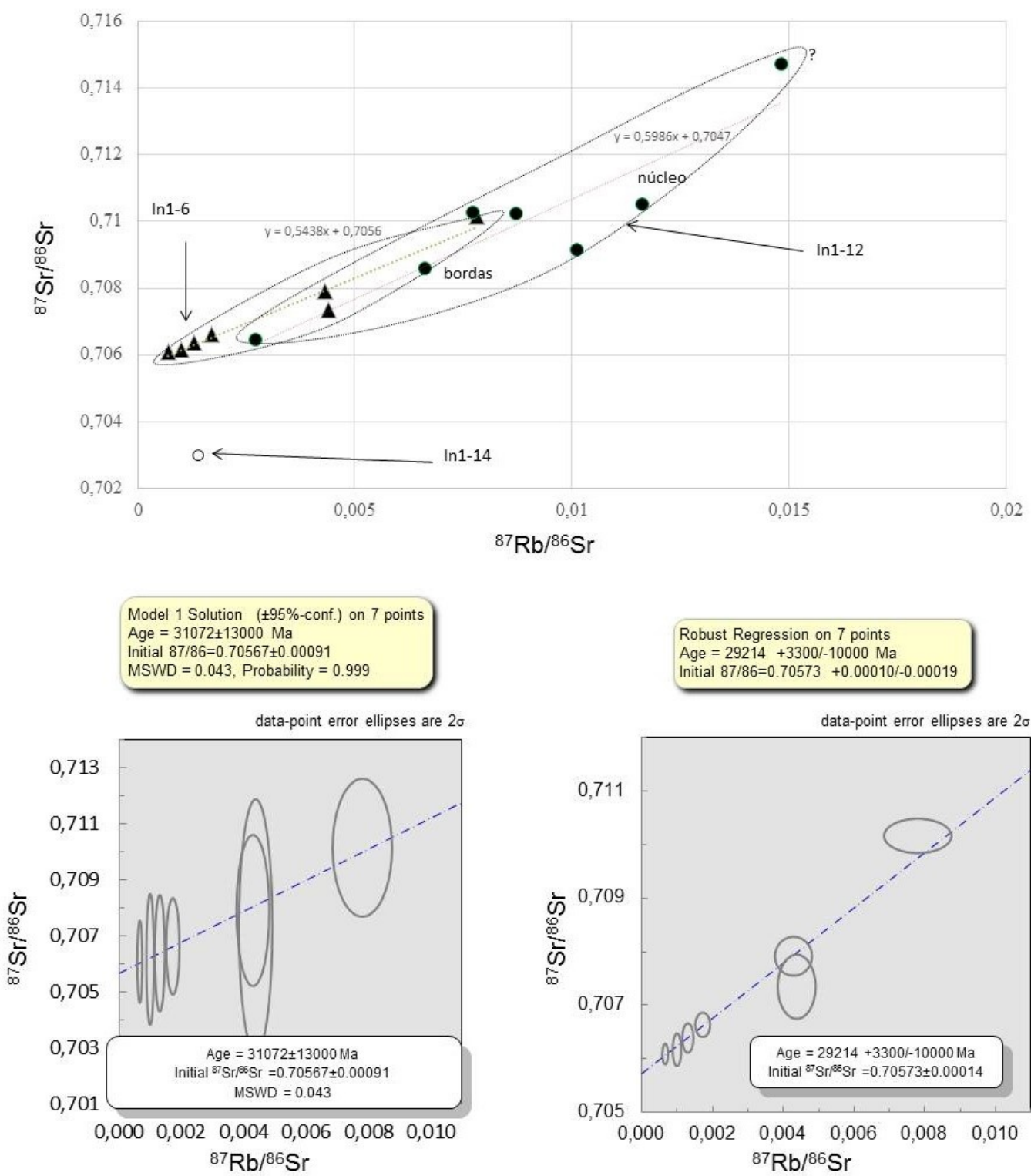

Figura 12- Projeção das razões de ${ }^{87} \mathrm{Rb} /{ }^{86} \mathrm{Sr}$ e ${ }^{87} \mathrm{Sr} /{ }^{86} \mathrm{Sr}$ obtidas por LA-MC-ICP-MS em cristais de clinopiroxênio das amostras amostras de peridotito com espinélio (In1-14), flogopita ilmenita wehrlito (In1-6) e harzburgito com clinopiroxênio secundário (In1-12), com o cálculo da isócrona para a amostra In1-6. 
As diferenças intra-amostras podem ser explicadas por pequenas inclusões de flogopita nos pontos de análises (juntamente com o aumento paralelo da razão $\mathrm{Rb} / \mathrm{Sr}$ ).

Embora haja evidentes correlações positivas entre ${ }^{87} \mathrm{Rb} /{ }^{86} \mathrm{Sr} \times{ }^{87} \mathrm{Sr} /{ }^{86} \mathrm{Sr}$ (Figura 12), as mesmas não possuem significado geocronológico, pois a inclinação obtida corresponderia a idades da ordem de $30 \mathrm{Ga}$ para a amostra In1-6 (Figura 12). Como a amostra In1-12 gerou inclinação semelhante, é assumido que estas idades anômalas seriam encontradas também nesta amostra. Dados de elementos traços em clinopiroxênio das amostras analisadas tem $\mathrm{Rb}$ entre 0-7 ppm, enquanto que $\mathrm{Sr}$ varia de 230-740 ppm, com consequente variação da razão $\mathrm{Rb} / \mathrm{Sr}$ entre 0,0007-0,0148. Isso mostra que o controle da razão ${ }^{87} \mathrm{Sr} /{ }^{86} \mathrm{Sr}$ estaria "tamponado" e apenas aportes massivos de material altamente radiogênico teriam efeito sobre a razão ${ }^{87} \mathrm{Sr} /{ }^{86} \mathrm{Sr}$ dos cristais analisados.

As razões iniciais ${ }^{87} \mathrm{Sr} /{ }^{86} \mathrm{Sr}_{\mathrm{i}}$ das análises são praticamente os mesmos que os valores obtidos nas análises, já que o valor da razão $\mathrm{Rb} / \mathrm{Sr}$ é inferior a $0,02 \mathrm{em}$ todas as análises consideradas neste estudo.

É a primeira vez que são descritas razões Sr para clinopiroxênio de xenólitos mantélicos do Alto Paranaíba, as razões obtidas em clinopiroxênio de amostras metassomatizadas tem composições mais radiogênicas que as rochas da APIP $\left({ }^{87} \mathrm{Sr} /{ }^{86} \mathrm{Sr}=0,705-0,706\right)$ (Meyer et al. 1991, Gibson et al. 1995, Bizzi et al. 1995, Guarino et al. 2013 e Felgate 2014). Estudos de isótopos radioativos em xenólitos mantélicos do Cráton São Francisco, até agora, somente foram abordados em Carlson et al. (2007; Re-Os em rocha total) e em Costa (2012; Sm-Nd em granada, clinopiroxênio e rocha total). Carlson et al. (2007) apresenta dados de ${ }^{187} \mathrm{Os} /{ }^{188} \mathrm{Os}=0,1057-0,1149 \mathrm{e}$ idade Re-depletion de 1,9 a 3,2 Ga em peridotitos (sendo os peridotitos com espinélio mais antigos) apontando para um manto Arqueano empobrecido.

Já Costa (2012) apresenta dados isótópicos de peridotitos e piroxenitos com granada e eclogitos do kimberlito Canastra 1 de razões ${ }^{143} \mathrm{Nd} /{ }^{144} \mathrm{Nd}=0,5118-0,5130 \mathrm{em}$ clinopiroxênio e de 0,5123-0,5143 em granada, com idades TDM de 0,03-3,03Ga. As amostras de granada peridotitos tem as maiores razões de ${ }^{143} \mathrm{Nd} /{ }^{144} \mathrm{Nd}(0,5126-0,5130)$ em clinopiroxênio, com idades modelo inferiores a $0,93 \mathrm{Ga}$, enquanto que piroxenitos com anfibólio (granada websteritos) tem as razões mais baixas $(0,5118) \mathrm{em}$ clinopiroxênio com idade modelo de 2,95 a 3,03. A autora ainda apresenta isócrona 
(com dados de granada, clinopiroxênio e rocha total) para o piroxenito com anfibólio de 1,5Ga, e compara esta idade a interpretação proposta por Carlson et al. 2007, que sugere que um componente pobre em olivina foi infiltrado no manto litosférico empobrecido entre 900 e 1700 Ma, e que fusão da mistura destes dois compenentes geraria os magmas da APIP. No entanto, as próprias idades isocrônicas obtidas em algumas amostras granada peridotitos (107-127 Ma), sugere interferência do processo de metassomatismo mantélico de idade cretácea nos xenólitos, de modo que a idade isocrônica do piroxenito com anfibólio pode ser uma "mistura" entre as idades dos peridotitos arqueanos e os processos de metassomatismo e magmatismo do Cretáceo.

A assinatura radiogênica registrada nos cristais de clinopiroxênio de xenólitos metassomatizados requer componentes de origem crustal (Zindler \& Hart 1986), o que teriam sido levados ao manto por subducção: 1- no Arqueano; 2- no Proterozóico, como defende Carlson et al. (2007). No entanto, o estudo de Rocha et al. (2011) sobre tomografia de ondas $\mathrm{P}$ e $\mathrm{S}$ identifica anomalias profundas sob a plataforma sulamericana com geometria que sugere a presença de material subductado da placa de Nazca sob o Craton São Francisco. 


\section{Capítulo VIII- Discussão integrada dos dados}

A tipologia de xenólitos geralmente está ligada ao ambiente tectônico e ao tipo de rocha vulcânica em que eles são encontrados. Websteritos, wehrlitos e piroxenitos são comuns em álcali basaltos; por outro lado, suítes empobrecidas como harzburgitos e dunitos são mais abundantes em kimberlitos. Xenólitos que sofreram processos de enriquecimento metassomático são comuns em ambos os tipos de eruptivas, assim como os lherzolitos (Haggerty, 1995). Estes últimos, de baixa pressão (com espinélio) ou alta pressão (com granada), são os tipos mais férteis, ou seja, são capazes de produzir magmas basálticos com alto $\mathrm{Ca}, \mathrm{Al}$ e $\mathrm{Fe}$; os lherzolitos considerados primitivos são aqueles que contêm pelo menos 15\% de clinopiroxênio (Le Roux et al. 2007, Sun \& McDonough 1989, McDonough \& Sun 1995).

Segundo Carlson et al. (2007) os xenólitos de peridotito presentes nas rochas vulcânicas alcalinas da região do Alto Paranaíba são geralmente empobrecidos em Ca, Al e Fe, indicando que são resíduos de extração de magmas produzidos por fusão parcial. De acordo com esses autores, idades modelo de empobrecimento de Re de 2,4 Ga para estes peridotitos indicam que esta área repousa sobre um manto litosférico empobrecido arqueano.

Nos corpos Indaiá 1, Limeira 1 e Forca a maioria dos xenólitos correspondem a peridotitos, dominantemente harzburgíticos, e flogopititos, mostrando que estes corpos de fato acompanham uma composição modal de litotipos xenolíticos semelhante à descrita na literatura para kimberlitos. Do mesmo modo, é característico o empobrecimento em $\mathrm{Ca}, \mathrm{Al}, \mathrm{Fe}$, que pode ser verificado pela óbvia escassez de clinopiroxênio nos harzburgitos, e pelo fato de este mineral já ser empobrecido em $\mathrm{Al}$ e Fe quando presente nestas rochas. A diversidade de texturas nos xenólitos reflete uma amostragem pelo kimberlito de zonas com diferentes condições geobarométricas, além das modificações provocadas pela passagem de fluidos metassomáticos, que afetaram as características originais da rocha.

Boa parte das amostras estudadas neste trabalho são portadoras de espinélio ou Cr-espinélio, representando a porção do manto litosférico mais rasa (fácies espinélio). Esta população de xenólitos pode ser dividida em três tipos principais: 
-Lherzolitos e harzburgitos com textura protogranular com espinélio castanhoavermelhado, representando as amostras mais ricas em clinopiroxênio primário e consequentemente mais enriquecidas em componentes férteis como $\mathrm{Ca}, \mathrm{Fe}$ e $\mathrm{Al}$;

-Harzburgitos e dunitos com textura transicional a equigranular com espinélio castanho-escuro (mais enriquecido em $\mathrm{Cr}$ e empobrecido em $\mathrm{Al}$, em relação ao tipo anterior), representando porção do manto que sofreu maior fusão parcial;

-Harzburgitos e dunitos com textura equigranular com espinélio castanho escuro e anfibólio pargasítico idiomórfico em equilíbrio textural (contatos de $120^{\circ}$ ) com os outros minerais, que sugere metassomatismo mantélico e posterior recristalização da rocha.

As diferenças texturais destas amostras indicam graus variados de deformação no manto, de modo que as amostras protogranulares (lherzolitos e harzburgitos com espinélio) seriam o correspondente mais próximo de uma rocha ígnea original, que foi um pouco deformada, segundo o que sugere a presença de kink bands (Mercier \& Nicolas 1975). Já as amostras granoblásticas (harzburgitos e dunitos com Cr-espinélio) seriam resultado de um processo que deformação maior, resultando em recristalização. Este processo pode ter sido acompanhado de fusão parcial, já que existe uma nítida correlação entre a textura, mineralogia e química mineral, ou seja, amostras mais empobrecidas têm cristais menores e contatos mais regulares entre os grãos que os xenólitos considerados mais férteis. A pargasita somente ocorre nos xenólitos portadores de Cr-espinélio, na forma de cristais idiomórficos, e poderia perfeitamente ser resultado da cristalização de líquido residual que não migrou durante este processo. No entanto, é provável que processos de metassomatismo mantélico posteriores tenham alterado a composição do anfibólio. Verifica-se diferença entre elementos traço em cristais de anfibólio, sendo o núcleo significantemente mais rico em ETRL, Ta e $\mathrm{Nb}$. As concentrações de ETRL das bordas de anfibólio são muito similares às do clinopiroxênio secundário (Figura 10C), sugerindo que a composição do anfibólio foi alterada pelo líquido que gerou o clinopiroxênio.

Os xenólitos com metassomatismo modal têm variadas proporções de minerais entre os bolsões das diferentes amostras. A maior parte destes xenólitos apresenta flogopita em abundância, com clinopiroxênio secundário associado comum. O mineral opaco mais frequente neste grupo de amostras é a cromita, porém em diversas amostras ocorre a substituição deste mineral por ilmenita ou mathiasita. Nos contatos entre ilmenita e silicatos são frequentes bordas de perovskita, e mais raramente granadas da 
série da moromotoíta (Nannini 2011). Nestas amostras, parte dos cristais de olivina e de

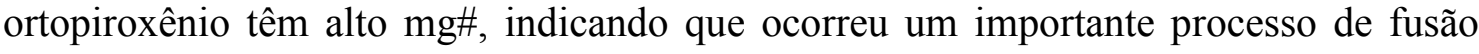
parcial. Já amostras com maior proporção de minerais metassomáticos têm olivina e ortopiroxênio com baixo mg\#, e geralmente têm coloração amarelada. Praticamente todos os cristais de clinopiroxênio destas amostras apresentam baixo Al e enriquecimento em ETRL, distintos dos clinopiroxênios das amostras portadoras de espinélio ou Cr- espinélio.

Uma explicação para o metassomatismo modal destas amostras é a presença de líquidos silicáticos e carbonatíticos que interagiram com o manto litosférico empobrecido (como indicado pela ausência de minerais ricos em $\mathrm{Al}$ e $\mathrm{Fe}$ ), sendo o componente silicático responsável pela formação de minerais ricos em LILE, como a flogopita e ricos em titânio como a mathiasita-loveringita, enquanto que o componente carbonatítico seria responsável pela formação de clinopiroxênio secundário pela reação com ortopiroxênio, liberando $\mathrm{CO}_{2}$ (Russell et al. 2010).

A ausência de granada nestas amostras não impede que as amostras com metassomatismo modal estejam em fácies granada. Considerando que a passagem de espinélio a granada em peridotitos ocorre no sistema $\mathrm{CaO}-\mathrm{MgO}-\mathrm{Al}_{2} \mathrm{O}_{3}-\mathrm{SiO}_{2}$ perto de 15 kbar a $1200 \mathrm{~K}\left(926,85^{\circ} \mathrm{C}\right)$ e cerca de 20 kbar para $1600 \mathrm{~K}\left(1326,85^{\circ} \mathrm{C}\right)$ (Jenkins e Newton, 1979), a substituição de metade do $\mathrm{Al}_{2} \mathrm{O}_{3}$ por $\mathrm{Cr}_{2} \mathrm{O}_{3}$ aumenta a pressão em cerca de 16 kbar (MacGregor 1974, Wood 1977), e a substituição total do $\mathrm{Al}_{2} \mathrm{O}_{3}$ resulta em um incremento de $\sim 28 \mathrm{kbar}\left(\mathrm{O}^{\prime}\right.$ Neill 1981), pode-se dizer que as cromitas, presentes em grande parte das amostras estudadas podem ser estáveis até $48 \mathrm{kbar}$ em fácies granada.

A rocha vulcânica da intrusão kimberlítica Forca é a única amostra estudada portadora de macrocristais de granada (piropo). A classificação dos corpos Indaiá 1, Limeira 1 e Forca 1 como kimberlitos do tipo I, devido à sua mineralogia marcada por macrocristais de olivina de alto $\mathrm{mg \# ,} \mathrm{ilmenita} \mathrm{com} \mathrm{alto} \mathrm{Mg}$, presença de monticellita em abundância (Tappe et al. 2005), implica que a geração destes magmas tenha sido no campo de estabilidade da granada (Shirey et al. 2013). Além disso, Guarino et al. (2013) fizeram estimativas de pressão da geração destes magmas através da projeção do diagrama de Gudfinnsson \& Presnall (2005), obtendo valores de com cerca de 50 kbar (pouco acima de $150 \mathrm{~km}, \sim 80 \mathrm{~km}$ dentro da zona da granada) para Indaiá 1 e Limeira 1, Uma alternativa para a ausência de granada nestas intrusões seria o metassomatismo 
através da substituição granada + líquido rico em $\mathrm{K}=$ flogopita + cromita (Erlank et al. 1987), no entanto não foram encontradas evidências texturais desta reação.

Os xenólitos com texturas em mosaico e fluidal, como as amostras In1-1 e In133, correspondem às amostras de alta temperatura, descritas na literatura (Boyd 1987) como associadas zonas com maior fluxo térmico mais alto no manto litosférico ou na astenosfera. Neste trabalho, foi identificado metassomatismo críptico, indicado pelos altos teores de $\mathrm{Ti}, \mathrm{Ca}$ e $\mathrm{Na}$ e ETRL nos cristais de olivina e ortopiroxênio destas amostras.

Os dados das idades das intrusões alcalinas da APIP pelo método U-Pb em perovskita (Sgarbi et al. 2004, Guarino et al. 2013 e Felgate 2014), mostram que os kimberlitos tendem a ser mais antigos (80-99 Ma) que os kamafugitos/lamproítos (72$84 \mathrm{Ma})$. Datações pouco mais antigas de macrocristais de flogopita ( $\mathrm{Rb} / \mathrm{Sr} ; 118-120$ Ma) nas intrusões denominadas Japecanga-6, Sucesso-1 e Canastra-1 (Bizzi et al. 1995, Pereira \& Fuck 2007) indicam que os minerais de origem metassomática no manto, tal como a própria flogopita, tenham idades mais antigas (cerca de apenas 10-20 Ma após o magmatismo basáltico da bacia do Paraná) que as idades de intrusão dos kimberlitos. Por outro lado, macrocristais de zircão analisados por Basei et al. (2003) tem idades semelhantes (80-85 Ma) as obtidas em perovskita, como indicado no início deste parágrafo.

A Figura 13 esboça um modelo de metassomatismo e magmatismo no manto da região do Alto Paranaíba, baseado em estudo de Carvalho (1997) de química mineral e geotermobarometria de xenólitos mantélicos com espinélio e com granada na APIP. Os dados de peridotitos protogranulares com granada da intrusão Três Ranchos 4 (em Goiás, a cerca de $50 \mathrm{~km}$ a NW das intrusões Indaiá 1 e Limeira 1) projetam em intervalo de 50-60 kbar e $900-100^{\circ} \mathrm{C}$, compatível com a geoterma de $36 \mathrm{~mW} / \mathrm{m}^{2}$ segundo o modelo cratônico de Polack \& Chapman (1977). Carvalho (1997) considera ainda que outras amostras com granada desta intrusão com textura porfiroclástica e mosaico porfiroclástica resultam em dados de geotermobarometria entre 40-60 kbar e 1000$1400^{\circ} \mathrm{C}$, sugerindo geotermas mais quentes $\left(>40 \mathrm{~mW} / \mathrm{m}^{2}\right)$. A geoterma de Pollack \& Chapman (1977) foi adotada nesta tese por ser compatível com região cratônica fria, tal qual esperado para o Cráton do São Francisco antes do incremento no valor geotérmico, atribuído aos processos de magmatismo e metassomatismo no cretáceo. É estimado que atualmente a geoterma varia de 40 a $50 \mathrm{~mW} / \mathrm{m}^{2}$ na região do Alto Paranaíba, segundo Alexandrino (2008). 


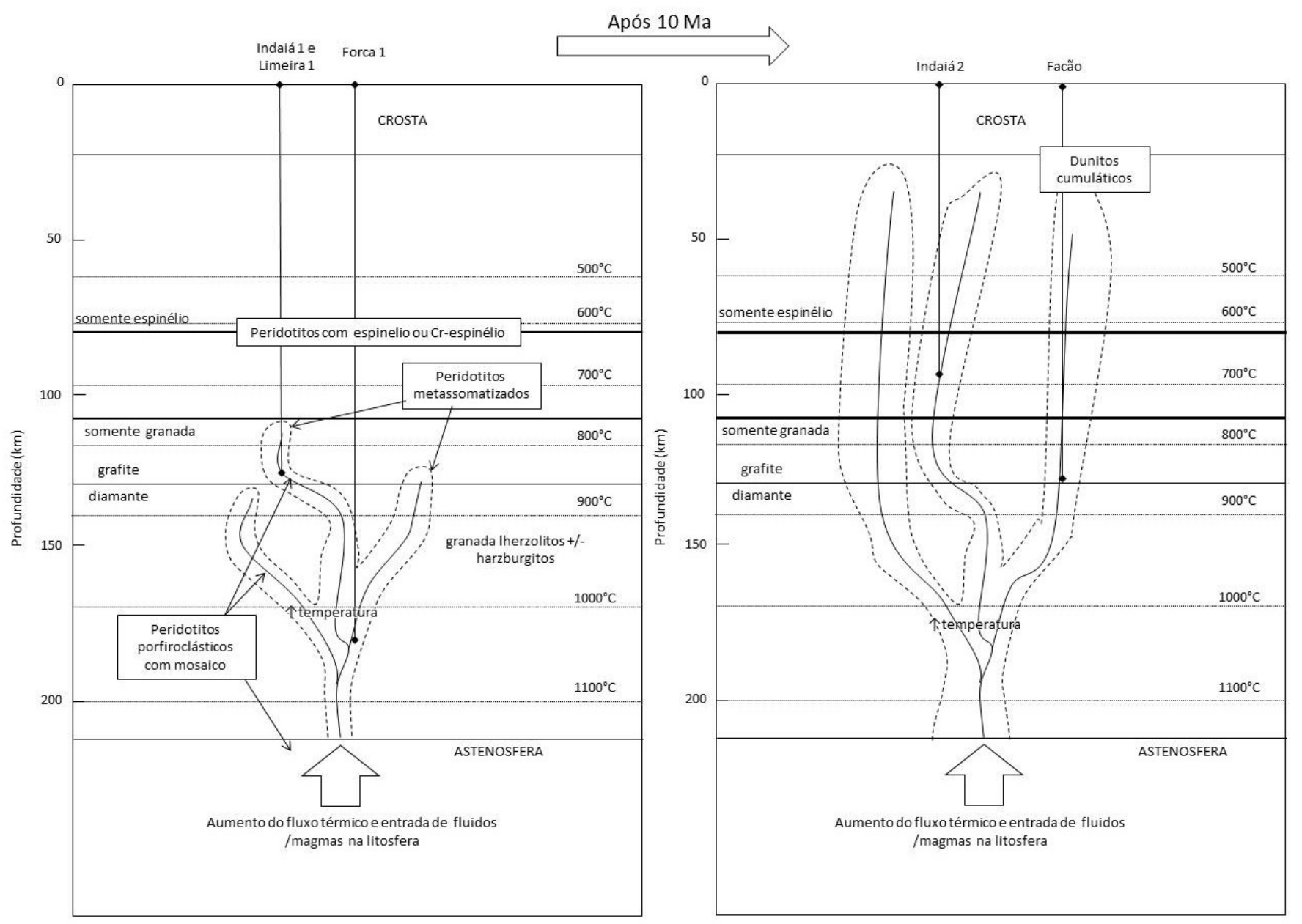

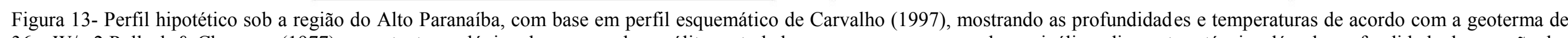

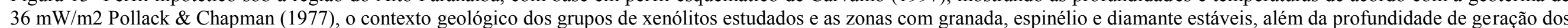
kimberlitos, lamproítos e kamafugitos estudados. 
1. Discussão dos modelos isotópicos

Isótopos de $\mathrm{Sr}, \mathrm{Nd}, \mathrm{Pb}, \mathrm{Os}$, entre outros, são comumente utilizados para inferir áreas-fonte e processos de geração de magmas no manto terrestre. Diferentes reservatórios são reconhecidos no manto, em função de suas assinaturas de elementostraço e de isótopos; entre eles, os mais conhecidos e utilizados são (Rollinson 1993, Zindler \& Hart 1986):

DMM (Depleted MORB Mantle) - apresenta as mais baixas razões ${ }^{207} \mathrm{~Pb} /{ }^{204} \mathrm{~Pb}$ $(<15,45),{ }^{206} \mathrm{~Pb} /{ }^{204} \mathrm{~Pb}(15,5-17,7),{ }^{87} \mathrm{Sr} /{ }^{86} \mathrm{Sr}(0,7015-0,7025)$ e ${ }^{187} \mathrm{Os} /{ }^{188} \mathrm{Os}(0,123-0,126)$, e alto ${ }^{143} \mathrm{Nd} /{ }^{144} \mathrm{Nd}(0,5133-0,5136)$.

EMI (Enriched Mantle I) - razões ${ }^{206} \mathrm{~Pb} /{ }^{204} \mathrm{~Pb}(15,46-15,49),{ }^{207} \mathrm{~Pb} /{ }^{204} \mathrm{~Pb}(17,6-$ $17,7),{ }^{87} \mathrm{Sr} /{ }^{86} \mathrm{Sr} \quad(\sim 0,705)$ e ${ }^{187} \mathrm{Os} /{ }^{188} \mathrm{Os} \quad(0,152)$, e alto ${ }^{143} \mathrm{Nd} /{ }^{144} \mathrm{Nd} \quad(<0,5112)$. Provavelmente é derivado de crosta inferior ou crosta de ilha oceânica ou seus respectivos sedimentos.

EMII (Enriched Mantle II) - razões ${ }^{207} \mathrm{~Pb} /{ }^{204} \mathrm{~Pb}(15,4-15,5),{ }^{206} \mathrm{~Pb} /{ }^{204} \mathrm{~Pb}(16,3-$ $17,3),{ }^{87} \mathrm{Sr} /{ }^{86} \mathrm{Sr}(>0,722)$ e ${ }^{187} \mathrm{Os} /{ }^{188} \mathrm{Os}(\sim 0,156)$, e alto ${ }^{143} \mathrm{Nd} /{ }^{144} \mathrm{Nd}(0,511-0,512)$. A alta razão ${ }^{87} \mathrm{Sr} /{ }^{86} \mathrm{Sr}$ necessita de alto $\mathrm{Rb}$ inicial e um tempo maior para geração de ${ }^{87} \mathrm{Sr}$, de modo que tais características são compatíveis com crosta superior (continental ou oceânica) e seus respectivos sedimentos, e podem ocorrer no manto devido a processos de subducção.

HIMU (High $\left.\mu-{ }^{238} \mathrm{U} /{ }^{204} \mathrm{~Pb}\right)$ - tem as mais altas razões de razões ${ }^{207} \mathrm{~Pb} /{ }^{204} \mathrm{~Pb}$ $(15,8-15,9)$ e ${ }^{206} \mathrm{~Pb} /{ }^{204} \mathrm{~Pb}(21,2-21,7)$, além de baixo ${ }^{87} \mathrm{Sr} /{ }^{86} \mathrm{Sr}(0,7025-0,7035)$; as razões ${ }^{187} \mathrm{Os} /{ }^{188} \mathrm{Os}$ são $\sim 0,15$, e ${ }^{143} \mathrm{Nd} /{ }^{144} \mathrm{Nd}$ é alta $(0,511-0,5121)$. Esta fonte com alto $\mathrm{U}$ e baixo $\mathrm{Rb}$ (refletido na baixa razão ${ }^{87} \mathrm{Sr} /{ }^{86} \mathrm{Sr}$ ) pode ser explicada por subducção e reciclagem de crosta oceânica hidratada (água do mar), ou pela perda localizada de $\mathrm{Pb}$ para o núcleo terrestre, ou ainda pela remoção de $\mathrm{Pb}$ e $\mathrm{Rb}$ por fluidos metassomáticos. Tais razões ${ }^{207} \mathrm{~Pb} /{ }^{204} \mathrm{~Pb}(15,8-15,9) \mathrm{e}{ }^{206} \mathrm{~Pb} /{ }^{204} \mathrm{~Pb}(21,2-21,7)$ requerem uma fonte mais antiga que $1 \mathrm{Ga}$.

O diagrama de razões isotópicas ${ }^{87} \mathrm{Sr} /{ }^{86} \mathrm{Sr}(\mathrm{i})$ vs. ${ }^{143} \mathrm{Nd} /{ }^{144} \mathrm{Nd}(\mathrm{i})$ da Figura 14 mostra a composição dos reservatórios mantélicos descritos por Zindler \& Hart (1986) além das composições de rochas máficas e ultramáficas alcalinas de diversos locais. Os kimberlitos e kamafugitos da região do Alto Paranaíba têm razões ${ }^{87} \mathrm{Sr} /{ }^{86} \mathrm{Sr}$ mais radiogênicas que os kimberlitos sul-africanos e razões ${ }^{143} \mathrm{Nd} /{ }^{144} \mathrm{Nd}$ mais baixas, motivo 
pelo qual foram chamados de kimberlitos transicionais (entre kimberlitos e orangeítos). Chama a atenção, no entanto, que os lamproítos australianos tenham composições totalmente distintas dos lamproítos americanos, evidenciando que a composição isotópica não deve ser um critério único para a classificação dessas rochas.

Na Figura 14 ainda são mostradas curvas de mistura de fontes mantélicas empobrecida (próxima a DMM) e enriquecida (próxima a EM2), a partir de modelamento feito por Guo et al. (2014) para kamafugitos do mundo (China, Itália, Uganda e Brasil) indicando que os kamafugitos brasileiros têm proporções variadas de componentes empobrecidos em relação a componentes enriquecidos (90-96\%). Nos trabalhos de Bizzi et al. (1995), Gibson et al. (1995), Guarino et al. (2013) e Felgate (2014) a origem dos kamafugitos e kimberlitos foi atribuída à mistura de componentes do tipo DMM ou HIMU com EM1. A identificação de clinopiroxênio secundário com assinatura ${ }^{87} \mathrm{Sr} /{ }^{86} \mathrm{Sr}$ mais radiogênica que EM1 permite pela primeira vez na literatura indicar que além de reservatório do tipo EM1 para a geração de kimberlitos e kamafugitos na APIP, podem participar componentes com razões de ${ }^{87} \mathrm{Sr} /{ }^{86} \mathrm{Sr}$ sugestivas de EM2, corroborando os modelamentos de Guo et al. (2014) envolvendo fontes do tipo EM2.

A presença de clinopiroxênio metassomático em xenólitos mantélicos com evidências de metassomatismo carbonatítico, grande aporte de $\mathrm{K}$ (flogopita) e composições isotópicas com razões ${ }^{87} \mathrm{Sr} /{ }^{86} \mathrm{Sr}$ em direção a EM2 sugerem que a origem do metassomatismo estaria ligada a processo de subducção de crosta superior que teria residido por um longo período de tempo no manto, já que a meia vida do ${ }^{87} \mathrm{Rb}$ é de $4,88 \times 10^{10}$ anos. Esta possível subducção, tem idade incerta, podendo ser Arqueana, Meso a Neoproterozóica (como sugere Carlson et al. 2007).

Considera-se nesta tese, seguindo as considerações de Carlson et al. (2007), Pereira \& Fuck (2007), Guarino et al. (2013) e Felgate (2014) de que o magmatismo ocorrido na APIP tenha sido gerado por fusão parcial no manto litosférico por um processo extensional, aproveitando zonas de fraqueza desenvolvidas durante a abertura do Oceâno Atlântico (proto-rift). Este processo teria promovido a desestabilização da litosfera cratônica empobrecida (harzburgitos e dunitos com cromita) e permitido a entrada de magmas/fluidos carbonatíticos, de baixa viscosidade com maior capacidade de infiltração (Karfunkel et al. 2014) e ricos em Ca e ETRL, gerando clinopiroxênio metassomático nos contatos com ortopiroxênio (análogo à amostra In1-12). Os cristais ricos em K (flogopita) teriam se originado pela ação de metassomatismo, a partir de 
líquido carbonatítico com componente silicático. A fusão de rochas refratárias e metassomatizadas poderia gerar um líquido silicático com maior conteúdo de $\mathrm{Ti}, \mathrm{Zr}$ e Hf e com teores um pouco mais baixos de ETR (análogo aos peridotitos metassomatizados), que também seria responsável por metassomatismo. Estas fusões poderiam por vezes gerar magmas capazes de atingir a superfície terrestre, como no caso dos kimberlitos. O processo de fusão e metassomatismo da litosfera se estenderia com maior volume e atingiria regiões mais rasas do manto litosférico (Figura 13). A partir de compostos mantélicos menos refratários (com maior concentração modal de piroxênio) seriam gerados magmas lamproíticos e kamafugitícos no APIP.

A hipótese de que o metassomatismo mantélico com idade próxima a eventos de magmatismo kimberlítico é sugerida por O’Reilly \& Griffin (2013), que inclusive aponta que este seria um meio para gerar diamantes. A relação geoquímica e geocronológica íntima entre xenólitos metassomatizados e eventos de magmatismo kimberlítico na África do Sul é registrado por Gregoire et al. (2002), que verifica semelhanças químicas entre xenólitos do tipo PIC com kimberlitos do tipo 1 e de xenólitos do tipo MARID com kimberlitos do tipo 2, e Giuliani et al. (2015) que fez uma revisão sobre minerais datados na área de Kimberley em xenólitos metassomatizados afere que a idade dos minerais metassomáticos não difere mais que 70 Ma em relação aos episódio de magmatismo atuantes na região.

As características texturais das amostras metassomatizadas, com minerais agregados em bolsões secundários e intersticiais; clinopiroxênio com padrões enriquecidos em ETRL $\mathrm{E}_{\mathrm{N}}\left(\sim 10 \mathrm{xETRP}_{\mathrm{N}}\right)$ e razões ${ }^{87} \mathrm{Sr} /{ }^{86} \mathrm{Sr}$ altas $(0,706-0,714)$ são assinaturas de um processo recente de metassomatismo, provavelmente do Cretáceo, assim como sugere Almeida et al. (2014). Futuros trabalhos devem determinar outras razões isotópicas $(\mathrm{Pb}, \mathrm{Nd}$ e Os) in situ em clinopiroxênio de xenólitos metassomatizados para estabelecer melhor o tipo de fonte do metassomatismo. 


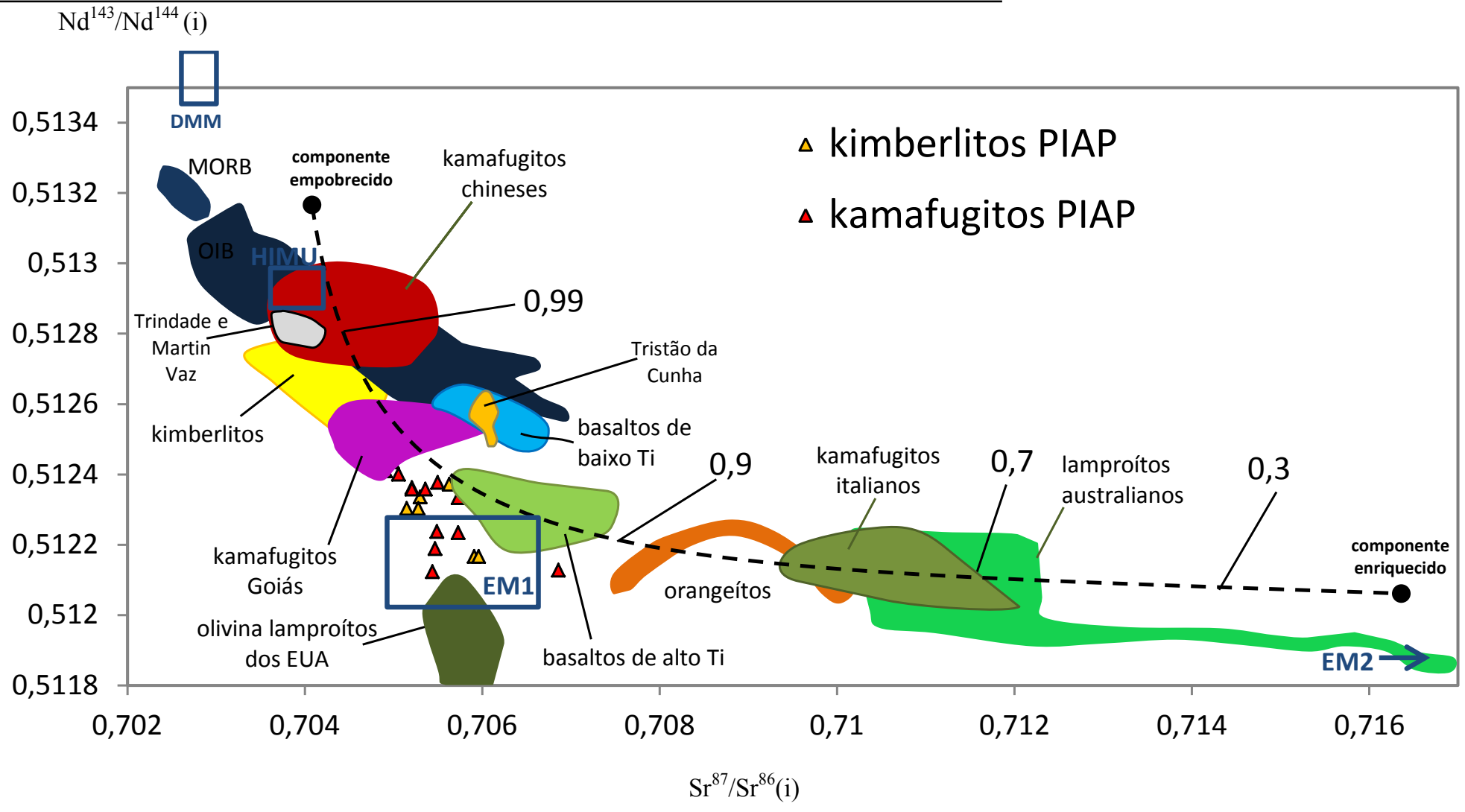

Figura 14- Composição isotópica $\mathrm{Sr}^{87} / \mathrm{Sr}^{86} \mathrm{i} v s$. $\mathrm{Nd}^{143} / \mathrm{Nd}^{144} \mathrm{i}$ de rochas máficas e ultramáficas, com destaque para os kamafugitos e lamproítos; e reservatórios mantélicos (Zindler \& Hart 1986), com curvas de mistura de componentes mantélicos para a geração de kamafugitos segundo Guo et al. (2014). Os campos composicionais de basaltos do tipos MORB, OIB, kimberlitos, orangeítos, lamproítos australianos e olivina-lamproitos dos EUA foram retirados de Mitchell (1986). Os campos de kamafugitos chineses, de Uganda e italianos foram retirados de Guo et al. (2014). Já os dados de basaltos da bacia do Paraná de alto Ti e baixo Ti, de amostras livres de contaminação (alto mg\#), foram extraídos de Rocha-Júnior (2011). Os dados de kimberlitos e kamafugitos da APIP (triângulos em destaque) foram retirados de Meyer et al. (1991), Guarino et al. (2013) e Felgate (2014), os de kamafugitos da PAG foram retirados de Carlson et al. (2007). Para as ilhas oceânicas Trindade e Martins Vaz os dados foram retirados de Marques et al. (1999), os da ilha de Tristão da Cunha foram retirados banco de dados da GEOROC (http://georoc.mpchmainz.gwdg.de/georoc/). 


\section{Capítulo IX- Conclusões}

A localização de kimberlitos, kamafugitos e rochas afins do oeste de Minas Gerais e regiões adjacentes coincide com área de baixa velocidade de ondas sísmicas no manto litosférico raso (Rocha et al. 2011). Entre os possíveis motivos para esta anomalia, destaca-se neste trabalho processos de metassomatismo na litosfera que poderiam corresponder aos observados em xenólitos mantélicos das intrusões Indaiá 1, Limeira 1 e Forca. Além disto, há descrições de outros xenólitos metassomatisados na região em trabalhos anteriores (Carvalho 1997, Almeida 2009 e Costa 2008).

Nas intrusões Indaiá 1, Limeira 1 e Forca, os xenólitos metassomatisados são harzburgitos ou dunitos com textura protogranular com bolsões contendo flogopita e clinopiroxênio, além de óxidos como cromita, ilmenita e titanatos raros (e.g., Almeida et al. 2014). Nestes grupos de amostras, olivina e ortopiroxênio apresentam significativa variação do mg\#, que é menor nas amostras com maior proporção modal de clinopiroxênio e flogopita, e nas amostras com coloração amarelada, refletindo uma maior intensidade do metassomatismo. Outra característica importante observada é a textura do clinopiroxênio destas amostras, que ocorre insterticial e em bordas de reação no ortopiroxênio, além do característico baixo teor de Al. Os minerais do grupo do espinélio relacionados a bolsões de flogopita nos xenólitos são cromitas, que em geral ocorrem com composição homogênea, porém por é bordejado por têm bordas de magnetita (resultante de reação com magma kimberlítico).

Uma amostra de harzburgito com bolsões de clinopiroxênio (In1-12), tem o clinopiroxênio com as maiores razões de $\operatorname{ETR}_{N}\left(\operatorname{La}_{\mathrm{N} \text { e }} \mathrm{Lu}_{\mathrm{N}}\right.$, respectivamente 25-43xPM e $1-2,5 \times \mathrm{PM})$ entre os peridotitos metassomatizados do conjunto, além de ter as mais baixas razões de Ti. Esta amostra apresenta padrão de $\mathrm{ETRL}_{\mathrm{N}}$ convexo e enriquecido em relação aos $\mathrm{ETRP}_{\mathrm{N}}$, o que ocorre com todos os clinopiroxênio metassomatizados. Análises de isótopos de $\mathrm{Sr}$ em clinopiroxênio da amostra In1-12 sugerem que existe um componente EM2 $\left({ }^{87} \mathrm{Sr} /{ }^{86} \mathrm{Sr}=0,706-0,714\right)$. Outra amostra analisada, o flogopita ilmenita wehrlito (In1-6) tem clinopiroxênio com ${ }^{87} \mathrm{Sr} /{ }^{86} \mathrm{Sr}=0,706-0,710$ o que também sugere a presença de componente EM2, que até então não foi descrito em rochas da APIP, sendo 
este o primeiro trabalho a efetuar este tipo de análise in situ em clinopiroxênio de xenólitos mantélicos.

Peridotitos com espinélio são frequentes nessas mesmas intrusões, e variam de férteis a empobrecidos em elementos basálticos: lherzolitos e harzburgitos com textura protogranular e espinélio; e harzburgitos e dunitos com textura granoblástica com $\mathrm{Cr}$ espinélio, podendo ocorrer anfibólio e clinopiroxênio secundário. Nestes grupos de amostras, olivina e ortopiroxênio apresentam alto mg\# em relação aos xenólitos metassomatisados, com aumento de mg\# nas amostras mais empobrecidas em clinopiroxênio. $\mathrm{O}$ clinopiroxênio tem alto $\mathrm{Al}$ em relação às amostras metassomatisadas, especialmente nos lherzolitos e harzburgitos com espinélio. Temperaturas de 640$840^{\circ} \mathrm{C}$, pelo termômetro de $\mathrm{Fe}-\mathrm{Mg}$ entre ortopiroxênio e clinopiroxênio, revelam que estas rochas são de manto litosférico raso. As amostras de peridotitos com espinélio tem maiores razões de $\operatorname{ETRP}_{\mathrm{N}}$ em clinopiroxênio que nas amostras com Cr-espinélio, de modo que as razões de $\mathrm{Y}_{\mathrm{N}}$ e $\mathrm{Yb}_{\mathrm{N}}$ (Norman 1998) sugerem processos de fusão parcial fracionada de maior e menor grau (5-8\% nas amostras com espinélio; 15-20\% nas amostras com Cr-espinélio). Análises de isótopos de $\mathrm{Sr}$ revelaram razões pouco radiogênicas de ${ }^{87} \mathrm{Sr} /{ }^{86} \mathrm{Sr}(0,703)$ no clinopiroxênio de uma amostra de peridotito com espinélio, compatível com componente empobrecido DMM.

Dunitos e harzburgitos porfiroclásticos com texturas em mosaico e fluidal foram identificados nas intrusões Indaiá 1 e Limeira 1, com olivina e ortopiroxênio com alto mg\# e valores significativos de Ti, Ca e Na, e ETRL, mais altos que nos outros tipos de xenólitos estudados, sugerindo metassomatismo críptico. A geração desta textura é atribuída a zonas com maior fluxo térmico no manto litosférico, ou seriam provenientes da astenosfera.

Os xenólitos observados no corpo Facão, classificado neste trabalho como sendo um lamproíto, apresentam textura cumulática e possíveis autólitos compostos por massa devitrificada (saponita) com K-richterita e clinopiroxênio, podendo conter wadeíta e zircão. A ausência de macrocristais de ortopiroxênio e xenólitos com ortopiroxênio nas intrusões Facão e Indaiá 2 sugere que todo o ortopiroxênio foi consumido, seja no manto, ou durante o transporte para a superfície no magma.

O metassomatismo mantélico teria sido gerado por fluidos com composição dominantemente carbonatítica, o que é evidenciado pelas altas razões $(\mathrm{La} / \mathrm{Yb})_{\mathrm{N}}$ e baixas 
razões Ti/Eu em clinopiroxênio nas amostras com flogopita e clinopiroxênio secundário em peridotitos com textura protogranular, que é sugestiva de litosfera. Processos distensivos atuantes associados a possíveis zonas de fraqueza relacionadas a formação do Oceano Atlântico, teriam possibilitado a formação de zonas de maior fluxo térmico, provenientes da astenosfera. Estas zonas desestabilizariam o manto litosferico, permitindo que fluidos de origem astenosférica chegassem a níveis mais rasos da litosfera, reagindo com os minerais preexistentes (eg. olivina, ortopiroxênio, clinopiroxênio, espinélio, granada) gerando primeiramente clinopiroxênio secundário com alto teor de ETR e baixo Ti por reação com fluidos carbonatíticos, já fluidos com componente silicático teria menos quantidade de ETR e maior quantidade de $\mathrm{K}$ e Ti, gerando flogopita, ilmenita e titanatos. A fusão desta litosfera metassomatizada seria capaz de gerar tanto kimberlitos (litosfera pouco metassomatizada), como kamafugitos e lamproítos (litosfera mais metassomatizada). 


\section{Capítulo X- Referências Bibliográficas}

Alexandrino C.H. 2008. Campo termal da província estrutural São Francisco e faixas móveis adjacentes. Tese de Doutorado em Geofísica - Observatório Nacional, Rio de Janeiro, 184p.

Alkmim F. F.\& Martins-Neto M. A. 2001. A bacia intracratônica do São Francisco: arcabouço estrutural e cenários evolutivos. Bacia do São Francisco: Geologia e Recursos Naturais. Cap. II: 9-30.

Almeida V.V. 2009. Mineralogia e petrologia de xenólitos mantélicos das regiões de Ubatuba (SP) e Monte Carmelo (MG): evidências de fusão parcial e metassomatismo no manto superior do sudeste do Brasil. Dissertação de Mestrado Instituto de Geociências, Universidade de São Paulo, 153p.

Almeida V.V., Janasi V.A., Svisero D.P., Nannini F. 2014. Mathiasite-loveringite and priderite in mantle xenoliths from the Alto Paranaíba Igneous Province, Brazil: genesis and constraints on mantle metasomatism. Central Euopean Journal of Geosciences 6(4): 614-632.

Anders E. \& Grevesse N. 1989. Abundances of the elements: meteoritic and solar. Geochimica et Cosmochimica Acta, 53: 197-214.

Araujo A.L.N., Carlson R.W., Gaspar J.C., Bizzi L.A. 2001. Petrology of kamafugites and kimberlites from the Alto Paranaíba Alkaline Province, Minas Gerais, Brazil. Contributions to Mineralogy and Petrology, 142(2): 63-177.

Arndt N. T., Guitreau M., Boullier A.M., Le Roex A., Tommasi A., Cordier P., Sobolev A. 2010. Olivine, and the origin of kimberlite. Journal of Petrology, 51: 573-602.

Ballhaus C., Berry R.F., Green D.H. 1991. High pressure experimental calibration of theolivine-orthopyroxene spinel oxygen geobarometer: implications for the oxidation state of the upper mantle. Contributions to Mineralogy and Petrology, 107: $27-40$.

Barbarin B. 1999. A review of the relationships between granitoid types, their origins and their geodynamic environments. Lithos. 46: 605-626.

Barbosa O., Braun O.P.G., Dyer R.C., Cunha C.A.B.R. 1970. Geologia da região do Triângulo Mineiro. Rio de Janeiro, DNPM/DFPM, Boletim 136, 140p.

Bardet M.G. 1977. Géologie du diamant. Part 3: gisements de diamants d'Asie, d'Amérique, d'Europe et d'Australasie. Mémoires du Bureau de Récherches Géologiques et Minières 83, 169p.

Basei M.A.S., Teixeira W., Svisero D.P., Martins V.T.S. 2003 Idades U-Pb em zircão, ${ }^{40} \mathrm{Ar}-{ }^{39} \mathrm{Ar}$ em flogopita, e caracteristicas isotópicas $(\mathrm{Nd}, \mathrm{Sr}$ e $\mathrm{Pb}$ ) das rochas 
kimberlíticas da Província Alcalina do Alto Paranaíba, Brasil. XII Simpósio de Geologia de Minas Gerais, p.45.

Bastin G.F., Van Loo F.J.J., Heijiligers H.J.M. 1984. Evaluation and use of Gaussian curvers in quantitative electron probe microanalisys: a new optimization. X-ray Spectrometry, 13: 91-97.

Beard A.D., Downes H., Mason P.R.D., Vetrin V.R. 2007. Depletion and enrichment processes in the lithospheric mantle beneath the Kola Peninsula (Russia): Evidence from spinel lherzolite and wehrlite xenoliths. Lithos, 94: 1-24.

Bertrand P. \& Merrier J.C.C. 1985. The mutual solubility of coexisting ortho- and clinopyroxene: toward an absolute geothermometer for the natural system? Earth and Planetary Science Letters, 76: 109-122.

Bianchini G., Beccaluva L., Bonadiman C., Nowell G., Pearson G., Siena F., Wilson M. 2007. Evidence of diverse depletion and metasomatic events in harzburgitelherzolite Almeida, V.V. 2009. Mineralogia e petrologia de xenólitos mantélicos das regiões de Ubatuba (SP) e Monte Carmelo (MG) mantle xenoliths from the Iberian plate (Olot, NE Spain): Implications for lithosphere accretionary processes. Lithos, 94: 25-45.

Bizzarro M., Simonetti A., Stevenson R. K., Kurszlaukis S. 2003. In situ ${ }^{87} \mathrm{Sr} /{ }^{86} \mathrm{Sr}$ investigation of igneous apatites and carbonates using laser-ablation MC-ICP-MS. Geochimica et Cosmochimica Acta, 67(2):289-302.

Bizzi L.A., DeWit M.J., Smith C.B., McDonald I., Armstrong R.A. 1995. Heterogeneous enriched mantle materials and Dupal-type magmatism along the SW margin of the São Francisco Craton, Brazil. Journal of Geodynamics, 20:469491.

Bizzi L.A. \& Araujo A.L.N., 2005. Dynamics of mantle-derived magmatism in the southwestern São Francisco Craton, Brazil. In: P. Comin-Chiaramonti and C.B. Gomes (Ed.), Mesozoic to Cenozoic Alkaline Magmatism in the Brazilian Platform. Editora da Universidade de São Paulo, São Paulo, pp. 241-365.

Bodinier J.L., Merlet C., Bedini R.M., Simien F., Remaidi M., Garrido C.J., 1996. Distribution of niobium, tantalum, and other highly incompatible trace elements in the lithospheric mantle: The spinel paradox. Geochimica et Cosmochimica Acta, 60(3): 545-550.

Bodinier J.L. \& Godard M. 2003. Orogenic, Ophiolic and Abyssal Peridotites. In: Carlson, R.W. (ed.), Treatise on Geochemistry, The Mantle and Core, 2: 103-170.

Boullier A.M., Nicolas A. 1975. Classification of textures and fabrics of peridotites xenoliths from South African Kimberlites. In: Ahrens L.H., Dawson J.B., Duncan A.R., Erlank A.J. (eds.) Physics and Chemistry of the Earth, 9: 467-475.

Boyd F.R. 1987. High- and low-temperature garnet peridotites and their possible relation to the lithosphere-asthenosphere boundary beneath southern Africa. In: Nixon, P.H. (ed.) Mantle Xenoliths. Chichester, John Wiley \& Sons. p.404-412. 
Brey G.P. \& Koehler T. 1990. Geothermobarometry in four-phase lherzolites II: New thermobarometers, and practical assessment of existing thermobarometers. Journal of Petrology, 31: 1353-1378.

Brey G.P., Bulatov V.K., Girnis A.V. 2008. Geobarometry for peridotites: experiments in simple and natural systems for 6 to $10 \mathrm{GPa}$. Journal of Petrology, $49(1): 3-24$.

Brod J.A., Gibson S.A., Thompson R.N., Junqueira-Brod T.C., Seer H.J., Moraes L.C., Boaventura G.R. 2000. The kamafugite-carbonatite association in the Alto Paranaíba Igneous Province (APIP) Southeastern Brazil. Revista Brasileira de Geociências 30(3):408-412.

Byron M.J. 1999. Physical volcanology and lithogeochemistry of the Mata da Corda Formation, Minas Gerais, Brazil. PhD Thesis from Department of Earth Sciences of Carleton University, Canada, 149p.

Campos J.E.G., Dardenne M.A. 1997. Origem e Evolução Tectônica da Bacia Sanfranciscana. Revista Brasileira de Geociências. 27(3):283-294.

Carlson R.W., Esperança S. \& Svisero D.P. 1996. Chemical and isotopic study of Cretaceous potassic rocks from southern Brazil. Contributions to Mineralogy and Petrology, 125:393-405.

Carlson R.W., Araujo A.L.N., Junqueira-Brod T.C., Gaspar J.C., Brod J.A., Petrinovic I.A., Hollanda M.H.B.M., Pimentel M.M., Sichel S. 2007. Chemical and isotopic relationships between peridotites xenoliths and mafic-ultrapotassic rocks from Southern Brazil. Chemical Geology, 242: 415-434.

Carmichael I.S.E. 1967. The iron-titanium oxides of salic volcanic rocks and their associated ferromagnesian silicates. Contributions to Mineralogy and Petrology, 14: 36-64.

Carvalho J.B. 1997. Petrologia de xenólitos mantélicos da Província do Alto Paranaíba, Minas Gerais. Tese de doutorado. Instituto de Geociências. Universidade de Brasília.

Chaves M.L.S.C., Brandão P.R.G., Girodo A.C., Benitez L. 2008. Kimberlito Canastra-1 (São Roque de Minas, MG): geologia, mineralogia e reservas diamantíferas. Revista Escola de Minas, 61(3): 357-364.

Class C. and le Roex A., 2011. South Atlantic DUPAL anomaly - Dynamic and compositional evidence against a recent shallow origin. Earth and Planetary Science Letters, 305(1-2): 92-102.

Coltorti M., Bonadiman C., Hinton R.W., Siena F., Upton B.G.J. 1999. Carbonatite metassomatism of the oceanic upper mantle: evidence from clinopyroxenes and glasses in ultramafic xenoliths of Grand Comore, Indian Ocean. Journal of Petrology 40: 133-165.

Condie K.C., Cox J., O’Reilly S.Y., Griffin W.L., Kerrich R. 2004. Distribution of high field strength and rare earth elements in mantle and lower crustal xenoliths 
from the southwestern United States: The role of grain-boundary phases. Geochimica et Cosmochimica Acta, 68 (19): 3919-3942.

Costa V.S. 1996. Estudos mineralógicos e químicos do kimberlito Batovi 6 (MT) em comparação com as intrusões Três Ranchos 4 (GO) e Limeira 1 (MG). Dissertação de Mestrado do Instituto de Geociênciasda, Universidade Estadual de Campinas, $112 \mathrm{p}$.

Costa G.V. 2008. Química mineral e geotermobarometria de xenólitos mantélicos do kimberlito Canastra-01. Dissertação de Mestrado, Instituto de Geociências, Universidade de Brasília, 137p.

Costa M.M.D. 2012. Petrografia e geoquímica isotópica de Sm-Nd em xenólitos mantélicos do kimberlito Canastra-1. Dissertação de Mestrado do Instituto de Geociências da Universidade de Brasília, Brasília, 138p.

Dalton J.A. \& Presnall D.C., 1998. The continuum of primary carbonatitic-kimberlitic melt compositions in equilibrium with lherzolite: data from the system $\mathrm{CaO}-\mathrm{MgO}-$ $\mathrm{Al}_{2} \mathrm{O}_{3}-\mathrm{SiO}_{2}-\mathrm{CO}_{2}$ at $6 \mathrm{GPa}$. Journal of Petrology, 39(11-12): 1953-1964.

Dardenne M.A., Schobbenhaus C. 2001. Metalogênese do Brasil. CPRM/UnB, Editora $\mathrm{UnB}, 392 \mathrm{p}$.

Dawson J.B. (ed.) 1980. Kimberlites and their xenoliths. Springer-Verlag, Berlin, $252 \mathrm{p}$.

Dawson J.B. 1984. Contrasting types of of upper mantle metasomatism. In: Kornprobst J. (ed) Kimberlites II: the mantle and crust -mantle relationships. Elsevier, Amsterdam, pp. 289-294.

Deer W.A., Howie R.A., Zussman J. 1992. An introduction to the rock forming minerals. Engleand Editors. Longamn Scientific and Technical, Harlow, 695 p.

Donatti-Filho J.P., Tappe S., Oliveira E.P., Heaman L.M. 2013. Age and origin of the Neoproterozoic Brauna kimberlites: Melt generation within the metasomatized base of the São Francisco craton, Brazil. Chemical Geology, 353: 19-35.

Eggins S.M., Rudnick R.L. \& McDonough W.F. 1998. The composition of peridotites and their minerals: a laser-ablation ICP-MS study. Earth and Planetary Science Letters, 154: 53-71.

Erlank A. J., Waters F. G., Hawkesworth C. J., Haggerty S. E., Allsopp H. L., Rickard R. S. \& Menzies M. (1987). Evidence for mantle metasomatism in peridotite nodules from the Kimberley pipes, South Africa. In: Menzies, M. \& Hawkesworth, C. J. (eds) Mantle Metasomatism. London: Academic Press, pp. 221-309.

Felgate M. R. 2014. The petrogenesis of Brazilian kimberlites and kamafugites intruded along the $125^{\circ}$ lineament: improved geochemical and geochronological constraints on magmatism in Rondonia and the Alto Paranaiba Igneous Province. $\mathrm{PhD}$ of School of Earth Sciences of The University of Melbourne, 275p.

Fernandes A.F., Karfunkel J., Hoover D.B., Sgarbi P.B.A., Sgarbi G.N.C., Oliveira G.D., Gomes J.C.S.P., Kambrock K. 2014. O conglomerado basal da Formação 
Capacete (Grupo Mata da Corda) e sua relação com as distribuições de diamantes em Coromandel, Minas Gerais, Brasil. Brazilian Journal of Geology, 44(1): 91103.

Finnerty A.A. \& Boyd F.R. 1978. Pressure dependent solubility of calcium in forsterite coexisting with diopside and enstatite. Carnegie Institution of Washington, Yearbook 77: 713-717.

Fragoso D.G.C., Uhlein A., Sanglard J.C.D., Suckau G.L., Guerzoni T.G., Faria P.H. 2011. Geologia dos Grupos Bambuí, Areado e Mata da Corda na Folha Presidente Olegário (1:100.000), MG: registro deposicional do neoproterozóico ao neocretáceo da Bacia do São Francisco. Geonomos, 19(1):28-38.

Gaillard F., Malki M., Iacono-Marziano G., Pichavant M., Scaillet B. 2008. Carbonatite melts and electrical conductivity in the asthenosphere. Science, 322: 1363-1365.

Gibson S.A., Thompson R.N., Leonardos O.H., Dickin A.P. \& Mitchell L.G. 1995. The late cretaceous impact of the Trindade mantle plume: evidence from large volume, mafic, potassic magmatism in southeastern Brazil. Journal of Petrology, 36(1): 189-229.

Giuliani A., Philips D., Woodhead J.D., Kamenetsky, Fiorentini M.L., Maas R., Soltys A., Armstrong R.A. 2015. Did diamond-bearing orangeites originate from MARIDveined peridotites in the lithospheric mantle? Nature Communications, 6:6837.

Gonzaga G.M. \& Tompkins L.A. 1991. Geologia do diamante. In: Schobbenhaus C., Queiroz E.T., Coelho C.E.S (org.). Principais Depósitos Minerais do Brasil. Brasília: DNPM/CPRM. Vol. 4. pp. 53-116.

Gregoire M., Bell D.R., Roux A.P.L. 2002. Trace element geochemistry of phlogopite-rich mafic mantle xenoliths: their classification and their relationship to phlogopite-bearing peridotites and kimberlites revisited. Contributions to Mineralogy and Petrology, 142: 603-625.

Griffin W.L., Smith D., Ryan C.G., O’Reilly S.Y. \& Win T.T. 1996. Trace element zoning in mantle minerals: Metasomatism and thermal events in the upper mantle. Canadian Mineralogist, 34: 1179-1193.

Guarino V., Wu F., Lustrino M., Melluso L., Brotzu P., Gomes C.B., Ruberti E., Tassinari C.C.G., Svisero D.P. 2013. U-Pb ages, Sr-Nd- isotope geochemistry, and petrogenesis of kimberlites, kamafugites and phlogopite-picrites of the Alto Paranaíba Igneous Province, Brazil. Chemical Geology, 353: 65-82.

Gudfinnsson G.H. \& Presnall D.C. 2005. Continuous gradations among primary carbonatitic, kimberlitic, melilititic, basaltic, picritic, and komatiitic melts in equilibrium with garnet lherzolite at 3-8 GPa. Journal of Petrology, 46: 16451659.

Guo P., Niu Y., Yu X. 2014. A synthesis and new perspective on the petrogenesis of kamafugites from West Qinling, China, in a global context. Journal of Asian Earth Sciences, 79: 86-96. 
Haggerty S.E., Smyth J.R., Erlank A.J., Rickard R.S. \& Dachin R.V. 1983. Lindsleyite (Ba) and Mathiasite $(\mathrm{K})$ : two new chromium-titanates in the crichtonite series from the uppermantle. American Mineralogist, 68: 494-505.

Haggerty S.E. 1995. Upper mantle mineralogy. Journal of Geodynamics, 20(4): 331364.

Hart S.R., 1984. A large-scale isotope anomaly in the Southern Hemisphere mantle. Nature, 309(5971): 753-757.

Harte B. 1977. Rock nomenclature with particular relation to deformation and recrystallization textures in olivine-bearing xenoliths. Journal of Geology, 85: 279288.

Hasui Y. \& Haralyi N.L.E. 1991. Aspectos lito-estruturais e geofísicos do soerguimento do Alto Paranaíba. Geociências, São Paulo, 10: 57-77.

Hawthorne F.C. \& Oberti R. 2007. Classification of Amphiboles. Reviews in Mineralogy \& Geochemistry, 67: 55-88.

Heaman L., Teixeira N.A., Gobbo L. \& Gaspar J.C. 1998. U-Pb mantle zircon ages for kimberlites from the Juína and Paranatinga provinces, Brazil. Proceedings of the $7^{\text {th }}$ International Kimberlite Conference, Cape Town. Extended Abstracts, 322-324.

Heinrich C.A., Pettke T., Halter W.E., Aigner-Torres M., Audétat A., Günther D., Hattendorf B., Bleiner D., Guillong M., Horn I., 2003. Quantitative multi-element analysis of minerals, fluid and melt inclusions by laser-ablation inductivelycoupled-plasma mass-spectrometry. Geochimica et Cosmochimica Acta, 67(18): 3473-3497.

Holmes A., 1950. Petrogenesis of katungite and its associates. American Mineralogist, 35: 772-792.

Ionov D.A., Bodinier J.-L., Mukasa S.B., Zanetti A., 2002. Mechanisms and Sources of Mantle Metasomatism: Major and Trace Element Compositions of Peridotite Xenoliths from Spitsbergen in the Context of Numerical Modelling. Journal of Petrology, 43(12): 2219.

Ionov D.A., Chazot G., Chauvel C., Merlet C., Bodinier J.-L., 2006. Trace element distribution in peridotite xenoliths from Tok, SE Siberian craton: A record of pervasive, multi-stage metasomatism in shallow refractory mantle. Geochimica et Cosmochimica Acta, 70(5): 1231-1260.

Jackson S.E., Longerich H.P., Dunning G.R., Fryer B.J. 1992. The application of laser ablation microprobe-inductively coupled plasma-mass-spectrometry (LAM-ICPMS) to in situ trace-element determinations in minerals. Canadian Mineralogist, 30: 1049-1064.

Janasi V.A., Vlach S.R.F., Ulbrich H.H.G.J. 1993. Enriched-mantle contributions to the Itu granitoid belt, southeastern Brazil: evidence from K-rich diorites and syenites, Anais da Academia Brasileira de Ciências, 65(1): 107-118. 
Janasi V.A., Andrade S., Ulbrich H.H.G.J. 1995. A correção do drift instrumental em ICP-AES com espectômetro seqüencial e a análise de elementos maiores, menores e traços em rochas. Boletim IG-USP-Série Cientifica, 26: 45-58.

Jaques A.L, Lewis J.D., Smith C.B. 1986. The kimberlites and lamproites of Western Australia. Geological Survey of Western Australia, Bulletin 132.

Jelsma H., Barnett W., Richards S., Lister G., 2009. Tectonic setting of kimberlites. Lithos, 112: 155-165.

Jenkins D.M. \& Newton R.C. 1979. Experimental determination of the spinel peridotite to garnet peridotite inversion at $900^{\circ} \mathrm{C}$ and $1000^{\circ} \mathrm{C}$ in the system $\mathrm{CaO}$ $\mathrm{MgO}-\mathrm{Al}_{2} \mathrm{O}_{3}-\mathrm{SiO}_{2}$, and at $900^{\circ} \mathrm{C}$ with natural garnet and olivine. Contributions to Mineralogy and Petrology, 68:407-419.

Jones A. P., Smith J. V. and Dawson J. B. (1982) Mantle metasomatism in 14 veined peridotite xenoliths from Bultfontein Mine, South Africa. Journal of Geology, 90:439-453.

Junqueira-Brod T.C., Riog H.L., Gaspar J.C., Brod J.A., Meneses P.R. 2002. A Província Alcalina de Goiás e a extensão de seu vulcanismo kamafugítico. Revista Brasileira de Geociências, 32(4):559-566.

Karfunkel J., Hoover D., Fernandes A.F., Sgarbi G.N.C., Kambrock K., Oliveira G.D. 2014. Diamantes da região de Coromandel, oeste de Minas Gerais, Brasil: atualização e novos dados sobre sua origem. Brazilian Journal of Geology, 44(2): 325-338.

Koehler T. \& Brey G.P. (1990). Calcium exchange between olivine and clinopyroxene calibrated as a geothermobarometer for natural peridotites from 2 to $60 \mathrm{~kb}$ with applications. Geochimica et Cosmochimica Acta, 54: 2375-2388.

Le Bas M.J. \& Streckeisen A.L. (1991): The IUGS systematics of igneous rocks. Journal of the Geological Society of London, 148: 825-833.

Le Maitre R.W., Bateman P., Dudek A., Keller J. 1989. A classification of igneous rocks and glossary of terms. Oxford, Blackwell Science publications, 193p.

Le Maitre R. W., Streckeisen A., Zanettin B., Le Bas M.J., Bonin B.,Bateman P., Bellieni G., Dudek A., Efremova S., Keller J., Lameyre J., Sabine P.A.,Schmid R., Sørensen H., Wooley A.R. (2002). Igneous Rocks: a Classification and Glossary of Terms: Recommendations of the International Union of Geological Sciences Subcommission on the Systematics of Igneous Rocks. Cambridge: Cambridge University Press, $236 \mathrm{p}$.

Le Roux V., Bodinier J.L., Thomassi A., Alard O., Dautria J.M., Vauchez A., Riches A.J.V. 2007. The Lherz spinel lherzolite: refertilized than pristine mantle. Earth and Planetary Science Letters. 259: 599-612. 
Leonardos O.H. \& Meyer H.O.A. 1991. Geology of Western Minas Gerais.In: Field Guide book of $5^{\text {th }}$ International Kimberlite Conference, Araxá. CPRM Special Publication 91(3): 17-24.

Leonardos O.H., Ulbrich M.N.C. \& Gaspar, J.C. 1991. The Mata da Corda volcanic rock. In: $5^{\text {th }}$ International Kimberlite Conference, 5th, Araxá, Brazil, 3: 65-73.

Liu K.H., Gao S.S., Silver P.G., Zang Y. 2003. Mantle layering across central South America, Journal of Geophysical Research, 108 (11): 2510-2519.

MacGregor I.D. 1974. The system $\mathrm{MgO}-\mathrm{Al}_{2} \mathrm{O}_{3}-\mathrm{SiO}_{2}$ : solubility of $\mathrm{Al}_{2} \mathrm{O}_{3}$ in enstatite for spinel and garnet peridotite compositions. American Mineralogist, 59: 110-119.

Marques L.S., Ulbrich M.N.C., Ruberti E., Tassinari C.G. 1999. Petrology, geochemistry and $\mathrm{Sr}-\mathrm{Nd}$ isotopes of the Trindade and Martin Vaz volcanic rocks (Southern Atlantic Ocean), Journal of Volcanology and Geothermal Research, 93(3): 191-216.

Martins-Neto M.A., Castro P.T.A., Hercos C.M. 1997. O Supergrupo São Francisco (Neoproterozóico) no Cráton do São Francisco em Minas Gerais. Belo Horizonte, SBG/MG, Boletim 14: 22-24.

Mcdonough W.F. \& Sun S. 1995. The composition of the Earth. Chemical Geology, 120: $223-253$.

Melluso L., Lustrino M., Ruberti E., Brotzu P., Gomes C.B., Morbidelli L., Morra V., Svisero D.P. 2008. Major- and trace-element composition of olivine, perovskite, clinopyroxene, $\mathrm{Cr}-\mathrm{Fe}-\mathrm{Ti}$ oxides, phlogopite and host kamafugites and kimberlites, Alto Paranaiba, Brazil. Canadian Mineralogist, 46: 19-40.

Mercier J.C.C. \& Nicolas A. 1975. Textures and fabrics of upper mantle peridotites as illustrated by xenoliths from basalts. Journal of Petrology, 16(2): 454-487.

Meyer H.O.A. \& Svisero D.P. 1991. Limeira and Indaiá intrusions, Minas Gerais. Field Guide Book, 5th International Kimberlite Conference, Araxá (Minas Gerais, Brazil). CPRM Special Publication, 3: 49-55.

Meyer H.O.A., Garwood B.L., Svisero D.P., Smith C.B. 1991. Alkaline ultrabasic intrusions in Western Minas Gerais, Brazil. In: Proceedings of the $5^{\text {th }}$ International Kimberlite Conference, v.1:140-155.

Mitchell R.H. 1986. Kimberlites: mineralogy, geochemistry and petrology. Plenum Press, N.Y., 422p.

Mitchell R.H. 1995. Kimberlites, orangeites and related rocks. Plenum Press, New York, 410p.

Mitchell R.H. \& Bergman S.C. 1991. Petrology of lamproites. Plenum Press, New York, 447p.

Morimoto N., Fabries J., Ferguson A.K., Ginzburg I.V., Ross M., Seifert F.A., Zussman J., Aoki K., Gottardi G. 1988. Nomenclature of pyroxenes. American Mineralogist, 73: 1123-1133. 
Murphy D. T., Collerson K. D. \& Kamber B. S. 2002. Lamproites from Gaussberg, Antarctica: possible transition zone melts of Archaean subducted sediments. Journal of Petrology, 43: 981-1001.

Nannini F. 2011. Petrografia e química mineral de xenólitos mantélicos da intrusão Kimberlítica Indaía, Monte Carmelo, MG. Dissertação de Mestrado do Instituto de Geociências da USP, São Paulo, 100 p.

Nickel K.G. \& Green D.H. 1985. Empirical geothermobarometry for garnet peridotites and implications for the nature of the lithosphere, kimberlites and diamonds. Earth and Planetary Science Letters, 73:158-170.

Nimis P. \& Taylor W. R. 2000. Single clinopyroxene thermobarometry for garnet peridotites. Part I. Calibration and testing of a Cr-in-Cpx barometer and an enstatite-in-Cpx thermometer. Contributions to Mineralogy and Petrology, 139(5): 541-554.

Nishijima P.S.T. 2013. Petrografia e geoquímica dos Kimberlitos Forca e Facão, Província Ígnea do Alto Paranaíba. Trabalho de Conclusão de Curso do IG UNICAMP, 52p.

Nixon P.H. 1987. Mantle Xenoliths. John Willey and Sons, New York, 844p.

Nixon P.H. \& Boyd F.R. 1973. Petrogenesis of the granular and sheared ultrabasic nodule suite in kimberlites. In: Nixon P.H.(ed) Lesotho Kimberlites. Maseru, Lesotho National Development Corporation, p.48-56.

Norman M.D. 1998. Melting and metasomatism in the continental lithosphere: laser ablation ICPMS analysis of minerals in spinel lherzolites from eastern Australia. Contributions to Mineralogy and Petrology, 130: 240-255.

Nowell G.M., Pearson D.G., Bell D.R., Carlson R.W., Smith C.B., Kempton P.D., Noble R. 2004. Hf isotope systematics of kimberlites and their megacrysts: new constraints on their source regions. Journal of Petrology, 45(8): 1583-1612.

O'Neill H.St.C. \& Wall V.J. 1987. The olivine-orthopyroxene-spinel oxygen geobarometer, the nickel precipitation curve, and the oxygen fugacity of the Earth's upper mantle. Journal of Petrology, 28: 1169-1191.

O'Reilly S.Y. \& Griffin W.L. 2013. Mantle metasomatism. In: D.E. Harlov \& Austrhein (ed.) Metasomatism and the chemical transformation of rock, Lecture Notes in Earth System Sciences, Springer-Verlag Berlin Heidelberg, 471-532.

Patiño-Douce A.E. 1999. What do experiments tell us about the relative contributions for crust and mantle to the origin of granitic magmas? In: Castro, A.; Fernandez, C. \& Vigneresse, J.L. (eds.): Understanding Granites: Integrating new and classical techniques. Geological Society, London, Special Publication, 168: 55-75.

Paton C., Hergt J.M., Phillips D., Woodhead J.D. and Shee S.R. 2007. New insights into the genesis of Indian kimberlites from the Dharwar Craton via in situ $\mathrm{Sr}$ isotope analysis of groundmass perovskite. Geology, 35(11): 1011-1014. 
Pearson D.G., Canil D. \& Shirey S.B. 2003. Mantle samples included in volcanic rocks: xenoliths and diamonds. In: Carlson, R.W. (ed.), Treatise on Geochemistry, The Mantle and Core, 2: 171-275.

Peate D.W., Hawkesworth C.J., Mantovani M.S.M., Rogers N.W., Turner S.P., 1999. Petrogenesis and stratigraphy of the high-Ti/Y Urubici magma type in the Paraná Flood Basalt Province and implications for the nature of 'Dupal'-type mantle in the South Atlantic Region. Journal of Petrology, 40(3): 451-473.

Pereira R.S. 2007. Cráton do São Francisco, kimberlitos e diamantes. Tese de Doutorado, Instituto de Geociências, Universidade de Brasília, 200 p.

Piccirillo E.M., Civetta L., Petrini R., Longinelli A., Bellieni G., Comin-Chiaramonti P., Marques L.S., Melfi A.J., 1989. Regional variations within the Parana flood basalts (southern Brazil): Evidence for subcontinental mantle heterogeneity and crustal contamination. Chemical Geology, 75(1-2): 103-122.

Pollack H.N. \& Chapman D.S. 1977. On the regional variation on heat flow, geotherms and lithospheric thickness. Tectonophysics, 38: 279-296.

Read G., Grutter H., Winter S., Luckman N., Gaunt F., Thomsen F. 2004. Stratigraphic relations, kimberlite emplacement and lithospheric thermal evolution, Quirico basin, Minas Gerais state, Brazil. Lithos, 77(1-4): 803-818.

Ringwood A.E., Kesson S.E., Hibberson W., Ware N., 1992. Origin of kimberlite and related magmas. Earth and Planetary Science Letters, 113(4): 521-538.

Rocha M.P. 2008.Tomografia sísmica com ondas P e S para o estudo do manto superior no Brasil. Tese de Doutorado, do Instituto de Astronomia, Geofísica e Ciências Atmosféricas, São Paulo, 86p.

Rocha M.P., Schimmel M., Assumpcao M., 2011. Upper-mantle seismic structure beneath SE and central Brazil from P- and S-wave regional traveltime tomography. Geophsical Hournal International, 184(1): 286.

Rocha M.L.G. de, Pires A.C.B., Carmelo A.C., Araújo Filho J.O. de. 2014. Geophysical characterization of the Azimuth $125^{\circ}$ lineament with aeromagnetic data: Contibutions to the geology of Central Brazil. Precambrian Research, 249: 273-287.

Rocha-Júnior E.R.V. 2011. Sistemática isotópica de Os-Nd-Pb-Sr e geoquímica de elementos traço litófilos e siderófilos de baslatos da Província Magmática do Paraná. Tese de Doutorado, do Instituto de Astronomia, Geofísica e Ciências Atmosféricas, São Paulo, 153p.

Rocha-Júnior E.R.V., Puchtel I.S., Marques L.S., Walker R.J., Machado F.B., Nardy A.J.R., Babinski M., Figueiredo A.M.G., 2012. Re-Os isotope and highly siderophile element systematics of the Paraná Continental Flood Basalts (Brazil). Earth and Planetary Scence Letters, 337-338: 164-173.

Rollinson H.R., 1993. Using geochemical data: evaluation, presentation, interpretation In: Hugh R. Rollinson. Geochemistry series. Harlow, Essex, England: Longman Scientific \& Technical ; New York, Wiley \& Sons, 352p. 
Russell J.K., Porritt L.A., Lavallee Y., Dingwell D.B. 2012. Kimberlite ascent by assimilation-fueled buoyancy. Nature, 481:352-355.

Ryan C. G., Griffin W. L. \& Pearson N. J. (1996). Garnet geotherms: pressuretemperature data from Cr-pyrope garnet xenocrysts in volcanic rocks. Journal of Geophysical Research, 101: 5611-5625.

Sahama T.G., 1974. Potassium rich alkaline rocks. In: Sorensen, H. (Ed.), The Alkaline Rocks. Wiley, London, pp. 96-109.

Schmidberger S.S., Simonetti A. and Francis D. 2003. Small-scale Sr isotope investigation of clinopyroxenes from peridotite xenoliths by laser ablation MCICP-MS--implications for mantle metasomatism. Chemical Geology, 199(3-4): 317-329.

Segal I., Halicz L., Platzner I.T. 2003. Accurate isotope ratio measurements of ytterbium by multiple collection inductively coupled plasma mass spectrometry applying erbium and hafnium in an improved double external normalization procedure. Journal of Analytical Atomic Spectrometry, 18(10): 12171223.

Seer H.J., Moraes L.M, Junges S.L. 2010. Novos dados U-Pb e Sm-Nd de granitos intrusivos no Grupo Araxá, Faixa Brasília Meridional, entre a região de Araxá e Monte Carmelo, MG. In: Congresso Brasileiro de Geologia, 45, Belém, PA. Anais, SBG, Resumo.

Sgarbi P.B.A., Gaspar J.C., Valença J.G., 2000. Brazilian Kamafugites. Revista Brasileira de Geociencias, 30(3): 417-420.

Sgarbi P.B.A., Heaman L.M., Gaspar J.C., 2004. U-Pb perovskite ages for Brazilian kamafugitic rocks: Further support for a temporal link to a mantle plume hotspot track. Journal of South American Earth Sciences, 16(8): 715-724.

Silva S. 2008. Petrografia e química mineral das intrusões Indaiá I e Indaiá II, oeste do estado de Minas Gerais. Dissertação de Mestrado do Instituto de Geociências, Universidade de São Paulo, 113p.

Streckeisen A.L. 1976. Classification of the common igneous rocks by means of their chemical composition: a provisional attempt. Neues Jahrbuch für Mineralogie, Monatshefte, 1: 1-15.

Sun S.S. \& Mcdonough W.F. 1989. Chemical and isotopic systematics of oceanic basalts: implications for mantle compositions and processes. In: Saunders, A.D. \& Norry, M.J. (eds.). Magmatism in the Ocean Basins, Special Publication Volume of Geologic Society of London, 42: 313-346.

Svisero D.P. \& Haralyi N.L.E. 1984. O Kimberlito Indaiá, Monte Carmelo, MG. Anais $33^{\circ}$ Congresso Brasileiro de Geologia,10: 5014-5026. 
Svisero D.P., Meyer H.O.A., Haralyi N.L.E. \& Hasui Y. 1984. A note on the geology of some Brazilian kimberlites. Journal of Geology, 92: 331-338.

Svisero D.P. \& Ulbrich M.N.C. 1992. Mineralogia, petrografia e geologia do kimberlito Limeira e intrusões associadas, município de Monte Carmelo, Minas Gerais. Boletim IG-USP. Série Especial, São Paulo, 12: 127-129.

Svisero D.P. 1995. Distribution and origin of diamonds in Brazil: an overview. Journal of Geodynamics, 20(4):493-514.

Tainton K.M. \& McKenzie D., 1994. The generation of kimberlites, lamproites, and their source rocks. Journal of Petrology, 35(3): 787-817.

Tappe S., Foley S.F., Jenner G.A., Kjarsgaard B.A. 2005. Integrating ultramafic lamprophyres into the IUGS classification of igneous rocks: rational and implications. Journal of Petrology, 46: 1893-1900.

Tappe S., Pearson D.G., Kjarsgaard B.A., Nowell G., Dowall D. 2013. Mantle transition zone input to kimberlite magmatism near a subduction zone: Origin of anomalous $\mathrm{Nd}-\mathrm{Hf}$ isotope systematics at Lac de Gras, Canada. Earth and Planetary Science Letters, 371-372: 235-251.

Thompson R.N., Gibson S.A., Mitchell J.G., Dickin A.P., Leonardos O.H., Brod J.A. \& Greenwood J.C. 1998. Migrating Cretaceous-Eocene magmatism in the Serra do Mar Alkaline Province, SE Brazil: melts from the deflected Trindade mantle plume? Journal of Petrology, 39: 1493-1526.

Toyoda K., Horiuchi H., Tokonami M. 1994. Dupal anomaly of Brazilian carbonatites - geochemical correlations with hotspots in the South-Atlantic and implications for the mantle source. Earth and Planetary Science Lettters, 126: 315-331.

Turner S., Regelous M., Kelley S., Hawkesworth C.J., Mantovani M. 1994. Magmatism and continental break-up in the South Atlantic: high precision 40Ar39Ar geochronology. Earth and Planetary Science Letters, 121: 333-348.

Ulbrich M.N.C., Leonardos O.H. 1991. As rochas ultrapotássicas da Mata da Corda, MG: lamproitos ou kamafugitos? Boletim IG-USP, Publicação Especial, 9:93-97.

VanDecar J.C.J.D.E., 1995. Seismic evidence for a fossil mantle plume beneath South America and implications for plate. Nature, 378: 25-31.

Wells P.R.A. 1977. Pyroxene thermometry in simple and complex systems. Contributions to Mineralogy and Petrology, 62: 129-139.

Wernick E. \& Menezes A.C. 2001. The Late Precambrian K-alkaline magmatism in the Ribeira Fold Belt: A case study of the Piracaia pluton, state of São Paulo, SE Brazil, and its potential mineralization $(\mathrm{Cu}, \mathrm{Zn}, \mathrm{Gd})$. Asian Journal of Earth Sciences, 19: 347-373. 
Witt-Eickschen G.E. \& Seck H.A. 1991. Solubility of Ca and Al in orthopyroxene from spinel peridotite: an improved version of an empirical geothermometer. Contributions to Mineralogy and Petrology, 106: 431-439.

Woolley A.R., Bergman S.C., Edgar A.D., Le Bas M.J., Mitchell R.H., Rock N.M.S., Smith B.H.S. 1996. Classification of lamprophyres, lamproites, kimberlites, and the kalsilitic, melilitic, and leucitic rocks. Canadian Mineralogist, 34: 175-186.

Wyatt B.A., Baumgartner M., Anckar E., Grutter H. 2004. Compositional classification of "kimberlitic" and "non-kimberlitic" ilmenite. Lithos, 77: 819-840.

Zindler A. and Hart S. 1986. Chemical Geodynamics. Annual Review of Earth and Planetary Sciences, 14: 493-571.

Zindler A. \& Jagoutz E. 1988. Mantle cryptology. Geochimica et Cosmochimica Acta, 52: 319-333. 


\section{ANEXO A}

Tabela com classificação das amostras estudadas e os métodos utilizados para cada amostra 
Tabela 18 - Relação das amostras estudadas dos corpos Indaiá-1 (com código de prefixo In1), Limeira-1 (Lm1), Forca (Fo) e Facão (Fac), com as principais características físicas e composicionais.

\begin{tabular}{|c|c|c|c|c|c|c|c|c|c|c|c|c|}
\hline $\begin{array}{l}\text { Código da } \\
\text { amostra }\end{array}$ & $\begin{array}{l}\text { Dimensão } \\
\text { máxima }(\mathrm{cm})\end{array}$ & Cor & Forma & Textura & $\begin{array}{c}\text { Composição mineralógica e porcentagem } \\
\text { modal }\end{array}$ & $\begin{array}{l}\text { Natureza }(* \text { sem } \\
\text { estimativa modal) }\end{array}$ & $\begin{array}{l}\text { Estrutura/ } \\
\text { mineral } \\
\text { alongado }\end{array}$ & Lâmina & Microssonda & MEV & Traços & Isótopos \\
\hline In1-1 & 5 & $\begin{array}{l}\text { cinza escuro } \\
\text { esverdeado }\end{array}$ & $\begin{array}{l}\text { esférico sub- } \\
\text { arredondado }\end{array}$ & $\begin{array}{l}\text { Porfiroclástica com } \\
\text { mosaico }\end{array}$ & $\begin{array}{l}60 \% \text { olivina }+39 \% \text { ortopiroxênio }+0,8 \% \\
\text { flogopita }+0,2 \% \text { clinopiroxênio }\end{array}$ & Harzburgito & $\begin{array}{l}\text { Foliado/ } \\
\text { ortopiroxênio }\end{array}$ & $\mathrm{x}$ & $\mathrm{x}$ & & $\mathrm{x}$ & \\
\hline In1-2 & 4,5 & $\begin{array}{l}\text { preto escuro } \\
\text { esverdeado }\end{array}$ & $\begin{array}{l}\text { tabular sub- } \\
\text { arredondado }\end{array}$ & Protogranular & $\begin{array}{c}86 \% \text { olivina }+7 \% \text { flogopita }+4 \% \\
\text { clinopiroxênio }+2 \% \text { ortopiroxênio }+0,8 \% \\
\text { cromita }+0,2 \% \text { ilmenita }\end{array}$ & Flogopita-dunito & Maciço & $\mathrm{x}$ & $\mathrm{x}$ & $\mathrm{x}$ & $\mathrm{x}$ & \\
\hline In1-3 & 3,5 & $\begin{array}{l}\text { verde pálido a } \\
\text { cinza claro }\end{array}$ & $\begin{array}{l}\text { elipsoidal } \\
\text { anguloso }\end{array}$ & Granoblástica & $\begin{array}{l}52 \% \text { olivina }+44 \% \text { ortopiroxênio }+2 \% \mathrm{Cr}- \\
\text { espinélio }+2 \% \text { clinopiroxênio }\end{array}$ & Harzburgito & $\begin{array}{l}\text { Levemente } \\
\text { foliado/ } \\
\text { espinélio }\end{array}$ & $\mathrm{x}$ & $\mathrm{x}$ & $\mathrm{x}$ & $\mathrm{x}$ & \\
\hline In1-4 & 2,5 & $\begin{array}{l}\text { cinza } \\
\text { esverdeado } \\
\text { pálido }\end{array}$ & $\begin{array}{l}\text { esférico sub- } \\
\text { arredondado }\end{array}$ & Porfiroclástica & $\begin{array}{l}57 \% \text { olivina }+28 \% \text { ortopiroxênio }+13 \% \\
\text { clinopiroxênio }+2 \% \text { espinélio }\end{array}$ & Lherzolito & $\begin{array}{l}\text { Levemente } \\
\text { foliado/ } \\
\text { ortopiroxênio }\end{array}$ & $\mathrm{x}$ & $\mathrm{x}$ & & $\mathrm{x}$ & \\
\hline In1-5 & 2 & preto & $\begin{array}{l}\text { tabular } \\
\text { arredondado }\end{array}$ & Protogranular & $\begin{array}{l}76 \% \text { olivina }+20 \% \text { ortopiroxênio }+3 \% \\
\text { clinopiroxênio }+1 \% \text { flogopita }+ \text { cromita }\end{array}$ & Harzburgito & maciço & $\mathrm{x}$ & & & & \\
\hline In1-6 & 2 & preto & $\begin{array}{l}\text { esférico } \\
\text { arredondado }\end{array}$ & $\begin{array}{l}\text { Intercrescimento } \\
\text { gráfico e veio de } \\
\quad \text { flogopita }\end{array}$ & $\begin{array}{c}39 \% \text { olivina }+26 \% \text { clinopiroxênio }+24 \% \\
\text { ilmenita }+8 \% \text { flogopita }+2 \% \text { carbonato }+ \\
1 \% \text { ortopiroxenio + zircão }\end{array}$ & $\begin{array}{l}\text { Flogopita- } \\
\text { ilmenita wehrlito }\end{array}$ & $\begin{array}{l}\text { Levemente } \\
\text { foliado/ } \\
\text { ilmenita }\end{array}$ & $\mathrm{x}$ & $\mathrm{x}$ & $\mathrm{x}$ & $\mathrm{x}$ & $\mathrm{x}$ \\
\hline In1-7 & 2,5 & branco & $\begin{array}{l}\text { esférico sub- } \\
\text { arredondado }\end{array}$ & Equigranular & quartzo + feldspato (alterado) & Granito & maciço & & & & & \\
\hline In1-8 & 2,6 & branco a bege & $\begin{array}{l}\text { esférico } \\
\text { arredondado }\end{array}$ & Equigranular & quartzo + feldspato (alterado) & Granito & maciço & & & & & \\
\hline In1-9a & 6 & $\begin{array}{l}\text { verde claro } \\
\text { amarelado }\end{array}$ & $\begin{array}{l}\text { elipsoidal sub- } \\
\text { anguloso }\end{array}$ & Protogranular & $\begin{array}{l}48 \% \text { olivina }+46 \% \text { ortopiroxênio }+3 \% \\
\text { clinopiroxênio }+3 \% \text { espinélio }\end{array}$ & Harzburgito & maciço & $\mathrm{x}$ & $\mathrm{x}$ & & & \\
\hline In $1-9 b$ & 6 & $\begin{array}{l}\text { verde claro } \\
\text { amarelado }\end{array}$ & $\begin{array}{l}\text { elipsoidal sub- } \\
\text { anguloso }\end{array}$ & Protogranular & $\begin{array}{l}67 \% \text { olivina }+24 \% \text { ortopiroxênio }+5 \% \\
\text { clinopiroxênio }+4 \% \text { espinélio }\end{array}$ & Lherzolito & $\begin{array}{l}\text { Levemente } \\
\text { foliado/ } \\
\text { olivina }\end{array}$ & $\mathrm{x}$ & & & & \\
\hline In $1-10$ & 2,3 & $\begin{array}{l}\text { cinza } \\
\text { esverdeado }\end{array}$ & $\begin{array}{l}\text { elipsoidal sunb- } \\
\text { arredondado }\end{array}$ & Porfiroclástica & $\begin{array}{l}81 \% \text { olivina }+14 \% \text { ortopiroxênio }+4 \% \\
\text { clinopiroxênio }+1 \% \text { espinélio }\end{array}$ & Harzburgito & $\begin{array}{c}\text { Levemente } \\
\text { foliado/ orto- } \\
e \\
\text { clinopiroxênio }\end{array}$ & $\mathrm{x}$ & & & & \\
\hline In1-11 & 5,5 & $\begin{array}{l}\text { bege } \\
\text { esverdeado }\end{array}$ & $\begin{array}{l}\text { elipsoidal } \\
\text { arredondado }\end{array}$ & Inequigranular & olivina + carbonato + matriz & Nódulo alterado & maciço & $\mathrm{x}$ & & & & \\
\hline In $1-12$ & 3 & $\begin{array}{l}\text { cinza } \\
\text { esverdeado } \\
\text { pálido }\end{array}$ & $\begin{array}{l}\text { tabular sub- } \\
\text { anguloso }\end{array}$ & Protogranular & $\begin{array}{c}86 \% \text { olivina }+11 \% \text { ortopiroxênio }+2,7 \% \\
\text { clinopiroxênio }+0,2 \% \text { flogopita }+0,1 \% \\
\text { cromita }\end{array}$ & Harzburgito & maciço & $\mathrm{x}$ & $\mathrm{x}$ & $\mathrm{x}$ & $\mathrm{x}$ & $\mathrm{x}$ \\
\hline
\end{tabular}




\begin{tabular}{|c|c|c|c|c|c|c|c|c|c|c|c|c|}
\hline $\begin{array}{l}\text { Código da } \\
\text { amostra }\end{array}$ & $\begin{array}{l}\text { Dimensão } \\
\text { máxima }(\mathrm{cm})\end{array}$ & Cor & Forma & Textura & $\begin{array}{l}\text { Composição mineralógica e porcentagem } \\
\text { modal }\end{array}$ & $\begin{array}{l}\text { Natureza }(* \text { sem } \\
\text { estimativa modal) }\end{array}$ & $\begin{array}{l}\text { Estrutura/ } \\
\text { mineral } \\
\text { alongado }\end{array}$ & Lâmina & Microssonda & MEV & Traços & Isótopos \\
\hline In1-13a & 2 & $\begin{array}{l}\text { cinza } \\
\text { esverdeado } \\
\text { escuro }\end{array}$ & $\begin{array}{l}\text { alongado sub- } \\
\text { arredondado }\end{array}$ & Protogranular & $\begin{array}{l}66 \% \text { olivina }+26,5 \% \text { ortopiroxênio }+7 \% \\
\text { clinopiroxênio }+0,5 \% \text { espinélio }\end{array}$ & Lherzolito & $\begin{array}{l}\text { Levemente } \\
\text { foliado/ } \\
\text { ortopiroxênio }\end{array}$ & $\mathrm{x}$ & $\mathrm{x}$ & & & \\
\hline In1-13b & 1,5 & verde & $\begin{array}{l}\text { esférico } \\
\text { anguloso }\end{array}$ & $\begin{array}{l}\text { Transicional } \\
\text { (granoblástica a } \\
\text { protogranular) }\end{array}$ & $\begin{array}{l}72 \% \text { olivina }+25,8 \% \text { ortopiroxênio }+2 \% \\
\text { clinopiroxênio }+0,2 \% \text { espinélio }\end{array}$ & Harzburgito & maciço & $\mathrm{x}$ & $\mathrm{x}$ & & & \\
\hline In1-14a & 4,5 & verde claro & $\begin{array}{l}\text { elipsoidal } \\
\text { anguloso }\end{array}$ & $\begin{array}{l}\text { Transicional } \\
\text { (granoblástica a } \\
\text { protogranular) }\end{array}$ & $\begin{array}{l}73 \% \text { olivina }+20 \% \text { ortopiroxênio }+5 \% \\
\quad \text { clinopiroxênio }+2 \% \text { espinélio }\end{array}$ & Lherzolito & $\begin{array}{l}\text { Levemente } \\
\text { foliado/ } \\
\text { olivina }\end{array}$ & $\mathrm{x}$ & $\mathrm{x}$ & & $\mathrm{x}$ & $\mathrm{x}$ \\
\hline In1-14b & 1,2 & $\begin{array}{c}\text { verde } \\
\text { acinzentado }\end{array}$ & $\begin{array}{l}\text { esférico } \\
\text { arredondado }\end{array}$ & $\begin{array}{l}\text { Transicional } \\
\text { (granoblástica a } \\
\text { protogranular) }\end{array}$ & $\begin{array}{l}65 \% \text { olivina }+31 \% \text { ortopiroxênio }+3 \% \\
\text { flogopita }+2 \% \text { clinopiroxênio }\end{array}$ & Harzburgito & maciço & $\mathrm{x}$ & & & & \\
\hline In1-14c & 2,2 & $\begin{array}{l}\text { cinza } \\
\text { esverdeado }\end{array}$ & $\begin{array}{l}\text { esférico sub- } \\
\text { arredondado }\end{array}$ & Protogranular & $\begin{array}{c}96,7 \% \text { olivina }+3 \% \text { espinélio }+0,3 \% \\
\text { clinopiroxênio }\end{array}$ & Dunito & maciço & $\mathrm{x}$ & $\mathrm{x}$ & & & \\
\hline In $1-15$ & 2,5 & verde escuro & $\begin{array}{l}\text { elipsoidal sub- } \\
\text { arredondado }\end{array}$ & Granoblástica & $\begin{array}{l}80 \% \text { olivina }+14 \% \text { ortopiroxênio }+5,7 \% \\
\quad \text { clinopiroxênio }+0,3 \% \text { espinélio }\end{array}$ & Lherzolito & maciço & $\mathrm{x}$ & & & & \\
\hline In1-16 & 2,8 & $\begin{array}{l}\text { cinza } \\
\text { esverdeado }\end{array}$ & $\begin{array}{c}\text { tabular } \\
\text { arredondado }\end{array}$ & Protogranular & $\begin{array}{l}87 \% \text { olivina }+9 \% \text { ortopiroxênio }+2 \% \\
\text { clinopiroxênio }+2 \% \text { espinélio }\end{array}$ & Harzburgito & $\begin{array}{l}\text { Levemente } \\
\text { foliado/ } \\
\text { olivina }\end{array}$ & $\mathrm{x}$ & & & & \\
\hline In1-17 & 1,5 & $\begin{array}{l}\text { cinza } \\
\text { esverdeado } \\
\text { escuro }\end{array}$ & $\begin{array}{l}\text { tabular } \\
\text { arredondado }\end{array}$ & & olivina & Megacristal & & & & & & \\
\hline In1-18 & 2 & verde escuro & $\begin{array}{l}\text { elipsoidal sub- } \\
\text { arredondado }\end{array}$ & $\longrightarrow$ & ortopiroxênio + olivina & Harzburgito * & maciço & & & & & \\
\hline In1-19a & 7 & verde claro & $\begin{array}{l}\text { esférico com } \\
\text { borda de reação } \\
\text { lobadas }\end{array}$ & Inequigranular seriada & $\begin{array}{l}\text { macrocristais de olivina e carbonato em } \\
\text { matriz de clorita, clinopiroxênio, apatita e } \\
\text { perovskita }\end{array}$ & Nódulo alterado & maciço & & & & & \\
\hline In1-19b & 3,5 & verde claro & $\begin{array}{l}\text { tabular com } \\
\text { bordas lobadas }\end{array}$ & Inequigranular seriada & $\begin{array}{l}\text { macrocristais de olivina e carbonato em } \\
\text { matriz de clorita, clinopiroxênio, apatita e } \\
\text { perovskita }\end{array}$ & Nódulo alterado & maciço & & & & & \\
\hline In1-20a & 3,5 & verde oliva & $\begin{array}{c}\text { elipsoidal } \\
\text { arredondado } \\
\text { (forma de gota) }\end{array}$ & - & olivina & Megacristal & & $\mathrm{x}$ & $\mathrm{x}$ & & $\mathrm{x}$ & \\
\hline In1-20b & 10 & $\begin{array}{l}\text { cinza } \\
\text { esverdeado }\end{array}$ & $\begin{array}{l}\text { esférico } \\
\text { anguloso }\end{array}$ & Protogranular & $\begin{array}{c}81 \% \text { olivina }+17 \% \text { ortopiroxênio }+1,8 \% \\
\text { flogopita }+0,2 \% \text { cromita }\end{array}$ & Harzburgito & maciço & $\mathrm{x}$ & $\mathrm{x}$ & & & \\
\hline In1-20c & 2,4 & $\begin{array}{l}\text { cinza } \\
\text { esverdeado }\end{array}$ & tabular anguloso & Porfiroclástica & $\begin{array}{l}88 \% \text { olivina }+9 \% \text { ortopiroxênio }+2 \% \\
\text { clinopiroxênio }+1 \% \text { espinélio }\end{array}$ & Harzburgito & maciço & $\mathrm{x}$ & & & & \\
\hline In1-20d & 2 & branco & $\begin{array}{c}\text { elipsoidal } \\
\text { subarredondado }\end{array}$ & Equigranular & Quartzo + feldspato (alterado) & Granito & maciço & $\mathrm{x}$ & & & & \\
\hline In1-20e & 3 & $\begin{array}{l}\text { cinza } \\
\text { esverdeado }\end{array}$ & $\begin{array}{l}\text { tabular } \\
\text { arredondado }\end{array}$ & Granoblástica & $\begin{array}{c}74 \% \text { olivina }+19 \% \text { ortopiroxênio }+3 \% \\
\text { clinopiroxênio }+3 \% \text { espinélio }+2 \% \\
\text { anfibólio }\end{array}$ & Lherzolito & $\begin{array}{l}\text { Levemente } \\
\text { foliado/ } \\
\text { olivina }\end{array}$ & $\mathrm{x}$ & & & & \\
\hline
\end{tabular}




\begin{tabular}{|c|c|c|c|c|c|c|c|c|c|c|c|c|}
\hline $\begin{array}{l}\text { Código da } \\
\text { amostra }\end{array}$ & $\begin{array}{l}\text { Dimensão } \\
\text { máxima }(\mathrm{cm})\end{array}$ & Cor & Forma & Textura & $\begin{array}{c}\text { Composição mineralógica e porcentagem } \\
\text { modal }\end{array}$ & $\begin{array}{l}\text { Natureza }(* \text { sem } \\
\text { estimativa modal) }\end{array}$ & $\begin{array}{l}\text { Estrutura/ } \\
\text { mineral } \\
\text { alongado }\end{array}$ & Lâmina & Microssonda & MEV & Traços & Isótopos \\
\hline In1-20f & 0,7 & $\begin{array}{c}\text { verde } \\
\text { esmeralda }\end{array}$ & $\begin{array}{l}\text { esférico } \\
\text { arredondado }\end{array}$ & $\longrightarrow$ & Clinopiroxênio & Macrocristal & & & & & & \\
\hline In $1-20 \mathrm{~g}$ & 1,8 & verde & $\begin{array}{l}\text { esférico com } \\
\text { borda lobada }\end{array}$ & Protogranular & $\begin{array}{c}\text { Olivina }+ \text { ortopiroxênio }+ \text { clinopiroxênio }+ \\
\text { espinélio }\end{array}$ & Lherzolito* & Maciço & & & & & \\
\hline In1-20h & 1,3 & verde & $\begin{array}{l}\text { elipsoidal sub- } \\
\text { arredondado }\end{array}$ & Protogranular & $\begin{array}{c}\text { Olivina }+ \text { ortopiroxênio }+ \text { clinopiroxênio }+ \\
\text { espinélio }\end{array}$ & Lherzolito* & Maciço & & & & & \\
\hline In1-20i & 2 & cinza escuro & $\begin{array}{l}\text { tabular sub- } \\
\text { anguloso }\end{array}$ & Protogranular & $\begin{array}{l}\text { Olivina }+ \text { ortopiroxênio }+ \text { clinopiroxênio }+ \\
\text { flogopita }\end{array}$ & Harzburgito* & Maciço & & & & & \\
\hline In $1-20 \mathrm{j}$ & 4,5 & verde claro & $\begin{array}{l}\text { amebóide sub- } \\
\text { arredondado }\end{array}$ & Inequigranular seriada & $\begin{array}{l}\text { Macrocristais de olivina e carbonato em } \\
\text { matriz não identificada }\end{array}$ & Nódulo alterado & Maciço & & & & & \\
\hline In1-201 & 2,1 & $\begin{array}{l}\text { verde claro } \\
\text { com nódulo } \\
\text { róseo incluso }\end{array}$ & $\begin{array}{l}\text { tabular } \\
\text { arredondado }\end{array}$ & $\begin{array}{l}\text { Equigranular fina } \\
\text { (autólito) e média } \\
\text { granito }\end{array}$ & $\begin{array}{l}\text { Macrocristais de olivina e carbonato em } \\
\text { matriz não identificada }\end{array}$ & Nódulo alterado & Maciço & & & & & \\
\hline In1-21a & 1 & preto & $\begin{array}{l}\text { elipsoidal } \\
\text { arredondado }\end{array}$ & $\longrightarrow$ & Ortopiroxênio & Megacristal & & & & & & \\
\hline In1-21b & 0,5 & preto & $\begin{array}{l}\text { elipsoidal } \\
\text { arredondado em } \\
\text { porção com } \\
\text { textura } \\
\text { fanerítica fina } \\
\text { no kimb. }\end{array}$ & $\longrightarrow$ & Flogopita & Macrocristal & & & & & & \\
\hline In1-22a & 1,8 & verde pálido & $\begin{array}{l}\text { tabular } \\
\text { arredondado }\end{array}$ & Protogranular & Olivina + ortopiroxênio + flogopita & Dunito* & Maciço & & & & & \\
\hline In $1-22 b$ & 1,3 & verde pálido & $\begin{array}{l}\text { tabular } \\
\text { arredondado }\end{array}$ & Protogranular & Olivina + ortopiroxênio + flogopita & Dunito* & Maciço & & & & & \\
\hline In1-23a & 1,5 & $\begin{array}{l}\text { cinza } \\
\text { esverdeado } \\
\text { escuro }\end{array}$ & tabular anguloso & Granoblástica & Olivina + ortopiroxênio & Harzburgito* & Maciço & & & & & \\
\hline In1-23b & 1,3 & $\begin{array}{c}\text { alterado } \\
\text { (esbraquiçado) }\end{array}$ & $\begin{array}{l}\text { elipsoidal } \\
\text { arredondado }\end{array}$ & Protogranular & $\begin{array}{c}\text { Olivina }+ \text { ortopiroxênio }+ \text { clinopiroxênio }+ \\
\text { espinélio }\end{array}$ & Lherzolito* & Maciço & & & & & \\
\hline In1-23c & 3 & $\begin{array}{c}\text { alterado } \\
\text { (esbraquiçado) }\end{array}$ & tabular anguloso & Protogranular & $\begin{array}{c}\text { Olivina }+ \text { ortopiroxênio }+ \text { clinopiroxênio }+ \\
\text { espinélio }\end{array}$ & Harzburgito* & Maciço & & & & & \\
\hline In1-23d & 1,5 & $\begin{array}{l}\text { verde } \\
\text { acinzentado } \\
\text { claro }\end{array}$ & $\begin{array}{l}\text { elipsoidal sub- } \\
\text { arredondado }\end{array}$ & Protogranular & $\begin{array}{c}\text { Olivina }+ \text { ortopiroxênio }+ \text { clinopiroxênio }+ \\
\text { espinélio }\end{array}$ & Lherzolito* & Maciço & & & & & \\
\hline In1-24a & 4 & cinza & $\begin{array}{l}\text { esférico } \\
\text { arredondado }\end{array}$ & Granoblástica & $\begin{array}{l}89,8 \% \text { olivina }+9 \% \text { ortopiroxênio }+1 \% \\
\text { Cr-espinélio }+0,2 \% \text { anfibólio }\end{array}$ & Dunito & $\begin{array}{l}\text { Levemente } \\
\text { foliado/ } \\
\text { olivina }\end{array}$ & $\mathrm{x}$ & $\mathrm{x}$ & & $\mathrm{x}$ & \\
\hline
\end{tabular}




\begin{tabular}{|c|c|c|c|c|c|c|c|c|c|c|c|c|}
\hline $\begin{array}{l}\text { Código da } \\
\text { amostra }\end{array}$ & $\begin{array}{l}\text { Dimensão } \\
\text { máxima }(\mathrm{cm})\end{array}$ & Cor & Forma & Textura & $\begin{array}{c}\text { Composição mineralógica e porcentagem } \\
\text { modal }\end{array}$ & $\begin{array}{l}\text { Natureza }(* \text { sem } \\
\text { estimativa modal) }\end{array}$ & $\begin{array}{l}\text { Estrutura/ } \\
\text { mineral } \\
\text { alongado }\end{array}$ & Lâmina & Microssonda & MEV & Traços & Isótopos \\
\hline In1-24b & 2 & preto & $\begin{array}{l}\text { triangular sub- } \\
\text { arredondado }\end{array}$ & Equigranular & $\begin{array}{l}81 \% \text { flogopita }+10 \% \text { ilmenita }+6 \% \\
\text { ortopiroxênio }+3 \% \text { olivina }\end{array}$ & $\begin{array}{c}\text { Flogopita } \\
\text { ortopiroxenito }\end{array}$ & Maciço & $\mathrm{x}$ & & & & \\
\hline In1-25a & 4 & cinza escuro & $\begin{array}{l}\text { tabular sub- } \\
\text { anguloso }\end{array}$ & Porfiroclástico & $\begin{array}{l}95,3 \% \text { olivina }+4 \% \text { ortopiroxênio }+0,6 \% \\
\text { flogopita }+0,1 \% \text { perovskita }+ \text { monticellita }\end{array}$ & Dunito & Foliado & $\mathrm{x}$ & $\mathrm{x}$ & & & \\
\hline In1-25b & 0,5 & cinza & $\begin{array}{l}\text { elipsoidal sub- } \\
\text { arredondado }\end{array}$ & Granular & $\begin{array}{l}84 \% \text { olivina }+13,8 \% \text { ortopiroxênio }+1 \% \\
\text { espinélio }+0,2 \% \text { flogopita }\end{array}$ & Lherzolito & Maciço & $\mathrm{x}$ & & & & \\
\hline In $1-26$ & 3 & $\begin{array}{l}\text { cinza } \\
\text { esverdeado }\end{array}$ & $\begin{array}{l}\text { elipsoidal sub- } \\
\text { arredondado }\end{array}$ & Granular & $\begin{array}{c}\text { Olivina }+ \text { ortopiroxênio }+ \text { clinopiroxênio }+ \\
\text { espinélio }\end{array}$ & Lherzolito* & Maciço & & & & & \\
\hline In1-27a & 2 & verde & $\begin{array}{l}\text { elipsoidal sub- } \\
\text { arredondado }\end{array}$ & Granular & Quartzo + feldspato (alterado) & Granito & Maciço & & & & & \\
\hline In1-27b & 2 & $\begin{array}{c}\text { cinza } \\
\text { esverdeado }\end{array}$ & $\begin{array}{l}\text { elipsoidal sub- } \\
\text { arredondado }\end{array}$ & Protogranular & $\begin{array}{c}\text { Olivina }+ \text { ortopiroxênio }+ \text { clinopiroxênio }+ \\
\text { espinélio }\end{array}$ & Lherzolito* & Maciço & & & & & \\
\hline In $1-28$ & 1,5 & $\begin{array}{l}\text { cinza } \\
\text { esverdeado }\end{array}$ & $\begin{array}{l}\text { elipsoidal sub- } \\
\text { anguloso }\end{array}$ & Granoblástica & $\begin{array}{c}\text { Olivina }+ \text { ortopiroxênio }+ \text { clinopiroxênio }+ \\
\text { espinélio }\end{array}$ & Lherzolito* & Maciço & & & & & \\
\hline In1-29 & 1,5 & $\begin{array}{l}\text { cinza } \\
\text { esverdeado }\end{array}$ & $\begin{array}{l}\text { elipsoidal sub- } \\
\text { anguloso }\end{array}$ & Granoblástica & $\begin{array}{c}\text { Olivina }+ \text { ortopiroxênio }+ \text { clinopiroxênio }+ \\
\text { espinélio }\end{array}$ & Lherzolito* & Maciço & & & & & \\
\hline In $1-30$ & 3,5 & verde & $\begin{array}{l}\text { elipsoidal sub- } \\
\text { arredondado }\end{array}$ & Inequigranular & $\begin{array}{l}\text { Macrocristais de olivina e carbonato em } \\
\text { matriz não identificada }\end{array}$ & Nódulo alterado & Maciço & & & & & \\
\hline In $1-31$ & 2 & $\begin{array}{l}\text { cinza róseo } \\
\text { escuro }\end{array}$ & $\begin{array}{l}\text { elipsoidal } \\
\text { arredondado }\end{array}$ & Cumulático & $\begin{array}{l}41 \% \text { flogopita }+23 \% \text { ortopiroxênio }+17 \% \\
\text { ilmenita }+18 \% \text { olivina }+ \\
\text { clinopiroxênio }\end{array}$ & $\begin{array}{c}\text { Flogopita } \\
\text { ortopiroxenito }\end{array}$ & Maciço & $\mathrm{x}$ & & & & \\
\hline In $1-32$ & 2 & $\begin{array}{l}\text { verde } \\
\text { acinzentado }\end{array}$ & $\begin{array}{l}\text { tabular } \\
\text { arredondado }\end{array}$ & Protogranular & $\begin{array}{c}\text { Olivina }+ \text { ortopiroxênio }+ \text { clinopiroxênio }+ \\
\text { espinélio }\end{array}$ & Lherzolito* & Maciço & & & & & \\
\hline In1-33 & 1 & cinza & $\begin{array}{l}\text { esférico } \\
\text { arredondado } \\
\text { com cúspides }\end{array}$ & $\begin{array}{l}\text { Porfiroclastica com } \\
\text { mosaico e fluidal }\end{array}$ & $\begin{array}{l}83 \% \text { olivina }+17 \% \text { ortopiroxênio }+ \\
\text { clinopiroxênio }+ \text { monticellita }+ \text { perovskita }\end{array}$ & Harzburgito & Maciço & $\mathrm{x}$ & $\mathrm{x}$ & $\mathrm{x}$ & $\mathrm{x}$ & \\
\hline In $1-34$ & 2 & $\begin{array}{c}\text { cinza } \\
\text { esverdeado }\end{array}$ & $\begin{array}{l}\text { tabular } \\
\text { arredondado }\end{array}$ & Granular média & $\begin{array}{l}86 \% \text { olivina }+9 \% \text { ortopiroxênio }+2 \% \\
\text { clinopiroxênio }+1 \% \text { espinélio }+0,7 \% \\
\text { carbonato }+0,3 \% \text { flogopita }\end{array}$ & Harzburgito & $\begin{array}{l}\text { Levemente } \\
\text { foliado/ } \\
\text { olivina }\end{array}$ & $\mathrm{x}$ & & & & \\
\hline In1-36 & 1 & marrom escuro & $\begin{array}{l}\text { placoidal } \\
\text { arredondado }\end{array}$ & - & $\begin{array}{c}\text { Flogopita com inclusões de ilmenita, clorita } \\
\text { e barita }\end{array}$ & Megacristal & & $\mathrm{x}$ & & $\mathrm{x}$ & & \\
\hline In $1-50$ & 2 & $\begin{array}{c}\text { cinza } \\
\text { esverdeado }\end{array}$ & $\begin{array}{l}\text { tabular sub- } \\
\text { anguloso }\end{array}$ & Granoblástica & $\begin{array}{c}87 \% \text { olivina }+10 \% \text { ortopiroxênio }+2 \% \\
\text { espinélio }+0,7 \% \text { anfibólio }+0,3 \% \\
\text { clinopiroxênio }\end{array}$ & Harzburgito & Maciço & $\mathrm{x}$ & $\mathrm{x}$ & & $\mathrm{x}$ & \\
\hline
\end{tabular}




\begin{tabular}{|c|c|c|c|c|c|c|c|c|c|c|c|c|}
\hline $\begin{array}{l}\text { Código da } \\
\text { amostra }\end{array}$ & $\begin{array}{l}\text { Dimensão } \\
\text { máxima }(\mathrm{cm})\end{array}$ & Cor & Forma & Textura & $\begin{array}{l}\text { Composição mineralógica e porcentagem } \\
\text { modal }\end{array}$ & $\begin{array}{l}\text { Natureza }(* \text { sem } \\
\text { estimativa modal) }\end{array}$ & $\begin{array}{l}\text { Estrutura/ } \\
\text { mineral } \\
\text { alongado }\end{array}$ & Lâmina & Microssonda & MEV & Traços & Isótopos \\
\hline In2-1 & 2,5 & $\begin{array}{c}\text { Branco } \\
\text { esverdeado }\end{array}$ & $\begin{array}{l}\text { Tabular } \\
\text { arredondado }\end{array}$ & Equigranular & $\begin{array}{l}\text { Feldspato potássico + plagioclásio + } \\
\text { quartzo + vidro (saponita) + K-richterita } \\
\text { +clinopiroxênio + hamotoma + flogopita }\end{array}$ & Granito & Maciço & $\mathrm{x}$ & $\mathrm{x}$ & $\mathrm{x}$ & & \\
\hline Lm1-1 & 5 & marrom escuro & $\begin{array}{l}\text { tabular } \\
\text { arredondado }\end{array}$ & Protogranular & $\begin{array}{l}94 \% \text { olivina }+3 \% \text { clinopiroxênio }+2,5 \% \\
\text { ortopiroxênio }+0,4 \% \text { flogopita }+0,1 \% \\
\text { cromita }+ \text { mathiasita }\end{array}$ & $\begin{array}{l}\text { Dunito com } \\
\text { flogopita }\end{array}$ & Maciço & $\mathrm{x}$ & $\mathrm{x}$ & $\mathrm{x}$ & $\mathrm{x}$ & \\
\hline Lm1-2 & 3 & $\begin{array}{c}\text { verde } \\
\text { esbranquiçado }\end{array}$ & $\begin{array}{l}\text { esférico sub- } \\
\text { arredondado }\end{array}$ & Protogranular & Olivina + ortopiroxênio + flogopita & $\begin{array}{l}\text { Harzburgito com } \\
\quad \text { flogopita }\end{array}$ & Maciço & & & & & \\
\hline Lm1-3 & 4 & marrom escuro & $\begin{array}{l}\text { tabular sub- } \\
\text { arredondado }\end{array}$ & Protogranular & Olivina + ortopiroxênio + flogopita & Lherzolito & Maciço & & & & & \\
\hline Lm1-4 & 3 & $\begin{array}{c}\text { cinza } \\
\text { esverdeado }\end{array}$ & $\begin{array}{l}\text { alongado } \\
\text { anguloso }\end{array}$ & Granoblástica & Olivina + ortopiroxênio + flogopita & Harzburgito & $\begin{array}{c}\text { Foliado/ } \\
\text { olivina }\end{array}$ & & & & & \\
\hline Lm1-5 & 2,5 & $\begin{array}{c}\text { cinza } \\
\text { esverdeado }\end{array}$ & $\begin{array}{l}\text { tabular sub- } \\
\text { arredondado }\end{array}$ & Granoblástica & Olivina + ortopiroxênio + flogopita & Harzburgito & $\begin{array}{c}\text { Foliado/ } \\
\text { olivina }\end{array}$ & & & & & \\
\hline Lm1-6 & 4 & $\begin{array}{c}\text { cinza } \\
\text { esverdeado }\end{array}$ & $\begin{array}{l}\text { tabular } \\
\text { arredondado }\end{array}$ & Granoblástica & Olivina + ortopiroxênio + flogopita & Harzburgito & Maciço & & & & & \\
\hline Lm1-7 & 1,8 & $\begin{array}{l}\text { cinza } \\
\text { amarelado }\end{array}$ & $\begin{array}{l}\text { tabular sub- } \\
\text { anguloso }\end{array}$ & Protogranular & Olivina + serpentina & Dunito & Maciço & & & & & \\
\hline Lm1-8 & 3 & $\begin{array}{l}\text { branco com } \\
\text { borda verde }\end{array}$ & $\begin{array}{l}\text { tabular sub- } \\
\text { anguloso }\end{array}$ & & Carbonato + borda de alteração & Carbonato & Maciço & & & & & \\
\hline Lm1-12 & 2,8 & $\begin{array}{c}\text { cinza } \\
\text { esbranquiçado }\end{array}$ & $\begin{array}{l}\text { tabular sub- } \\
\text { anguloso }\end{array}$ & & Carbonato + borda de alteração & Carbonato & Maciço & & & & & \\
\hline Lm1-14a & 2,5 & $\begin{array}{l}\text { amarelo } \\
\text { acinzentado }\end{array}$ & $\begin{array}{l}\text { cúbico sub- } \\
\text { arredondado }\end{array}$ & Protogranular & olivina + serpentina & Dunito & Maciço & $\mathrm{x}$ & $\mathrm{x}$ & $\mathrm{x}$ & & \\
\hline Lm1-14b & 2,5 & marrom escuro & $\begin{array}{c}\text { tabular } \\
\text { subarredondado }\end{array}$ & Equigranular & augita + alteração + carbonato & Clinopiroxenito & Maciço & $\mathrm{x}$ & $\mathrm{x}$ & $\mathrm{x}$ & $\mathrm{x}$ & \\
\hline Lm1-15a & 5 & $\begin{array}{l}\text { cinza } \\
\text { amarelado }\end{array}$ & $\begin{array}{l}\text { amebóide sub- } \\
\text { anguloso }\end{array}$ & Protogranular & $\begin{array}{c}96 \% \text { olivina }+1 \% \text { ortopiroxênio }+1 \% \\
\text { clinopiroxênio }+1 \% \text { flogopita }+1 \% \\
\text { cromita }\end{array}$ & $\begin{array}{l}\text { Dunito com } \\
\text { flogopita }\end{array}$ & Maciço & $\mathrm{x}$ & $\mathrm{x}$ & $\mathrm{x}$ & & \\
\hline Lm1-15b & 5 & $\begin{array}{l}\text { cinza } \\
\text { amarelado }\end{array}$ & $\begin{array}{l}\text { amebóide sub- } \\
\text { anguloso }\end{array}$ & Protogranular & $\begin{array}{c}98 \% \text { olivina }+0,5 \% \text { ortopiroxênio }+0,5 \% \\
\text { clinopiroxênio }+0,5 \% \text { flogopita }+0,5 \% \\
\text { cromita }\end{array}$ & $\begin{array}{l}\text { Dunito com } \\
\text { flogopita }\end{array}$ & Maciço & $\mathrm{x}$ & & & & \\
\hline Lm1-17a & 10 & $\begin{array}{l}\text { cinza } \\
\text { amarelado }\end{array}$ & $\begin{array}{l}\text { elipsoidal } \\
\text { anguloso }\end{array}$ & Protogranular & $\begin{array}{l}75,5 \% \text { olivina }+19 \% \text { ortopiroxênio }+ \\
3,3 \% \text { espinélio }+1,9 \% \text { clinopiroxênio }\end{array}$ & Harzburgito & Maciço & $\mathrm{x}$ & $\mathrm{x}$ & $\mathrm{x}$ & & \\
\hline Lm1-17b & 10 & $\begin{array}{l}\text { cinza } \\
\text { amarelado }\end{array}$ & $\begin{array}{l}\text { elipsoidal } \\
\text { anguloso }\end{array}$ & Protogranular & $\begin{array}{l}80,5 \% \text { olivina }+8 \% \text { ortopiroxênio }+7,5 \% \\
\text { clinopiroxênio }+4 \% \text { espinélio }\end{array}$ & Lherzolito & Maciço & $\mathrm{x}$ & $\mathrm{x}$ & $\mathrm{x}$ & $\mathrm{x}$ & \\
\hline
\end{tabular}




\begin{tabular}{|c|c|c|c|c|c|c|c|c|c|c|c|c|}
\hline $\begin{array}{l}\text { Código da } \\
\text { amostra }\end{array}$ & $\begin{array}{l}\text { Dimensão } \\
\text { máxima }(\mathrm{cm})\end{array}$ & Cor & Forma & Textura & $\begin{array}{c}\text { Composição mineralógica e porcentagem } \\
\text { modal }\end{array}$ & $\begin{array}{l}\text { Natureza }(* \text { sem } \\
\text { estimativa modal) }\end{array}$ & $\begin{array}{l}\text { Estrutura/ } \\
\text { mineral } \\
\text { alongado }\end{array}$ & Lâmina & Microssonda & $\mathrm{MEV}$ & Traços & Isótopos \\
\hline Lm1-17b' & 0,4 & amarelo & tabular anguloso & & olivina & Macrocristal & & & & & & \\
\hline Lm1-18 & 0,8 & $\begin{array}{l}\text { amarelo } \\
\text { acinzentado }\end{array}$ & $\begin{array}{l}\text { cúbico } \\
\text { subarredondado }\end{array}$ & Granoblástica & Olivina + ortopiroxênio + espinélio & Harzburgito & Maciço & & & & & \\
\hline Lm1-19 & 3 & $\begin{array}{l}\text { verde } \\
\text { acinzentado }\end{array}$ & tabular anguloso & Inequigranular fino & $\begin{array}{l}\text { Carbonato }+ \text { olivina }+ \text { clinopiroxênio }+ \\
\text { clorita }+ \text { apatita }+ \text { perovskita }\end{array}$ & Nódulo alterado & Maciço & & & & & \\
\hline Lm1-20a & 10 & $\begin{array}{c}\text { cinza } \\
\text { amarelado }\end{array}$ & $\begin{array}{l}\text { elipsoidal } \\
\text { anguloso }\end{array}$ & Granoblástica & $\begin{array}{l}93 \% \text { olivina }+4 \% \text { ortopiroxênio }+2 \% \\
\text { clinopiroxênio }+1 \% \text { espinélio }\end{array}$ & Dunito & $\begin{array}{c}\text { Foliado/ } \\
\text { olivina }\end{array}$ & $\mathrm{x}$ & $\mathrm{x}$ & $\mathrm{x}$ & $\mathrm{x}$ & \\
\hline Lm1-20b & & & & Granoblástica & $\begin{array}{l}95 \% \text { olivina }+3 \% \text { ortopiroxênio }+1 \% \\
\text { clinopiroxênio }+1 \% \text { espinélio }\end{array}$ & Dunito & $\begin{array}{c}\text { Foliado/ } \\
\text { olivina }\end{array}$ & $\mathrm{x}$ & $\mathrm{x}$ & $\mathrm{x}$ & & \\
\hline Lm1-21 & 2,8 & $\begin{array}{c}\text { marrom } \\
\text { esbranquiçado }\end{array}$ & $\begin{array}{l}\text { elipsoidal } \\
\text { arredondado }\end{array}$ & & Silex & Silexito & Maciço & & & & & \\
\hline Lm1-22 & 3,2 & $\begin{array}{c}\text { cinza } \\
\text { esverdeado }\end{array}$ & tabular anguloso & Protogranular & $\begin{array}{c}92 \% \text { olivina }+3 \% \text { ortopiroxênio }+3 \% \\
\text { clinopiroxênio }+2 \% \text { ilmenita }+1 \% \\
\text { flogopita }+ \text { priderita }\end{array}$ & $\begin{array}{l}\text { Dunito com } \\
\text { flogopita }\end{array}$ & Maciço & $\mathrm{x}$ & $\mathrm{x}$ & $\mathrm{x}$ & & \\
\hline Lm1-24 & 2 & $\begin{array}{l}\text { rosa claro com } \\
\text { borda verde }\end{array}$ & tabular anguloso & & carbonato & Carbonato & Maciço & & & & & \\
\hline Lm1-25 & 9 & $\begin{array}{c}\text { cinza } \\
\text { esverdeado }\end{array}$ & $\begin{array}{l}\text { elipsoidal } \\
\text { anguloso }\end{array}$ & Inequigranular & $\begin{array}{l}\text { Carbonato }+ \text { olivina }+ \text { clinopiroxênio }+ \\
\text { clorita }+ \text { apatita }+ \text { perovskita }\end{array}$ & Nódulo alterado & $\begin{array}{c}\text { Foliado/ } \\
\text { matriz }\end{array}$ & $\mathrm{x}$ & $\mathrm{x}$ & $\mathrm{x}$ & & \\
\hline Lm1-26a & 8 & $\begin{array}{l}\text { cinza escuro } \\
\text { amarelado }\end{array}$ & $\begin{array}{l}\text { elipsoidal } \\
\text { arredondado }\end{array}$ & Protogranular & $\begin{array}{c}87,5 \% \text { olivina }+5,5 \% \text { ortopiroxênio }+2 \% \\
\text { clinopiroxênio }+3 \% \text { flogopita }+1 \% \\
\text { cromita }+1 \% \text { ilmenita }\end{array}$ & $\begin{array}{l}\text { Harzburgito com } \\
\text { flogopita }\end{array}$ & Maciço & $\mathrm{x}$ & $\mathrm{x}$ & $\mathrm{x}$ & & \\
\hline Lm1-26b & 8 & $\begin{array}{l}\text { cinza escuro } \\
\text { amarelado }\end{array}$ & $\begin{array}{l}\text { elipsoidal } \\
\text { arredondado }\end{array}$ & Protogranular & $\begin{array}{c}93 \% \text { olivina }+3 \% \text { ortopiroxênio }+1 \% \\
\text { clinopiroxênio }+1 \% \text { flogopita }+0,5 \% \\
\text { cromita }+0,5 \% \text { ilmenita }\end{array}$ & $\begin{array}{l}\text { Dunito com } \\
\text { flogopita }\end{array}$ & Maciço & $\mathrm{x}$ & & & & \\
\hline Lm1-27 & 3,6 & $\begin{array}{c}\text { branco } \\
\text { acinzentado }\end{array}$ & $\begin{array}{l}\text { elipsoidal } \\
\text { arredondado }\end{array}$ & Granular média & feldspato e quartzo alterado & Granito alterado & Maciço & $\mathrm{x}$ & & & & \\
\hline Lm1-28 & 3,5 & $\begin{array}{l}\text { amarelo } \\
\text { cinzentado }\end{array}$ & $\begin{array}{l}\text { tabular sub- } \\
\text { anguloso }\end{array}$ & Protogranular & $\begin{array}{c}96 \% \text { olivina }+1 \% \text { flogopita }+1 \% \text { cromita } \\
+1 \% \text { carbonato }+ \text { ortopiroxênio }+ \\
\text { clinopiroxênio }+ \text { serpentina }\end{array}$ & $\begin{array}{l}\text { Dunito com } \\
\text { flogopita }\end{array}$ & Maciço & $\mathrm{x}$ & & & & \\
\hline Lm1-29 & 4 & cinza escuro & $\begin{array}{l}\text { tabular sub- } \\
\text { arredondado }\end{array}$ & Protogranular & olivina + serpentina & Dunito & Maciço & $\mathrm{x}$ & & & & \\
\hline Lm1-30 & 3 & $\begin{array}{c}\text { cinza } \\
\text { amarelado }\end{array}$ & $\begin{array}{l}\text { esférico } \\
\text { anguloso }\end{array}$ & Granoblástico & $\begin{array}{l}92,5 \% \text { olivina }+6 \% \text { ortopiroxênio }+1 \% \\
\text { espinélio }+0,5 \% \text { clinopiroxênio }\end{array}$ & Harzburgito & Maciço & $\mathrm{x}$ & & & & \\
\hline Lm1-31 & 6 & $\begin{array}{l}\text { cinza escuro } \\
\text { amarelado }\end{array}$ & tabular anguloso & & olivina & Megacristal & & & & & & \\
\hline
\end{tabular}




\begin{tabular}{|c|c|c|c|c|c|c|c|c|c|c|c|c|}
\hline $\begin{array}{l}\text { Código da } \\
\text { amostra }\end{array}$ & $\begin{array}{l}\text { Dimensão } \\
\text { máxima }(\mathrm{cm})\end{array}$ & Cor & Forma & Textura & $\begin{array}{c}\text { Composição mineralógica e porcentagem } \\
\text { modal }\end{array}$ & $\begin{array}{l}\text { Natureza }(* \text { sem } \\
\text { estimativa modal) }\end{array}$ & $\begin{array}{l}\text { Estrutura/ } \\
\text { mineral } \\
\text { alongado }\end{array}$ & Lâmina & Microssonda & MEV & Traços & Isótopos \\
\hline Lm1-32 & 2 & cinza & $\begin{array}{l}\text { triangular } \\
\text { subarredondado }\end{array}$ & $\begin{array}{l}\text { Porfiroclástico com } \\
\text { mosaico }\end{array}$ & $\begin{array}{c}97,5 \% \text { olivina }+2,5 \% \text { ortopiroxênio }+ \\
\text { clinopiroxênio }+ \text { monticellita }+ \text { Ti- } \\
\text { magnetita }\end{array}$ & Dunito & Maciço & $\mathrm{x}$ & & & & \\
\hline Lm1-33 & 0,3 & cinza & $\begin{array}{l}\text { esférico } \\
\text { arredondado }\end{array}$ & Protogranular & Olivina + ortopiroxênio + flogopita & Flogopita dunito & Maciço & & & & & \\
\hline Lm1-34 & 2 & $\begin{array}{c}\text { cinza } \\
\text { amarelado }\end{array}$ & $\begin{array}{l}\text { tabular sub- } \\
\text { anguloso }\end{array}$ & Granoblástica & 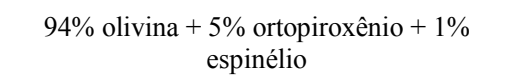 & Harzburgito & Maciço & $\mathrm{x}$ & & & & \\
\hline Lm1-35 & 0,5 & $\begin{array}{l}\text { cinza } \\
\text { amarelado }\end{array}$ & $\begin{array}{l}\text { esférico sub- } \\
\text { arredondado }\end{array}$ & Protogranular & Olivina + serpentina & Dunito & Maciço & & & & & \\
\hline Lm1-36 & 3 & $\begin{array}{l}\text { cinza } \\
\text { esverdeado }\end{array}$ & $\begin{array}{l}\text { elipsoidal sub- } \\
\text { anguloso }\end{array}$ & $\begin{array}{l}\text { Transicional } \\
\text { (porfiroclástico a } \\
\text { granoblástico) }\end{array}$ & $\begin{array}{c}93 \% \text { olivina }+5 \% \text { ortopiroxênio }+2 \% \\
\text { espinélio }+ \text { serpentina }\end{array}$ & Harzburgito & Maciço & $\mathrm{x}$ & & & & \\
\hline Lm1-37 & 0,4 & cinza & $\begin{array}{l}\text { arredondado } \\
\text { sub-anguloso }\end{array}$ & Protogranular & Olivina + serpentina & Dunito & Maciço & & & & & \\
\hline Lm1-38 & 2 & cinza escuro & $\begin{array}{l}\text { tabular siub- } \\
\text { arredondado }\end{array}$ & Protogranular & $\begin{array}{l}84 \% \text { olivina }+7 \% \text { clinopiroxênio }+3 \% \\
\text { ortopiroxênio }+2 \% \text { flogopita }+4 \% \text { cromita }\end{array}$ & $\begin{array}{l}\text { Wehrlito com } \\
\text { ilmenita e } \\
\text { flogopita }\end{array}$ & Maciço & $\mathrm{x}$ & & & & \\
\hline Lm1-39 & 2,8 & $\begin{array}{c}\text { cinza } \\
\text { alaranjado }\end{array}$ & tabular anguloso & Inequigranular fina & $\begin{array}{l}\text { Carbonato }+ \text { olivina }+ \text { clinopiroxênio }+ \\
\text { clorita }+ \text { apatita }+ \text { perovskita }\end{array}$ & Nódulo alterado & Maciço & & & & & \\
\hline Lm1-40 & 1,8 & $\begin{array}{l}\text { marrom } \\
\text { acinzentado }\end{array}$ & $\begin{array}{l}\text { esférico sub- } \\
\text { anguloso }\end{array}$ & Equigranular fino & Piroxênio alterado + carbonato + apatita & $\begin{array}{l}\text { Piroxenito } \\
\text { alterado }\end{array}$ & Foliado & $\mathrm{x}$ & & & & \\
\hline Lm1-41 & 2 & cinza escuro & $\begin{array}{l}\text { esférico sub- } \\
\text { arredondado }\end{array}$ & & $99 \%$ olivina $+1 \%$ ilmenita + cromita & $\begin{array}{l}\text { Megacristal } \\
\text { geminado }\end{array}$ & & $\mathrm{x}$ & & & & \\
\hline Fo-1 & 1,5 & amarelo & $\begin{array}{l}\text { esférico } \\
\text { anguloso }\end{array}$ & Protogranular & $\begin{array}{c}50 \% \text { olivina }+5 \% \text { clinopiroxênio }+5 \% \\
\text { ortopiroxênio alterado }+1 \% \text { espinélio }+ \\
38 \% \text { carbonato }\end{array}$ & Lherzolito & Maciço & $\mathrm{x}$ & $\mathrm{x}$ & $\mathrm{x}$ & & \\
\hline Fo-2 & 3,6 & $\begin{array}{l}\text { cinza } \\
\text { esverdeado }\end{array}$ & $\begin{array}{l}\text { amebóide sub- } \\
\text { arredondado }\end{array}$ & Granoblástico & $\begin{array}{l}55 \% \text { olivina }+28 \% \text { ortopiroxênio }+10,5 \% \\
\text { clinopiroxênio }+6,5 \% \text { espinélio }\end{array}$ & $\begin{array}{l}\text { Espinélio } \\
\text { lherzolito }\end{array}$ & $\begin{array}{l}\text { Levemente } \\
\text { foliado/ } \\
\text { olivina }\end{array}$ & $\mathrm{x}$ & $\mathrm{x}$ & $\mathrm{x}$ & & \\
\hline Fo-3 & 4 & $\begin{array}{l}\text { marrom } \\
\text { acinzentado }\end{array}$ & $\begin{array}{l}\text { elipsoidal } \\
\text { arredondado }\end{array}$ & & clinopiroxênio & Megacristal & & $\mathrm{x}$ & $\mathrm{x}$ & $\mathrm{x}$ & $\mathrm{x}$ & \\
\hline Fo-4 & 3,2 & $\begin{array}{l}\text { marrom } \\
\text { avermelhado }\end{array}$ & $\begin{array}{l}\text { esférico } \\
\text { arredondado }\end{array}$ & & $\begin{array}{c}\text { clorita }+ \\
\text { epidoto+anfibólio+ilmenita+titanita+clorita }\end{array}$ & $\begin{array}{l}\text { Metabásica } \\
\text { alterada }\end{array}$ & Maciço & $\mathrm{x}$ & $\mathrm{x}$ & $\mathrm{x}$ & & \\
\hline Fo-5 & 3,3 & $\begin{array}{c}\text { amarelo } \\
\text { avermelhado }\end{array}$ & $\begin{array}{l}\text { cúbico } \\
\text { arredondado }\end{array}$ & Protogranular & $\begin{array}{c}80 \% \text { olivina }+9 \% \text { flogopita }+8 \% \text { cromita } \\
+3 \% \text { clinopiroxênio }\end{array}$ & $\begin{array}{c}\text { Flogopita } \\
\text { ilmenita dunito }\end{array}$ & Maciço & $\mathrm{x}$ & $\mathrm{x}$ & $\mathrm{x}$ & & \\
\hline
\end{tabular}




\begin{tabular}{|c|c|c|c|c|c|c|c|c|c|c|c|c|}
\hline $\begin{array}{l}\text { Código da } \\
\text { amostra }\end{array}$ & $\begin{array}{l}\text { Dimensão } \\
\text { máxima }(\mathrm{cm})\end{array}$ & Cor & Forma & Textura & $\begin{array}{c}\text { Composição mineralógica e porcentagem } \\
\text { modal }\end{array}$ & $\begin{array}{l}\text { Natureza }(* \text { sem } \\
\text { estimativa modal) }\end{array}$ & $\begin{array}{l}\text { Estrutura/ } \\
\text { mineral } \\
\text { alongado }\end{array}$ & Lâmina & Microssonda & MEV & Traços & Isótopos \\
\hline Fo-6 & 3 & $\begin{array}{l}\text { cinza } \\
\text { amarelado }\end{array}$ & $\begin{array}{l}\text { esférico } \\
\text { arredondado }\end{array}$ & Granoblástico & $\begin{array}{l}90 \% \text { olivina }+6 \% \text { ortopiroxênio }+3 \% \\
\text { clinopiroxênio }+1 \% \text { espinélio }\end{array}$ & Harzburgito & Maciço & $\mathrm{x}$ & $\mathrm{x}$ & $\mathrm{x}$ & & \\
\hline Fo-7 & 3,2 & $\begin{array}{l}\text { amarelo } \\
\text { avermelhado }\end{array}$ & $\begin{array}{l}\text { tabular muito } \\
\text { anguloso }\end{array}$ & Protogranular & $\begin{array}{c}\text { olivina }+ \text { ortopiroxênio } \\
\text { cromita }\end{array}$ & Harzburgito & Maciço & & & & & \\
\hline Fo-8 & 2 & $\begin{array}{c}\text { cinza } \\
\text { esverdeado }\end{array}$ & $\begin{array}{l}\text { tabular } \\
\text { arredondado }\end{array}$ & & Olivina & Megacristal & & & & & & \\
\hline Fac-1 & 0,8 & preto & $\begin{array}{l}\text { esférico sub- } \\
\text { arredondado } \\
\text { com cúspide }\end{array}$ & Afanítico & $\begin{array}{c}\text { vidro (saponita) }+ \text { harmotoma }+ \\
\text { clinopiroxênio }+ \text { K-richterita }+ \text { apatita }\end{array}$ & Autólito & & $\mathrm{x}$ & $\mathrm{x}$ & $\mathrm{x}$ & & \\
\hline $\mathrm{Fac}-2$ & 3,5 & $\begin{array}{c}\text { verde } \\
\text { esbranquiçado }\end{array}$ & $\begin{array}{l}\text { elipsoidal } \\
\text { arredondado }\end{array}$ & Cumulática & 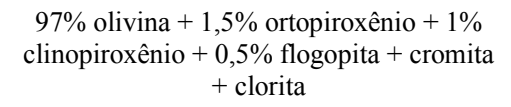 & Dunito & $\begin{array}{l}\text { Foliação de } \\
\text { fluxo/ olivina }\end{array}$ & $\mathrm{x}$ & $\mathrm{x}$ & $\mathrm{x}$ & & \\
\hline Fac-3 & 0,1 & $\begin{array}{c}\text { verde } \\
\text { esbranquiçado }\end{array}$ & $\begin{array}{l}\text { elipsoidal } \\
\text { arredondado }\end{array}$ & & olivina com inclusões de ilmenita e cromita & Macrocristal & & $\mathrm{x}$ & $\mathrm{x}$ & $\mathrm{x}$ & & \\
\hline $\mathrm{Fac}-4$ & 1,2 & cinza escuro & $\begin{array}{l}\text { ameboide sub- } \\
\text { arredondado }\end{array}$ & $\begin{array}{l}\text { Material corroído por } \\
\text { reação }\end{array}$ & $\begin{array}{c}\text { clinopiroxênio + harmotoma + apatita + k- } \\
\text { richterita + vidro (saponita) + wadeíta + } \\
\text { zircão + calcopirita }\end{array}$ & Autólito & Foliação & $\mathrm{x}$ & $\mathrm{x}$ & $\mathrm{x}$ & & \\
\hline Fac-5 & 1,5 & cinza escuro & $\begin{array}{l}\text { elipsoidal sub- } \\
\text { arredondado }\end{array}$ & Protogranular & $\begin{array}{c}84 \% \text { clinopiroxênio }+5,5 \% \text { flogopita }+ \\
0,5 \% \text { ilmenita }+3,5 \% \text { perovskita }+6,5 \% \\
\text { harmotoma }+ \text { clorita }\end{array}$ & $\begin{array}{c}\text { Flogopita } \\
\text { perovskita } \\
\text { clinopiroxenito }\end{array}$ & Maciço & $\mathrm{x}$ & $\mathrm{x}$ & $\mathrm{x}$ & $\mathrm{x}$ & \\
\hline Fac-6 & 1 & cinza escuro & $\begin{array}{l}\text { esférico } \\
\text { arredondado }\end{array}$ & Fanerítico fino & $\begin{array}{c}40 \% \text { clinopiroxênio }+45 \% \text { harmotoma }+ \\
15 \% \text { flogopita }+ \text { clorita }\end{array}$ & Autólito & $\begin{array}{l}\text { Foliação de } \\
\text { fluxo/matriz }\end{array}$ & $\mathrm{x}$ & $\mathrm{x}$ & $\mathrm{x}$ & & \\
\hline Fac-7 & 1,2 & $\begin{array}{c}\text { verde } \\
\text { esbranquiçado }\end{array}$ & $\begin{array}{l}\text { tabular sub- } \\
\text { anguloso }\end{array}$ & Cumulático & $\begin{array}{c}90 \% \text { olivina }+5,5 \% \text { clinopiroxênio }+3 \% \\
\text { ortopiroxênio }+1 \% \text { ilmenita }+0,5 \% \\
\text { flogopita }+ \text { clorita }\end{array}$ & Wehrlito & Maciço & $\mathrm{x}$ & $\mathrm{x}$ & $\mathrm{x}$ & & \\
\hline Fac-8 & 1,2 & $\begin{array}{c}\text { verde } \\
\text { esbranquiçado }\end{array}$ & $\begin{array}{l}\text { elipsoidal } \\
\text { arredondado }\end{array}$ & Cumulático & $\begin{array}{c}97 \% \text { olivina }+2,5 \% \text { ilmenita }+0,5 \% \\
\text { clinopiroxênio }+ \text { flogopita }+ \text { clorita }\end{array}$ & Dunito & Maciço & $\mathrm{x}$ & $\mathrm{x}$ & $\mathrm{x}$ & & \\
\hline
\end{tabular}


ANEXO B

Imagens das amostras de mão

Imagens das lâminas e de MEV:

Autólitos

Macrocristais

Nódulos esverdeados

Xenólitos crustais

Piroxenitos

Dunitos cumuláticos

Megacristais

Lherzolitos e harzburgitos com espinélio

Harzburgitos e dunitos com Cr-espinélio

Harzburgitos e dunitos com Cr-espinélio com pargasita

Dunitos com textura protogranular sem espinélio

Harzburgito com textura porfiroclástica em mosaico

Peridotitos protogranulares com bolsões de flogopita

Peridotitos protogranulares com bolsões de clinopiroxênio

Flogopita ilmenita wehrlito

Flogopitito e flogopita ortopiroxenito 


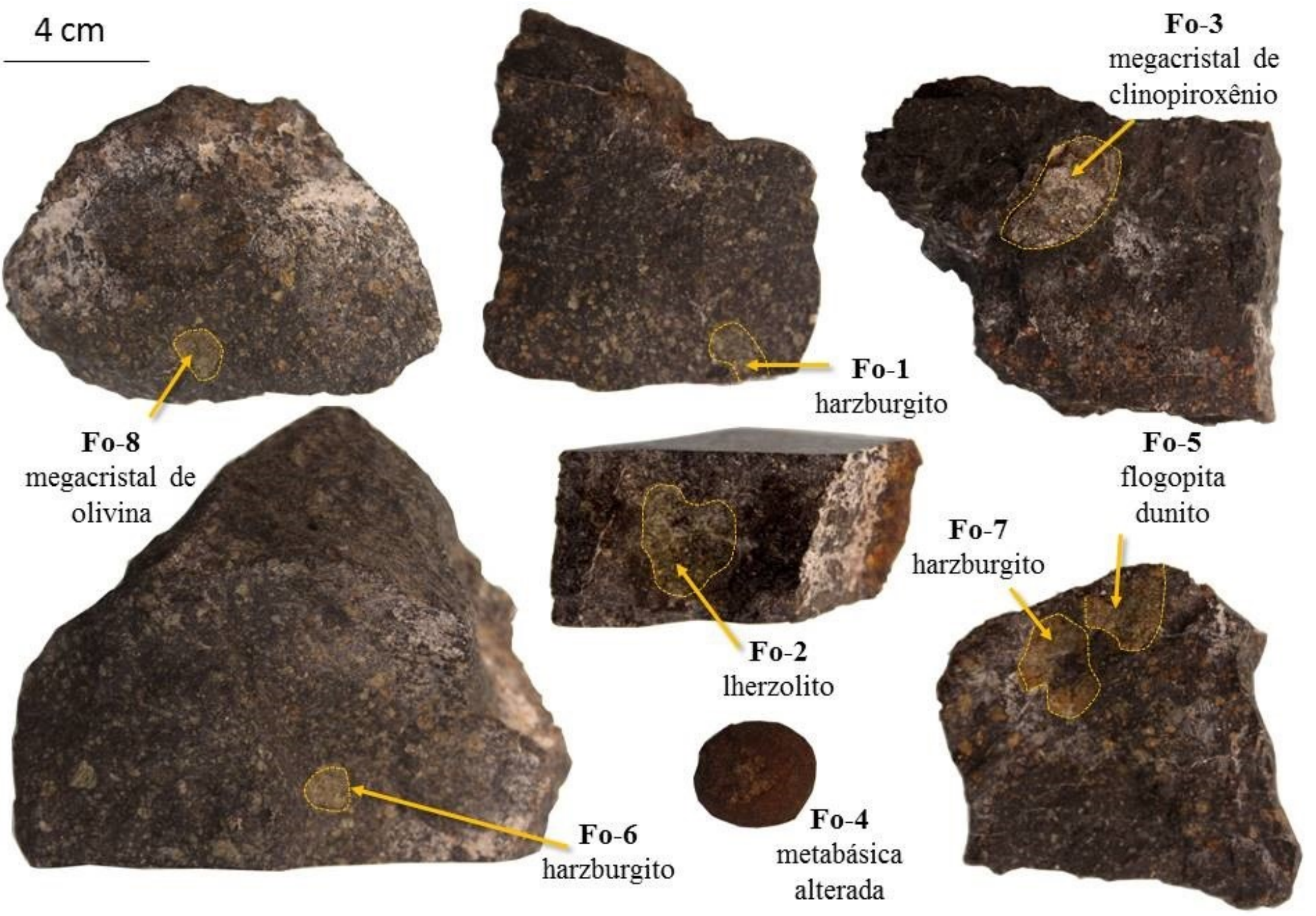

Figura 15 - Imagens de amostras de mão da intrusão Forca, com detalhe para os nódulos investigados neste trabalho. 


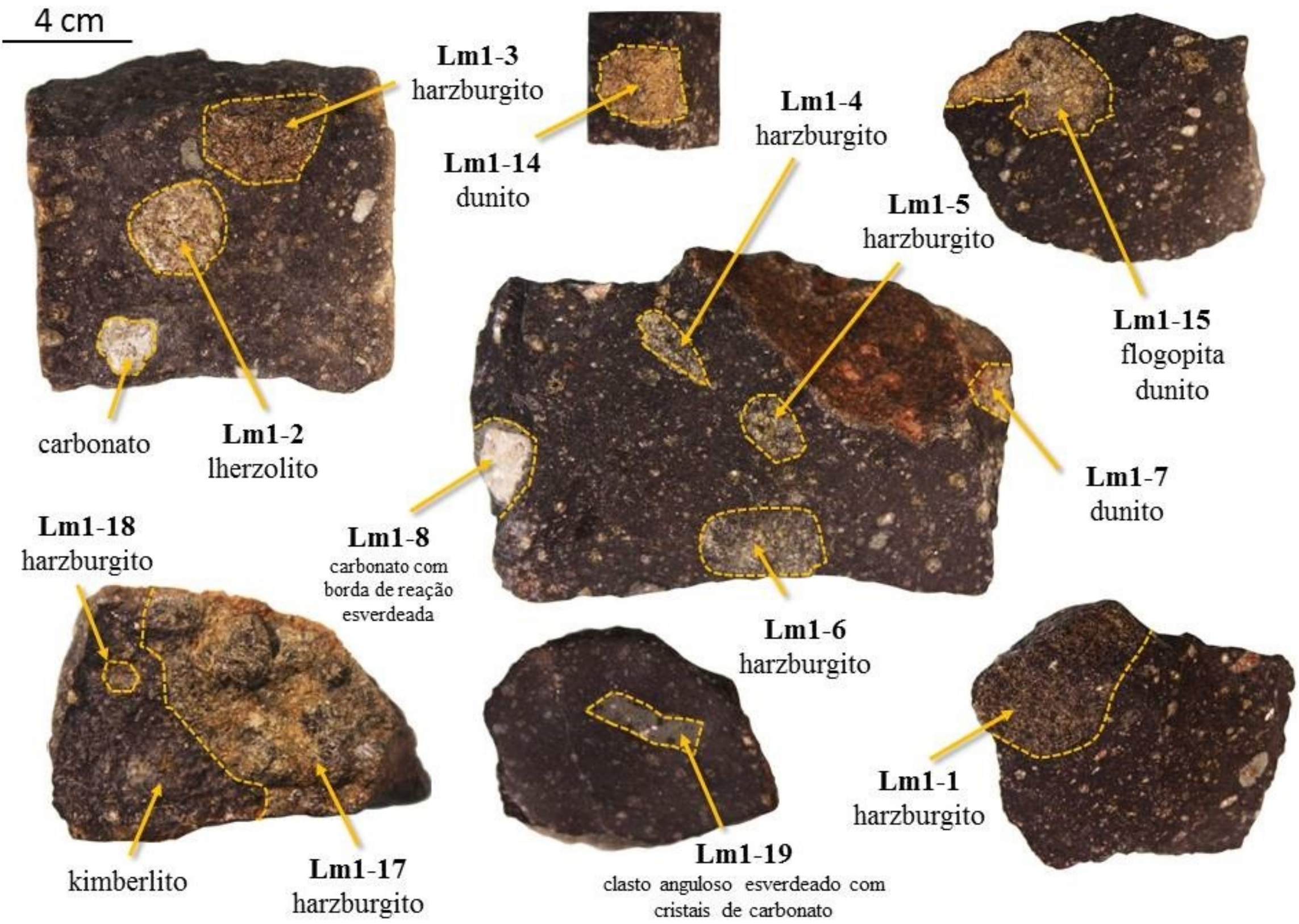

Figura 16 - Imagens de amostras de mão da intrusão Limeira 1, com detalhe para os xenólitos investigados neste trabalho. 


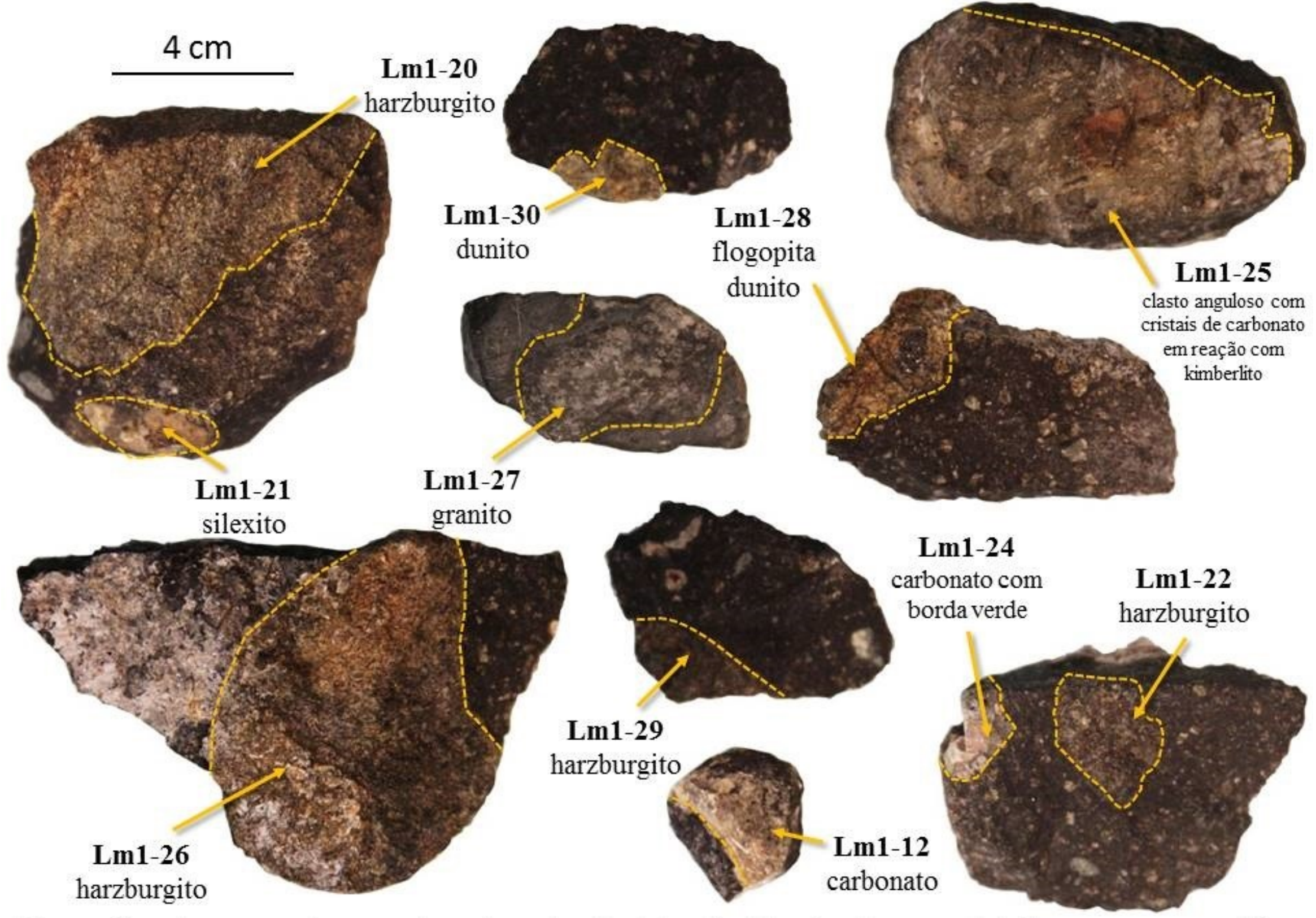

Figura 17 - Imagens de amostras de mão da intrusão Limeira 1, com detalhe para os xenólitos investigados neste trabalho. 


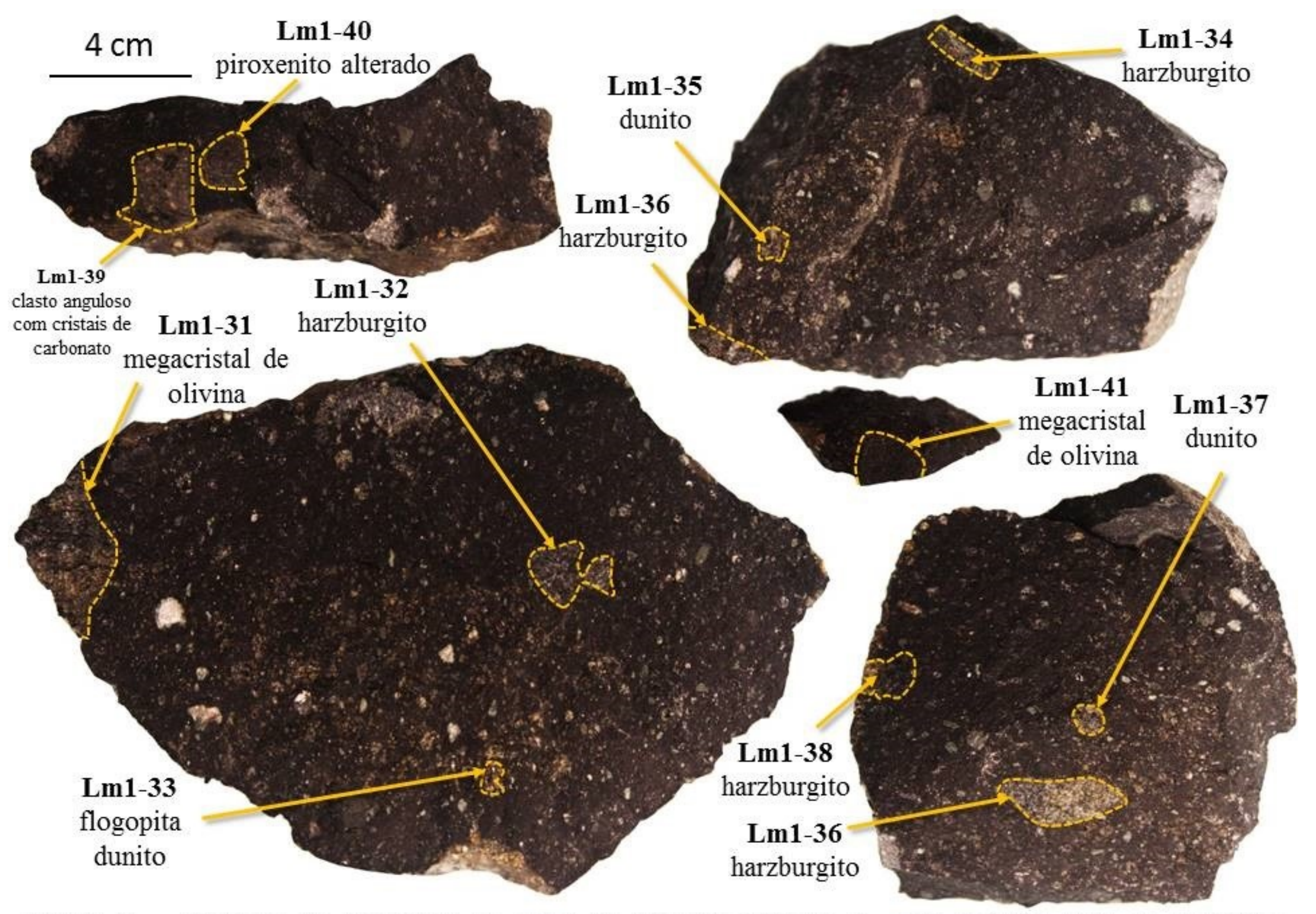

Figura 18 - Imagens de amostras de mão da intrusão Limeira 1, com detalhe para os xenólitos investigados neste trabalho. 


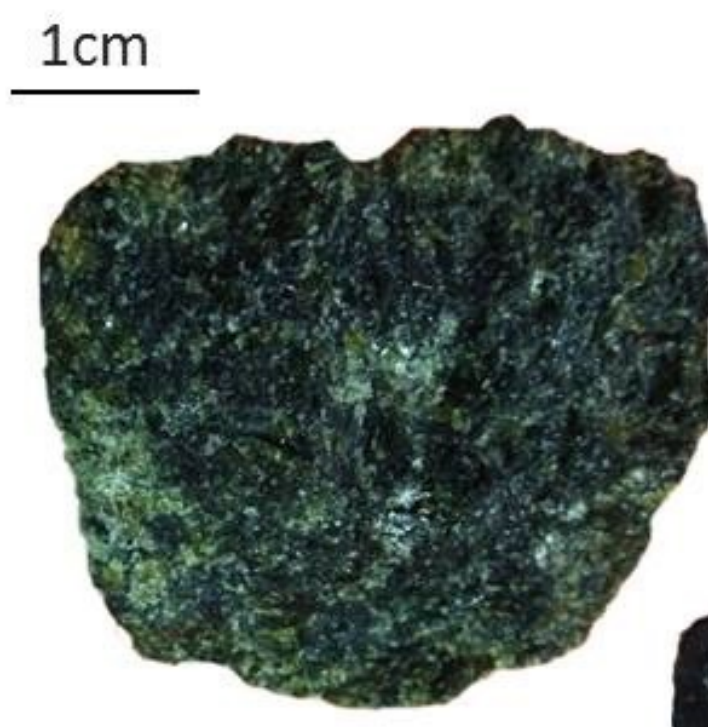

In1-1

harzburgito

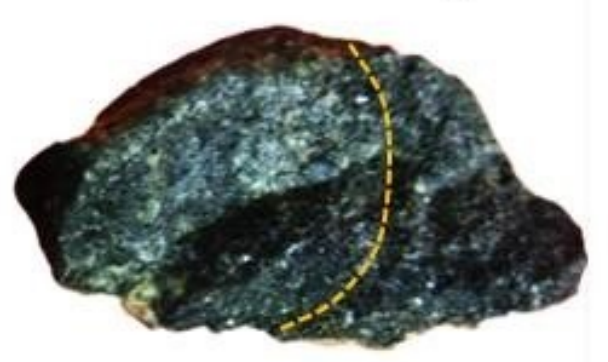

In1-6

flogopita

ilmenita

wehrlito
In1-4

lherzolito
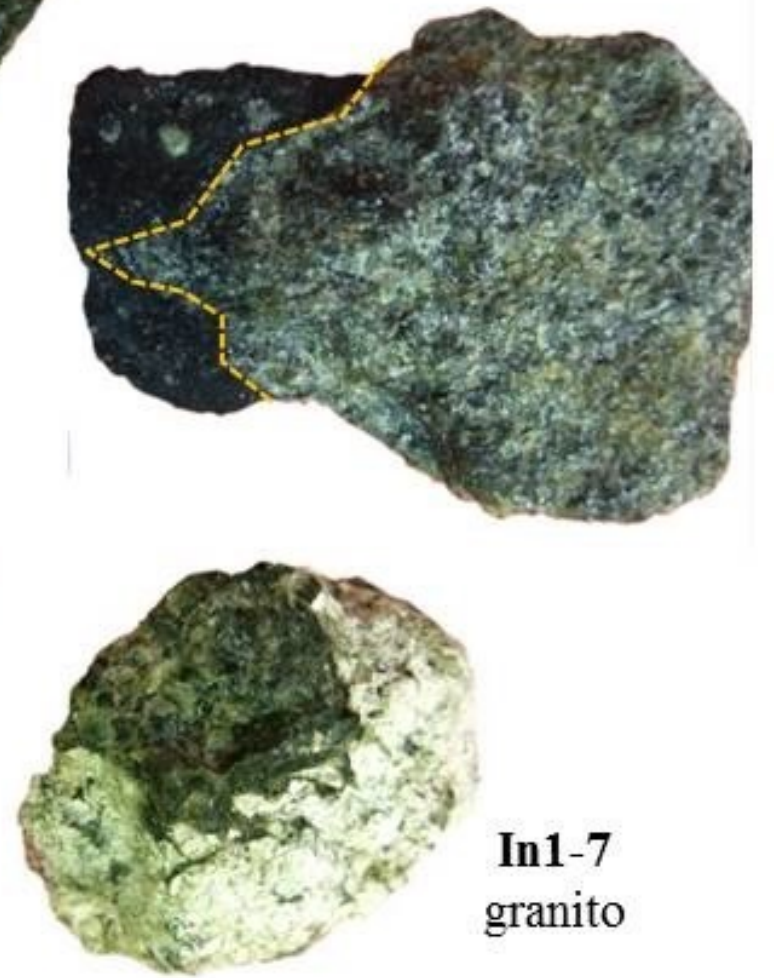

In1-11

nódulo arredondado esverdeado com cristais de carbonato

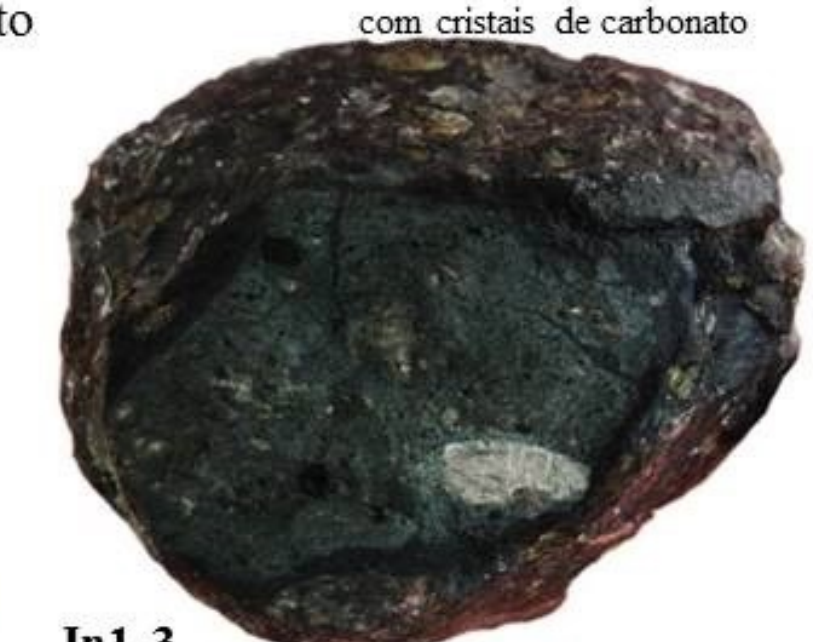

harzburgito

In1-2

flogopita dunito

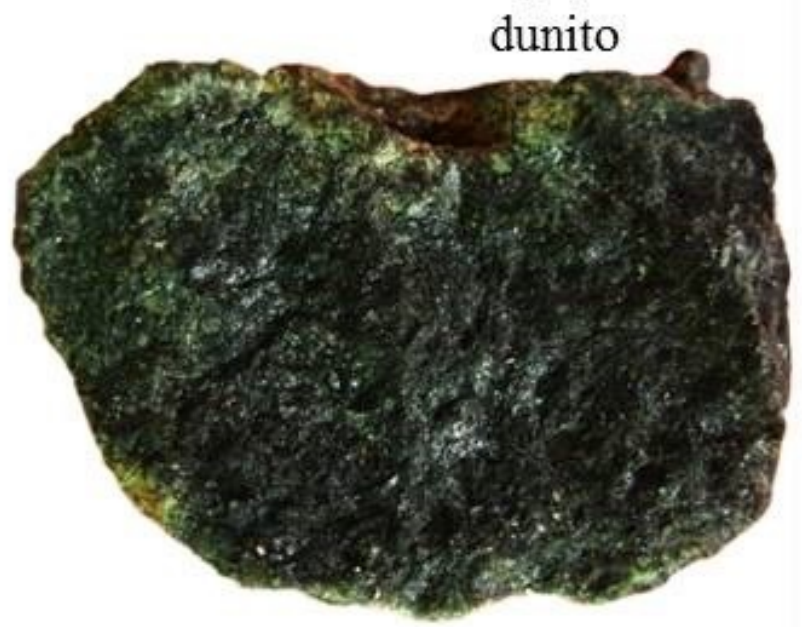

Figura 19 - Imagens de amostras de mão da intrusão Indaiá 1, com detalhe para os xenólitos investigados neste trabalho. 


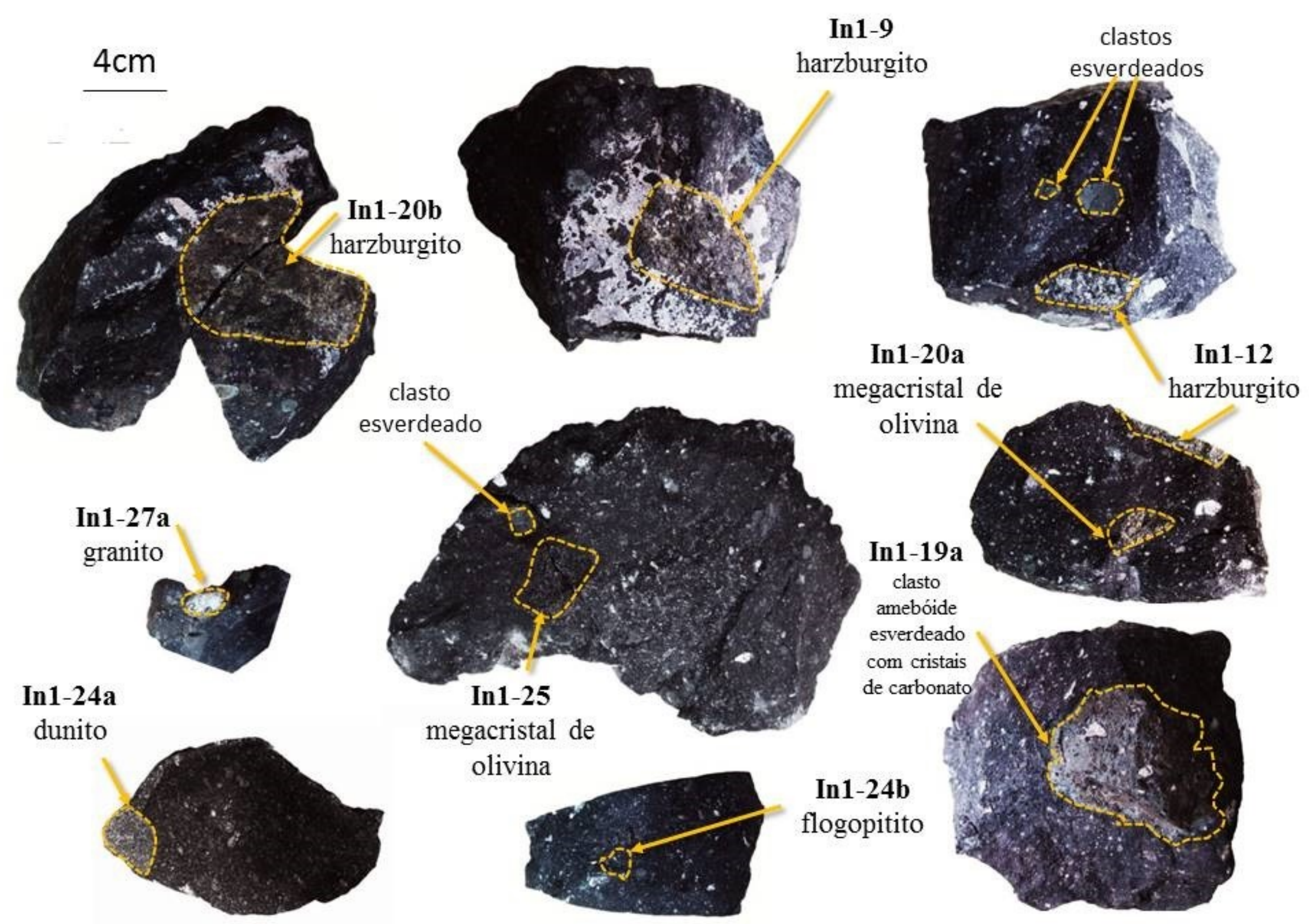

Figura 20 - Imagens de amostras de mão da intrusão Indaiá 1, com detalhe para os nódulos investigados neste trabalho. 


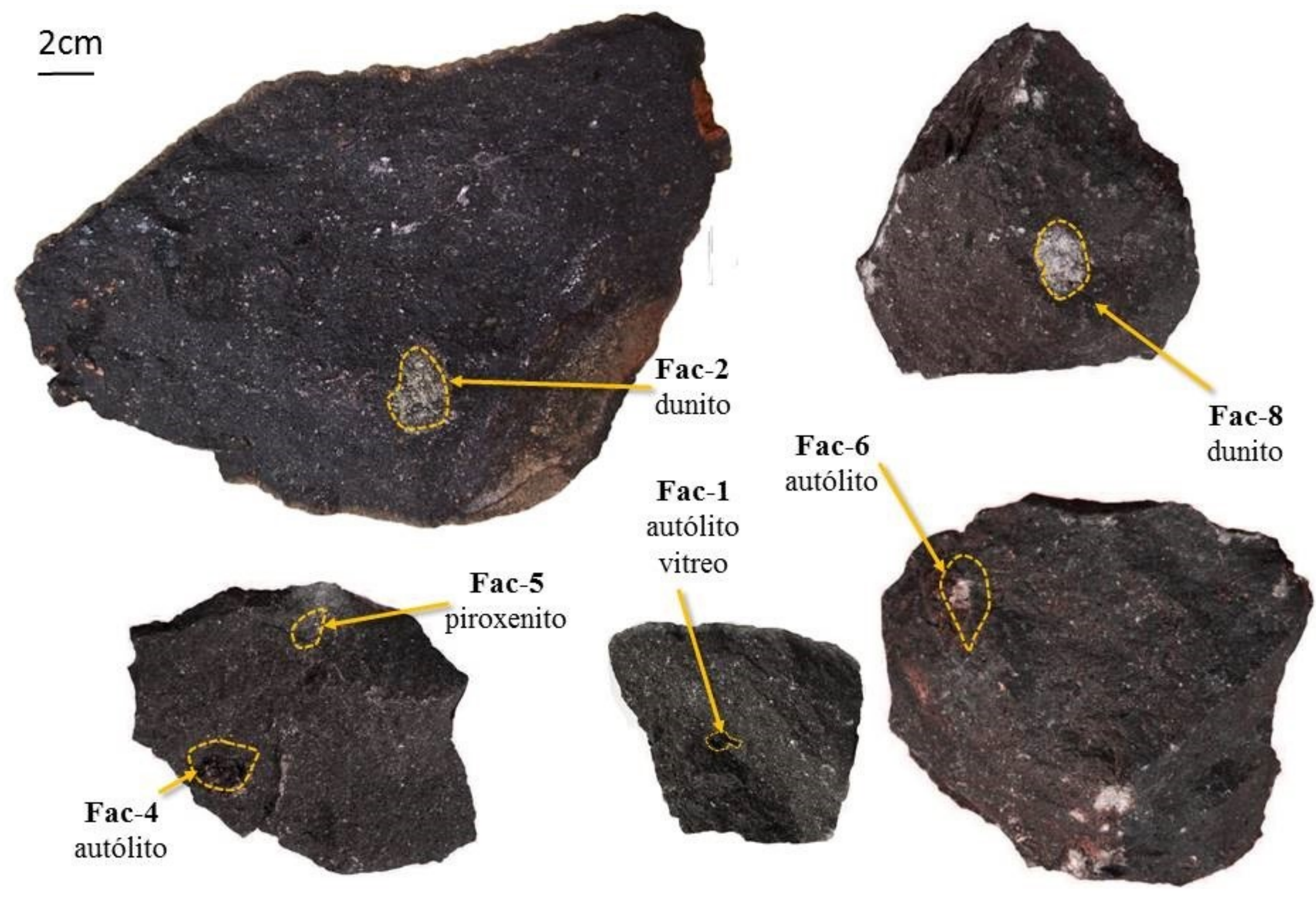

Figura 21 - Imagens de amostras de mão da intrusão Facão, com detalhe para os nódulos investigados neste trabalho. 


\section{$2 \mathrm{~cm}$}
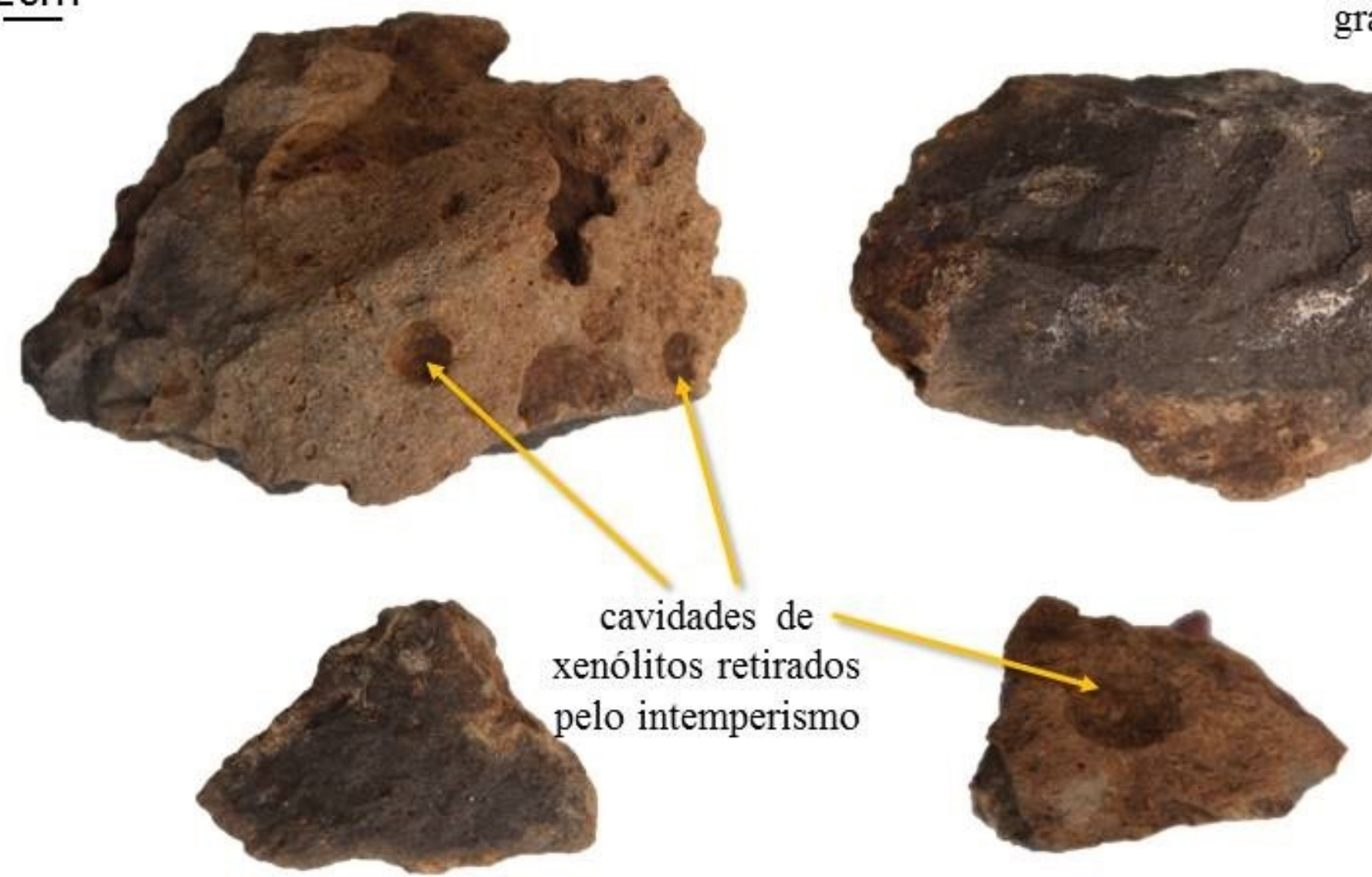

Figura 22 - Imagens de amostras de mão da intrusão Indaiá 2, com detalhe para os nódulos investigados neste trabalho.

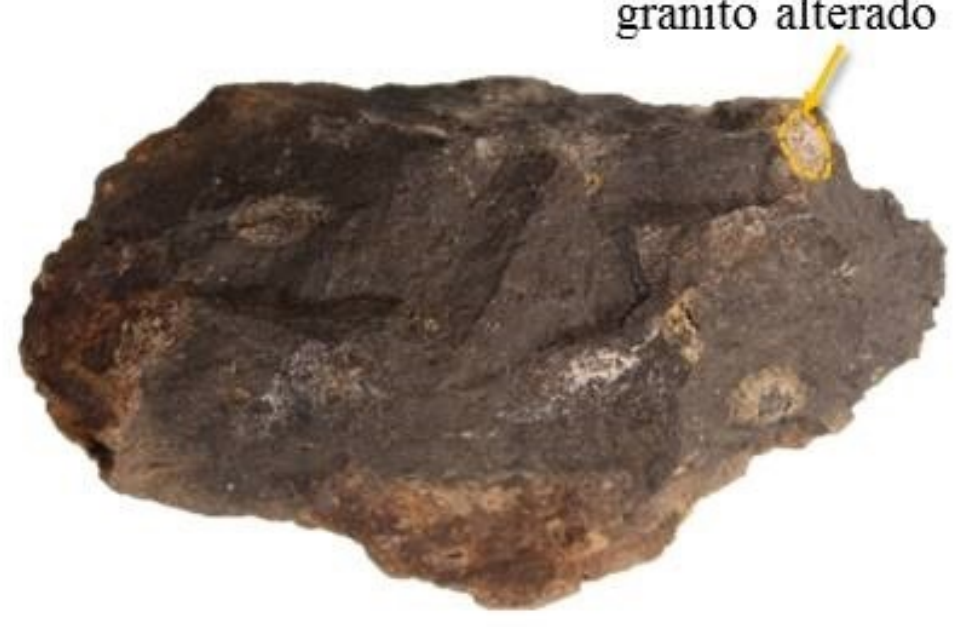

cavidades de xenólitos retirados

pelo intemperismo

In2-1

granito alterado 

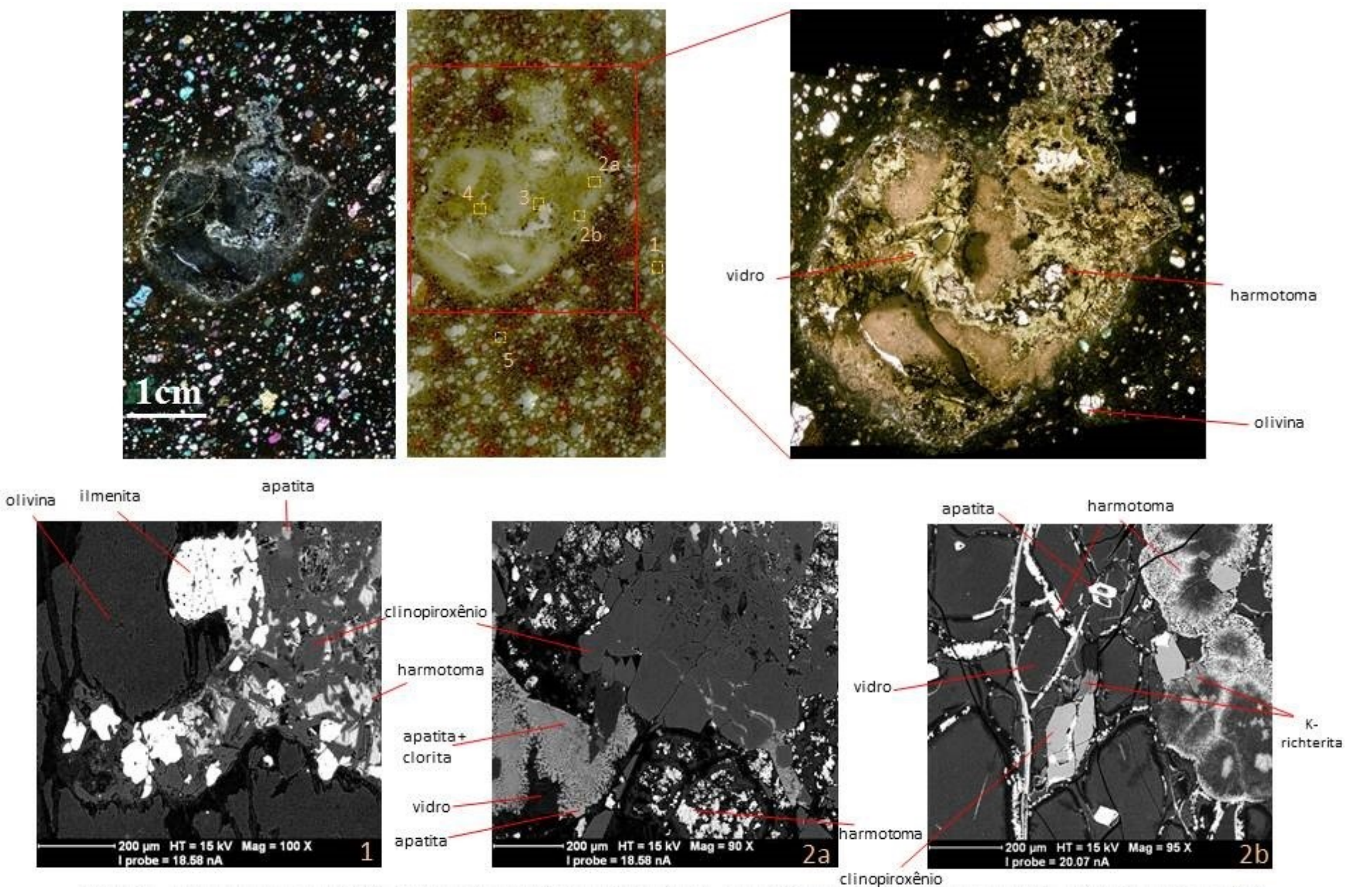

Figura 23 - Imagens de microscópio óptico e de MEV da amostra Fac-1, de autólito de textura vítrea e formato subcircular em meio à lava lamproítica com textura porfirítica, dada a presença de macrocristais de olivina. 1- macrocristal de olivina homogêneo com inclusão de ilmenita em meio a matriz composta por clinopiroxênio, harmotoma e apatita; 2 a- borda de autólito vitreo exibindo

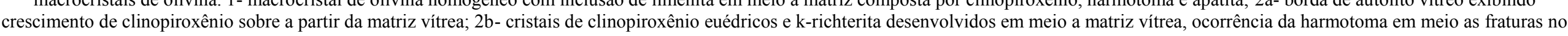
vidro (saponita), e bordas globulares de harmotoma sugerindo reação com o vidro (saponita). 

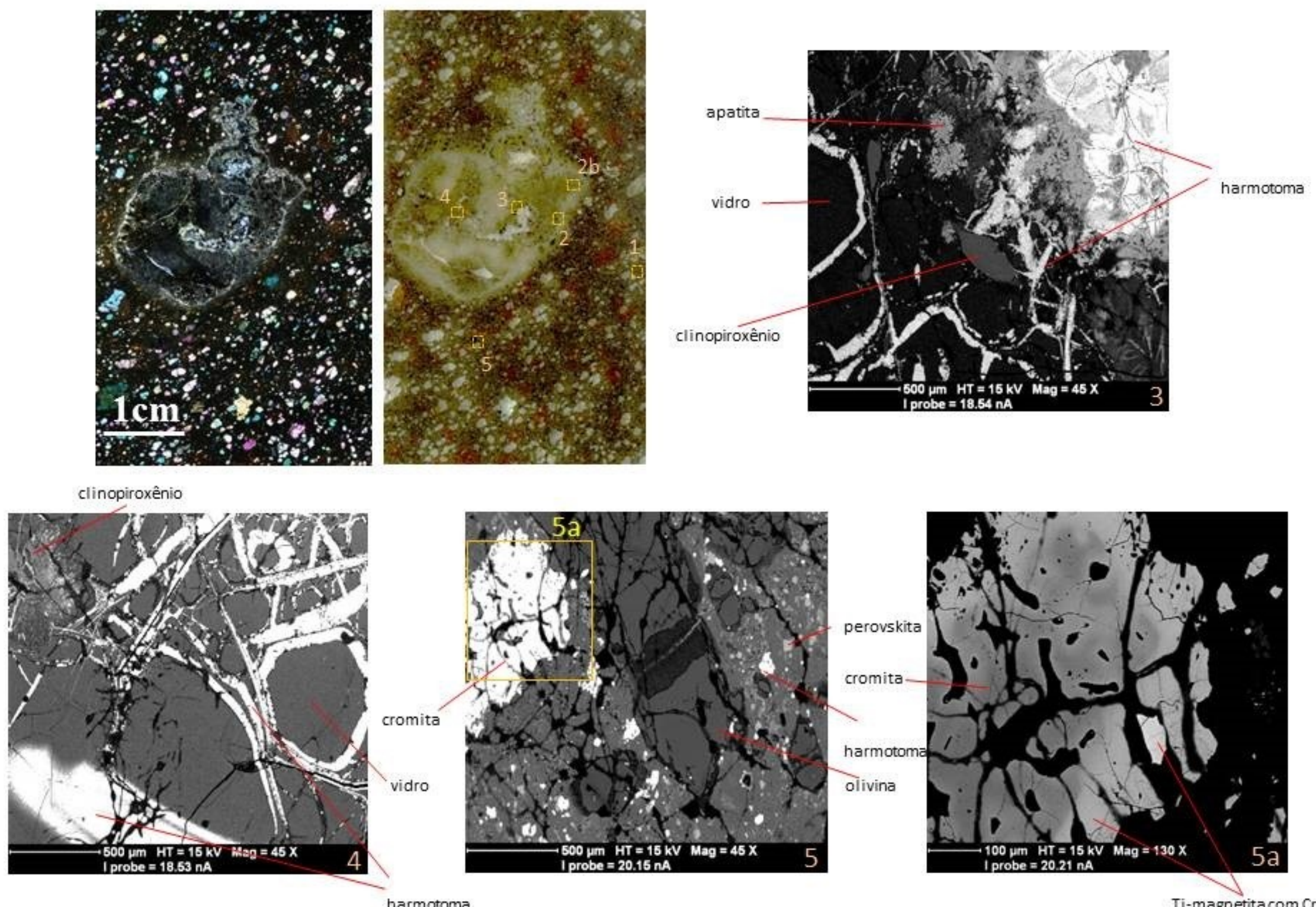

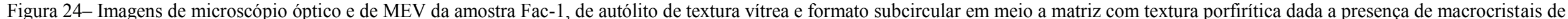

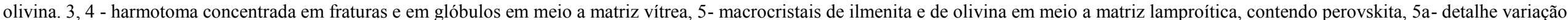
composicional do centro (cromita) para a borda (Ti-magnetita). 


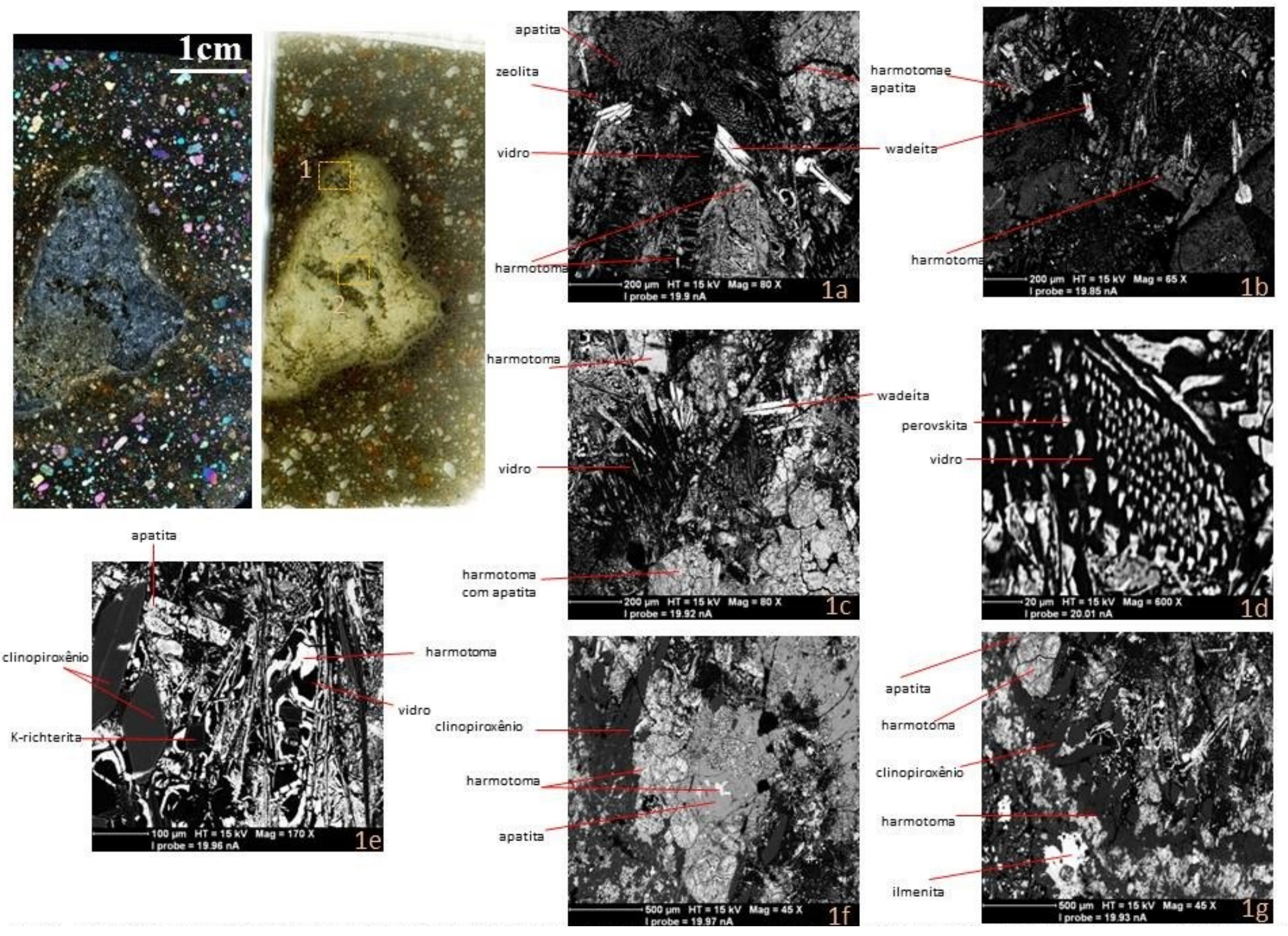

Figura 25 - Imagens de microscópio óptico e de MEV da amostra Fac-4, de autólito vitreo exibindo texturas complexas de desiquilíbrio químico com abundante harmotoma. 1a e 1b e 1c- cristais de

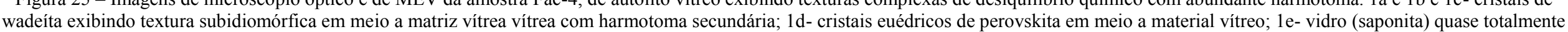

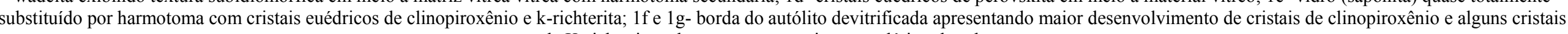
de K-richterita, e harmotoma e apatita secundárias abundantes. 


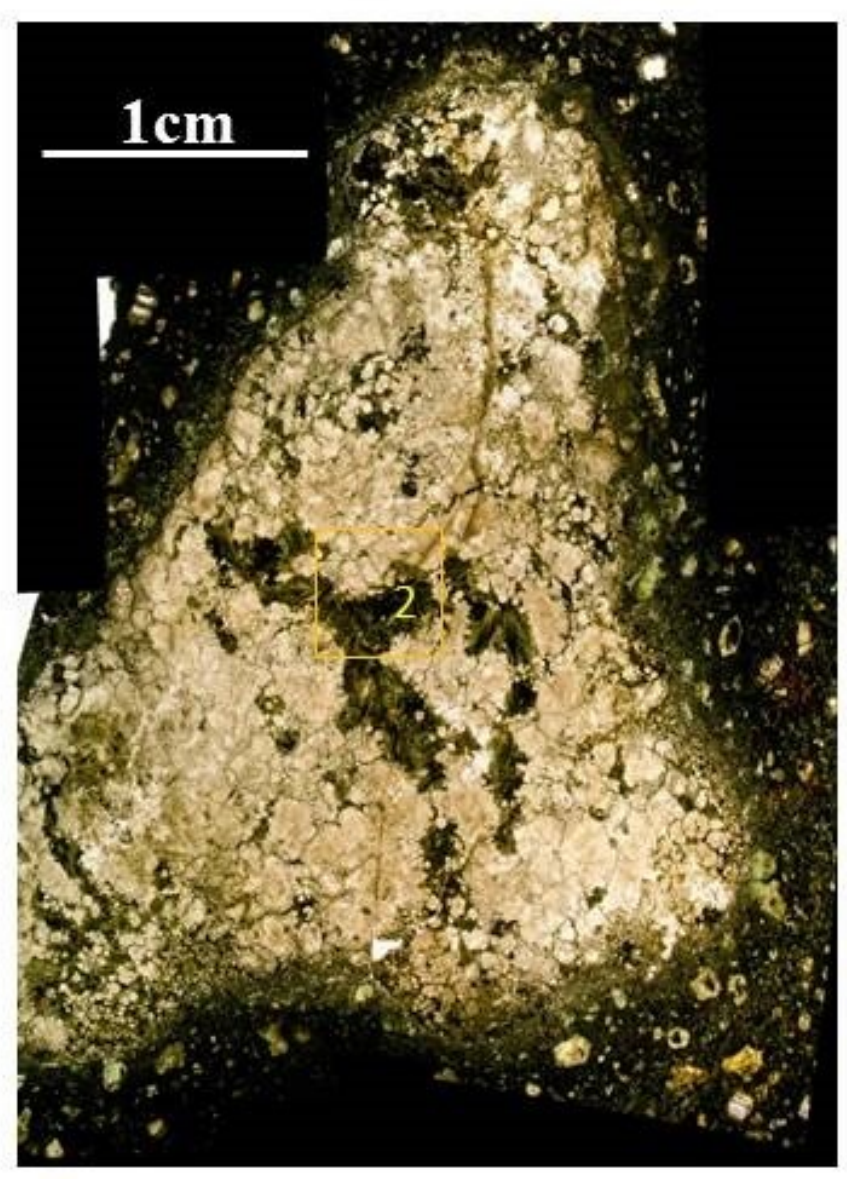

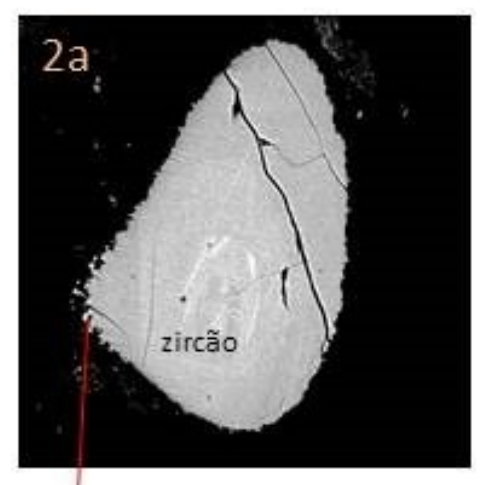

baddeleyita

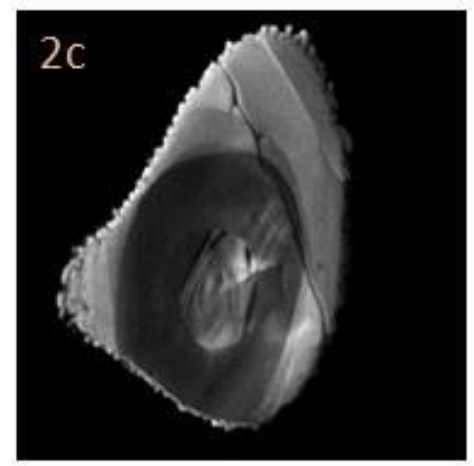

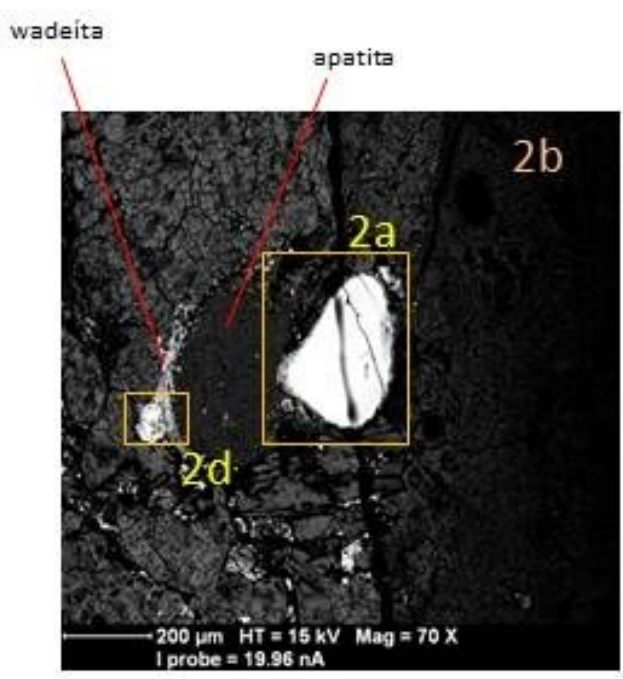

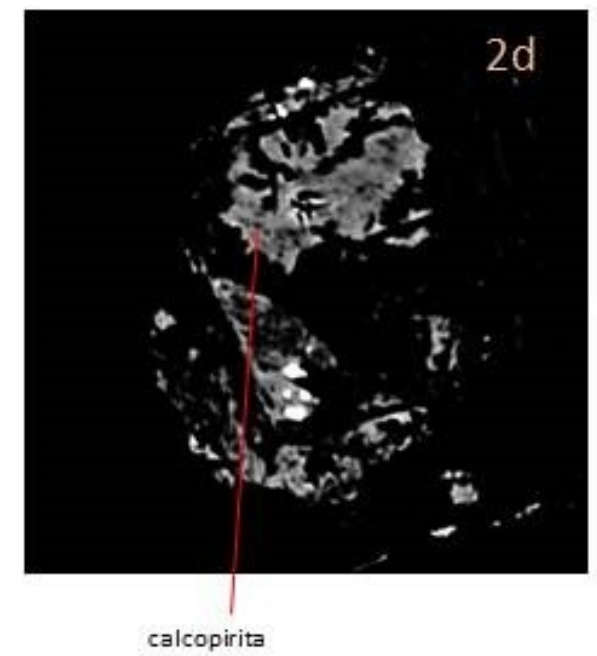

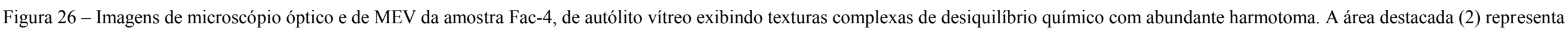

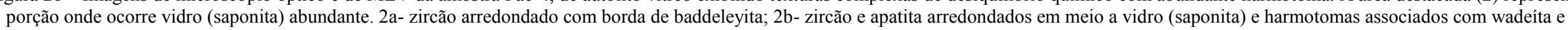
sulfetos; 2c- catodoluminescência de zircão mostrando heterogeneidade isotópica no zircão; $2 \mathrm{~d}$ - detalhe de calcopirita e pirita em meio a clorita. 

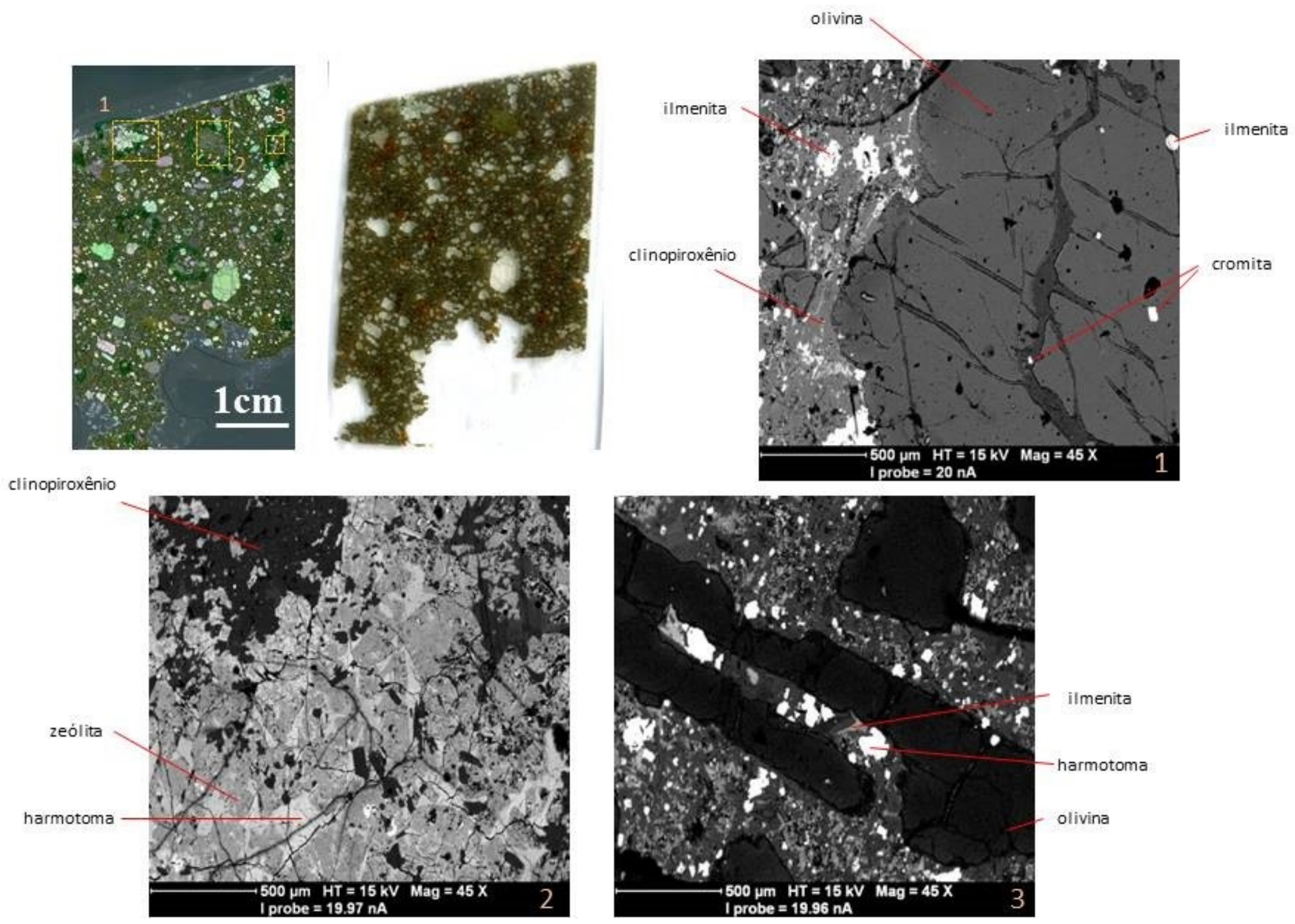

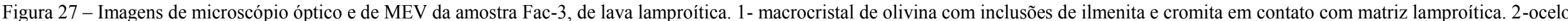
preenchido por harmotoma exibindo heterogeineidade com relação ao conteúdo de bário. 3- cristal idiomórfico de olivina com bordas ricas em Fe e material da matriz penetrando em fratura. 


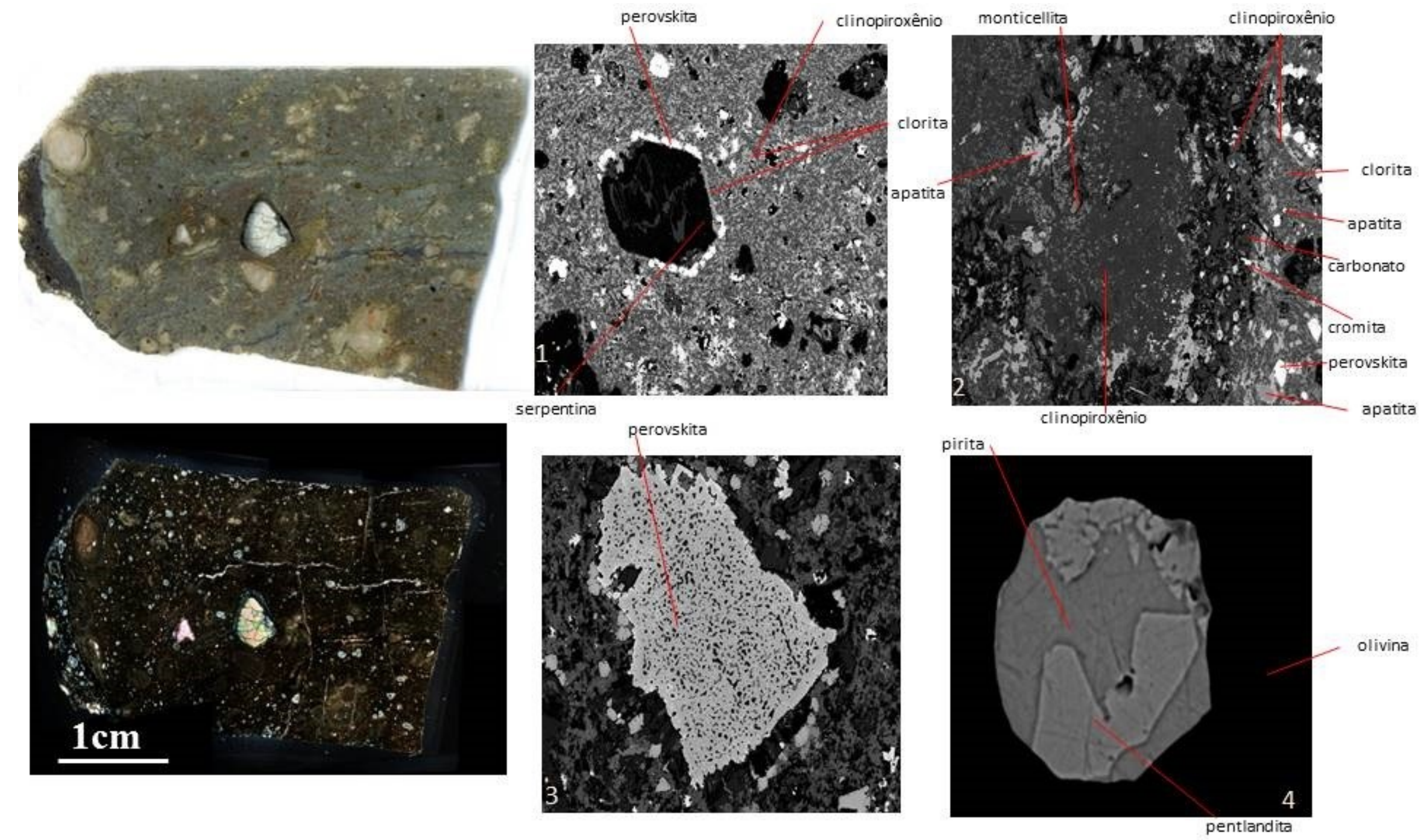

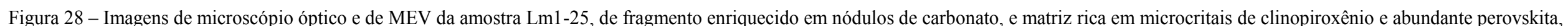

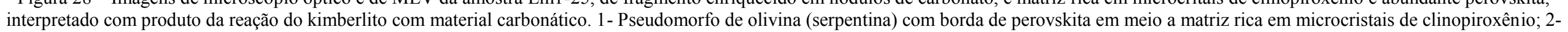

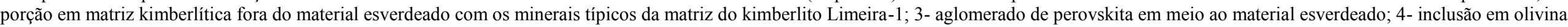
com sulfetos intercrescidos (pirita e pentlandita) 


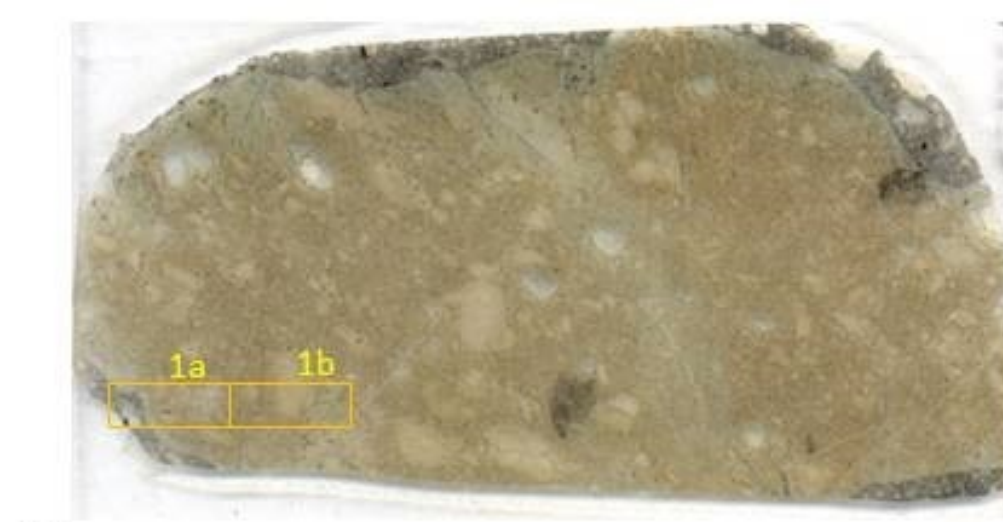

olivina
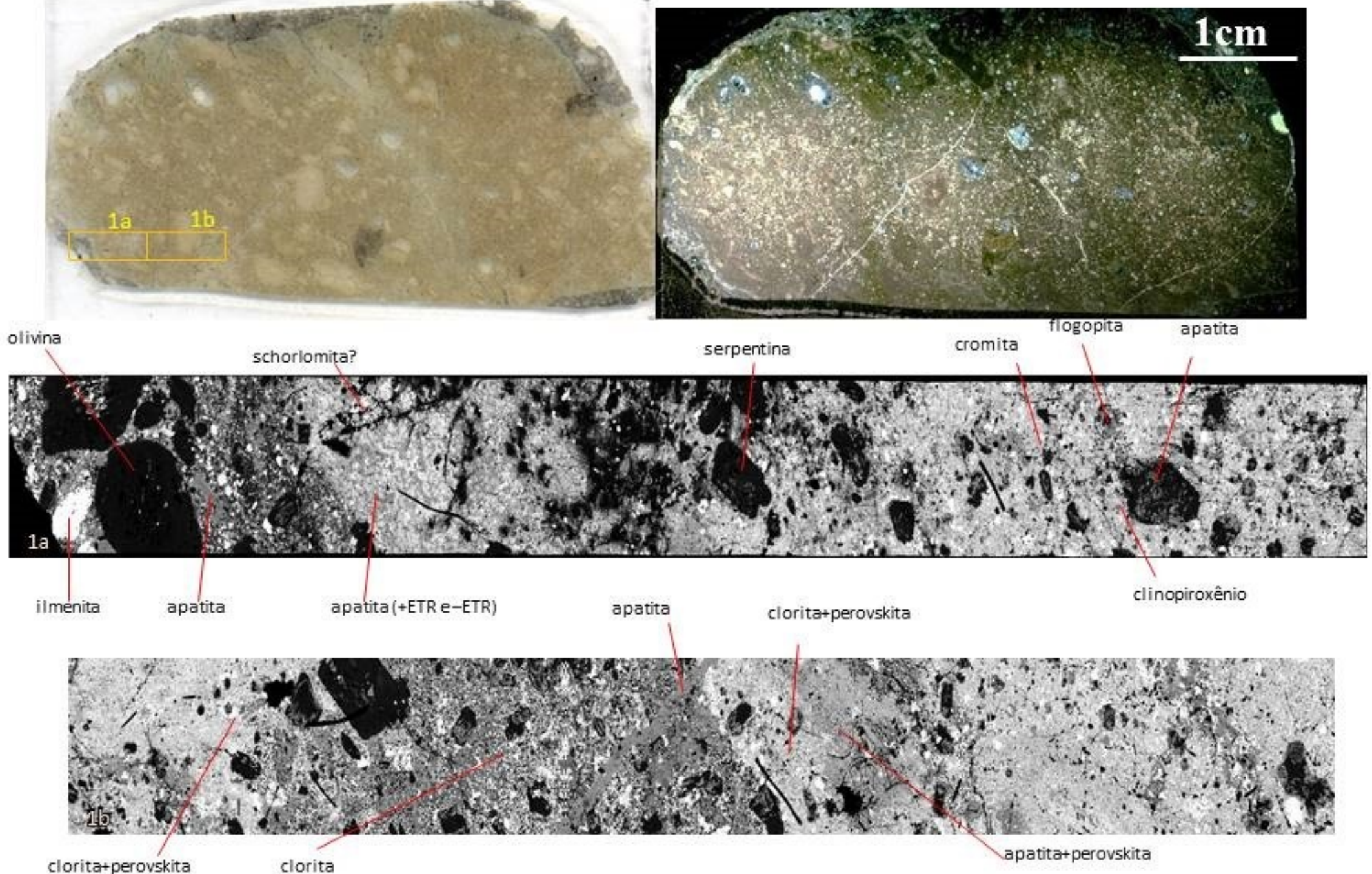

Figura 29 - Imagens de microscópio óptico e de MEV da amostra In1-11, de autólito de com nódulos de carbonato e olivina e matriz alterada com clinopiroxênio.1a e 1b- seção transversal de MEV partindo da borda do nódulo carbonático. 

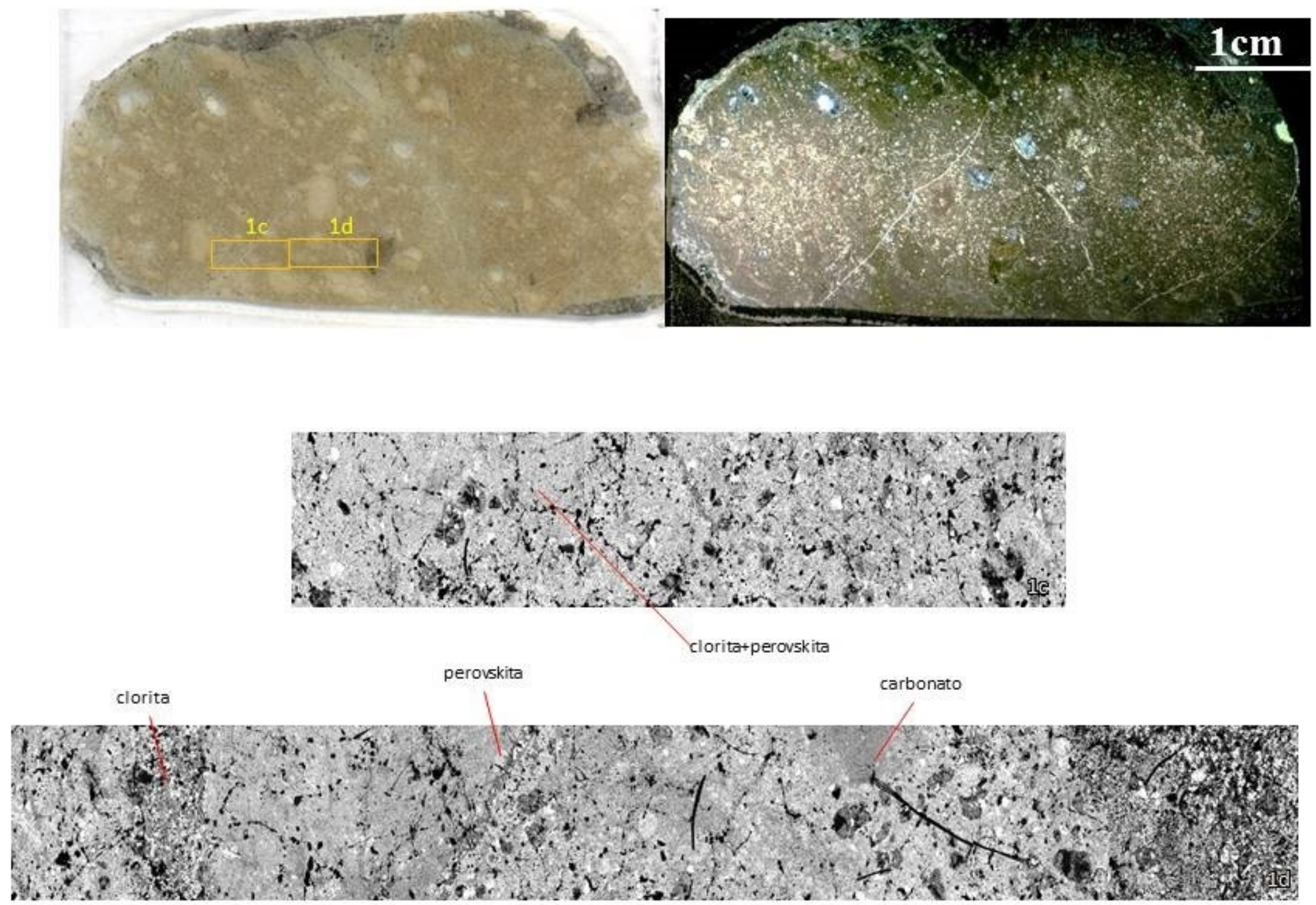

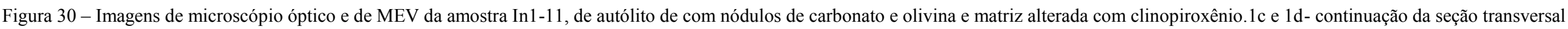
de MEV partindo da borda do nódulo carbonático. 

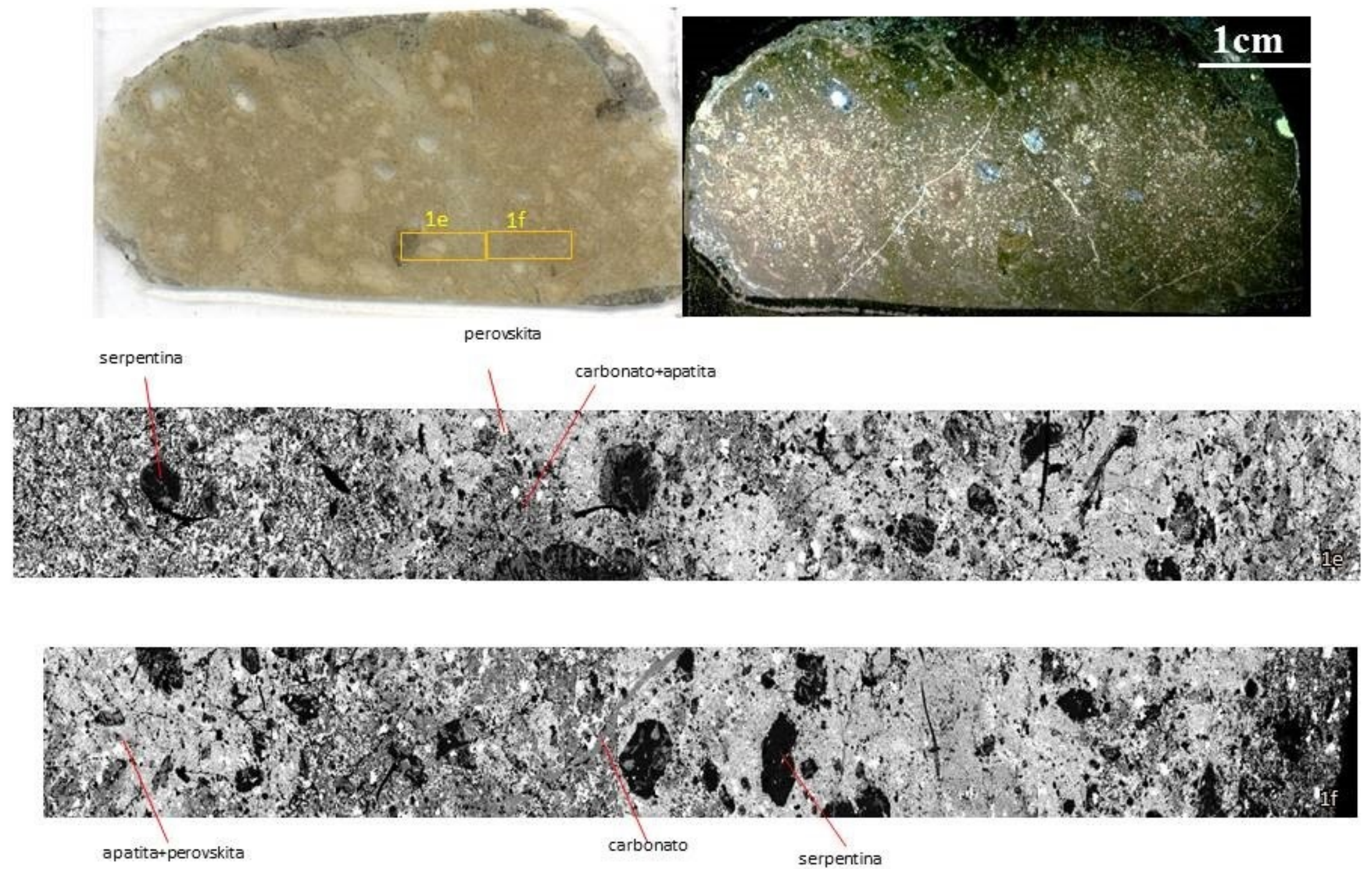

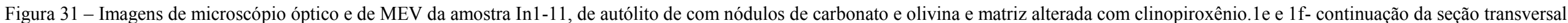
de MEV partindo da borda do nódulo carbonático. 


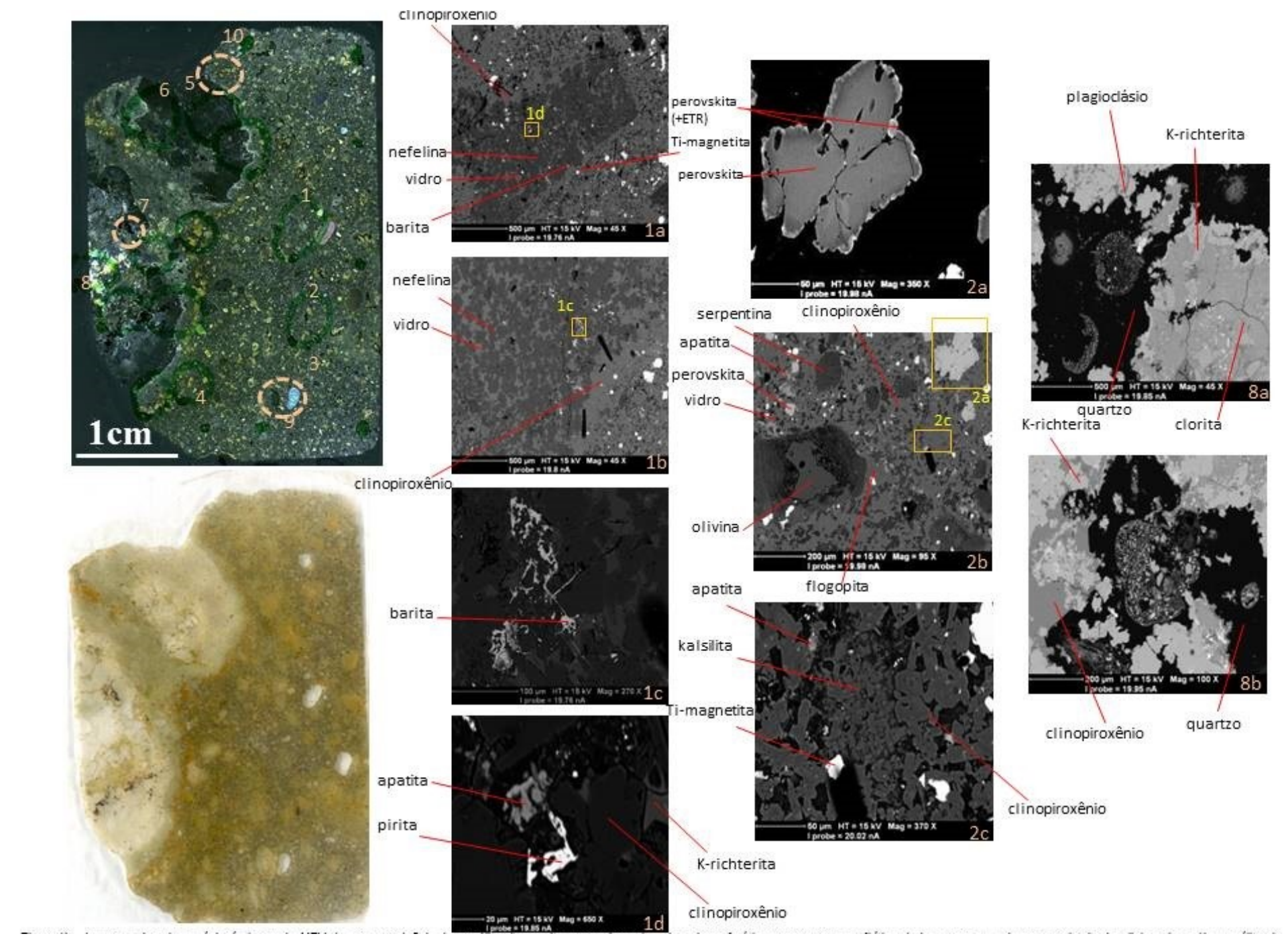

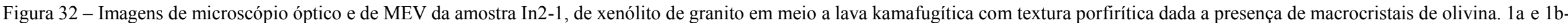

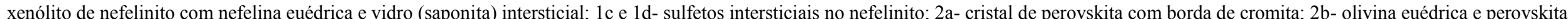

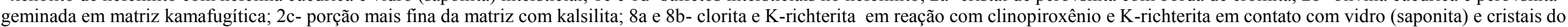
granito. 


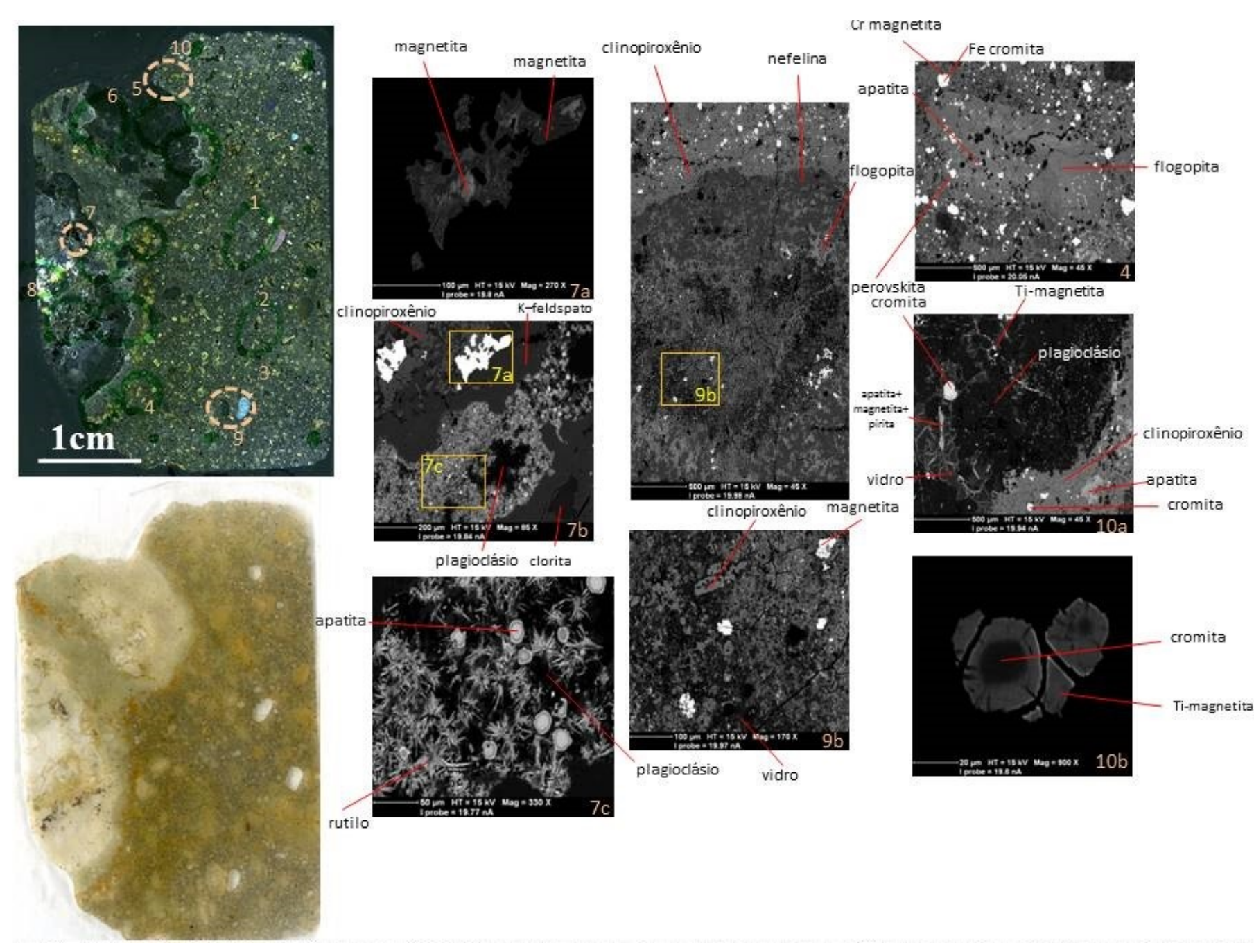

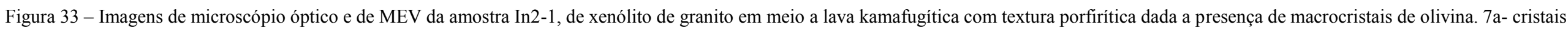

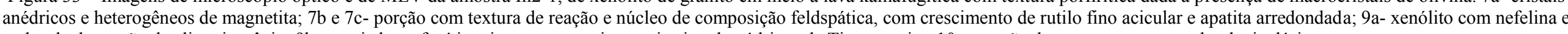

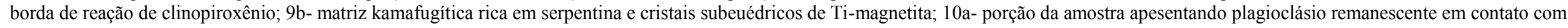

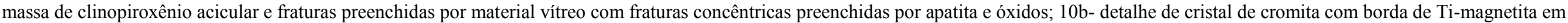
meio a massa fina de clinopiroxênio. 


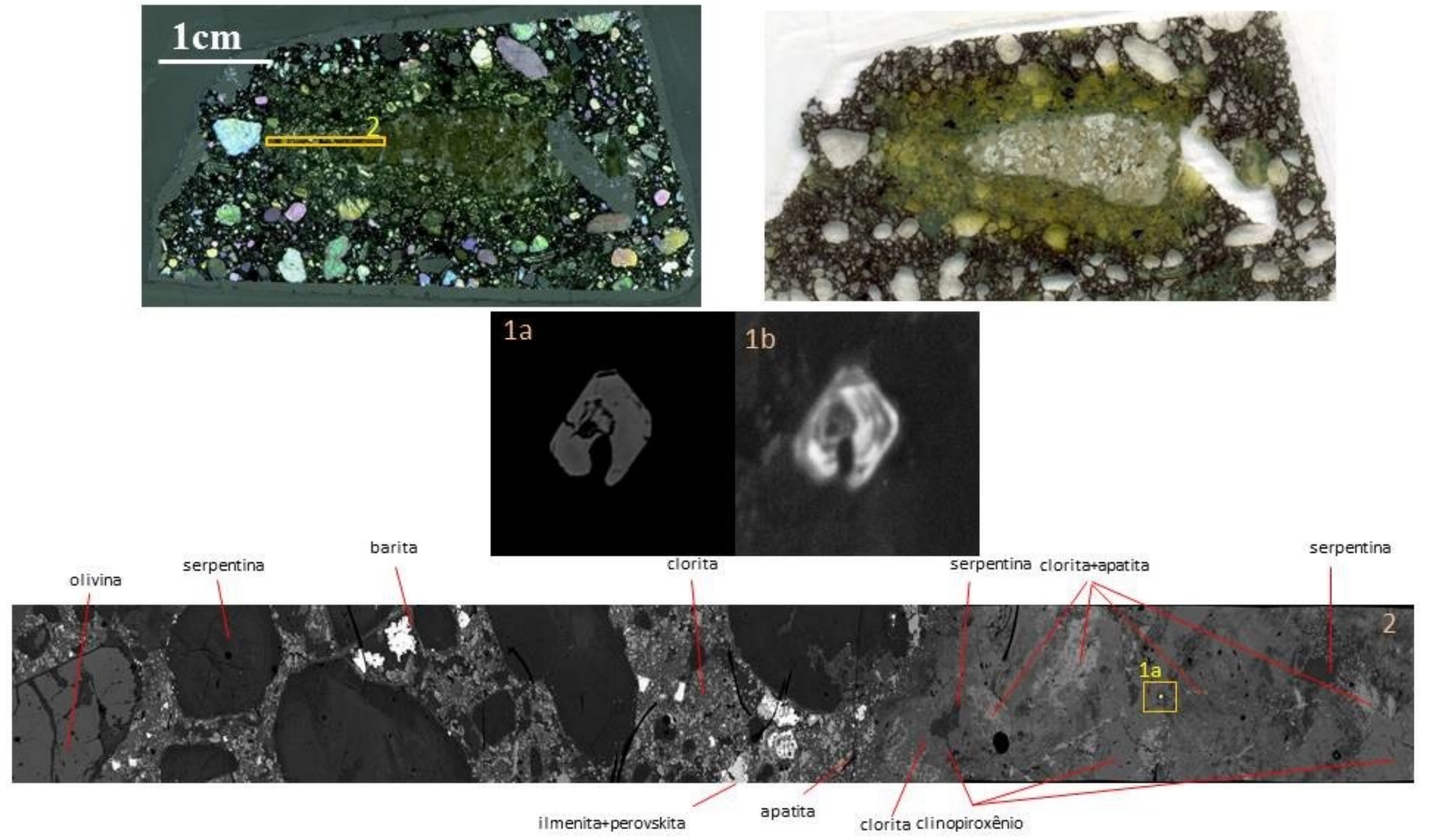

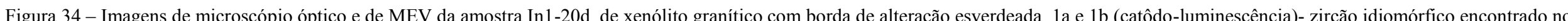
centro do xenólito granítico; 2- seção de MEV mostrando macrocristal de olivina fora da borda de alteração, a esquerda, e pseudomorfos de olivina para o centro, na parte direita ocorrem minerais reliquiares de plagioclásio alterado e meio a matriz composto por clinopiroxênio que possivelmente é produto da reação entre granito e magma kimberlítico. 


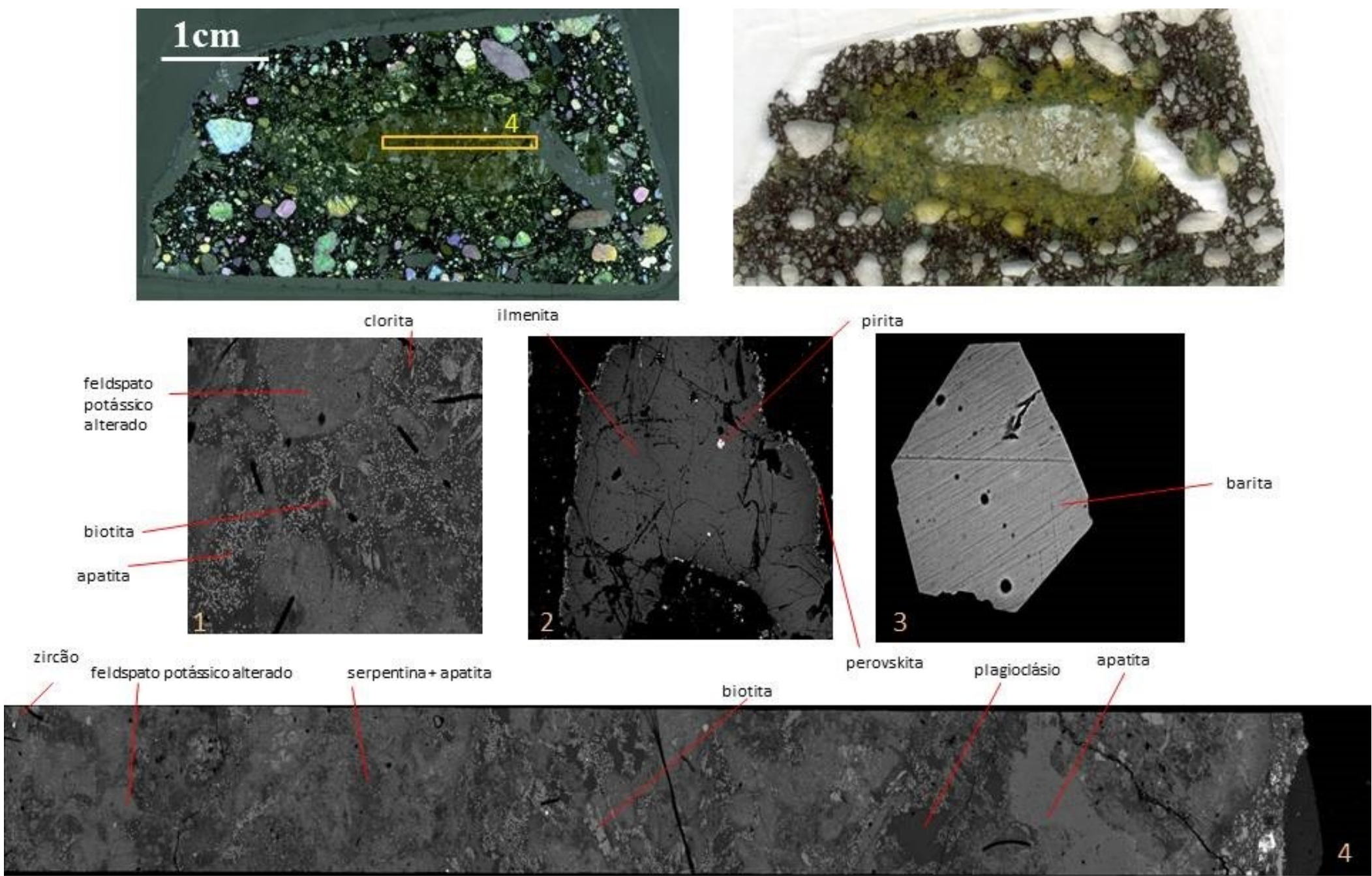

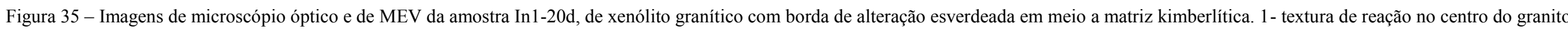
alterado com feldspato potássico alterado e biotita reliquiar; 2- macrocristal de ilmenita anédrico com inclusão de pirita; 3- macrocristal idiomórfico de barita em meio porção carbonática da matriz. 

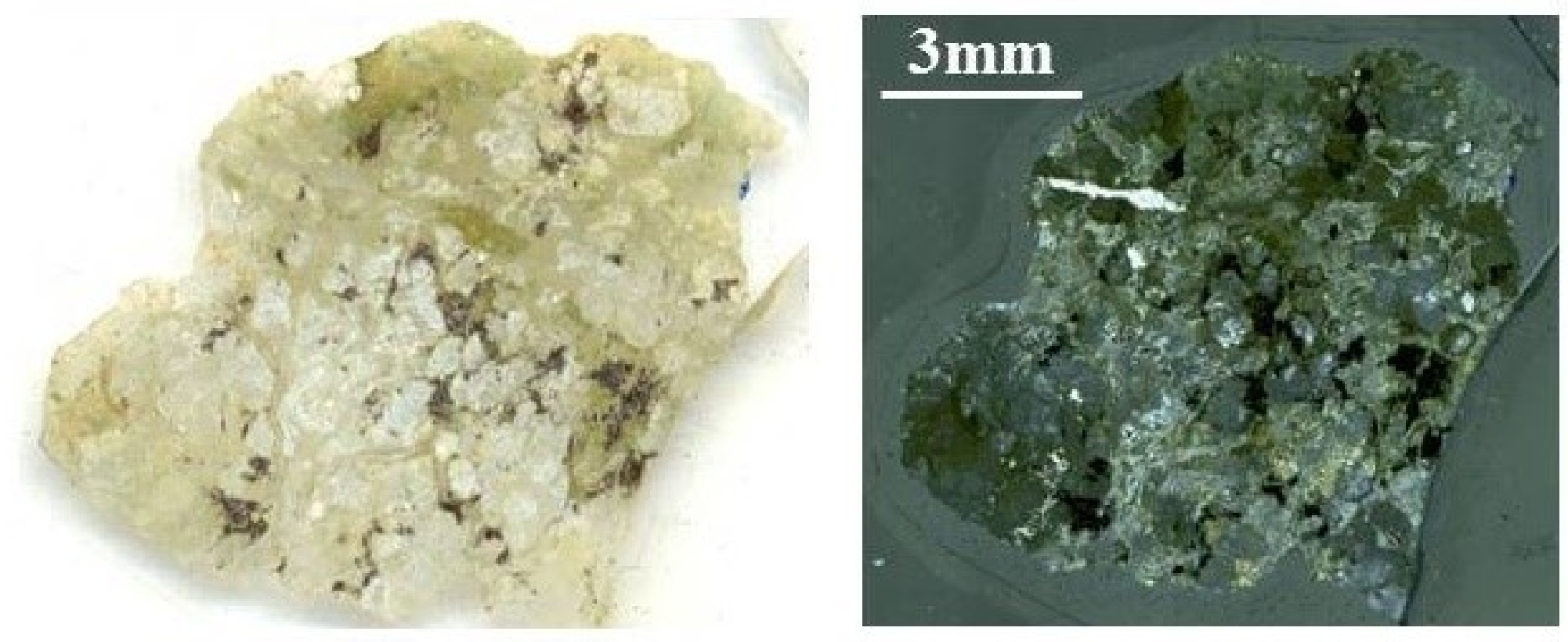

Figura 36 - Imagens de microscópio óptico e de MEV da amostra In1-7, de xenólito granítico. 

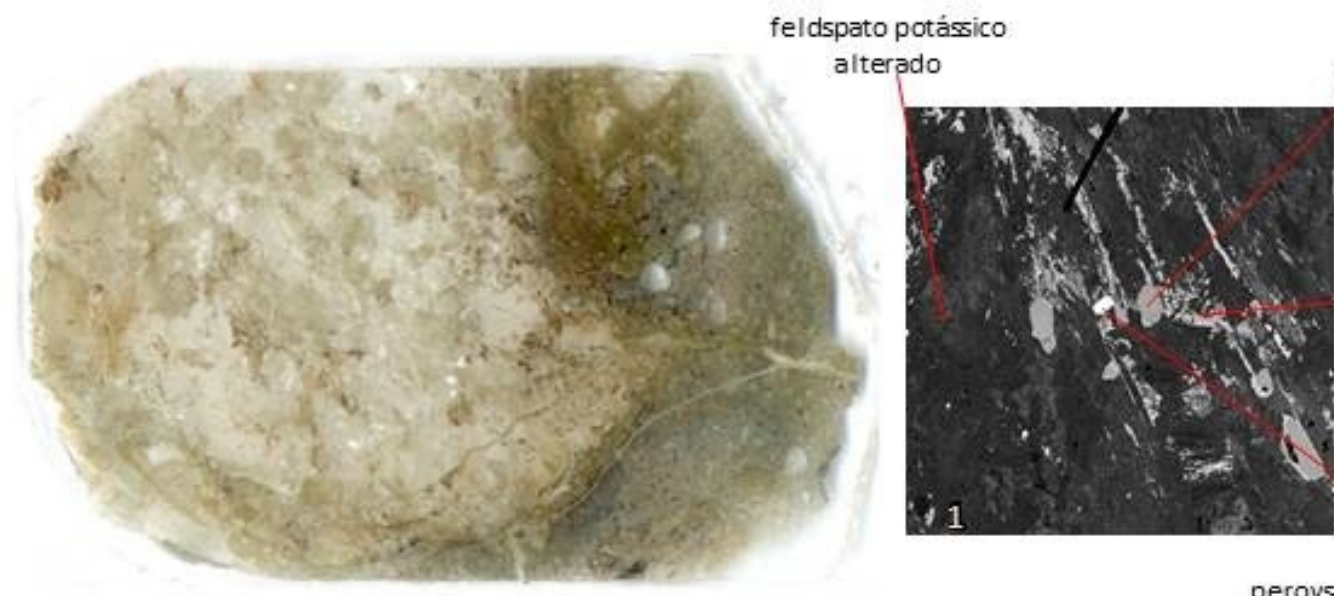

clinopiroxênio
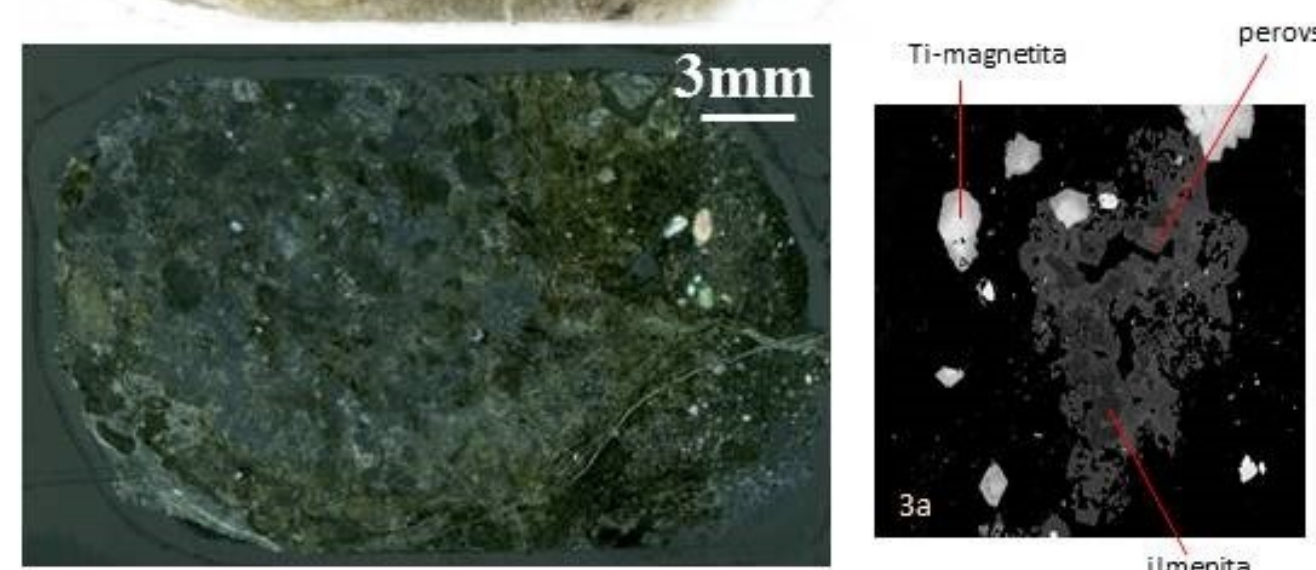

ilmenita
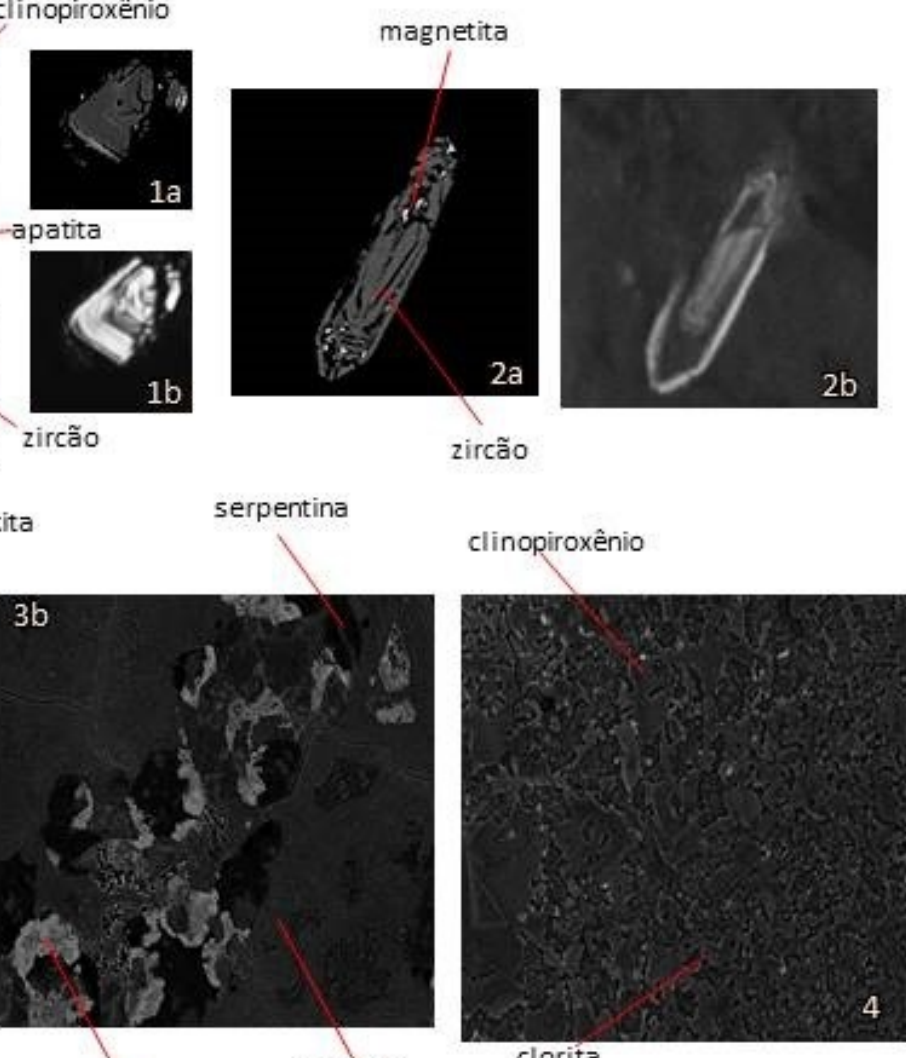

zirca

perovskita

ilmenita

clinopiroxênio

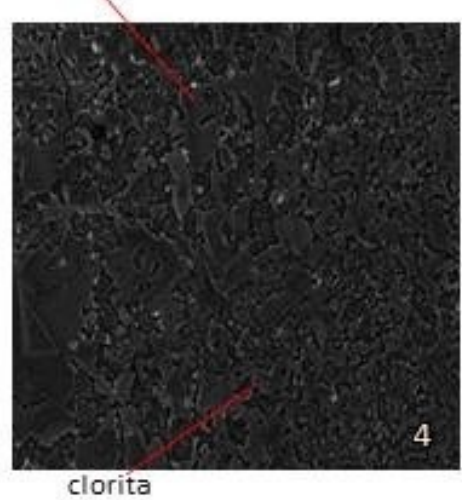

clorita

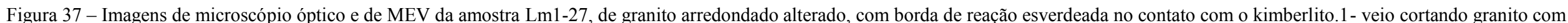

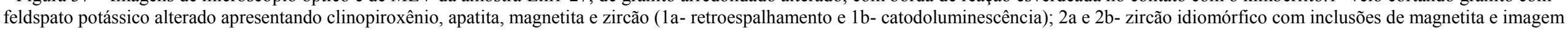

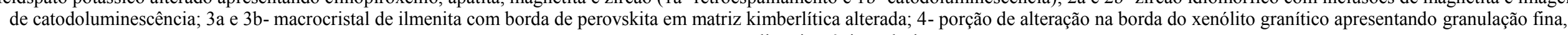
composta por clinopiroxênio e clorita. 


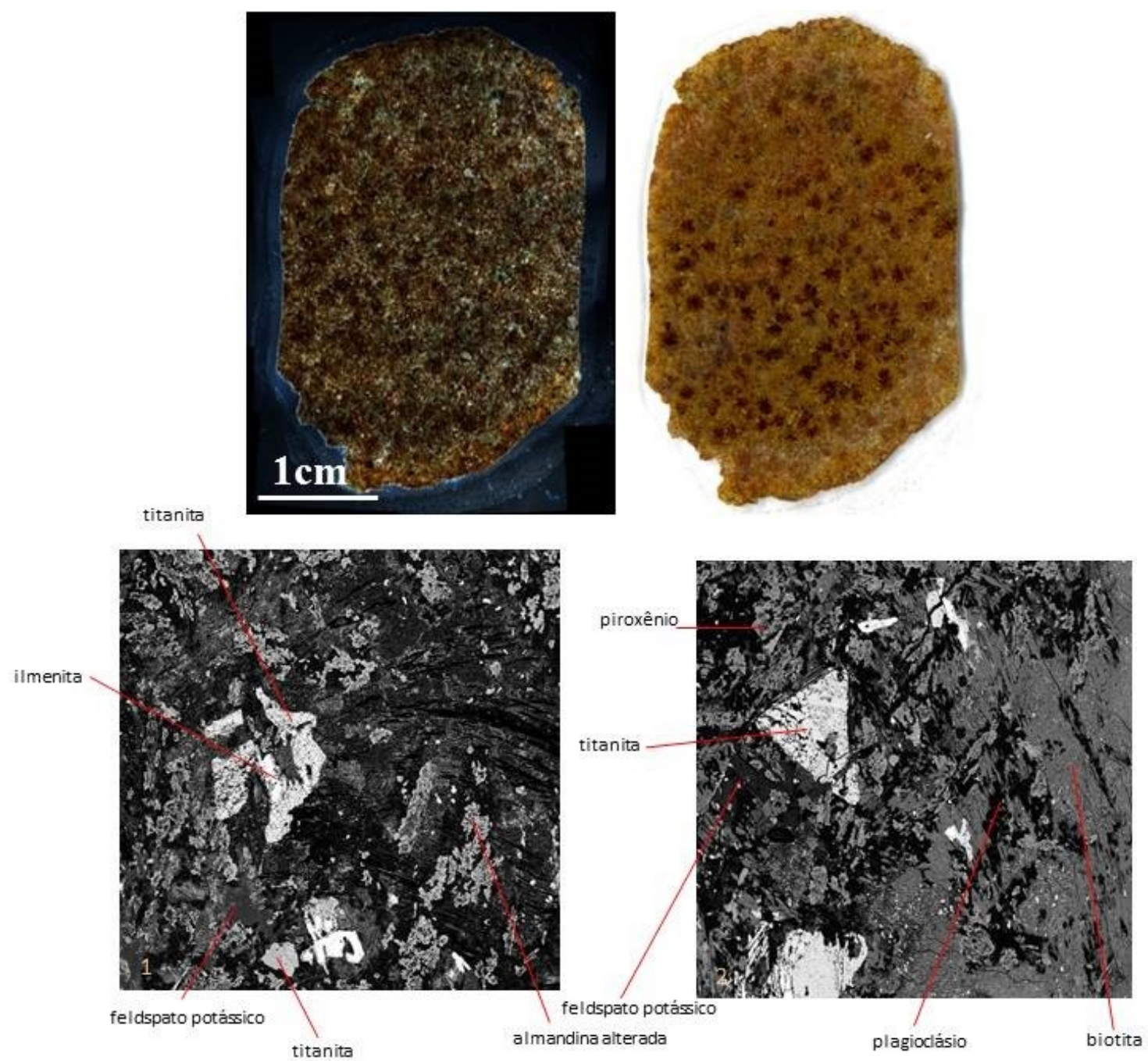

Figura 38 - Imagens de microscópio óptico e de MEV da amostra Fo-4, de xenólito crustal circular alterado composto por feldspato potássico, plagioclásio, biotita, ilmenita sem Mg e titanita. 

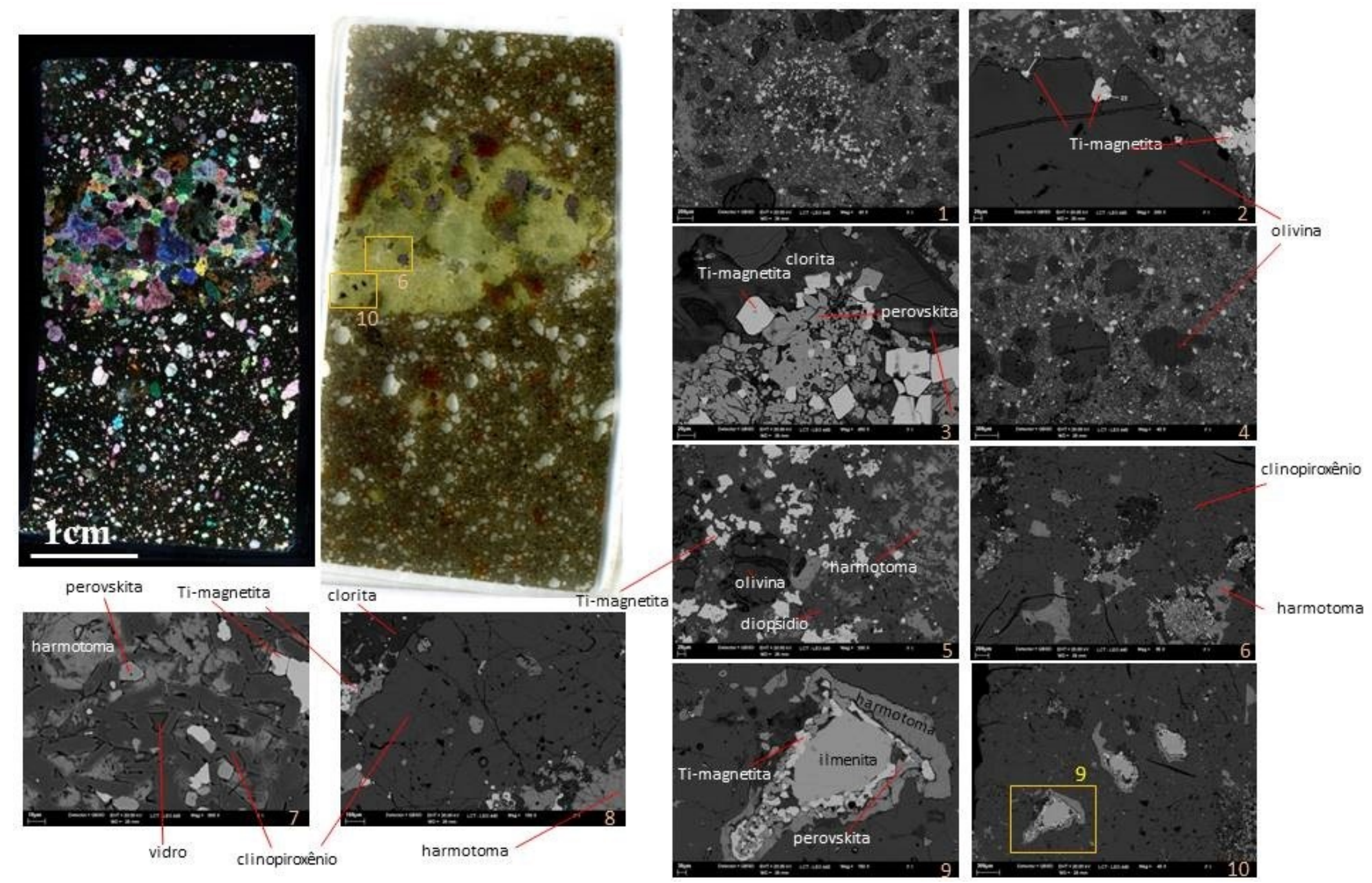

Figura 39 - Imagens de microscópio óptico e de MEV da amostra Fac-5, de piroxenito com bolsões de flogopita alaranjada, clorita e perovskita. 1- matriz do kamafugito exibindo concentração de

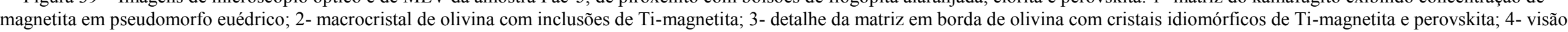
geral da matriz do kamafugito, com macrocristais de olivina; 5- detalhe da matriz do kamafugito; 6- inclusões (ou infiltrações) de harmotoma em meio ao piroxenito; 7- matriz rica em clinopiroxênio idiomórfico com zonação composicional exibindo vidro(saponita) intersticial; 8- detalhe de contato do piroxênio com harmotoma no piroxenito; 9 e 10- ilmenita inclusa (ou infiltrada) em piroxenito apresentando borda de magnetita e harmotoma. 


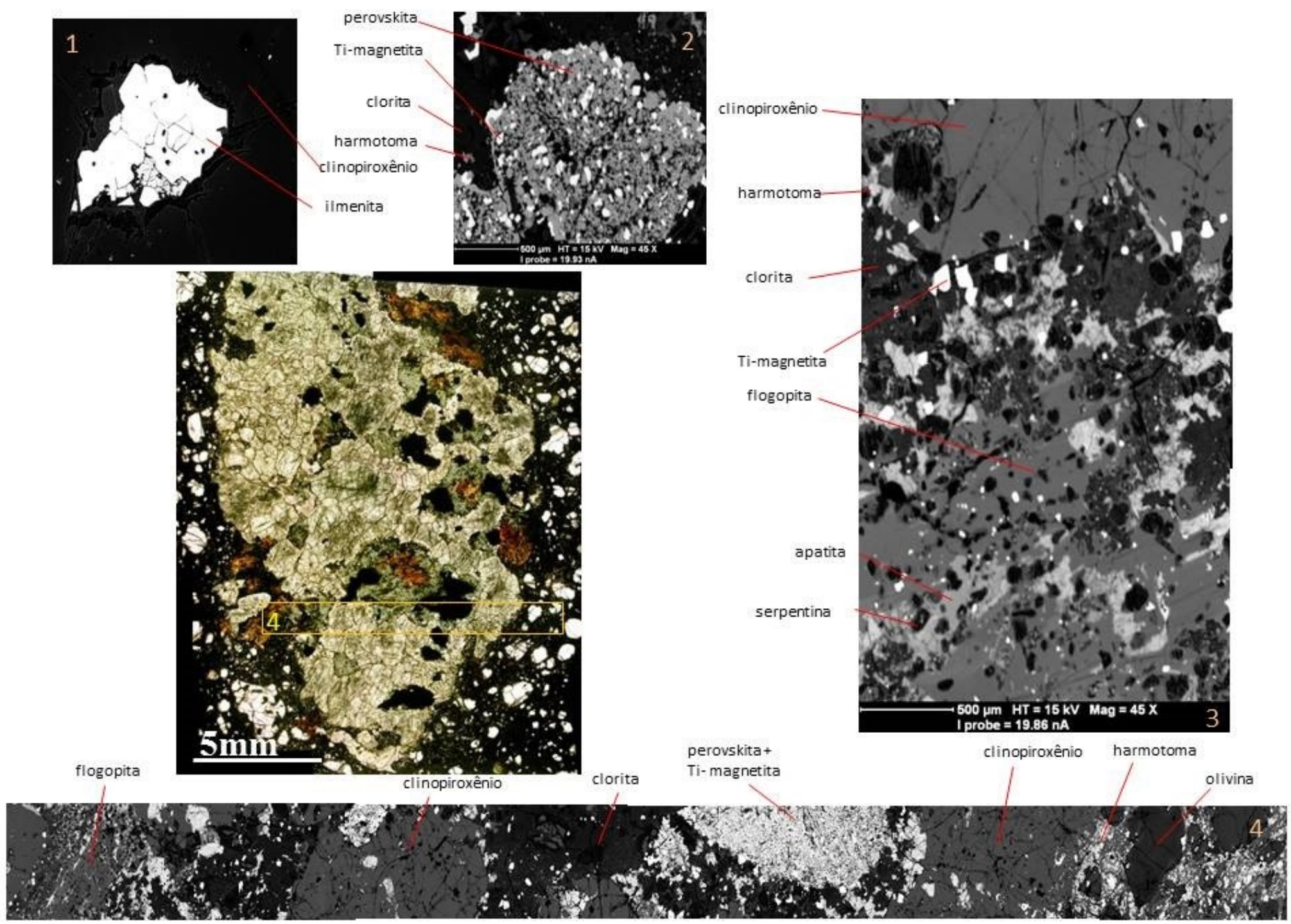

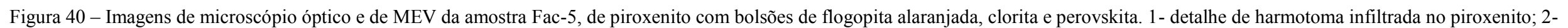

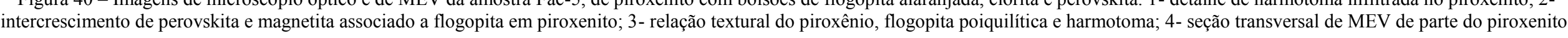




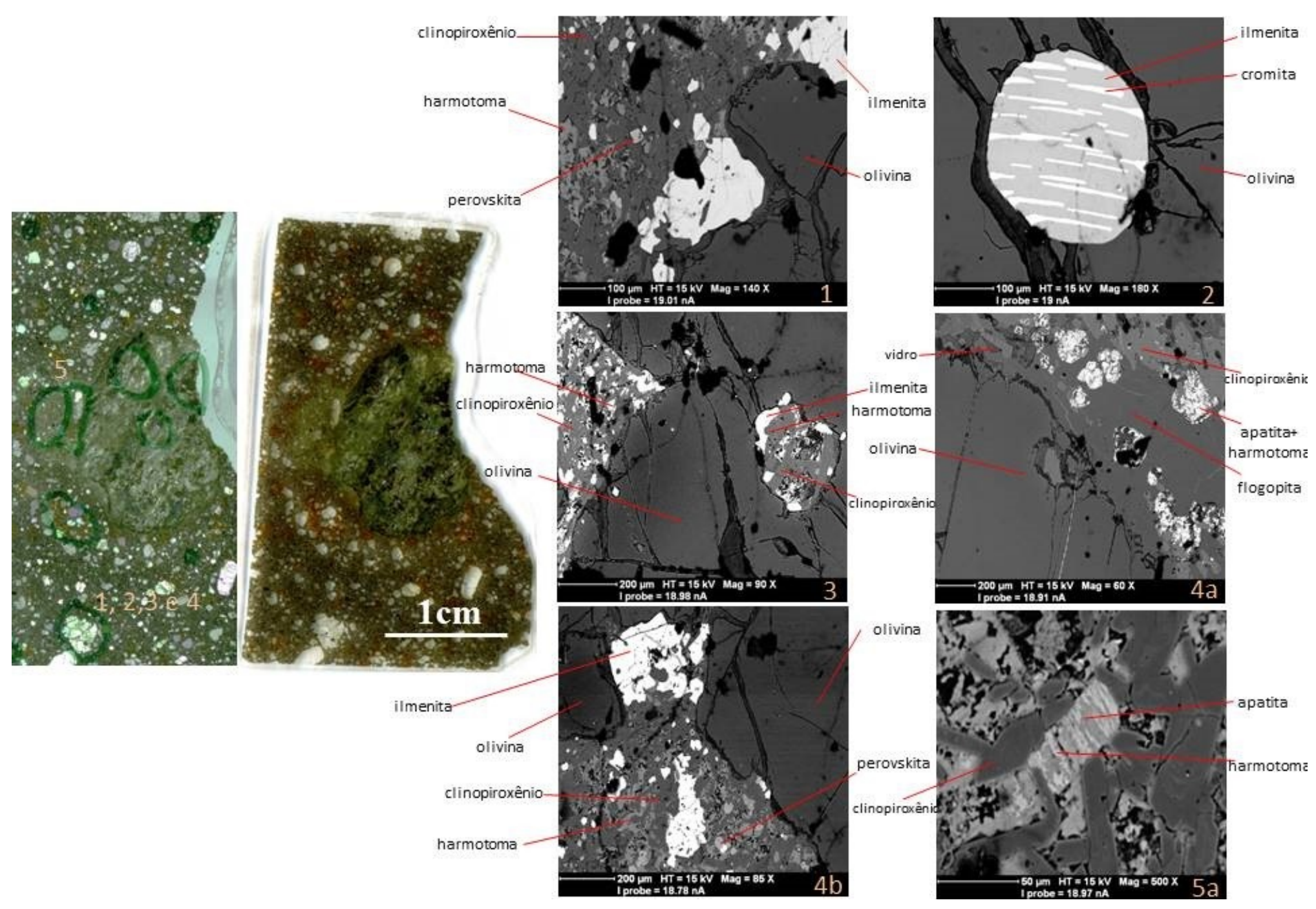

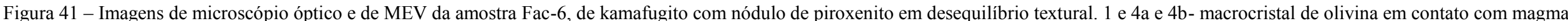

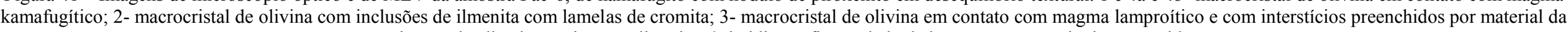
matriz; 5a- detalhe da matriz com clinopiroxênio idiomórfico ao lado de harmotoma e apatita intercrescidas. 


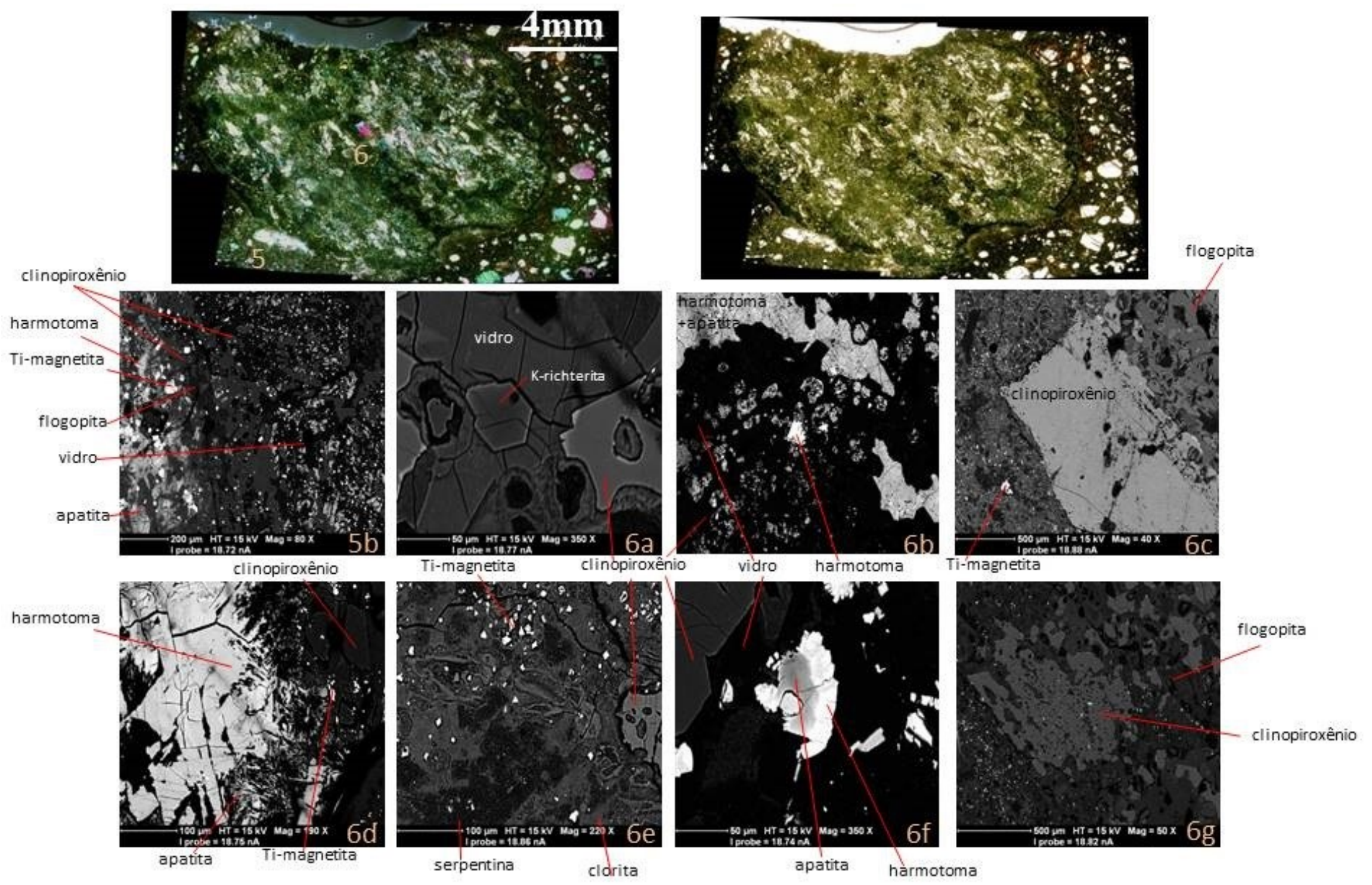

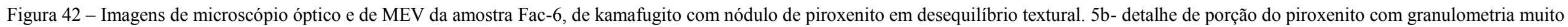

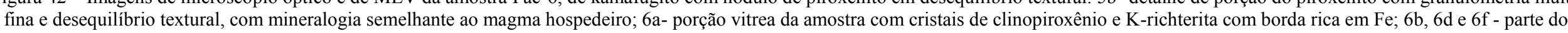
piroxenito com harmotoma anédrica em contato com clorita; $6 \mathrm{c}, 6 \mathrm{e}$ e $6 \mathrm{~g}$ - macrocristais de clinopiroxênio remanescentes do piroxenito rodeados por material muito fino ou por flogopita e magnetita. 

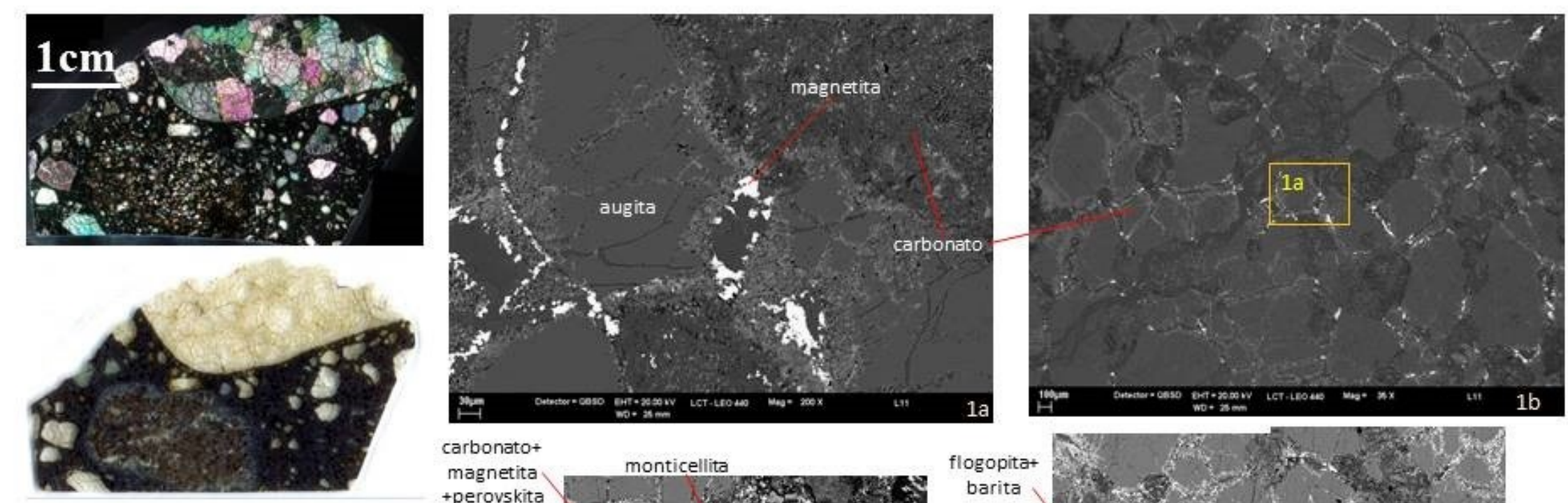

carbonato+

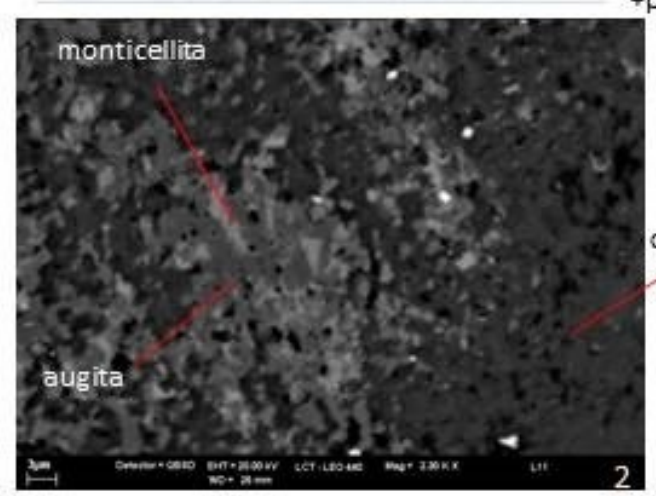

+perovskita
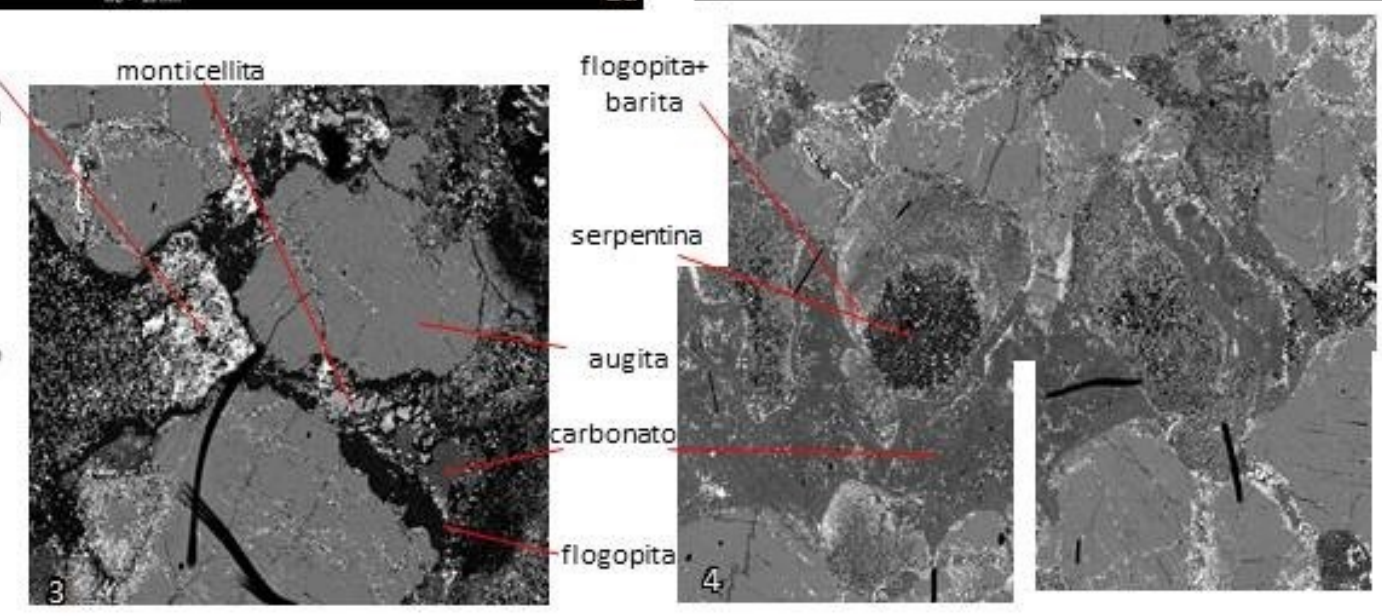

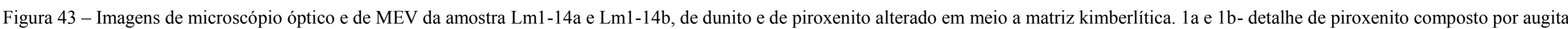

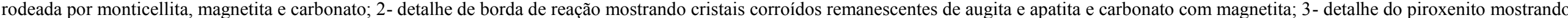

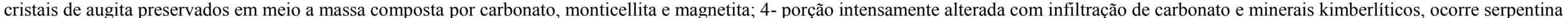
na forma de pseudomorfo de olivina no centro. 


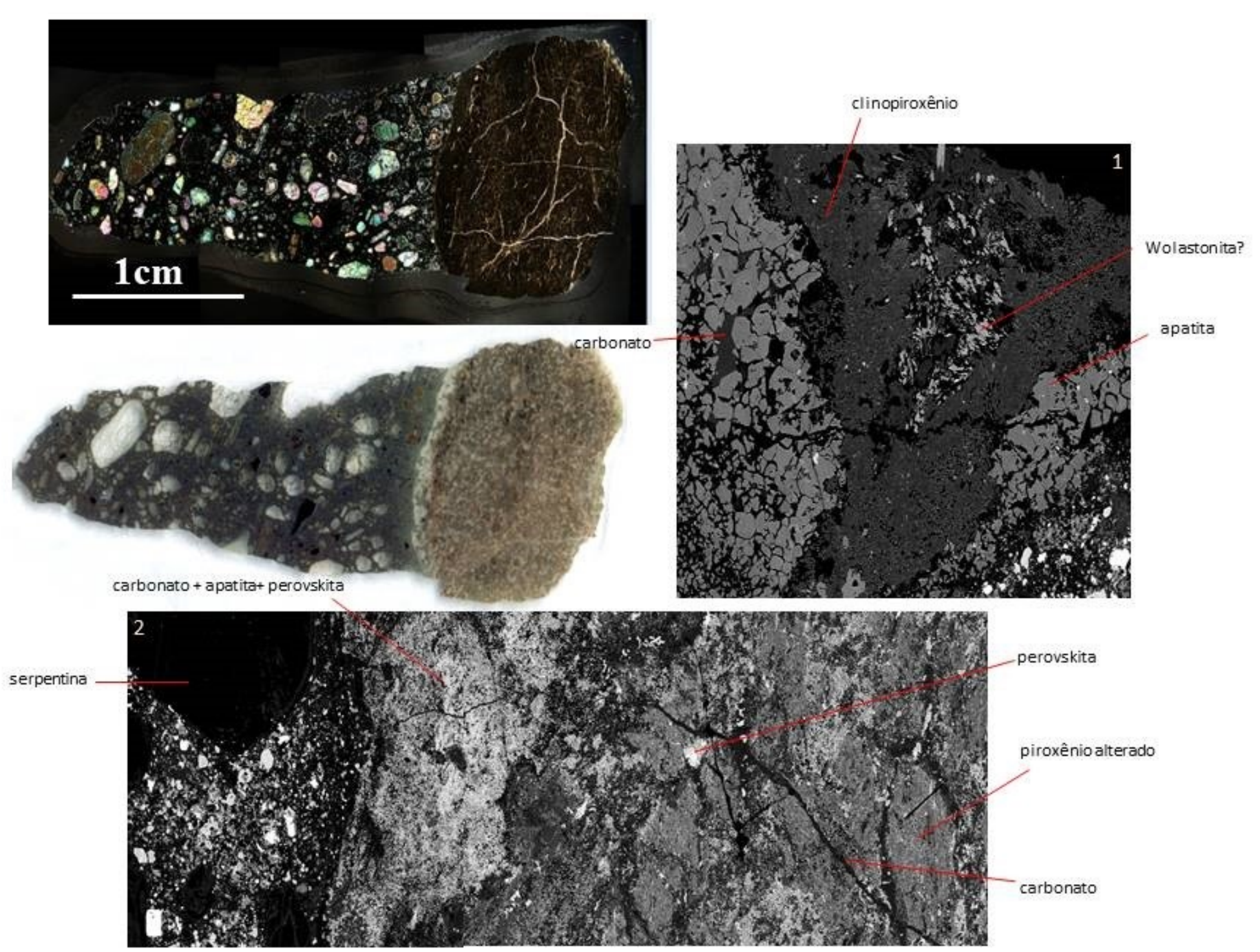

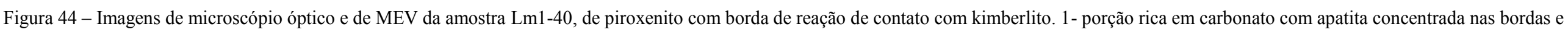
wollastonita no centro; 2- visualização em MEV da matriz kimberlítica, passando para a borda de reação e chegando ao centro do xenólito crustal. 


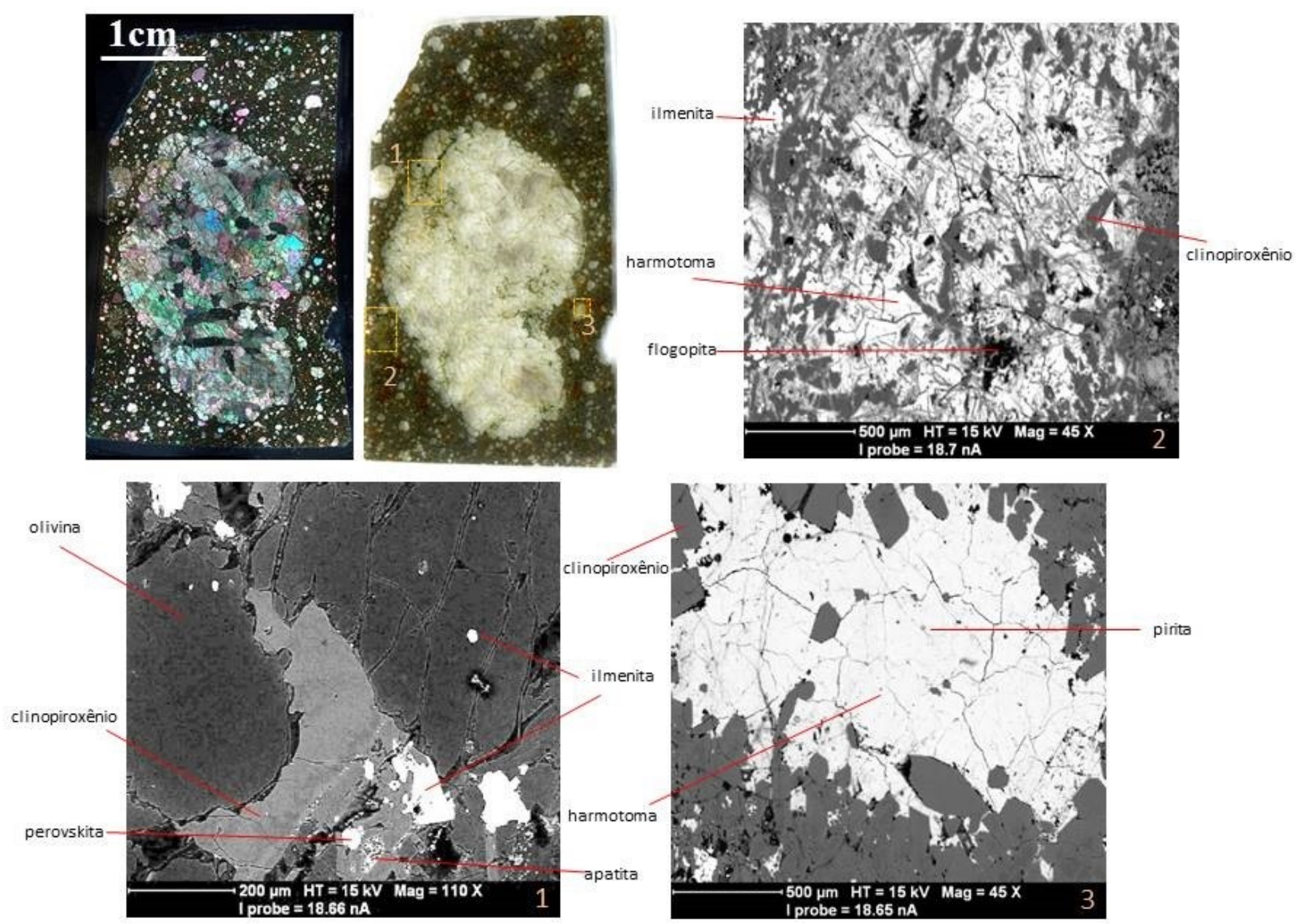

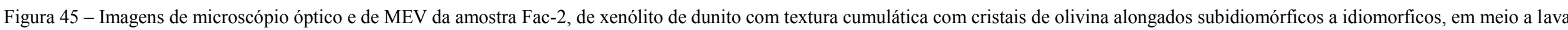
lamproítica. 1- olivina apresentando heterogeneidade química, com inclusão de ilmenita, em contato com clinopiroxênio intersticial associados a ilmenita e a perovskita; 2- porção da matriz rica em harmotoma; 3- ocelo preenchido por harmotoma com inclusão de pirita. 


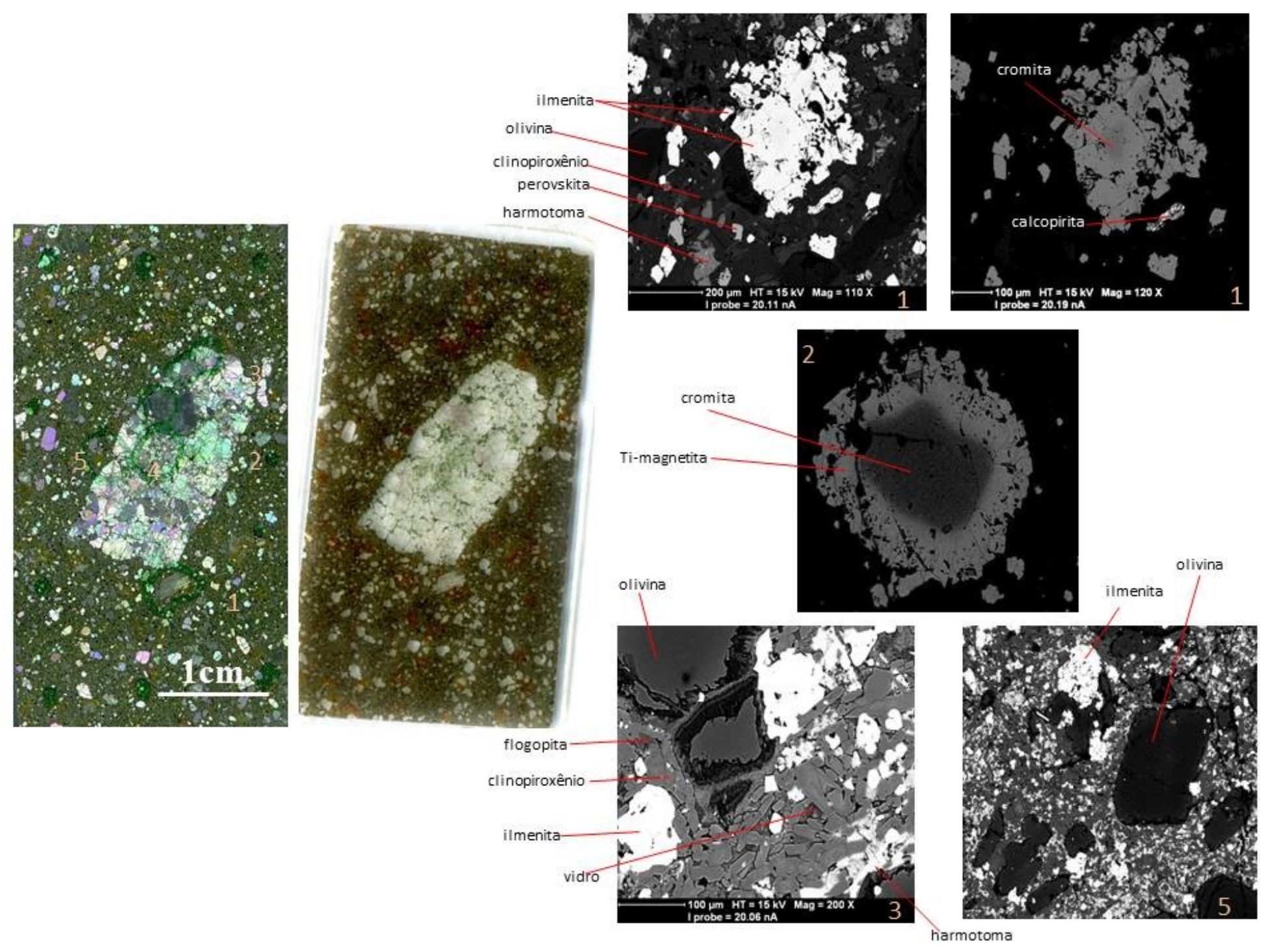

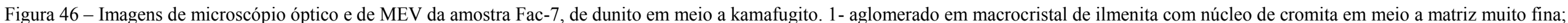

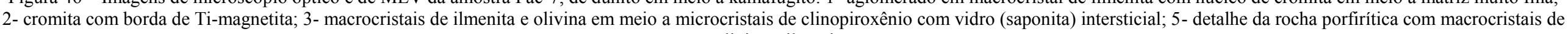
olivina e ilmenita. 

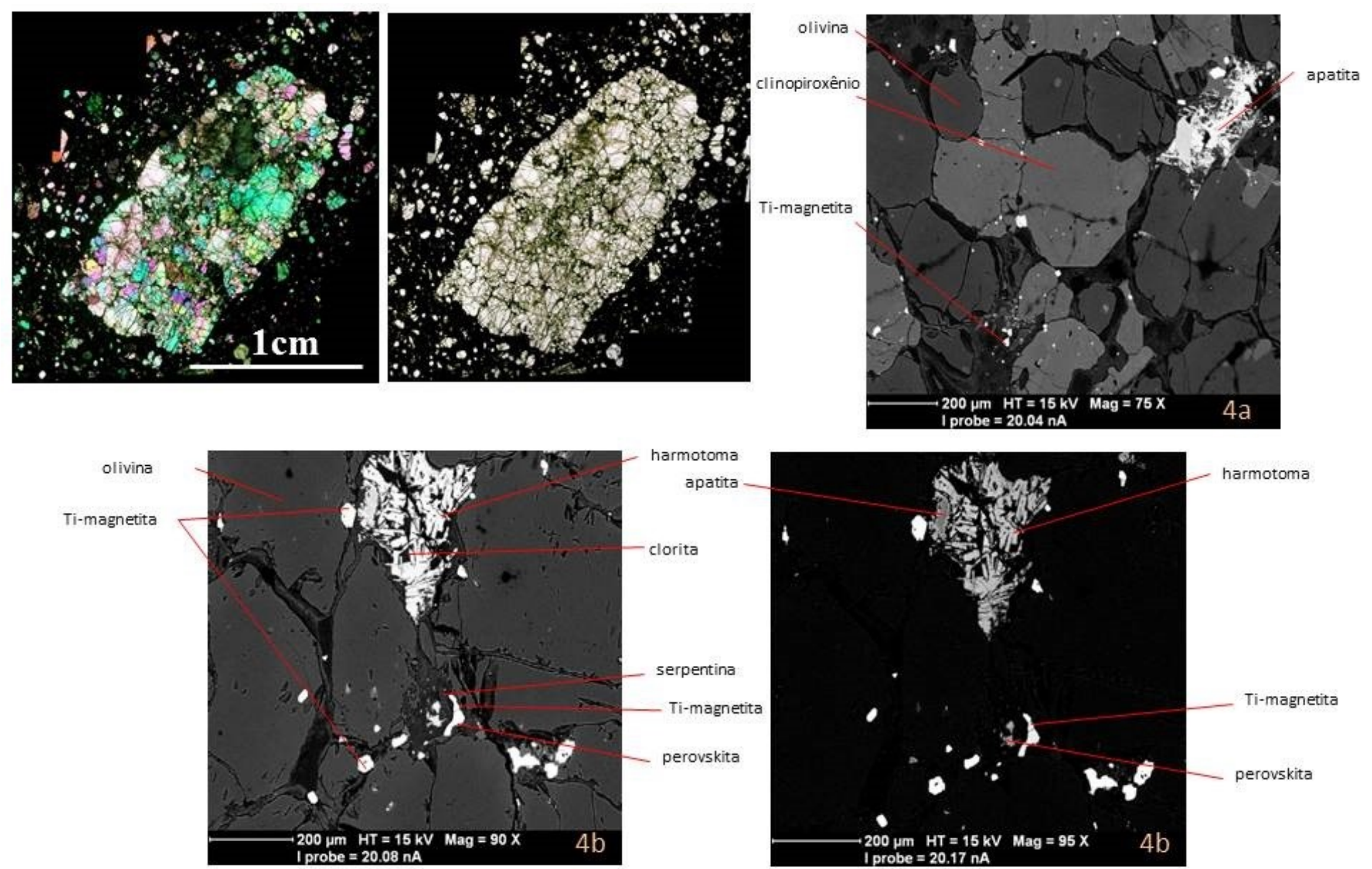

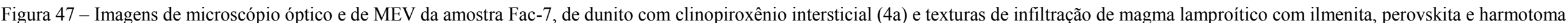
(4b). 

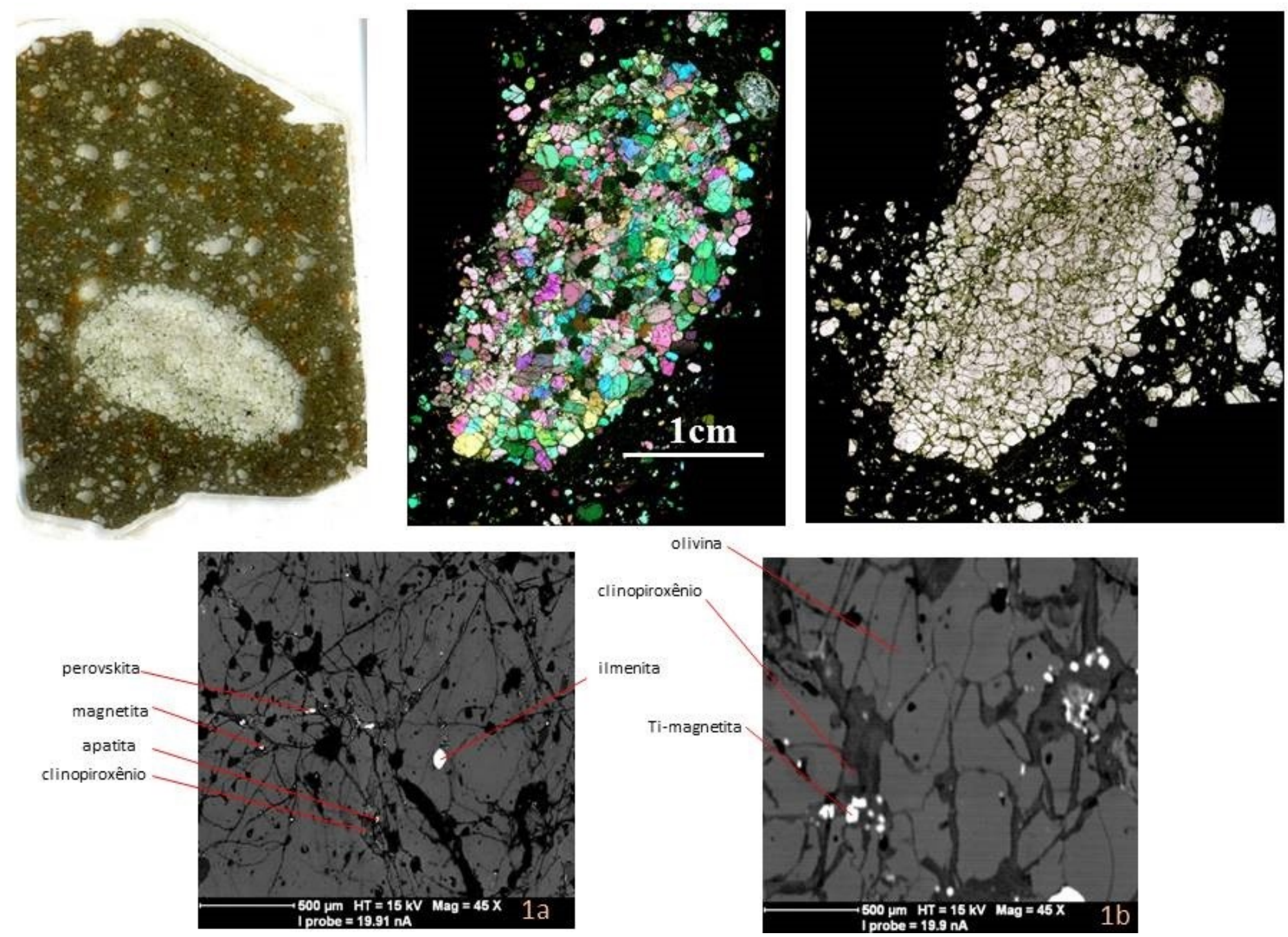

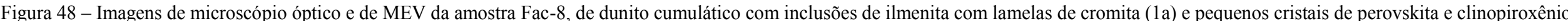
(1b) infiltrados nas microfraturas. 

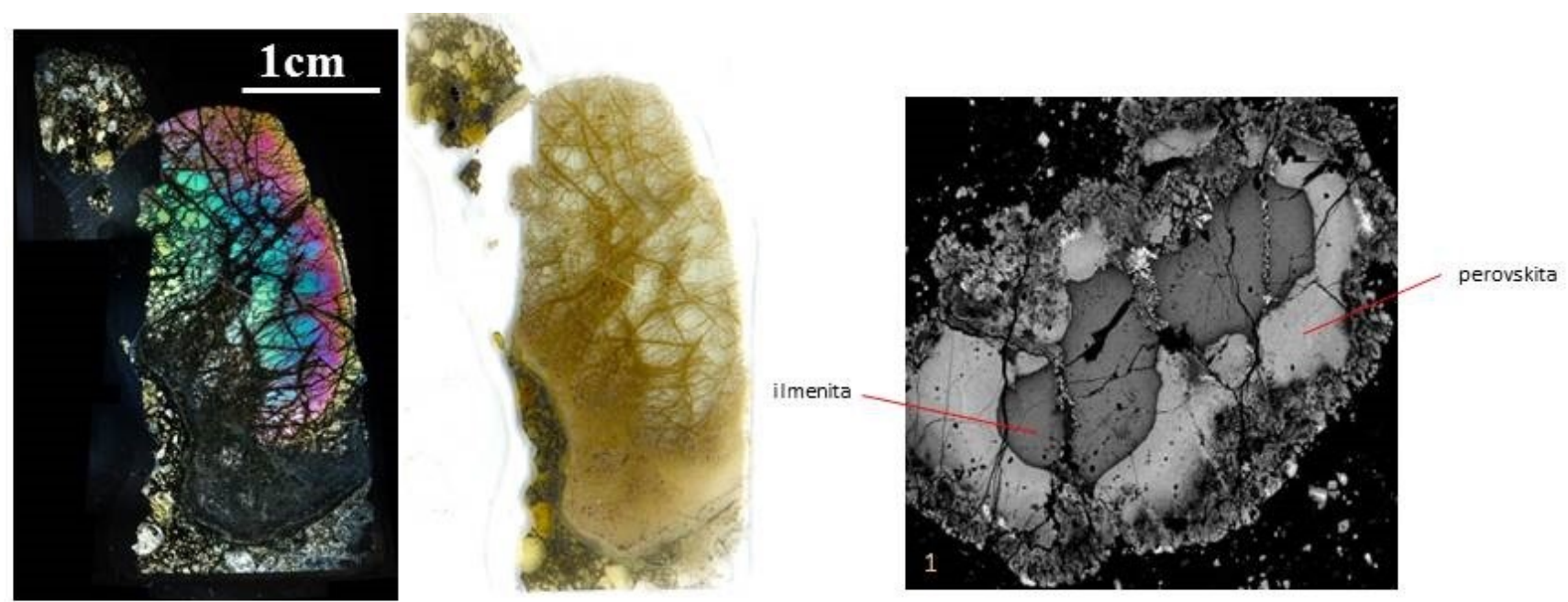

carbonato

kinoshitalita

carbonato
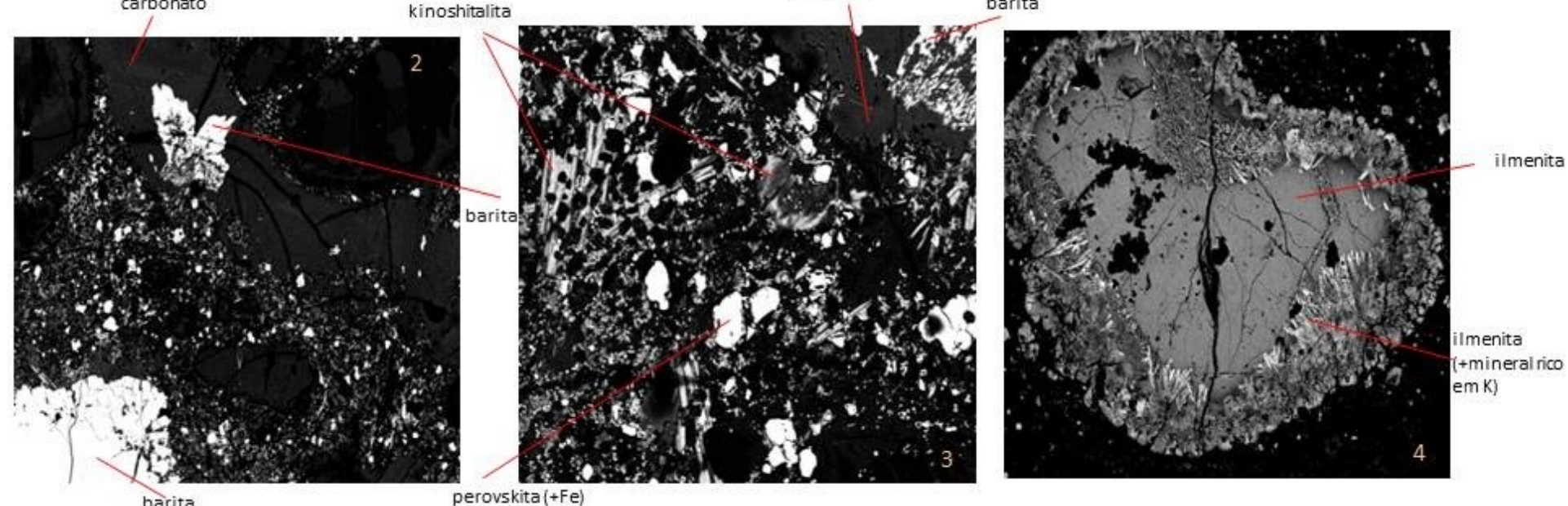

Figura 49 - Imagens de microscópio óptico e de MEV da amostra Fo-3, de megacristal de clinopiroxênio com borda de alteração em matriz kimberlítica. 1- macrocristal de ilmenita manteado por

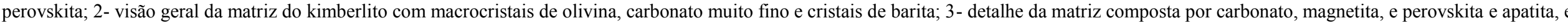
flogopita rica em barita com textura poiquilítica; 4- macrocristal de ilmenita bordejado por perovskita com alteração secundária com enriquecimento de $\mathrm{K}$. 

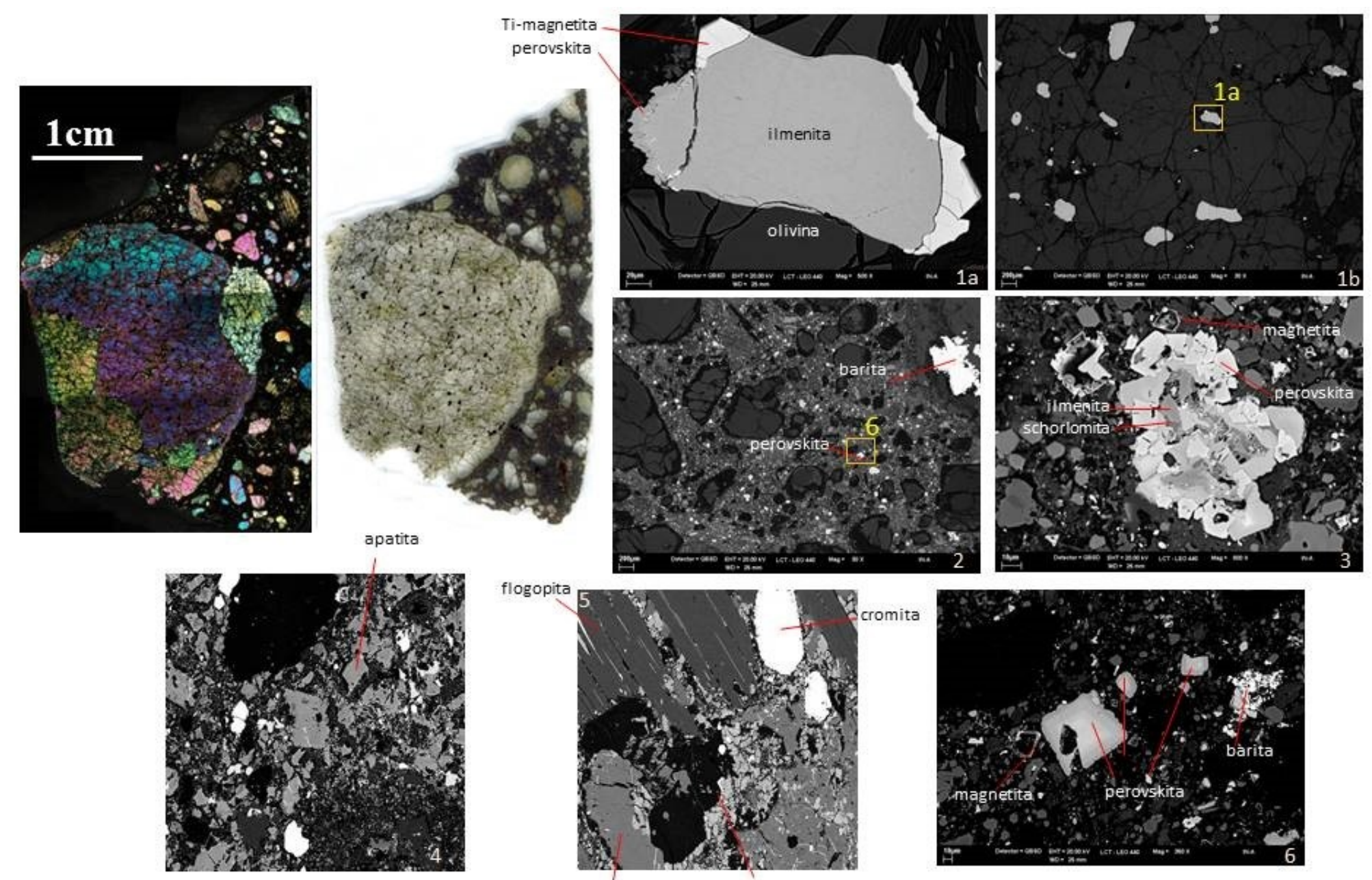

olivina

monticellita

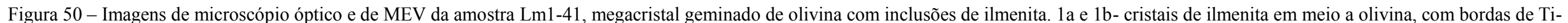

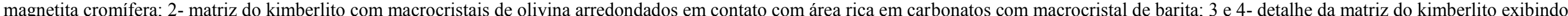

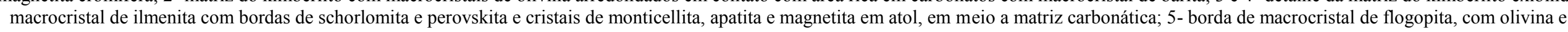
monticellita associada e ilmenita idiomórfica; 6- detalhe da matriz kimberlítica, com perovskita com zonação composicional, e cristais aglomerados de barita. 


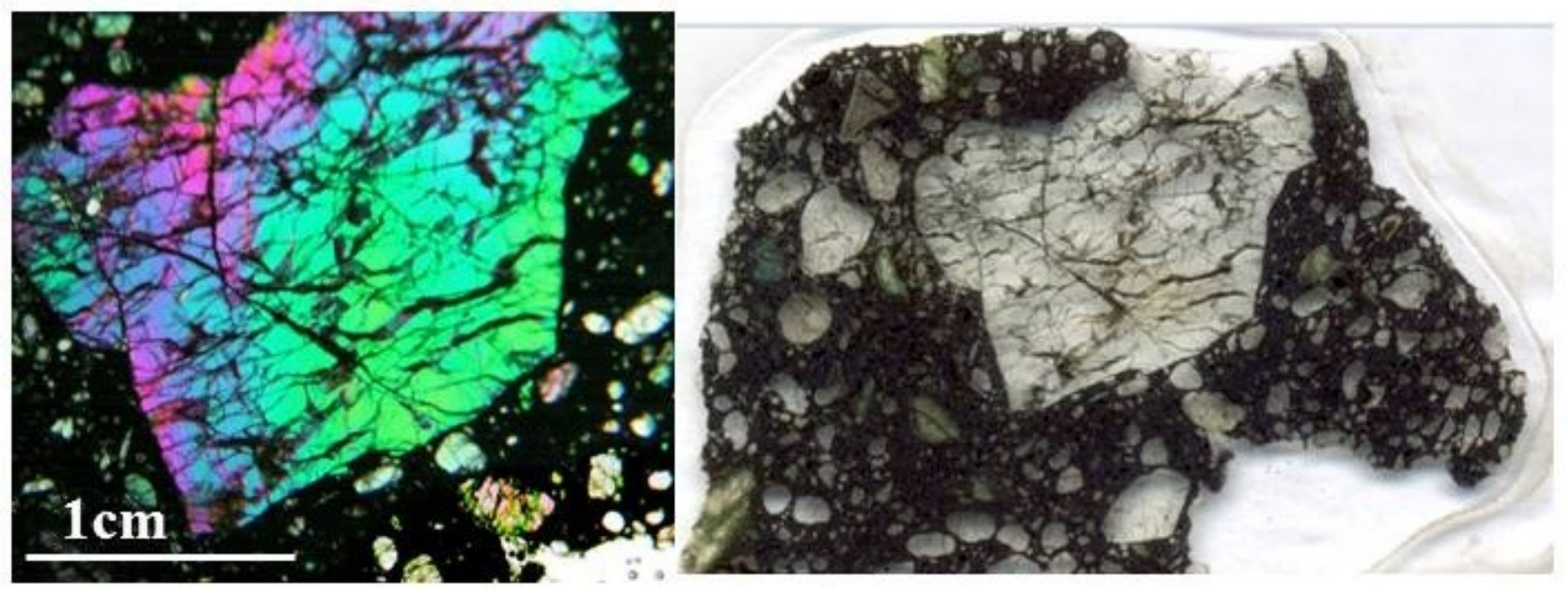

Figura 51 - Imagens de microscópio óptico da amostra In1-18, de megacristal anédrico anguloso de olivina com extinção ondulante em meio a matriz kimberlítica. 


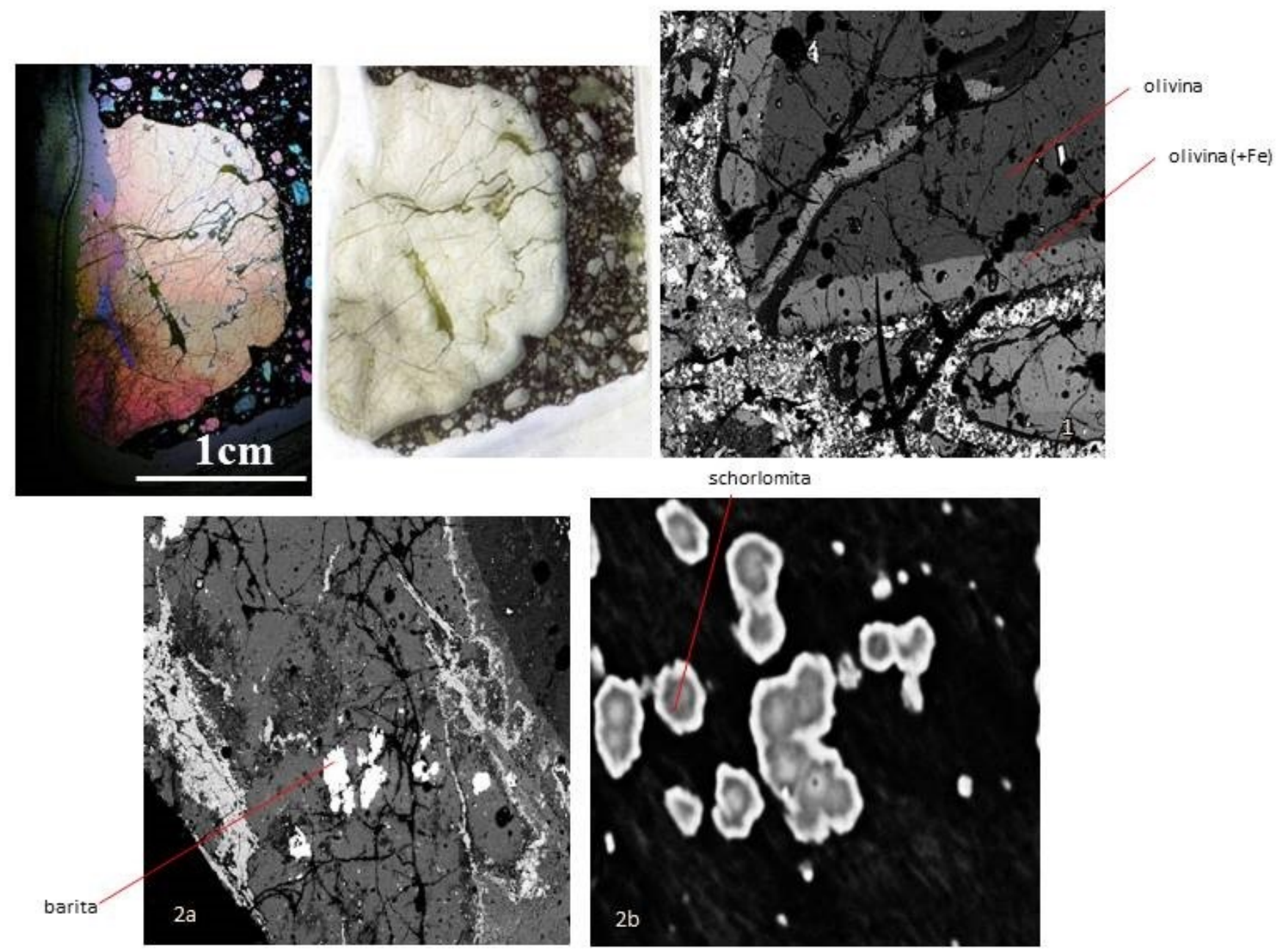

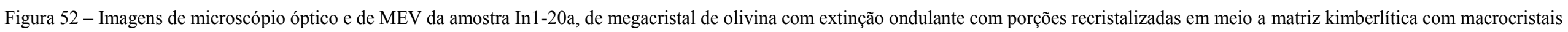
de olivina e porções esverdeados com carbonato de barita.1- Macrocristal de olivina com borda e fratura enriquecida em Fe; $2 \mathrm{a}$ e $2 \mathrm{~b}$ - porção rica em carbonato, com barita e cristais muito finos de schorlomita. 

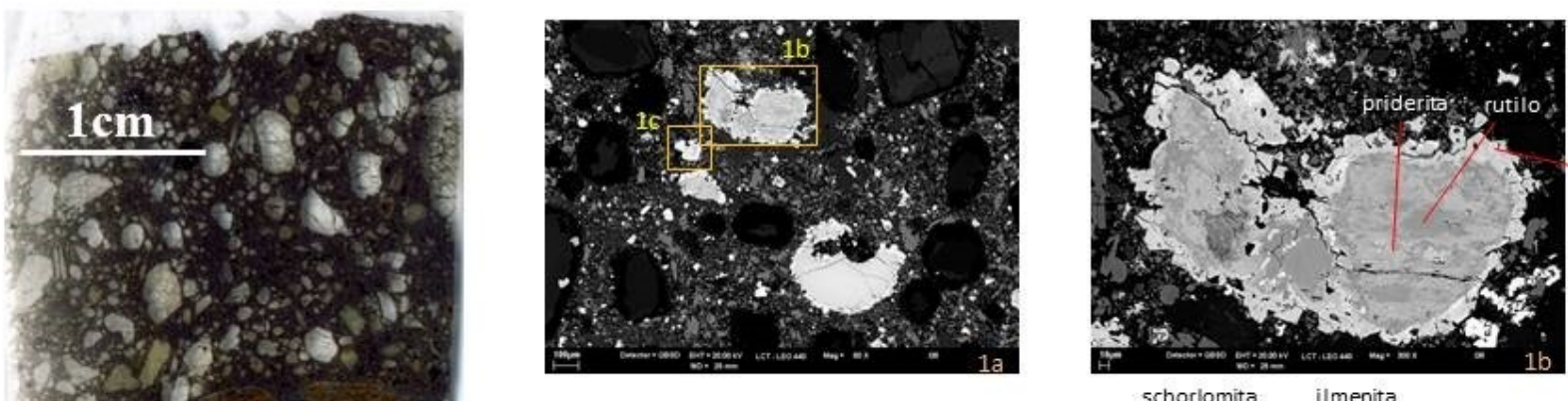

perovskita
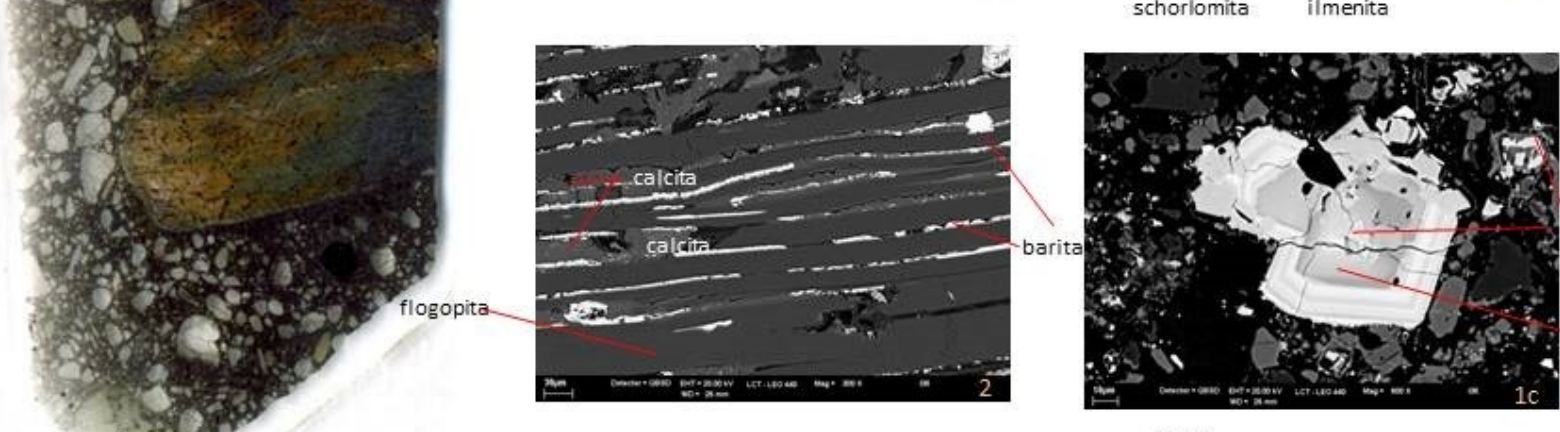

Ti-magnetita
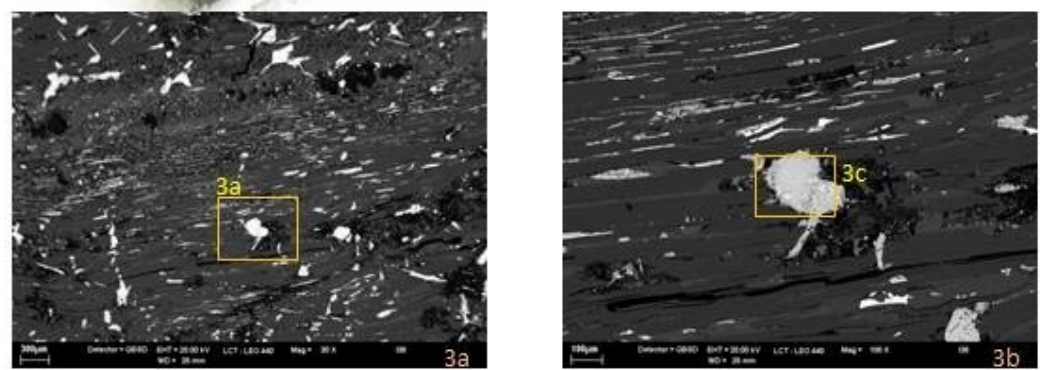

barita

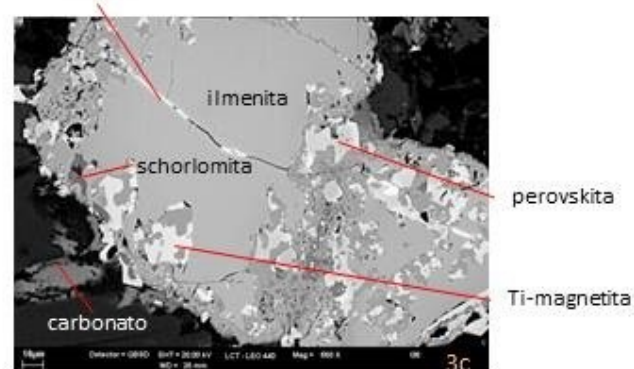

Figura 53 - Imagens de microscópio óptico e de MEV da amostra In1-36, com megacristal de flogopita em meio a matriz kimberlítica.1a- matriz composta por apatita, carbonato e magnetita, com macrocristais de olivina e de óxidos; 1b- macrocristal de ilmenita com rutilo sendo substituido por priderita e borda de perovskita; $1 \mathrm{c}$ - cristal de perovskita idiomórfico geminado com núcleo de Ti-

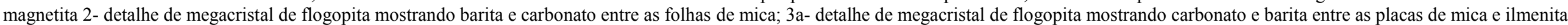
orientada obliquamente; $3 \mathrm{~b}$ e $3 \mathrm{c}$ - ilmenita anédrica com borda de reação com perovskita e Ti- magnetita e fraturas preenchidas por barita. 

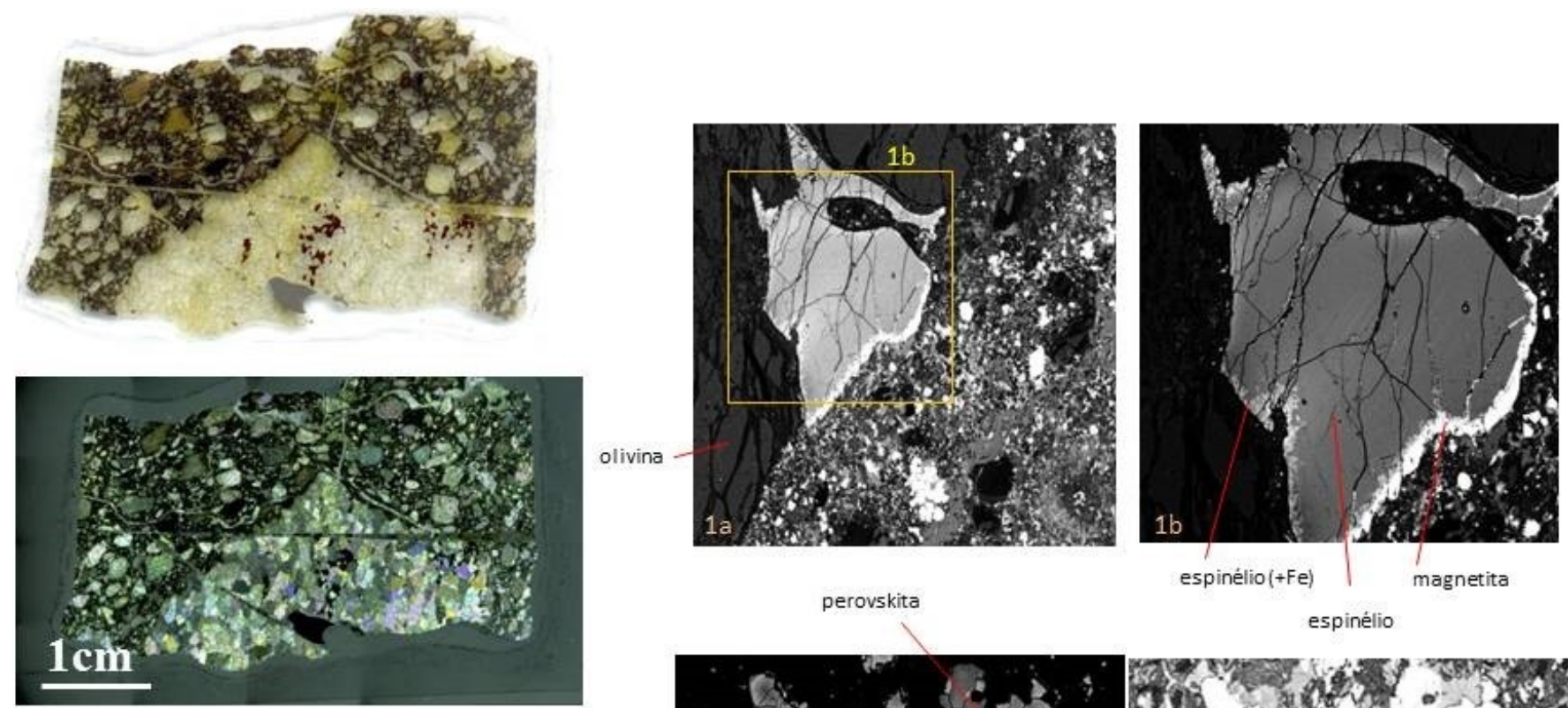

perovskita

espinélio
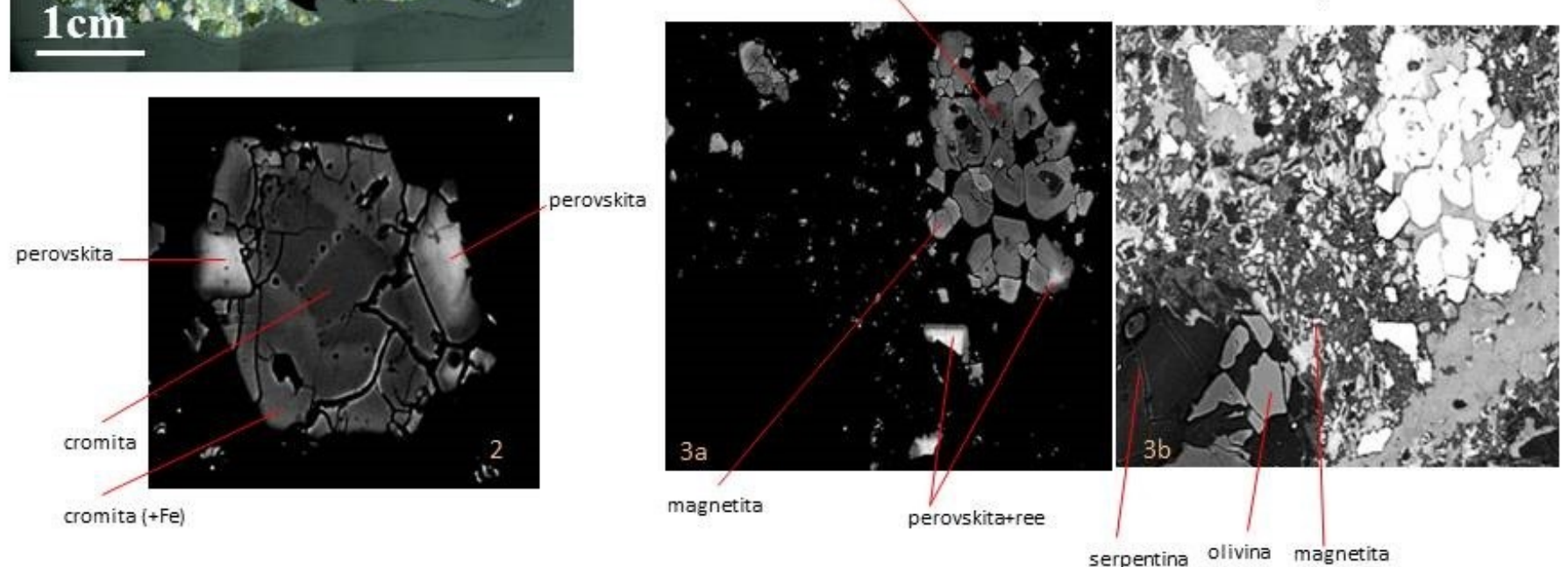

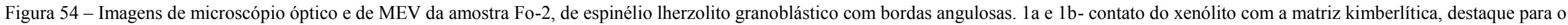

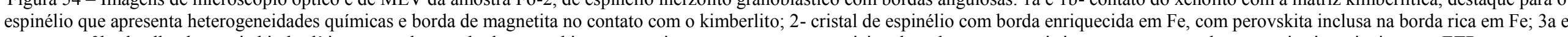
3b- detalhe da matriz kimberlítica com aglomerado de perovskita e magnetita com zonação composicional, onde as cores mais intensas correspondem aos cristais mais ricos em ETR. 

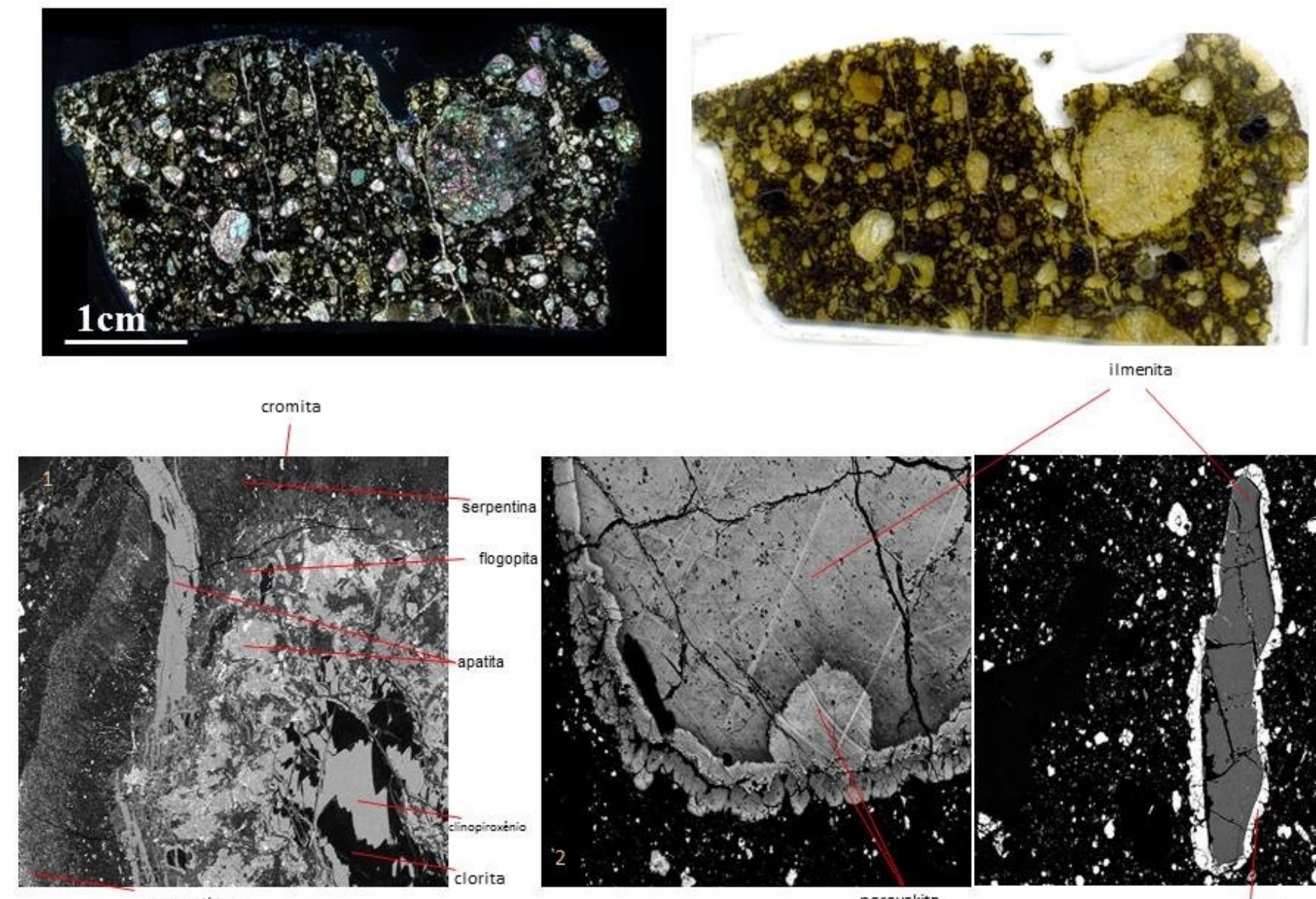

serpentina+

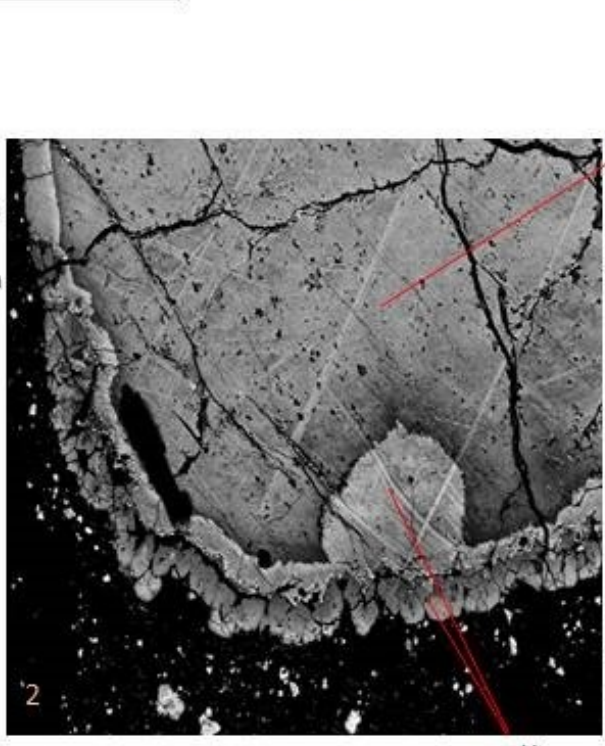

perovskita

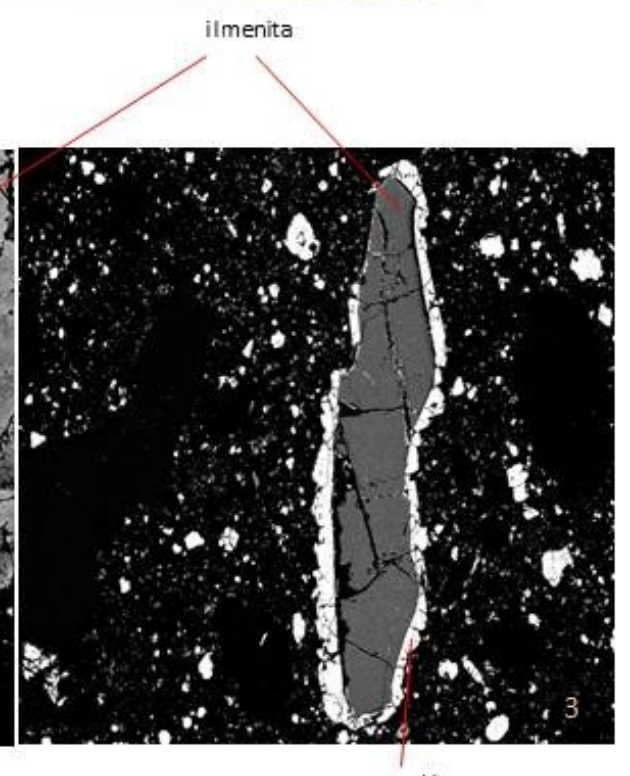

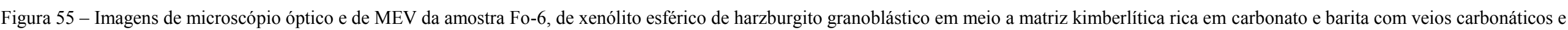

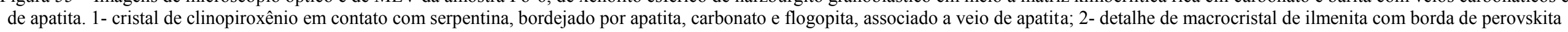
com composição heterogênea; 3 - cristal alongado de ilmenita bordejado por perovskita em meio a matriz kimberlítica. 

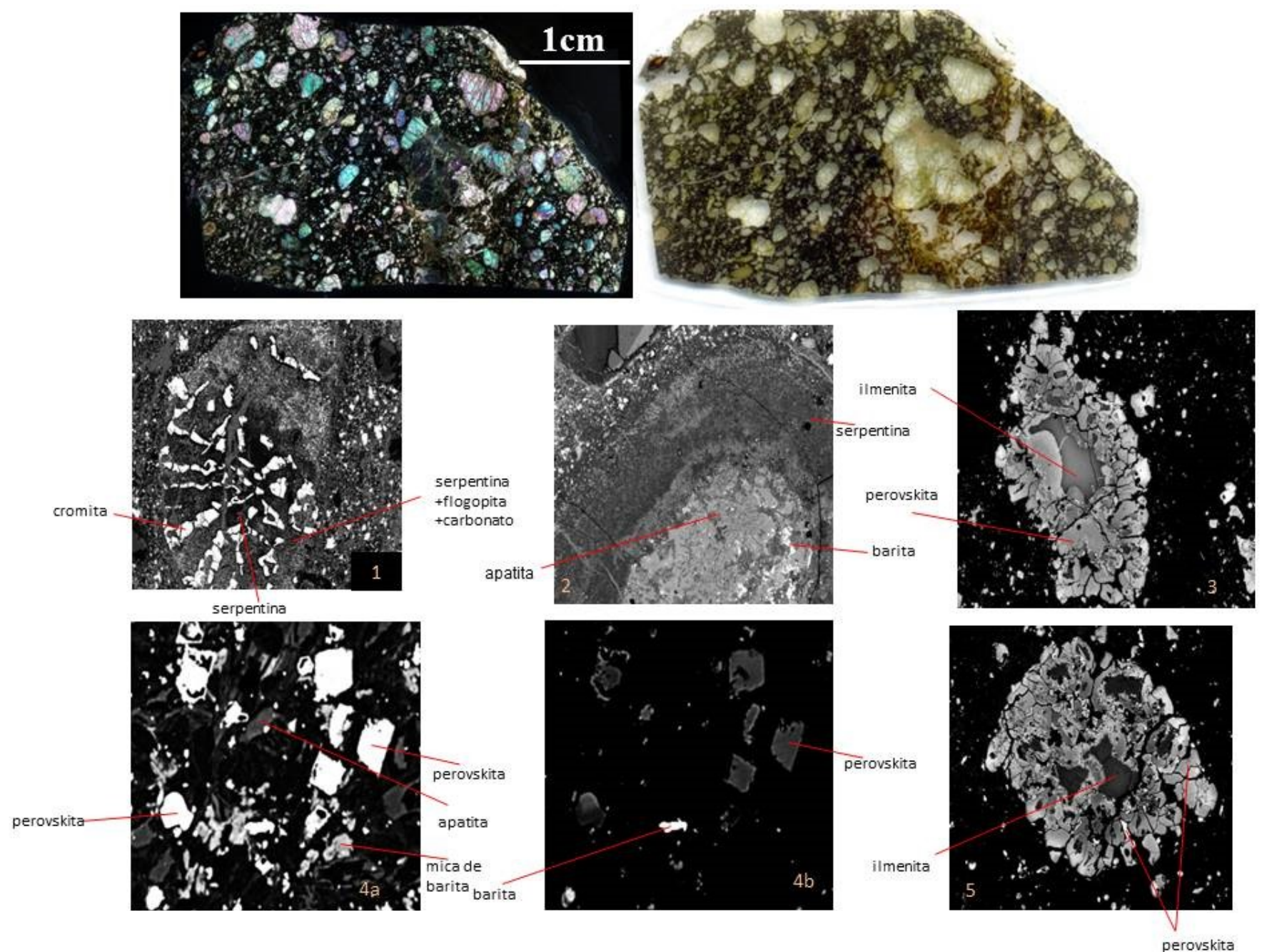

Figura 56 - Imagens de microscópio óptico e de MEV da amostra Fo-1, de lherzolito protogranular em contato com porção rica em carbonato, em meio a matriz kimberlítica. 1- estrutura de formato

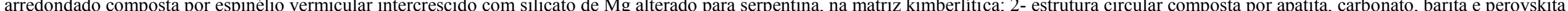

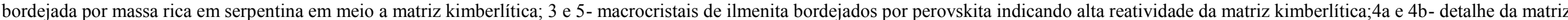
kimberlítica apresentando cristais idiomórficos de perovskita e apatita além de mica rica em Ba e barita em matriz carbonática. 


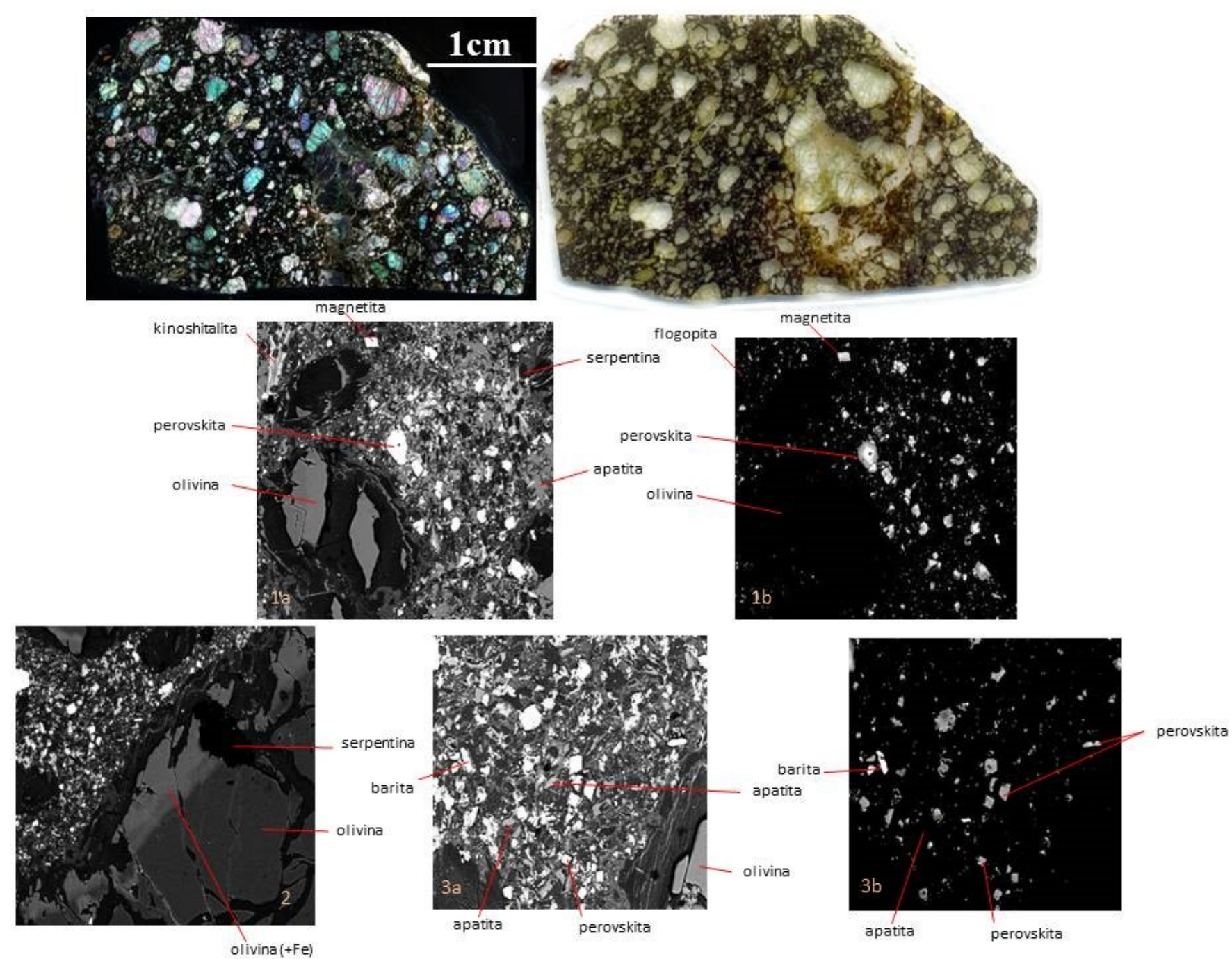

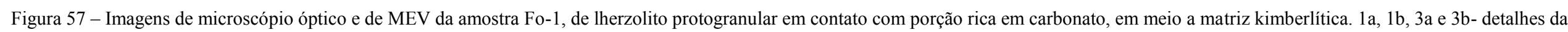
matriz kimberlítica com macrocristais de olivina com serpentina nas bordas e fraturas, perovskita zonada e magnetita idiomórficas, barita e flogopita rica em barita em material carbonático apatita e serpentina; 2- contato entre matriz e macrocristal de olivina. 

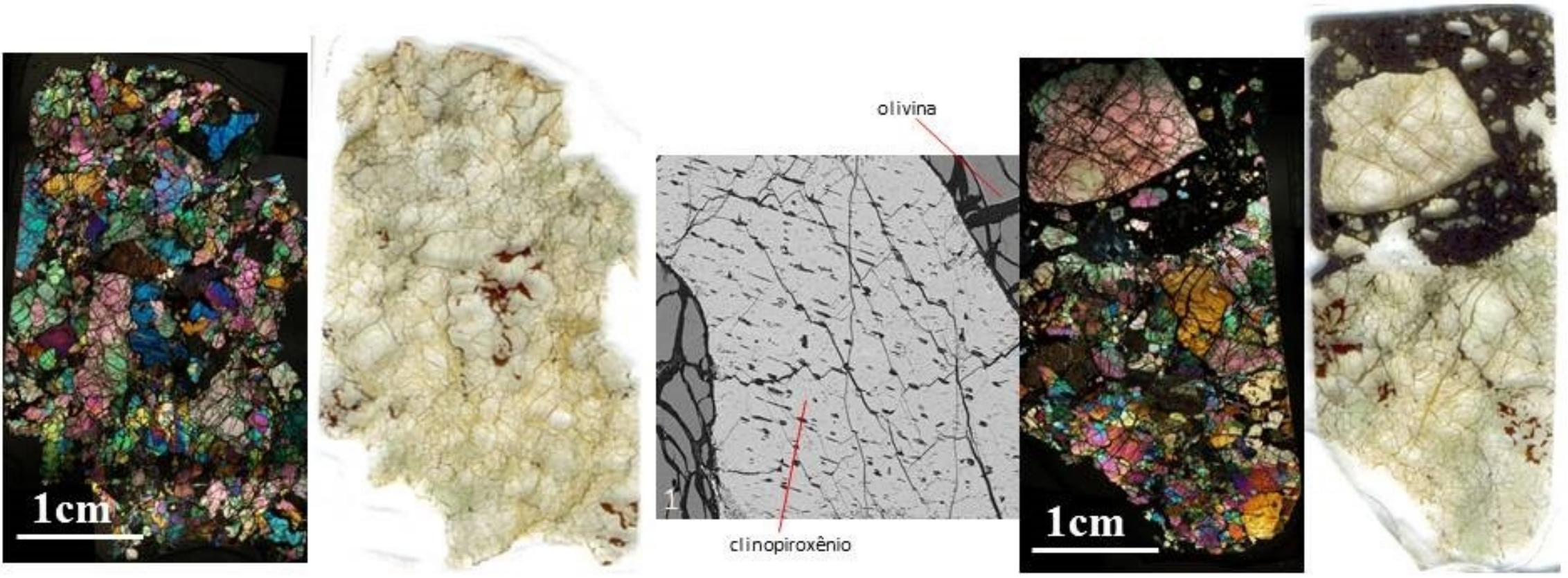

Figura 58 - Imagens de microscópio óptico e de MEV das amostras Lm1-17a, Lm1-17b e lm1-17b' respectivamente de harzburgito protogranular, lherzolito protogranular e megacristal de olivina. 1detalhe de espinélio com clivagem proeminente e composição homogênea. 

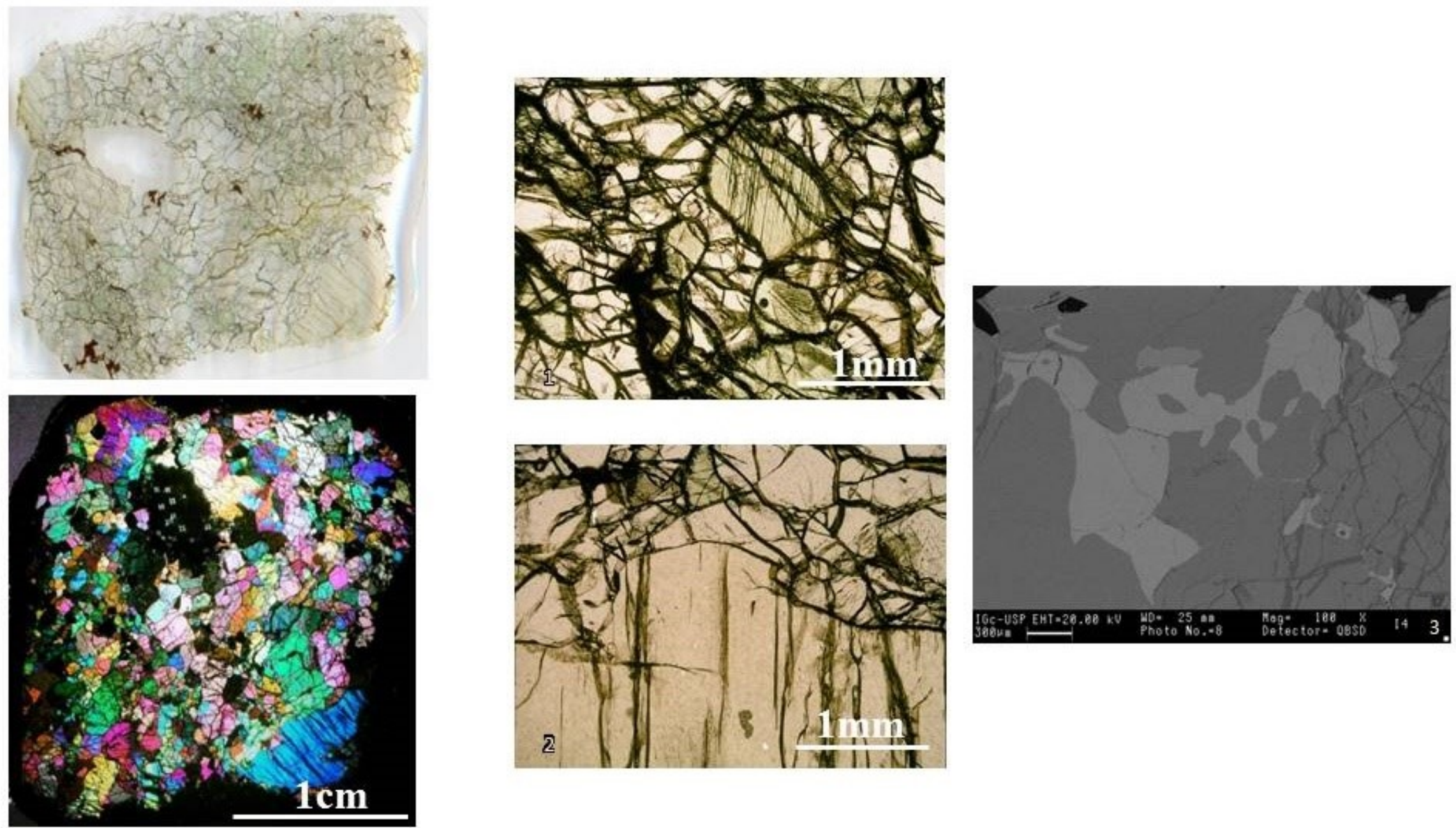

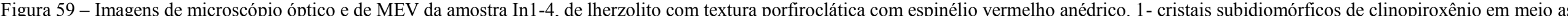
olivinas; 2- cristal de ortopiroxênio com contato irregular com olivina (acima);3-imagem de espinélio mostrando homogeneidade química em todos os minerais componentes do xenólito. 

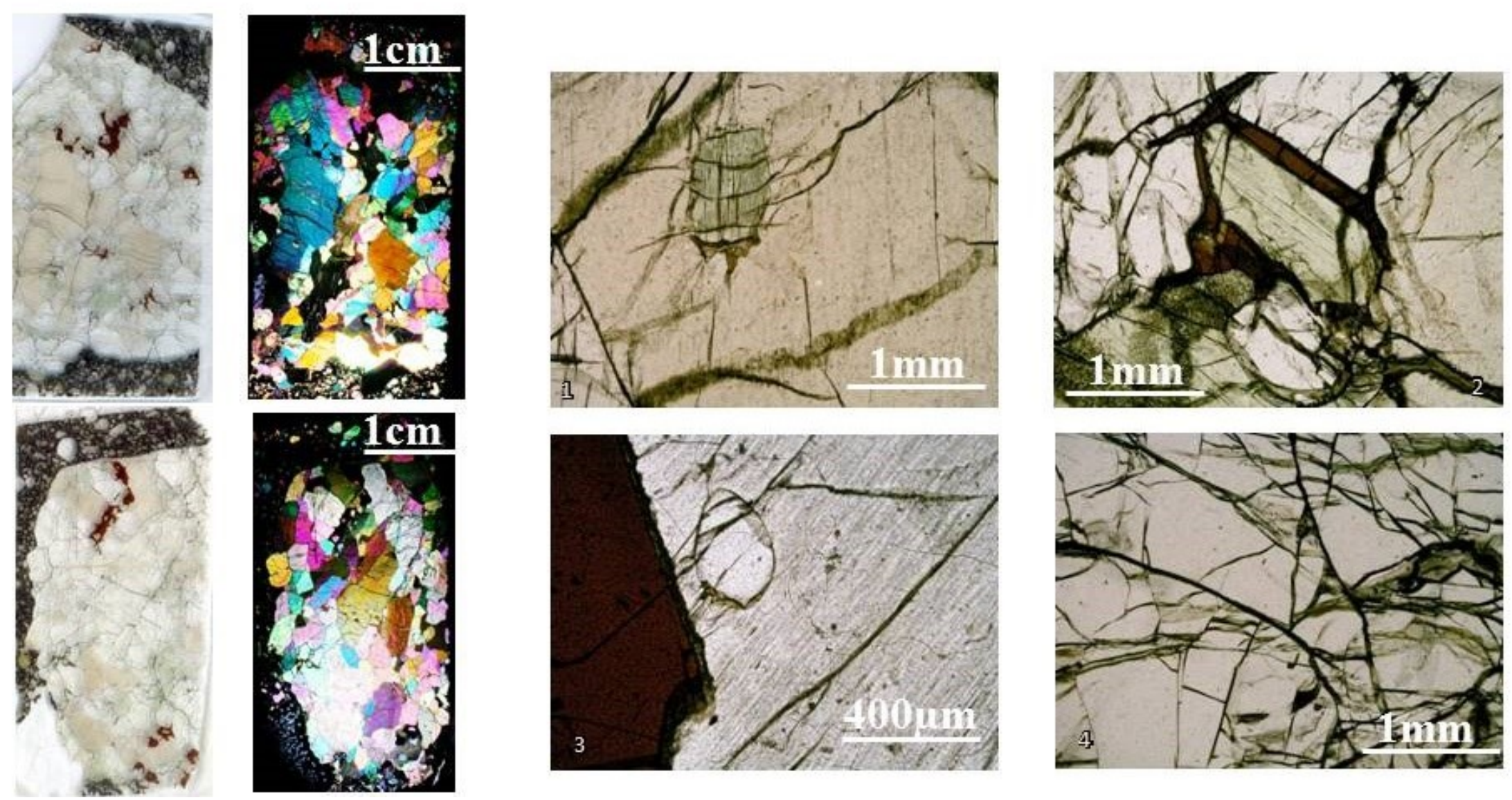

Figura 60 - Imagens de microscópio óptico e da amostra In1-9a e In1-9b, de respectivamente harzburgito e lherzolito, ambos com textura protogranular e com espinélio vermelho associado ao

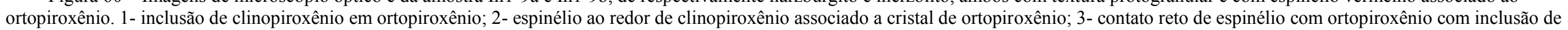
olivina; detalhe das fraturas de olivina, algumas são preenchidas por serpentina. 

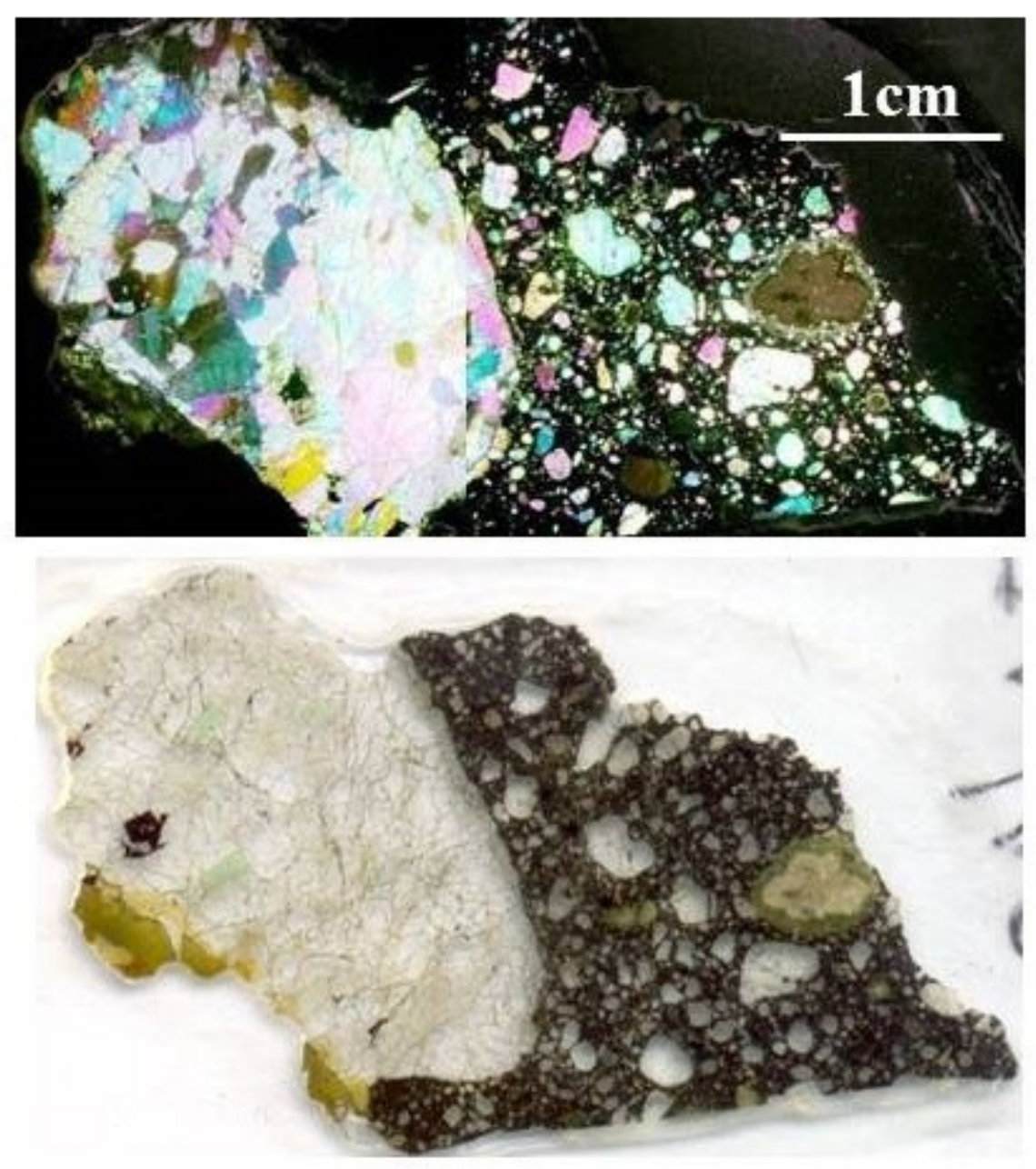

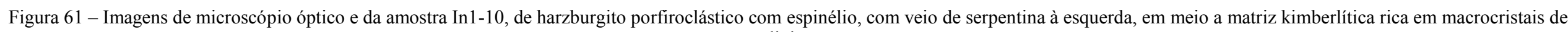
olivina. 


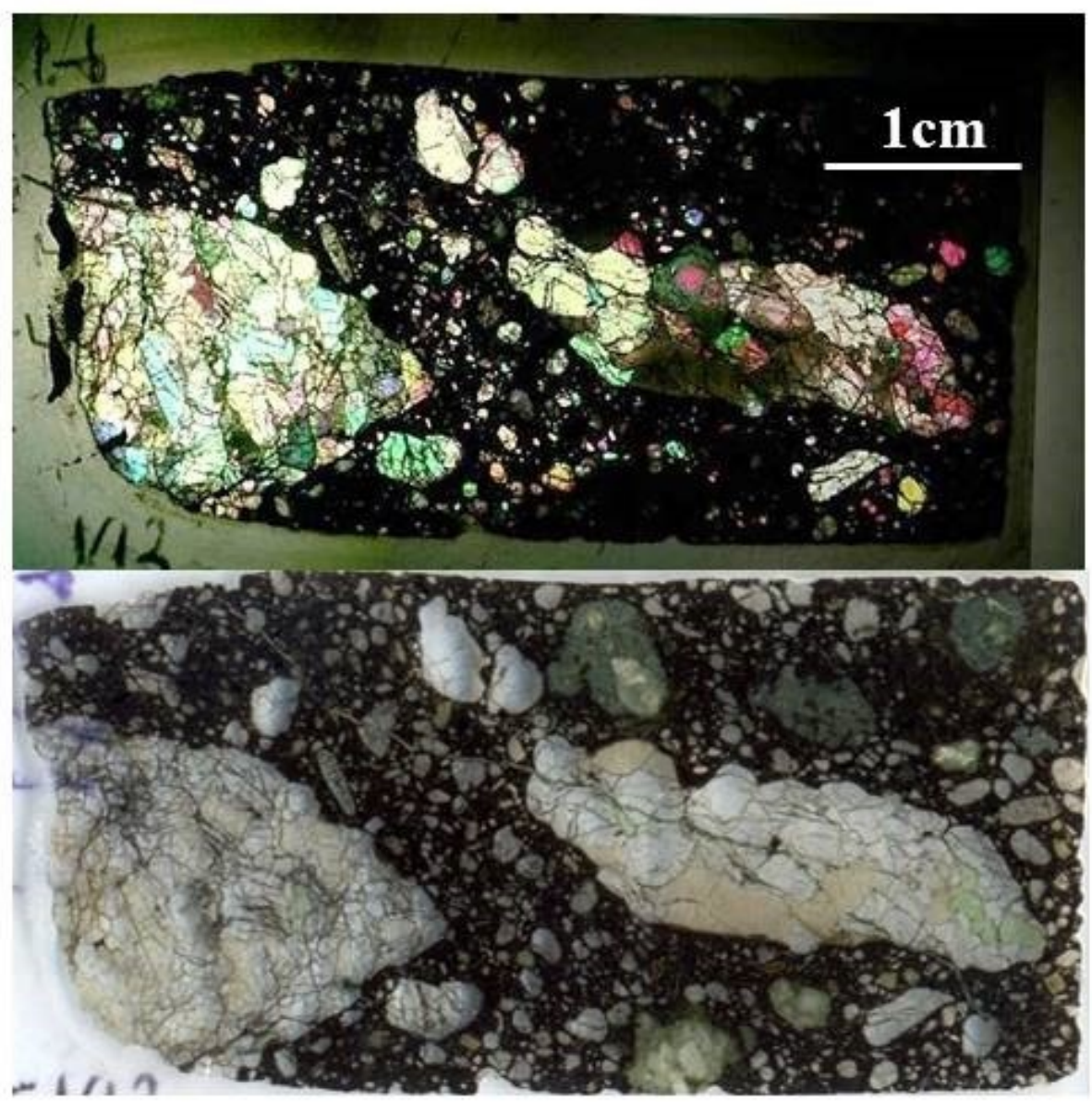

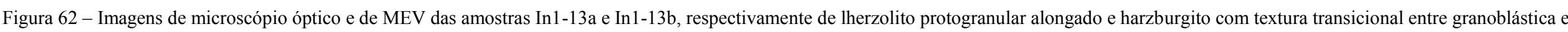
protogranular em meio a matriz kimberlítica. 

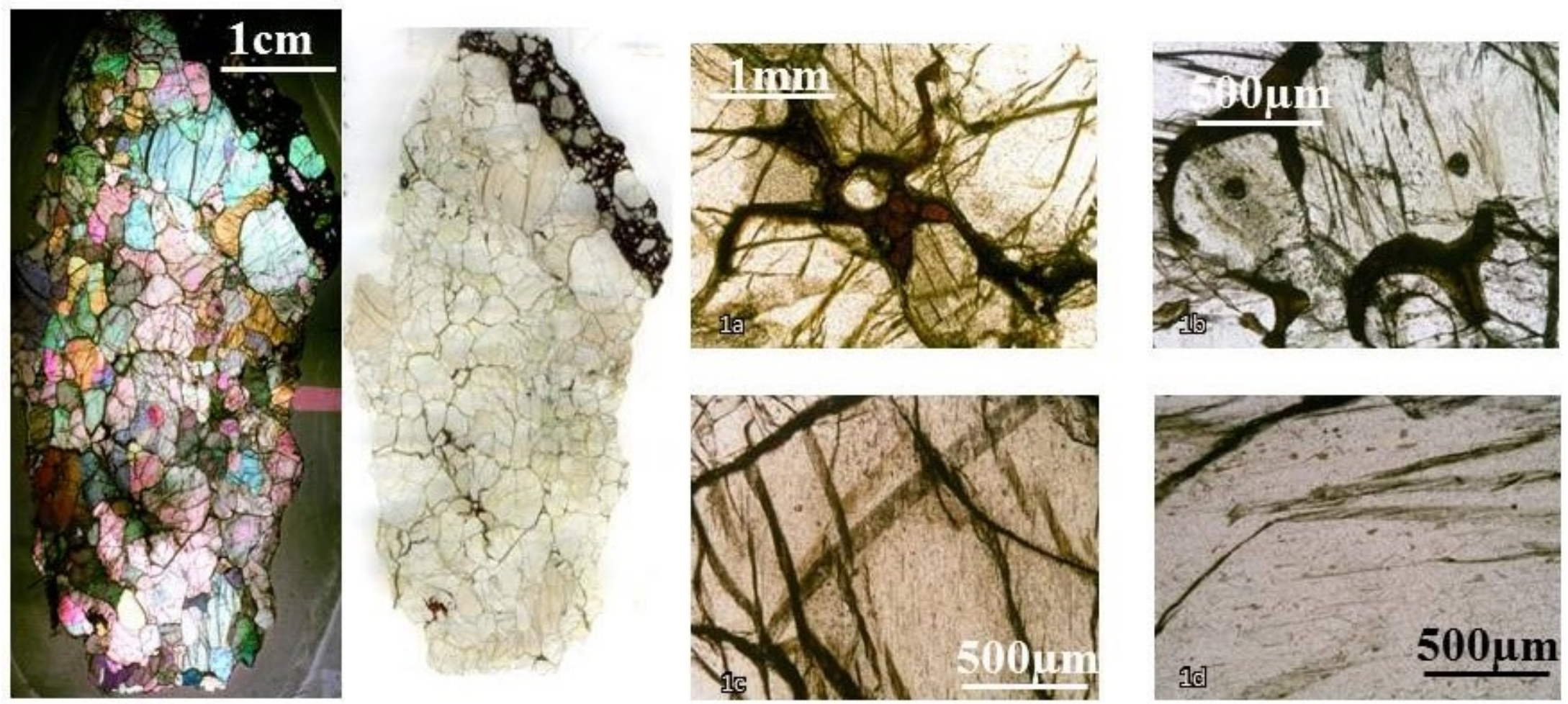

Figura 63 - Imagens de microscópio óptico da amostra In1-14a, de lherzolito com espinélio com textura transicional entre granoblástica e protogranular. 1- espinélio intersticial em meio a olivina e ortopiroxênio; 2- clinopiroxênio com clivagem proeminente com espinélio em suas bordas; 3 e 4- detalhe de cristais de ortopiroxênio com clivagem bem marcada e inclusões de finas placas de espinélio paralelas e obliquas a clivagem principal. 

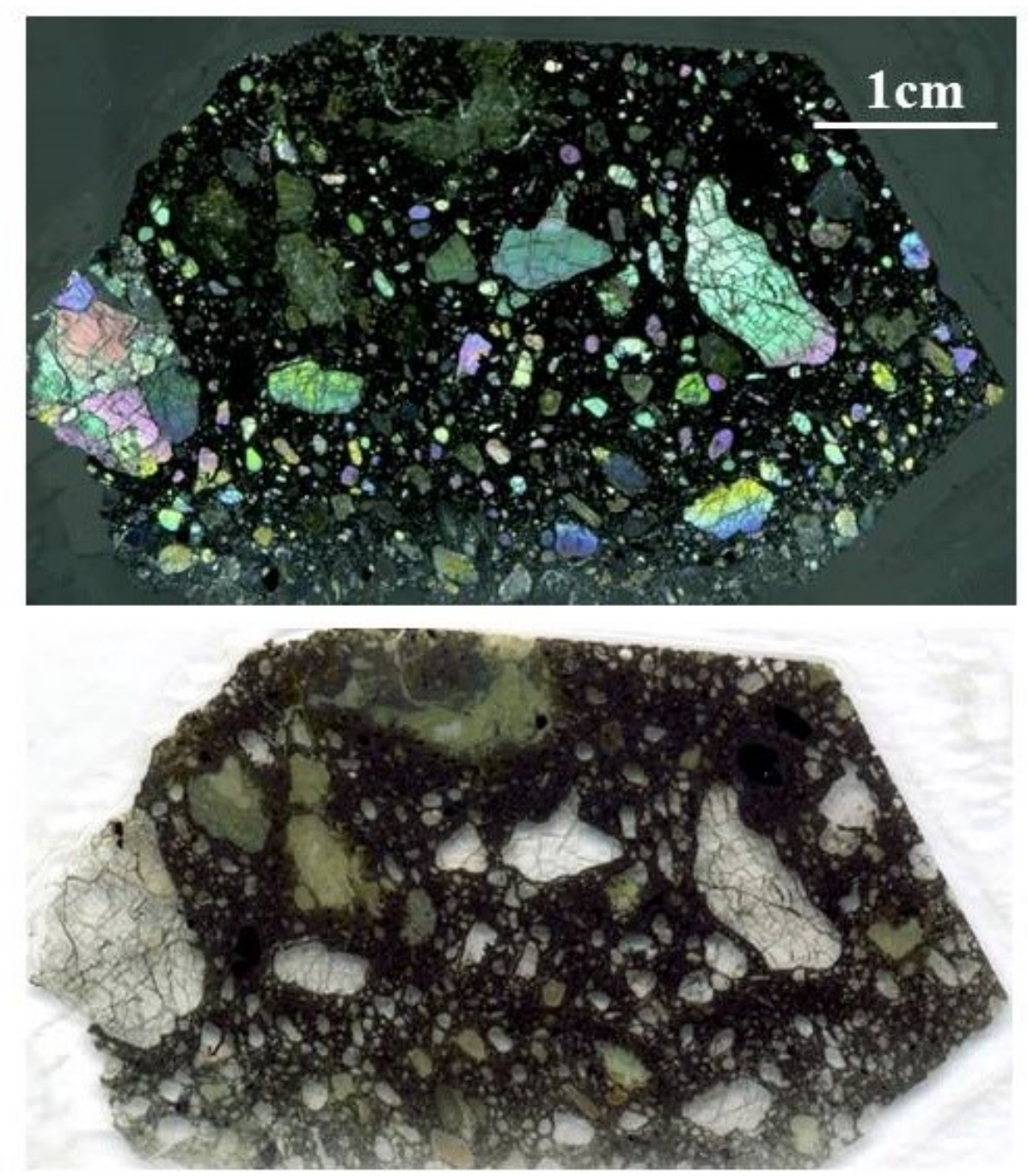

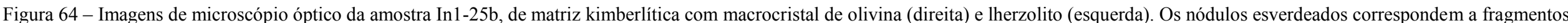
cloritizados de material crustal. 

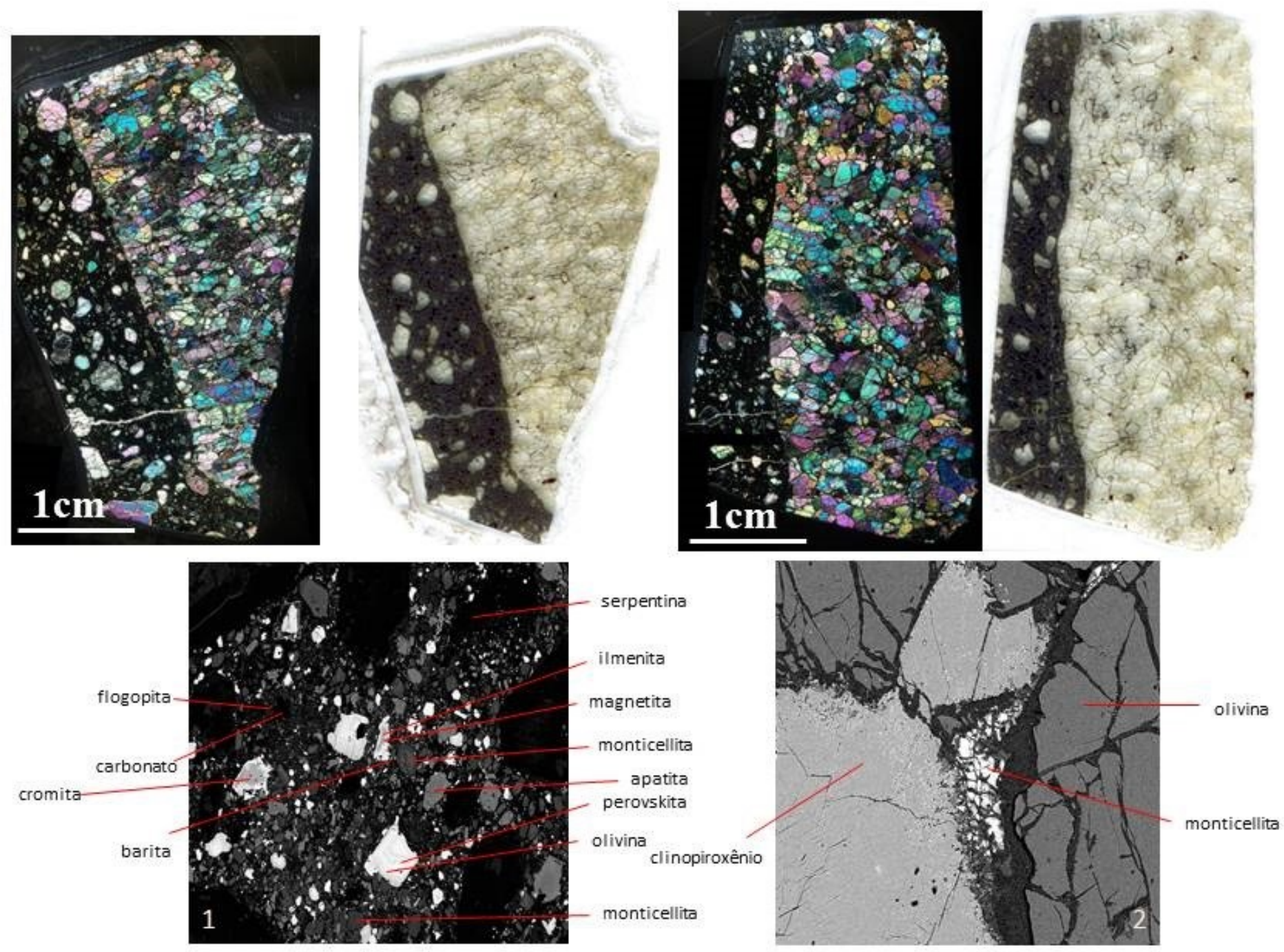

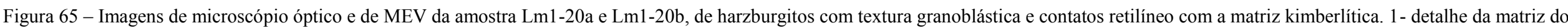
kimberlito composta por carbonato, monticellita, apatita, magnetita, flogopita, perovskita idiomórfica e barita; 2 - detalhe de monticellita intersticial entre olivina e clinopiroxênio. 


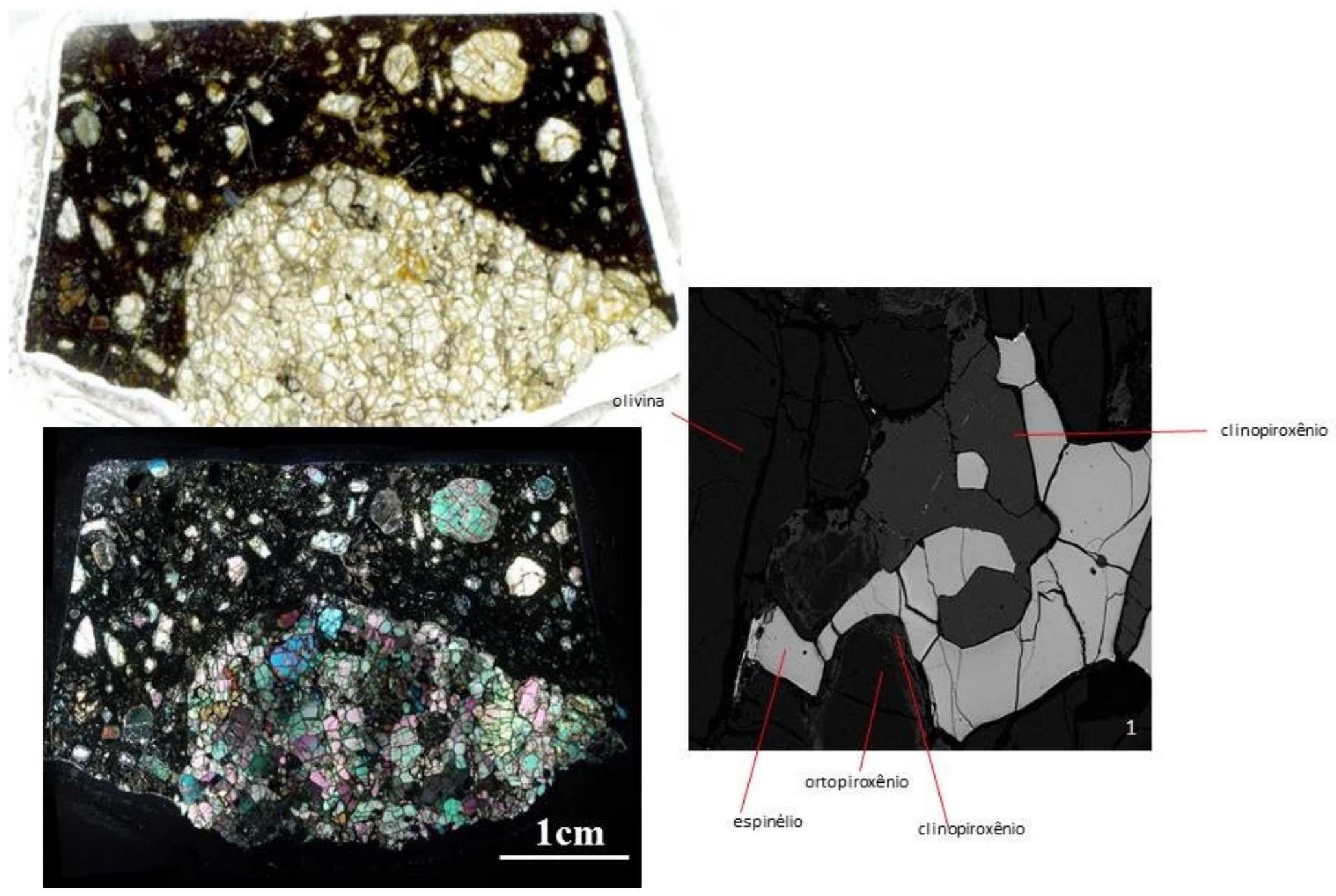

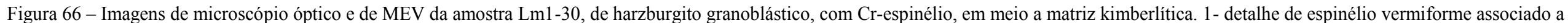
clinopiroxênio e ortopiroxênio com borda de clinopiroxênio. 

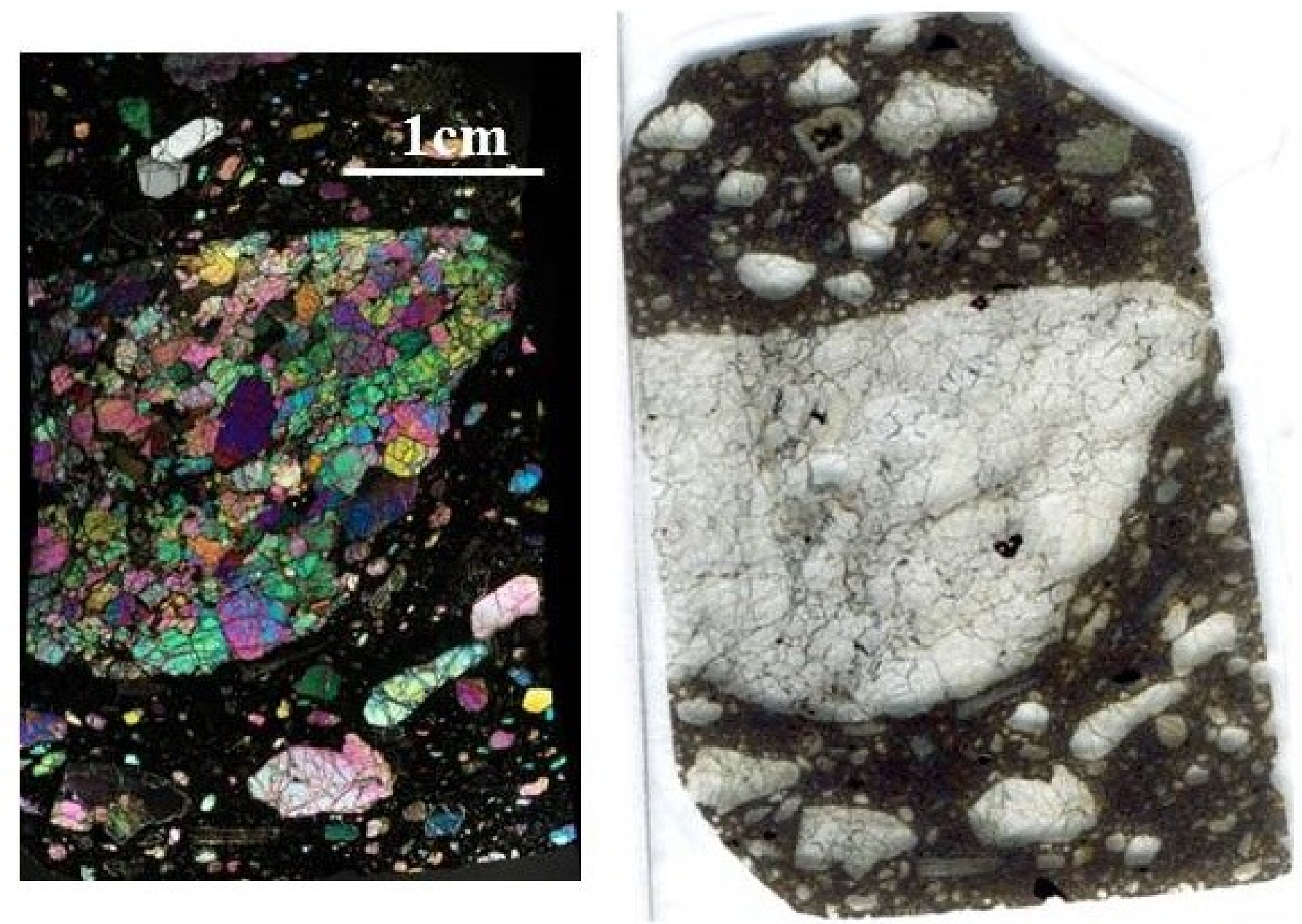

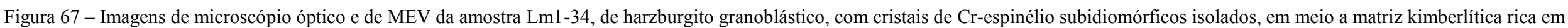
macrocristais de olivina e ilmenita. 

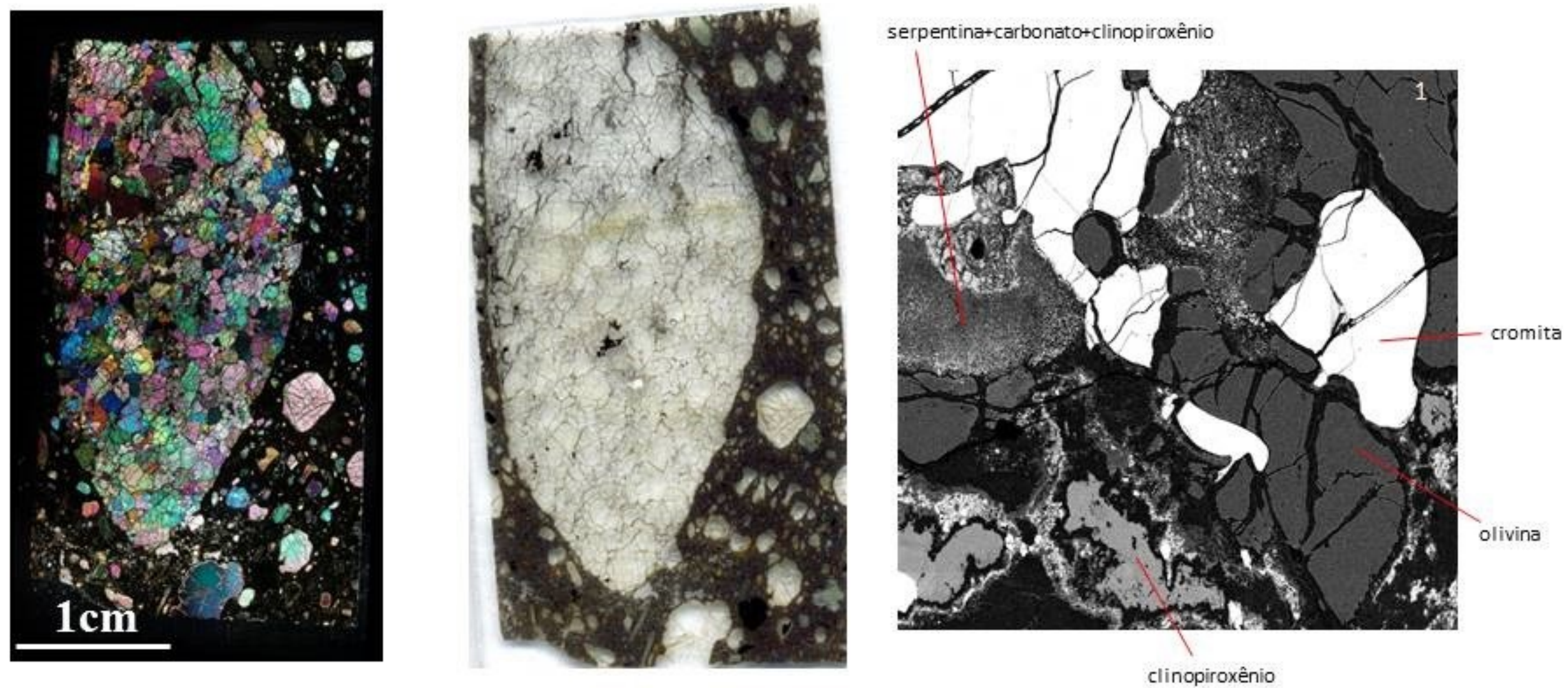

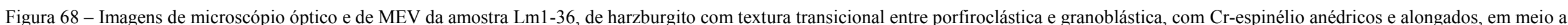
matriz kimberlítica. 1 - cromita anédrica associada a olivina e clinopiroxênio em textura afetada por corrosão gerando uma massa composta por serpentina e carbonato. 

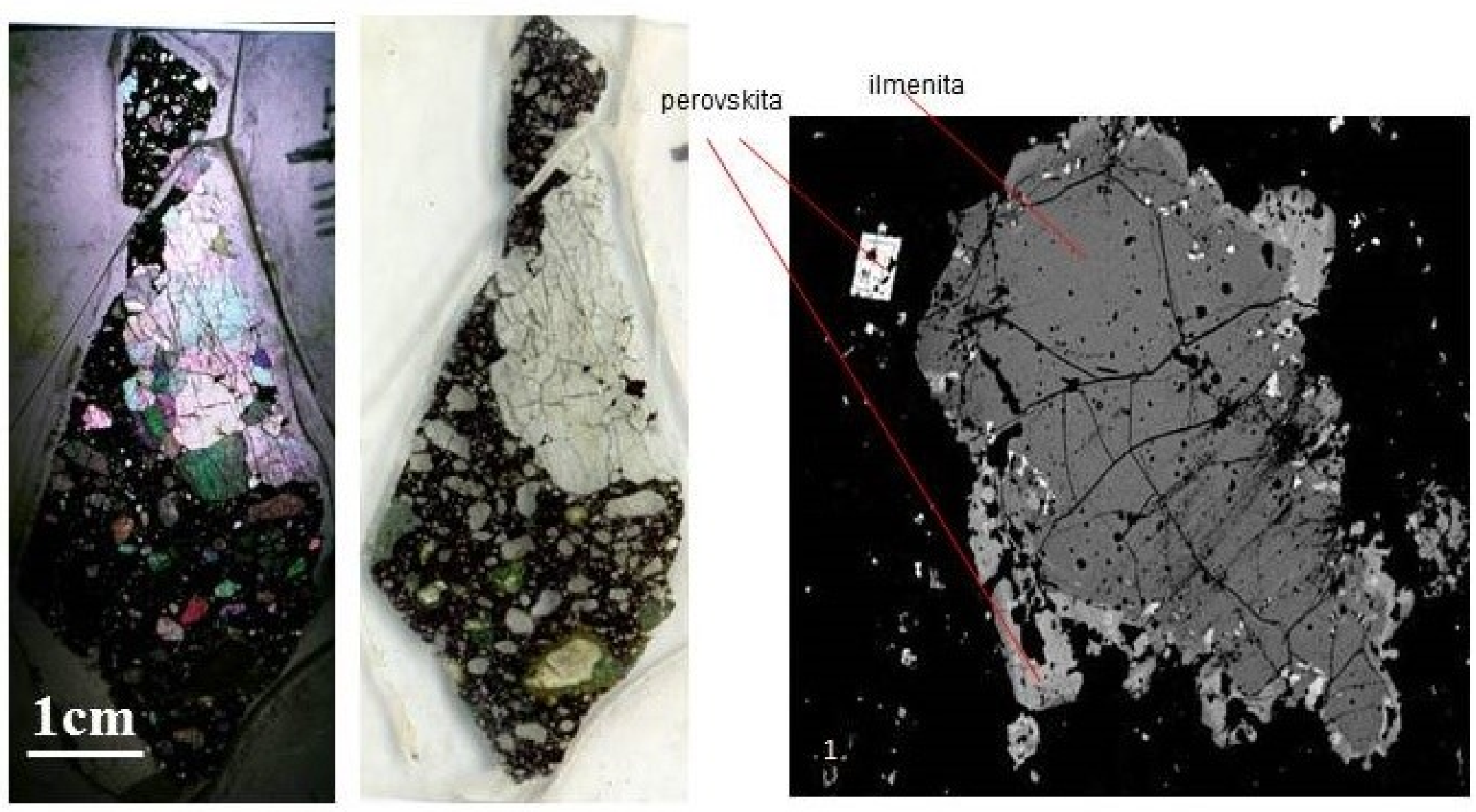

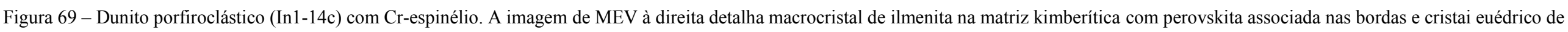
pervskita isolado. Este cristal tem maior densidade devido à maior concentração em ETR 

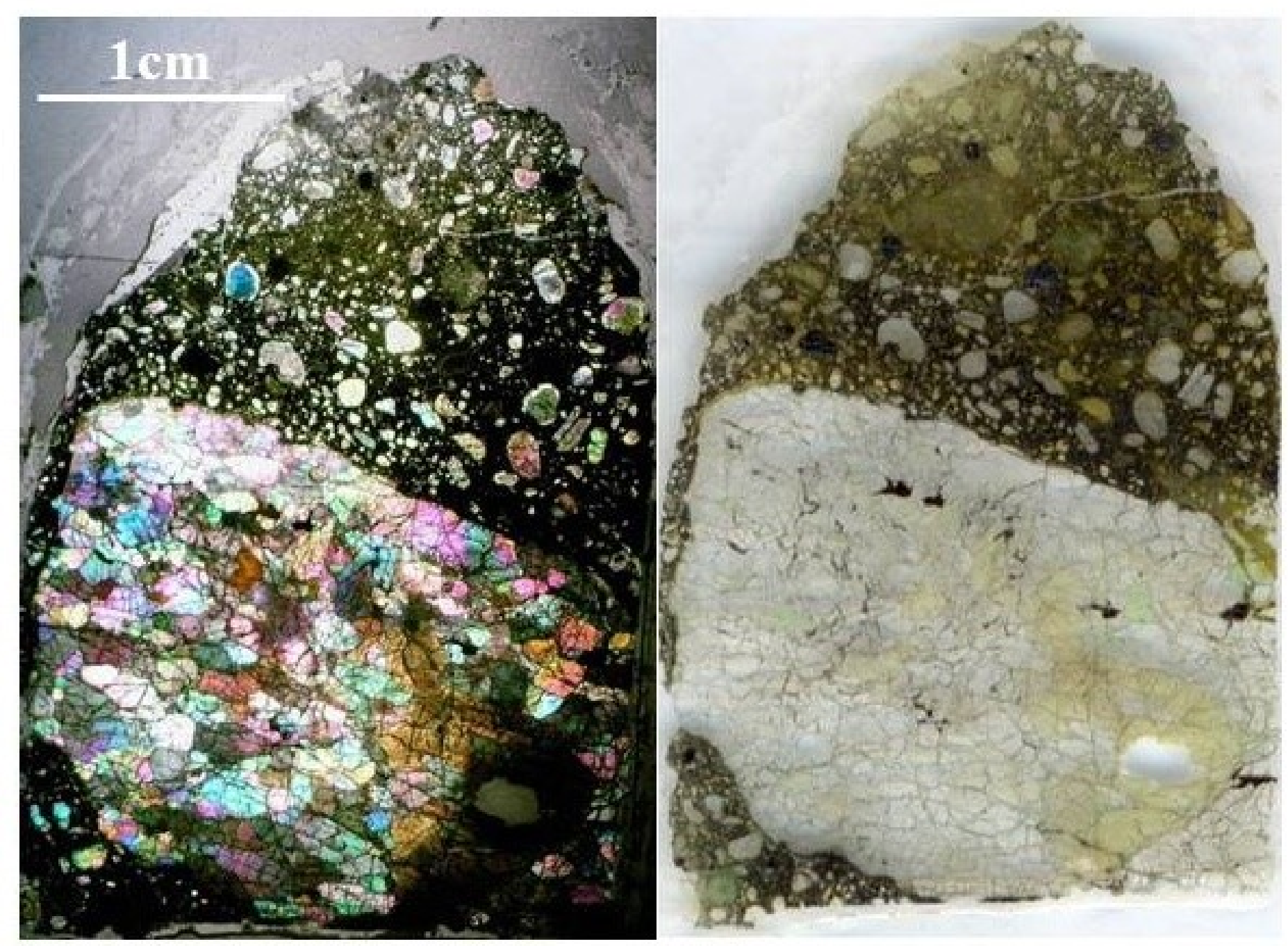

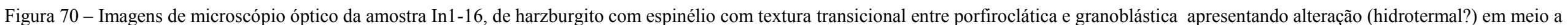
matriz kimberlítica alterada. 

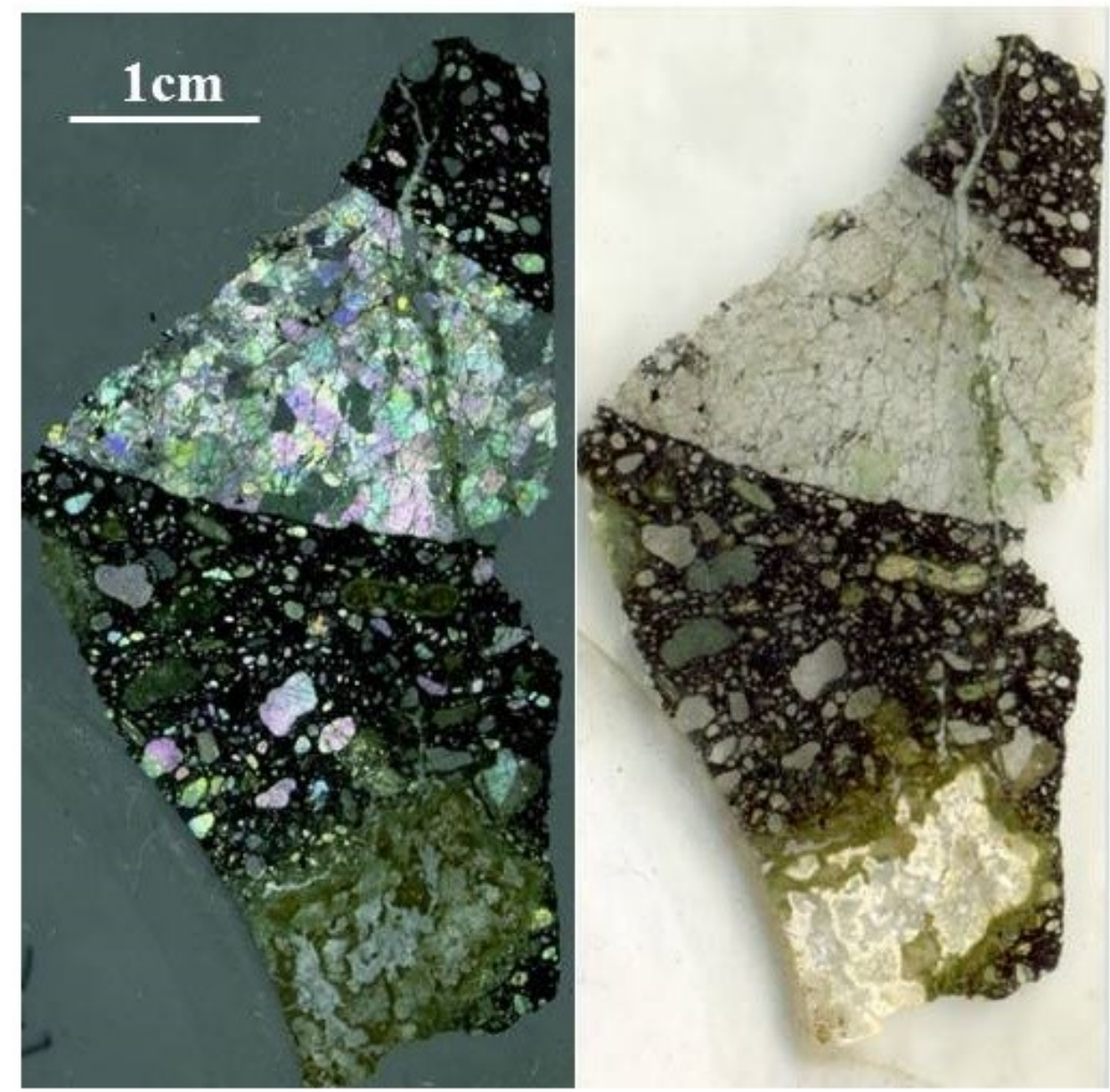

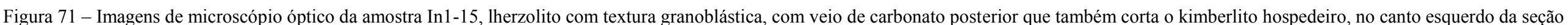
ocorre xenólito granítico muito alterado. 

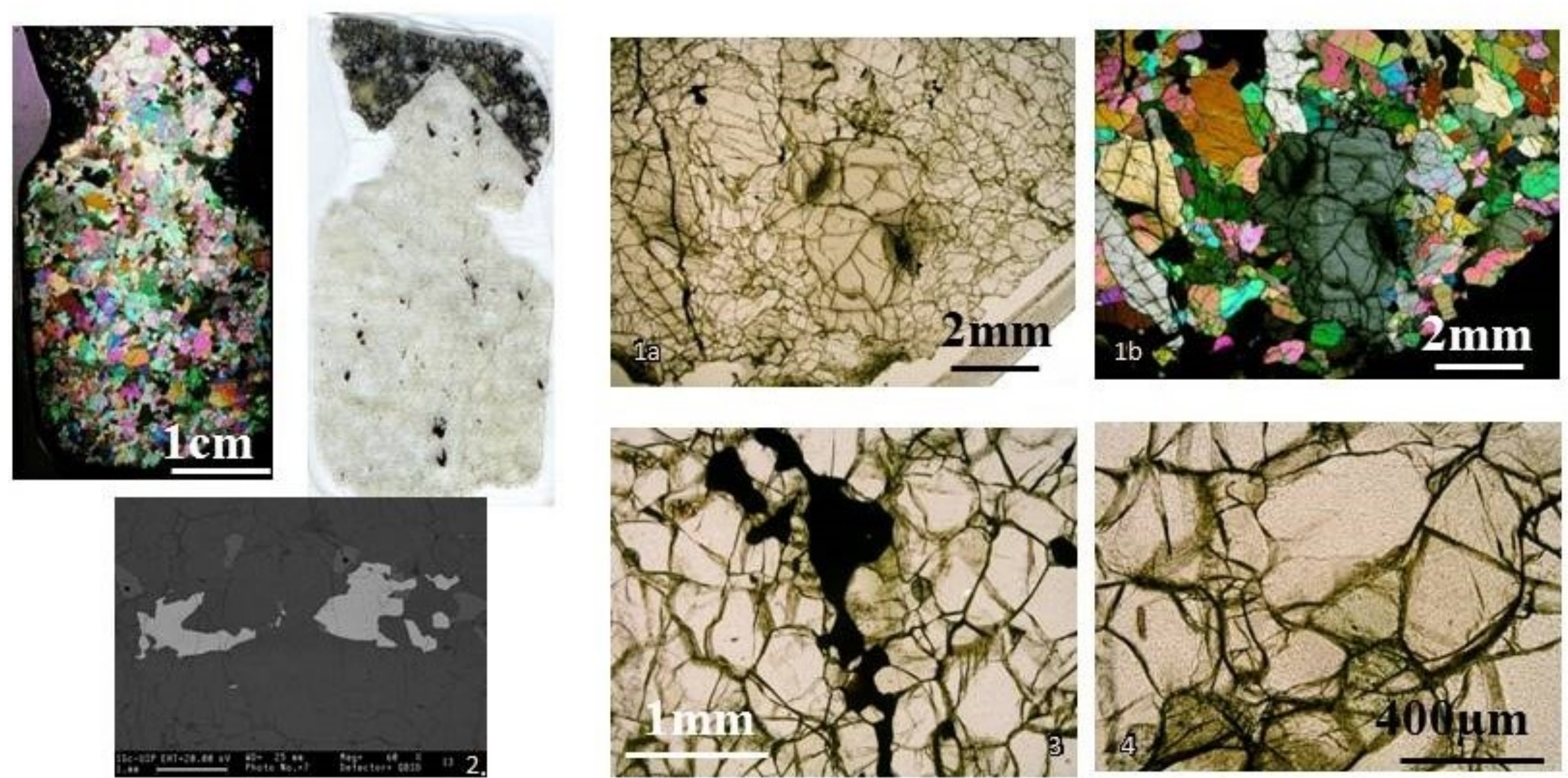

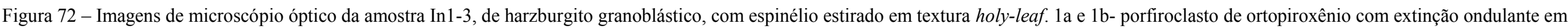

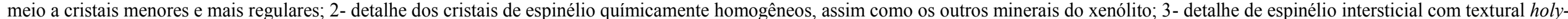
leaf, estirado; 4- cristais de clinopiroxênio em equilíbrio textural com olivina. 

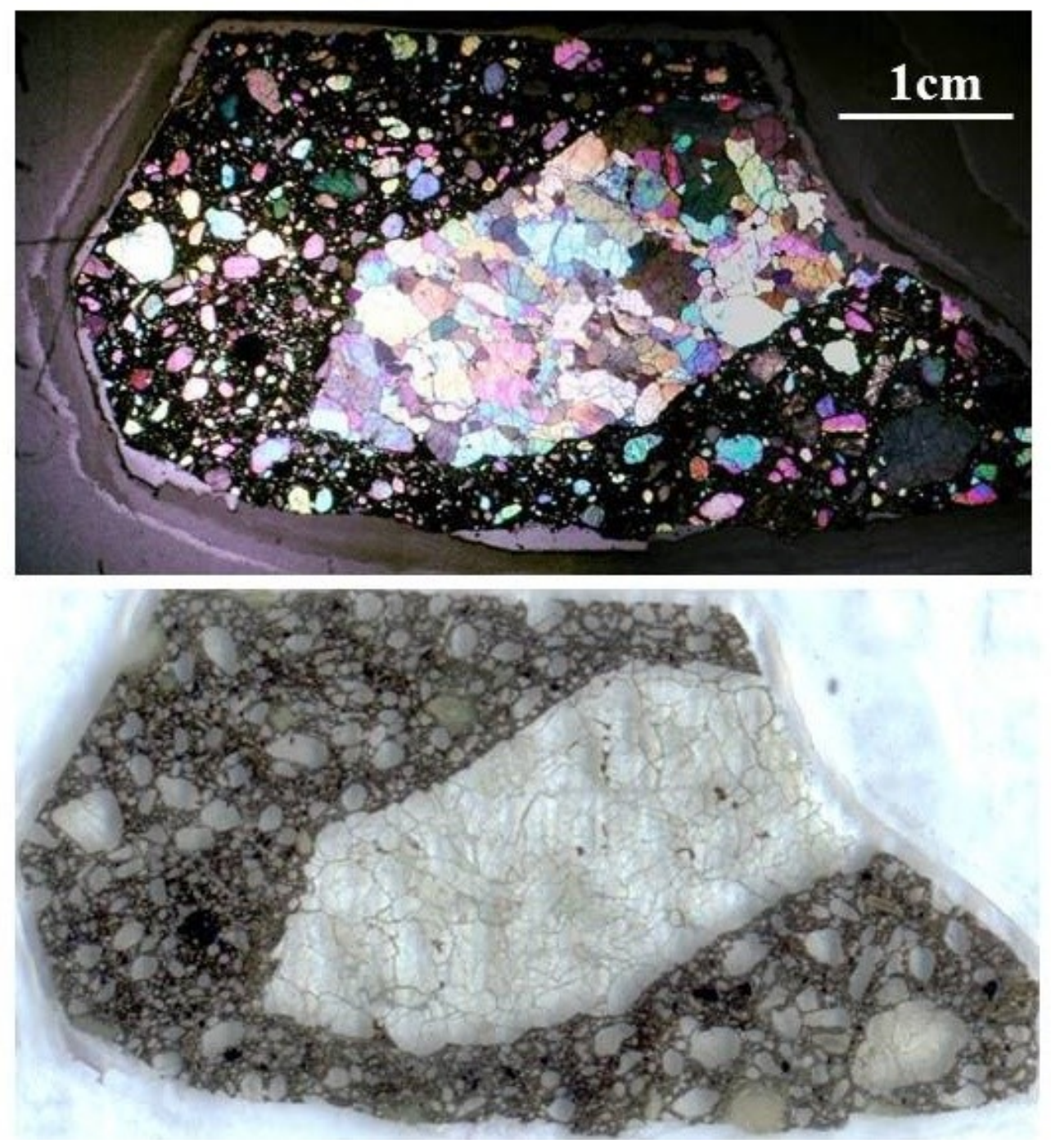

Figura 73 - Imagens de microscópio óptico e de MEV da amostra In1-20c, de harzburgito com textura granoblástica em meio a matriz rica em macrocristais de olivina e ilmenita arredondados. 

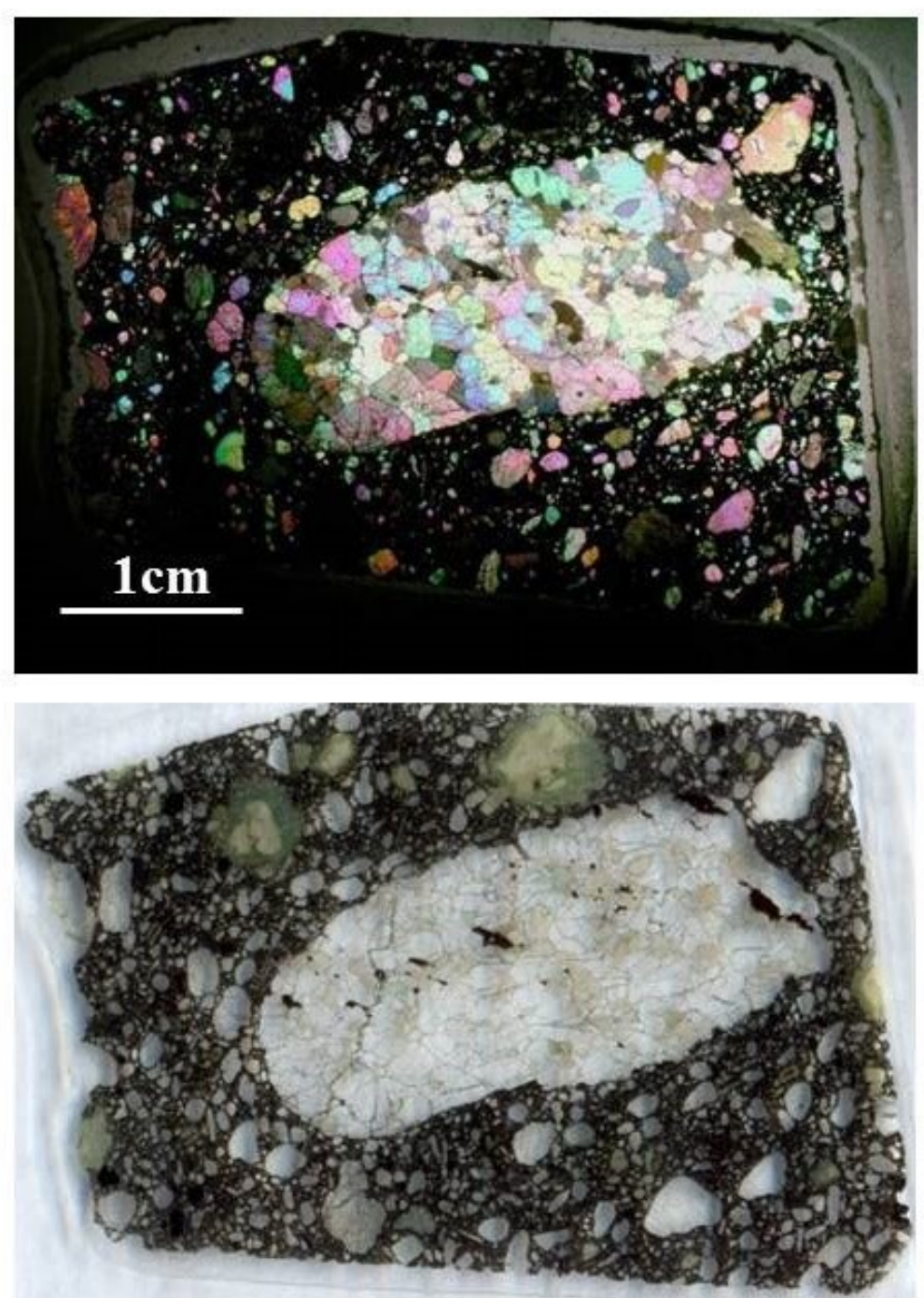

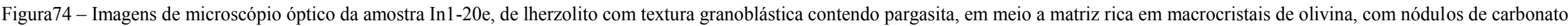
com borda verde de alteração. 

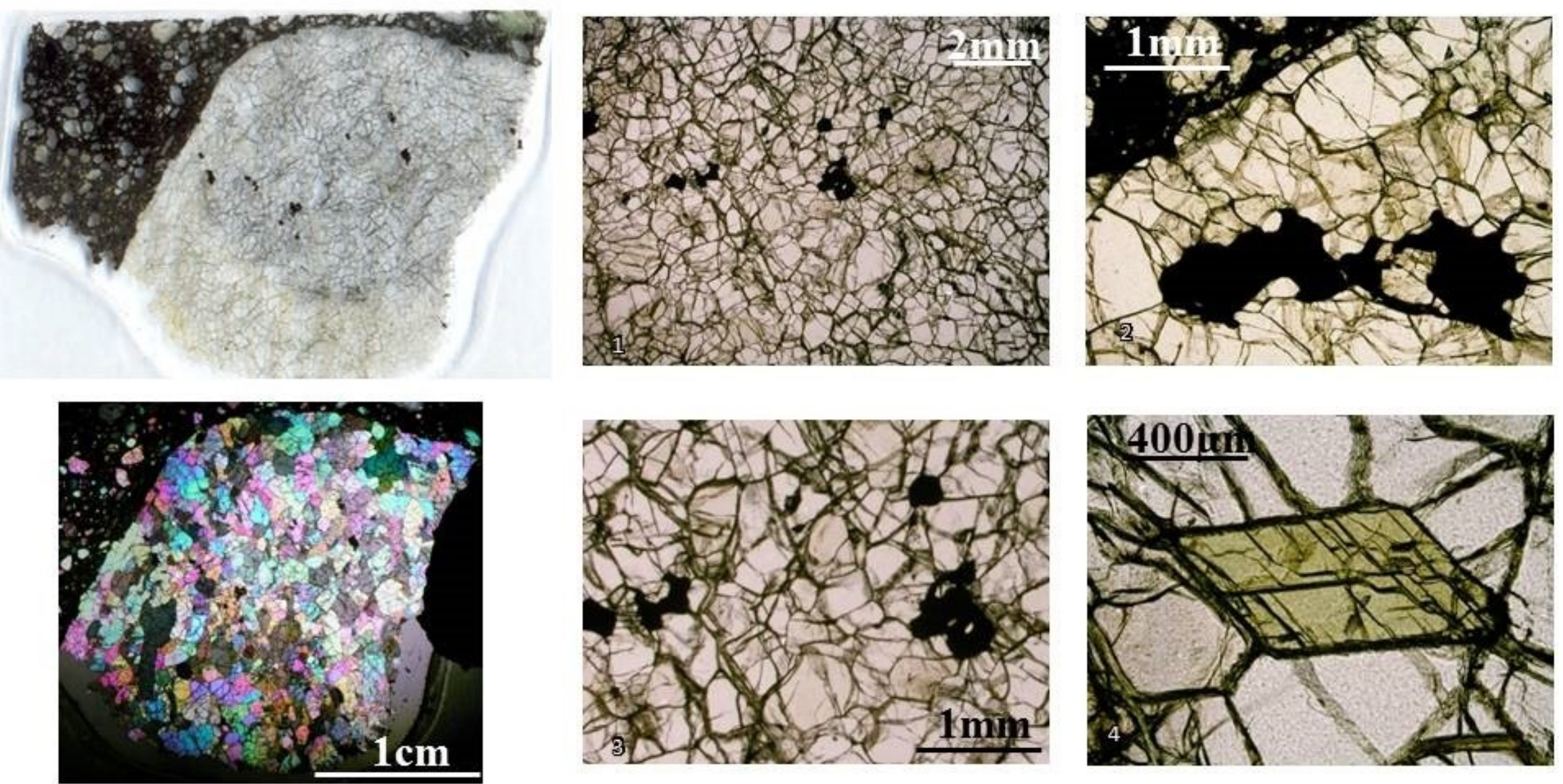

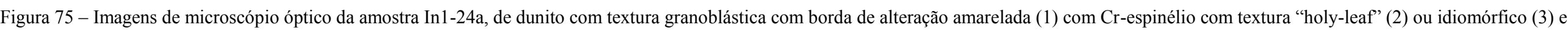
pargasita idiomórfica entre cristais de olivina em equilíbrio textural. 

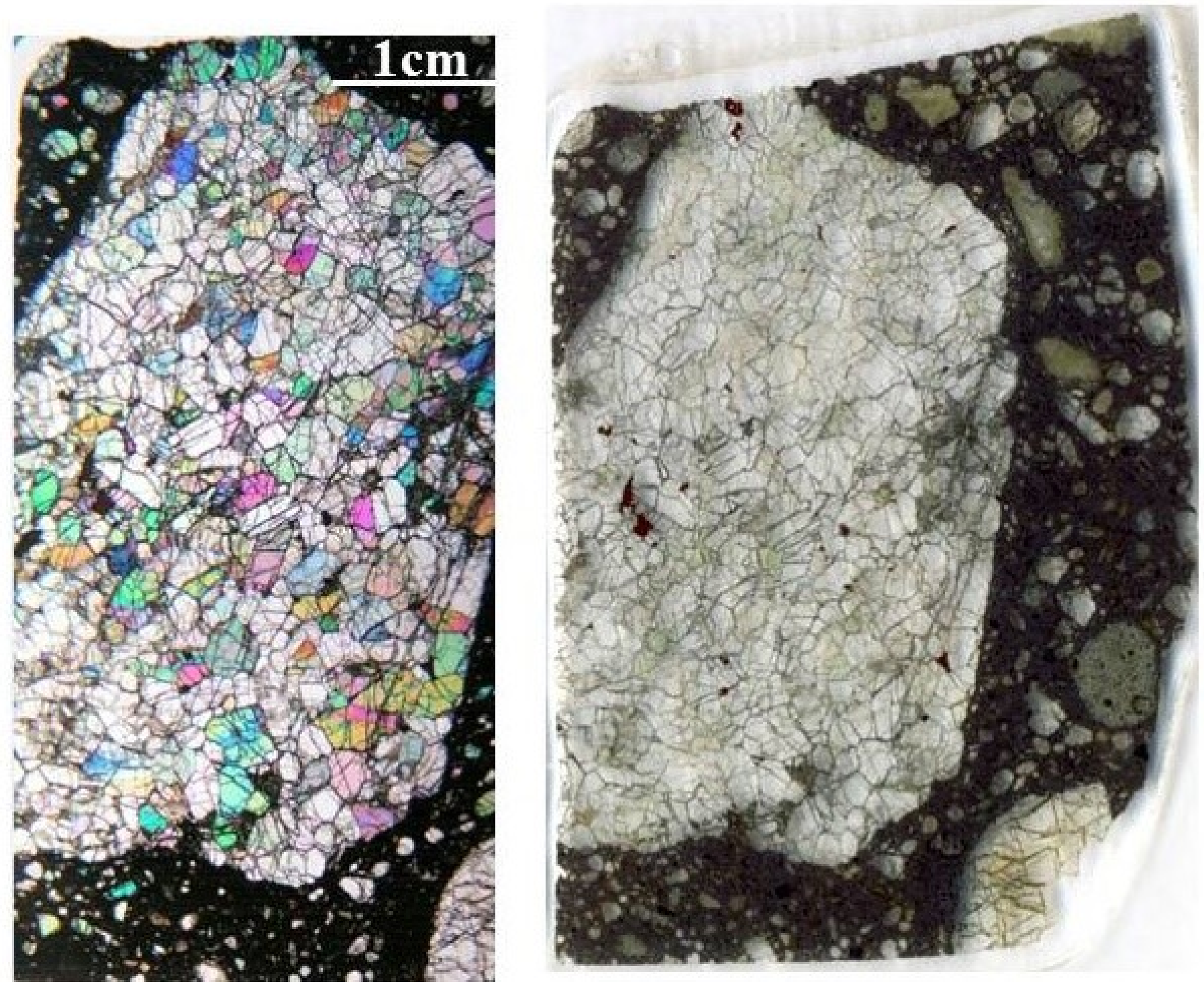

Figura 76 - Imagens de microscópio óptico da amostra In1-34, de harzburgito com textura granoblástica contendo pargasita. 

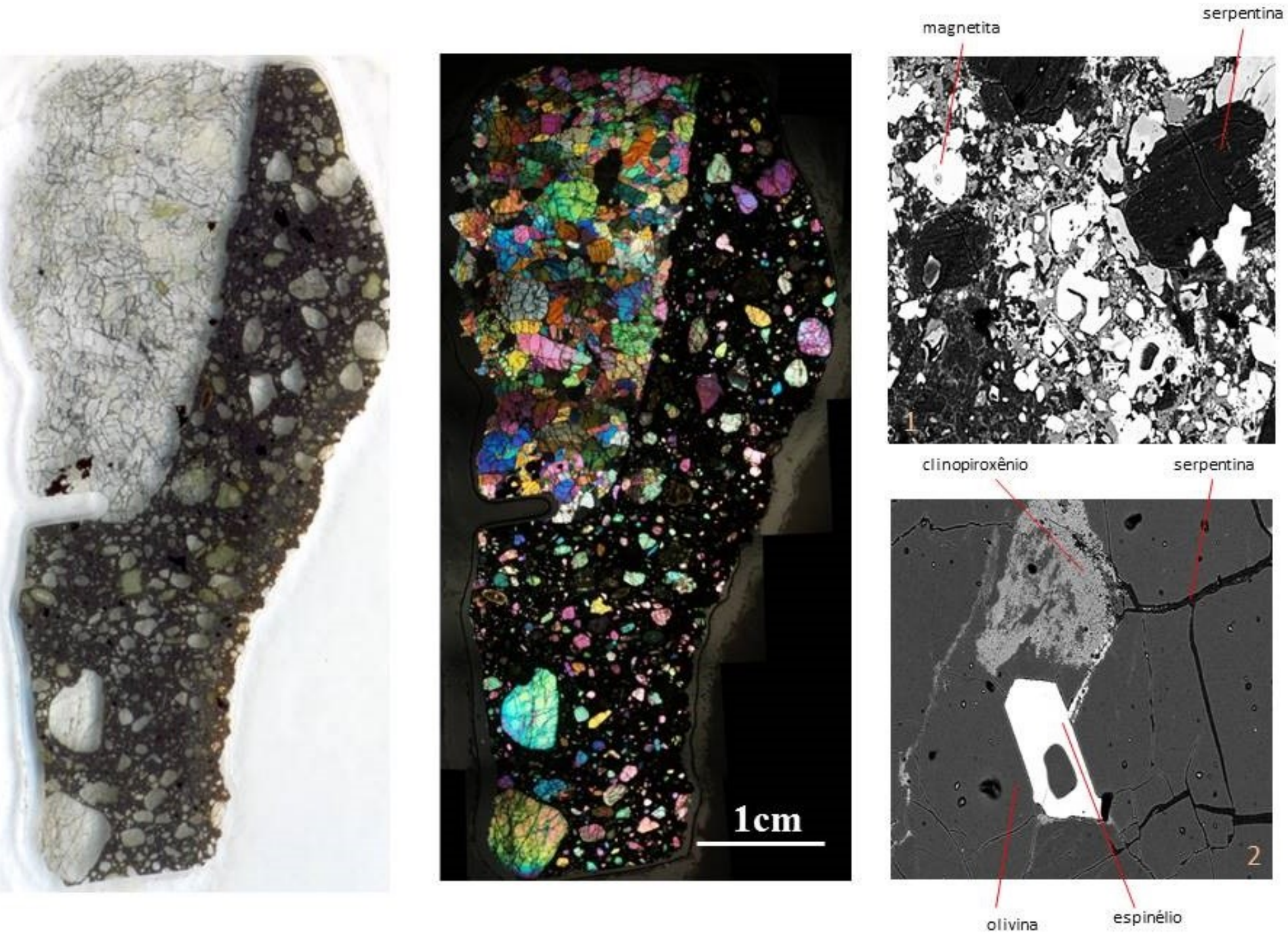

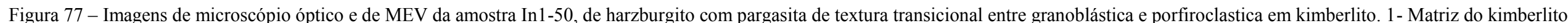
composta por magnetita idiomórfica, carbonato e pseudomorfos de olivina; 2- Cr-espinélio idiomórfico com inclusão de olivina clinopiroxênio substituindo olivina. 

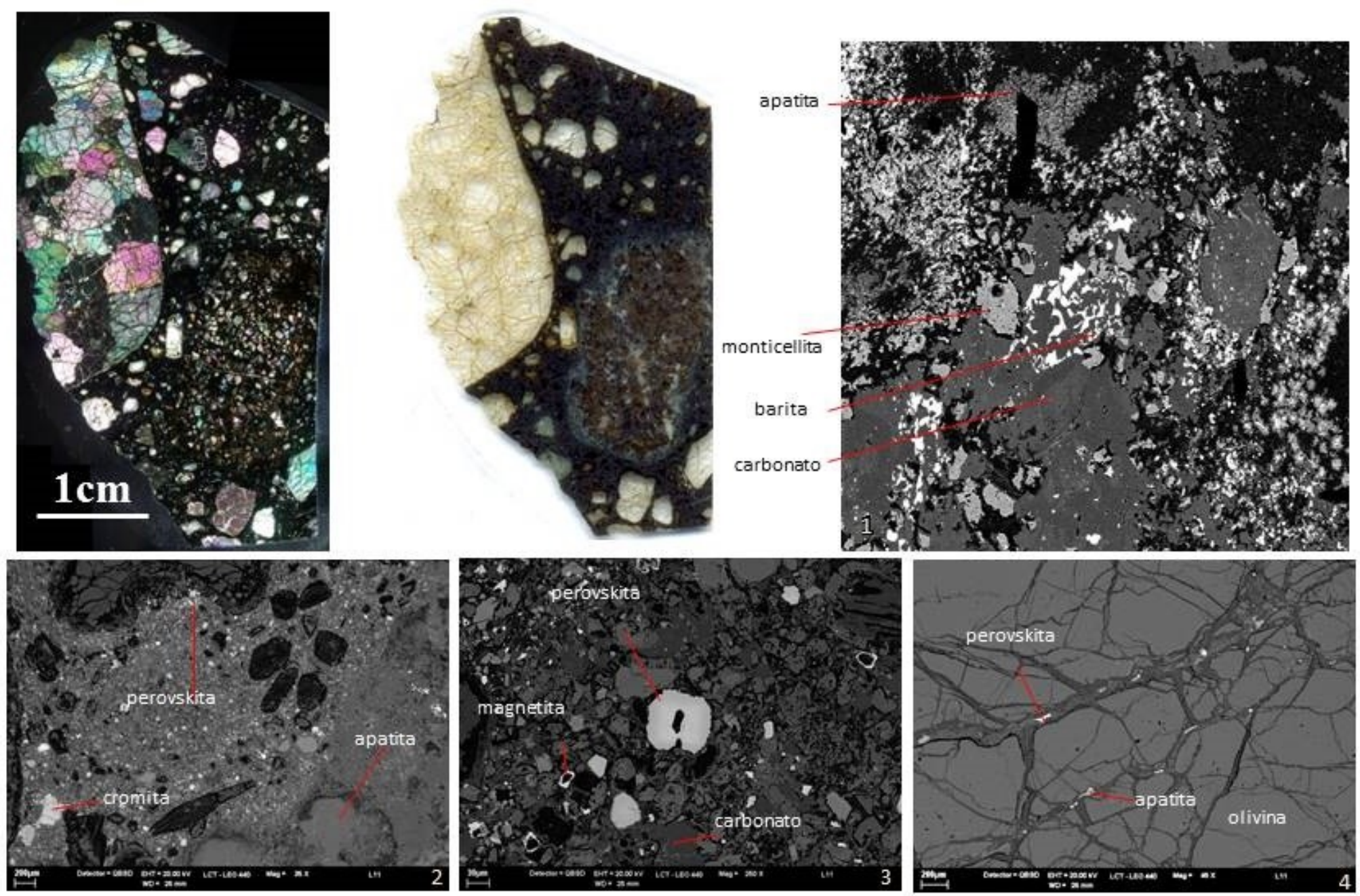

Figura 78 - Imagens de microscópio óptico e de MEV da amostra Lm1-14a e Lm1-14b, de dunito e de piroxenito alterado em meio a matriz kimberlítica. 1- porção da matriz enriquecida em carbonatos, com presenca de barita, monticellita e apatita; 2- matriz de kimberlito exibindo cristais idiomórficos arredondados de olivina em massa composta por carbonato, apatita, serpentina, cromita e perovskita; 3 detalhe da matriz exibindo massa carbonática com apatita, monticellita, perovskita com inclusão de olivina e magnetita em atol; 4- fraturas em dunito com presença de serpentina, ilmenita, apatita, cromita e perovskita. 

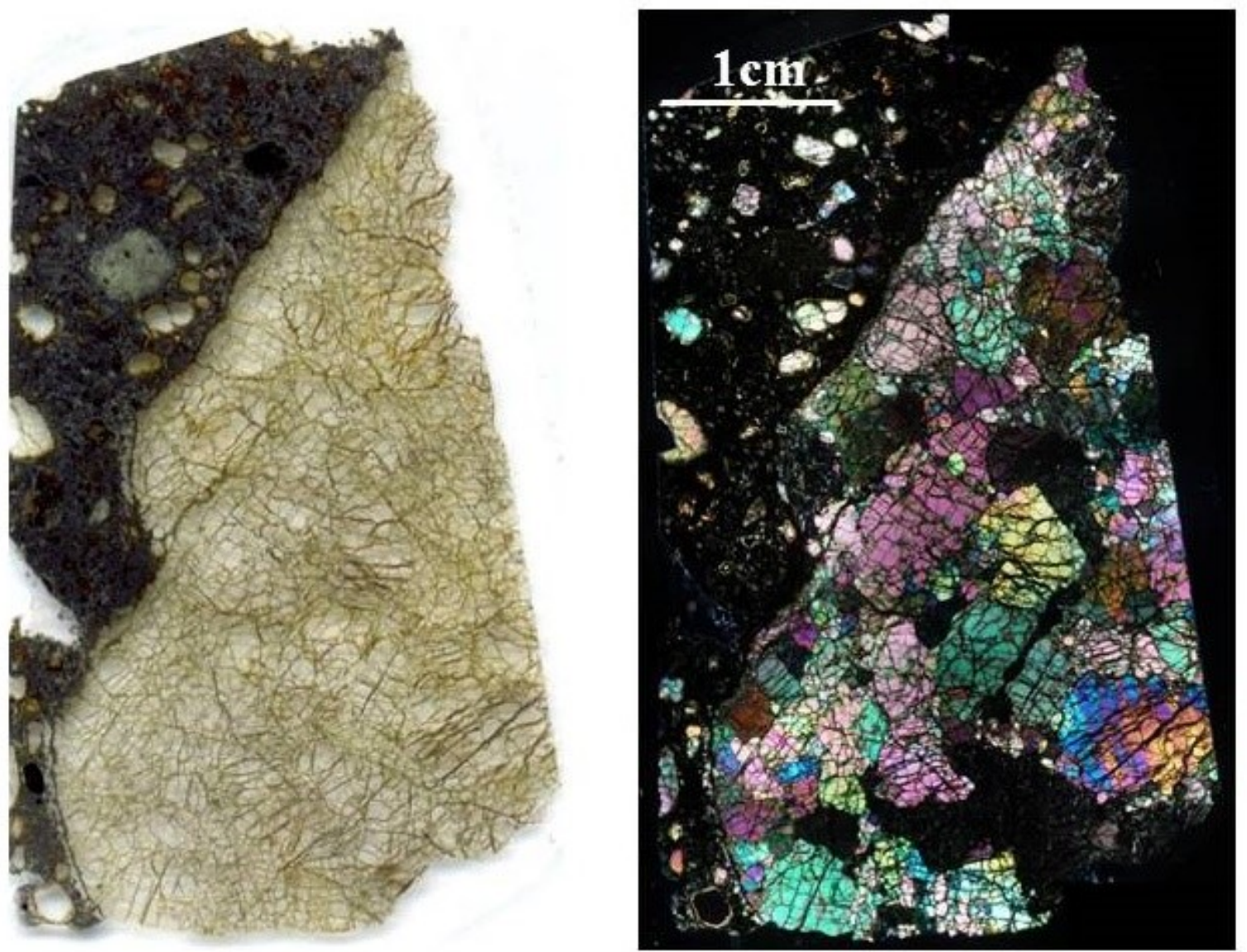

Figura 79 - Imagens de microscópio óptico e de MEV da amostra Lm1-29, de dunito composto somente por olivina, e serpentina nas fraturas, em meio a matriz kimberlítica. 

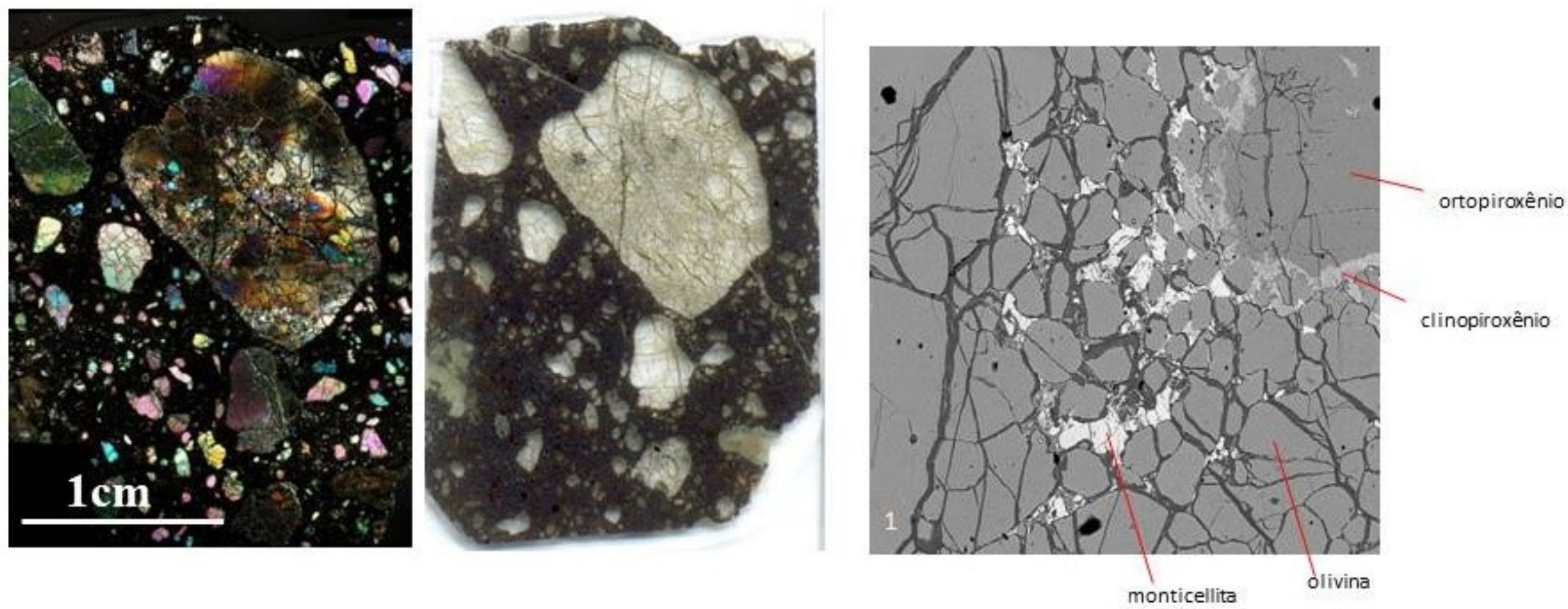

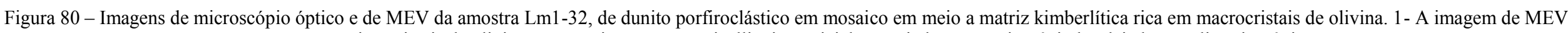
mostra os microcristais de olivina em mosaico, com monticellita intersticial, associados a ortopiroxênio bordejado por clinopiroxênio. 

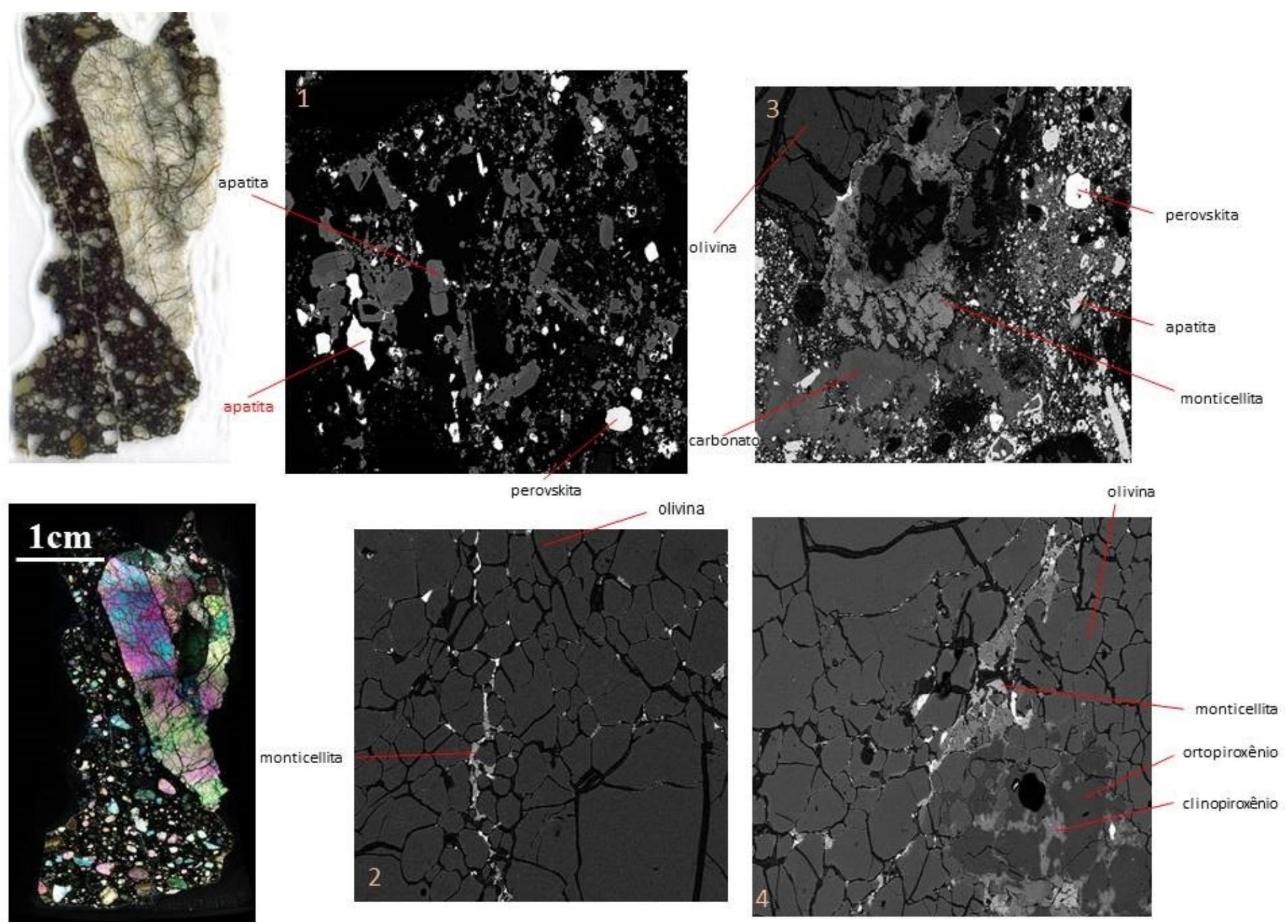

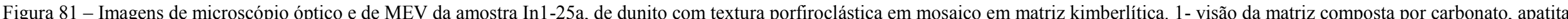

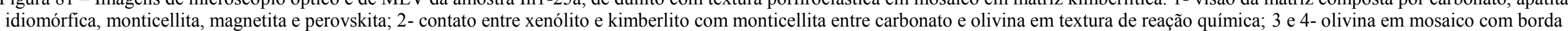
enriquecida em Fe e monticellita intersticial e ortopiroxênio residula bordejado por cliopiroxênio e olivina recristalizada. 


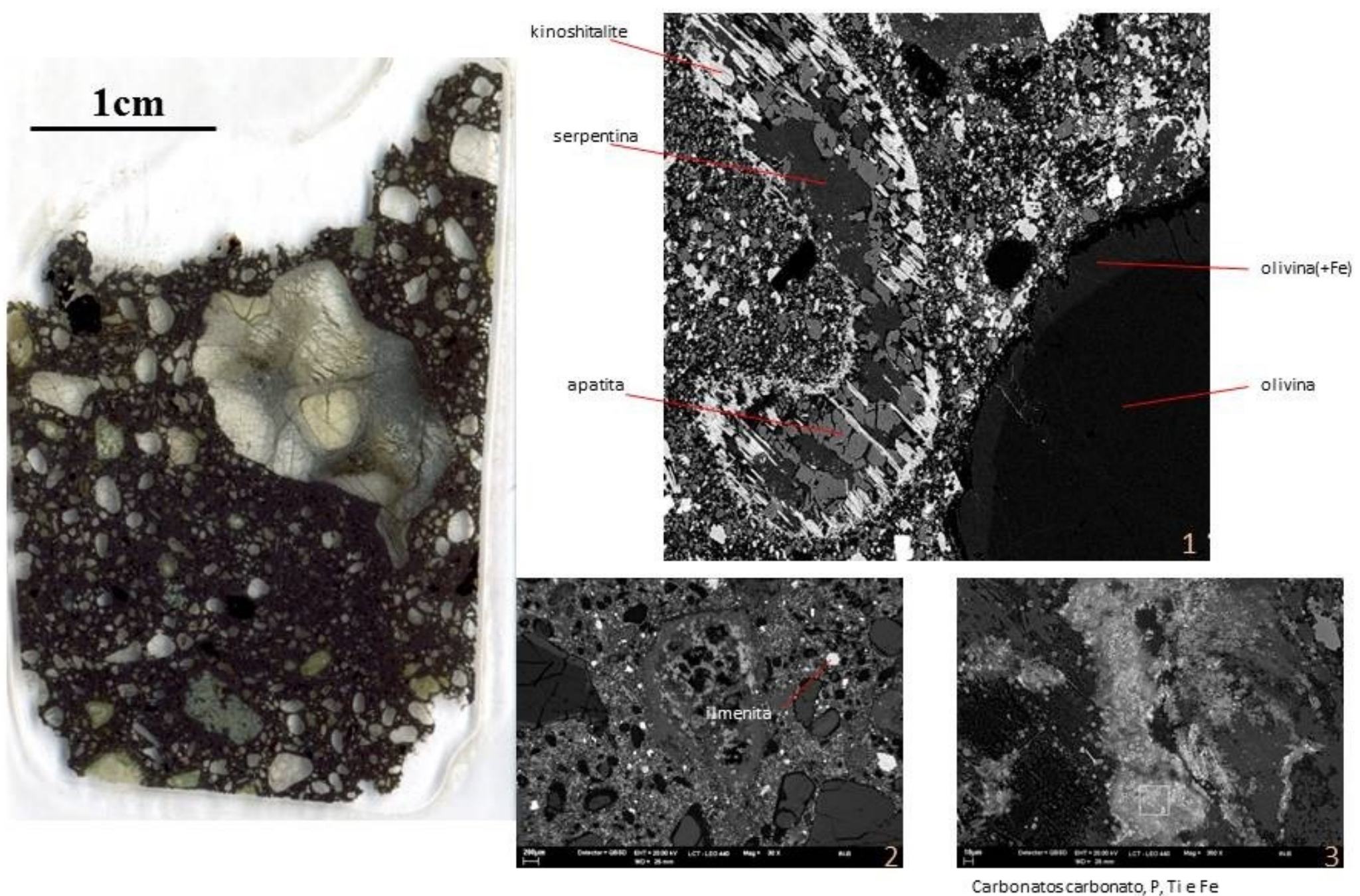

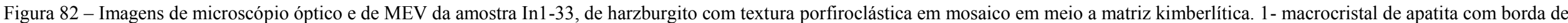
mica rica em Ba; 2- matriz composta por serpentina, apatita e olivina; 3- porção da matriz rica em carbonato e apatita. 
ortopiroxênio
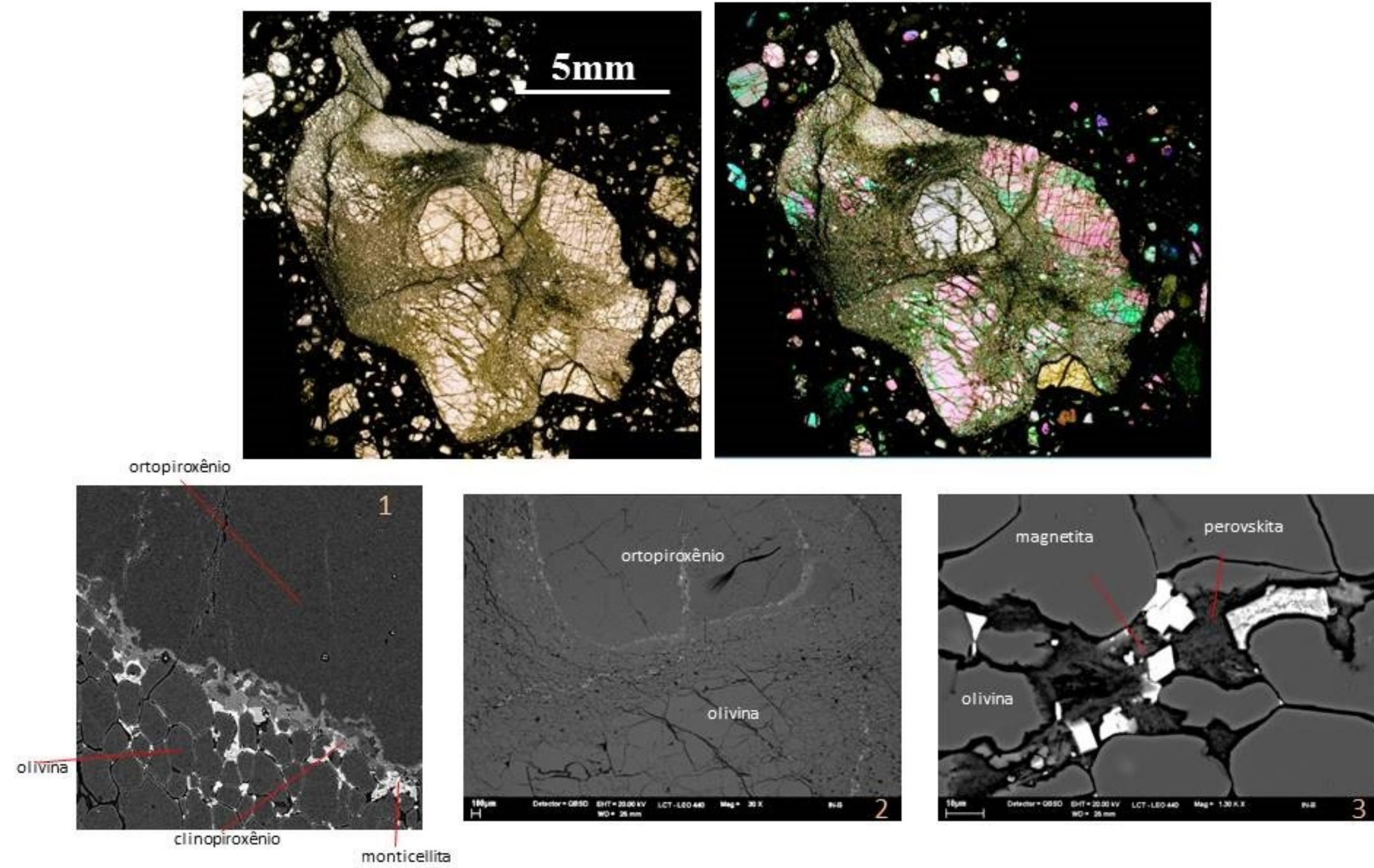

Figura 83 - Imagens de microscópio óptico e de MEV da amostra In1-33, de harzburgito com textura porfiroclástica em mosaico e fluidal.1 e 2- contato entre olivina em mosaico e porfiroclastos de ortopiroxênio apresentando clinopiroxênio e monticellita intersticial; 3- em alguns limites de grãos ocorrem perovskita e magnetita. 


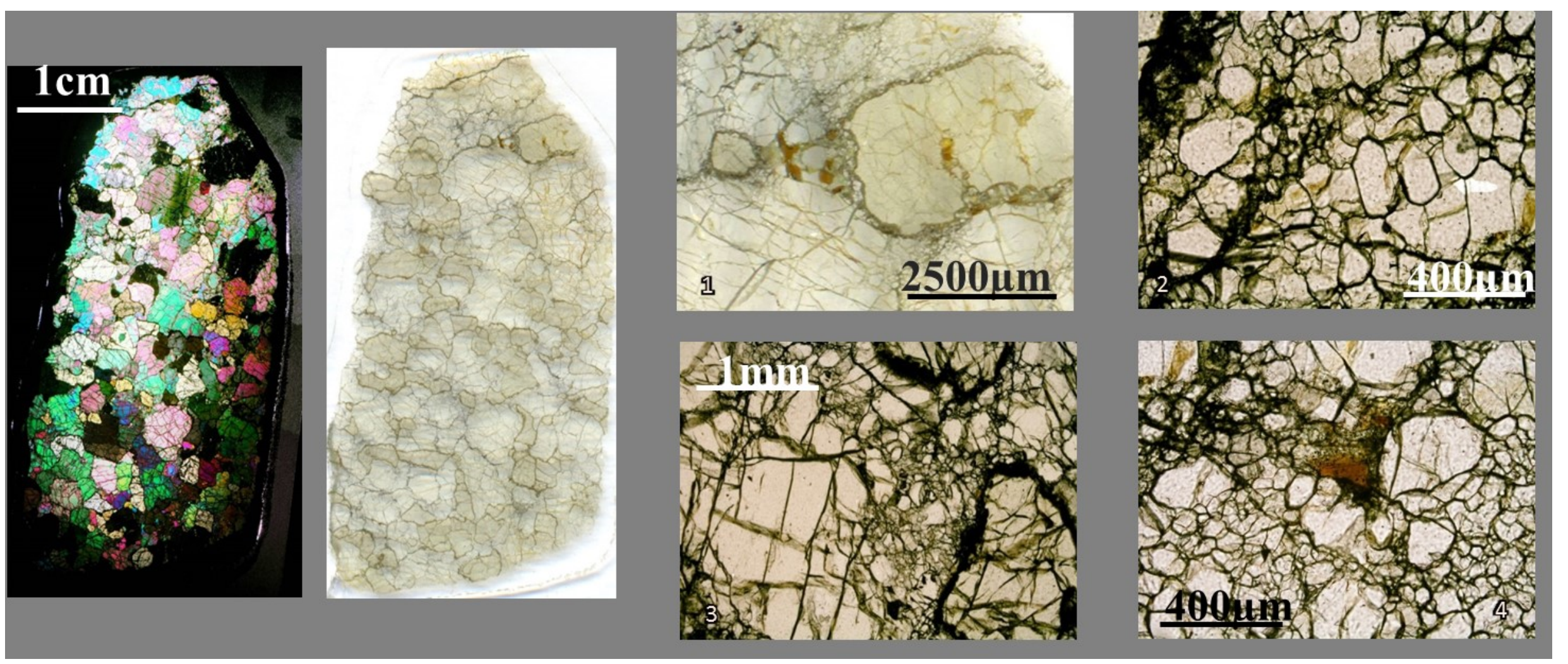

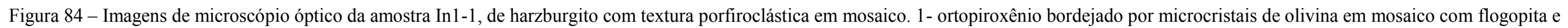
clinopiroxênio insterticial; 2- detalhe da textura em mosaico; 3- cristais maiores de olivina em contato com cristais em mosaico e com cristais de ortopiroxênio;4- flogopita intesticial nos cristais de flogopita. 

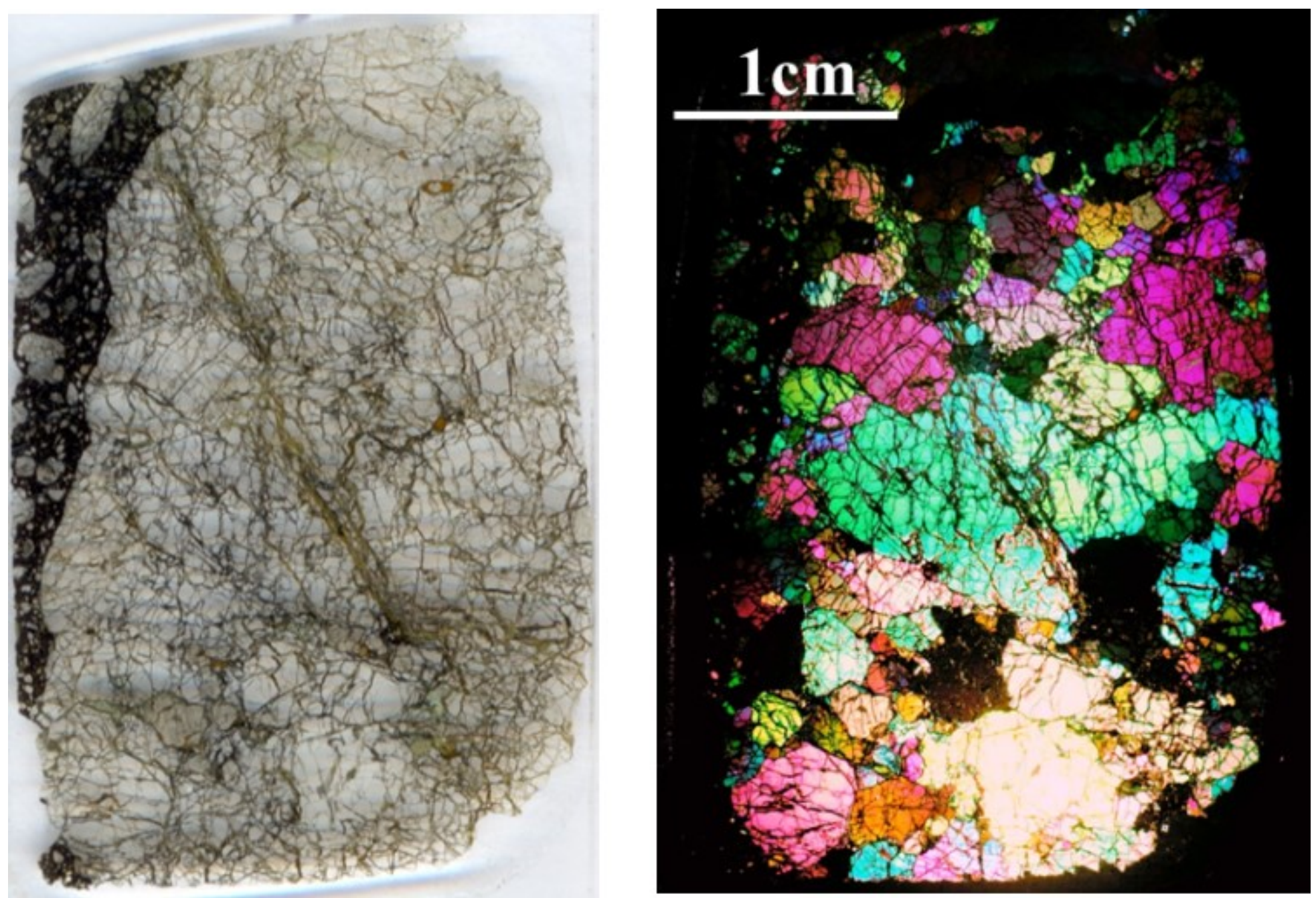

Figura 85 - Imagens de microscópio óptico e de MEV da amostra In1-5, de harzburgito protogranular com flogopita e clinopiroxênio secundários. 

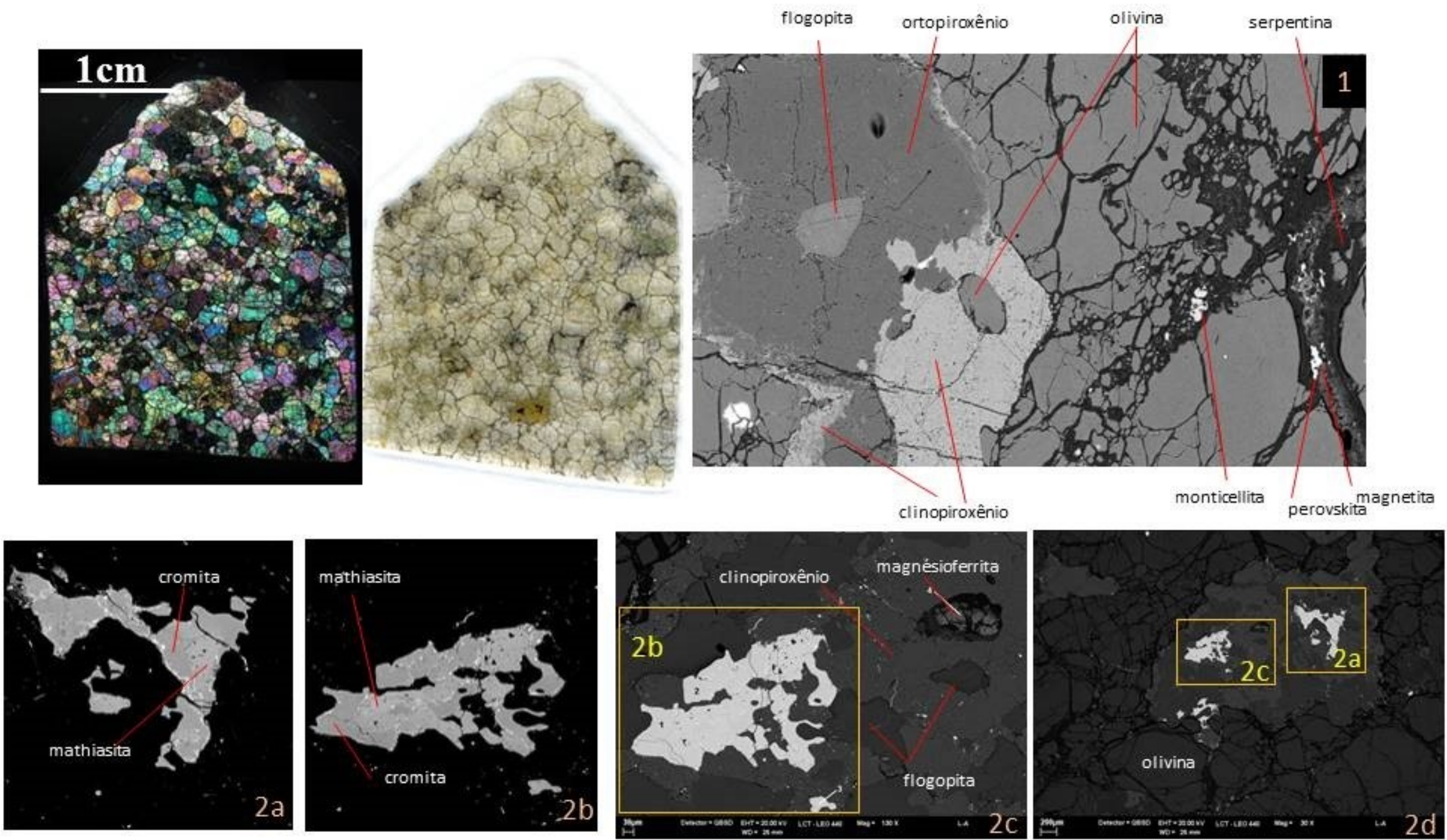

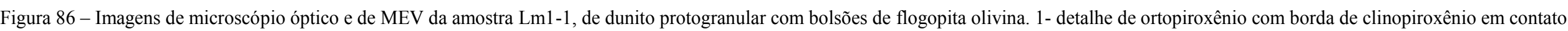

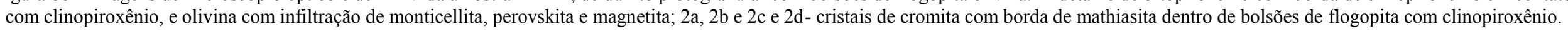



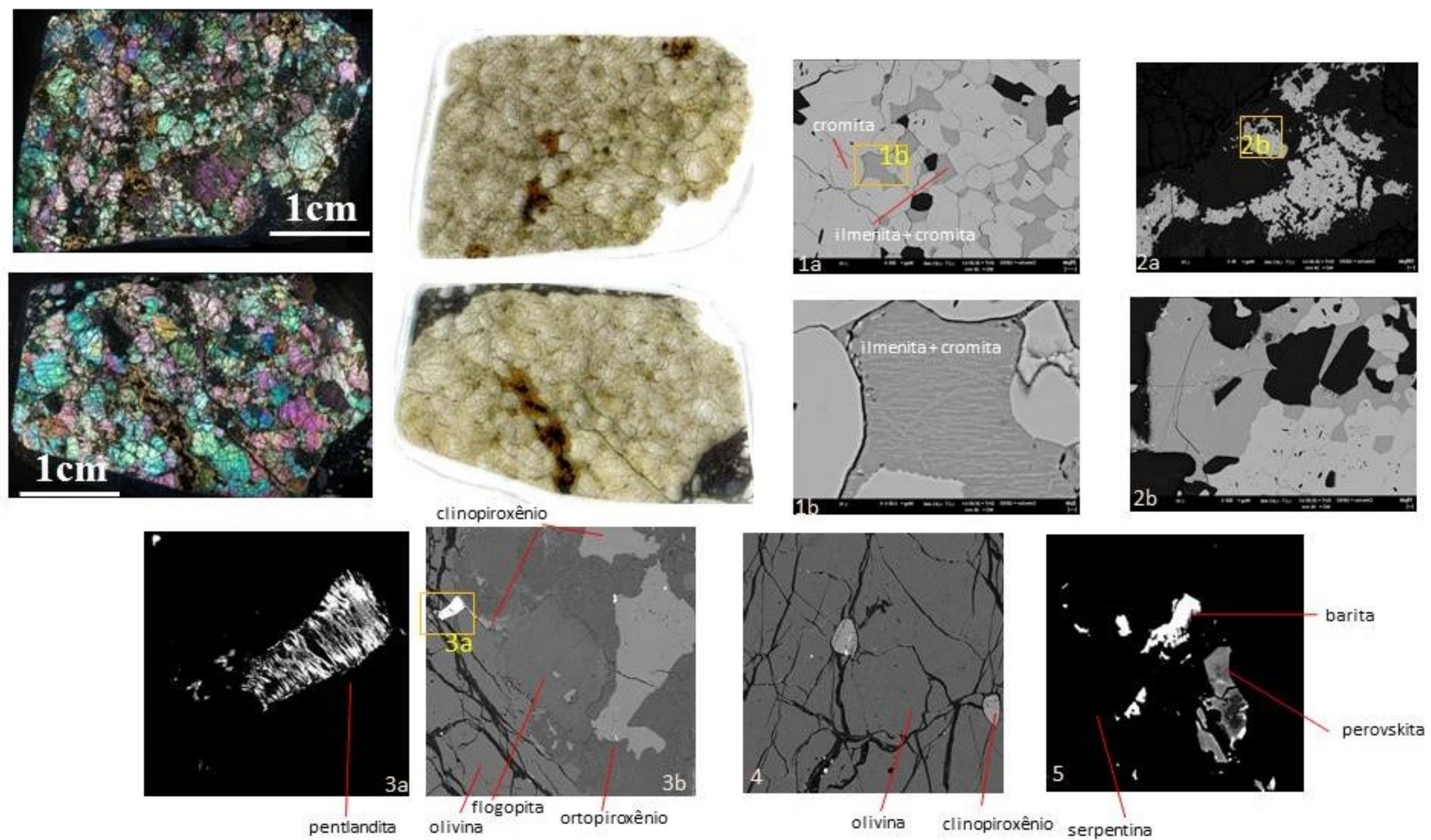

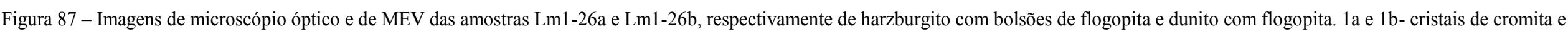
ilmenita em equilíbrio textural, os cristais de cromita apresentam lamelas finas de cromita; $2 \mathrm{a}$ e $2 \mathrm{~b}$ - ilmenita e cromita em meio a cristais de flogopita, a ilmenita ocorre aqui maior e sem lamelas de

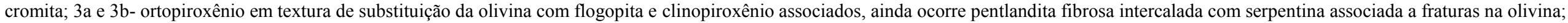
4- clinopiroxênio com forma arredondada em meio as fraturas na olivina; 5- perovskita e barita na matriz kimberlítica na amostra Lm1-26b. 

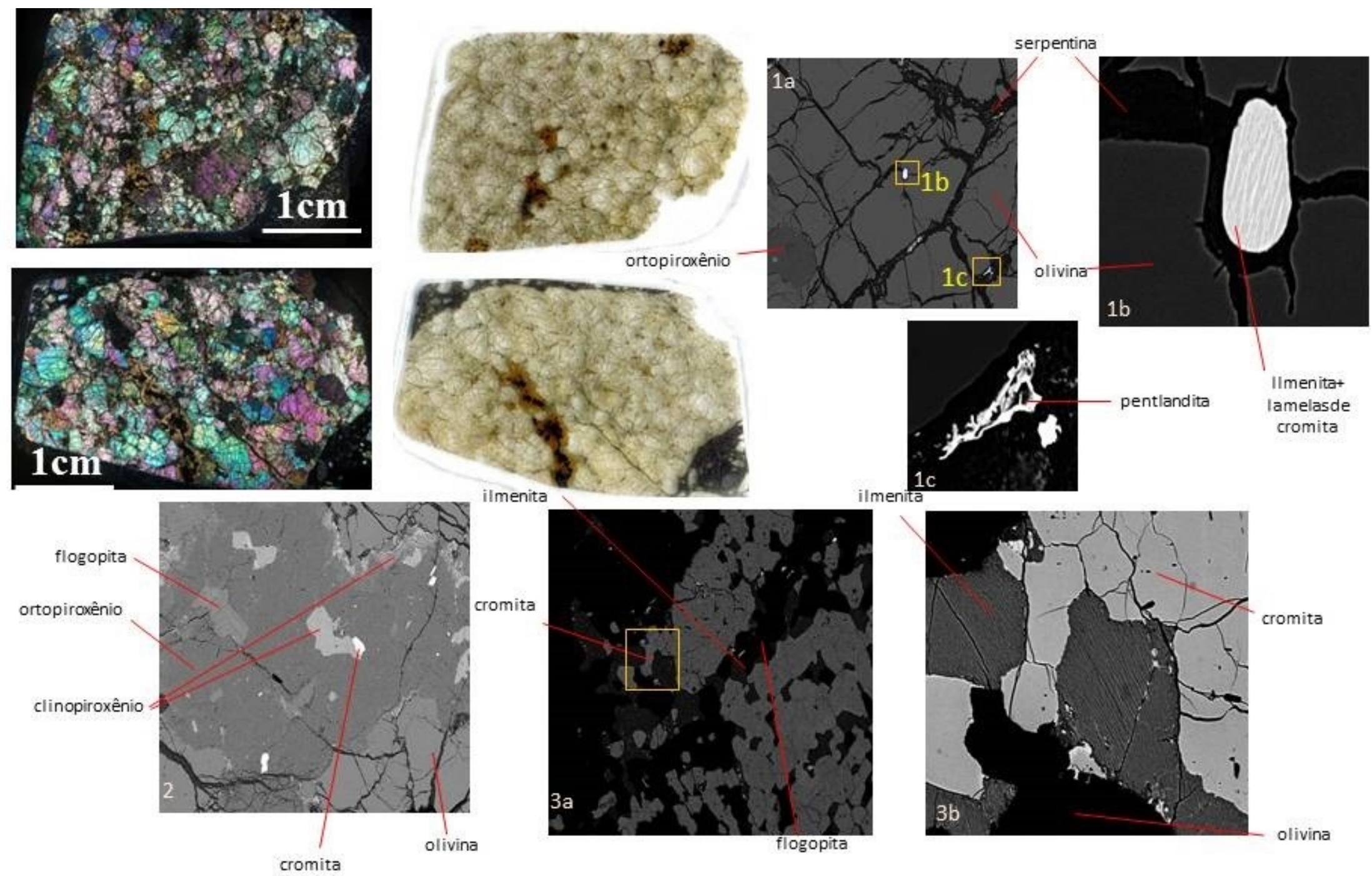

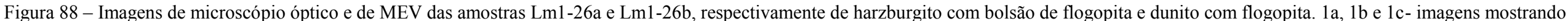

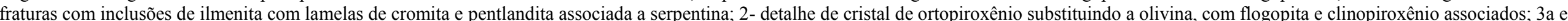
3b- associação de cromita homogênea e ilmenita com lamelas de cromita em meio a olivina associados a bolsões de flogopita. 

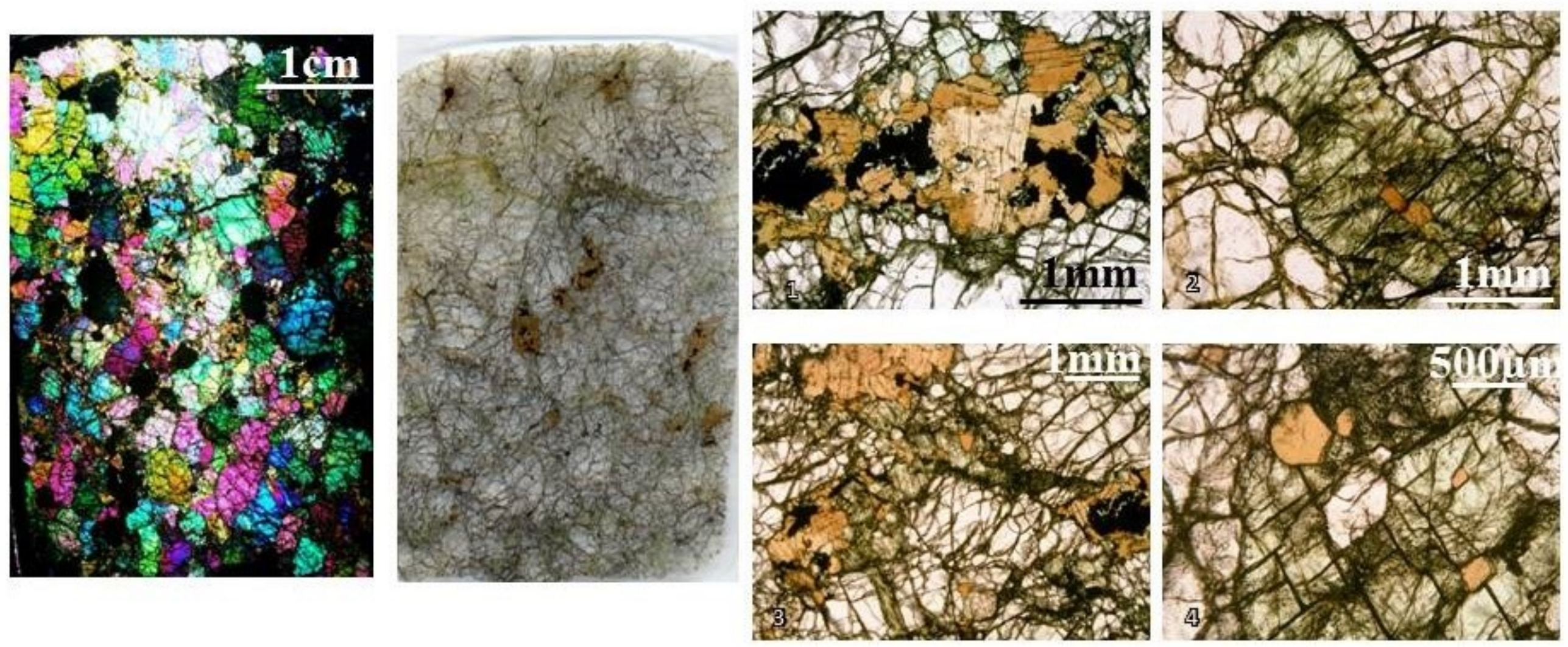

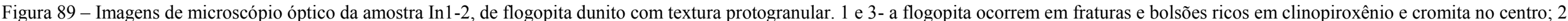
e 4- cristal anédrico de clinopiroxênio com inclusão de flogopita. 

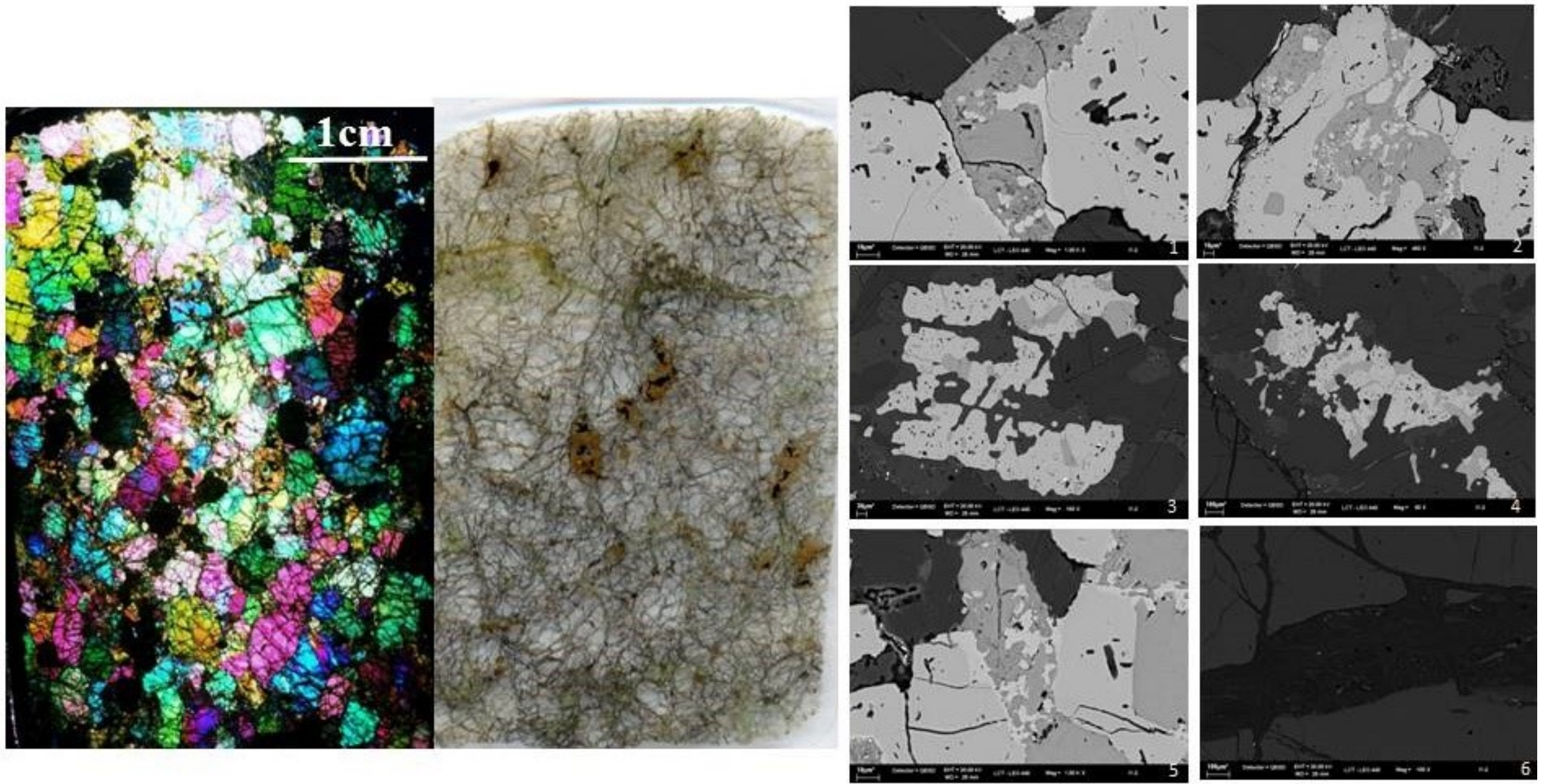

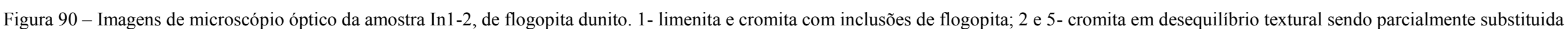
por ilmenita; 3 e 4 ilmenita e cromita em equilíbrio textural dentro de bolsão de flogopita; 5 - fratura de olivina preeenchida por serpentina. 

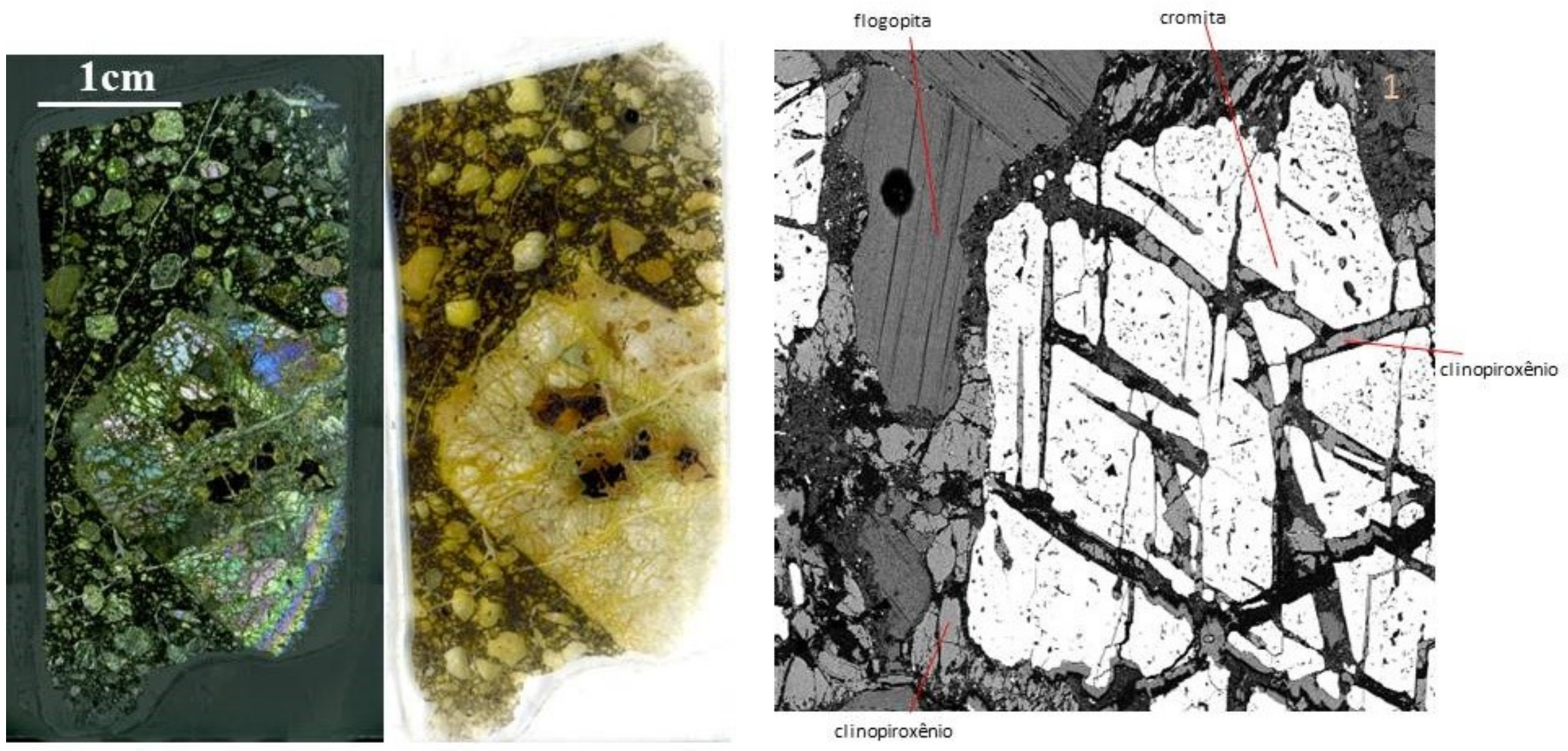

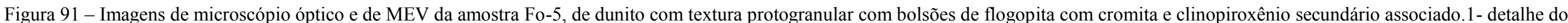
bolsão de flogopita com cromita homogênea com clinopiroxênio nas clivagens e na borda. 

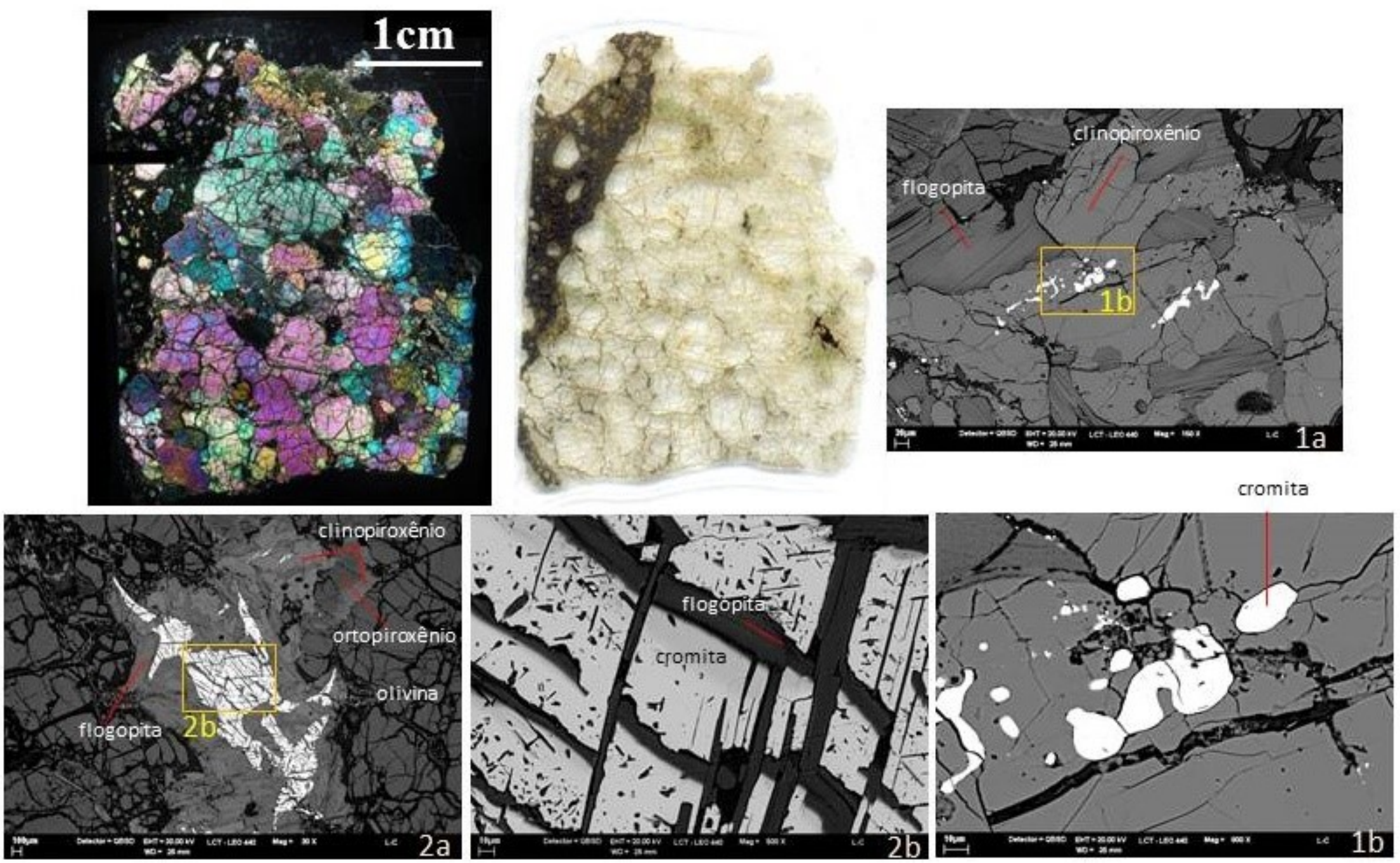

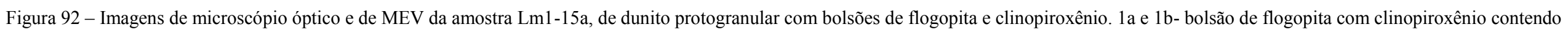

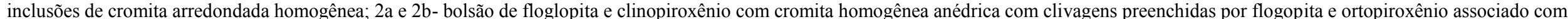
borda de clinopiroxênio. 

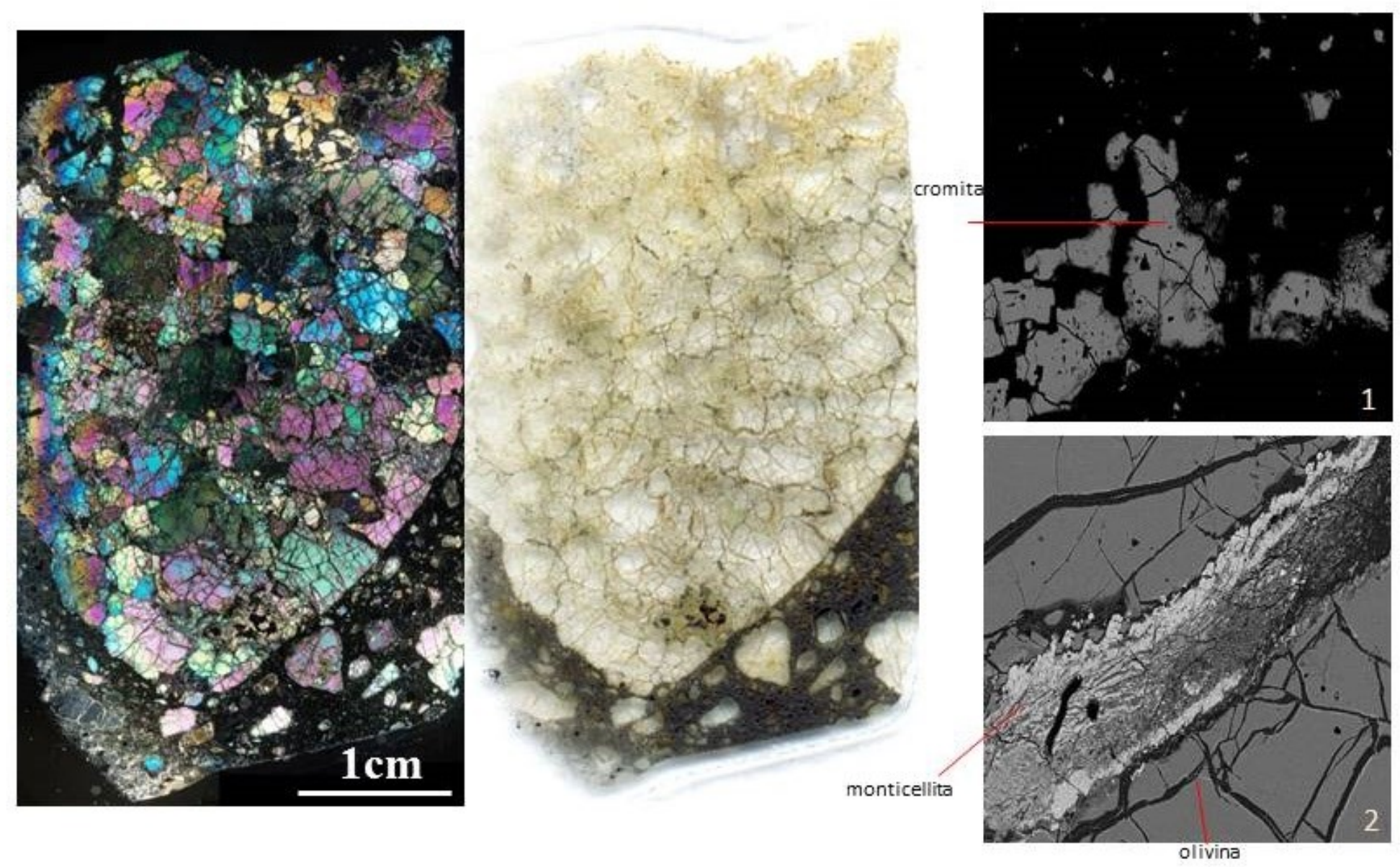

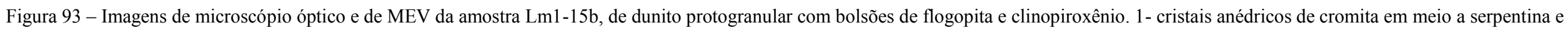
clinopiroxênio; 2- fratura em olivina preenchida por apatita e serpentina. 

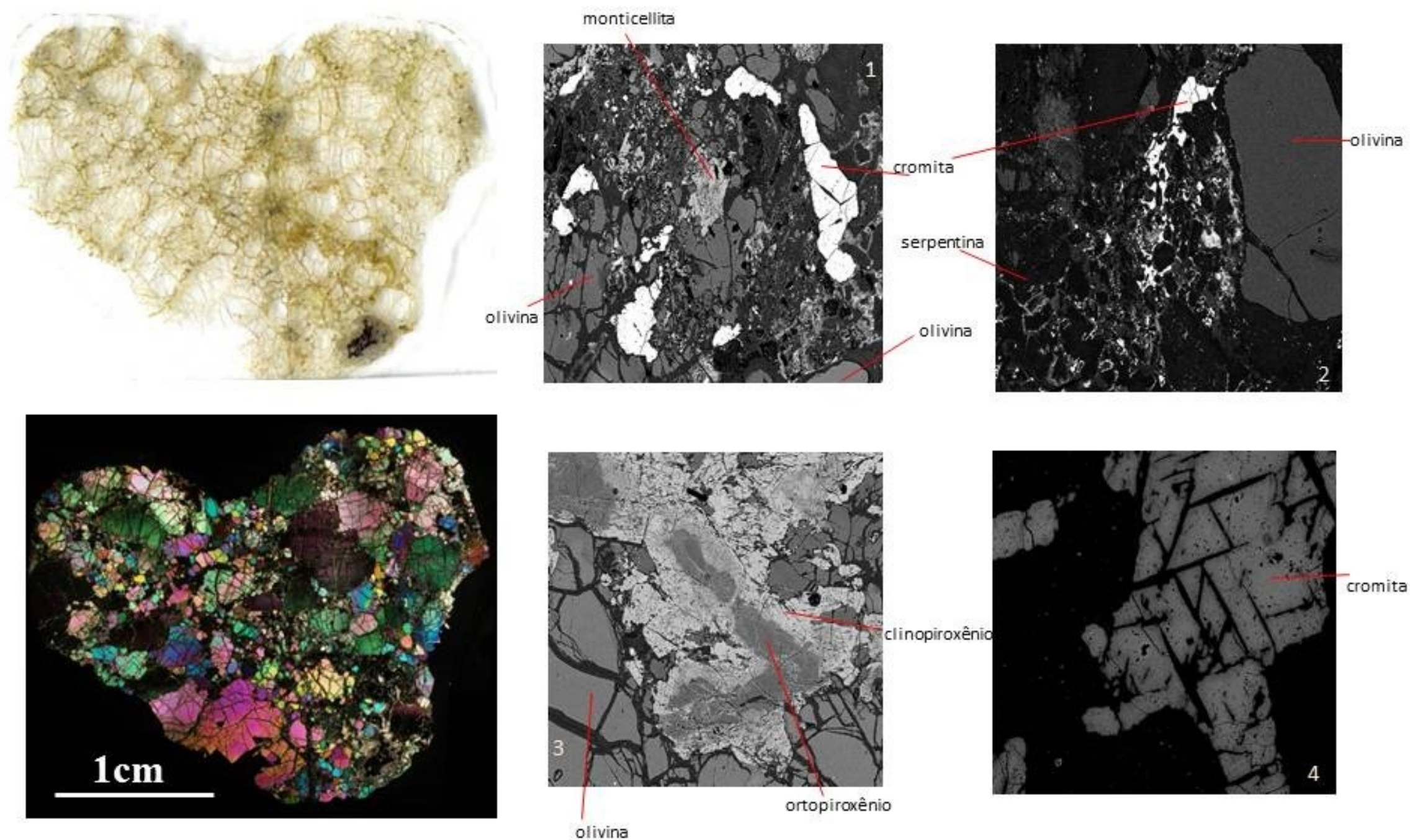

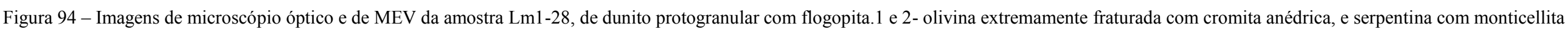
secundárias; 3- clinopiroxênio bordejando ortopiroxênio nos contatos com olivina; 4- cromita quimicamente homogênea com flogopita nas clivagens. 

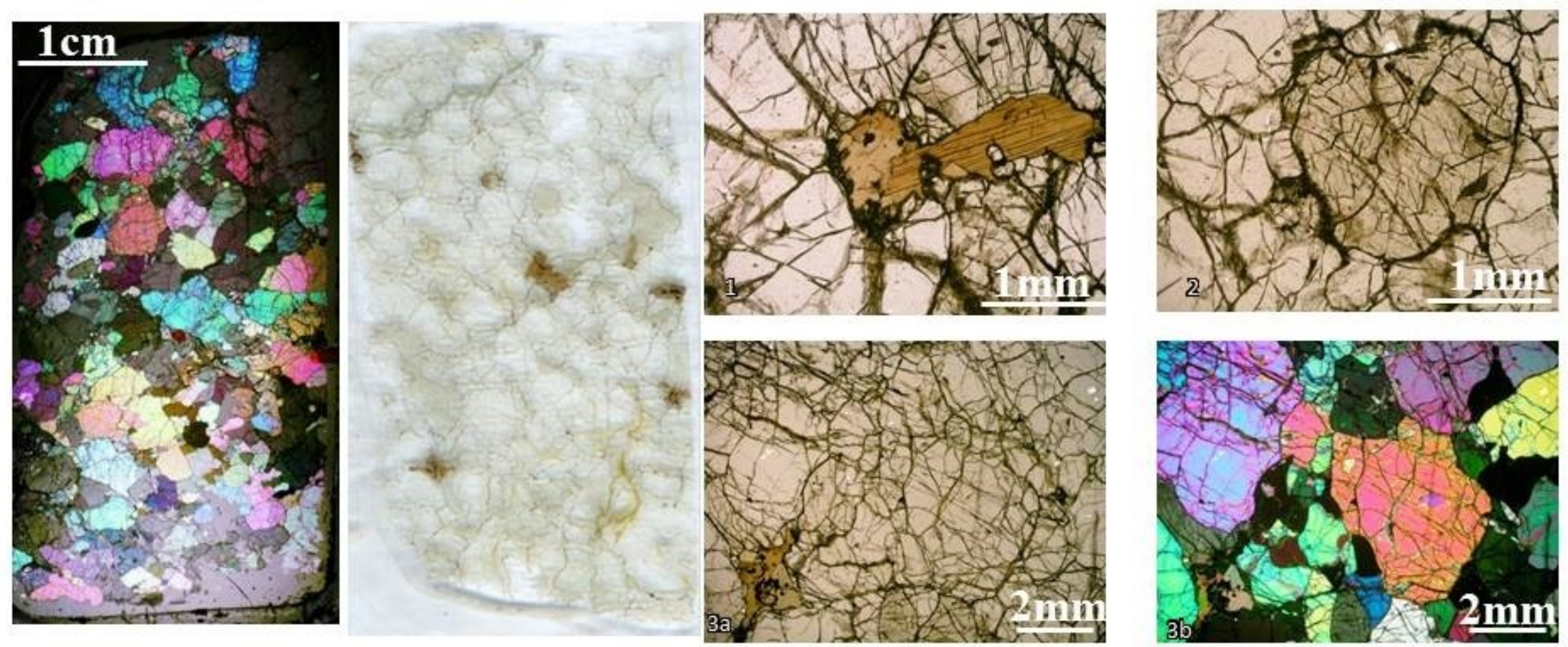

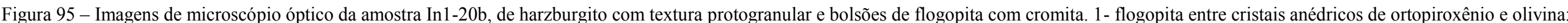

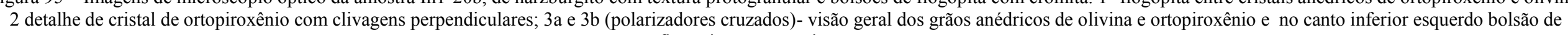
flogopita com cromita no centro. 
cromita
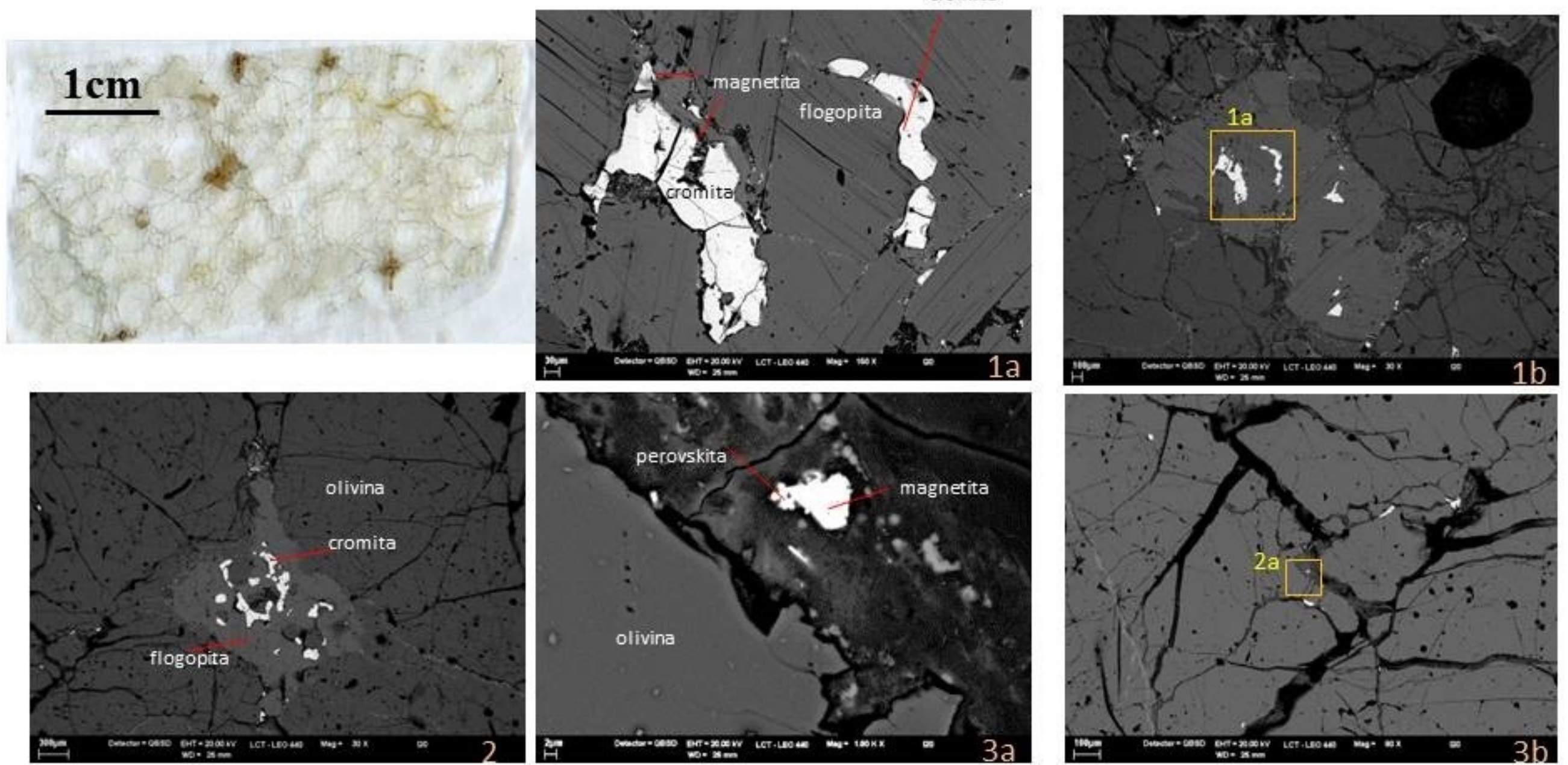

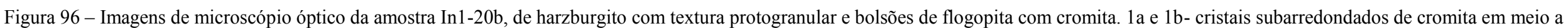

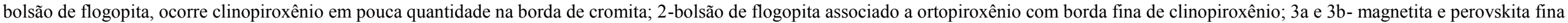
infiltrados nas fraturas de olivina. 

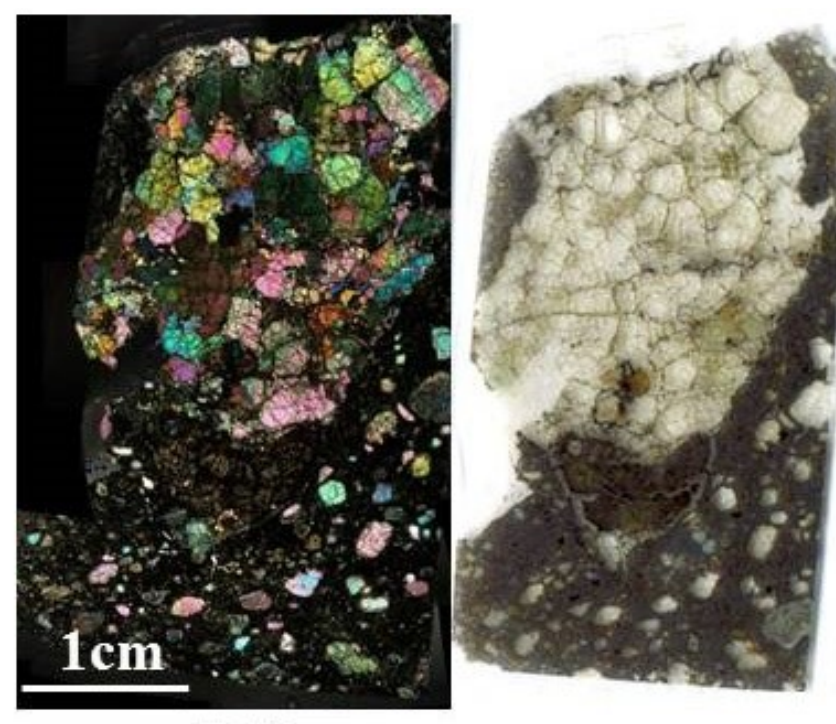

ilmenita
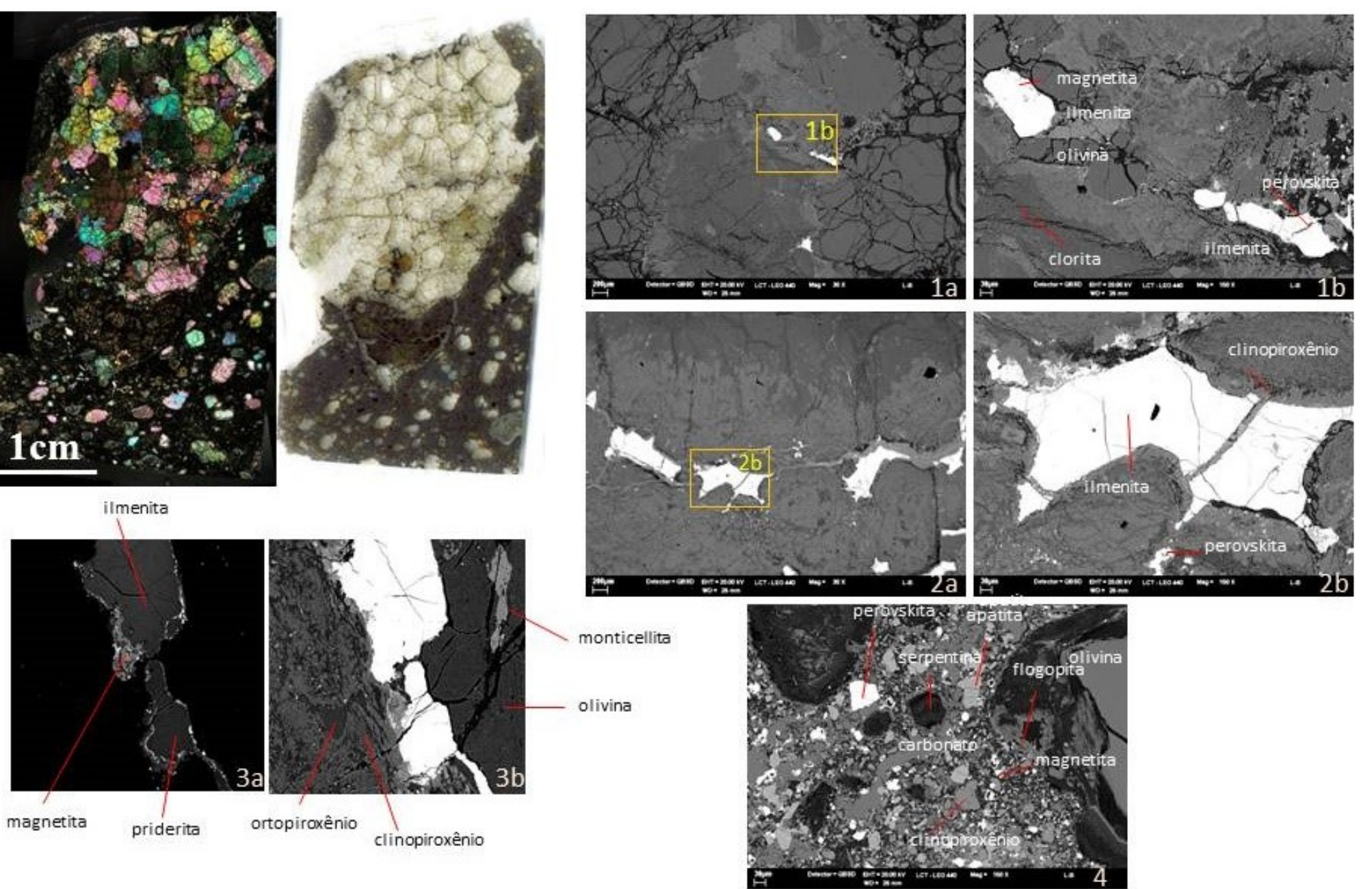

Figura 97 - Imagens de microscópio óptico e de MEV da amostra Lm1-22, de dunito com flogopita e clinopiroxênio secundários. 1a e 1b- bolsão composto por flogopita, clinopiroxênio e ilmenita

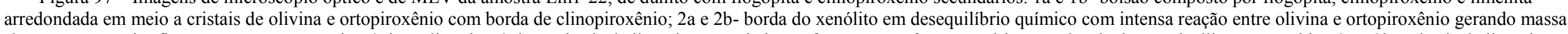

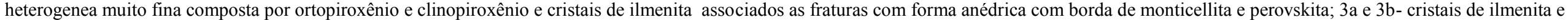

priderita anédricos com borda de perovskita, magnetita e monticellita ao lado de textura de reação química intensa com massa muito fina de clinopiroxênio e ortopiroxênio; 4- detalhe da matriz do kimberlito. 

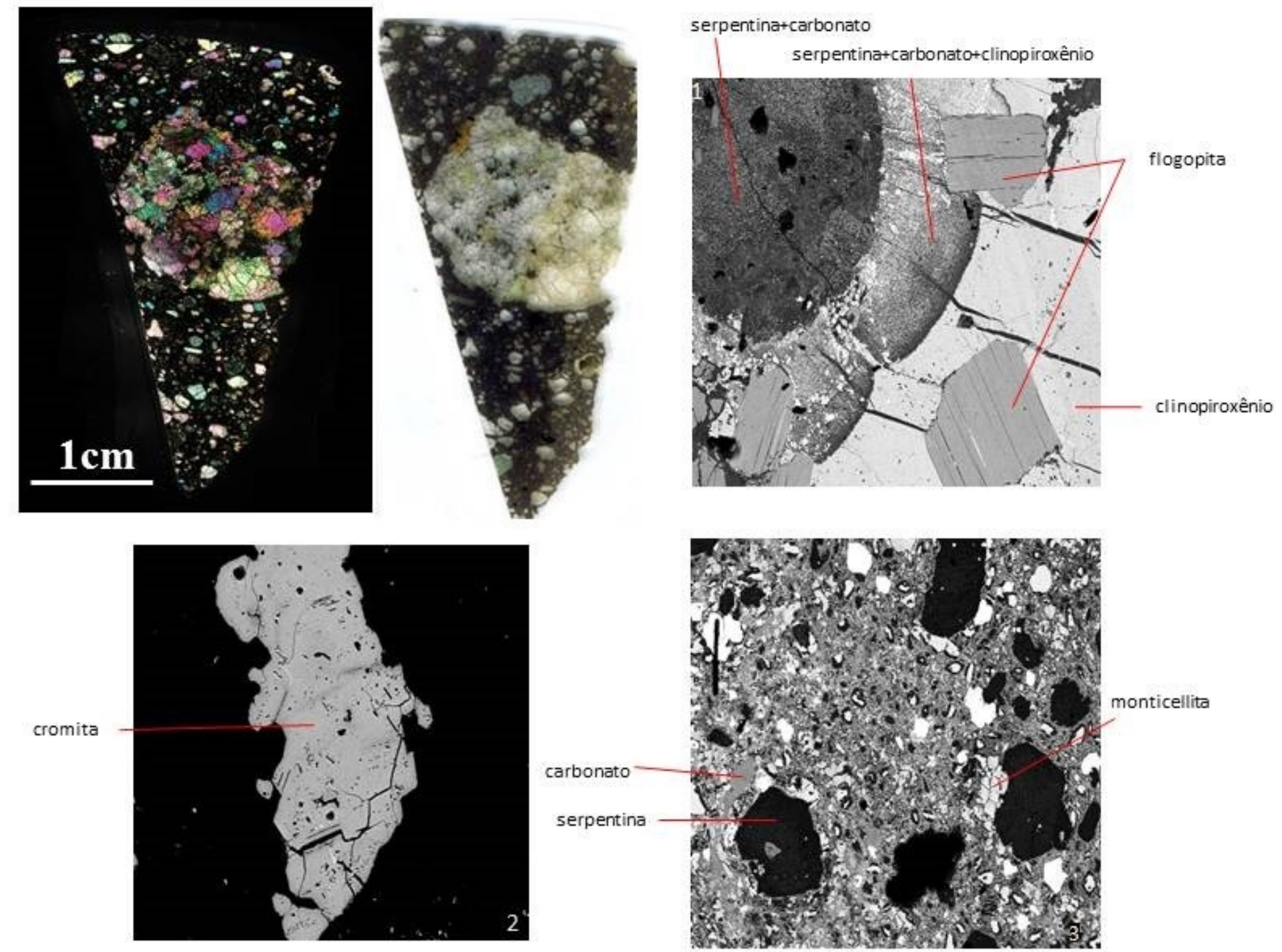

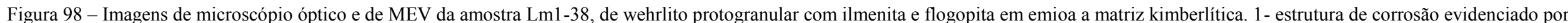

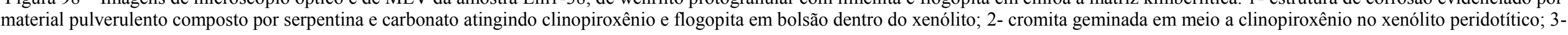
matriz kimberlítica apresentando pseudomorfos de olivina idiomórficos (serpentina), carbonato, monticellita, magnetita e perovskita. 

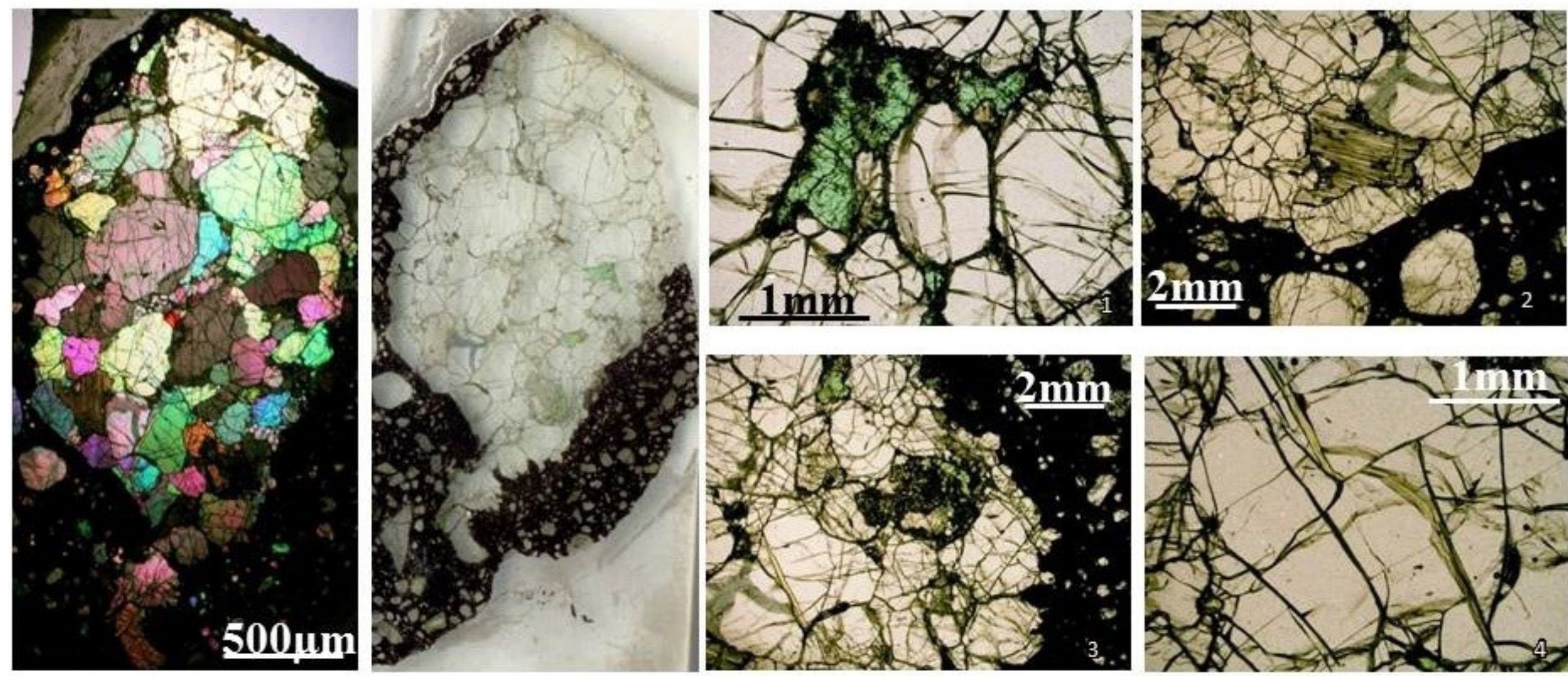

Figura 99 - Imagens de microscópio óptico da amostra In1-12, de harzburgito com textura protogranular e bolsões de clinopiroxênio com flogopita e cromita associados. 1- bolsão de clinopiroxênio secundário em meio a cristais idiomórficos de olivina; detalhe de ortopiroxênio com geminação; 3 - contato de xenólito com kimberlito com textura de infiltração de carbonato e reação com o clinopiroxênio; 4- detalhe de fraturas na olivina, algumas delas são preenchidas por serpentina. 

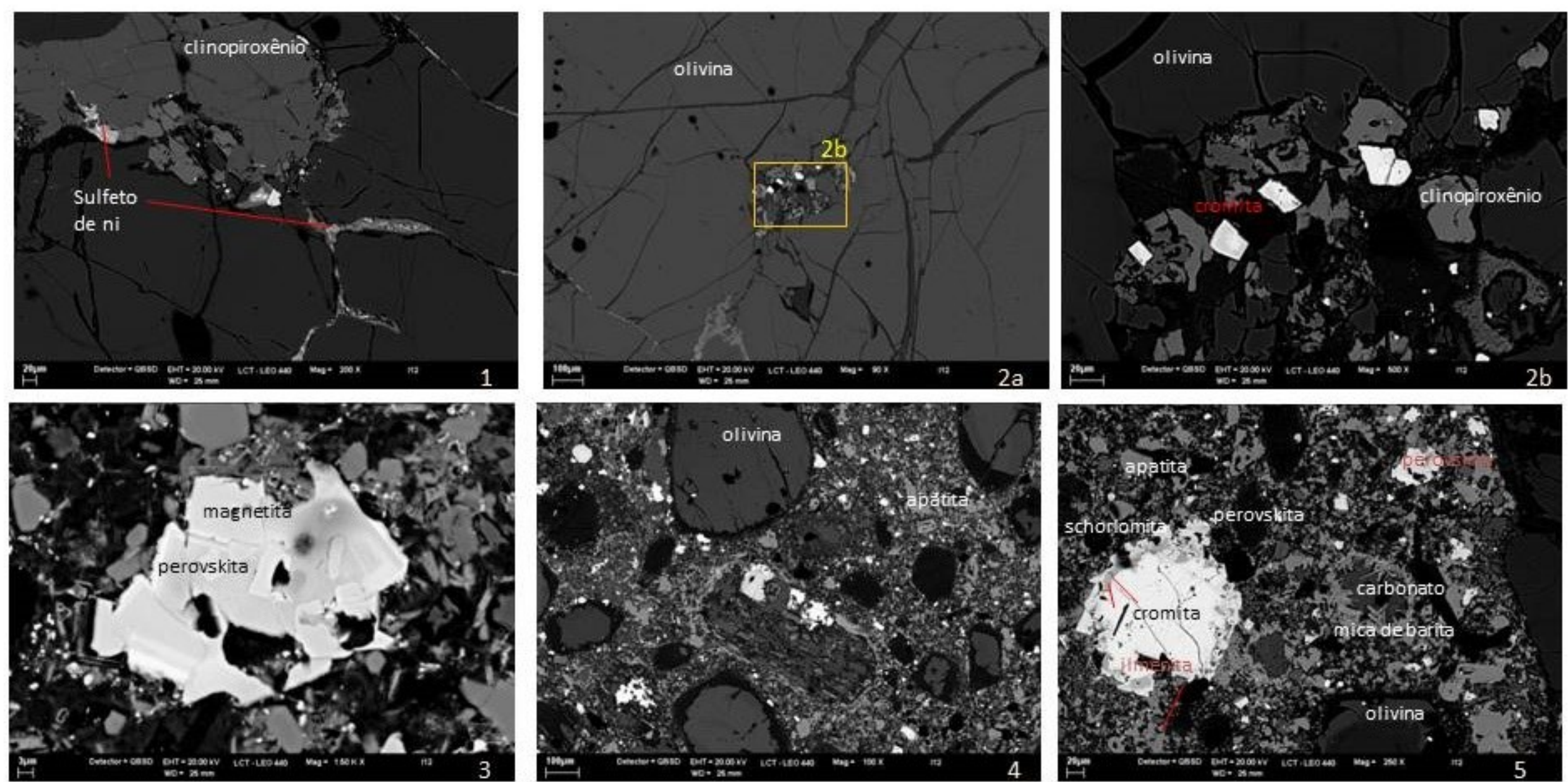

Figura 100 - Imagens de microscópio óptico da amostra In1-20b, de harzburgito com textura protogranular e bolsões de flogopita com cromita. 1- pentlandita associada a serpentina intersticial no harzburgito; $2 \mathrm{a}$ e 2b-cromita idiomórfica em meio a fraturas no harzburgito contendo serpentina e clinopiroxênio em desequilíbrio químico; 3 - perovskita intercrescida com magnetita em matriz kimberlítica; 4- matriz kimberlítica com macrocristais arredondados de olivina; 5 - macrocristal de cromita com bordas de schorlomita e perovskita em meio a matriz kimberlítica. 

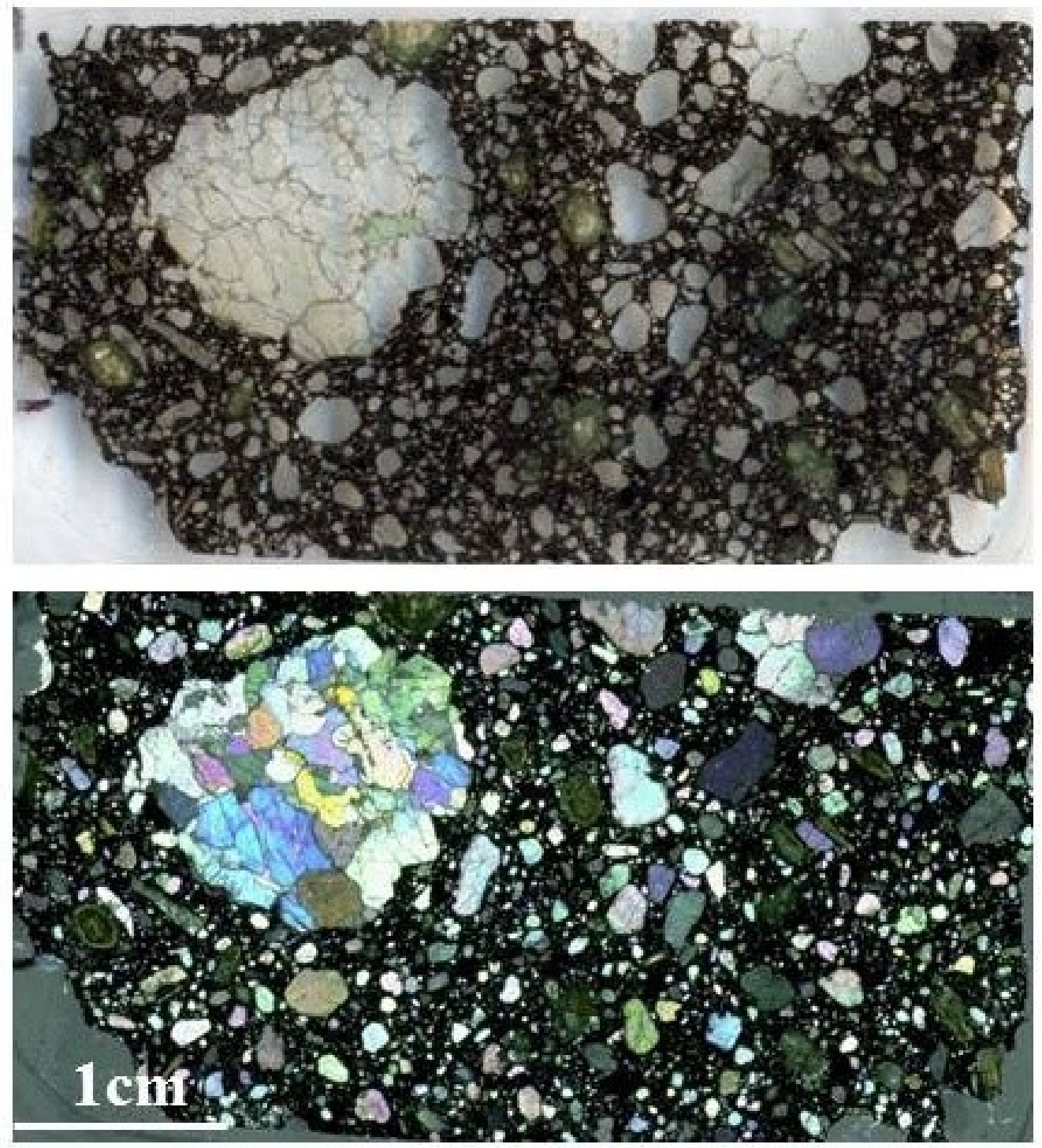

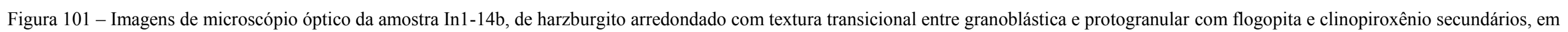
meio a matriz kimberlítica. 

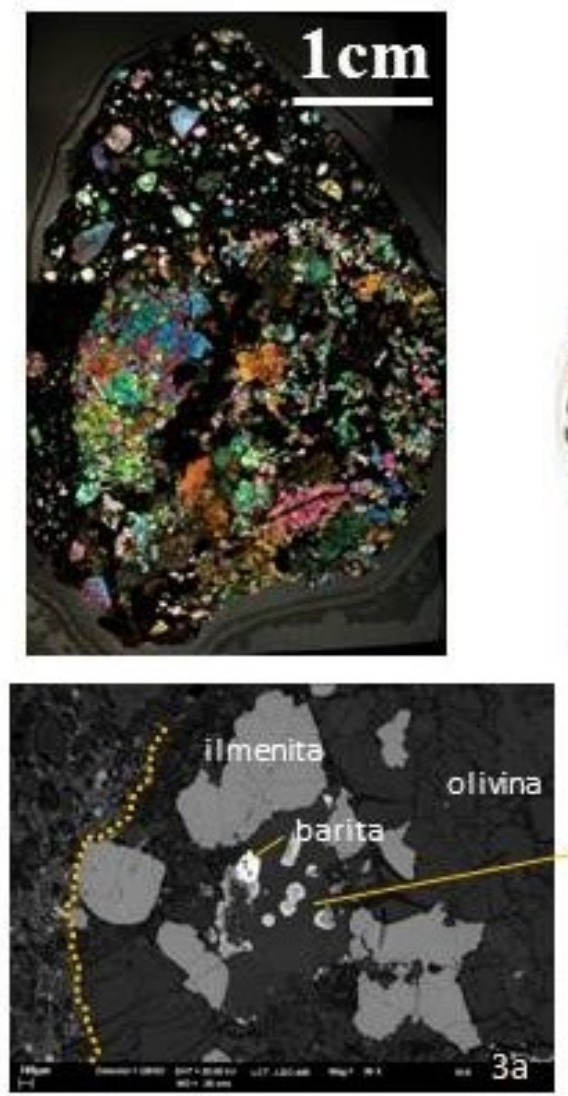
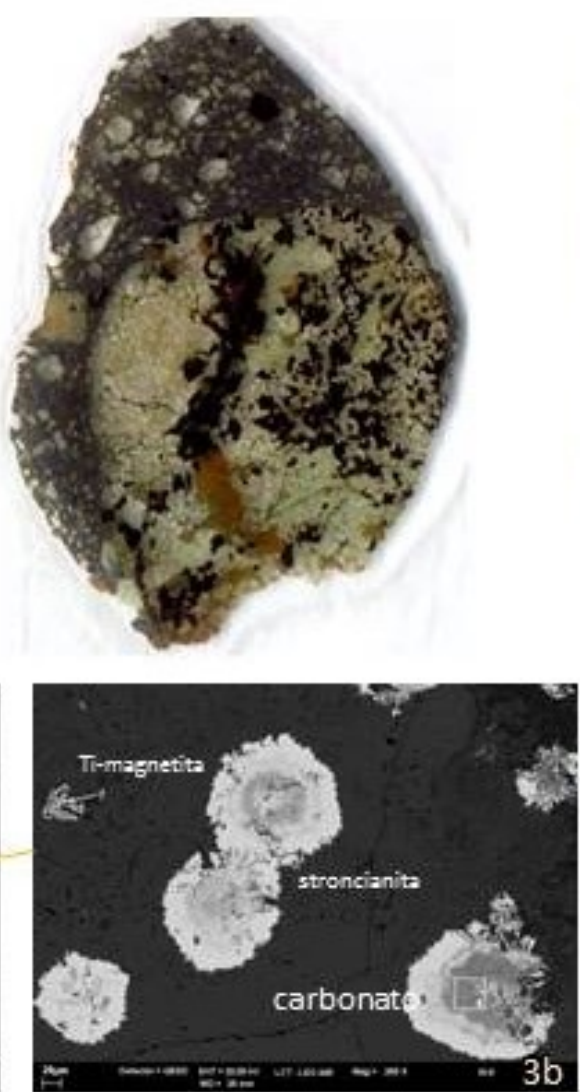
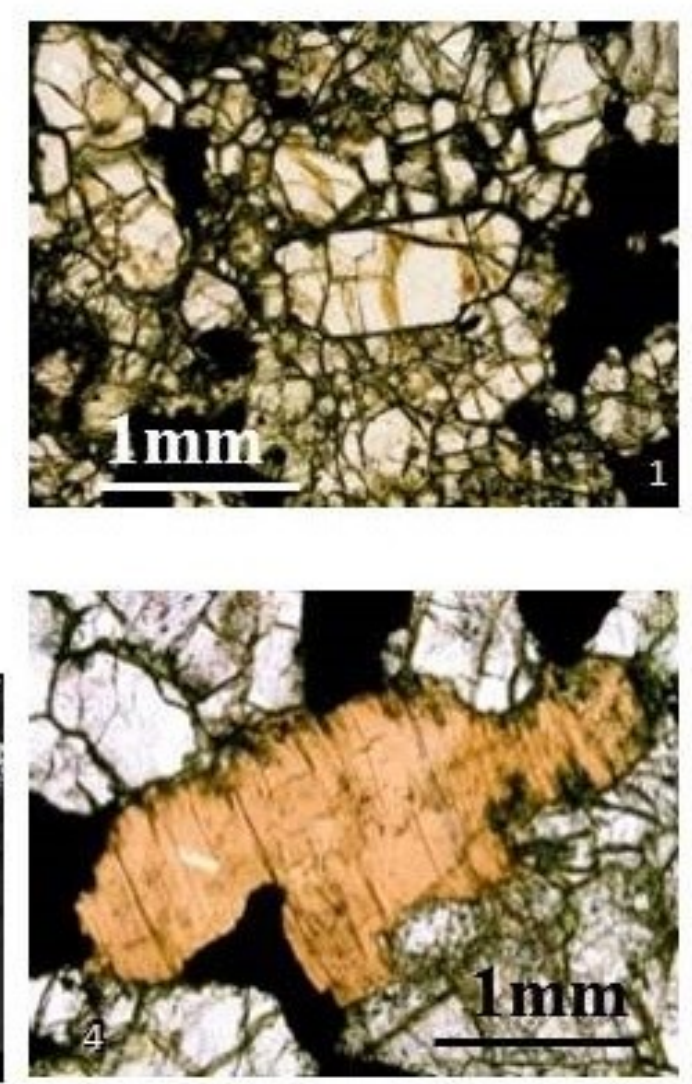
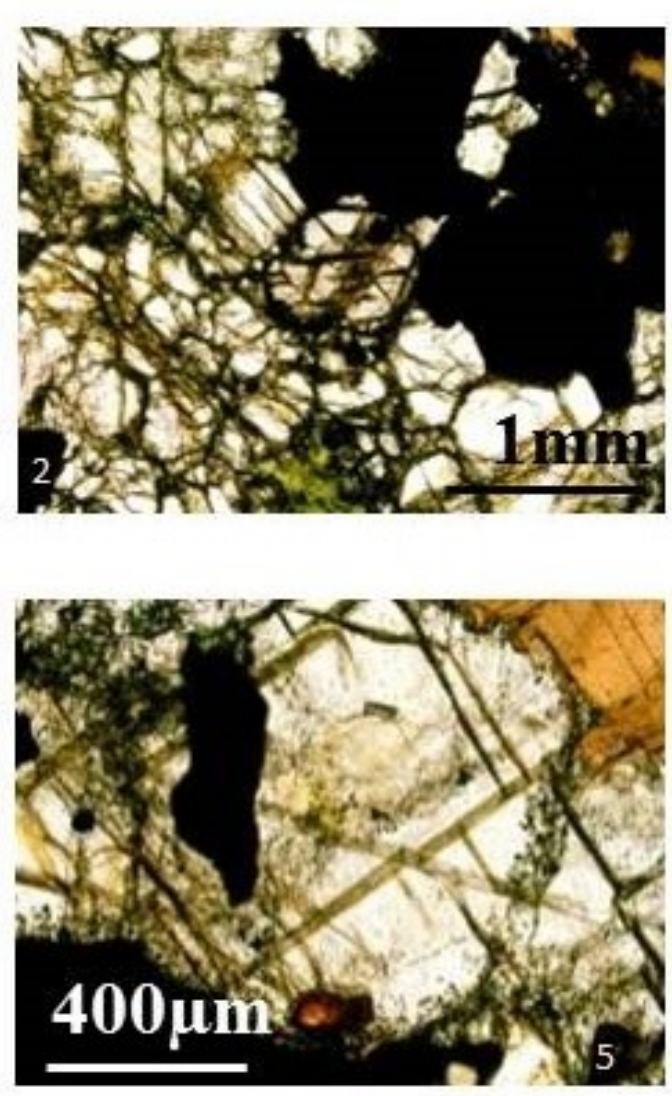

Figura 102 - Imagens de microscópio óptico e de MEV da amostra In1-6, de flogopita ilmenita wehrlito arredondado. 1- porção do xenólito com cristais idiomórficos de olivina em meio a cristais de

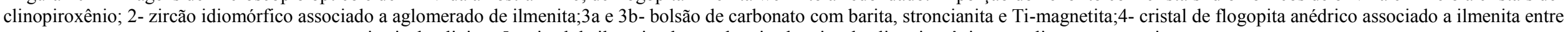
cristais de olivina; 5- cristal de ilmenita dentro de cristal maior de clinopiroxênio com clivagens proeminentes. 

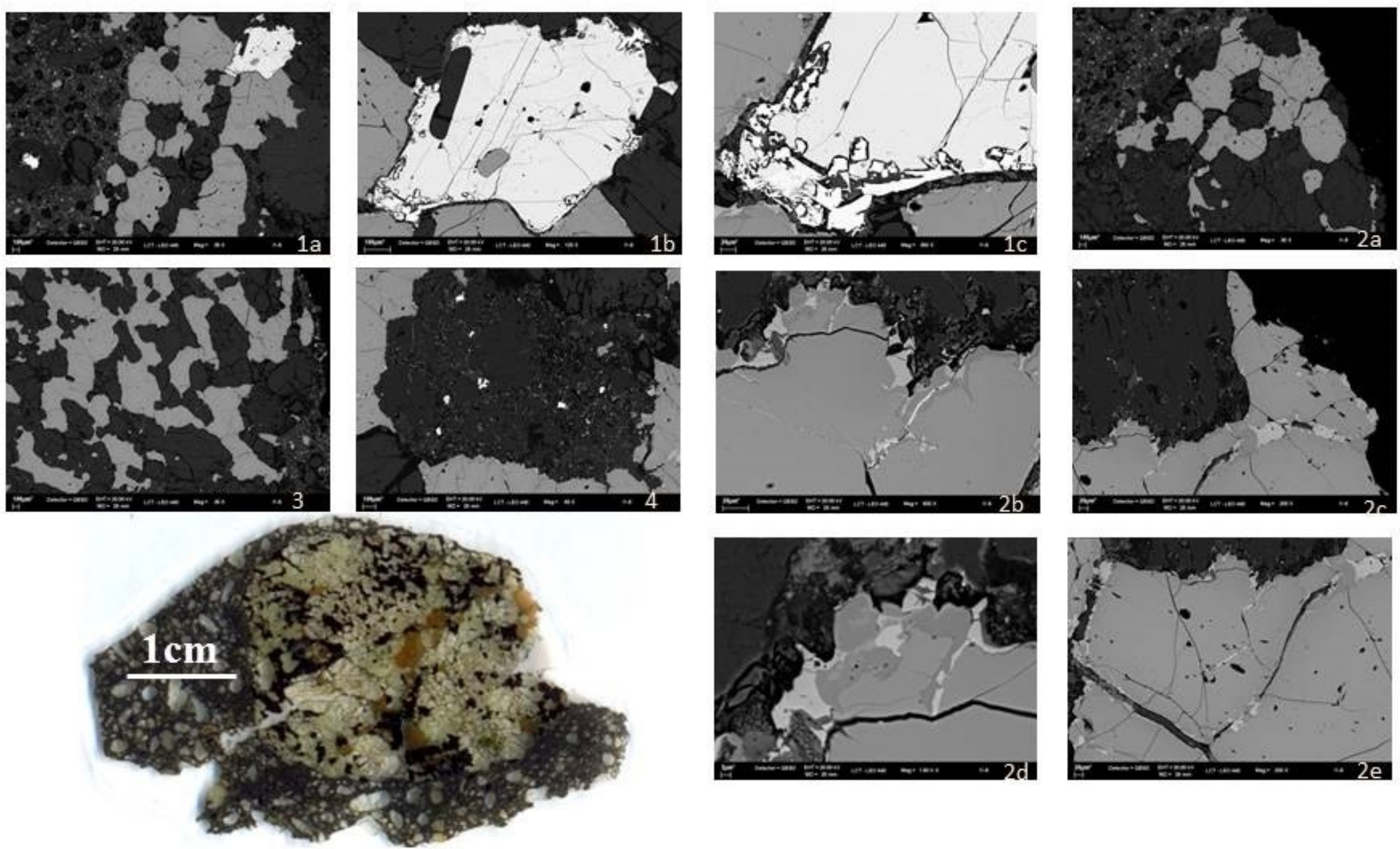

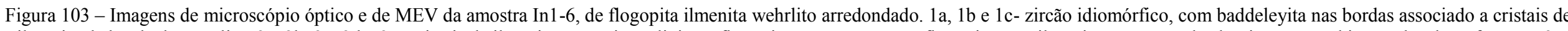
ilmenita da borda do xenólito; $2 \mathrm{a}, 2 \mathrm{~b}, 2 \mathrm{c}, 2 \mathrm{~d}$ e 2e- cristais de ilmenita em meio a olivina e flogopita, no contato com flogopita com ilmenita ocorrem schorlomita e perovskita nas bordas e fraturas; 3 possível textura de intercrescimento de ilmenita e olivina; 4- porção do xenólito com flogopita e minerais da matriz do kimberlito, como magnetita e carbonato. 

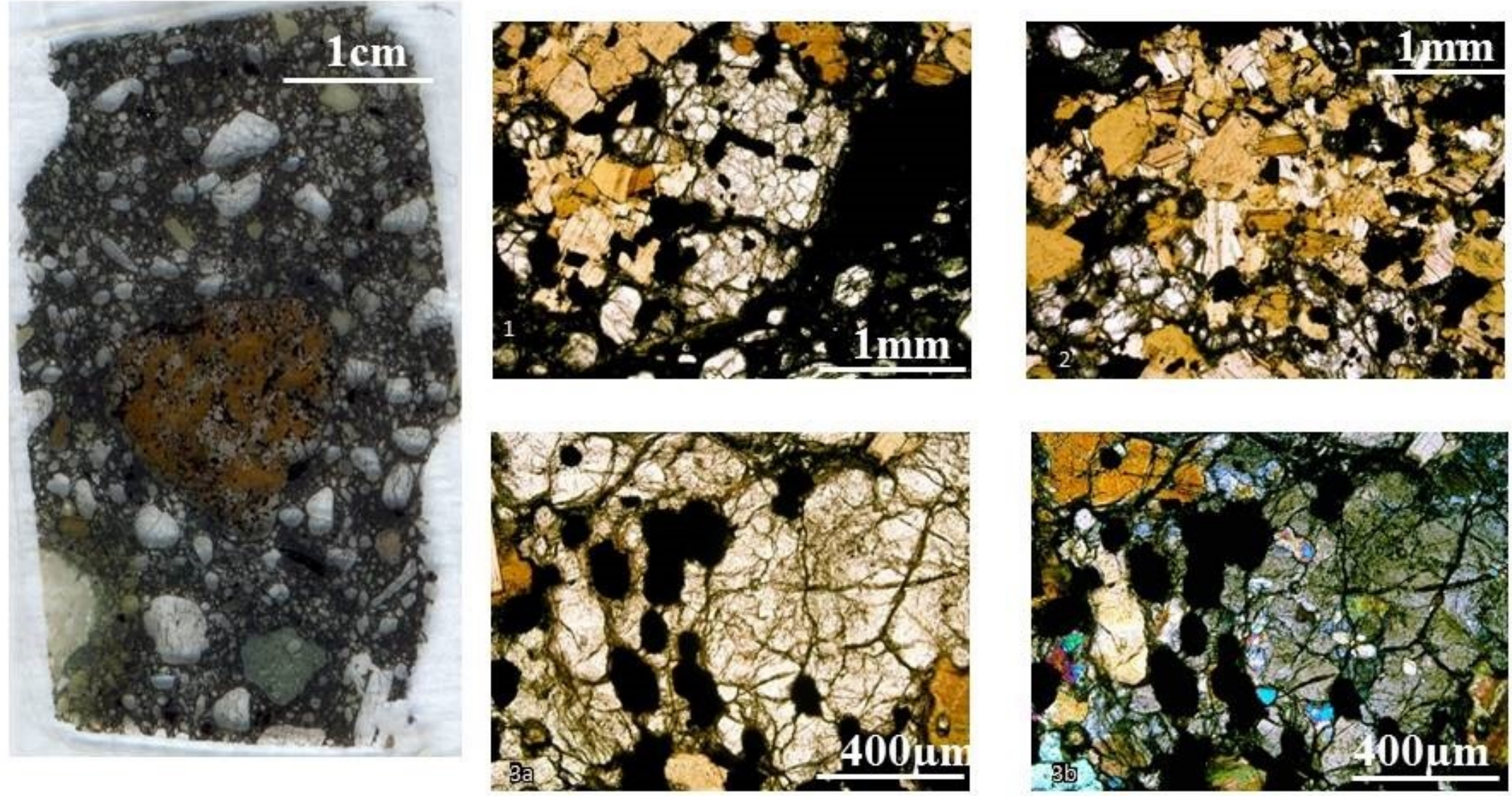

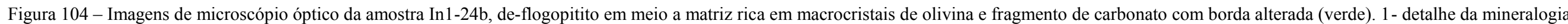

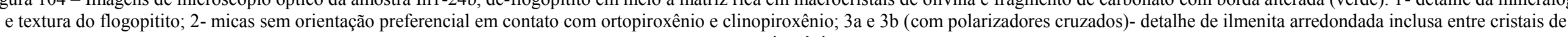
ortopiroxênio. 

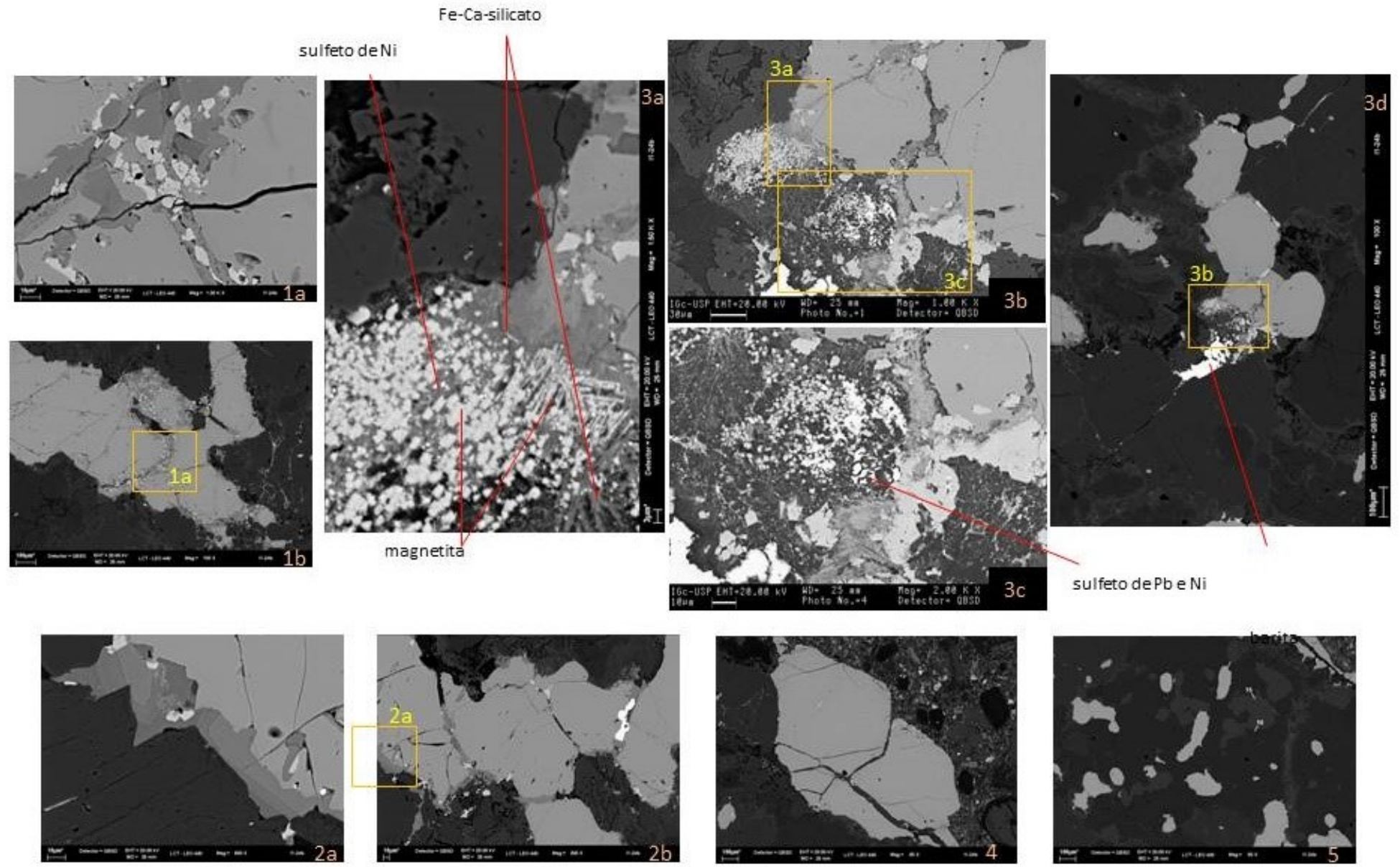

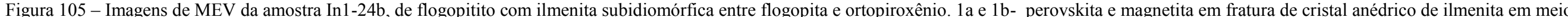

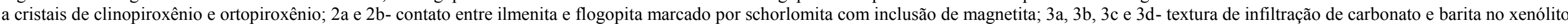

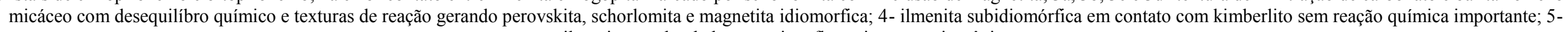
ilmenita arredondada em meio a flogopita e ortopiroxênio. 

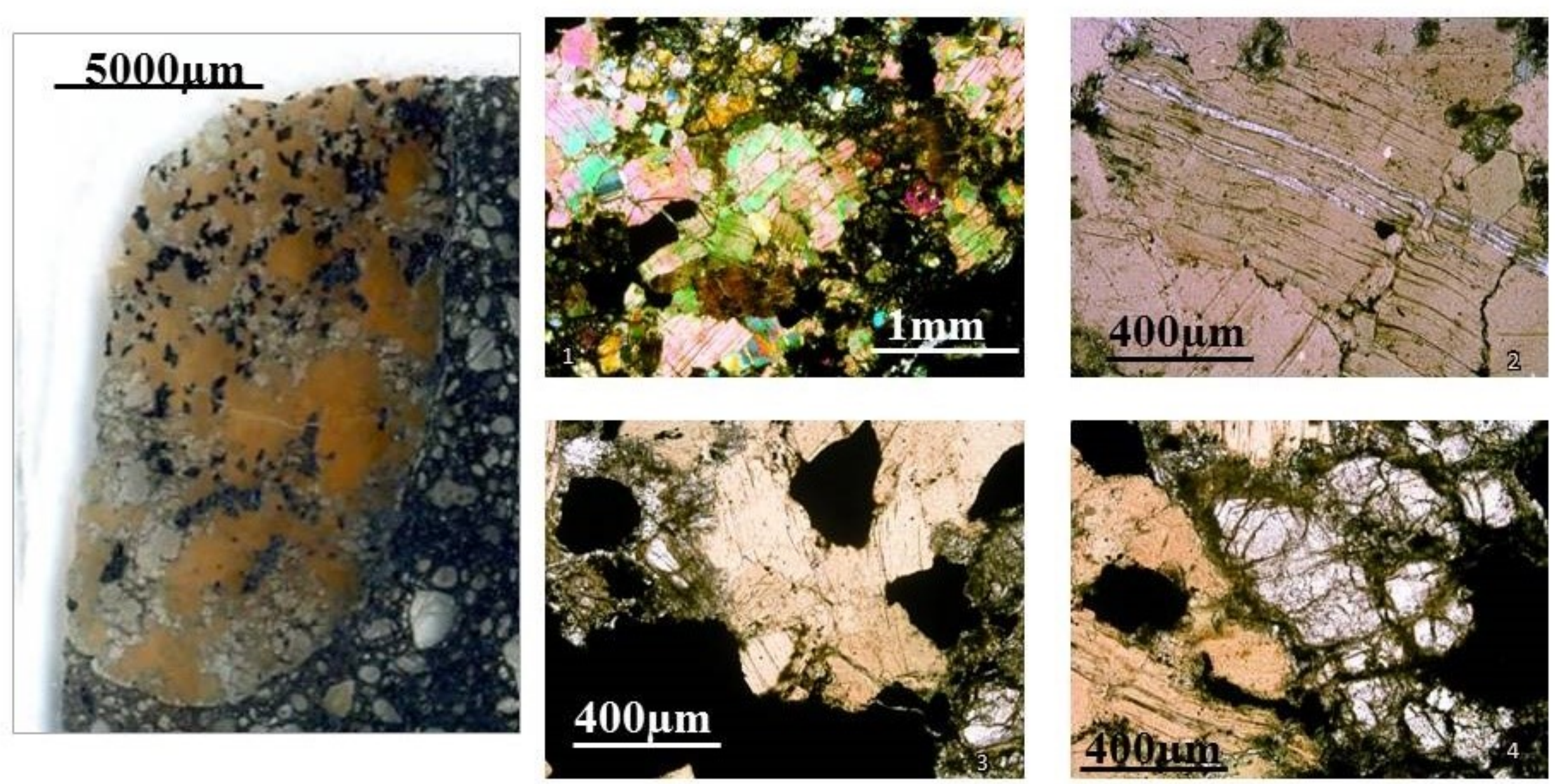

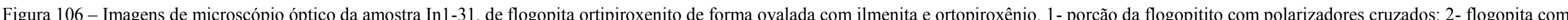
barita entre as placas; 3 e 4 - relação de contato entre flogopita, óxidos e clinopiroxênio. 

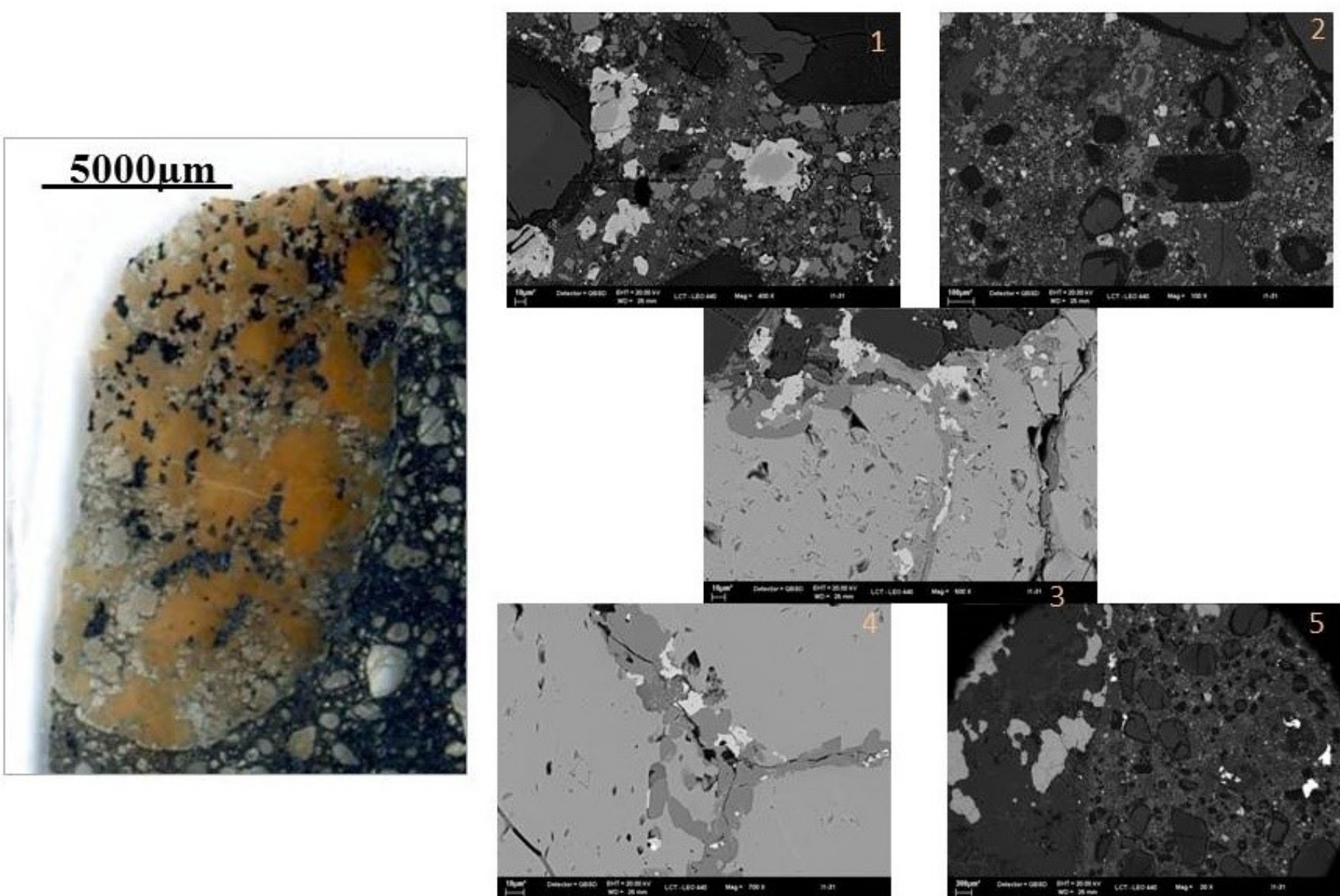

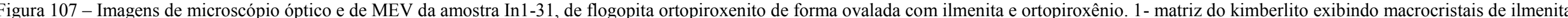

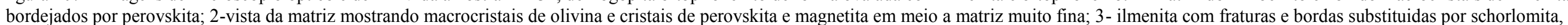
perovskita e magnetita; 4- contato do flogopitito com a matriz kimberlítica. 


\section{ANEXO C}

Tabelas com as composições de elementos maiores de minerais de xenólitos e rochas hospedeiras, com a seguinte ordem:

\section{Olivina}

Ortopiroxênio

Clinopiroxênio

Minerais do grupo do espinélio

Anfibólio

Ilmenita

Flogopita

Titanatos

Perovskita

Monticellita

Saponita

Harmotoma

Nefelina 
Tabela 19- Composição química de olivina em lherzolitos e harzburgitos com espinélio dos corpos Indaiá 1 e Limeira 1.

\begin{tabular}{|c|c|c|c|c|c|c|c|c|c|c|c|c|c|c|c|c|c|c|c|}
\hline $\begin{array}{l}\text { Código da } \\
\text { amostra }\end{array}$ & In1-4-2 & In1-4-2' & In1-9-1 & In1-9-2 & In1-9-3 & In1-9-4 & In1-13a-1 & In1-13a-2 & In1-13a-3 & In1-14a-1 & In1-14a-2 & In1-14a-4 & In1-14a-5 & In1-14a-6 & In1-14a-7 & Lm1-17-12 & Lm1-17-11 & Lm1-17-10 & Lm1-17-3 \\
\hline Tipo & \multicolumn{2}{|c|}{$\begin{array}{l}\text { lherzolito protogranular } \\
\text { com espinélio }\end{array}$} & \multicolumn{4}{|c|}{ Iherzolito protogranular com espinélio } & \multicolumn{3}{|c|}{ lherzolito protogranular com espinélio } & \multicolumn{6}{|c|}{ Iherzolito protogranular com espinélio } & \multicolumn{4}{|c|}{ harzburgito protogranular com espinélio } \\
\hline $\mathrm{SiO}_{2}$ & 40,00 & 39,56 & 40,89 & 40,85 & 40,94 & 40,61 & 40,59 & 41,59 & 41,25 & 40,34 & 40,48 & 40,88 & 40,84 & 40,79 & 40,61 & 40,74 & 40,88 & 40,96 & 40,71 \\
\hline $\mathrm{TiO}_{2}$ & 0,00 & 0,00 & 0,00 & 0,00 & 0,00 & 0,00 & 0,00 & 0,00 & 0,00 & 0,00 & 0,08 & 0,00 & 0,01 & 0,05 & 0,00 & 0,01 & 0,00 & 0,00 & 0,01 \\
\hline $\mathrm{Al}_{2} \mathrm{O}_{3}$ & 0,09 & 0,07 & 0,03 & 0,01 & 0,02 & 0,03 & 0,00 & 0,00 & 0,01 & 0,02 & 0,00 & 0,00 & 0,00 & 0,00 & 0,00 & 0,00 & 0,00 & 0,00 & 0,07 \\
\hline $\mathrm{FeO}$ & 9,62 & 9,13 & 8,79 & 8,55 & 9,01 & 8,78 & 7,63 & 8,04 & 8,65 & 8,28 & 8,53 & 8,96 & 8,70 & 8,76 & 8,51 & 8,74 & 9,28 & 8,96 & 9,24 \\
\hline $\mathrm{MnO}$ & 0,10 & 0,13 & 0,14 & 0,13 & 0,08 & 0,11 & 0,08 & 0,12 & 0,05 & 0,14 & 0,15 & 0,16 & 0,12 & 0,12 & 0,11 & 0,22 & 0,12 & 0,20 & 0,19 \\
\hline $\mathrm{MgO}$ & 49,42 & 49,51 & 51,57 & 51,82 & 51,64 & 51,98 & 50,21 & 51,20 & 51,04 & 51,02 & 51,08 & 51,56 & 51,23 & 51,18 & 51,88 & 50,26 & 50,14 & 50,68 & 50,65 \\
\hline $\mathrm{CaO}$ & 0,01 & 0,00 & 0,00 & 0,02 & 0,00 & 0,00 & 0,03 & 0,01 & 0,02 & 0,03 & 0,03 & 0,00 & 0,00 & 0,01 & 0,02 & 0,00 & 0,01 & 0,04 & 0,00 \\
\hline $\mathrm{Na}_{2} \mathrm{O}$ & 0,10 & 0,00 & 0,00 & 0,01 & 0,00 & 0,00 & 0,01 & 0,00 & 0,00 & 0,03 & 0,02 & 0,00 & 0,00 & 0,00 & 0,00 & 0,03 & 0,00 & 0,04 & 0,04 \\
\hline $\mathrm{K}_{2} \mathrm{O}$ & 0,01 & 0,01 & 0,00 & 0,00 & 0,00 & 0,01 & 0,01 & 0,00 & 0,00 & 0,00 & 0,01 & 0,01 & 0,00 & 0,00 & 0,00 & 0,00 & 0,00 & 0,01 & 0,00 \\
\hline $\mathrm{Cr}_{2} \mathrm{O}_{3}$ & 0,02 & 0,01 & 0,00 & 0,01 & 0,01 & 0,00 & 0,01 & 0,00 & 0,02 & 0,01 & 0,01 & 0,01 & 0,00 & 0,03 & 0,00 & 0,00 & 0,00 & 0,05 & 0,01 \\
\hline $\mathrm{NiO}$ & 0,41 & 0,39 & 0,38 & 0,41 & 0,40 & 0,40 & 0,39 & 0,42 & 0,44 & 0,43 & 0,38 & 0,42 & 0,36 & 0,43 & 0,40 & 0,34 & 0,41 & 0,47 & 0,36 \\
\hline Total & 99,78 & 98,83 & 101,80 & 101,79 & 102,11 & 101,92 & 98,96 & 101,37 & 101,47 & 100,29 & 100,78 & 101,98 & 101,25 & 101,36 & 101,53 & 100,34 & 100,84 & 101,41 & 101,27 \\
\hline $\mathrm{TSi}$ & 0,980 & 0,977 & 0,977 & 0,975 & 0,976 & 0,968 & 0,996 & 0,997 & 0,990 & 0,977 & 0,977 & 0,976 & 0,981 & 0,980 & 0,971 & 0,990 & 0,990 & 0,985 & 0,980 \\
\hline $\mathrm{TFe}^{3+}$ & 0,020 & 0,023 & 0,023 & 0,025 & 0,024 & 0,032 & 0,004 & 0,003 & 0,010 & 0,023 & 0,023 & 0,024 & 0,019 & 0,020 & 0,029 & 0,010 & 0,010 & 0,015 & 0,020 \\
\hline TAl & 0,000 & 0,000 & 0,000 & 0,000 & 0,000 & 0,000 & 0,000 & 0,000 & 0,000 & 0,000 & 0,000 & 0,000 & 0,000 & 0,000 & 0,000 & 0,000 & 0,000 & 0,000 & 0,000 \\
\hline Ttotal & 1,000 & 1,000 & 1,000 & 1,000 & 1,000 & 1,000 & 1,000 & 1,000 & 1,000 & 1,000 & 1,000 & 1,000 & 1,000 & 1,000 & 1,000 & 1,000 & 1,000 & 1,000 & 1,000 \\
\hline $\mathrm{M} 1 \mathrm{Fe}^{3+}$ & 0,022 & 0,021 & 0,022 & 0,025 & 0,024 & 0,032 & 0,004 & 0,003 & 0,009 & 0,024 & 0,021 & 0,024 & 0,019 & 0,018 & 0,029 & 0,012 & 0,010 & 0,016 & 0,019 \\
\hline M1Al & 0,002 & 0,002 & 0,001 & 0,000 & 0,001 & 0,001 & 0,000 & 0,000 & 0,000 & 0,001 & 0,000 & 0,000 & 0,000 & 0,000 & 0,000 & 0,000 & 0,000 & 0,000 & 0,002 \\
\hline M1Mg & 1,805 & 1,822 & 1,837 & 1,843 & 1,835 & 1,846 & 1,837 & 1,831 & 1,826 & 1,842 & 1,837 & 1,834 & 1,835 & 1,832 & 1,849 & 1,820 & 1,811 & 1,817 & 1,819 \\
\hline${\mathrm{M} 1 \mathrm{Fe}^{2+}}^{2+}$ & 0,155 & 0,144 & 0,130 & 0,120 & 0,131 & 0,111 & 0,148 & 0,156 & 0,154 & 0,121 & 0,128 & 0,130 & 0,137 & 0,138 & 0,112 & 0,155 & 0,169 & 0,150 & 0,148 \\
\hline M1K & 0,000 & 0,000 & 0,000 & 0,000 & 0,000 & 0,000 & 0,000 & 0,000 & 0,000 & 0,000 & 0,000 & 0,000 & 0,000 & 0,000 & 0,000 & 0,000 & 0,000 & 0,000 & 0,000 \\
\hline $\mathrm{M} 1 \mathrm{Ni}$ & 0,008 & 0,008 & 0,007 & 0,008 & 0,008 & 0,008 & 0,008 & 0,008 & 0,008 & 0,008 & 0,007 & 0,008 & 0,007 & 0,008 & 0,008 & 0,007 & 0,008 & 0,009 & 0,007 \\
\hline $\mathrm{M} 1 \mathrm{Cr}$ & 0,000 & 0,000 & 0,000 & 0,000 & 0,000 & 0,000 & 0,000 & 0,000 & 0,000 & 0,000 & 0,000 & 0,000 & 0,000 & 0,000 & 0,000 & 0,000 & 0,000 & 0,001 & 0,000 \\
\hline M1Mn & 0,002 & 0,003 & 0,003 & 0,003 & 0,002 & 0,002 & 0,002 & 0,002 & 0,001 & 0,003 & 0,003 & 0,003 & 0,002 & 0,002 & 0,002 & 0,005 & 0,002 & 0,004 & 0,004 \\
\hline M1Ti & 0,000 & 0,000 & 0,000 & 0,000 & 0,000 & 0,000 & 0,000 & 0,000 & 0,000 & 0,000 & 0,002 & 0,000 & 0,000 & 0,001 & 0,000 & 0,000 & 0,000 & 0,000 & 0,000 \\
\hline $\mathrm{M} 1 \mathrm{Ca}$ & 0,002 & 0,002 & 0,001 & 0,000 & 0,001 & 0,001 & 0,000 & 0,000 & 0,000 & 0,001 & 0,000 & 0,000 & 0,000 & 0,000 & 0,000 & 0,000 & 0,000 & 0,000 & 0,002 \\
\hline M1 Total & 1,997 & 2,002 & 2,001 & 1,999 & 2,000 & 2,001 & 1,999 & 2,000 & 2,000 & 1,999 & 1,999 & 2,000 & 2,000 & 2,000 & 2,000 & 1,998 & 2,000 & 1,997 & 2,000 \\
\hline $\mathrm{mg} \#$ & 0,902 & 0,906 & 0,913 & 0,915 & 0,911 & 0,913 & 0,921 & 0,919 & 0,913 & 0,917 & 0,914 & 0,911 & 0,913 & 0,912 & 0,916 & 0,911 & 0,906 & 0,910 & 0,907 \\
\hline $\mathrm{Fa}$ & 0,098 & 0,094 & 0,087 & 0,085 & 0,089 & 0,087 & 0,079 & 0,081 & 0,087 & 0,083 & 0,086 & 0,089 & 0,087 & 0,088 & 0,084 & 0,089 & 0,094 & 0,090 & 0,093 \\
\hline
\end{tabular}


Tabela 20- Composição química de olivina em lherzolitos e harzburgitos com espinélio dos corpos Indaiá 1 e Limeira 1.

\begin{tabular}{|c|c|c|c|c|c|c|c|c|c|c|c|c|c|c|c|c|c|}
\hline $\begin{array}{c}\text { Código da } \\
\text { amostra }\end{array}$ & Fo-2-4 & Fo-2-7d & Fo-2-7e & Fo-2-29 & Fo-2-38 & Fo-2-21 & Fo-1-19a & Fo-1-19b & Fo-1-19c & Fo-1-25 & Fo-1-26 & Fo-6-11 & Fo-6-9 & Fo-6-12 & Fo-6-25 & Fo-6-10 & Fo-6-1 \\
\hline & \multicolumn{6}{|c|}{ espinélio lherzolito granoblástico } & \multicolumn{3}{|c|}{ harzburgito protogranular com espinélio } & \multicolumn{2}{|c|}{$\begin{array}{l}\text { harzburgito borda de } \\
\text { reação carbonato }\end{array}$} & \multicolumn{6}{|c|}{ harzburgito granoblástico com espinélio } \\
\hline $\begin{array}{l}\text { Tipo } \\
\mathrm{SiO}_{2}\end{array}$ & 40,80 & 40,43 & 39.82 & 41,56 & 40,95 & 40,87 & 40,43 & 41,45 & 39,23 & 40,13 & 40,50 & 40,22 & 39.48 & 40,50 & 40,48 & 40,74 & 40,43 \\
\hline $\mathrm{TiO}_{2}$ & 0,04 & 0,07 & 0,00 & 0,00 & 0,01 & 0,00 & 0,00 & 0,00 & 0,00 & 0,04 & 0,00 & 0,00 & 0,00 & 0,03 & 0,03 & 0,00 & 0,02 \\
\hline $\mathrm{Al}_{2} \mathrm{O}_{3}$ & 0,01 & 0,00 & 0,00 & 0,01 & 0,00 & 0,00 & 0,05 & 0,00 & 0,01 & 0,00 & 0,03 & 0,00 & 0,03 & 0,07 & 0,10 & 0,07 & 0,00 \\
\hline $\mathrm{FeO}$ & 9,33 & 8,59 & 13,41 & 9,15 & 9,00 & 8,79 & 8,51 & 8,23 & 11,02 & 8,03 & 8,44 & 7,63 & 7,83 & 7,48 & 8,04 & 7,81 & 10,44 \\
\hline $\mathrm{MnO}$ & 0,16 & 0,12 & 0,17 & 0,19 & 0,11 & 0,11 & 0,20 & 0,12 & 0,19 & 0,17 & 0,16 & 0,04 & 0,06 & 0,02 & 0,16 & 0,20 & 0,17 \\
\hline $\mathrm{MgO}$ & 50,62 & 50,30 & 47,70 & 50,55 & 50,26 & 50,05 & 50,77 & 51,25 & 48,51 & 51,39 & 50,89 & 50,85 & 50,80 & 51,46 & 51,46 & 50,82 & 49,55 \\
\hline $\mathrm{CaO}$ & 0,06 & 0,05 & 0,10 & 0,02 & 0,01 & 0,03 & 0,01 & 0,01 & 0,01 & 0,04 & 0,00 & 0,00 & 0,00 & 0,04 & 0,00 & 0,00 & 0,04 \\
\hline $\mathrm{Na}_{2} \mathrm{O}$ & 0,03 & 0,00 & 0,03 & 0,00 & 0,00 & 0,00 & 0,04 & 0,07 & 0,07 & 0,09 & 0,00 & 0,14 & 0,30 & 0,18 & 0,03 & 0,11 & 0,11 \\
\hline $\mathrm{K}_{2} \mathrm{O}$ & 0,00 & 0,02 & 0,03 & 0,00 & 0,00 & 0,01 & 0,00 & 0,01 & 0,00 & 0,00 & 0,04 & 0,00 & 0,02 & 0,01 & 0,00 & 0,00 & 0,01 \\
\hline $\mathrm{Cr}_{2} \mathrm{O}_{3}$ & 0,01 & 0,00 & 0,00 & 0,00 & 0,00 & 0,00 & 0,09 & 0,00 & 0,00 & 0,00 & 0,00 & 0,05 & 0,05 & 0,01 & 0,00 & 0,00 & 0,00 \\
\hline $\mathrm{NiO}$ & 0,44 & 0,38 & 0,25 & 0,48 & 0,43 & 0,38 & 0,46 & 0,43 & 0,43 & 0,39 & 0,36 & 0,32 & 0,44 & 0,40 & 0,41 & 0,34 & 0,29 \\
\hline Total & 101,49 & 99,95 & 101,52 & 101,97 & 100,77 & 100,24 & 100,56 & 101,56 & 99,48 & 100,28 & 100,41 & 99,24 & 99,02 & 100,20 & 100,71 & 100,08 & 101,06 \\
\hline $\mathrm{TSi}$ & 0,981 & 0,985 & 0,974 & 0,996 & 0,992 & 0,995 & 0,978 & 0,992 & 0,969 & 0,970 & 0,980 & 0,981 & 0,964 & 0,977 & 0,975 & 0,988 & 0,981 \\
\hline $\mathrm{TFe}^{3+}$ & 0,019 & 0,015 & 0,026 & 0,004 & 0,008 & 0,005 & 0,022 & 0,008 & 0,031 & 0,030 & 0,020 & 0,019 & 0,036 & 0,023 & 0,025 & 0,012 & 0,019 \\
\hline TAl & 0,000 & 0,000 & 0,000 & 0,000 & 0,000 & 0,000 & 0,000 & 0,000 & 0,000 & 0,000 & 0,000 & 0,000 & 0,000 & 0,000 & 0,000 & 0,000 & 0,000 \\
\hline Ttotal & 1,000 & 1,000 & 1,000 & 1,000 & 1,000 & 1,000 & 1,000 & 1,000 & 1,000 & 1,000 & 1,000 & 1,000 & 1,000 & 1,000 & 1,000 & 1,000 & 1,000 \\
\hline $\mathrm{M}^{1 \mathrm{Fe}^{3+}}$ & 0,018 & 0,013 & 0,029 & 0,003 & 0,008 & 0,006 & 0,019 & 0,011 & 0,034 & 0,033 & 0,020 & 0,024 & 0,048 & 0,029 & 0,022 & 0,016 & 0,024 \\
\hline M1Al & 0,000 & 0,000 & 0,000 & 0,000 & 0,000 & 0,000 & 0,002 & 0,000 & 0,000 & 0,000 & 0,001 & 0,000 & 0,001 & 0,002 & 0,003 & 0,002 & 0,000 \\
\hline M1Mg & 1,815 & 1,827 & 1,739 & 1,806 & 1,815 & 1,816 & 1,831 & 1,829 & 1,787 & 1,851 & 1,837 & 1,849 & 1,849 & 1,851 & 1,848 & 1,836 & 1,792 \\
\hline${\mathrm{M} 1 \mathrm{Fe}^{2+}}^{++}$ & 0,151 & 0,147 & 0,219 & 0,176 & 0,166 & 0,168 & 0,131 & 0,146 & 0,163 & 0,099 & 0,131 & 0,113 & 0,076 & 0,100 & 0,114 & 0,130 & 0,169 \\
\hline $\mathrm{M} 1 \mathrm{~K}$ & 0,000 & 0,000 & 0,001 & 0,000 & 0,000 & 0,000 & 0,000 & 0,000 & 0,000 & 0,000 & 0,001 & 0,000 & 0,001 & 0,000 & 0,000 & 0,000 & 0,000 \\
\hline M1Ni & 0,009 & 0,007 & 0,005 & 0,009 & 0,008 & 0,007 & 0,009 & 0,008 & 0,009 & 0,008 & 0,007 & 0,006 & 0,009 & 0,008 & 0,008 & 0,007 & 0,006 \\
\hline $\mathrm{M} 1 \mathrm{Cr}$ & 0,000 & 0,000 & 0,000 & 0,000 & 0,000 & 0,000 & 0,001 & 0,000 & 0,000 & 0,000 & 0,000 & 0,001 & 0,001 & 0,000 & 0,000 & 0,000 & 0,000 \\
\hline M1Mn & 0,003 & 0,002 & 0,004 & 0,004 & 0,002 & 0,002 & 0,004 & 0,002 & 0,004 & 0,003 & 0,003 & 0,001 & 0,001 & 0,000 & 0,003 & 0,004 & 0,003 \\
\hline M1Ti & 0,001 & 0,001 & 0,000 & 0,000 & 0,000 & 0,000 & 0,000 & 0,000 & 0,000 & 0,001 & 0,000 & 0,000 & 0,000 & 0,000 & 0,001 & 0,000 & 0,000 \\
\hline $\mathrm{M} 1 \mathrm{Ca}$ & 0,000 & 0,000 & 0,000 & 0,000 & 0,000 & 0,000 & 0,002 & 0,000 & 0,000 & 0,000 & 0,001 & 0,000 & 0,001 & 0,002 & 0,003 & 0,002 & 0,000 \\
\hline M1Total & 1,998 & 1,999 & 1,996 & 2,000 & 2,000 & 1,999 & 1,999 & 1,997 & 1,996 & 1,995 & 2,001 & 1,993 & 1,987 & 1,992 & 2,001 & 1,997 & 1,994 \\
\hline $\mathrm{mg \#}$ & 0,906 & 0,913 & 0,864 & 0,908 & 0,909 & 0,910 & 0,914 & 0,917 & 0,887 & 0,919 & 0,915 & 0,922 & 0,920 & 0,925 & 0,919 & 0,921 & 0,894 \\
\hline fa & 0,094 & 0,087 & 0,136 & 0,092 & 0,091 & 0,090 & 0,086 & 0,083 & 0,113 & 0,081 & 0,085 & 0,078 & 0,080 & 0,075 & 0,081 & 0,079 & 0,106 \\
\hline
\end{tabular}


Tabela 21- Composição química de olivina em harzburgitos e dunitos com Cr-espinélio dos corpos Indaiá 1 e Limeira 1.

\begin{tabular}{|c|c|c|c|c|c|c|c|c|c|c|c|c|c|c|c|c|c|c|c|c|}
\hline $\begin{array}{l}\text { Código } \\
\text { da } \\
\text { amostra }\end{array}$ & $\begin{array}{r}\text { In1-3-2 } \\
\text { ha }\end{array}$ & $\begin{array}{l}\text { In1-3-3 } \\
\text { burgito grc }\end{array}$ & $\begin{array}{l}\text { In1-3-4 } \\
\text { blástico }\end{array}$ & $\begin{array}{l}\text { In1-3-5 } \\
\text { m Cr-espir }\end{array}$ & $\begin{array}{l}\text { In1-3-6 } \\
\text { io }\end{array}$ & In1-14c-1a & In1-14c-3 & $\begin{array}{l}\text { In1-14c-4 } \\
\text { dunito com }\end{array}$ & $\begin{array}{l}\text { In1-14c-5 } \\
\text { Cr-espinélio }\end{array}$ & In1-14c-8 & In1-14c-9 & Lm1-20a-5 & Lm1-20a-7 & Lm1-20a-4 & $\begin{array}{r}\text { Lm1-20a-3 } \\
\text { harzbur }\end{array}$ & $\begin{array}{l}\mathrm{Lm} 1-20 \mathrm{a}-2 \\
\text { sito com Cr}\end{array}$ & $\begin{array}{l}\text { Lm1-20a-1 } \\
\text { espinélio }\end{array}$ & Lm1-20-1 & Lm1-20-5' & Lm1-20- \\
\hline $\mathrm{SiO}_{2}$ & 40,51 & 41,25 & 41,05 & 40,16 & 40,27 & 41,09 & 41,66 & 41,53 & 41,60 & 41,29 & 41,49 & 40,63 & 40,52 & 40,71 & 40,96 & 40,88 & 40,85 & 40,64 & 41,67 & 41,46 \\
\hline $\mathrm{TiO}_{2}$ & 0,04 & 0,08 & 0,00 & 0,00 & 0,00 & 0,00 & 0,00 & 0,00 & 0,00 & 0,00 & 0,03 & 0,00 & 0,00 & 0,00 & 0,00 & 0,00 & 0,00 & 0,00 & 0,00 & 0,00 \\
\hline $\mathrm{Al}_{2} \mathrm{O}_{3}$ & 0,03 & 0,00 & 0,01 & 0,00 & 0,00 & 0,02 & 0,03 & 0,01 & 0,09 & 0,02 & 0,01 & 0,03 & 0,06 & 0,00 & 0,00 & 0,03 & 0,02 & 0,03 & 0,01 & 0,00 \\
\hline $\mathrm{FeO}$ & 7,49 & 8,00 & 7,74 & 7,16 & 7,23 & 8,92 & 8,34 & 8,39 & 8,05 & 8,41 & 8,65 & 8,24 & 8,11 & 8,06 & 8,40 & 8,27 & 8,39 & 7,84 & 8,57 & 8,46 \\
\hline $\mathrm{MnO}$ & 0,11 & 0,05 & 0,14 & 0,11 & 0,09 & 0,15 & 0,09 & 0,14 & 0,19 & 0,12 & 0,12 & 0,08 & 0,08 & 0,10 & 0,04 & 0,12 & 0,08 & 0,13 & 0,03 & 0,16 \\
\hline $\mathrm{MgO}$ & 50,13 & 51,59 & 51,19 & 50,29 & 50,87 & 51,13 & 51,12 & 50,84 & 50,97 & 50,34 & 50,35 & 50,24 & 50,22 & 50,30 & 50,23 & 50,52 & 50,70 & 50,91 & 51,06 & 50,94 \\
\hline $\mathrm{CaO}$ & 0,00 & 0,01 & 0,00 & 0,03 & 0,02 & 0,01 & 0,01 & 0,02 & 0,00 & 0,02 & 0,02 & 0,00 & 0,00 & 0,00 & 0,00 & 0,00 & 0,00 & 0,00 & 0,06 & 0,01 \\
\hline $\mathrm{Na}_{2} \mathrm{O}$ & 0,00 & 0,00 & 0,02 & 0,01 & 0,02 & 0,06 & 0,04 & 0,00 & 0,03 & 0,11 & 0,07 & 0,00 & 0,02 & 0,05 & 0,05 & 0,00 & 0,00 & 0,03 & 0,01 & 0,02 \\
\hline $\mathrm{K}_{2} \mathrm{O}$ & 0,00 & 0,00 & 0,00 & 0,00 & 0,00 & 0,02 & 0,00 & 0,02 & 0,00 & 0,03 & 0,01 & 0,02 & 0,00 & 0,04 & 0,01 & 0,01 & 0,00 & 0,01 & 0,02 & 0,00 \\
\hline $\mathrm{Cr}_{2} \mathrm{O}_{3}$ & 0,00 & 0,02 & 0,03 & 0,00 & 0,00 & 0,05 & 0,03 & 0,01 & 0,00 & 0,00 & 0,00 & 0,00 & 0,00 & 0,00 & 0,06 & 0,00 & 0,02 & 0,06 & 0,07 & 0,00 \\
\hline $\mathrm{NiO}$ & 0,39 & 0,44 & 0,46 & 0,37 & 0,36 & 0,40 & 0,31 & 0,46 & 0,41 & 0,43 & 0,38 & 0,49 & 0,46 & 0,36 & 0,42 & 0,41 & 0,48 & 0,25 & 0,43 & 0,39 \\
\hline Total & 98,69 & 101,44 & 100,63 & 98,12 & 98,86 & 101,86 & 101,63 & 101,42 & 101,34 & 100,78 & 101,13 & 99,74 & 99,47 & 99,61 & 100,17 & 100,25 & 100,55 & 99,92 & 101,93 & 101,44 \\
\hline $\mathrm{TSi}$ & 0,996 & 0,987 & 0,990 & 0,991 & 0,986 & 0,983 & 0,997 & 0,998 & 0,999 & 0,998 & 1,001 & 0,991 & 0,991 & 0,993 & 0,996 & 0,992 & 0,989 & 0,987 & 0,996 & 0,995 \\
\hline $\mathrm{TFe}^{3+}$ & 0,004 & 0,013 & 0,010 & 0,009 & 0,014 & 0,017 & 0,003 & 0,002 & 0,001 & 0,002 & 0,000 & 0,009 & 0,009 & 0,007 & 0,004 & 0,008 & 0,011 & 0,013 & 0,004 & 0,005 \\
\hline TAl & 0,000 & 0,000 & 0,000 & 0,000 & 0,000 & 0,000 & 0,000 & 0,000 & 0,000 & 0,000 & 0,000 & 0,000 & 0,000 & 0,000 & 0,000 & 0,000 & 0,000 & 0,000 & 0,000 & 0,000 \\
\hline Ttotal & 1,000 & 1,000 & 1,000 & 1,000 & 1,000 & 1,000 & 1,000 & 1,000 & 1,000 & 1,000 & 1,001 & 1,000 & 1,000 & 1,000 & 1,000 & 1,000 & 1,000 & 1,000 & 1,000 & 1,000 \\
\hline${\mathrm{M} 1 \mathrm{Fe}^{3+}}^{3+}$ & 0,002 & 0,009 & 0,010 & 0,009 & 0,015 & 0,018 & 0,003 & 0,002 & 0,000 & 0,007 & 0,001 & 0,008 & 0,009 & 0,010 & 0,005 & 0,007 & 0,010 & 0,013 & 0,002 & 0,005 \\
\hline M1Al & 0,001 & 0,000 & 0,000 & 0,000 & 0,000 & 0,001 & 0,001 & 0,000 & 0,002 & 0,001 & 0,000 & 0,001 & 0,002 & 0,000 & 0,000 & 0,001 & 0,000 & 0,001 & 0,000 & 0,000 \\
\hline $\mathrm{M} 1 \mathrm{Mg}$ & 1,838 & 1,841 & 1,841 & 1,850 & 1,856 & 1,823 & 1,824 & 1,821 & 1,824 & 1,814 & 1,810 & 1,828 & 1,830 & 1,830 & 1,821 & 1,828 & 1,830 & 1,843 & 1,820 & 1,823 \\
\hline${\mathrm{M} 1 \mathrm{Fe}^{2+}}^{2+}$ & 0,149 & 0,139 & 0,137 & 0,130 & 0,119 & 0,143 & 0,161 & 0,164 & 0,160 & 0,161 & 0,173 & 0,151 & 0,148 & 0,147 & 0,162 & 0,153 & 0,148 & 0,133 & 0,165 & 0,160 \\
\hline M1K & 0,000 & 0,000 & 0,000 & 0,000 & 0,000 & 0,001 & 0,000 & 0,000 & 0,000 & 0,001 & 0,000 & 0,001 & 0,000 & 0,001 & 0,000 & 0,000 & 0,000 & 0,000 & 0,001 & 0,000 \\
\hline $\mathrm{M} 1 \mathrm{Ni}$ & 0,008 & 0,008 & 0,009 & 0,007 & 0,007 & 0,008 & 0,006 & 0,009 & 0,008 & 0,008 & 0,007 & 0,010 & 0,009 & 0,007 & 0,008 & 0,008 & 0,009 & 0,005 & 0,008 & 0,008 \\
\hline $\mathrm{M} 1 \mathrm{Cr}$ & 0,000 & 0,000 & 0,000 & 0,000 & 0,000 & 0,001 & 0,000 & 0,000 & 0,000 & 0,000 & 0,000 & 0,000 & 0,000 & 0,000 & 0,001 & 0,000 & 0,000 & 0,001 & 0,001 & 0,000 \\
\hline M1Mn & 0,002 & 0,001 & 0,003 & 0,002 & 0,002 & 0,003 & 0,002 & 0,003 & 0,004 & 0,002 & 0,002 & 0,002 & 0,002 & 0,002 & 0,001 & 0,002 & 0,002 & 0,003 & 0,001 & 0,003 \\
\hline M1Ti & 0,001 & 0,002 & 0,000 & 0,000 & 0,000 & 0,000 & 0,000 & 0,000 & 0,000 & 0,000 & 0,001 & 0,000 & 0,000 & 0,000 & 0,000 & 0,000 & 0,000 & 0,000 & 0,000 & 0,000 \\
\hline $\mathrm{M} 1 \mathrm{Ca}$ & 0,001 & 0,000 & 0,000 & 0,000 & 0,000 & 0,001 & 0,001 & 0,000 & 0,002 & 0,001 & 0,000 & 0,001 & 0,002 & 0,000 & 0,000 & 0,001 & 0,000 & 0,001 & 0,000 & 0,000 \\
\hline M1Total & 2,001 & 2,000 & 1,999 & 1,999 & 1,999 & 1,998 & 1,998 & 2,000 & 2,001 & 1,995 & 1,996 & 2,001 & 2,001 & 1,997 & 1,998 & 2,001 & 2,000 & 1,999 & 1,998 & 1,999 \\
\hline $\mathrm{mg} \#$ & 0,923 & 0,920 & 0,922 & 0,926 & 0,926 & 0,911 & 0,916 & 0,915 & 0,919 & 0,914 & 0,912 & 0,916 & 0,917 & 0,917 & 0,914 & 0,916 & 0,915 & 0,920 & 0,914 & 0,915 \\
\hline fa & 0,077 & 0,080 & 0,078 & 0,074 & 0,074 & 0,089 & 0,084 & 0,085 & 0,081 & 0,086 & 0,088 & 0,084 & 0,083 & 0,083 & 0,086 & 0,084 & 0,085 & 0,080 & 0,086 & 0,085 \\
\hline
\end{tabular}


Tabela 22- Composição química de olivina em harzburgitos e dunitos com Cr-espinélio dos corpos Indaiá 1 e Limeira 1.

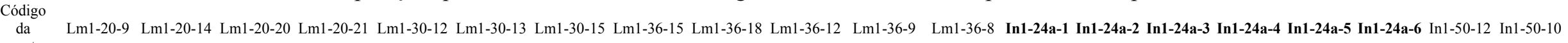

\begin{tabular}{|c|c|c|c|c|c|c|c|c|c|c|c|c|c|c|c|c|c|c|c|c|}
\hline \multirow{2}{*}{$\begin{array}{l}\text { tipo } \\
\mathrm{SiO}_{2}\end{array}$} & \multicolumn{4}{|c|}{ harzburgito granoblástico com Cr-espinélio } & \multicolumn{3}{|c|}{$\begin{array}{l}\text { harzburgito granoblástico com Cr- } \\
\text { espinélio }\end{array}$} & \multicolumn{5}{|c|}{ harzburgito granoblástico com Cr-espinélio } & \multicolumn{6}{|c|}{ dunito granoblástico com Cr-espinélio e pargasita } & \multicolumn{2}{|c|}{$\begin{array}{l}\text { harzburgito com } \mathrm{Cr} \\
\text { espinélio e pargasita }\end{array}$} \\
\hline & 41,13 & 41,25 & 41,71 & 40,98 & 40,98 & 41,42 & 41,42 & 41,53 & 41,47 & 41,17 & 41,33 & 41,55 & 40,59 & 40,65 & 40,27 & 40,73 & 40,91 & 41,07 & 40,77 & 40,40 \\
\hline $\mathrm{TiO}_{2}$ & 0,00 & 0,01 & 0,00 & 0,00 & 0,00 & 0,00 & 0,00 & 0,01 & 0,03 & 0,00 & 0,01 & 0,00 & 0,01 & 0,00 & 0,04 & 0,00 & 0,00 & 0,06 & 0,02 & 0,00 \\
\hline $\mathrm{Al}_{2} \mathrm{O}_{3}$ & 0,03 & 0,00 & 0,03 & 0,04 & 0,00 & 0,18 & 0,17 & 0,00 & 0,03 & 0,04 & 0,00 & 0,02 & 0,00 & 0,02 & 0,00 & 0,01 & 0,00 & 0,01 & 0,00 & 0,00 \\
\hline $\mathrm{FeO}$ & 8,32 & 8,23 & 8,21 & 8,45 & 8,36 & 8,51 & 8,21 & 7,62 & 7,13 & 7,26 & 7,27 & 7,36 & 7,45 & 7,58 & 8,02 & 7,99 & 7,95 & 8,17 & 7,74 & 7,92 \\
\hline $\mathrm{MnO}$ & 0,16 & 0,04 & 0,12 & 0,12 & 0,15 & 0,19 & 0,07 & 0,17 & 0,09 & 0,08 & 0,01 & 0,12 & 0,13 & 0,09 & 0,11 & 0,08 & 0,10 & 0,10 & 0,10 & 0,15 \\
\hline $\mathrm{MgO}$ & 50,82 & 50,58 & 50,87 & 50,87 & 51,19 & 51,09 & 51,32 & 51,15 & 51,49 & 51,03 & 51,17 & 51,59 & 51,88 & 51,91 & 52,30 & 51,84 & 51,46 & 52,10 & 51,69 & 51,89 \\
\hline $\mathrm{CaO}$ & 0,00 & 0,00 & 0,07 & 0,05 & 0,00 & 0,00 & 0,01 & 0,02 & 0,00 & 0,07 & 0,01 & 0,00 & 0,03 & 0,00 & 0,00 & 0,00 & 0,00 & 0,02 & 0,02 & 0,01 \\
\hline $\mathrm{Na}_{2} \mathrm{O}$ & 0,02 & 0,01 & 0,00 & 0,02 & 0,13 & 0,17 & 0,07 & 0,00 & 0,00 & 0,04 & 0,00 & 0,03 & 0,00 & 0,00 & 0,00 & 0,01 & 0,00 & 0,00 & 0,00 & 0,02 \\
\hline $\mathrm{K}_{2} \mathrm{O}$ & 0,00 & 0,00 & 0,01 & 0,00 & 0,06 & 0,02 & 0,02 & 0,02 & 0,04 & 0,08 & 0,00 & 0,00 & 0,00 & 0,00 & 0,02 & 0,00 & 0,00 & 0,00 & 0,00 & 0,02 \\
\hline $\mathrm{Cr}_{2} \mathrm{O}_{3}$ & 0,01 & 0,00 & 0,00 & 0,01 & 0,00 & 0,02 & 0,00 & 0,00 & 0,03 & 0,02 & 0,00 & 0,09 & 0,01 & 0,00 & 0,02 & 0,00 & 0,00 & 0,00 & 0,02 & 0,00 \\
\hline $\mathrm{NiO}$ & 0,27 & 0,37 & 0,42 & 0,43 & 0,33 & 0,41 & 0,32 & 0,42 & 0,44 & 0,51 & 0,43 & 0,44 & 0,47 & 0,42 & 0,40 & 0,42 & 0,41 & 0,42 & 0,42 & 0,34 \\
\hline Total & 100,75 & 100,49 & 101,44 & 100,97 & 101,20 & 102,01 & 101,63 & 100,94 & 100,75 & 100,29 & 100,23 & 101,20 & 100,56 & 100,67 & 101,15 & 101,08 & 100,83 & 101,96 & 100,78 & 100,75 \\
\hline $\mathrm{TSi}$ & 0,993 & 0,999 & 1,001 & 0,988 & 0,983 & 0,988 & 0,990 & 0,999 & 0,997 & 0,995 & 0,999 & 0,996 & 0,977 & 0,977 & 0,963 & 0,976 & 0,984 & 0,977 & 0,980 & 0,971 \\
\hline $\mathrm{TFe}^{3+}$ & 0,007 & 0,001 & 0,000 & 0,012 & 0,017 & 0,012 & 0,010 & 0,001 & 0,003 & 0,005 & 0,001 & 0,004 & 0,023 & 0,023 & 0,037 & 0,024 & 0,016 & 0,023 & 0,020 & 0,029 \\
\hline $\mathrm{TAl}$ & 0,000 & 0,000 & 0,000 & 0,000 & 0,000 & 0,000 & 0,000 & 0,000 & 0,000 & 0,000 & 0,000 & 0,000 & 0,000 & 0,000 & 0,000 & 0,000 & 0,000 & 0,000 & 0,000 & 0,000 \\
\hline T Total & 1,000 & 1,000 & 1,001 & 1,000 & 1,000 & 1,000 & 1,000 & 1,000 & 1,000 & 1,000 & 1,000 & 1,000 & 1,000 & 1,000 & 1,000 & 1,000 & 1,000 & 1,000 & 1,000 & 1,000 \\
\hline $\mathrm{M} 1 \mathrm{Fe}^{3+}$ & 0,007 & 0,001 & 0,000 & 0,012 & 0,024 & 0,014 & 0,009 & 0,001 & 0,001 & 0,007 & 0,000 & 0,002 & 0,023 & 0,023 & 0,035 & 0,024 & 0,016 & 0,021 & 0,018 & 0,031 \\
\hline M1Al & 0,001 & 0,000 & 0,001 & 0,001 & 0,000 & 0,005 & 0,005 & 0,000 & 0,001 & 0,001 & 0,000 & 0,001 & 0,000 & 0,001 & 0,000 & 0,000 & 0,000 & 0,000 & 0,000 & 0,000 \\
\hline $\mathrm{M} 1 \mathrm{Mg}$ & 1,829 & 1,826 & 1,820 & 1,828 & 1,831 & 1,817 & 1,829 & 1,835 & 1,846 & 1,839 & 1,844 & 1,843 & 1,861 & 1,860 & 1,865 & 1,853 & 1,846 & 1,848 & 1,853 & 1,859 \\
\hline${\mathrm{M} 1 \mathrm{Fe}^{2+}}^{2+}$ & 0,153 & 0,164 & 0,165 & 0,146 & 0,127 & 0,143 & 0,145 & 0,151 & 0,139 & 0,135 & 0,146 & 0,141 & 0,104 & 0,107 & 0,088 & 0,113 & 0,129 & 0,119 & 0,118 & 0,099 \\
\hline M1K & 0,000 & 0,000 & 0,000 & 0,000 & 0,002 & 0,001 & 0,001 & 0,001 & 0,001 & 0,002 & 0,000 & 0,000 & 0,000 & 0,000 & 0,001 & 0,000 & 0,000 & 0,000 & 0,000 & 0,001 \\
\hline M1Ni & 0,005 & 0,007 & 0,008 & 0,008 & 0,006 & 0,008 & 0,006 & 0,008 & 0,008 & 0,010 & 0,008 & 0,008 & 0,009 & 0,008 & 0,008 & 0,008 & 0,008 & 0,008 & 0,008 & 0,007 \\
\hline $\mathrm{M} 1 \mathrm{Cr}$ & 0,000 & 0,000 & 0,000 & 0,000 & 0,000 & 0,000 & 0,000 & 0,000 & 0,000 & 0,000 & 0,000 & 0,001 & 0,000 & 0,000 & 0,000 & 0,000 & 0,000 & 0,000 & 0,000 & 0,000 \\
\hline M1Mn & 0,003 & 0,001 & 0,002 & 0,003 & 0,003 & 0,004 & 0,001 & 0,003 & 0,002 & 0,002 & 0,000 & 0,002 & 0,003 & 0,002 & 0,002 & 0,002 & 0,002 & 0,002 & 0,002 & 0,003 \\
\hline M1Ti & 0,000 & 0,000 & 0,000 & 0,000 & 0,000 & 0,000 & 0,000 & 0,000 & 0,001 & 0,000 & 0,000 & 0,000 & 0,000 & 0,000 & 0,001 & 0,000 & 0,000 & 0,001 & 0,000 & 0,000 \\
\hline $\mathrm{M} 1 \mathrm{Ca}$ & 0,001 & 0,000 & 0,001 & 0,001 & 0,000 & 0,005 & 0,005 & 0,000 & 0,001 & 0,001 & 0,000 & 0,001 & 0,000 & 0,001 & 0,000 & 0,000 & 0,000 & 0,000 & 0,000 & 0,000 \\
\hline M1Total & 2,000 & 2,000 & 1,998 & 1,999 & 1,994 & 1,997 & 2,001 & 2,000 & 2,001 & 1,998 & 2,000 & 1,999 & 1,999 & 2,001 & 2,000 & 2,000 & 2,000 & 1,999 & 2,000 & 1,999 \\
\hline $\mathrm{mg \#}$ & 0,916 & 0,916 & 0,917 & 0,915 & 0,916 & 0,915 & 0,918 & 0,923 & 0,928 & 0,926 & 0,926 & 0,926 & 0,925 & 0,924 & 0,921 & 0,920 & 0,920 & 0,919 & 0,922 & 0,921 \\
\hline fa & 0,084 & 0,084 & 0,083 & 0,085 & 0,084 & 0,085 & 0,082 & 0,077 & 0,072 & 0,074 & 0,074 & 0,074 & 0,075 & 0,076 & 0,079 & 0,080 & 0,080 & 0,081 & 0,078 & 0,079 \\
\hline
\end{tabular}


Tabela 23- Composição química de olivina em dunitos sem espinélio dos corpos Indaiá 1 e Limeira 1.

\begin{tabular}{|c|c|c|c|c|c|c|c|c|c|c|c|c|c|c|c|c|c|}
\hline $\begin{array}{l}\text { Código } \\
\text { da } \\
\text { amostra }\end{array}$ & $\begin{array}{l}\text { Lm1-14- } \\
\quad 11\end{array}$ & Lm1-14-5 & Lm1-14-2 & Lm1-14-6 & Lm1-29-2 & Lm1-29-4 & $\begin{array}{l}\text { Lm1-29- } \\
3 \mathrm{a}\end{array}$ & Lm1-29-5 & Lm1-29-6 & Lm1-29-9 & Lm1-29-7 & Lm1-32-1 & Lm1-32-2a & Lm1-32-2b & Lm1-32-2d & Lm1-32-3 & Lm1-32-3b \\
\hline tipo & $\begin{array}{l}\text { borda de } \\
\text { dunito }\end{array}$ & dunit & to porfiroclá & stico & & & dun & to porfiroclá & stico & & & dunito $\mathrm{pc}$ & oclastico & $\begin{array}{l}\text { cristais em } \\
\text { mosaico em } \\
\text { dunito }\end{array}$ & & porfiroclast & \\
\hline $\mathrm{SiO}_{2}$ & 40,96 & 38,95 & 39,22 & 40,52 & 39,59 & 40,02 & 40,30 & 39,92 & 40,32 & 40,28 & 40,29 & 39,36 & 39,75 & 40,40 & 40,27 & 41,35 & 40,10 \\
\hline $\mathrm{TiO}_{2}$ & 0,04 & 0,00 & 0,01 & 0,00 & 0,01 & 0,01 & 0,07 & 0,03 & 0,03 & 0,03 & 0,01 & 0,00 & 0,03 & 0,00 & 0,05 & 0,00 & 0,00 \\
\hline $\mathrm{Al}_{2} \mathrm{O}_{3}$ & 0,02 & 0,00 & 0,00 & 0,00 & 0,00 & 0,10 & 0,01 & 0,00 & 0,00 & 0,00 & 0,11 & 0,03 & 0,03 & 0,08 & 0,00 & 0,00 & 0,01 \\
\hline $\mathrm{FeO}$ & 7,95 & 7,72 & 7,93 & 8,01 & 12,40 & 12,25 & 12,07 & 12,12 & 12,24 & 11,92 & 12,80 & 10,73 & 10,85 & 11,16 & 11,03 & 7,30 & 10,71 \\
\hline $\mathrm{MnO}$ & 0,14 & 0,14 & 0,09 & 0,10 & 0,12 & 0,11 & 0,14 & 0,16 & 0,11 & 0,13 & 0,18 & 0,08 & 0,04 & 0,15 & 0,09 & 0,13 & 0,22 \\
\hline $\mathrm{MgO}$ & 50,54 & 50,52 & 50,94 & 51,20 & 45,57 & 47,69 & 47,15 & 47,42 & 47,55 & 47,52 & 47,55 & 48,83 & 48,88 & 48,63 & 48,69 & 51,29 & 49,91 \\
\hline $\mathrm{CaO}$ & 0,03 & 0,05 & 0,05 & 0,09 & 0,10 & 0,07 & 0,10 & 0,04 & 0,05 & 0,13 & 0,22 & 0,11 & 0,03 & 0,15 & 0,12 & 0,01 & 0,07 \\
\hline $\mathrm{Na}_{2} \mathrm{O}$ & 0,29 & 0,20 & 0,06 & 0,09 & 0,00 & 0,02 & 0,11 & 0,00 & 0,02 & 0,18 & 0,11 & 0,05 & 0,04 & 0,05 & 0,13 & 0,01 & 0,07 \\
\hline $\mathrm{K}_{2} \mathrm{O}$ & 0,01 & 0,00 & 0,00 & 0,01 & 0,05 & 0,00 & 0,00 & 0,00 & 0,00 & 0,02 & 0,01 & 0,05 & 0,01 & 0,00 & 0,03 & 0,00 & 0,00 \\
\hline $\mathrm{Cr}_{2} \mathrm{O}_{3}$ & 0,04 & 0,03 & 0,04 & 0,05 & 0,04 & 0,00 & 0,03 & 0,14 & 0,07 & 0,04 & 0,06 & 0,06 & 0,12 & 0,11 & 0,04 & 0,00 & 0,00 \\
\hline $\mathrm{NiO}$ & 0,51 & 0,40 & 0,54 & 0,57 & 0,27 & 0,46 & 0,46 & 0,45 & 0,35 & 0,43 & 0,55 & 0,44 & 0,35 & 0,42 & 0,46 & 0,51 & 0,33 \\
\hline Total & 100,54 & 98,02 & 98,89 & 100,64 & 98,15 & 100,74 & 100,44 & 100,28 & 100,74 & 100,68 & 101,88 & 99,73 & 100,11 & 101,14 & 100,91 & 100,61 & 101,41 \\
\hline $\mathrm{TSi}$ & 0,990 & 0,961 & 0,961 & 0,977 & 1,003 & 0,984 & 0,995 & 0,987 & 0,992 & 0,990 & 0,982 & 0,969 & 0,976 & 0,985 & 0,982 & 0,997 & 0,969 \\
\hline $\mathrm{TFe}^{3+}$ & 0,010 & 0,039 & 0,039 & 0,023 & 0,000 & 0,016 & 0,005 & 0,013 & 0,008 & 0,010 & 0,018 & 0,031 & 0,024 & 0,015 & 0,018 & 0,003 & 0,031 \\
\hline TAl & 0,000 & 0,000 & 0,000 & 0,000 & 0,000 & 0,000 & 0,000 & 0,000 & 0,000 & 0,000 & 0,000 & 0,000 & 0,000 & 0,000 & 0,000 & 0,000 & 0,000 \\
\hline Ttotal & 1,000 & 1,000 & 1,000 & 1,000 & 1,003 & 1,000 & 1,000 & 1,000 & 1,000 & 1,000 & 1,000 & 1,000 & 1,000 & 1,000 & 1,000 & 1,000 & 1,000 \\
\hline $\mathrm{M} 1 \mathrm{Fe}^{3+}$ & 0,021 & 0,048 & 0,041 & 0,026 & 0,000 & 0,014 & 0,007 & 0,008 & 0,006 & 0,017 & 0,019 & 0,032 & 0,021 & 0,012 & 0,022 & 0,004 & 0,034 \\
\hline M1Al & 0,000 & 0,000 & 0,000 & 0,000 & 0,000 & 0,003 & 0,000 & 0,000 & 0,000 & 0,000 & 0,003 & 0,001 & 0,001 & 0,002 & 0,000 & 0,000 & 0,000 \\
\hline $\mathrm{M} 1 \mathrm{Mg}$ & 1,820 & 1,858 & 1,860 & 1,841 & 1,721 & 1,747 & 1,735 & 1,747 & 1,743 & 1,741 & 1,728 & 1,792 & 1,788 & 1,767 & 1,770 & 1,843 & 1,798 \\
\hline${\mathrm{M} 1 \mathrm{Fe}^{2+}}^{2+}$ & 0,129 & 0,072 & 0,082 & 0,113 & 0,263 & 0,222 & 0,237 & 0,229 & 0,238 & 0,218 & 0,224 & 0,158 & 0,177 & 0,200 & 0,185 & 0,140 & 0,152 \\
\hline $\mathrm{M} 1 \mathrm{~K}$ & 0,000 & 0,000 & 0,000 & 0,000 & 0,002 & 0,000 & 0,000 & 0,000 & 0,000 & 0,001 & 0,000 & 0,002 & 0,000 & 0,000 & 0,001 & 0,000 & 0,000 \\
\hline $\mathrm{M} 1 \mathrm{Ni}$ & 0,010 & 0,008 & 0,011 & 0,011 & 0,005 & 0,009 & 0,009 & 0,009 & 0,007 & 0,008 & 0,011 & 0,009 & 0,007 & 0,008 & 0,009 & 0,010 & 0,006 \\
\hline $\mathrm{M} 1 \mathrm{Cr}$ & 0,001 & 0,000 & 0,000 & 0,001 & 0,001 & 0,000 & 0,000 & 0,002 & 0,001 & 0,001 & 0,001 & 0,001 & 0,002 & 0,001 & 0,000 & 0,000 & 0,000 \\
\hline M1Mn & 0,003 & 0,003 & 0,002 & 0,002 & 0,003 & 0,002 & 0,003 & 0,003 & 0,002 & 0,003 & 0,004 & 0,002 & 0,001 & 0,003 & 0,002 & 0,003 & 0,004 \\
\hline M1Ti & 0,001 & 0,000 & 0,000 & 0,000 & 0,000 & 0,000 & 0,001 & 0,001 & 0,001 & 0,001 & 0,000 & 0,000 & 0,000 & 0,000 & 0,001 & 0,000 & 0,000 \\
\hline $\mathrm{M} 1 \mathrm{Ca}$ & 0,000 & 0,000 & 0,000 & 0,000 & 0,000 & 0,003 & 0,000 & 0,000 & 0,000 & 0,000 & 0,003 & 0,001 & 0,001 & 0,002 & 0,000 & 0,000 & 0,000 \\
\hline M1Total & 1,986 & 1,989 & 1,996 & 1,993 & 1,994 & 2,000 & 1,993 & 1,999 & 1,998 & 1,988 & 1,992 & 1,996 & 1,998 & 1,996 & 1,991 & 1,999 & 1,995 \\
\hline mg\# & 0,919 & 0,921 & 0,920 & 0,919 & 0,868 & 0,874 & 0,874 & 0,875 & 0,874 & 0,877 & 0,869 & 0,890 & 0,889 & 0,886 & 0,887 & 0,926 & 0,893 \\
\hline $\mathrm{fa}$ & 0,081 & 0,079 & 0,080 & 0,081 & 0,132 & 0,126 & 0,126 & 0,125 & 0,126 & 0,123 & 0,131 & 0,110 & 0,111 & 0,114 & 0,113 & 0,074 & 0,107 \\
\hline
\end{tabular}


Tabela 24- Composição química de olivina em dunitos e harzburgitos sem espinélio dos corpos Indaiá 1 e Limeira 1.

\begin{tabular}{|c|c|c|c|c|c|c|c|c|c|c|c|c|c|c|c|}
\hline \multirow[t]{2}{*}{ Código } & In1-25a-6a & In1-25a-2 & In1-25a-3 & In1-25a-6 & In1-25a-8 & In1-25a-1C & $11-25 a-11 a$ & In $1-25 a-4$ & In1-33-6 & In1-33-8a & In1-33-7 & In1-33-5 & In1-33-4 & In1-33-11d & \multirow{2}{*}{$\begin{array}{l}\text { In1-33-11e } \\
\text { centro de } \\
\text { porfiroclatos }\end{array}$} \\
\hline & $\begin{array}{l}\text { cristais em mosaico } \\
\text { em dunito } \\
\text { porfiroclático }\end{array}$ & dunito $\mathrm{pc}$ & clático & $\begin{array}{l}\text { cristais em mosaico } \\
\text { dunito porfiroclático }\end{array}$ & $\begin{array}{c}\text { dunito } \\
\text { porfiroclático }\end{array}$ & cristais em $\mathrm{m}$ & porfiroclático & $\begin{array}{c}\text { dunito } \\
\text { porfiroclático } \\
\text { com mosaico }\end{array}$ & \multicolumn{6}{|c|}{ harzburgito porfiroclático com mosaico } & \\
\hline $\mathrm{SiO}_{2}$ & 40,38 & 40,43 & 40,90 & 40,99 & 40,25 & 39,88 & 40,41 & 41,08 & 40,25 & 40,77 & 40,29 & 39,73 & 39,75 & 40,50 & 41,72 \\
\hline $\mathrm{TiO}_{2}$ & 0,00 & 0,02 & 0,00 & 0,01 & 0,06 & 0,05 & 0,00 & 0,05 & 0,06 & 0,00 & 0,03 & 0,04 & 0,00 & 0,08 & 0,00 \\
\hline $\mathrm{Al}_{2} \mathrm{O}_{3}$ & 0,03 & 0,02 & 0,04 & 0,00 & 0,00 & 0,01 & 0,00 & 0,01 & 0,02 & 0,02 & 0,04 & 0,04 & 0,03 & 0,02 & 0,06 \\
\hline $\mathrm{FeO}$ & 11,88 & 11,14 & 11,61 & 11,56 & 11,39 & 11,47 & 11,69 & 11,74 & 11,29 & 11,28 & 11,22 & 11,47 & 11,13 & 12,54 & 7,52 \\
\hline $\mathrm{MnO}$ & 0,18 & 0,13 & 0,11 & 0,19 & 0,16 & 0,09 & 0,16 & 0,16 & 0,19 & 0,15 & 0,14 & 0,11 & 0,14 & 0,21 & 0,12 \\
\hline $\mathrm{MgO}$ & 47,96 & 47,89 & 48,33 & 48,22 & 48,04 & 47,98 & 48,51 & 48,39 & 48,44 & 47,80 & 47,90 & 48,11 & 47,74 & 47,69 & 51,26 \\
\hline $\mathrm{CaO}$ & 0,11 & 0,12 & 0,08 & 0,11 & 0,07 & 0,10 & 0,17 & 0,13 & 0,16 & 0,15 & 0,09 & 0,16 & 0,14 & 0,11 & 0,01 \\
\hline $\mathrm{Na}_{2} \mathrm{O}$ & 0,00 & 0,05 & 0,02 & 0,07 & 0,00 & 0,03 & 0,00 & 0,01 & 0,01 & 0,02 & 0,04 & 0,03 & 0,04 & 0,05 & 0,04 \\
\hline $\mathrm{K}_{2} \mathrm{O}$ & 0,02 & 0,04 & 0,01 & 0,03 & 0,03 & 0,01 & 0,04 & 0,02 & 0,05 & 0,00 & 0,00 & 0,00 & 0,01 & 0,00 & 0,00 \\
\hline $\mathrm{Cr}_{2} \mathrm{O}_{3}$ & 0,06 & 0,07 & 0,09 & 0,01 & 0,15 & 0,10 & 0,11 & 0,06 & 0,07 & 0,05 & 0,07 & 0,08 & 0,09 & 0,03 & 0,00 \\
\hline $\mathrm{NiO}$ & 0,44 & 0,41 & 0,40 & 0,43 & 0,49 & 0,44 & 0,50 & 0,35 & 0,35 & 0,37 & 0,44 & 0,43 & 0,34 & 0,19 & 0,36 \\
\hline Total & 101,06 & 100,31 & 101,57 & 101,63 & 100,64 & 100,16 & 101,58 & 101,99 & 100,89 & 100,62 & 100,27 & 100,20 & 99,40 & 101,42 & 101,09 \\
\hline $\mathrm{TSi}$ & 0,989 & 0,995 & 0,995 & 0,997 & 0,988 & 0,983 & 0,983 & 0,996 & 0,984 & 1,001 & 0,992 & 0,978 & 0,986 & 0,990 & 1,001 \\
\hline $\mathrm{TFe}^{3+}$ & 0,011 & 0,005 & 0,005 & 0,003 & 0,012 & 0,017 & 0,017 & 0,004 & 0,016 & 0,000 & 0,008 & 0,022 & 0,014 & 0,010 & 0,000 \\
\hline TAl & 0,000 & 0,000 & 0,000 & 0,000 & 0,000 & 0,000 & 0,000 & 0,000 & 0,000 & 0,000 & 0,000 & 0,000 & 0,000 & 0,000 & 0,000 \\
\hline Ttotal & 1,000 & 1,000 & 1,000 & 1,000 & 1,000 & 1,000 & 1,000 & 1,000 & 1,000 & 1,001 & 1,000 & 1,000 & 1,000 & 1,000 & 1,001 \\
\hline $\mathrm{M} 1 \mathrm{Fe}^{3+}$ & 0,009 & 0,005 & 0,002 & 0,007 & 0,005 & 0,013 & 0,015 & 0,001 & 0,013 & 0,000 & 0,006 & 0,018 & 0,012 & 0,008 & 0,000 \\
\hline M1Al & 0,001 & 0,001 & 0,001 & 0,000 & 0,000 & 0,000 & 0,000 & 0,000 & 0,001 & 0,001 & 0,001 & 0,001 & 0,001 & 0,001 & 0,002 \\
\hline $\mathrm{M} 1 \mathrm{Mg}$ & 1,750 & 1,757 & 1,753 & 1,748 & 1,759 & 1,763 & 1,759 & 1,749 & 1,765 & 1,750 & 1,758 & 1,766 & 1,766 & 1,738 & 1,835 \\
\hline $\mathrm{M} 1 \mathrm{Fe}^{2+}$ & 0,223 & 0,219 & 0,230 & 0,225 & 0,217 & 0,206 & 0,206 & 0,233 & 0,202 & 0,232 & 0,218 & 0,197 & 0,205 & 0,238 & 0,151 \\
\hline M1K & 0,001 & 0,001 & 0,000 & 0,001 & 0,001 & 0,000 & 0,001 & 0,001 & 0,002 & 0,000 & 0,000 & 0,000 & 0,000 & 0,000 & 0,000 \\
\hline $\mathrm{M} 1 \mathrm{Ni}$ & 0,009 & 0,008 & 0,008 & 0,008 & 0,010 & 0,009 & 0,010 & 0,007 & 0,007 & 0,007 & 0,009 & 0,008 & 0,007 & 0,004 & 0,007 \\
\hline $\mathrm{M} 1 \mathrm{Cr}$ & 0,001 & 0,001 & 0,001 & 0,000 & 0,002 & 0,001 & 0,001 & 0,001 & 0,001 & 0,001 & 0,001 & 0,001 & 0,001 & 0,000 & 0,000 \\
\hline M1Mn & 0,004 & 0,003 & 0,002 & 0,004 & 0,003 & 0,002 & 0,003 & 0,003 & 0,004 & 0,003 & 0,003 & 0,002 & 0,003 & 0,004 & 0,002 \\
\hline M1Ti & 0,000 & 0,000 & 0,000 & 0,000 & 0,001 & 0,001 & 0,000 & 0,001 & 0,001 & 0,000 & 0,001 & 0,001 & 0,000 & 0,001 & 0,000 \\
\hline $\mathrm{M} 1 \mathrm{Ca}$ & 0,001 & 0,001 & 0,001 & 0,000 & 0,000 & 0,000 & 0,000 & 0,000 & 0,001 & 0,001 & 0,001 & 0,001 & 0,001 & 0,001 & 0,002 \\
\hline M1Total & 1,998 & 1,995 & 1,998 & 1,994 & 1,998 & 1,996 & 1,996 & 1,996 & 1,996 & 1,994 & 1,997 & 1,995 & 1,995 & 1,995 & 1,998 \\
\hline mg\# & 0,878 & 0,885 & 0,881 & 0,881 & 0,883 & 0,882 & 0,881 & 0,880 & 0,884 & 0,883 & 0,884 & 0,882 & 0,884 & 0,871 & 0,924 \\
\hline fa & 0,122 & 0,115 & 0,119 & 0,119 & 0,117 & 0,118 & 0,119 & 0,120 & 0,116 & 0,117 & 0,116 & 0,118 & 0,116 & 0,129 & 0,076 \\
\hline
\end{tabular}


Tabela 24- Composição química de olivina em harzburgitos e dunitos com flogopita dos corpos Indaiá 1 e Limeira 1.

\begin{tabular}{|c|c|c|c|c|c|c|c|c|c|c|c|c|c|c|c|c|c|c|c|}
\hline $\begin{array}{l}\text { Código } \\
\text { da }\end{array}$ & In1-1-1* & In1-1-2* & In1-1-3* & In1-1-4* & In1-1-5 & In1-1-6 & In1-1-7 & In1-2-1 & In1-2-2 & Lm1-1-1 & Lm1-1-1c & Lm1-1-1d & Lm1-1-1f & Lm1-15-18 & Lm1-15-20 & Lm1-15-9' & Lm1-15-17 & Lm1-15-11 & Lm1- \\
\hline tipo & \multicolumn{4}{|c|}{$\begin{array}{l}\text { harzburgito porfiroclástico } \\
\text { alterado }\end{array}$} & \multicolumn{3}{|c|}{$\begin{array}{l}\text { harzburgito porfiroclástico sem } \\
\text { alteração }\end{array}$} & \multicolumn{2}{|c|}{ flogopita dunito } & \multicolumn{4}{|c|}{ harzburgito com bolsões de flogopita e titanato } & \multicolumn{6}{|c|}{ harzburgito com bolsões de flogopita } \\
\hline $\mathrm{SiO}_{2}$ & 40,45 & 39,87 & 39,95 & 39,68 & 40,44 & 41,40 & 40,82 & 39,95 & 40,31 & 40,12 & 41,16 & 40,09 & 40,41 & 40,67 & 40,66 & 40,51 & 40,74 & 40,44 & 40,97 \\
\hline $\mathrm{TiO}_{2}$ & 0,04 & 0,05 & 0,06 & 0,05 & 0,00 & 0,01 & 0,05 & 0,04 & 0,00 & 0,00 & 0,00 & 0,05 & 0,01 & 0,00 & 0,00 & 0,00 & 0,01 & 0,03 & 0,00 \\
\hline $\mathrm{Al}_{2} \mathrm{O}_{3}$ & 0,03 & 0,05 & 0,06 & 0,04 & 0,06 & 0,06 & 0,05 & 0,04 & 0,00 & 0,00 & 0,03 & 0,03 & 0,00 & 0,00 & 0,00 & 0,02 & 0,00 & 0,01 & 0,06 \\
\hline $\mathrm{FeO}$ & 10,03 & 11,29 & 11,36 & 10,43 & 8,15 & 8,32 & 8,11 & 10,65 & 11,13 & 11,09 & 11,30 & 11,15 & 11,51 & 7,83 & 8,31 & 7,67 & 8,00 & 8,57 & 8,16 \\
\hline $\mathrm{MnO}$ & 0,12 & 0,15 & 0,09 & 0,13 & 0,10 & 0,10 & 0,14 & 0,17 & 0,15 & 0,15 & 0,07 & 0,24 & 0,14 & 0,14 & 0,08 & 0,08 & 0,17 & 0,12 & 0,14 \\
\hline $\mathrm{MgO}$ & 49,26 & 48,83 & 49,39 & 49,45 & 51,11 & 50,77 & 50,42 & 49,42 & 49,19 & 48,09 & 48,95 & 48,57 & 48,54 & 51,21 & 51,45 & 51,17 & 51,63 & 51,20 & 51,18 \\
\hline $\mathrm{CaO}$ & 0,12 & 0,14 & 0,13 & 0,14 & 0,10 & 0,09 & 0,14 & 0,03 & 0,04 & 0,06 & 0,03 & 0,27 & 0,04 & 0,00 & 0,07 & 0,00 & 0,02 & 0,03 & 0,03 \\
\hline $\mathrm{Na}_{2} \mathrm{O}$ & 0,03 & 0,02 & 0,03 & 0,01 & 0,02 & 0,03 & 0,02 & 0,00 & 0,01 & 0,02 & 0,00 & 0,01 & 0,03 & 0,02 & 0,06 & 0,03 & 0,08 & 0,00 & 0,15 \\
\hline $\mathrm{K}_{2} \mathrm{O}$ & 0,00 & 0,00 & 0,00 & 0,00 & 0,00 & 0,00 & 0,00 & 0,01 & 0,00 & 0,00 & 0,03 & 0,08 & 0,01 & 0,02 & 0,02 & 0,01 & 0,05 & 0,00 & 0,00 \\
\hline $\mathrm{Cr}_{2} \mathrm{O}_{3}$ & 0,10 & 0,07 & 0,09 & 0,11 & 0,15 & 0,15 & 0,10 & 0,02 & 0,02 & 0,02 & 0,00 & 0,04 & 0,07 & 0,08 & 0,04 & 0,05 & 0,00 & 0,00 & 0,00 \\
\hline $\mathrm{NiO}$ & 0,42 & 0,43 & 0,41 & 0,38 & 0,42 & 0,41 & 0,42 & 0,41 & 0,34 & 0,40 & 0,41 & 0,31 & 0,34 & 0,30 & 0,37 & 0,30 & 0,36 & 0,49 & 0,40 \\
\hline Total & 100,60 & 100,88 & 101,57 & 100,41 & 100,56 & 101,34 & 100,27 & 100,72 & 101,19 & 99,94 & 101,98 & 100,84 & 101,09 & 100,26 & 101,05 & 99,85 & 101,05 & 100,89 & 101,09 \\
\hline $\mathrm{TSi}$ & 0,986 & 0,973 & 0,968 & 0,969 & 0,977 & 0,996 & 0,991 & 0,974 & 0,980 & 0,989 & 0,995 & 0,979 & 0,986 & 0,984 & 0,977 & 0,983 & 0,977 & 0,975 & 0,984 \\
\hline $\mathrm{TFe}^{3+}$ & 0,014 & 0,027 & 0,032 & 0,031 & 0,023 & 0,003 & 0,009 & 0,026 & 0,020 & 0,011 & 0,005 & 0,021 & 0,014 & 0,016 & 0,023 & 0,017 & 0,023 & 0,025 & 0,016 \\
\hline TAl & 0,000 & 0,000 & 0,000 & 0,000 & 0,000 & 0,001 & 0,000 & 0,000 & 0,000 & 0,000 & 0,000 & 0,000 & 0,000 & 0,000 & 0,000 & 0,000 & 0,000 & 0,000 & 0,000 \\
\hline Ttotal & 1,000 & 1,000 & 1,000 & 1,000 & 1,000 & 1,000 & 1,000 & 1,000 & 1,000 & 1,000 & 1,000 & 1,000 & 1,000 & 1,000 & 1,000 & 1,000 & 1,000 & 1,000 & 1,000 \\
\hline $\mathrm{M} \mathrm{Fe}^{3+}$ & 0,010 & 0,022 & 0,027 & 0,025 & 0,017 & 0,000 & 0,004 & 0,024 & 0,020 & 0,011 & 0,005 & 0,020 & 0,013 & 0,015 & 0,026 & 0,017 & 0,027 & 0,024 & 0,021 \\
\hline M1Al & 0,001 & 0,001 & 0,002 & 0,001 & 0,002 & 0,001 & 0,001 & 0,001 & 0,000 & 0,000 & 0,001 & 0,001 & 0,000 & 0,000 & 0,000 & 0,001 & 0,000 & 0,000 & 0,002 \\
\hline $\mathrm{M} 1 \mathrm{Mg}$ & 1,791 & 1,777 & 1,784 & 1,800 & 1,841 & 1,820 & 1,825 & 1,795 & 1,783 & 1,768 & 1,764 & 1,769 & 1,766 & 1,847 & 1,842 & 1,851 & 1,846 & 1,839 & 1,832 \\
\hline $\mathrm{M}_{1} \mathrm{Fe}^{2+}$ & 0,181 & 0,182 & 0,171 & 0,157 & 0,125 & 0,164 & 0,152 & 0,167 & 0,186 & 0,207 & 0,218 & 0,188 & 0,208 & 0,127 & 0,118 & 0,122 & 0,110 & 0,123 & 0,126 \\
\hline M1K & 0,000 & 0,000 & 0,000 & 0,000 & 0,000 & 0,000 & 0,000 & 0,000 & 0,000 & 0,000 & 0,001 & 0,003 & 0,000 & 0,001 & 0,000 & 0,000 & 0,001 & 0,000 & 0,000 \\
\hline $\mathrm{M} 1 \mathrm{Ni}$ & 0,008 & 0,008 & 0,008 & 0,007 & 0,008 & 0,008 & 0,008 & 0,008 & 0,007 & 0,008 & 0,008 & 0,006 & 0,007 & 0,006 & 0,007 & 0,006 & 0,007 & 0,009 & 0,008 \\
\hline $\mathrm{M} 1 \mathrm{Cr}$ & 0,001 & 0,001 & 0,001 & 0,001 & 0,002 & 0,002 & 0,001 & 0,000 & 0,000 & 0,000 & 0,000 & 0,001 & 0,001 & 0,001 & 0,000 & 0,001 & 0,000 & 0,000 & 0,000 \\
\hline M1Mn & 0,002 & 0,003 & 0,002 & 0,003 & 0,002 & 0,002 & 0,003 & 0,004 & 0,003 & 0,003 & 0,001 & 0,005 & 0,003 & 0,003 & 0,002 & 0,002 & 0,003 & 0,002 & 0,003 \\
\hline M1Ti & 0,001 & 0,001 & 0,001 & 0,001 & 0,000 & 0,000 & 0,001 & 0,001 & 0,000 & 0,000 & 0,000 & 0,001 & 0,000 & 0,000 & 0,000 & 0,000 & 0,000 & 0,000 & 0,000 \\
\hline $\mathrm{M} 1 \mathrm{Ca}$ & 0,001 & 0,001 & 0,002 & 0,001 & 0,002 & 0,002 & 0,001 & 0,001 & 0,000 & 0,000 & 0,001 & 0,001 & 0,000 & 0,000 & 0,000 & 0,001 & 0,000 & 0,000 & 0,002 \\
\hline M1Total & 1,996 & 1,997 & 1,997 & 1,997 & 1,998 & 1,998 & 1,997 & 2,000 & 1,999 & 1,998 & 2,000 & 1,993 & 1,998 & 1,999 & 1,995 & 1,999 & 1,996 & 1,999 & 1,994 \\
\hline $\mathrm{mg} \#$ & 0,897 & 0,885 & 0,886 & 0,894 & 0,918 & 0,916 & 0,917 & 0,892 & 0,887 & 0,885 & 0,885 & 0,886 & 0,883 & 0,921 & 0,917 & 0,922 & 0,920 & 0,914 & 0,918 \\
\hline $\mathrm{fa}$ & 0,103 & 0,115 & 0,114 & 0,106 & 0,082 & 0,084 & 0,083 & 0,108 & 0,113 & 0,115 & 0,115 & 0,114 & 0,117 & 0,079 & 0,083 & 0,078 & 0,080 & 0,086 & 0,082 \\
\hline
\end{tabular}


Tabela 25- Composição química de olivina em harzburgitos e dunitos com flogopita dos corpos Indaiá 1 e Limeira 1.

\begin{tabular}{|c|c|c|c|c|c|c|c|c|c|c|c|c|c|c|c|c|c|}
\hline $\begin{array}{l}\text { Código } \\
\text { da } \\
\text { amostra }\end{array}$ & Lm1-15-10 & Lm1-15-15 & Lm1-15-14a & Lm1-15-14b & Lm1-15-16 & Lm1-22-1 & Lm1-22-2 & Lm1-22-13 & Lm1-22-12 & Lm1-22-11 & Lm1-22-20 & $\begin{array}{c}\text { Lm1-26a- } \\
\quad 1\end{array}$ & $\begin{array}{l}\text { Lm1-26a- } \\
\quad 2\end{array}$ & $\begin{array}{l}\text { Lm1-26a- } \\
\quad 6\end{array}$ & $\begin{array}{c}\text { Lm1-26a- } \\
\quad 7\end{array}$ & $\begin{array}{c}\text { Lm1-26a- } \\
8\end{array}$ & $\begin{array}{c}\mathrm{Lm} 1-26 \mathrm{a}- \\
\quad 10 \mathrm{~b}\end{array}$ \\
\hline tipo & \multicolumn{5}{|c|}{ harzburgito com bolsões de flogopita } & \multicolumn{5}{|c|}{ flogopita dunito com clinopiroxênio secundário } & $\begin{array}{l}\text { microcristal em } \\
\text { mosaico de } \\
\text { flogopita dunito }\end{array}$ & \multicolumn{6}{|c|}{ harzburgito com bolsões de flogopita } \\
\hline $\mathrm{SiO}_{2}$ & 41,31 & 40,65 & 40,74 & 41,03 & 40,37 & 40,17 & 39,82 & 40,40 & 40,67 & 40,08 & 40,26 & 40,42 & 39,26 & 39,82 & 39,72 & 40,01 & 39,55 \\
\hline $\mathrm{TiO}_{2}$ & 0,00 & 0,00 & 0,00 & 0,00 & 0,07 & 0,00 & 0,00 & 0,02 & 0,00 & 0,00 & 0,04 & 0,00 & 0,00 & 0,04 & 0,02 & 0,02 & 0,00 \\
\hline $\mathrm{Al}_{2} \mathrm{O}_{3}$ & 0,09 & 0,01 & 0,00 & 0,02 & 0,12 & 0,00 & 0,06 & 0,15 & 0,00 & 0,09 & 0,00 & 0,03 & 0,01 & 0,02 & 0,00 & 0,08 & 0,07 \\
\hline $\mathrm{FeO}$ & 7,99 & 8,00 & 8,21 & 5,21 & 8,33 & 10,84 & 9,88 & 10,97 & 11,50 & 11,90 & 11,12 & 12,96 & 13,10 & 12,90 & 12,84 & 13,31 & 13,08 \\
\hline $\mathrm{MnO}$ & 0,12 & 0,07 & 0,13 & 0,28 & 0,16 & 0,16 & 0,20 & 0,10 & 0,18 & 0,21 & 0,11 & 0,11 & 0,12 & 0,16 & 0,13 & 0,16 & 0,12 \\
\hline $\mathrm{MgO}$ & 51,32 & 50,61 & 50,99 & 52,00 & 51,16 & 48,54 & 48,79 & 48,44 & 48,16 & 47,66 & 47,73 & 46,84 & 46,38 & 46,52 & 46,70 & 47,18 & 47,01 \\
\hline $\mathrm{CaO}$ & 0,00 & 0,01 & 0,05 & 0,28 & 0,00 & 0,02 & 0,00 & 0,01 & 0,07 & 0,01 & 0,06 & 0,00 & 0,01 & 0,07 & 0,03 & 0,02 & 0,01 \\
\hline $\mathrm{Na}_{2} \mathrm{O}$ & 0,29 & 0,18 & 0,15 & 0,15 & 0,15 & 0,13 & 0,09 & 0,00 & 0,00 & 0,04 & 0,05 & 0,09 & 0,05 & 0,11 & 0,31 & 0,20 & 0,04 \\
\hline $\mathrm{K}_{2} \mathrm{O}$ & 0,14 & 0,01 & 0,07 & 0,04 & 0,01 & 0,00 & 0,00 & 0,04 & 0,00 & 0,00 & 0,01 & 0,00 & 0,00 & 0,00 & 0,00 & 0,00 & 0,02 \\
\hline $\mathrm{Cr}_{2} \mathrm{O}_{3}$ & 0,00 & 0,03 & 0,09 & 0,06 & 0,00 & 0,03 & 0,00 & 0,07 & 0,00 & 0,00 & 0,00 & 0,04 & 0,00 & 0,11 & 0,00 & 0,02 & 0,05 \\
\hline $\mathrm{NiO}$ & 0,28 & 0,38 & 0,36 & 0,17 & 0,51 & 0,37 & 0,26 & 0,38 & 0,37 & 0,42 & 0,37 & 0,14 & 0,41 & 0,34 & 0,32 & 0,40 & 0,32 \\
\hline Total & 101,55 & 99,96 & 100,79 & 99,23 & 100,88 & 100,27 & 99,09 & 100,58 & 100,96 & 100,40 & 99,77 & 100,64 & 99,33 & 100,08 & 100,08 & 101,39 & 100,27 \\
\hline $\mathrm{TSi}$ & 0,986 & 0,987 & 0,982 & 0,993 & 0,972 & 0,985 & 0,984 & 0,990 & 0,995 & 0,987 & 0,996 & 0,998 & 0,982 & 0,989 & 0,984 & 0,980 & 0,979 \\
\hline $\mathrm{TFe}^{3+}$ & 0,014 & 0,013 & 0,018 & 0,007 & 0,028 & 0,015 & 0,016 & 0,010 & 0,005 & 0,013 & 0,004 & 0,002 & 0,018 & 0,011 & 0,016 & 0,020 & 0,021 \\
\hline TAl & 0,000 & 0,000 & 0,000 & 0,000 & 0,000 & 0,000 & 0,000 & 0,000 & 0,000 & 0,000 & 0,000 & 0,000 & 0,000 & 0,000 & 0,000 & 0,000 & 0,000 \\
\hline Ttotal & 1,000 & 1,000 & 1,000 & 1,000 & 1,000 & 1,000 & 1,000 & 1,000 & 1,000 & 1,000 & 1,000 & 1,000 & 1,000 & 1,000 & 1,000 & 1,000 & 1,000 \\
\hline${\mathrm{M} 1 F e^{3+}}^{3+}$ & 0,029 & 0,021 & 0,024 & 0,013 & 0,030 & 0,020 & 0,018 & 0,004 & 0,005 & 0,012 & 0,006 & 0,005 & 0,020 & 0,011 & 0,030 & 0,026 & 0,019 \\
\hline M1Al & 0,003 & 0,000 & 0,000 & 0,000 & 0,003 & 0,000 & 0,002 & 0,004 & 0,000 & 0,003 & 0,000 & 0,001 & 0,000 & 0,001 & 0,000 & 0,002 & 0,002 \\
\hline $\mathrm{M} 1 \mathrm{Mg}$ & 1,826 & 1,832 & 1,832 & 1,876 & 1,836 & 1,775 & 1,797 & 1,769 & 1,757 & 1,750 & 1,759 & 1,724 & 1,730 & 1,723 & 1,725 & 1,723 & 1,735 \\
\hline${\mathrm{M} 1 F e^{2+}}^{2+}$ & 0,116 & 0,129 & 0,123 & 0,086 & 0,110 & 0,187 & 0,169 & 0,210 & 0,225 & 0,220 & 0,220 & 0,261 & 0,236 & 0,246 & 0,220 & 0,227 & 0,231 \\
\hline $\mathrm{M} 1 \mathrm{~K}$ & 0,004 & 0,000 & 0,002 & 0,001 & 0,000 & 0,000 & 0,000 & 0,001 & 0,000 & 0,000 & 0,000 & 0,000 & 0,000 & 0,000 & 0,000 & 0,000 & 0,001 \\
\hline M1Ni & 0,005 & 0,007 & 0,007 & 0,003 & 0,010 & 0,007 & 0,005 & 0,007 & 0,007 & 0,008 & 0,007 & 0,003 & 0,008 & 0,007 & 0,006 & 0,008 & 0,006 \\
\hline $\mathrm{M} 1 \mathrm{Cr}$ & 0,000 & 0,000 & 0,001 & 0,001 & 0,000 & 0,000 & 0,000 & 0,001 & 0,000 & 0,000 & 0,000 & 0,000 & 0,000 & 0,001 & 0,000 & 0,000 & 0,001 \\
\hline M1Mn & 0,002 & 0,002 & 0,003 & 0,006 & 0,003 & 0,003 & 0,004 & 0,002 & 0,004 & 0,004 & 0,002 & 0,002 & 0,003 & 0,003 & 0,003 & 0,003 & 0,002 \\
\hline M1Ti & 0,000 & 0,000 & 0,000 & 0,000 & 0,001 & 0,000 & 0,000 & 0,000 & 0,000 & 0,000 & 0,001 & 0,000 & 0,000 & 0,001 & 0,000 & 0,000 & 0,000 \\
\hline $\mathrm{M} 1 \mathrm{Ca}$ & 0,003 & 0,000 & 0,000 & 0,000 & 0,003 & 0,000 & 0,002 & 0,004 & 0,000 & 0,003 & 0,000 & 0,001 & 0,000 & 0,001 & 0,000 & 0,002 & 0,002 \\
\hline M1Total & 1,989 & 1,991 & 1,992 & 1,986 & 1,996 & 1,993 & 1,998 & 2,004 & 1,998 & 2,000 & 1,996 & 1,997 & 1,997 & 1,993 & 1,984 & 1,992 & 2,000 \\
\hline $\mathrm{mg} \#$ & 0,920 & 0,919 & 0,917 & 0,947 & 0,916 & 0,889 & 0,898 & 0,887 & 0,882 & 0,877 & 0,884 & 0,866 & 0,863 & 0,865 & 0,866 & 0,863 & 0,865 \\
\hline fa & 0,080 & 0,081 & 0,083 & 0,053 & 0,084 & 0,111 & 0,102 & 0,113 & 0,118 & 0,123 & 0,116 & 0,134 & 0,137 & 0,135 & 0,134 & 0,137 & 0,135 \\
\hline
\end{tabular}


Tabela 26- Composição química de olivina em harzburgitos e dunitos com flogopita dos corpos Indaiá 1 e Limeira 1.

\begin{tabular}{|c|c|c|c|c|c|c|c|c|c|c|c|c|c|c|c|c|c|c|c|}
\hline \multirow{2}{*}{$\begin{array}{c}\text { Código } \\
\text { da } \\
\text { amostra } \\
\text { tipo }\end{array}$} & $\begin{array}{l}\text { Lm1-28- } \\
2 \mathrm{~b}\end{array}$ & $\begin{array}{l}\text { Lm1-28- } \\
\quad 3\end{array}$ & $\begin{array}{l}\mathrm{Lm} 1-28- \\
\quad 4\end{array}$ & $\begin{array}{l}\text { Lm1-28- } \\
5\end{array}$ & $\begin{array}{l}\text { Lm1-28- } \\
6 \mathrm{~b}\end{array}$ & $\begin{array}{c}\text { Lm1-28- } \\
6 \mathrm{a}\end{array}$ & $\begin{array}{c}\text { Lm1-28- } \\
\quad 7\end{array}$ & $\begin{array}{l}\text { Lm1-28- } \\
\quad 8\end{array}$ & $\begin{array}{l}\text { Lm1-28- } \\
\quad 11\end{array}$ & In1-20b-1 & In1-20b-2 & In1-20b-3 & In1-20b-4 & In1-20b-5 & Fo-5-2" & Fo-5-4 & Fo-5-5 & Fo-5-6 & Fo-5-8 \\
\hline & \multicolumn{9}{|c|}{ dunito com bolsões de flogopita } & \multicolumn{5}{|c|}{ harzburgito com bolsões de flogopita } & \multicolumn{5}{|c|}{ flogopita dunito com Cr-espinélio } \\
\hline $\mathrm{SiO}_{2}$ & 40,78 & 40,80 & 41,08 & 40,85 & 40,87 & 41,23 & 40,95 & 41,43 & 41,65 & 40,88 & 40,77 & 39,84 & 40,22 & 40,38 & 39,50 & 38,90 & 40,02 & 40,46 & 40,49 \\
\hline $\mathrm{TiO}_{2}$ & 0,00 & 0,00 & 0,01 & 0,07 & 0,03 & 0,02 & 0,00 & 0,02 & 0,00 & 0,00 & 0,00 & 0,06 & 0,07 & 0,04 & 0,04 & 0,00 & 0,06 & 0,03 & 0,03 \\
\hline $\mathrm{Al}_{2} \mathrm{O}_{3}$ & 0,00 & 0,02 & 0,01 & 0,00 & 0,01 & 0,00 & 0,00 & 0,01 & 0,00 & 0,03 & 0,02 & 0,03 & 0,05 & 0,02 & 0,02 & 0,04 & 0,00 & 0,03 & 0,07 \\
\hline $\mathrm{FeO}$ & 8,87 & 8,43 & 7,67 & 8,92 & 8,70 & 8,70 & 8,73 & 8,62 & 8,67 & 6,85 & 6,95 & 6,95 & 7,64 & 6,87 & 10,04 & 9,48 & 9,68 & 9,70 & 9,82 \\
\hline $\mathrm{MnO}$ & 0,19 & 0,11 & 0,20 & 0,12 & 0,12 & 0,13 & 0,04 & 0,16 & 0,18 & 0,09 & 0,10 & 0,10 & 0,10 & 0,10 & 0,13 & 0,16 & 0,12 & 0,23 & 0,18 \\
\hline $\mathrm{MgO}$ & 50,04 & 50,04 & 50,92 & 50,01 & 50,25 & 50,30 & 50,64 & 50,82 & 50,87 & 51,90 & 51,16 & 51,60 & 51,89 & 51,46 & 49,76 & 48,97 & 49,61 & 49,78 & 49,51 \\
\hline $\mathrm{CaO}$ & 0,01 & 0,00 & 0,02 & 0,02 & 0,01 & 0,00 & 0,04 & 0,03 & 0,06 & 0,02 & 0,05 & 0,06 & 0,05 & 0,09 & 0,10 & 0,04 & 0,05 & 0,05 & 0,01 \\
\hline $\mathrm{Na}_{2} \mathrm{O}$ & 0,01 & 0,05 & 0,07 & 0,08 & 0,02 & 0,00 & 0,01 & 0,05 & 0,02 & 0,01 & 0,01 & 0,00 & 0,01 & 0,02 & 0,04 & 0,08 & 0,06 & 0,00 & 0,06 \\
\hline $\mathrm{K}_{2} \mathrm{O}$ & 0,00 & 0,01 & 0,00 & 0,01 & 0,00 & 0,00 & 0,03 & 0,02 & 0,00 & 0,00 & 0,02 & 0,01 & 0,00 & 0,02 & 0,00 & 0,00 & 0,00 & 0,01 & 0,01 \\
\hline $\mathrm{Cr}_{2} \mathrm{O}_{3}$ & 0,07 & 0,00 & 0,07 & 0,03 & 0,01 & 0,00 & 0,02 & 0,01 & 0,02 & 0,02 & 0,04 & 0,04 & 0,09 & 0,05 & 0,01 & 0,09 & 0,04 & 0,04 & 0,03 \\
\hline $\mathrm{NiO}$ & 0,37 & 0,38 & 0,32 & 0,42 & 0,45 & 0,34 & 0,32 & 0,45 & 0,22 & 0,44 & 0,37 & 0,39 & 0,37 & 0,39 & 0,27 & 0,53 & 0,33 & 0,30 & 0,38 \\
\hline Total & 100,34 & 99,85 & 100,37 & 100,53 & 100,47 & 100,72 & 100,75 & 101,62 & 101,69 & 100,25 & 99,48 & 99,08 & 100,50 & 99,45 & 99,90 & 98,30 & 99,98 & 100,61 & 100,59 \\
\hline $\mathrm{TSi}$ & 0,992 & 0,995 & 0,993 & 0,992 & 0,992 & 0,998 & 0,990 & 0,994 & 0,998 & 0,985 & 0,992 & 0,970 & 0,968 & 0,981 & 0,966 & 0,967 & 0,979 & 0,984 & 0,986 \\
\hline $\mathrm{TFe}^{3+}$ & 0,008 & 0,005 & 0,007 & 0,008 & 0,008 & 0,002 & 0,010 & 0,006 & 0,002 & 0,015 & 0,008 & 0,030 & 0,032 & 0,019 & 0,034 & 0,033 & 0,021 & 0,016 & 0,014 \\
\hline TAl & 0,000 & 0,000 & 0,000 & 0,000 & 0,000 & 0,000 & 0,000 & 0,000 & 0,000 & 0,000 & 0,000 & 0,000 & 0,000 & 0,000 & 0,000 & 0,000 & 0,000 & 0,000 & 0,000 \\
\hline Ttotal & 1,000 & 1,000 & 1,000 & 1,000 & 1,000 & 1,000 & 1,000 & 1,000 & 1,000 & 1,000 & 1,000 & 1,000 & 1,000 & 1,000 & 1,000 & 1,000 & 1,000 & 1,000 & 1,000 \\
\hline${\mathrm{M} 1 \mathrm{Fe}^{3+}}^{3+}$ & 0,006 & 0,007 & 0,007 & 0,009 & 0,008 & 0,001 & 0,011 & 0,008 & 0,002 & 0,014 & 0,007 & 0,026 & 0,025 & 0,017 & 0,033 & 0,033 & 0,021 & 0,013 & 0,013 \\
\hline M1Al & 0,000 & 0,001 & 0,000 & 0,000 & 0,000 & 0,000 & 0,000 & 0,000 & 0,000 & 0,001 & 0,001 & 0,001 & 0,002 & 0,001 & 0,000 & 0,001 & 0,000 & 0,001 & 0,002 \\
\hline $\mathrm{M} 1 \mathrm{Mg}$ & 1,815 & 1,820 & 1,836 & 1,810 & 1,818 & 1,816 & 1,825 & 1,817 & 1,817 & 1,864 & 1,855 & 1,874 & 1,863 & 1,864 & 1,815 & 1,814 & 1,808 & 1,805 & 1,797 \\
\hline${\mathrm{M} 1 F e^{2+}}^{2+}$ & 0,166 & 0,160 & 0,142 & 0,164 & 0,161 & 0,174 & 0,155 & 0,159 & 0,169 & 0,109 & 0,125 & 0,086 & 0,097 & 0,104 & 0,139 & 0,131 & 0,156 & 0,168 & 0,172 \\
\hline $\mathrm{M} 1 \mathrm{~K}$ & 0,000 & 0,000 & 0,000 & 0,000 & 0,000 & 0,000 & 0,001 & 0,000 & 0,000 & 0,000 & 0,001 & 0,000 & 0,000 & 0,001 & 0,000 & 0,000 & 0,000 & 0,000 & 0,000 \\
\hline M1Ni & 0,007 & 0,007 & 0,006 & 0,008 & 0,009 & 0,007 & 0,006 & 0,009 & 0,004 & 0,009 & 0,007 & 0,008 & 0,007 & 0,008 & 0,005 & 0,011 & 0,007 & 0,006 & 0,007 \\
\hline $\mathrm{M} 1 \mathrm{Cr}$ & 0,001 & 0,000 & 0,001 & 0,000 & 0,000 & 0,000 & 0,000 & 0,000 & 0,000 & 0,000 & 0,001 & 0,000 & 0,001 & 0,001 & 0,000 & 0,001 & 0,001 & 0,000 & 0,000 \\
\hline M1Mn & 0,004 & 0,002 & 0,004 & 0,002 & 0,002 & 0,003 & 0,001 & 0,003 & 0,004 & 0,002 & 0,002 & 0,002 & 0,002 & 0,002 & 0,003 & 0,003 & 0,003 & 0,005 & 0,004 \\
\hline M1Ti & 0,000 & 0,000 & 0,000 & 0,001 & 0,001 & 0,000 & 0,000 & 0,000 & 0,000 & 0,000 & 0,000 & 0,001 & 0,001 & 0,001 & 0,001 & 0,000 & 0,001 & 0,001 & 0,001 \\
\hline $\mathrm{M} 1 \mathrm{Ca}$ & 0,000 & 0,001 & 0,000 & 0,000 & 0,000 & 0,000 & 0,000 & 0,000 & 0,000 & 0,001 & 0,001 & 0,001 & 0,002 & 0,001 & 0,000 & 0,001 & 0,000 & 0,001 & 0,002 \\
\hline M1Total & 1,999 & 1,998 & 1,997 & 1,996 & 1,999 & 2,000 & 1,999 & 1,997 & 1,997 & 2,000 & 1,999 & 1,999 & 2,000 & 1,997 & 1,996 & 1,996 & 1,996 & 1,999 & 1,999 \\
\hline $\mathrm{mg} \#$ & 0,910 & 0,914 & 0,922 & 0,909 & 0,911 & 0,912 & 0,912 & 0,913 & 0,913 & 0,931 & 0,929 & 0,930 & 0,924 & 0,930 & 0,898 & 0,902 & 0,901 & 0,901 & 0,900 \\
\hline fa & 0,090 & 0,086 & 0,078 & 0,091 & 0,089 & 0,088 & 0,088 & 0,087 & 0,087 & 0,069 & 0,071 & 0,070 & 0,076 & 0,070 & 0,102 & 0,098 & 0,099 & 0,099 & 0,100 \\
\hline
\end{tabular}


Tabela 27- Composição química de olivina em peridotitos com clinopiroxênio metassomático dos corpos Indaiá 1 e Limeira 1.

\begin{tabular}{|c|c|c|c|c|c|c|c|c|c|c|c|c|}
\hline $\begin{array}{l}\text { Código } \\
\text { da } \\
\text { amostra }\end{array}$ & Lm1-38-7 & Lm1-38-12 & Lm1-38-3 & Lm1-38-4 & In1-6-1 & In1-6-2 & In1-6-3 & In1-6-4 & In1-12-1 & In1-12-2 & In1-12-3 & In1-12-4 \\
\hline tipo & \multicolumn{4}{|c|}{ flogopita wherlito } & \multicolumn{4}{|c|}{ flogopita ilmenita wehrlito } & \multicolumn{4}{|c|}{ harzburgito com bolsões de clinopiroxênio } \\
\hline $\mathrm{SiO}_{2}$ & 40,08 & 39,94 & 40,99 & 40,86 & 39,43 & 39,26 & 39,52 & 39,39 & 41,21 & 41,10 & 41,72 & 41,01 \\
\hline $\mathrm{TiO}_{2}$ & 0,00 & 0,00 & 0,00 & 0,00 & 0,00 & 0,02 & 0,00 & 0,00 & 0,00 & 0,04 & 0,05 & 0,06 \\
\hline $\mathrm{Al}_{2} \mathrm{O}_{3}$ & 0,05 & 0,02 & 0,00 & 0,00 & 0,00 & 0,00 & 0,02 & 0,04 & 0,00 & 0,00 & 0,00 & 0,02 \\
\hline $\mathrm{FeO}$ & 9,39 & 9,35 & 8,62 & 8,99 & 15,84 & 15,91 & 15,39 & 15,36 & 7,85 & 7,36 & 7,62 & 7,47 \\
\hline $\mathrm{MnO}$ & 0,11 & 0,18 & 0,10 & 0,15 & 0,20 & 0,20 & 0,19 & 0,12 & 0,07 & 0,12 & 0,12 & 0,11 \\
\hline $\mathrm{MgO}$ & 49,94 & 49,89 & 51,28 & 50,79 & 45,21 & 45,30 & 45,21 & 44,58 & 52,02 & 51,14 & 51,64 & 51,51 \\
\hline $\mathrm{CaO}$ & 0,04 & 0,01 & 0,03 & 0,08 & 0,02 & 0,01 & 0,02 & 0,05 & 0,03 & 0,01 & 0,00 & 0,00 \\
\hline $\mathrm{Na}_{2} \mathrm{O}$ & 0,06 & 0,00 & 0,00 & 0,04 & 0,01 & 0,00 & 0,02 & 0,01 & 0,00 & 0,03 & 0,00 & 0,01 \\
\hline $\mathrm{K}_{2} \mathrm{O}$ & 0,02 & 0,00 & 0,00 & 0,02 & 0,00 & 0,01 & 0,00 & 0,00 & 0,00 & 0,00 & 0,00 & 0,01 \\
\hline $\mathrm{Cr}_{2} \mathrm{O}_{3}$ & 0,01 & 0,03 & 0,01 & 0,00 & 0,04 & 0,00 & 0,03 & 0,00 & 0,00 & 0,00 & 0,05 & 0,00 \\
\hline $\mathrm{NiO}$ & 0,29 & 0,42 & 0,36 & 0,33 & 0,23 & 0,22 & 0,22 & 0,27 & 0,44 & 0,39 & 0,37 & 0,43 \\
\hline Total & 99,99 & 99,85 & 101,39 & 101,26 & 100,97 & 100,93 & 100,62 & 99,82 & 101,63 & 100,20 & 101,57 & 100,62 \\
\hline $\mathrm{TSi}$ & 0,978 & 0,977 & 0,983 & 0,983 & 0,982 & 0,978 & 0,986 & 0,992 & 0,983 & 0,994 & 0,997 & 0,987 \\
\hline $\mathrm{TFe}^{3+}$ & 0,022 & 0,023 & 0,017 & 0,017 & 0,018 & 0,022 & 0,014 & 0,008 & 0,017 & 0,006 & 0,003 & 0,013 \\
\hline TAl & 0,000 & 0,000 & 0,000 & 0,000 & 0,000 & 0,000 & 0,000 & 0,000 & 0,000 & 0,000 & 0,000 & 0,000 \\
\hline Ttotal & 1,000 & 1,000 & 1,000 & 1,000 & 1,000 & 1,000 & 1,000 & 1,000 & 1,000 & 1,000 & 1,000 & 1,000 \\
\hline $\mathrm{M} 1 \mathrm{Fe}^{3+}$ & 0,024 & 0,022 & 0,016 & 0,019 & 0,018 & 0,022 & 0,013 & 0,007 & 0,017 & 0,006 & 0,000 & 0,011 \\
\hline M1Al & 0,001 & 0,001 & 0,000 & 0,000 & 0,000 & 0,000 & 0,001 & 0,001 & 0,000 & 0,000 & 0,000 & 0,001 \\
\hline M1Mg & 1,817 & 1,819 & 1,834 & 1,822 & 1,678 & 1,681 & 1,682 & 1,674 & 1,850 & 1,844 & 1,840 & 1,849 \\
\hline${\mathrm{M} 1 \mathrm{Fe}^{2+}}^{2+}$ & 0,146 & 0,146 & 0,140 & 0,145 & 0,294 & 0,287 & 0,294 & 0,308 & 0,122 & 0,137 & 0,149 & 0,127 \\
\hline M1K & 0,001 & 0,000 & 0,000 & 0,001 & 0,000 & 0,000 & 0,000 & 0,000 & 0,000 & 0,000 & 0,000 & 0,000 \\
\hline $\mathrm{M} 1 \mathrm{Ni}$ & 0,006 & 0,008 & 0,007 & 0,006 & 0,005 & 0,004 & 0,004 & 0,006 & 0,008 & 0,008 & 0,007 & 0,008 \\
\hline $\mathrm{M} 1 \mathrm{Cr}$ & 0,000 & 0,000 & 0,000 & 0,000 & 0,000 & 0,000 & 0,000 & 0,000 & 0,000 & 0,000 & 0,001 & 0,000 \\
\hline M1Mn & 0,002 & 0,004 & 0,002 & 0,003 & 0,004 & 0,004 & 0,004 & 0,003 & 0,001 & 0,002 & 0,002 & 0,002 \\
\hline M1Ti & 0,000 & 0,000 & 0,000 & 0,000 & 0,000 & 0,000 & 0,000 & 0,000 & 0,000 & 0,001 & 0,001 & 0,001 \\
\hline $\mathrm{M} 1 \mathrm{Ca}$ & 0,001 & 0,001 & 0,000 & 0,000 & 0,000 & 0,000 & 0,001 & 0,001 & 0,000 & 0,000 & 0,000 & 0,001 \\
\hline M1Total & 1,998 & 2,000 & 1,999 & 1,996 & 1,999 & 2,000 & 1,999 & 1,999 & 1,999 & 1,998 & 2,000 & 2,000 \\
\hline $\mathrm{mg} \#$ & 0,905 & 0,905 & 0,914 & 0,910 & 0,836 & 0,835 & 0,840 & 0,838 & 0,922 & 0,925 & 0,924 & 0,925 \\
\hline fa & 0,095 & 0,095 & 0,086 & 0,090 & 0,164 & 0,165 & 0,160 & 0,162 & 0,078 & 0,075 & 0,076 & 0,075 \\
\hline
\end{tabular}


Tabela 28- Composição química de megacristais de olivina dos corpos Indaiá 1 e Limeira 1.

Código da Lm1-17-2 Lm1-17-1

\begin{tabular}{|c|c|c|c|}
\hline \multirow{2}{*}{$\begin{array}{l}\text { tipo } \\
\mathrm{SiO}_{2}\end{array}$} & \multicolumn{3}{|c|}{ megacristal de olivina } \\
\hline & 40,09 & 40,04 & 39 \\
\hline $\mathrm{TiO}_{2}$ & 0,05 & 0,04 & 0,0 \\
\hline $\mathrm{Al}_{2} \mathrm{O}_{3}$ & 0,00 & 0,00 & 0,0 \\
\hline $\mathrm{FeO}$ & 14,04 & 13,33 & 13 , \\
\hline $\mathrm{MnO}$ & 0,20 & 0,31 & 0,1 \\
\hline $\mathrm{MgO}$ & 46,10 & 46,54 & 45 \\
\hline $\mathrm{CaO}$ & 0,01 & 0,05 & 10 \\
\hline $\mathrm{Na}_{2} \mathrm{O}$ & 0,02 & 0,00 & 0 , \\
\hline $\mathrm{K}_{2} \mathrm{O}$ & 0,02 & 0,03 & 0,0 \\
\hline $\mathrm{Cr}_{2} \mathrm{O}_{3}$ & 0,01 & 0,03 & 0,0 \\
\hline $\mathrm{NiO}$ & 0,31 & 0,23 & 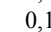 \\
\hline Total & 100,84 & 100,61 & 99 , \\
\hline $\mathrm{TSi}$ & 0,993 & 0,991 & 0,9 \\
\hline $\mathrm{TFe}^{3+}$ & 0,007 & 0,009 & 0,0 \\
\hline TAl & 0,000 & 0,000 & 0,0 \\
\hline Ttotal & 1,000 & 1,000 & 1,0 \\
\hline $\mathrm{M} 1 \mathrm{Fe}^{3+}$ & 0,007 & 0,007 & $\begin{array}{l}1,0 \\
0,0\end{array}$ \\
\hline M1Al & 0,000 & 0,000 & 0,0 \\
\hline $\mathrm{M} 1 \mathrm{Mg}$ & 1,703 & 1,718 & 1,7 \\
\hline${\mathrm{M} 1 F e^{2+}}^{2}$ & 0,277 & 0,261 & 02 \\
\hline M1K & 0,001 & 0,001 & 0,0 \\
\hline $\mathrm{M} 1 \mathrm{Ni}$ & 0,006 & 0,005 & 0,0 \\
\hline $\mathrm{M} 1 \mathrm{Cr}$ & 0,000 & 0,000 & \\
\hline M1Mn & 0,004 & 0,006 & \\
\hline M1Ti & 0,001 & 0,001 & \\
\hline $\mathrm{M} 1 \mathrm{Ca}$ & 0,000 & 0,000 & 0,0 \\
\hline M1Total & 1,999 & 1,999 & \\
\hline $\mathrm{mg} \#$ & 0,854 & 0,862 & \\
\hline fa & 0,146 & 0,138 & 0,1 \\
\hline
\end{tabular}

Lm1-40-11a

$$
\begin{gathered}
\text { borda de } \\
\text { megacristal }
\end{gathered}
$$$$
39,62
$$$$
0,00
$$$$
\begin{gathered}
0,00 \\
0,16 \\
12,52
\end{gathered}
$$

0,67

0,16

45,84

0,00

0,00

0,03
0,19

99,70

0,996

0,000

0,003

0,000

1,710
0,279

0,000

0,000

$\begin{array}{ll}0,000 & 0,004 \\ 0,000\end{array}$

$0,000 \quad 0,005$

$\begin{array}{ll}2,000 & 1,991 \\ 0,857 & 0,868 \\ 0,143 & 0,132\end{array}$

$\begin{array}{ll}0,857 & 0,868 \\ 0,143 & 0,132\end{array}$
Lm1-40-11b Lm1-40-11c

Lm1-41-5

Lm1-41-8 Lm1-41-13a

In1-20a-6

In1-20a-4

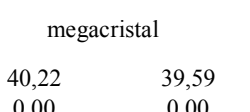

$\begin{array}{ll}40,22 & 39,59 \\ 0,00 & 0,00\end{array}$

$0,05 \quad 0,17$

6,87

0,16
51,12
0,02

0,02
0,32
0,00

0,00

0,03

0,28
99,06

99,06
0,979
0,021
0,000

0,979
0,021
0,000
1,000

1,000
0,034
0,001
1,855

0,034
0,001
1,855
0,085
0,000

0,000

0,005

0,000

0,001

$1,986-0,005$

$\begin{array}{ll}1,986 & 1,997 \\ 0,930 & 0,926 \\ 0,070 & 0,074\end{array}$

6

\begin{tabular}{cc|} 
megacristal & \\
& \\
39,84 & 39,39 \\
0,05 & 0,01 \\
0,00 & 0,03 \\
12,70 & 11,56 \\
0,20 & 0,17 \\
46,44 & 47,07 \\
0,05 & 0,08 \\
0,18 & 0,17 \\
0,01 & 0,00 \\
0,00 & 0,00 \\
0,25 & 0,24 \\
99,73 & 98,72 \\
0,992 & 0,985 \\
0,008 & 0,015 \\
0,000 & 0,000 \\
1,000 & 1,000 \\
0,016 & 0,022 \\
0,000 & 0,001 \\
1,723 & 1,754 \\
0,240 & 0,204 \\
0,000 & 0,000 \\
0,005 & 0,005 \\
0,000 & 0,000 \\
0,004 & 0,004 \\
0,001 & 0,000 \\
0,000 & 0,001 \\
1,990 & 1,991 \\
0,867 & 0,879 \\
0,133 & 0,121 \\
&
\end{tabular}

39,54
0,00
0,02
17,07
0,37
44,67
0,05
0,06
0,04
0,02
0,13
101,97
0,980
0,020
0,000
1,000
0,023
0,001
1,650
0,310
0,001
0,003
0,000
0,008
0,000
0,001
1,996
0,823
0,177

$$
\text { megacristal }
$$

40,74
0,01

0,01

12,16

12,16
0,17
47,71
0,05

0,05

0,09
0,01

0,01
0,04

0,32
101,35

0,996

0,004

0,000
1,000

0,006

0,001

1,738
0,238

$0,000 \quad 0,000$

$0,006 \quad 0,004$

$\begin{array}{ll}0,001 & 0,001 \\ 0,004 & 0,003\end{array}$

$\begin{array}{ll}0,000 & 0,000 \\ 0,001 & 0,000\end{array}$

$1,996 \quad 2,000$

0,125

40,33
0,00
0,01
13,17
0,14
47,94
0,02
0,00
0,00
0,04
0,23
101,88
0,982
0,018
0,000
1,000
0,016
0,000
1,741
0,234
0,000
0,004
0,001
0,003
0,000
0,000
2,000
0,866
0,134

0,134

In1-20a-3

In1-20a-1

Lm1-25-6a Lm1-25-6c Lm1-25-6b

$\begin{array}{cc}40,10 & 40,26 \\ 0,04 & 0,03 \\ 0,01 & 0,00 \\ 12,49 & 12,62 \\ 0,16 & 0,09 \\ 47,16 & 47,44 \\ 0,04 & 0,01 \\ 0,00 & 0,07 \\ 0,01 & 0,02 \\ 0,01 & 0,00 \\ 0,37 & 0,32 \\ 100,37 & 100,87 \\ 0,991 & 0,989 \\ 0,009 & 0,011 \\ 0,000 & 0,000 \\ 1,000 & 1,000 \\ 0,007 & 0,013 \\ 0,000 & 0,000 \\ 1,738 & 1,738 \\ 0,242 & 0,236 \\ 0,000 & 0,001 \\ 0,007 & 0,006 \\ 0,000 & 0,000 \\ 0,003 & 0,002 \\ 0,001 & 0,001 \\ 0,000 & 0,000 \\ 1,999 & 1,997 \\ 0,871 & 0,870 \\ 0,129 & 0,130\end{array}$

megacristal de nódulo esverdeado

$\begin{array}{lll}39,59 & 39,52 & 39,60\end{array}$

$\begin{array}{lll}0,06 & 0,03 & 0,04 \\ 0,03 & 0,03 & 0,02\end{array}$

$\begin{array}{lll}0,03 & 0,03 & 0,02 \\ 12,62 & 12,15 & 12,02\end{array}$

$\begin{array}{ccc}12,62 & 12,15 & 12,02 \\ 0,08 & 0,15 & 0,20\end{array}$

$\begin{array}{lll}0,08 & 0,15 & 0,20 \\ 47,65 & 47,83 & 47,6\end{array}$

$\begin{array}{lll}0,03 & 0,16 & 0,07 \\ 0,07 & 0,00 & 0,00\end{array}$

$\begin{array}{lll}0,07 & 0,00 & 0,00 \\ 0,00 & 0,00 & 0,00\end{array}$

$\begin{array}{lll}0,00 & 0,00 & 0,00 \\ 0,05 & 0,03 & 0,08\end{array}$

$\begin{array}{lll}0,30 & 0,45 & 0,49\end{array}$

$\begin{array}{ccc}100,48 & 100,37 & 100,14 \\ 0,975 & 0,974 & 0,979\end{array}$

$\begin{array}{lll}0,975 & 0,974 & 0,979 \\ 0,025 & 0,026 & 0,021\end{array}$

$\begin{array}{lll}0,025 & 0,026 & 0,021 \\ 0,000 & 0,000 & 0,000\end{array}$

$\begin{array}{lll}1,000 & 1,000 & 1,000\end{array}$

$\begin{array}{lll}0,024 & 0,023 & 0,016 \\ 0,001 & 0,001 & 0,001\end{array}$

$\begin{array}{lll}1,750 & 1,757 & 1,754 \\ 0,212 & 0,201 & 0,211\end{array}$

$\begin{array}{lll}1,212 & 0,201 & 0,211 \\ 0,000 & 0,000 & 0,000\end{array}$

$\begin{array}{lll}0,006 & 0,009 & 0,010 \\ 0,001 & 0,000 & 0,001\end{array}$

$\begin{array}{lll}0,002 & 0,000 & 0,001 \\ 0,003 & 0,004\end{array}$

$\begin{array}{lll}0,001 & 0,001 & 0,001 \\ 0,001 & 0,001 & 0,001\end{array}$

$\begin{array}{lll}0,001 & 0,001 & 0,001 \\ 1,997 & 1,997 & 1,999\end{array}$

$\begin{array}{lll}1,997 & 1,997 & 1,999 \\ 0,871 & 0,875 & 0,876\end{array}$

$\begin{array}{ll}0,129 & 0,875 \\ 0 & \end{array}$

0,124 
Tabela 29- Composição química de macrocristais de olivina dos corpos Indaiá 1 e Limeira 1.

\begin{tabular}{|c|c|c|c|c|c|c|c|c|c|c|c|c|c|c|c|c|c|c|c|}
\hline $\begin{array}{l}\text { Código } \\
\text { da } \\
\text { amostra }\end{array}$ & In1-36-12 & Lm1-20-4b & Lm1-25-4a & $\begin{array}{l}\text { Lm1-27- } \\
\quad 1\end{array}$ & Lm1-30-1 & $\begin{array}{l}\text { Lm1- } \\
30-2 b\end{array}$ & $\begin{array}{l}\text { Lm1- } \\
30-2\end{array}$ & $\begin{array}{l}\text { Lm1- } \\
30-3\end{array}$ & Lm1-32-4a & Lm1-36-3 & Lm1-36-4 & Lm1-40-4 & Lm1-41-1 & Lm1-41-6 & In1-27a-1a & In1-20a-7b & In1-20d-ol & In1-20d-1a & In1-20d-1" \\
\hline tin & macrocristal & macrocristal & $\begin{array}{l}\text { macrocristal } \\
\text { de autólito }\end{array}$ & $\begin{array}{c}\text { xenólito } \\
\text { granitico } \\
\text { borda }\end{array}$ & \multicolumn{4}{|c|}{ macrocristal } & macrocristal & \multicolumn{2}{|c|}{ macrocristal } & macrocristal & \multicolumn{2}{|c|}{ macrocristal } & $\begin{array}{c}\text { macrocristal } \\
\text { em borda de } \\
\text { reação }\end{array}$ & \multicolumn{2}{|c|}{ macrocristal } & \multicolumn{2}{|c|}{$\begin{array}{l}\text { macrocristal borda de } \\
\text { reação com granito }\end{array}$} \\
\hline $\mathrm{SiO}_{2}$ & 41,31 & 40,11 & 40,76 & 40,35 & 39,98 & 39,45 & 40,17 & 40,82 & 40,31 & 39,74 & 40,90 & 40,18 & 40,43 & 40,44 & 39,39 & 39,48 & 41,06 & 39,39 & 39,91 \\
\hline $\mathrm{TiO}_{2}$ & 0,00 & 0,02 & 0,00 & 0,05 & 0,04 & 0,02 & 0,00 & 0,00 & 0,06 & 0,00 & 0,00 & 0,00 & 0,02 & 0,00 & 0,01 & 0,02 & 0,06 & 0,00 & 0,00 \\
\hline $\mathrm{Al}_{2} \mathrm{O}_{3}$ & 0,01 & 0,04 & 0,03 & 0,00 & 0,17 & 0,06 & 0,00 & 0,15 & 0,00 & 0,01 & 0,01 & 0,00 & 0,00 & 0,02 & 0,00 & 0,06 & 0,02 & 0,01 & 0,15 \\
\hline $\mathrm{FeO}$ & 7,95 & 11,68 & 8,95 & 11,38 & 12,31 & 12,81 & 10,52 & 7,95 & 12,15 & 12,41 & 12,33 & 11,83 & 10,97 & 9,24 & 12,12 & 13,71 & 8,83 & 13,11 & 12,22 \\
\hline $\mathrm{MnO}$ & 0,05 & 0,23 & 0,15 & 0,18 & 0,10 & 0,11 & 0,24 & 0,08 & 0,11 & 0,17 & 0,19 & 0,11 & 0,19 & 0,18 & 0,16 & 0,26 & 0,18 & 0,25 & 0,22 \\
\hline $\mathrm{MgO}$ & 51,31 & 48,05 & 50,59 & 48,50 & 47,81 & 47,53 & 49,37 & 50,78 & 47,97 & 47,56 & 47,93 & 48,94 & 48,30 & 49,52 & 46,80 & 45,98 & 51,03 & 46,57 & 47,15 \\
\hline $\mathrm{CaO}$ & 0,00 & 0,03 & 0,01 & 0,07 & 0,09 & 0,06 & 0,00 & 0,00 & 0,07 & 0,06 & 0,07 & 0,00 & 0,00 & 0,04 & 0,03 & 0,12 & 0,05 & 0,04 & 0,13 \\
\hline $\mathrm{Na}_{2} \mathrm{O}$ & 0,00 & 0,02 & 0,06 & 0,00 & 0,05 & 0,38 & 0,25 & 0,08 & 0,02 & 0,01 & 0,06 & 0,00 & 0,25 & 0,08 & 0,07 & 0,00 & 0,01 & 0,04 & 0,00 \\
\hline $\mathrm{K}_{2} \mathrm{O}$ & 0,00 & 0,00 & 0,00 & 0,02 & 0,03 & 0,00 & 0,00 & 0,02 & 0,04 & 0,01 & 0,09 & 0,01 & 0,05 & 0,00 & 0,00 & 0,00 & 0,00 & 0,03 & 0,00 \\
\hline $\mathrm{Cr}_{2} \mathrm{O}_{3}$ & 0,00 & 0,05 & 0,08 & 0,00 & 0,01 & 0,00 & 0,00 & 0,00 & 0,00 & 0,02 & 0,00 & 0,07 & 0,04 & 0,01 & 0,00 & 0,00 & 0,08 & 0,08 & 0,00 \\
\hline $\mathrm{NiO}$ & 0,35 & 0,36 & 0,45 & 0,40 & 0,35 & 0,42 & 0,39 & 0,49 & 0,26 & 0,21 & 0,32 & 0,27 & 0,40 & 0,24 & 0,18 & 0,13 & 0,46 & 0,11 & 0,48 \\
\hline Total & 100,98 & 100,58 & 101,08 & 100,95 & 100,93 & 100,83 & 100,95 & 100,37 & 100,98 & 100,19 & 101,91 & 101,40 & 100,65 & 99,77 & 98,76 & 99,76 & 101,79 & 99,62 & 100,26 \\
\hline $\mathrm{TSi}$ & 0,993 & 0,985 & 0,983 & 0,986 & 0,980 & 0,968 & 0,975 & 0,988 & 0,987 & 0,982 & 0,994 & 0,977 & 0,989 & 0,990 & 0,987 & 0,987 & 0,983 & 0,983 & 0,987 \\
\hline $\mathrm{TFe}^{3+}$ & 0,007 & 0,015 & 0,017 & 0,014 & 0,020 & 0,032 & 0,025 & 0,012 & 0,013 & 0,018 & 0,006 & 0,023 & 0,011 & 0,010 & 0,013 & 0,013 & 0,017 & 0,017 & 0,013 \\
\hline TAl & 0,000 & 0,000 & 0,000 & 0,000 & 0,000 & 0,000 & 0,000 & 0,000 & 0,000 & 0,000 & 0,000 & 0,000 & 0,000 & 0,000 & 0,000 & 0,000 & 0,000 & 0,000 & 0,000 \\
\hline Ttotal & 1,000 & 1,000 & 1,000 & 1,000 & 1,000 & 1,000 & 1,000 & 1,000 & 1,000 & 1,000 & 1,000 & 1,000 & 1,000 & 1,000 & 1,000 & 1,000 & 1,000 & 1,000 & 1,000 \\
\hline $\mathrm{M} \mathrm{Fe}^{3+}$ & 0,006 & 0,013 & 0,016 & 0,013 & 0,016 & 0,048 & 0,037 & 0,012 & 0,013 & 0,018 & 0,011 & 0,021 & 0,022 & 0,013 & 0,016 & 0,011 & 0,012 & 0,017 & 0,009 \\
\hline M1Al & 0,000 & 0,001 & 0,001 & 0,000 & 0,005 & 0,002 & 0,000 & 0,004 & 0,000 & 0,000 & 0,000 & 0,000 & 0,000 & 0,001 & 0,000 & 0,002 & 0,001 & 0,000 & 0,005 \\
\hline $\mathrm{M} 1 \mathrm{Mg}$ & 1,839 & 1,759 & 1,819 & 1,767 & 1,747 & 1,738 & 1,787 & 1,832 & 1,751 & 1,751 & 1,737 & 1,774 & 1,761 & 1,807 & 1,748 & 1,713 & 1,822 & 1,732 & 1,738 \\
\hline $\mathrm{M}^{2} \mathrm{Fe}^{2+}$ & 0,147 & 0,212 & 0,148 & 0,205 & 0,216 & 0,182 & 0,152 & 0,136 & 0,223 & 0,220 & 0,234 & 0,196 & 0,191 & 0,166 & 0,224 & 0,262 & 0,149 & 0,239 & 0,231 \\
\hline M1K & 0,000 & 0,000 & 0,000 & 0,001 & 0,001 & 0,000 & 0,000 & 0,001 & 0,001 & 0,000 & 0,003 & 0,000 & 0,001 & 0,000 & 0,000 & 0,000 & 0,000 & 0,001 & 0,000 \\
\hline M1Ni & 0,007 & 0,007 & 0,009 & 0,008 & 0,007 & 0,008 & 0,008 & 0,009 & 0,005 & 0,004 & 0,006 & 0,005 & 0,008 & 0,005 & 0,004 & 0,003 & 0,009 & 0,002 & 0,010 \\
\hline $\mathrm{M} 1 \mathrm{Cr}$ & 0,000 & 0,001 & 0,001 & 0,000 & 0,000 & 0,000 & 0,000 & 0,000 & 0,000 & 0,000 & 0,000 & 0,001 & 0,001 & 0,000 & 0,000 & 0,000 & 0,001 & 0,001 & 0,000 \\
\hline M1Mn & 0,001 & 0,005 & 0,003 & 0,004 & 0,002 & 0,002 & 0,005 & 0,002 & 0,002 & 0,004 & 0,004 & 0,002 & 0,004 & 0,004 & 0,003 & 0,006 & 0,004 & 0,005 & 0,005 \\
\hline M1Ti & 0,000 & 0,000 & 0,000 & 0,001 & 0,001 & 0,000 & 0,000 & 0,000 & 0,001 & 0,000 & 0,000 & 0,000 & 0,000 & 0,000 & 0,000 & 0,000 & 0,001 & 0,000 & 0,000 \\
\hline $\mathrm{M} 1 \mathrm{Ca}$ & 0,000 & 0,001 & 0,001 & 0,000 & 0,005 & 0,002 & 0,000 & 0,004 & 0,000 & 0,000 & 0,000 & 0,000 & 0,000 & 0,001 & 0,000 & 0,002 & 0,001 & 0,000 & 0,005 \\
\hline M1Total & 2,000 & 1,999 & 1,998 & 1,998 & 2,000 & 1,982 & 1,988 & 2,000 & 1,997 & 1,998 & 1,996 & 2,000 & 1,988 & 1,996 & 1,996 & 1,998 & 1,999 & 1,997 & 2,001 \\
\hline mg\# & 0,920 & 0,880 & 0,910 & 0,884 & 0,874 & 0,869 & 0,893 & 0,919 & 0,876 & 0,872 & 0,874 & 0,881 & 0,887 & 0,905 & 0,873 & 0,857 & 0,912 & 0,864 & 0,873 \\
\hline fa & 0,080 & 0,120 & 0,090 & 0,116 & 0,126 & 0,131 & 0,107 & 0,081 & 0,124 & 0,128 & 0,126 & 0,119 & 0,113 & 0,095 & 0,127 & 0,143 & 0,088 & 0,136 & 0,127 \\
\hline
\end{tabular}


Tabela 30- Composição química de macrocristais de olivina do corpo Forca.

\begin{tabular}{|c|c|c|c|c|c|c|c|c|c|c|c|c|c|c|c|}
\hline $\begin{array}{l}\text { Código } \\
\text { da } \\
\text { amostra }\end{array}$ & Fo-2-35 & Fo-1-6b & Fo-1-7 & Fo-1-8 & Fo-1-17a & Fo-1-17b & Fo-1-18 & Fo-5-16 & Fo-5-15 & Fo-6-4 & Fo-6-5 & Fo-6-20 & Fo-6-15 & Fo-6-14 & Fo-6-19 \\
\hline tipo & macrocristal & \multicolumn{2}{|c|}{ macrocristal centro } & macrocristal borda & & macrocristal & & \multicolumn{2}{|c|}{ macrocristal } & \multicolumn{6}{|c|}{ macrocristal } \\
\hline $\mathrm{SiO}_{2}$ & 41,26 & 41,26 & 41,09 & 39,43 & 40,69 & 39,79 & 39,69 & 40,63 & 39,28 & 39,38 & 39,55 & 39,11 & 37,92 & 38,06 & 41,34 \\
\hline $\mathrm{TiO}_{2}$ & 0,08 & 0,00 & 0,00 & 0,04 & 0,02 & 0,01 & 0,06 & 0,00 & 0,00 & 0,03 & 0,06 & 0,09 & 0,00 & 0,00 & 0,04 \\
\hline $\mathrm{Al}_{2} \mathrm{O}_{3}$ & 0,00 & 0,01 & 0,00 & 0,04 & 0,02 & 0,00 & 0,04 & 0,00 & 0,03 & 0,00 & 0,04 & 0,02 & 0,02 & 0,06 & 0,10 \\
\hline $\mathrm{FeO}$ & 7,29 & 7,97 & 7,88 & 15,02 & 8,02 & 9,39 & 15,30 & 10,15 & 16,95 & 15,12 & 14,79 & 13,55 & 16,09 & 17,51 & 7,66 \\
\hline $\mathrm{MnO}$ & 0,15 & 0,14 & 0,19 & 0,23 & 0,14 & 0,15 & 0,18 & 0,12 & 0,26 & 0,22 & 0,18 & 0,25 & 0,12 & 0,18 & 0,10 \\
\hline $\mathrm{MgO}$ & 51,55 & 51,94 & 51,57 & 46,58 & 51,49 & 49,98 & 45,66 & 50,32 & 44,42 & 46,37 & 45,89 & 46,34 & 44,19 & 42,88 & 51,70 \\
\hline $\mathrm{CaO}$ & 0,02 & 0,03 & 0,02 & 0,08 & 0,00 & 0,03 & 0,10 & 0,05 & 0,07 & 0,15 & 0,11 & 0,04 & 0,07 & 0,10 & 0,02 \\
\hline $\mathrm{Na}_{2} \mathrm{O}$ & 0,00 & 0,03 & 0,08 & 0,00 & 0,04 & 0,04 & 0,07 & 0,12 & 0,06 & 0,04 & 0,46 & 0,42 & 0,10 & 0,20 & 0,11 \\
\hline $\mathrm{K}_{2} \mathrm{O}$ & 0,00 & 0,03 & 0,01 & 0,00 & 0,00 & 0,02 & 0,00 & 0,00 & 0,05 & 0,00 & 0,00 & 0,02 & 0,00 & 0,01 & 0,00 \\
\hline $\mathrm{Cr}_{2} \mathrm{O}_{3}$ & 0,00 & 0,04 & 0,01 & 0,00 & 0,07 & 0,02 & 0,08 & 0,02 & 0,04 & 0,02 & 0,08 & 0,00 & 0,02 & 0,00 & 0,04 \\
\hline $\mathrm{NiO}$ & 0,36 & 0,33 & 0,47 & 0,36 & 0,37 & 0,53 & 0,36 & 0,41 & 0,26 & 0,52 & 0,32 & 0,12 & 0,42 & 0,28 & 0,40 \\
\hline Total & 100,70 & 101,78 & 101,32 & 101,78 & 100,87 & 99,97 & 101,54 & 101,81 & 101,41 & 101,85 & 101,48 & 99,95 & 98,96 & 99,28 & 101,50 \\
\hline $\mathrm{TSi}$ & 0,993 & 0,983 & 0,984 & 0,969 & 0,979 & 0,971 & 0,981 & 0,976 & 0,979 & 0,968 & 0,973 & 0,971 & 0,964 & 0,971 & 0,987 \\
\hline $\mathrm{TFe}^{3+}$ & 0,007 & 0,017 & 0,016 & 0,031 & 0,021 & 0,029 & 0,019 & 0,024 & 0,021 & 0,032 & 0,027 & 0,029 & 0,036 & 0,029 & 0,013 \\
\hline TAl & 0,000 & 0,000 & 0,000 & 0,000 & 0,000 & 0,000 & 0,000 & 0,000 & 0,000 & 0,000 & 0,000 & 0,000 & 0,000 & 0,000 & 0,000 \\
\hline Ttotal & 1,000 & 1,000 & 1,000 & 1,000 & 1,000 & 1,000 & 1,000 & 1,000 & 1,000 & 1,000 & 1,000 & 1,000 & 1,000 & 1,000 & 1,000 \\
\hline $\mathrm{M} 1 \mathrm{Fe}^{3+}$ & 0,005 & 0,018 & 0,020 & 0,029 & 0,020 & 0,030 & 0,017 & 0,029 & 0,023 & 0,032 & 0,043 & 0,046 & 0,040 & 0,037 & 0,013 \\
\hline M1Al & 0,000 & 0,000 & 0,000 & 0,001 & 0,001 & 0,000 & 0,001 & 0,000 & 0,001 & 0,000 & 0,001 & 0,001 & 0,001 & 0,002 & 0,003 \\
\hline $\mathrm{M} 1 \mathrm{Mg}$ & 1,849 & 1,845 & 1,841 & 1,706 & 1,846 & 1,819 & 1,683 & 1,802 & 1,650 & 1,699 & 1,684 & 1,716 & 1,675 & 1,631 & 1,840 \\
\hline $\mathrm{M}_{1} \mathrm{Fe}^{2+}$ & 0,135 & 0,124 & 0,122 & 0,249 & 0,120 & 0,133 & 0,281 & 0,151 & 0,309 & 0,247 & 0,235 & 0,207 & 0,266 & 0,307 & 0,127 \\
\hline M1K & 0,000 & 0,001 & 0,000 & 0,000 & 0,000 & 0,001 & 0,000 & 0,000 & 0,002 & 0,000 & 0,000 & 0,001 & 0,000 & 0,000 & 0,000 \\
\hline $\mathrm{M} 1 \mathrm{Ni}$ & 0,007 & 0,006 & 0,009 & 0,007 & 0,007 & 0,010 & 0,007 & 0,008 & 0,005 & 0,010 & 0,006 & 0,002 & 0,009 & 0,006 & 0,008 \\
\hline $\mathrm{M} 1 \mathrm{Cr}$ & 0,000 & 0,001 & 0,000 & 0,000 & 0,001 & 0,000 & 0,001 & 0,000 & 0,001 & 0,000 & 0,001 & 0,000 & 0,000 & 0,000 & 0,000 \\
\hline M1Mn & 0,003 & 0,003 & 0,004 & 0,005 & 0,003 & 0,003 & 0,004 & 0,002 & 0,005 & 0,004 & 0,004 & 0,005 & 0,003 & 0,004 & 0,002 \\
\hline M1Ti & 0,001 & 0,000 & 0,000 & 0,001 & 0,000 & 0,000 & 0,001 & 0,000 & 0,000 & 0,000 & 0,001 & 0,002 & 0,000 & 0,000 & 0,001 \\
\hline $\mathrm{M} 1 \mathrm{Ca}$ & 0,000 & 0,000 & 0,000 & 0,001 & 0,001 & 0,000 & 0,001 & 0,000 & 0,001 & 0,000 & 0,001 & 0,001 & 0,001 & 0,002 & 0,003 \\
\hline M1Total & 2,000 & 1,998 & 1,996 & 1,999 & 1,999 & 1,997 & 1,995 & 1,993 & 1,996 & 1,994 & 1,976 & 1,980 & 1,993 & 1,989 & 1,997 \\
\hline $\mathrm{mg} \#$ & 0,926 & 0,921 & 0,921 & 0,847 & 0,920 & 0,905 & 0,842 & 0,898 & 0,824 & 0,845 & 0,847 & 0,859 & 0,830 & 0,814 & 0,923 \\
\hline fa & 0,074 & 0,079 & 0,079 & 0,153 & 0,080 & 0,095 & 0,158 & 0,102 & 0,176 & 0,155 & 0,153 & 0,141 & 0,170 & 0,186 & 0,077 \\
\hline
\end{tabular}


Tabela 31- Composição química de macrocristais de olivina dos corpos Indaiá 2 e Facão.

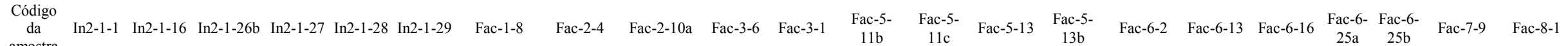

\begin{tabular}{|c|c|c|c|c|c|c|c|c|c|c|c|c|c|c|c|c|c|c|c|c|c|c|}
\hline tipo & & & macr & rital & & & $\begin{array}{l}\text { macrocristal } \\
\text { centro }\end{array}$ & & $\begin{array}{c}\text { borda } \\
\text { macrocristal }\end{array}$ & $\begin{array}{l}\text { olivina } \\
\text { com } \\
\text { ilmenita }\end{array}$ & & & lacrocrist & & & & nacrocrista & & $\begin{array}{r}\text { reaçã } \\
\text { xen }\end{array}$ & $\begin{array}{l}\text { o com } \\
\text { olito }\end{array}$ & macr. & \\
\hline $\mathrm{SiO}_{2}$ & 40,63 & 40,00 & 40,95 & 39,91 & 40,46 & 40,93 & 39,75 & 41,42 & 40,04 & 40,91 & 40,06 & 41,27 & 40,66 & 40,27 & 39,90 & 39,93 & 39,79 & 39,49 & 38,91 & 39,99 & 39,18 & 39,68 \\
\hline $\mathrm{TiO}_{2}$ & 0,03 & 0,01 & 0,01 & 0,00 & 0,00 & 0,05 & 0,04 & 0,02 & 0,04 & 0,06 & 0,00 & 0,00 & 0,00 & 0,04 & 0,02 & 0,01 & 0,00 & 0,00 & 0,04 & 0,02 & 0,02 & 0,02 \\
\hline $\mathrm{Al}_{2} \mathrm{O}_{3}$ & 0,00 & 0,00 & 0,09 & 0,00 & 0,00 & 0,00 & 0,05 & 0,04 & 0,00 & 0,09 & 0,00 & 0,03 & 0,00 & 0,00 & 0,02 & 0,03 & 0,00 & 0,00 & 0,03 & 0,00 & 0,00 & 0,00 \\
\hline $\mathrm{FeO}$ & 12,25 & 11,26 & 9,88 & 14,89 & 11,69 & 9,42 & 13,91 & 8,53 & 10,36 & 10,55 & 14,48 & 10,70 & 11,75 & 11,31 & 13,60 & 13,39 & 14,83 & 10,79 & 13,34 & 13,11 & 10,35 & 13,89 \\
\hline $\mathrm{MnO}$ & 0,19 & 0,08 & 0,13 & 0,20 & 0,21 & 0,12 & 0,21 & 0,11 & 0,18 & 0,22 & 0,15 & 0,22 & 0,13 & 0,21 & 0,13 & 0,19 & 0,22 & 0,13 & 0,20 & 0,26 & 0,18 & 0,27 \\
\hline $\mathrm{MgO}$ & 48,03 & 48,59 & 49,55 & 45,15 & 48,57 & 49,00 & 45,78 & 50,63 & 48,89 & 47,90 & 45,65 & 48,64 & 48,40 & 48,67 & 47,13 & 47,06 & 46,19 & 48,46 & 45,19 & 46,08 & 48,77 & 45,41 \\
\hline $\mathrm{CaO}$ & 0,07 & 0,16 & 0,38 & 0,82 & 0,01 & 0,31 & 0,08 & 0,12 & 0,17 & 0,23 & 0,06 & 0,20 & 0,12 & 0,23 & 0,09 & 0,22 & 0,07 & 0,10 & 0,29 & 0,22 & 0,06 & 0,10 \\
\hline $\mathrm{Na}_{2} \mathrm{O}$ & 0,06 & 0,00 & 0,07 & 0,08 & 0,09 & 0,04 & 0,00 & 0,08 & 0,00 & 0,01 & 0,02 & 0,18 & 0,00 & 0,20 & 0,16 & 0,02 & 0,00 & 0,03 & 0,01 & 0,00 & 0,08 & 0,14 \\
\hline $\mathrm{K}_{2} \mathrm{O}$ & 0,03 & 0,01 & 0,00 & 0,03 & 0,03 & 0,00 & 0,03 & 0,01 & 0,01 & 0,01 & 0,01 & 0,00 & 0,00 & 0,00 & 0,01 & 0,04 & 0,00 & 0,00 & 0,02 & 0,00 & 0,01 & 0,12 \\
\hline $\mathrm{Cr}_{2} \mathrm{O}_{3}$ & 0,00 & 0,00 & 0,02 & 0,09 & 0,00 & 0,04 & 0,00 & 0,14 & 0,04 & 0,09 & 0,00 & 0,09 & 0,01 & 0,11 & 0,00 & 0,10 & 0,00 & 0,17 & 0,74 & 0,12 & 0,00 & 0,03 \\
\hline $\mathrm{NiO}$ & 0,30 & 0,51 & 0,29 & 0,32 & 0,23 & 0,19 & 0,30 & 0,39 & 0,39 & 0,37 & 0,31 & 0,38 & 0,37 & 0,36 & 0,38 & 0,29 & 0,28 & 0,41 & 0,23 & 0,21 & 0,24 & 0,13 \\
\hline Total & 101,60 & 100,61 & 101,37 & 101,48 & 101,29 & 100,10 & 100,15 & 101,49 & 100,10 & 100,43 & 100,74 & 101,70 & 101,43 & 101,41 & 101,44 & 101,27 & 101,38 & 99,57 & 99,01 & 100,01 & 98,89 & 99,79 \\
\hline TSi & 0,990 & 0,979 & 0,990 & 0,988 & 0,985 & 1,002 & 0,992 & 0,995 & 0,982 & 1,005 & 0,996 & 1,000 & 0,990 & 0,978 & 0,978 & 0,981 & 0,982 & 0,975 & 0,984 & 0,997 & 0,970 & 0,993 \\
\hline $\mathrm{TFe}^{3+}$ & 0,010 & 0,021 & 0,010 & 0,012 & 0,015 & 0,000 & 0,008 & 0,005 & 0,018 & 0,000 & 0,004 & 0,000 & 0,010 & 0,022 & 0,022 & 0,019 & 0,018 & 0,025 & 0,006 & 0,002 & 0,030 & 0,007 \\
\hline TAl & 0,000 & 0,000 & 0,000 & 0,000 & 0,000 & 0,000 & 0,000 & 0,000 & 0,000 & 0,000 & 0,000 & 0,000 & 0,000 & 0,000 & 0,000 & 0,000 & 0,000 & 0,000 & 0,001 & 0,000 & 0,000 & 0,000 \\
\hline Ttotal & 1,000 & 1,000 & 1,000 & 1,000 & 1,000 & 1,002 & 1,000 & 1,000 & 1,000 & 1,005 & 1,000 & 1,000 & 1,000 & 1,000 & 1,000 & 1,000 & 1,000 & 1,000 & 0,991 & 0,998 & 1,000 & 1,000 \\
\hline $\mathrm{M} 1 \mathrm{Fe}^{3+}$ & 0,013 & 0,020 & 0,010 & 0,015 & 0,020 & 0,000 & 0,006 & 0,003 & 0,015 & 0,000 & 0,006 & 0,005 & 0,010 & 0,026 & 0,029 & 0,016 & 0,018 & 0,020 & 0,000 & 0,000 & 0,033 & 0,016 \\
\hline M1Al & 0,000 & 0,000 & 0,003 & 0,000 & 0,000 & 0,000 & 0,001 & 0,001 & 0,000 & 0,003 & 0,000 & 0,001 & 0,000 & 0,000 & 0,001 & 0,001 & 0,000 & 0,000 & 0,000 & 0,000 & 0,000 & 0,000 \\
\hline M1Mg & 1,744 & 1,774 & 1,786 & 1,666 & 1,763 & 1,788 & 1,703 & 1,813 & 1,788 & 1,755 & 1,691 & 1,756 & 1,757 & 1,763 & 1,722 & 1,724 & 1,700 & 1,785 & 1,704 & 1,712 & 1,800 & 1,694 \\
\hline $\mathrm{M} \mathrm{Fe}^{2+}$ & 0,226 & 0,190 & 0,180 & 0,281 & 0,202 & 0,193 & 0,275 & 0,164 & 0,180 & 0,217 & 0,291 & 0,211 & 0,220 & 0,182 & 0,228 & 0,240 & 0,270 & 0,178 & 0,277 & 0,272 & 0,151 & 0,268 \\
\hline M1K & 0,001 & 0,000 & 0,000 & 0,001 & 0,001 & 0,000 & 0,0 & 0,000 & 0,000 & 0,000 & 0,000 & 0,000 & 0,000 & 0,000 & 0,000 & 0,001 & 0,000 & 0,000 & 0,001 & 0,000 & 0,000 & 0,004 \\
\hline M1Ni & 0,006 & 0,010 & 0,006 & 0,006 & 0,004 & 0,004 & 0, & 0,008 & 0,008 & 0,007 & 0,006 & 0,007 & 0,007 & 0,007 & 0,008 & 0,006 & 0,005 & 0,008 & 0,005 & 0,004 & 0,005 & 0,003 \\
\hline $\mathrm{M} 1 \mathrm{Cr}$ & 0,000 & 0,000 & 0,000 & 0,001 & 0,000 & 0,000 & 0,0 & 0,002 & 0,0 & 0,001 & 0,0 & 0,001 & 0,000 & 0,001 & 0,000 & 0,001 & 0,000 & 0,002 & 0,010 & 0,002 & 0,000 & 0,000 \\
\hline M1Mn & 0,004 & 0,002 & 0,003 & 0,0 & 0,0 & 0,0 & 0,0 & 0,002 & 0,0 & 0,0 & 0,0 & 0,004 & 0,0 & 0,0 & 0,003 & 0,004 & 0,005 & 0,003 & 0,004 & 0,006 & 0,004 & 0,006 \\
\hline M1Ti & 0,001 & 0,000 & 0,000 & 0,000 & 0,000 & 0,001 & 0,001 & 0,000 & 0,001 & 0,001 & 0,000 & 0,000 & 0,000 & 0,001 & 0,000 & 0,000 & 0,000 & 0,000 & 0,001 & 0,000 & 0,000 & 0,000 \\
\hline $\mathrm{M} 1 \mathrm{Ca}$ & 0,000 & 0,000 & 0,003 & 0,00 & 0,000 & 0,0 & 0,0 & 0,001 & 0,0 & 0,00 & 0,0 & 0,001 & 0,000 & 0,000 & 0,001 & 0,001 & 0,000 & 0,000 & 0,001 & 0,000 & 0,000 & 0,000 \\
\hline M1Total & 1,995 & 1,996 & 1,989 & 1,974 & 1,996 & 1,988 & 1,999 & 1,994 & 1,996 & 1,991 & 1,998 & 1,987 & 1,997 & 1,984 & 1,991 & 1,994 & 1,998 & 1,996 & 2,002 & 1,996 & 1,994 & 1,991 \\
\hline $\mathrm{mg} \#$ & 0,875 & 0,885 & 0,899 & 0,844 & 0,881 & 0,903 & 0,854 & 0,914 & 0,894 & 0,890 & 0,849 & 0,890 & 0,880 & 0,885 & 0,861 & 0,862 & 0,847 & 0,889 & 0,858 & 0,862 & 0,894 & 0,854 \\
\hline fa & 0,125 & 0,115 & 0,101 & 0,156 & 0,119 & 0,097 & 0,146 & 0,086 & 0,106 & 0,110 & 0,151 & 0,110 & 0,120 & 0,115 & 0,139 & 0,138 & 0,153 & 0,111 & 0,142 & 0,138 & 0,106 & 0,146 \\
\hline
\end{tabular}


Tabela 32- Composição química de olivina em peridotitos do corpo Facão.

\begin{tabular}{|c|c|c|c|c|c|c|c|c|c|c|c|c|c|c|c|c|}
\hline $\begin{array}{l}\text { Código da } \\
\text { amostra }\end{array}$ & Fac-2-5 & Fac-2-6 & Fac-2-7 & Fac-2-8b & Fac-2-8c & Fac-2-9 & Fac-2-8a & Fac-7-7 & Fac-7-2 & Fac-7-1b & Fac-7-10 & Fac-7-3 & Fac-7-6c & Fac-8-2 & Fac-8-8 & Fac-8-10 \\
\hline tipo & & dunito & & $\begin{array}{l}\text { dunito } \\
\text { centro de } \\
\text { cristal }\end{array}$ & dunito & borda dunito & dunito & \multicolumn{2}{|c|}{ wehrlito } & $\begin{array}{l}\text { borda de } \\
\text { wehrlito }\end{array}$ & & wehrlito & & & dunito & \\
\hline $\mathrm{SiO}_{2}$ & 40,69 & 40,21 & 40,59 & 41,43 & 40,54 & 39,86 & 40,88 & 40,25 & 39,48 & 38,98 & 39,91 & 39,82 & 40,05 & 39,72 & 40,94 & 40,48 \\
\hline $\mathrm{TiO}_{2}$ & 0,00 & 0,04 & 0,00 & 0,02 & 0,03 & 0,00 & 0,06 & 0,00 & 0,02 & 0,05 & 0,00 & 0,00 & 0,00 & 0,00 & 0,00 & 0,04 \\
\hline $\mathrm{Al}_{2} \mathrm{O}_{3}$ & 0,01 & 0,00 & 0,00 & 0,00 & 0,00 & 0,00 & 0,00 & 0,03 & 0,00 & 0,00 & 0,08 & 0,00 & 0,07 & 0,00 & 0,00 & 0,00 \\
\hline $\mathrm{FeO}$ & 11,01 & 10,99 & 10,55 & 10,23 & 10,32 & 10,73 & 10,26 & 10,90 & 13,54 & 13,09 & 13,70 & 13,20 & 12,01 & 14,39 & 14,12 & 13,67 \\
\hline $\mathrm{MnO}$ & 0,07 & 0,19 & 0,20 & 0,17 & 0,16 & 0,15 & 0,16 & 0,02 & 0,26 & 0,17 & 0,13 & 0,18 & 0,26 & 0,25 & 0,27 & 0,19 \\
\hline $\mathrm{MgO}$ & 48,61 & 49,41 & 49,26 & 49,08 & 49,38 & 48,77 & 49,28 & 49,20 & 47,22 & 47,32 & 46,27 & 46,54 & 47,50 & 45,49 & 44,74 & 45,27 \\
\hline $\mathrm{CaO}$ & 0,05 & 0,05 & 0,05 & 0,09 & 0,06 & 0,11 & 0,13 & 0,07 & 0,06 & 0,03 & 0,64 & 0,03 & 0,10 & 0,05 & 0,08 & 0,04 \\
\hline $\mathrm{Na}_{2} \mathrm{O}$ & 0,00 & 0,00 & 0,00 & 0,10 & 0,00 & 0,02 & 0,08 & 0,00 & 0,00 & 0,00 & 0,00 & 0,00 & 0,10 & 0,01 & 0,11 & 0,00 \\
\hline $\mathrm{K}_{2} \mathrm{O}$ & 0,01 & 0,02 & 0,00 & 0,01 & 0,01 & 0,04 & 0,00 & 0,00 & 0,01 & 0,00 & 0,02 & 0,04 & 0,01 & 0,01 & 0,05 & 0,04 \\
\hline $\mathrm{Cr}_{2} \mathrm{O}_{3}$ & 0,04 & 0,00 & 0,00 & 0,00 & 0,06 & 0,05 & 0,08 & 0,03 & 0,00 & 0,03 & 0,04 & 0,00 & 0,07 & 0,00 & 0,00 & 0,00 \\
\hline $\mathrm{NiO}$ & 0,31 & 0,35 & 0,31 & 0,36 & 0,42 & 0,40 & 0,43 & 0,24 & 0,31 & 0,33 & 0,30 & 0,34 & 0,38 & 0,35 & 0,11 & 0,35 \\
\hline Total & 100,81 & 101,27 & 100,96 & 101,48 & 100,98 & 100,11 & 101,37 & 100,74 & 100,90 & 100,01 & 101,09 & 100,14 & 100,54 & 100,28 & 100,42 & 100,09 \\
\hline $\mathrm{TSi}$ & 0,994 & 0,976 & 0,988 & 1,003 & 0,986 & 0,978 & 0,991 & 0,981 & 0,973 & 0,967 & 0,985 & 0,989 & 0,986 & 0,992 & 1,022 & 1,012 \\
\hline $\mathrm{TFe}^{3+}$ & 0,006 & 0,024 & 0,012 & 0,000 & 0,014 & 0,022 & 0,009 & 0,019 & 0,027 & 0,033 & 0,015 & 0,011 & 0,014 & 0,008 & 0,000 & 0,000 \\
\hline TAl & 0,000 & 0,000 & 0,000 & 0,000 & 0,000 & 0,000 & 0,000 & 0,000 & 0,000 & 0,000 & 0,000 & 0,000 & 0,000 & 0,000 & 0,000 & 0,000 \\
\hline Ttotal & 1,000 & 1,000 & 1,000 & 1,003 & 1,000 & 1,000 & 1,000 & 1,000 & 1,000 & 1,000 & 1,000 & 1,000 & 1,000 & 1,000 & 1,022 & 1,012 \\
\hline${\mathrm{M} 1 F e^{3+}}^{3+}$ & 0,004 & 0,023 & 0,013 & 0,000 & 0,011 & 0,022 & 0,008 & 0,017 & 0,027 & 0,030 & 0,012 & 0,012 & 0,015 & 0,009 & 0,000 & 0,000 \\
\hline M1Al & 0,000 & 0,000 & 0,000 & 0,000 & 0,000 & 0,000 & 0,000 & 0,001 & 0,000 & 0,000 & 0,002 & 0,000 & 0,002 & 0,000 & 0,000 & 0,000 \\
\hline M1Mg & 1,770 & 1,788 & 1,786 & 1,772 & 1,790 & 1,785 & 1,780 & 1,788 & 1,735 & 1,749 & 1,703 & 1,724 & 1,743 & 1,693 & 1,666 & 1,688 \\
\hline${\mathrm{M} 1 \mathrm{Fe}^{2+}}^{2+}$ & 0,215 & 0,176 & 0,190 & 0,207 & 0,184 & 0,177 & 0,191 & 0,187 & 0,225 & 0,208 & 0,256 & 0,252 & 0,218 & 0,283 & 0,295 & 0,286 \\
\hline M1K & 0,000 & 0,001 & 0,000 & 0,000 & 0,000 & 0,001 & 0,000 & 0,000 & 0,000 & 0,000 & 0,001 & 0,001 & 0,000 & 0,000 & 0,002 & 0,001 \\
\hline $\mathrm{M} 1 \mathrm{Ni}$ & 0,006 & 0,007 & 0,006 & 0,007 & 0,008 & 0,008 & 0,008 & 0,005 & 0,006 & 0,007 & 0,006 & 0,007 & 0,008 & 0,007 & 0,002 & 0,007 \\
\hline $\mathrm{M} 1 \mathrm{Cr}$ & 0,001 & 0,000 & 0,000 & 0,000 & 0,001 & 0,001 & 0,001 & 0,000 & 0,000 & 0,000 & 0,001 & 0,000 & 0,001 & 0,000 & 0,000 & 0,000 \\
\hline M1Mn & 0,001 & 0,004 & 0,004 & 0,003 & 0,003 & 0,003 & 0,003 & 0,000 & 0,005 & 0,004 & 0,003 & 0,004 & 0,005 & 0,005 & 0,006 & 0,004 \\
\hline M1Ti & 0,000 & 0,001 & 0,000 & 0,000 & 0,001 & 0,000 & 0,001 & 0,000 & 0,000 & 0,001 & 0,000 & 0,000 & 0,000 & 0,000 & 0,000 & 0,001 \\
\hline $\mathrm{M} 1 \mathrm{Ca}$ & 0,000 & 0,000 & 0,000 & 0,000 & 0,000 & 0,000 & 0,000 & 0,001 & 0,000 & 0,000 & 0,002 & 0,000 & 0,002 & 0,000 & 0,000 & 0,000 \\
\hline M1Total & 1,999 & 1,999 & 1,999 & 1,990 & 1,999 & 1,996 & 1,993 & 1,999 & 1,998 & 1,999 & 1,985 & 1,999 & 1,995 & 1,998 & 1,970 & 1,987 \\
\hline $\mathrm{mg} \#$ & 0,887 & 0,889 & 0,893 & 0,895 & 0,895 & 0,890 & 0,895 & 0,889 & 0,861 & 0,866 & 0,858 & 0,863 & 0,876 & 0,849 & 0,850 & 0,855 \\
\hline fa & 0,113 & 0,111 & 0,107 & 0,105 & 0,105 & 0,110 & 0,105 & 0,111 & 0,139 & 0,134 & 0,142 & 0,137 & 0,124 & 0,151 & 0,150 & 0,145 \\
\hline
\end{tabular}


Tabela 33- Composição química de ortopiroxênio em harzburgitos e lherzolitos com espinélio do corpo Indaiá 1.

\begin{tabular}{|c|c|c|c|c|c|c|c|c|c|c|c|c|c|c|c|c|c|}
\hline $\begin{array}{c}\text { Código da } \\
\text { amostra } \\
\text { Tipo }\end{array}$ & $\begin{array}{l}\text { In1-4-3' } \\
\text { lherzolito } \\
\text { e }\end{array}$ & $\begin{array}{l}\text { In1-4-1' } \\
\text { ranular com } \\
\text { io }\end{array}$ & In1-9-1 & In1-9-2 & $\begin{array}{r}\text { In1-9-3 } \\
\text { zolito proto }\end{array}$ & $\begin{array}{r}\text { In1-9-4 } \\
\text { ar com esp }\end{array}$ & In1-9-5 & In1-9-6 & In1-13a-1 & In1-13a-2 & $\begin{array}{r}\text { In1-13a-3 } \\
\text { therzolitc }\end{array}$ & $\begin{array}{c}\text { In1-13a-4 } \\
\text { otogranular c }\end{array}$ & $\begin{array}{l}\text { In1-13a-5 } \\
\text { espinélio }\end{array}$ & In1-13a-6 & In1-13a-7 & $\begin{array}{r}\text { In1-13b-1 } \\
\text { harzburgito } \\
\text { e }\end{array}$ & $\begin{array}{l}\text { In1-13b-2 } \\
\text { granular com } \\
\text { lio }\end{array}$ \\
\hline $\mathrm{SiO}_{2}$ & 54,34 & 54,72 & 56,38 & 56,03 & 55,83 & 56,72 & 56,50 & 55,33 & 56,52 & 51,29 & 54,51 & 56,87 & 55,33 & 56,32 & 56,89 & 56,85 & 56,23 \\
\hline $\mathrm{TiO}_{2}$ & 0,15 & 0,03 & 0,09 & 0,06 & 0,06 & 0,01 & 0,10 & 0,04 & 0,06 & 0,04 & 0,00 & 0,12 & 0,01 & 0,05 & 0,00 & 0,04 & 0,13 \\
\hline $\mathrm{Al}_{2} \mathrm{O}_{3}$ & 4,02 & 4,73 & 2,30 & 2,72 & 3,34 & 2,37 & 2,86 & 2,87 & 2,02 & 7,08 & 3,83 & 1,84 & 3,30 & 2,82 & 1,52 & 2,60 & 2,14 \\
\hline $\mathrm{FeO}$ & 6,75 & 6,63 & 5,84 & 5,53 & 5,77 & 5,64 & 5,83 & 5,67 & 5,52 & 6,13 & 5,65 & 5,15 & 5,85 & 5,19 & 5,42 & 5,44 & 5,29 \\
\hline $\mathrm{MnO}$ & 0,14 & 0,17 & 0,16 & 0,17 & 0,19 & 0,15 & 0,12 & 0,18 & 0,17 & 0,16 & 0,15 & 0,16 & 0,15 & 0,12 & 0,14 & 0,11 & 0,16 \\
\hline $\mathrm{MgO}$ & 33,86 & 34,03 & 33,94 & 33,28 & 33,33 & 33,67 & 35,85 & 35,51 & 36,22 & 34,50 & 35,85 & 37,07 & 35,90 & 35,23 & 36,00 & 35,88 & 35,84 \\
\hline $\mathrm{CaO}$ & 0,26 & 0,24 & 0,14 & 0,12 & 0,14 & 0,07 & 0,14 & 0,21 & 0,14 & 0,12 & 0,16 & 0,10 & 0,20 & 1,25 & 0,10 & 0,21 & 0,56 \\
\hline $\mathrm{Na}_{2} \mathrm{O}$ & 0,20 & 0,17 & 0,00 & 0,00 & 0,04 & 0,01 & 0,04 & 0,04 & 0,02 & 0,01 & 0,03 & 0,03 & 0,01 & 0,06 & 0,04 & 0,00 & 0,02 \\
\hline $\mathrm{K}_{2} \mathrm{O}$ & 0,00 & 0,02 & 0,00 & 0,00 & 0,00 & 0,01 & 0,00 & 0,00 & 0,01 & 0,01 & 0,00 & 0,00 & 0,01 & 0,00 & 0,47 & 0,00 & 0,00 \\
\hline $\mathrm{Cr}_{2} \mathrm{O}_{3}$ & 0,50 & 0,35 & 0,15 & 0,26 & 0,31 & 0,17 & 0,34 & 0,32 & 0,27 & 2,65 & 1,00 & 0,19 & 0,80 & 0,53 & 0,15 & 0,58 & 0,30 \\
\hline $\mathrm{NiO}$ & 0,13 & 0,16 & n.d. & n.d. & n.d. & n.d. & n.d. & n.d. & n.d. & n.d. & n.d. & n.d. & n.d. & n.d. & n.d. & n.d. & n.d. \\
\hline Total & 100,35 & 101,26 & 98,98 & 98,16 & 99,00 & 98,82 & 101,76 & 100,16 & 100,95 & 101,98 & 101,18 & 101,55 & 101,55 & 101,56 & 100,73 & 101,71 & 100,68 \\
\hline $\mathrm{TSi}$ & 1,866 & 1,860 & 1,961 & 1,967 & 1,944 & 1,977 & 1,903 & 1,891 & 1,915 & 1,740 & 1,847 & 1,910 & 1,869 & 1,903 & 1,931 & 1,917 & 1,912 \\
\hline $\mathrm{TFe}^{3+}$ & 0,087 & 0,085 & 0,000 & 0,000 & 0,000 & 0,000 & 0,063 & 0,089 & 0,075 & 0,117 & 0,111 & 0,090 & 0,096 & 0,059 & 0,069 & 0,035 & 0,071 \\
\hline TAl & 0,046 & 0,055 & 0,039 & 0,033 & 0,056 & 0,023 & 0,034 & 0,020 & 0,010 & 0,143 & 0,042 & 0,000 & 0,035 & 0,038 & 0,000 & 0,048 & 0,017 \\
\hline $\mathrm{T}$ total & 2,000 & 2,000 & 2,000 & 2,000 & 2,000 & 2,000 & 2,000 & 2,000 & 2,000 & 2,000 & 2,000 & 2,000 & 2,000 & 2,000 & 2,000 & 2,000 & 2,000 \\
\hline M2Al & 0,116 & 0,135 & 0,055 & 0,080 & 0,081 & 0,074 & 0,080 & 0,096 & 0,071 & 0,141 & 0,110 & 0,073 & 0,096 & 0,074 & 0,061 & 0,055 & 0,069 \\
\hline $\mathrm{M} 2 \mathrm{Cr}$ & 0,009 & 0,006 & 0,003 & 0,005 & 0,006 & 0,003 & 0,006 & 0,006 & 0,005 & 0,047 & 0,018 & 0,003 & 0,014 & 0,009 & 0,003 & 0,010 & 0,005 \\
\hline $\mathrm{M}^{2} \mathrm{Fe}^{3+}$ & 0,000 & 0,000 & 0,000 & 0,000 & 0,000 & 0,000 & 0,000 & 0,000 & 0,000 & 0,000 & 0,000 & 0,004 & 0,000 & 0,000 & 0,025 & 0,000 & 0,000 \\
\hline M2Ti & 0,004 & 0,001 & 0,002 & 0,002 & 0,002 & 0,000 & 0,002 & 0,001 & 0,002 & 0,001 & 0,000 & 0,003 & 0,000 & 0,001 & 0,000 & 0,001 & 0,003 \\
\hline M2Ni & 0,004 & 0,004 & 0,000 & 0,000 & 0,000 & 0,000 & 0,000 & 0,000 & 0,000 & 0,000 & 0,000 & 0,000 & 0,000 & 0,000 & 0,000 & 0,000 & 0,000 \\
\hline${\mathrm{M} 2 \mathrm{Fe}^{2+}}^{2+}$ & 0,000 & 0,000 & 0,000 & 0,000 & 0,000 & 0,000 & 0,000 & 0,000 & 0,000 & 0,000 & 0,000 & 0,000 & 0,000 & 0,000 & 0,000 & 0,000 & 0,000 \\
\hline $\mathrm{M} 2 \mathrm{Mg}$ & 0,867 & 0,854 & 0,940 & 0,914 & 0,911 & 0,922 & 0,912 & 0,897 & 0,923 & 0,811 & 0,872 & 0,916 & 0,890 & 0,915 & 0,911 & 0,934 & 0,922 \\
\hline M2Mn & 0,000 & 0,000 & 0,000 & 0,000 & 0,000 & 0,000 & 0,000 & 0,000 & 0,000 & 0,000 & 0,000 & 0,000 & 0,000 & 0,000 & 0,000 & 0,000 & 0,000 \\
\hline M2total & 1,000 & 1,000 & 1,000 & 1,000 & 1,000 & 1,000 & 1,000 & 1,000 & 1,000 & 1,000 & 1,000 & 1,000 & 1,000 & 1,000 & 1,000 & 1,000 & 1,000 \\
\hline $\mathrm{XMg}$ & 0,867 & 0,871 & 0,820 & 0,828 & 0,819 & 0,828 & 0,888 & 0,912 & 0,907 & 0,934 & 0,939 & 0,939 & 0,918 & 0,860 & 0,910 & 0,870 & 0,895 \\
\hline $\mathrm{XFe}^{2+}$ & 0,107 & 0,103 & 0,170 & 0,162 & 0,168 & 0,164 & 0,101 & 0,073 & 0,081 & 0,057 & 0,049 & 0,050 & 0,070 & 0,088 & 0,059 & 0,119 & 0,079 \\
\hline XMn & 0,004 & 0,005 & 0,005 & 0,005 & 0,006 & 0,004 & 0,003 & 0,005 & 0,005 & 0,005 & 0,004 & 0,005 & 0,004 & 0,003 & 0,004 & 0,003 & 0,005 \\
\hline $\mathrm{XCa}$ & 0,010 & 0,009 & 0,005 & 0,004 & 0,005 & 0,003 & 0,005 & 0,008 & 0,005 & 0,004 & 0,006 & 0,004 & 0,007 & 0,045 & 0,004 & 0,008 & 0,020 \\
\hline $\mathrm{XNa}$ & 0,013 & 0,011 & 0,000 & 0,000 & 0,002 & 0,000 & 0,002 & 0,003 & 0,001 & 0,001 & 0,002 & 0,002 & 0,000 & 0,004 & 0,003 & 0,000 & 0,001 \\
\hline Xtotal & 1,000 & 0,999 & 1,000 & 1,000 & 1,000 & 0,999 & 1,000 & 1,000 & 1,000 & 1,000 & 1,000 & 1,000 & 0,999 & 1,000 & 0,980 & 1,000 & 1,000 \\
\hline$\# \mathrm{mg}$ & 0,899 & 0,901 & 0,912 & 0,915 & 0,912 & 0,914 & 0,916 & 0,918 & 0,921 & 0,909 & 0,919 & 0,928 & 0,916 & 0,924 & 0,922 & 0,922 & 0,923 \\
\hline
\end{tabular}


Tabela 34- Composição química de ortopiroxênio em harzburgitos e lherzolitos com espinélio do corpo Indaiá 1.

Código

amostra
In1-14a-1 In1-14a-2 In1-14a-3 In1-14a-4 In1-14a-5 In1-14a-6 In1-14a-7 In1-14a-8

lherzolito protogranular com espinélio

\begin{tabular}{|c|c|c|c|c|c|c|c|c|}
\hline \multirow{2}{*}{ Tipo } & \\
\hline & & & & 5632 & 5551 & & & 5602 \\
\hline $\begin{array}{l}\mathrm{SiO}_{2} \\
\mathrm{TiO}_{2}\end{array}$ & $\begin{array}{c}56,39 \\
0,13\end{array}$ & $\begin{array}{c}55,31 \\
0,12\end{array}$ & $\begin{array}{c}51,85 \\
0,00\end{array}$ & $\begin{array}{c}56,32 \\
0,00\end{array}$ & $\begin{array}{c}55,51 \\
0,02\end{array}$ & $\begin{array}{c}56,46 \\
0,02\end{array}$ & $\begin{array}{l}0,00 \\
0,00\end{array}$ & $\begin{array}{c}0,16 \\
0,16\end{array}$ \\
\hline $\mathrm{Al}_{2} \mathrm{O}_{3}$ & 3,02 & 3,63 & 8,62 & 2,59 & 3,06 & 2,98 & 2,94 & 2,57 \\
\hline $\mathrm{FeO}$ & 5,93 & 5,52 & 6,23 & 5,70 & 5,62 & 5,75 & 5,72 & 5,69 \\
\hline $\mathrm{MnO}$ & 0,14 & 0,16 & 0,15 & 0,17 & 0,13 & 0,16 & 0,12 & 0,13 \\
\hline $\mathrm{MgO}$ & 33,52 & 33,06 & 31,88 & 33,79 & 33,03 & 32,95 & 33,38 & 35,74 \\
\hline $\mathrm{CaO}$ & 0,11 & 0,14 & 0,08 & 0,35 & 0,34 & 0,43 & 0,15 & 0,18 \\
\hline $\mathrm{Na}_{2} \mathrm{O}$ & 0,04 & 0,00 & 0,01 & 0,00 & 0,05 & 0,06 & 0,01 & 0,05 \\
\hline $\mathrm{K}_{2} \mathrm{O}$ & 0,00 & 0,00 & 0,00 & 0,00 & 0,00 & 0,00 & 0,02 & 0,02 \\
\hline $\mathrm{Cr}_{2} \mathrm{O}_{3}$ & 0,32 & 0,44 & 1,17 & 0,26 & 0,39 & 0,33 & 0,34 & 0,22 \\
\hline $\mathrm{NiO}$ & n.d. & n.d. & n.d. & n.d. & n.d. & n.d. & n.d. & n.d. \\
\hline Total & 99,60 & 98,38 & 99,98 & 99,17 & 98,15 & 99,13 & 98,98 & 100,77 \\
\hline $\mathrm{TSi}$ & 1,954 & 1,939 & 1,794 & 1,956 & 1,950 & 1,967 & 1,963 & 1,903 \\
\hline $\mathrm{TFe}^{3+}$ & 0,000 & 0,000 & 0,008 & 0,000 & 0,000 & 0,000 & 0,000 & 0,077 \\
\hline TAl & 0,046 & 0,061 & 0,198 & 0,044 & 0,050 & 0,033 & 0,037 & 0,020 \\
\hline $\mathrm{T}$ total & 2,000 & 2,000 & 2,000 & 2,000 & 2,000 & 2,000 & 2,000 & 2,000 \\
\hline M2A1 & 0,077 & 0,089 & 0,153 & 0,062 & 0,077 & 0,090 & 0,083 & 0,083 \\
\hline $\mathrm{M} 2 \mathrm{Cr}$ & 0,006 & 0,008 & 0,021 & 0,005 & 0,007 & 0,006 & 0,006 & 0,004 \\
\hline $\mathrm{M}_{2} \mathrm{Fe}^{3+}$ & 0,000 & 0,000 & 0,000 & 0,000 & 0,000 & 0,000 & 0,000 & 0,000 \\
\hline M2Ti & 0,003 & 0,003 & 0,000 & 0,000 & 0,001 & 0,001 & 0,000 & 0,004 \\
\hline M2Ni & 0,000 & 0,000 & 0,000 & 0,000 & 0,000 & 0,000 & 0,000 & 0,000 \\
\hline $\mathrm{M}_{2} \mathrm{Fe}^{2+}$ & 0,000 & 0,000 & 0,000 & 0,000 & 0,000 & 0,000 & 0,000 & 0,000 \\
\hline $\mathrm{M} 2 \mathrm{Mg}$ & 0,914 & 0,900 & 0,825 & 0,933 & 0,915 & 0,903 & 0,910 & 0,909 \\
\hline $\mathrm{M} 2 \mathrm{Mn}$ & 0,000 & 0,000 & 0,000 & 0,000 & 0,000 & 0,000 & 0,000 & 0,000 \\
\hline M2total & 1,000 & 1,000 & 1,000 & 1,000 & 1,000 & 1,000 & 1,000 & 1,000 \\
\hline $\mathrm{XMg}$ & 0,818 & 0,828 & 0,819 & 0,816 & 0,815 & 0,808 & 0,823 & 0,901 \\
\hline $\mathrm{XFe}^{2+}$ & 0,172 & 0,162 & 0,173 & 0,166 & 0,165 & 0,168 & 0,167 & 0,085 \\
\hline XMn & 0,004 & 0,005 & 0,004 & 0,005 & 0,004 & 0,005 & 0,003 & 0,004 \\
\hline $\mathrm{XCa}$ & 0,004 & 0,005 & 0,003 & 0,013 & 0,013 & 0,016 & 0,005 & 0,007 \\
\hline $\mathrm{XNa}$ & 0,002 & 0,000 & 0,001 & 0,000 & 0,004 & 0,004 & 0,001 & 0,003 \\
\hline Xtotal & 1,000 & 1,000 & 1,000 & 1,000 & 1,000 & 1,000 & 0,999 & 0,999 \\
\hline \#mg & 0,910 & 0,914 & 0,901 & 0,914 & 0,913 & 0,911 & 0,912 & 0,918 \\
\hline
\end{tabular}

Fo-2-37' borda de espinélio 55,74 55,74
0,02 3,08 3,08
6,13
0,19
34,50 34,50 0,40 0,00 0,00
0,35
0,23
100,64 100,64
1,907 1,907 0,045 2,048 2,000 0,006

0,006

0,000

0,000

0,006

0,910

0,000

1,000

0,849

0,130

0,005

0,015

0,000

1,000

0,909

Fo-2-28 Fo-2-20' espinélio lherzolito granoblástico

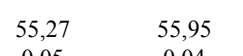
$0,05 \quad 0,04$ 3,06
5,79 0,19 $33,93-0,08$ $\begin{array}{ll}3,94 & 34,45 \\ 0,94 & 0,37\end{array}$ $0,04 \quad 0,03$ $0,00 \quad 0,00$ $\begin{array}{ll}0,31 & 0,24 \\ 0,09 & 0,11\end{array}$ $\begin{array}{ll}99,67 & 99,97 \\ 1,609 & 1,925\end{array}$ $\begin{array}{ll}1,909 & 1,925 \\ 0,044 & 0,034\end{array}$ $0,047 \quad 0,041$ $\begin{array}{ll}0,000 & 2,000 \\ 0,077 & 0,064\end{array}$ $0,006 \quad 0,004$ $\begin{array}{ll}0,000 & 0,000 \\ 0,001 & 0,001\end{array}$ $\begin{array}{ll}0,000 & 0,001 \\ 0,003 & 0,003\end{array}$ $\begin{array}{ll}0,000 & 0,000 \\ 0,913 & 0,928\end{array}$ $0,000 \quad 0,000$ $\begin{array}{ll}1,000 & 1,000 \\ 0,834 & 0,839\end{array}$

$0,123 \quad 0,143$

$0,006 \quad 0,002$

Lm1-17-14 Lm1-17-9 Lm1-17-6 Lm1-17-5 Lm1-17harzburgito protogranular com espinélio

$\begin{array}{ccccccc}53,52 & 55,64 & 54,98 & 54,10 & 54,70 & 55,84 & 54,93 \\ 0,01 & 0,00 & 0,00 & 0,00 & 0,00 & 0,02 & 0,04 \\ 4,95 & 4,04 & 4,46 & 5,15 & 4,45 & 3,60 & 4,40 \\ 5,65 & 5,50 & 5,77 & 5,58 & 5,93 & 5,85 & 5,70 \\ 0,19 & 0,14 & 0,09 & 0,11 & 0,26 & 0,06 & 0,20 \\ 33,82 & 34,29 & 34,22 & 33,75 & 34,07 & 34,05 & 33,05 \\ 0,37 & 0,28 & 0,45 & 0,43 & 0,29 & 0,74 & 1,47 \\ 0,06 & 0,02 & 0,00 & 0,08 & 0,05 & 0,09 & 0,28 \\ 0,00 & 0,04 & 0,01 & 0,03 & 0,00 & 0,02 & 0,07 \\ 0,61 & 0,39 & 0,54 & 0,56 & 0,60 & 0,39 & 0,59 \\ 0,02 & 0,04 & 0,18 & 0,06 & 0,24 & 0,15 & 0,08 \\ 99,18 & 100,38 & 100,70 & 99,85 & 100,60 & 100,82 & 100,81 \\ 1,853 & 1,904 & 1,878 & 1,862 & 1,873 & 1,907 & 1,879 \\ 0,067 & 0,014 & 0,040 & 0,049 & 0,052 & 0,029 & 0,058 \\ 0,080 & 0,082 & 0,082 & 0,090 & 0,076 & 0,064 & 0,063 \\ 2,000 & 2,000 & 2,000 & 2,000 & 2,000 & 2,000 & 2,000 \\ 0,122 & 0,081 & 0,098 & 0,119 & 0,104 & 0,081 & 0,114 \\ 0,011 & 0,007 & 0,010 & 0,010 & 0,011 & 0,007 & 0,011 \\ 0,000 & 0,000 & 0,000 & 0,000 & 0,000 & 0,000 & 0,000 \\ 0,000 & 0,000 & 0,000 & 0,000 & 0,000 & 0,001 & 0,001 \\ 0,001 & 0,001 & 0,005 & 0,002 & 0,006 & 0,004 & 0,002 \\ 0,000 & 0,000 & 0,000 & 0,000 & 0,000 & 0,000 & 0,000 \\ 0,866 & 0,911 & 0,888 & 0,869 & 0,879 & 0,907 & 0,872 \\ 0,000 & 0,000 & 0,000 & 0,000 & 0,000 & 0,000 & 0,000 \\ 1,000 & 1,000 & 1,000 & 1,000 & 1,000 & 1,000 & 1,000 \\ 0,880 & 0,839 & 0,855 & 0,862 & 0,860 & 0,826 & 0,813 \\ 0,097 & 0,143 & 0,125 & 0,112 & 0,118 & 0,138 & 0,105 \\ 0,005 & 0,004 & 0,003 & 0,003 & 0,008 & 0,002 & 0,006 \\ 0,014 & 0,010 & 0,016 & 0,016 & 0,011 & 0,027 & 0,054 \\ 0,004 & 0,001 & 0,000 & 0,005 & 0,004 & 0,006 & 0,018 \\ 1,000 & 0,998 & 1,000 & 0,999 & 1,000 & 0,999 & 0,997 \\ 0,914 & 0,917 & 0,914 & 0,915 & 0,911 & 0,912 & 0,912\end{array}$


Tabela 35- Composição química de ortopiroxênio em harzburgitos e dunitos com cr-espinélio do corpo Indaiá 1.

\begin{tabular}{|c|c|c|c|c|c|c|c|c|c|c|c|c|c|c|c|c|c|c|}
\hline $\begin{array}{c}\text { Código } \\
\text { da } \\
\text { amostra } \\
\text { Tipo }\end{array}$ & In1-3-1 & In1-3-2 & $\begin{array}{c}\text { In1-3-3 } \\
\text { harzburgito gr }\end{array}$ & $\begin{array}{l}\text { In1-3-4 } \\
\text { oblástico cc }\end{array}$ & $\begin{array}{l}\text { In1-3-5 } \\
\text { Cr-espinélio }\end{array}$ & In1-3-6 & In1-3-7 & Lm1-20a-10 & Lm1-20a-6 & $\begin{array}{c}\text { Lm1-20a- } \\
\text { 11a } \\
\text { harzburs }\end{array}$ & $\begin{array}{c}\text { Lm1-20a- } \\
16 \\
\text { ito granoblás }\end{array}$ & $\begin{array}{l}\text { Lm1-20-6a } \\
\text { ico com Cr-es }\end{array}$ & $\begin{array}{l}\mathrm{Lm} 1-20- \\
12 \mathrm{~b} \\
\text { inélio }\end{array}$ & Lm1-20-13 & Lm1-20-8 & $\begin{array}{r}\text { Lm1-30-9 } \\
\text { harzbu }\end{array}$ & $\begin{array}{l}\mathrm{Lm} 1-30-11 \\
\text { gito com } \mathrm{Cr}-\mathrm{c}\end{array}$ & $\begin{array}{l}\text { Lm1-30-4a } \\
\text { spinélio }\end{array}$ \\
\hline $\mathrm{SiO}_{2}$ & 56,90 & 56,45 & 57,49 & 57,31 & 56,93 & 56,96 & 57,27 & 55,85 & 55,69 & 55,78 & 55,48 & 56,83 & 56,12 & 56,51 & 56,33 & 55,56 & 56,58 & 56,27 \\
\hline $\mathrm{TiO}_{2}$ & 0,11 & 0,07 & 0,06 & 0,06 & 0,00 & 0,07 & 0,07 & 0,02 & 0,02 & 0,00 & 0,00 & 0,00 & 0,04 & 0,00 & 0,00 & 0,05 & 0,01 & 0,02 \\
\hline $\mathrm{Al}_{2} \mathrm{O}_{3}$ & 1,42 & 1,66 & 1,65 & 1,76 & 1,87 & 1,90 & 1,66 & 2,46 & 2,59 & 2,64 & 2,68 & 2,64 & 2,64 & 2,47 & 2,36 & 2,21 & 2,08 & 2,41 \\
\hline $\mathrm{FeO}$ & 5,04 & 5,01 & 5,34 & 4,86 & 4,98 & 5,31 & 5,31 & 5,88 & 5,64 & 5,81 & 5,43 & 5,72 & 5,64 & 5,56 & 5,69 & 5,84 & 5,69 & 5,71 \\
\hline $\mathrm{MnO}$ & 0,13 & 0,12 & 0,13 & 0,11 & 0,14 & 0,15 & 0,13 & 0,19 & 0,22 & 0,16 & 0,12 & 0,07 & 0,09 & 0,11 & 0,05 & 0,15 & 0,17 & 0,13 \\
\hline $\mathrm{MgO}$ & 36,71 & 36,42 & 36,46 & 35,56 & 36,15 & 36,23 & 36,42 & 34,20 & 34,31 & 34,50 & 34,70 & 35,00 & 35,02 & 34,65 & 34,78 & 35,10 & 35,38 & 35,71 \\
\hline $\mathrm{CaO}$ & 0,26 & 0,43 & 0,45 & 0,61 & 0,32 & 0,21 & 0,47 & 0,42 & 0,36 & 0,38 & 0,52 & 0,54 & 0,47 & 0,45 & 0,35 & 0,46 & 0,29 & 0,50 \\
\hline $\mathrm{Na}_{2} \mathrm{O}$ & 0,00 & 0,03 & 0,04 & 0,00 & 0,01 & 0,01 & 0,05 & 0,00 & 0,04 & 0,00 & 0,17 & 0,03 & 0,07 & 0,00 & 0,10 & 0,09 & 0,15 & 0,15 \\
\hline $\mathrm{K}_{2} \mathrm{O}$ & 0,00 & 0,01 & 0,02 & 0,01 & 0,01 & 0,00 & 0,00 & 0,01 & 0,00 & 0,01 & 0,00 & 0,00 & 0,02 & 0,02 & 0,00 & 0,00 & 0,05 & 0,00 \\
\hline $\mathrm{Cr}_{2} \mathrm{O}_{3}$ & 0,37 & 0,42 & 0,42 & 0,40 & 0,48 & 0,49 & 0,54 & 0,34 & 0,40 & 0,28 & 0,46 & 0,57 & 0,29 & 0,43 & 0,32 & 0,42 & 0,28 & 0,52 \\
\hline $\mathrm{NiO}$ & n.d. & n.d. & n.d. & n.d. & n.d. & n.d. & n.d. & 0,06 & 0,00 & 0,00 & 0,17 & 0,07 & 0,03 & 0,03 & 0,01 & 0,09 & 0,00 & 0,12 \\
\hline Total & 100,93 & 100,62 & 102,05 & 100,68 & 100,88 & 101,33 & 101,92 & 99,44 & 99,29 & 99,57 & 99,73 & 101,48 & 100,43 & 100,23 & 100,00 & 99,98 & 100,68 & 101,53 \\
\hline $\mathrm{TSi}$ & 1,926 & 1,917 & 1,929 & 1,951 & 1,931 & 1,925 & 1,925 & 1,934 & 1,929 & 1,925 & 1,909 & 1,927 & 1,917 & 1,939 & 1,934 & 1,908 & 1,926 & 1,901 \\
\hline $\mathrm{TFe}^{3+}$ & 0,069 & 0,079 & 0,058 & 0,006 & 0,042 & 0,049 & 0,061 & 0,016 & 0,020 & 0,029 & 0,065 & 0,017 & 0,050 & 0,004 & 0,028 & 0,080 & 0,064 & 0,088 \\
\hline TAl & 0,004 & 0,004 & 0,013 & 0,043 & 0,027 & 0,026 & 0,015 & 0,050 & 0,051 & 0,045 & 0,027 & 0,056 & 0,033 & 0,057 & 0,038 & 0,013 & 0,010 & 0,011 \\
\hline $\mathrm{T}$ total & 2,000 & 2,000 & 2,000 & 2,000 & 2,000 & 2,000 & 2,000 & 2,000 & 2,000 & 2,000 & 2,000 & 2,000 & 2,000 & 2,000 & 2,000 & 2,000 & 2,000 & 2,000 \\
\hline $\mathrm{M} 2 \mathrm{Al}$ & 0,052 & 0,063 & 0,052 & 0,028 & 0,048 & 0,050 & 0,051 & 0,050 & 0,055 & 0,062 & 0,082 & 0,049 & 0,073 & 0,043 & 0,058 & 0,077 & 0,073 & 0,085 \\
\hline $\mathrm{M} 2 \mathrm{Cr}$ & 0,007 & 0,007 & 0,007 & 0,007 & 0,009 & 0,009 & 0,010 & 0,006 & 0,007 & 0,005 & 0,008 & 0,010 & 0,005 & 0,008 & 0,006 & 0,008 & 0,005 & 0,009 \\
\hline $\mathrm{M} 2 \mathrm{Fe}^{3+}$ & 0,000 & 0,000 & 0,000 & 0,000 & 0,000 & 0,000 & 0,000 & 0,000 & 0,000 & 0,000 & $\begin{array}{l}0,000 \\
0,000\end{array}$ & $\begin{array}{l}0,000 \\
0,000\end{array}$ & $\begin{array}{l}0,000 \\
0,000\end{array}$ & $\begin{array}{l}0,000 \\
0,000\end{array}$ & $\begin{array}{l}0,000 \\
0,000\end{array}$ & $\begin{array}{l}0,000 \\
0,000\end{array}$ & 0,000 & $\begin{array}{l}0,000 \\
0,00\end{array}$ \\
\hline M2Ti & 0,003 & 0,002 & 0,002 & 0,002 & 0,000 & 0,002 & 0,002 & 0,001 & 0,001 & 0,000 & 0,000 & 0,000 & 0,001 & 0,000 & 0,000 & 0,001 & 0,000 & 0,001 \\
\hline $\mathrm{M} 2 \mathrm{Ni}$ & 0,000 & 0,000 & 0,000 & 0,000 & 0,000 & 0,000 & 0,000 & 0,002 & 0,000 & 0,000 & 0,005 & 0,002 & 0,001 & 0,001 & 0,000 & 0,002 & 0,000 & 0,003 \\
\hline${\mathrm{M} 2 \mathrm{Fe}^{2+}}^{2+}$ & 0,000 & 0,000 & 0,000 & 0,000 & 0,000 & 0,000 & 0,000 & 0,000 & 0,000 & 0,000 & 0,000 & 0,000 & 0,000 & 0,000 & 0,000 & 0,000 & 0,000 & 0,000 \\
\hline M2Mg & 0,939 & 0,928 & 0,939 & 0,963 & 0,943 & 0,940 & 0,937 & 0,941 & 0,937 & 0,933 & 0,905 & 0,938 & 0,920 & 0,949 & 0,936 & 0,912 & 0,921 & 0,902 \\
\hline M2Mn & 0,000 & 0,000 & 0,000 & 0,000 & 0,000 & 0,000 & 0,000 & 0,000 & 0,000 & 0,000 & 0,000 & 0,000 & 0,000 & 0,000 & 0,000 & 0,000 & 0,000 & 0,000 \\
\hline M2total & 1,000 & 1,000 & 1,000 & 1,000 & 1,000 & 1,000 & 1,000 & 1,000 & 1,000 & 1,000 & 1,000 & 1,000 & 1,000 & 1,000 & 1,000 & 1,000 & 1,000 & 1,000 \\
\hline $\mathrm{XMg}$ & 0,914 & 0,916 & 0,885 & 0,842 & 0,885 & 0,886 & 0,887 & 0,824 & 0,834 & 0,842 & 0,874 & 0,831 & 0,864 & 0,824 & 0,844 & 0,885 & 0,874 & 0,896 \\
\hline $\mathrm{XFe}^{2+}$ & 0,073 & 0,063 & 0,092 & 0,133 & 0,099 & 0,102 & 0,089 & 0,154 & 0,143 & 0,139 & 0,092 & 0,145 & 0,111 & 0,155 & 0,135 & 0,088 & 0,098 & 0,073 \\
\hline $\mathrm{XMn}$ & 0,004 & 0,003 & 0,004 & 0,003 & 0,004 & 0,004 & 0,004 & 0,006 & 0,006 & 0,005 & 0,003 & 0,002 & 0,003 & 0,003 & 0,001 & 0,004 & 0,005 & 0,004 \\
\hline $\mathrm{XCa}$ & 0,009 & 0,016 & 0,016 & 0,022 & 0,012 & 0,008 & 0,017 & 0,016 & 0,013 & 0,014 & 0,019 & 0,020 & 0,017 & 0,017 & 0,013 & 0,017 & 0,010 & 0,018 \\
\hline $\mathrm{XNa}$ & 0,000 & 0,002 & 0,002 & 0,000 & 0,000 & 0,001 & 0,003 & 0,000 & 0,003 & 0,000 & 0,011 & 0,002 & 0,005 & 0,000 & 0,006 & 0,006 & 0,010 & 0,010 \\
\hline Xtotal & 1,000 & 0,999 & 0,999 & 1,000 & 1,000 & 1,000 & 1,000 & 0,999 & 1,000 & 1,000 & 1,000 & 1,000 & 0,999 & 0,999 & 1,000 & 1,000 & 0,998 & 1,000 \\
\hline$\# \mathrm{mg}$ & 0,928 & 0,928 & 0,924 & 0,929 & 0,928 & 0,924 & 0,924 & 0,912 & 0,916 & 0,914 & 0,919 & 0,916 & 0,917 & 0,917 & 0,916 & 0,915 & 0,917 & 0,918 \\
\hline
\end{tabular}


Tabela 36- Composição química de ortopiroxênio em harzburgitos e dunitos com cr-espinélio do corpo Indaiá 1.

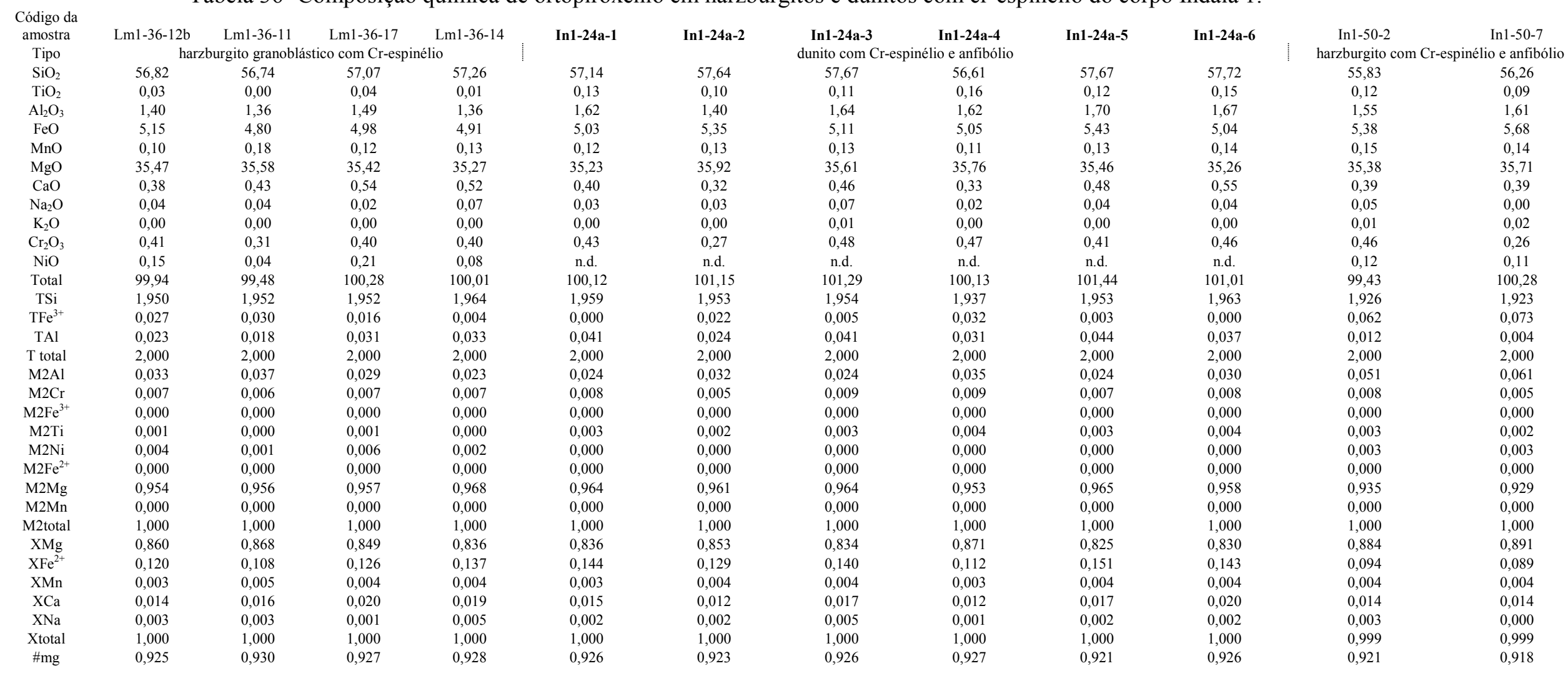


Tabela 37- Composição química de ortopiroxênio em harzburgitos e dunitos com flogopita do corpo Indaiá 1.

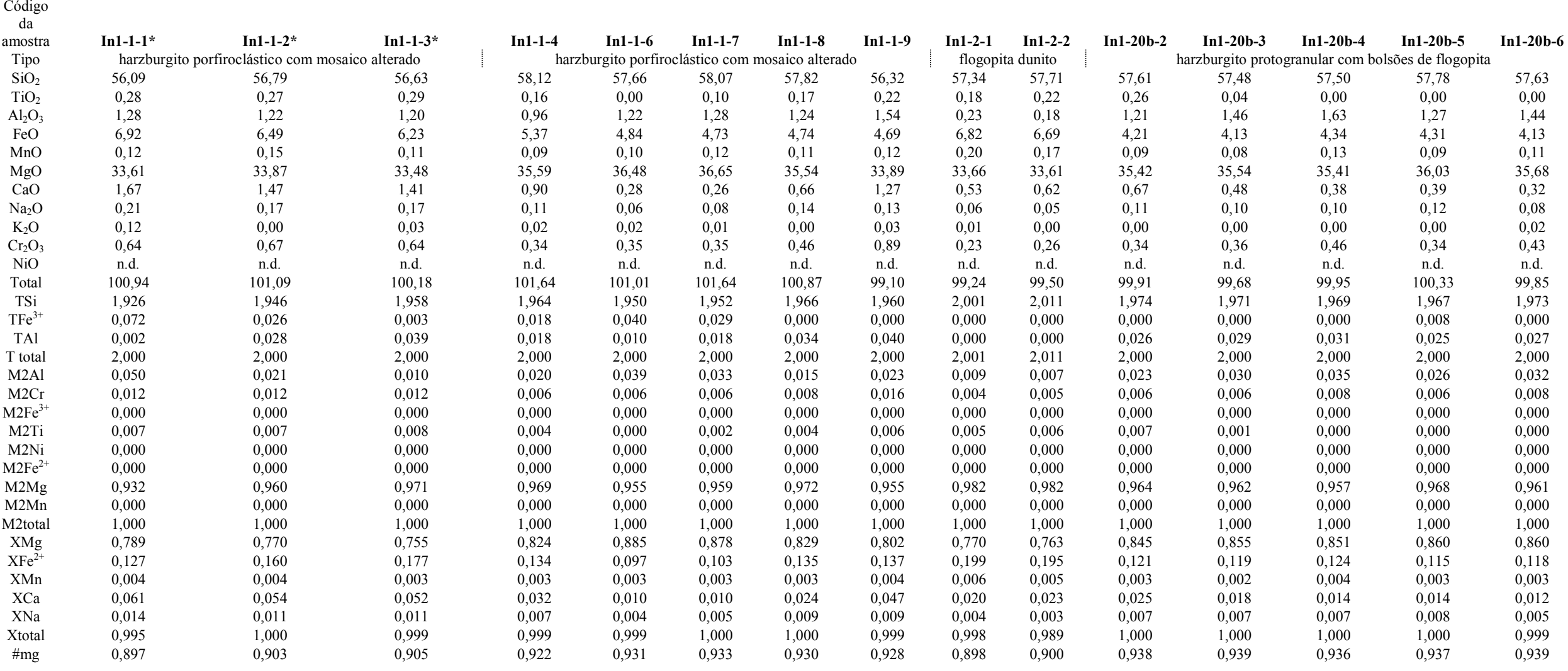


Tabela 38- Composição química de ortopiroxênio em harzburgitos e dunitos com flogopita do corpo Indaiá 1.

\begin{tabular}{|c|c|c|c|c|c|c|c|c|c|c|c|}
\hline \multirow{3}{*}{$\begin{array}{c}\text { Código da amostra } \\
\text { Tipo }\end{array}$} & Lm1-1-9a & Lm1-1-9b & Lm1-15-11 & Lm1-15-1 & Lm1-15-10 & Lm1-26a-4b & Lm1-26a-4c & Lm1-26a-7c & Lm1-26a-7d & Lm1-26a-9 & \multirow{3}{*}{$\begin{array}{c}\text { Lm1-28-9b } \\
\text { dunito com } \\
\text { bolsões de } \\
\text { flogopita }\end{array}$} \\
\hline & \multirow{2}{*}{\multicolumn{2}{|c|}{ harzburgito com bolsões de flogopita e titanato }} & \multirow{2}{*}{\multicolumn{3}{|c|}{ harzburgito com bolsões de flogopita }} & \multirow{2}{*}{\multicolumn{5}{|c|}{ harzburgito com bolsões de flogopita }} & \\
\hline & & & & & & & & & & & \\
\hline $\mathrm{SiO}_{2}$ & 56,46 & 55,62 & 57,25 & 57,98 & 57,49 & 55,55 & 55,31 & 54,80 & 55,55 & 56,39 & 58,04 \\
\hline $\mathrm{TiO}_{2}$ & 0,31 & 0,28 & 0,00 & 0,01 & 0,02 & 0,13 & 0,17 & 0,24 & 0,22 & 0,22 & 0,04 \\
\hline $\mathrm{Al}_{2} \mathrm{O}_{3}$ & 0,33 & 0,39 & 1,31 & 0,32 & 0,09 & 0,43 & 0,33 & 0,35 & 0,35 & 0,35 & 0,07 \\
\hline $\mathrm{FeO}$ & 6,78 & 6,74 & 4,90 & 4,84 & 5,08 & 7,65 & 7,46 & 7,93 & 7,93 & 8,00 & 3,91 \\
\hline $\mathrm{MnO}$ & 0,11 & 0,19 & 0,11 & 0,16 & 0,14 & 0,15 & 0,17 & 0,09 & 0,18 & 0,23 & 0,05 \\
\hline $\mathrm{MgO}$ & 34,39 & 33,99 & 36,12 & 36,27 & 36,72 & 33,19 & 33,30 & 33,89 & 33,77 & 33,90 & 36,67 \\
\hline $\mathrm{CaO}$ & 0,89 & 0,89 & 0,22 & 0,40 & 0,48 & 0,81 & 0,82 & 0,71 & 0,81 & 0,76 & 0,88 \\
\hline $\mathrm{Na}_{2} \mathrm{O}$ & 0,11 & 0,12 & 0,36 & 0,13 & 0,15 & 0,27 & 0,33 & 0,15 & 0,10 & 0,19 & 0,01 \\
\hline $\mathrm{K}_{2} \mathrm{O}$ & 0,00 & 0,05 & 0,01 & 0,02 & 0,00 & 0,01 & 0,00 & 0,02 & 0,02 & 0,02 & 0,06 \\
\hline $\mathrm{Cr}_{2} \mathrm{O}_{3}$ & 0,31 & 0,32 & 0,29 & 0,27 & 0,27 & 0,36 & 0,33 & 0,26 & 0,27 & 0,39 & 0,24 \\
\hline $\mathrm{NiO}$ & 0,12 & 0,12 & 0,02 & 0,01 & 0,07 & 0,10 & 0,09 & 0,14 & 0,13 & 0,20 & 0,11 \\
\hline Total & 99,79 & 98,71 & 100,59 & 100,41 & 100,51 & 98,64 & 98,32 & 98,59 & 99,33 & 100,66 & 100,07 \\
\hline $\mathrm{TSi}$ & 1,955 & 1,947 & 1,941 & 1,974 & 1,953 & 1,952 & 1,947 & 1,924 & 1,939 & 1,945 & 1,978 \\
\hline $\mathrm{TFe}^{3+}$ & 0,045 & 0,053 & 0,059 & 0,026 & 0,047 & 0,048 & 0,053 & 0,076 & 0,061 & 0,055 & 0,022 \\
\hline TAl & 0,000 & 0,000 & 0,000 & 0,000 & 0,000 & 0,000 & 0,000 & 0,000 & 0,000 & 0,000 & 0,000 \\
\hline $\mathrm{T}$ total & 2,000 & 2,000 & 2,000 & 2,000 & 2,000 & 2,000 & 2,000 & 2,000 & 2,000 & 2,000 & 2,000 \\
\hline $\mathrm{M} 2 \mathrm{Al}$ & 0,013 & 0,016 & 0,053 & 0,013 & 0,004 & 0,018 & 0,014 & 0,014 & 0,014 & 0,014 & 0,003 \\
\hline $\mathrm{M} 2 \mathrm{Cr}$ & 0,006 & 0,006 & 0,005 & 0,005 & 0,005 & 0,007 & 0,006 & 0,005 & 0,005 & 0,007 & 0,004 \\
\hline $\mathrm{M}^{2} \mathrm{Fe}^{3+}$ & 0,008 & 0,018 & 0,017 & 0,009 & 0,040 & 0,026 & 0,037 & 0,049 & 0,030 & 0,025 & 0,010 \\
\hline M2Ti & 0,008 & 0,007 & 0,000 & 0,000 & 0,000 & 0,003 & 0,005 & 0,006 & 0,006 & 0,006 & 0,001 \\
\hline $\mathrm{M} 2 \mathrm{Ni}$ & 0,003 & 0,003 & 0,001 & 0,000 & 0,002 & 0,003 & 0,002 & 0,004 & 0,004 & 0,006 & 0,003 \\
\hline $\mathrm{M}^{2} \mathrm{Fe}^{2+}$ & 0,000 & 0,000 & 0,000 & 0,000 & 0,000 & 0,000 & 0,000 & 0,000 & 0,000 & 0,000 & 0,000 \\
\hline $\mathrm{M} 2 \mathrm{Mg}$ & 0,961 & 0,949 & 0,925 & 0,972 & 0,949 & 0,944 & 0,936 & 0,922 & 0,941 & 0,942 & 0,979 \\
\hline $\mathrm{M} 2 \mathrm{Mn}$ & 0,000 & 0,000 & 0,000 & 0,000 & 0,000 & 0,000 & 0,000 & 0,000 & 0,000 & 0,000 & 0,000 \\
\hline M2total & 1,000 & 1,000 & 1,000 & 1,000 & 1,000 & 1,000 & 1,000 & 1,000 & 1,000 & 1,000 & 1,000 \\
\hline $\mathrm{XMg}$ & 0,814 & 0,824 & 0,901 & 0,869 & 0,911 & 0,795 & 0,812 & 0,851 & 0,817 & 0,801 & 0,884 \\
\hline $\mathrm{XFe}^{2+}$ & 0,143 & 0,127 & 0,063 & 0,103 & 0,058 & 0,151 & 0,130 & 0,108 & 0,140 & 0,150 & 0,080 \\
\hline XMn & 0,003 & 0,006 & 0,003 & 0,005 & 0,004 & 0,004 & 0,005 & 0,003 & 0,005 & 0,007 & 0,001 \\
\hline $\mathrm{XCa}$ & 0,033 & 0,033 & 0,008 & 0,015 & 0,018 & 0,030 & 0,031 & 0,027 & 0,030 & 0,028 & 0,032 \\
\hline $\mathrm{XNa}$ & 0,007 & 0,008 & 0,024 & 0,008 & 0,010 & 0,018 & 0,022 & 0,010 & 0,007 & 0,013 & 0,001 \\
\hline Xtotal & 1,000 & 0,998 & 0,999 & 0,999 & 1,000 & 0,999 & 1,000 & 0,999 & 0,999 & 0,999 & 0,997 \\
\hline \#mg & 0,900 & 0,900 & 0,929 & 0,930 & 0,928 & 0,886 & 0,888 & 0,884 & 0,884 & 0,883 & 0,944 \\
\hline
\end{tabular}


Tabela 39- Composição química de ortopiroxênio em flogopitito e harzburgitos com clinopiroxênio secundário do corpo Indaiá 1.

In1-24b-2 In1-24b-3 In1-24b-4

$\begin{array}{lll}57,68 & \text { flogopitito } & \\ 04,20 & 58,26\end{array}$

$\begin{array}{ccc}57,68 & 54,20 & 58,26 \\ 0,28 & 0,17 & 0,19\end{array}$

$0,28 \quad 0,31 \quad 0,21$

$\begin{array}{lll}9,06 & 8,53 & 9,32 \\ 0,23 & 0,17 & 0,17\end{array}$

$33,26 \quad 31,71 \quad 32,99$

$\begin{array}{lll}0,72 & 1,43 & 0,68 \\ 0,09 & 0,38 & 0,09\end{array}$

$\begin{array}{lll}0,09 & 0,38 & 0,09 \\ 0,01 & 1,15 & 0,01\end{array}$

$\begin{array}{lll}0,01 & 1,15 & 0,01 \\ 0,02 & 0,07 & 0,06\end{array}$

$\begin{array}{lll}0,02 & 0,07 & 0,06 \\ \text { n.d. } & \text { n.d. } & \text { n.d. }\end{array}$

$101,61 \quad 98,12 \quad 101,99$

$\begin{array}{lll}1,980 & 1,918 & 1,997 \\ 0,019 & 0,082 & 0,000\end{array}$

$\begin{array}{lll}1,980 & 0,082 & 0,000 \\ 0,019 & 0,000 & 0,003\end{array}$

$\begin{array}{lll}2,000 & 2,000 & 2,000\end{array}$

$0,011 \quad 0,013 \quad 0,005$

$\begin{array}{lll}0,000 & 0,001 & 0,001 \\ 0,000 & 0,134 & 0,000\end{array}$

$\begin{array}{lll}0,000 & 0,134 & 0,000 \\ 0,007 & 0,005 & 0,005\end{array}$

$\begin{array}{lll}0,000 & 0,000 & 0,000\end{array}$

$\begin{array}{lll}0,000 & 0,000 & 0,000 \\ 0,982 & 0,847 & 0,989\end{array}$

$\begin{array}{lll}0,982 & 0,847 & 0,989 \\ 0,000 & 0,000 & 0,000\end{array}$

$\begin{array}{lll}1,000 & 0,000 & 0,000 \\ 0,720 & 0,000 & 1,000 \\ 0,241 & 0,036 & 0,697\end{array}$

$\begin{array}{lll}0,720 & 0,826 & 0,697\end{array}$

$\begin{array}{lll}0,007 & 0,005 & 0,267 \\ 0,005\end{array}$

$\begin{array}{lll}0,026 & 0,054 & 0,025\end{array}$

$\begin{array}{lll}1,000 & 0,026 & 0,006 \\ 0,848 & 0,999\end{array}$

0,867

$\begin{array}{cc}\text { In1-24b-5 } & \text { In1-24b-6 } \\ & \\ 57,43 & 57,82 \\ 0,08 & 0,16 \\ 0,26 & 0,25 \\ 8,70 & 9,42 \\ 0,14 & 0,19 \\ 33,24 & 32,75 \\ 0,49 & 0,60 \\ 0,12 & 0,09 \\ 0,02 & 0,01 \\ 0,14 & 0,10 \\ \text { n.d. } & \text { n.d. } \\ 100,62 & 101,37 \\ 1,987 & 1,994 \\ 0,013 & 0,000 \\ 0,000 & 0,006 \\ 2,000 & 2,000 \\ 0,011 & 0,005 \\ 0,003 & 0,002 \\ 0,000 & 0,000 \\ 0,002 & 0,004 \\ 0,000 & 0,000 \\ 0,000 & 0,000 \\ 0,985 & 0,990 \\ 0,000 & 0,000 \\ 1,000 & 1,000 \\ 0,730 & 0,695 \\ 0,239 & 0,272 \\ 0,004 & 0,005 \\ 0,018 & 0,022 \\ 0,008 & 0,006 \\ 0,999 & 1,000 \\ 0,872 & 0,861 \\ & \end{array}$

$\begin{array}{cccc}\text { In1-12-1 } & \begin{array}{c}\text { In1-12-2 } \\ \text { harzburgito com bolsões de clinopiroxênio }\end{array} & \text { In1-12-4 } \\ 57,88 & 57,18 & 58,69 & 57,66 \\ 0,00 & 0,00 & 0,01 & 0,04 \\ 0,11 & 1,00 & 0,26 & 1,24 \\ 4,78 & 4,60 & 4,94 & 4,92 \\ 0,14 & 0,13 & 0,10 & 0,12 \\ 37,43 & 37,08 & 37,25 & 36,47 \\ 0,27 & 0,20 & 0,17 & 0,16 \\ 0,04 & 0,04 & 0,01 & 0,01 \\ 0,00 & 0,00 & 0,00 & 0,01 \\ 0,14 & 0,31 & 0,25 & 0,27 \\ \text { n.d. } & \text { n.d. } & \text { n.d. } & \text { n.d. } \\ 100,78 & 100,55 & 101,66 & 100,90 \\ 1,956 & 1,938 & 1,972 & 1,953 \\ 0,044 & 0,062 & 0,028 & 0,031 \\ 0,000 & 0,000 & 0,000 & 0,016 \\ 2,000 & 2,000 & 2,000 & 2,000 \\ 0,004 & 0,040 & 0,010 & 0,034 \\ 0,002 & 0,006 & 0,004 & 0,005 \\ 0,036 & 0,011 & 0,007 & 0,000 \\ 0,000 & 0,000 & 0,000 & 0,001 \\ 0,000 & 0,000 & 0,000 & 0,000 \\ 0,000 & 0,000 & 0,000 & 0,000 \\ 0,957 & 0,944 & 0,978 & 0,960 \\ 0,000 & 0,000 & 0,000 & 0,000 \\ 1,000 & 1,000 & 1,000 & 1,000 \\ 0,929 & 0,930 & 0,887 & 0,881 \\ 0,055 & 0,057 & 0,103 & 0,108 \\ 0,004 & 0,004 & 0,003 & 0,004 \\ 0,010 & 0,007 & 0,006 & 0,006 \\ 0,003 & 0,002 & 0,000 & 0,001 \\ 1,000 & 1,000 & 1,000 & 1,000 \\ 0,933 & 0,935 & 0,931 & 0,930\end{array}$

$$
57,34
$$$$
\begin{array}{r}
0,03 \\
0,00
\end{array}
$$$$
\begin{aligned}
& 0,00 \\
& 5,36
\end{aligned}
$$$$
\begin{aligned}
& 5,36 \\
& 0,12
\end{aligned}
$$$$
\begin{gathered}
0,12 \\
35,64 \\
0,22 \\
0,01
\end{gathered}
$$$$
\begin{aligned}
& 0,01 \\
& 0,01 \\
& 0,18
\end{aligned}
$$$$
\begin{array}{r}
0,10 \\
99,01 \\
1,985
\end{array}
$$$$
\begin{array}{r}
99,01 \\
1,985 \\
0,015
\end{array}
$$$$
\begin{aligned}
& 1,985 \\
& 0,015
\end{aligned}
$$$$
0,000
$$$$
\begin{aligned}
& 2,000 \\
& 0,000
\end{aligned}
$$$$
\begin{aligned}
& 0,000 \\
& 0,003 \\
& 0,005
\end{aligned}
$$$$
\begin{aligned}
& 0,003 \\
& 0,005
\end{aligned}
$$$$
0,001
$$$$
0,003
$$$$
0,988
$$$$
\begin{aligned}
& 0,000 \\
& 1,000
\end{aligned}
$$$$
0,852
$$$$
0,135
$$$$
\begin{aligned}
& 0,004 \\
& 0,008
\end{aligned}
$$$$
\begin{aligned}
& 0,000 \\
& 1,000
\end{aligned}
$$

0,922

$\begin{array}{cc}\text { Lm1-22-8a } & \text { Lm1-22-7a } \\ \text { flogopita dunito com clinopiroxênio secundário } \\ 55,68 & 56,33 \\ 0,24 & 0,14 \\ 0,14 & 0,17 \\ 7,36 & 6,70 \\ 0,12 & 0,10 \\ 33,53 & 34,23 \\ 0,70 & 0,62 \\ 0,18 & 0,00 \\ 0,13 & 0,00 \\ 0,14 & 0,20 \\ 0,14 & 0,01 \\ 98,37 & 98,51 \\ 1,958 & 1,974 \\ 0,042 & 0,026 \\ 0,000 & 0,000 \\ 2,000 & 2,000 \\ 0,006 & 0,007 \\ 0,003 & 0,004 \\ 0,035 & 0,002 \\ 0,006 & 0,004 \\ 0,004 & 0,000 \\ 0,000 & 0,000 \\ 0,946 & 0,983 \\ 0,000 & 0,000 \\ 1,000 & 1,000 \\ 0,812 & 0,805 \\ 0,140 & 0,169 \\ 0,004 & 0,003 \\ 0,027 & 0,023 \\ 0,012 & 0,000 \\ 0,994 & 1,000 \\ 0,890 & 0,901 \\ & \end{array}$

Lm1-22-10

56,16

0,04

6,94

0,23
34,15

0,61

0,00

0,02

0,18

98,76

1,965

0,035

0,000

2,000

0,013

0,003

0,013

0,003

0,000

0,966

1,000

0,815
0,155

0,155
0,007

0,023

0,000
0,999

0,898 
Código da amostra

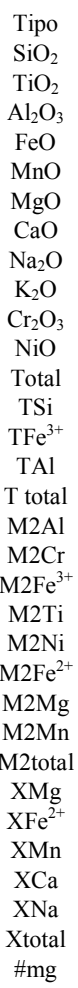

Tabela 40- Composição química de ortopiroxênio em dunitos e harzburgitos sem espinélio do corpo Indaiá 1.

\begin{tabular}{|c|c|c|c|c|c|c|c|c|}
\hline \multicolumn{2}{|c|}{$\begin{array}{l}\text { 11-25a-6f } \\
\text { dunito porfiroclástico com mosaico }\end{array}$} & $\begin{array}{l}\text { In1-33-9 } \\
\text { harzburgito porfiroclástico } \\
\text { em mosaico (borda de }\end{array}$ & $\begin{array}{l}\text { In1-33-2 } \\
\text { harzburgito porfiroclástico } \\
\text { em mosaico (núcleo de }\end{array}$ & $\begin{array}{l}\text { In1-33-1 } \\
\text { harzburgito porfiroclástico } \\
\text { em mosaico (borda de }\end{array}$ & $\begin{array}{l}\text { In1-33-3 } \\
\text { harzburgito porfiroclástico } \\
\text { em mosaico (núcleo de }\end{array}$ & $\begin{array}{l}\text { In1-33-9 } \\
\text { harzburgito porfiroclástico } \\
\text { em mosaico borda de }\end{array}$ & $\begin{array}{c}\text { Lm1-14-4a } \\
\text { dunito } \\
\text { protogranular }\end{array}$ & $\begin{array}{l}\text { Lm1-32-2e } \\
\text { dunito } \\
\text { porfiroclástico }\end{array}$ \\
\hline 56,35 & 56,95 & 56,39 & 55,12 & 56,12 & 56,46 & 56,60 & 57,32 & 56,54 \\
\hline 0,17 & 0,20 & 0,22 & 0,24 & 0,28 & 0,26 & 0,24 & 0,16 & 0,17 \\
\hline 1,08 & 1,17 & 1,08 & 1,15 & 1,19 & 1,23 & 1,13 & 0,45 & 1,02 \\
\hline 6,72 & 7,04 & 6,77 & 6,85 & 7,03 & 7,17 & 7,08 & 4,74 & 6,84 \\
\hline 0,05 & 0,16 & 0,08 & 0,18 & 0,10 & 0,09 & 0,09 & 0,17 & 0,08 \\
\hline 33,31 & 33,68 & 33,03 & 32,54 & 33,37 & 33,33 & 33,54 & 36,18 & 34,19 \\
\hline 0,96 & 1,39 & 1,02 & 1,09 & 1,36 & 1,49 & 1,47 & 0,78 & 1,38 \\
\hline 0,20 & 0,18 & 0,23 & 0,25 & 0,13 & 0,05 & 0,10 & 0,24 & 0,25 \\
\hline 0,00 & 0,02 & 0,00 & 0,37 & 0,00 & 0,00 & 0,01 & 0,00 & 0,00 \\
\hline 0,48 & 0,59 & 0,39 & 0,55 & 0,56 & 0,63 & 0,50 & 0,32 & 0,46 \\
\hline 0,10 & 0,07 & 0,22 & 0,11 & 0,15 & 0,05 & 0,23 & 0,05 & 0,21 \\
\hline 99,42 & 101,44 & 99,43 & 98,44 & 100,30 & 100,77 & 100,98 & 100,42 & 101,14 \\
\hline 1,963 & 1,948 & 1,966 & 1,942 & 1,942 & 1,948 & 1,946 & 1,951 & 1,933 \\
\hline 0,012 & 0,033 & 0,009 & 0,058 & 0,035 & 0,015 & 0,033 & 0,049 & 0,067 \\
\hline 0,025 & 0,019 & 0,025 & 0,000 & 0,022 & 0,037 & 0,020 & 0,000 & 0,000 \\
\hline 2,000 & 2,000 & 2,000 & 2,000 & 2,000 & 2,000 & 2,000 & 2,000 & 2,000 \\
\hline 0,019 & 0,028 & 0,020 & 0,048 & 0,026 & 0,013 & 0,025 & 0,018 & 0,041 \\
\hline 0,009 & 0,011 & 0,007 & 0,010 & 0,010 & 0,012 & 0,009 & 0,006 & 0,008 \\
\hline 0,000 & 0,000 & 0,000 & 0,006 & 0,000 & 0,000 & 0,000 & 0,025 & 0,013 \\
\hline 0,004 & 0,005 & 0,006 & 0,006 & 0,007 & 0,007 & 0,006 & 0,004 & 0,004 \\
\hline 0,003 & 0,002 & 0,006 & 0,003 & 0,004 & 0,001 & 0,006 & 0,001 & 0,006 \\
\hline 0,000 & 0,000 & 0,000 & 0,000 & 0,000 & 0,000 & 0,000 & 0,000 & 0,000 \\
\hline 0,965 & 0,955 & 0,961 & 0,927 & 0,952 & 0,967 & 0,953 & 0,946 & 0,927 \\
\hline 0,000 & 0,000 & 0,000 & 0,000 & 0,000 & 0,000 & 0,000 & 0,000 & 0,000 \\
\hline 1,000 & 1,000 & 1,000 & 1,000 & 1,000 & 1,000 & 1,000 & 1,000 & 1,000 \\
\hline 0,765 & 0,763 & 0,756 & 0,782 & 0,770 & 0,747 & 0,766 & 0,890 & 0,816 \\
\hline 0,184 & 0,169 & 0,188 & 0,138 & 0,168 & 0,192 & 0,170 & 0,061 & 0,115 \\
\hline 0,002 & 0,005 & 0,002 & 0,005 & 0,003 & 0,003 & 0,003 & 0,005 & 0,002 \\
\hline 0,036 & 0,051 & 0,038 & 0,041 & 0,050 & 0,055 & 0,054 & 0,028 & 0,051 \\
\hline 0,013 & 0,012 & 0,016 & 0,017 & 0,009 & 0,003 & 0,006 & 0,016 & 0,017 \\
\hline 1,000 & 0,999 & 1,000 & 0,983 & 1,000 & 1,000 & 1,000 & 1,000 & 1,000 \\
\hline 0,898 & 0,895 & 0,897 & 0,894 & 0,894 & 0,892 & 0,894 & 0,931 & 0,899 \\
\hline
\end{tabular}


Tabela 41- Composição química de clinopiroxênio em lherzolitos e harzburgitos com espinélio do corpo Indaiá 1.

\begin{tabular}{|c|c|c|c|c|c|c|c|c|c|c|c|c|c|c|c|}
\hline $\begin{array}{l}\text { Código } \\
\text { da } \\
\text { amostra }\end{array}$ & In1-4-1 & In1-4-2 & In1-4-3 & In1-4-4a & In1-4-4b & In1-4-5 & In1-9-1 & In1-9-2 & In1-9-3 & In1-9-4 & In1-9-5 & In1-9-6 & In1-9-7 & In1-9-8 & In1-9-9 \\
\hline Tipo & \multicolumn{6}{|c|}{ Iherzolito protogranular com espinélio } & \multicolumn{9}{|c|}{ Iherzolito protogranular com espinélio } \\
\hline $\mathrm{SiO}_{2}$ & 53,47 & 52,56 & 52,61 & 52,47 & 52,78 & 53,37 & 53,68 & 53,40 & 53,46 & 53,13 & 53,65 & 53,51 & 53,42 & 52,72 & 53,75 \\
\hline $\mathrm{TiO}_{2}$ & 0,32 & 0,20 & 0,40 & 0,31 & 0,35 & 0,26 & 0,34 & 0,23 & 0,24 & 0,17 & 0,19 & 0,35 & 0,29 & 0,32 & 0,27 \\
\hline $\mathrm{Al}_{2} \mathrm{O}_{3}$ & 6,11 & 7,10 & 6,46 & 6,73 & 5,97 & 6,49 & 4,46 & 4,29 & 4,09 & 3,79 & 3,96 & 3,71 & 3,69 & 4,24 & 4,24 \\
\hline $\mathrm{FeO}$ & 1,76 & 2,03 & 2,00 & 2,07 & 1,77 & 1,87 & 1,43 & 1,53 & 1,42 & 1,36 & 1,48 & 1,34 & 1,41 & 1,42 & 1,47 \\
\hline $\mathrm{MnO}$ & 0,09 & 0,08 & 0,11 & 0,05 & 0,06 & 0,09 & 0,04 & 0,05 & 0,04 & 0,07 & 0,08 & 0,05 & 0,05 & 0,07 & 0,08 \\
\hline $\mathrm{MgO}$ & 14,65 & 15,08 & 14,86 & 14,64 & 14,50 & 14,37 & 14,78 & 14,62 & 14,80 & 15,11 & 14,92 & 16,53 & 16,23 & 15,86 & 15,61 \\
\hline $\mathrm{CaO}$ & 21,99 & 21,32 & 21,94 & 21,86 & 22,61 & 22,33 & 22,62 & 22,35 & 22,24 & 22,69 & 22,59 & 23,05 & 22,55 & 22,84 & 22,47 \\
\hline $\mathrm{Na}_{2} \mathrm{O}$ & 1,77 & 1,67 & 1,69 & 1,67 & 1,65 & 1,68 & 1,36 & 1,66 & 1,51 & 1,35 & 1,42 & 1,40 & 1,47 & 1,47 & 1,64 \\
\hline $\mathrm{K}_{2} \mathrm{O}$ & 0,00 & 0,00 & 0,00 & 0,02 & 0,01 & 0,00 & 0,00 & 0,00 & 0,01 & 0,00 & 0,00 & 0,00 & 0,00 & 0,00 & 0,02 \\
\hline $\mathrm{Cr}_{2} \mathrm{O}_{3}$ & 0,90 & 1,14 & 1,01 & 1,06 & 0,89 & 1,00 & 0,77 & 0,99 & 0,85 & 0,61 & 0,92 & 0,65 & 0,73 & 0,83 & 0,86 \\
\hline $\mathrm{NiO}$ & n.d. & n.d. & n.d. & n.d. & n.d. & n.d. & n.d. & n.d. & n.d. & n.d. & n.d. & n.d. & n.d. & n.d. & n.d. \\
\hline Total & 101,06 & 101,16 & 101,07 & 100,86 & 100,58 & 101,46 & 99,46 & 99,11 & 98,65 & 98,26 & 99,21 & 100,60 & 99,82 & 99,78 & 100,41 \\
\hline $\mathrm{TSi}$ & 1,914 & 1,877 & 1,883 & 1,883 & 1,900 & 1,906 & 1,957 & 1,952 & 1,963 & 1,956 & 1,961 & 1,916 & 1,929 & 1,907 & 1,933 \\
\hline $\mathrm{TFe}^{3+}$ & 0,000 & 0,000 & 0,010 & 0,001 & 0,002 & 0,000 & 0,000 & 0,000 & 0,000 & 0,000 & 0,000 & 0,059 & 0,038 & 0,053 & 0,015 \\
\hline TAl & 0,086 & 0,123 & 0,107 & 0,116 & 0,099 & 0,094 & 0,043 & 0,048 & 0,037 & 0,044 & 0,039 & 0,025 & 0,033 & 0,041 & 0,052 \\
\hline $\mathrm{T}$ total & 2,000 & 2,000 & 2,000 & 2,000 & 2,000 & 2,000 & 2,000 & 2,000 & 2,000 & 2,000 & 2,000 & 2,000 & 2,000 & 2,000 & 2,000 \\
\hline $\mathrm{M} 2 \mathrm{Al}$ & 0,172 & 0,176 & 0,165 & 0,168 & 0,155 & 0,179 & 0,148 & 0,137 & 0,140 & 0,120 & 0,131 & 0,132 & 0,124 & 0,140 & 0,127 \\
\hline $\mathrm{M} 2 \mathrm{Cr}$ & 0,017 & 0,021 & 0,019 & 0,020 & 0,017 & 0,019 & 0,015 & 0,019 & 0,016 & 0,012 & 0,018 & 0,012 & 0,014 & 0,016 & 0,016 \\
\hline${\mathrm{M} 2 \mathrm{Fe}^{3+}}^{3+}$ & 0,000 & 0,000 & 0,000 & 0,000 & 0,000 & 0,000 & 0,000 & 0,000 & 0,000 & 0,000 & 0,000 & 0,000 & 0,000 & 0,000 & 0,000 \\
\hline $\mathrm{M} 2 \mathrm{Ti}$ & 0,009 & 0,005 & 0,011 & 0,008 & 0,010 & 0,007 & 0,009 & 0,006 & 0,007 & 0,005 & 0,005 & 0,009 & 0,008 & 0,009 & 0,007 \\
\hline $\mathrm{M} 2 \mathrm{Ni}$ & 0,000 & 0,000 & 0,000 & 0,000 & 0,000 & 0,000 & 0,000 & 0,000 & 0,000 & 0,000 & 0,000 & 0,000 & 0,000 & 0,000 & 0,000 \\
\hline $\mathrm{M} 2 \mathrm{Fe}^{2+}$ & 0,021 & 0,000 & 0,012 & 0,021 & 0,041 & 0,030 & 0,024 & 0,041 & 0,027 & 0,035 & 0,033 & 0,000 & 0,000 & 0,000 & 0,012 \\
\hline $\mathrm{M} 2 \mathrm{Mg}$ & 0,782 & 0,803 & 0,793 & 0,783 & 0,778 & 0,765 & 0,803 & 0,797 & 0,810 & 0,829 & 0,813 & 0,882 & 0,874 & 0,855 & 0,837 \\
\hline M2Mn & 0,000 & 0,000 & 0,000 & 0,000 & 0,000 & 0,000 & 0,000 & 0,000 & 0,000 & 0,000 & 0,000 & 0,000 & 0,000 & 0,000 & 0,000 \\
\hline M2total & 1,000 & 1,000 & 1,000 & 1,000 & 1,000 & 1,000 & 1,000 & 1,000 & 1,000 & 1,000 & 1,000 & 1,000 & 1,000 & 1,000 & 1,000 \\
\hline XMg & 0,000 & 0,006 & 0,000 & 0,000 & 0,000 & 0,000 & 0,000 & 0,000 & 0,000 & 0,000 & 0,000 & 0,036 & 0,019 & 0,020 & 0,000 \\
\hline $\mathrm{XFe}^{2+}$ & 0,031 & 0,061 & 0,038 & 0,041 & 0,011 & 0,026 & 0,019 & 0,005 & 0,016 & 0,007 & 0,012 & 0,000 & 0,005 & 0,000 & 0,017 \\
\hline $\mathrm{XMn}$ & 0,003 & 0,002 & 0,003 & 0,001 & 0,002 & 0,003 & 0,001 & 0,002 & 0,001 & 0,002 & 0,003 & 0,002 & 0,001 & 0,002 & 0,002 \\
\hline $\mathrm{XCa}$ & 0,843 & 0,816 & 0,841 & 0,841 & 0,872 & 0,855 & 0,884 & 0,875 & 0,875 & 0,895 & 0,884 & 0,884 & 0,872 & 0,885 & 0,866 \\
\hline $\mathrm{XNa}$ & 0,123 & 0,115 & 0,117 & 0,116 & 0,115 & 0,116 & 0,096 & 0,117 & 0,108 & 0,096 & 0,101 & 0,097 & 0,103 & 0,103 & 0,114 \\
\hline Xtotal & 1,000 & 1,000 & 1,000 & 0,999 & 1,000 & 1,000 & 1,000 & 1,000 & 1,000 & 1,000 & 1,000 & 1,019 & 1,000 & 1,010 & 0,999 \\
\hline$\# \mathrm{mg}$ & 0,937 & 0,930 & 0,930 & 0,927 & 0,936 & 0,932 & 0,949 & 0,945 & 0,949 & 0,952 & 0,947 & 0,937 & 0,954 & 0,942 & 0,950 \\
\hline $\mathrm{Ca} / \mathrm{ca}+\mathrm{Al}$ & 0,766 & 0,732 & 0,755 & 0,747 & 0,775 & 0,758 & 0,822 & 0,826 & 0,832 & 0,845 & 0,838 & 0,849 & 0,847 & 0,831 & 0,828 \\
\hline $\mathrm{Cr} \#$ & 0,062 & 0,067 & 0,065 & 0,066 & 0,062 & 0,064 & 0,072 & 0,093 & 0,085 & 0,067 & 0,094 & 0,073 & 0,081 & 0,080 & 0,083 \\
\hline
\end{tabular}


Tabela 42- Composição química de clinopiroxênio em lherzolitos e harzburgitos com espinélio dos corpos Indaiá 1, Limeira 1 e Forca.

\begin{tabular}{|c|c|c|c|c|c|c|c|c|c|c|c|c|c|c|c|c|c|c|c|}
\hline $\begin{array}{c}\text { Código } \\
\text { da }\end{array}$ & In1-13a-1 & In1-13a-2 & In1-13a-3 & In1-13a-4 & In1-13b-1 & In1-14a-1 & In1-14a-2 & In1-14a-3 & In1-14a-4 & In1-14a-5 & In1-14a-6 & Lm1-17b-7 & L1-17a-12 & Lml-17-4 & Fo-2-26 & Fo-2-27 & Fo-2-22 & Fo-1-20a & Fo-6-24 \\
\hline Tipo & \multicolumn{5}{|c|}{ Iherzolito protogranular com espinélio } & \multicolumn{6}{|c|}{ Iherzolito protogranular com espinélio } & \multicolumn{3}{|c|}{ harzburgito protogranular com espinélio } & \multicolumn{2}{|c|}{$\begin{array}{l}\text { borda espinélio } \\
\text { lherzolito }\end{array}$} & $\begin{array}{l}\text { centro } \\
\text { espinélio } \\
\text { lherzolito }\end{array}$ & harzburgito & $\begin{array}{l}\text { espinélio } \\
\text { harzburgito } \\
\text { centro }\end{array}$ \\
\hline $\mathrm{SiO}_{2}$ & 52,85 & 52,91 & 52,94 & 52,66 & 53,12 & 53,71 & 53,81 & 52,85 & 54,25 & 51,32 & 54,26 & 51,71 & 52,22 & 52,97 & 52,62 & 51,39 & 52,53 & 52,65 & 52,57 \\
\hline $\mathrm{TiO}_{2}$ & 0,40 & 0,46 & 0,36 & 0,30 & 0,03 & 0,21 & 0,27 & 0,15 & 0,25 & 0,27 & 0,30 & 0,01 & 0,07 & 0,00 & 0,12 & 0,10 & 0,17 & 0,14 & 0,08 \\
\hline $\mathrm{Al}_{2} \mathrm{O}_{3}$ & 3,78 & 3,87 & 3,95 & 3,68 & 3,39 & 3,80 & 3,61 & 4,46 & 4,03 & 6,50 & 3,79 & 5,73 & 5,52 & 5,07 & 3,17 & 3,00 & 3,83 & 0,96 & 3,95 \\
\hline $\mathrm{FeO}$ & 1,39 & 1,61 & 1,45 & 1,32 & 1,47 & 1,61 & 1,45 & 1,61 & 1,48 & 1,75 & 1,32 & 1,76 & 1,67 & 2,04 & 1,26 & 1,42 & 1,26 & 2,59 & 1,21 \\
\hline $\mathrm{MnO}$ & 0,04 & 0,05 & 0,05 & 0,06 & 0,05 & 0,06 & 0,05 & 0,05 & 0,06 & 0,07 & 0,07 & 0,10 & 0,15 & 0,08 & 0,12 & 0,00 & 0,05 & 0,11 & 0,07 \\
\hline $\mathrm{MgO}$ & 16,03 & 15,90 & 15,76 & 15,84 & 16,50 & 14,89 & 14,85 & 15,31 & 14,83 & 15,19 & 14,74 & 15,33 & 15,19 & 15,58 & 16,56 & 16,42 & 16,05 & 18,08 & 16,40 \\
\hline $\mathrm{CaO}$ & 22,74 & 22,27 & 21,82 & 22,59 & 23,11 & 22,69 & 23,03 & 22,63 & 22,80 & 21,76 & 22,54 & 22,23 & 22,32 & 19,62 & 24,29 & 23,94 & 23,48 & 22,49 & 22,71 \\
\hline $\mathrm{Na}_{2} \mathrm{O}$ & 1,53 & 1,56 & 1,48 & 1,60 & 1,27 & 1,34 & 1,45 & 1,26 & 1,48 & 1,37 & 1,52 & 1,29 & 1,30 & 1,38 & 0,95 & 0,97 & 1,16 & 1,24 & 1,38 \\
\hline $\mathrm{K}_{2} \mathrm{O}$ & 0,00 & 0,00 & 0,02 & 0,00 & 0,00 & 0,00 & 0,00 & 0,00 & 0,00 & 0,00 & 0,00 & 0,09 & 0,01 & 0,00 & 0,00 & 0,02 & 0,02 & 0,02 & 0,03 \\
\hline $\mathrm{Cr}_{2} \mathrm{O}_{3}$ & 1,36 & 1,39 & 1,36 & 1,40 & 1,20 & 0,75 & 0,87 & 0,92 & 0,84 & 1,30 & 0,87 & 0,98 & 0,92 & 0,91 & 0,90 & 0,60 & 1,05 & 1,02 & 1,20 \\
\hline $\mathrm{NiO}$ & n.d. & n.d. & n.d. & n.d. & n.d. & n.d. & n.d. & n.d. & n.d. & n.d. & n.d. & 0,00 & 0,02 & 0,03 & 0,01 & 0,00 & 0,02 & 0,12 & 0,09 \\
\hline Total & 100,12 & 100,03 & 99,19 & 99,43 & 100,13 & 99,04 & 99,39 & 99,24 & 100,02 & 99,54 & 99,41 & 97,96 & 98,08 & 97,69 & 99,05 & 97,85 & 98,47 & 98,16 & 98,33 \\
\hline $\mathrm{TSi}$ & 1,909 & 1,915 & 1,932 & 1,915 & 1,917 & 1,967 & 1,964 & 1,929 & 1,967 & 1,866 & 1,979 & 1,883 & 1,901 & 1,959 & 1,902 & 1,894 & 1,907 & 1,910 & 1,902 \\
\hline $\mathrm{TFe}^{3+}$ & 0,042 & 0,024 & 0,000 & 0,042 & 0,052 & 0,000 & 0,000 & 0,000 & 0,000 & 0,009 & 0,000 & 0,036 & 0,005 & 0,000 & 0,078 & 0,106 & 0,046 & 0,090 & 0,065 \\
\hline TAl & 0,049 & 0,062 & 0,068 & 0,043 & 0,031 & 0,033 & 0,036 & 0,071 & 0,033 & 0,125 & 0,021 & 0,081 & 0,094 & 0,041 & 0,020 & 0,000 & 0,047 & 0,000 & 0,033 \\
\hline $\mathrm{T}$ total & 2,000 & 2,000 & 2,000 & 2,000 & 2,000 & 2,000 & 2,000 & 2,000 & 2,000 & 2,000 & 2,000 & 2,000 & 2,000 & 2,000 & 2,000 & 2,000 & 2,000 & 2,000 & 2,000 \\
\hline $\mathrm{M} 2 \mathrm{Al}$ & 0,112 & 0,103 & 0,102 & 0,114 & 0,113 & 0,131 & 0,119 & 0,120 & 0,139 & 0,154 & 0,142 & 0,165 & 0,143 & 0,180 & 0,115 & 0,130 & 0,116 & 0,041 & 0,135 \\
\hline $\mathrm{M} 2 \mathrm{Cr}$ & 0,026 & 0,027 & 0,026 & 0,027 & 0,023 & 0,014 & 0,017 & 0,018 & 0,016 & 0,025 & 0,017 & 0,019 & 0,018 & 0,018 & 0,017 & 0,012 & 0,020 & 0,020 & 0,023 \\
\hline $\mathrm{M} 2 \mathrm{Fe}^{3+}$ & 0,000 & 0,000 & 0,000 & 0,000 & 0,000 & 0,000 & 0,000 & 0,000 & 0,000 & 0,000 & 0,000 & 0,000 & 0,000 & 0,000 & 0,000 & 0,011 & 0,000 & 0,081 & 0,000 \\
\hline M2Ti & 0,011 & 0,012 & 0,010 & 0,008 & 0,001 & 0,006 & 0,007 & 0,004 & 0,007 & 0,007 & 0,008 & 0,000 & 0,002 & 0,000 & 0,003 & 0,003 & 0,005 & 0,004 & 0,002 \\
\hline M2Ni & 0,000 & 0,000 & 0,000 & 0,000 & 0,000 & 0,000 & 0,000 & 0,000 & 0,000 & 0,000 & 0,000 & 0,000 & 0,001 & 0,001 & 0,000 & 0,000 & 0,001 & 0,003 & 0,003 \\
\hline $\mathrm{M}^{2} \mathrm{Fe}^{2+}$ & 0,000 & 0,000 & 0,005 & 0,000 & 0,000 & 0,036 & 0,044 & 0,025 & 0,036 & 0,000 & 0,031 & 0,000 & 0,012 & 0,000 & 0,000 & 0,000 & 0,000 & 0,000 & 0,000 \\
\hline $\mathrm{M} 2 \mathrm{Mg}$ & 0,863 & 0,858 & 0,857 & 0,858 & 0,887 & 0,813 & 0,808 & 0,833 & 0,801 & 0,823 & 0,802 & 0,832 & 0,825 & 0,859 & 0,893 & 0,902 & 0,869 & 0,978 & 0,884 \\
\hline M2Mn & 0,000 & 0,000 & 0,000 & 0,000 & 0,000 & 0,000 & 0,001 & 0,000 & 0,000 & 0,000 & 0,000 & 0,000 & 0,000 & 0,000 & 0,000 & 0,000 & 0,000 & 0,000 & 0,000 \\
\hline M2total & 1,000 & 1,000 & 1,000 & 1,000 & 1,000 & 1,000 & 0,997 & 1,000 & 1,000 & 1,000 & 1,000 & 1,000 & 1,000 & 1,000 & 1,029 & 1,058 & 1,000 & 1,000 & 1,000 \\
\hline XMg & 0,012 & 0,000 & 0,000 & 0,008 & 0,024 & 0,000 & 0,000 & 0,000 & 0,000 & 0,009 & 0,000 & 0,016 & 0,000 & 0,058 & 0,000 & 0,000 & 0,010 & 0,126 & 0,000 \\
\hline $\mathrm{XFe}^{2+}$ & 0,000 & 0,025 & 0,039 & 0,000 & 0,000 & 0,013 & 0,000 & 0,024 & 0,008 & 0,044 & 0,009 & 0,018 & 0,033 & 0,063 & 0,000 & 0,000 & 0,000 & 0,000 & 0,000 \\
\hline XMn & 0,001 & 0,002 & 0,002 & 0,002 & 0,001 & 0,002 & 0,000 & 0,002 & 0,002 & 0,002 & 0,002 & 0,003 & 0,005 & 0,002 & 0,004 & 0,000 & 0,002 & 0,003 & 0,002 \\
\hline $\mathrm{XCa}$ & 0,880 & 0,864 & 0,853 & 0,880 & 0,894 & 0,890 & 0,901 & 0,885 & 0,886 & 0,848 & 0,881 & 0,867 & 0,870 & 0,778 & 0,941 & 0,946 & 0,913 & 0,874 & 0,880 \\
\hline $\mathrm{XNa}$ & 0,107 & 0,110 & 0,105 & 0,113 & 0,089 & 0,095 & 0,103 & 0,089 & 0,104 & 0,097 & 0,108 & 0,091 & 0,092 & 0,099 & 0,067 & 0,069 & 0,082 & 0,087 & 0,097 \\
\hline Xtotal & 1,000 & 1,000 & 0,999 & 1,002 & 1,008 & 1,000 & 1,003 & 1,000 & 1,000 & 1,000 & 1,000 & 0,095 & 1,000 & 1,000 & 1,011 & 1,015 & 1,006 & 1,091 & 1,027 \\
\hline mg\# & 0,953 & 0,946 & 0,951 & 0,953 & 0,944 & 0,943 & 0,948 & 0,944 & 0,947 & 0,939 & 0,952 & 0,939 & 0,942 & 0,932 & 0,919 & 0,885 & 0,950 & 0,852 & 0,931 \\
\hline $\mathrm{Ca} / \mathrm{ca}+\mathrm{Al}$ & 0,846 & 0,839 & 0,834 & 0,848 & 0,861 & 0,845 & 0,853 & 0,822 & 0,837 & 0,753 & 0,844 & 0,779 & 0,786 & 0,779 & 0,875 & 0,879 & 0,848 & 0,955 & 0,839 \\
\hline $\mathrm{Cr} \#$ & 0,139 & 0,139 & 0,133 & 0,146 & 0,137 & 0,081 & 0,097 & 0,085 & 0,085 & 0,082 & 0,093 & 0,071 & 0,069 & 0,075 & 0,113 & 0,083 & 0,109 & 0,323 & 0,119 \\
\hline
\end{tabular}


Tabela 43- Composição química de clinopiroxênio em dunitos e harzburgitos com Cr-espinélio dos corpos Indaiá 1, Limeira 1 e Forca.

\begin{tabular}{|c|c|c|c|c|c|c|c|c|c|c|c|c|c|c|c|c|c|c|}
\hline \multirow{2}{*}{$\begin{array}{l}\text { Código } \\
\text { da } \\
\text { amostra }\end{array}$} & In1-3-1 & In1-3-2 & In1-3-3 & In1-3-4 & In1-3-5 & In1-3-6 & In1-3-7 & Lm1-20a-14 & Lm1-20a-15 & Lm1-20a-17 & Lm1-20b-7 & Lm1-20b-23 & Lm1-20b-23b & Lm1-30-10b & Lm1-30-8 & Lm1-30-4b & Lm1-36-7b & In1-50-9 \\
\hline & \multicolumn{7}{|c|}{ harzburgito granoblástico com Cr-espinélio } & \multicolumn{3}{|c|}{$\begin{array}{l}\text { harzburgito granoblástico com Cr- } \\
\text { espinélio }\end{array}$} & \multicolumn{3}{|c|}{$\begin{array}{l}\text { harzburgito granoblástico com Cr- } \\
\text { espinélio }\end{array}$} & \multicolumn{3}{|c|}{$\begin{array}{l}\text { harzburgito granoblástico com } \mathrm{Cr}- \\
\text { espinélio }\end{array}$} & $\begin{array}{l}\text { harzburgito } \\
\text { com Cr- }\end{array}$ & $\begin{array}{l}\text { harzburgito } \\
\text { com Cr-sp e }\end{array}$ \\
\hline $\begin{array}{l}11 p 0 \\
\mathrm{SiO}_{2}\end{array}$ & 52,75 & 53,69 & 53,29 & 53,62 & 54,03 & 54,03 & 53,12 & 52,37 & 52,57 & 53,58 & 54,15 & 53,11 & 54,80 & 53,47 & 52,52 & 53,12 & 53,85 & 51,57 \\
\hline $\mathrm{TiO}_{2}$ & 0,07 & 0,06 & 0,03 & 0,10 & 0,00 & 0,00 & 0,04 & 0,08 & 0,02 & 0,00 & 0,00 & 0,07 & 0,05 & 0,06 & 0,04 & 0,00 & 0,02 & 2,08 \\
\hline $\mathrm{Al}_{2} \mathrm{O}_{3}$ & 2,10 & 1,86 & 1,96 & 2,22 & 2,06 & 2,13 & 2,13 & 3,09 & 3,31 & 3,52 & 3,25 & 3,70 & 2,65 & 2,48 & 2,51 & 1,53 & 1,89 & 3,79 \\
\hline $\mathrm{FeO}$ & 1,70 & 1,54 & 1,55 & 1,79 & 1,38 & 1,59 & 1,73 & 1,46 & 1,94 & 1,67 & 1,65 & 1,39 & 1,42 & 1,65 & 1,77 & 2,13 & 1,56 & 1,41 \\
\hline $\mathrm{MnO}$ & 0,05 & 0,05 & 0,04 & 0,11 & 0,07 & 0,02 & 0,07 & 0,02 & 0,10 & 0,09 & 0,09 & 0,00 & 0,03 & 0,08 & 0,00 & 0,04 & 0,09 & 0,00 \\
\hline $\mathrm{MgO}$ & 17,76 & 18,16 & 17,45 & 18,37 & 17,63 & 17,57 & 17,62 & 16,28 & 16,40 & 16,37 & 16,47 & 15,93 & 17,28 & 17,06 & 16,92 & 18,92 & 17,14 & 15,52 \\
\hline $\mathrm{CaO}$ & 22,14 & 21,73 & 23,05 & 22,18 & 23,31 & 23,34 & 22,42 & 23,56 & 23,07 & 22,85 & 23,26 & 22,82 & 23,41 & 22,28 & 22,07 & 20,17 & 22,64 & 21,82 \\
\hline $\mathrm{K}_{2} \mathrm{O}$ & 0,00 & 0,00 & 0,01 & 0,00 & 0,00 & 0,01 & 0,00 & 0,00 & 0,01 & 0,02 & 0,00 & 0,00 & 0,02 & 0,00 & 0,00 & 1,61 & 0,03 & 0,03 \\
\hline $\mathrm{Cr}_{2} \mathrm{O}_{3}$ & 1,01 & 0,86 & 0,87 & 1,09 & 0,91 & 0,96 & 1,04 & 1,03 & 0,99 & 1,06 & 1,30 & 1,24 & 0,81 & 0,72 & 0,84 & 0,35 & 0,97 & 1,84 \\
\hline $\mathrm{NiO}$ & n.d. & n.d. & n.d. & n.d. & n.d. & n.d. & n.d. & 0,02 & 0,10 & 0,01 & 0,11 & 0,01 & 0,11 & 0,08 & 0,02 & 0,00 & 0,00 & 0,00 \\
\hline Total & 98,35 & 98,71 & 99,14 & 100,30 & 100,10 & 100,40 & 98,90 & 99,02 & 98,51 & 99,18 & 100,28 & 98,27 & 100,58 & 97,87 & 97,43 & 98,20 & 98,18 & 98,52 \\
\hline $\mathrm{TSi}$ & 1,937 & 1,961 & 1,940 & 1,929 & 1,951 & 1,946 & 1,942 & 1,913 & 1,912 & 1,928 & 1,937 & 1,930 & 1,948 & 1,962 & 1,950 & 1,942 & 1,968 & 1,925 \\
\hline $\mathrm{TFe}^{3+}$ & 0,038 & 0,008 & 0,058 & 0,049 & 0,016 & 0,025 & 0,025 & 0,066 & 0,057 & 0,035 & 0,002 & 0,008 & 0,023 & 0,000 & 0,001 & 0,058 & 0,000 & 0,000 \\
\hline TAl & 0,026 & 0,031 & 0,003 & 0,023 & 0,033 & 0,029 & 0,033 & 0,021 & 0,030 & 0,037 & 0,060 & 0,061 & 0,029 & 0,038 & 0,049 & 0,000 & 0,032 & 0,075 \\
\hline $\mathrm{T}$ total & 2,000 & 2,000 & 2,000 & 2,000 & 2,000 & 2,000 & 2,000 & 2,000 & 2,000 & 2,000 & 2,000 & 2,000 & 2,000 & 2,000 & 2,000 & 2,000 & 2,000 & 2,000 \\
\hline M2Al & 0,065 & 0,048 & 0,081 & 0,071 & 0,055 & 0,061 & 0,058 & 0,112 & 0,112 & 0,112 & 0,077 & 0,097 & 0,082 & 0,070 & 0,060 & 0,066 & 0,049 & 0,091 \\
\hline $\mathrm{M} 2 \mathrm{Cr}$ & 0,019 & 0,017 & 0,017 & 0,021 & 0,017 & 0,018 & 0,020 & 0,020 & 0,019 & 0,020 & 0,024 & 0,024 & 0,015 & 0,014 & 0,016 & 0,007 & 0,019 & 0,036 \\
\hline${\mathrm{M} 2 \mathrm{Fe}^{3+}}^{3+}$ & 0,000 & 0,000 & 0,000 & 0,000 & 0,000 & 0,000 & 0,000 & 0,000 & 0,000 & 0,000 & 0,000 & 0,000 & 0,000 & 0,000 & 0,000 & 0,074 & 0,000 & 0,058 \\
\hline M2Ti & 0,002 & 0,002 & 0,001 & 0,003 & 0,000 & 0,000 & 0,001 & 0,002 & 0,001 & 0,000 & 0,000 & 0,002 & 0,001 & 0,002 & 0,001 & 0,000 & 0,001 & 0,011 \\
\hline $\mathrm{M}^{2} \mathrm{Fe}^{2+}$ & 0,000 & 0,000 & 0,000 & 0,000 & 0,000 & 0,000 & 0,000 & 0,000 & 0,000 & 0,000 & 0,017 & 0,013 & 0,000 & 0,000 & 0,000 & 0,000 & 0,000 & 0,000 \\
\hline $\mathrm{M} 2 \mathrm{Mg}$ & 0,972 & 0,988 & 0,947 & 0,985 & 0,949 & 0,943 & 0,960 & 0,886 & 0,889 & 0,878 & 0,878 & 0,863 & 0,916 & 0,933 & 0,936 & 0,853 & 0,934 & 0,814 \\
\hline M2Mn & 0,000 & 0,000 & 0,000 & 0,000 & 0,000 & 0,000 & 0,000 & 0,000 & 0,000 & 0,000 & 0,000 & 0,000 & 0,000 & 0,000 & 0,000 & 0,000 & 0,000 & 0,000 \\
\hline M2total & 1,000 & 1,000 & 1,000 & 1,000 & 1,000 & 1,000 & 1,000 & 1,000 & 1,000 & 1,000 & 1,000 & 1,000 & 1,000 & 1,000 & 1,000 & 1,000 & 1,000 & 1,000 \\
\hline $\mathrm{XMg}$ & 0,058 & 0,055 & 0,046 & 0,080 & 0,021 & 0,023 & 0,040 & 0,021 & 0,023 & 0,010 & 0,000 & 0,000 & 0,017 & 0,021 & 0,015 & 0,177 & 0,002 & 0,050 \\
\hline $\mathrm{XFe}^{2+}$ & 0,015 & 0,039 & 0,000 & 0,005 & 0,026 & 0,023 & 0,028 & 0,000 & 0,002 & 0,016 & 0,030 & 0,021 & 0,019 & 0,051 & 0,054 & 0,000 & 0,048 & 0,044 \\
\hline XMn & 0,002 & 0,002 & 0,001 & 0,003 & 0,002 & 0,001 & 0,002 & 0,000 & 0,003 & 0,003 & 0,003 & 0,000 & 0,001 & 0,002 & 0,000 & 0,001 & 0,003 & 0,000 \\
\hline $\mathrm{XCa}$ & 0,871 & 0,850 & 0,899 & 0,855 & 0,902 & 0,901 & 0,878 & 0,922 & 0,899 & 0,881 & 0,892 & 0,889 & 0,892 & 0,876 & 0,878 & 0,790 & 0,886 & 0,873 \\
\hline $\mathrm{XNa}$ & 0,054 & 0,054 & 0,064 & 0,057 & 0,049 & 0,052 & 0,052 & 0,078 & 0,072 & 0,089 & 0,076 & 0,091 & 0,070 & 0,050 & 0,053 & 0,023 & 0,060 & 0,032 \\
\hline Xtotal & 1,000 & 1,000 & 1,010 & 1,000 & 1,000 & 1,0 & 1,0 & 1,022 & 0,999 & 0,999 & 1,000 & 1,000 & 0,999 & 1,000 & 1,000 & 0,992 & 0,999 & 0,999 \\
\hline \#mg & 0,949 & 0,955 & 0,943 & 0,948 & 0,958 & 0,952 & 0,948 & 0,931 & 0,938 & 0,946 & 0,947 & 0,953 & 0,956 & 0,949 & 0,945 & 0,886 & 0,951 & 0,951 \\
\hline $\mathrm{Ca} / \mathrm{Ca}+\mathrm{Al}$ & 0,905 & 0,914 & 0,915 & 0,901 & 0,911 & 0,909 & 0,905 & 0,874 & 0,864 & 0,855 & 0,867 & 0,849 & 0,889 & 0,891 & 0,889 & 0,923 & 0,916 & 0,840 \\
\hline $\mathrm{Cr}^{\#}$ & 0176 & 0172 & 0165 & 0180 & 0165 & 0168 & 0179 & 0129 & 0118 & 0119 & 0151 & 0130 & 0120 & 0115 & 0130 & 0.092 & 0187 & 0.179 \\
\hline
\end{tabular}


Tabela 44- Composição química de clinopiroxênio em harzburgitos e dunitos com flogopita dos corpos Indaiá 1 e Limeira 1.

\begin{tabular}{|c|c|c|c|c|c|c|c|c|c|c|c|c|c|c|c|c|}
\hline $\begin{array}{l}\text { Código } \\
\text { da } \\
\text { amostra }\end{array}$ & In1-1-1 & In1-2-1 & In1-2-2 & In1-2-3 & In1-2-4 & In1-2-5 & In1-2-6 & Lm1-1-4c & Lm1-1-4 & $\begin{array}{c}\text { Lm1-1- } \\
10\end{array}$ & Lm1-26a-5 & Lm1-26a-3d & Lm1-26a-12 & Lm1-26a-14 & Lm1-26a-13 & Lm1-28-9c \\
\hline Tipo & $\begin{array}{l}\text { Harzburgito } \\
\text { porfiroclástico }\end{array}$ & \multicolumn{6}{|c|}{ flogopita dunito } & harzburgito & $\begin{array}{l}\text { m bolsões } \\
\text { titanato }\end{array}$ & ogopita e & \multicolumn{5}{|c|}{ harzburgito com bolsões de flogopita } & $\begin{array}{l}\text { dunito com } \\
\text { bolsões de } \\
\text { flogopita }\end{array}$ \\
\hline $\mathrm{SiO}_{2}$ & 53,24 & 54,94 & 54,88 & 55,63 & 54,91 & 55,53 & 54,79 & 54,61 & 54,34 & 51,53 & 53,77 & 52,46 & 52,20 & 51,67 & 51,36 & 54,28 \\
\hline $\mathrm{TiO}_{2}$ & 1,46 & 0,33 & 0,27 & 0,19 & 0,30 & 0,17 & 0,51 & 0,34 & 0,31 & 0,43 & 0,33 & 0,26 & 0,30 & 0,26 & 0,29 & 0,12 \\
\hline $\mathrm{Al}_{2} \mathrm{O}_{3}$ & 0,30 & 0,36 & 0,42 & 0,41 & 0,67 & 0,40 & 0,22 & 0,80 & 0,79 & 0,76 & 0,55 & 0,63 & 0,78 & 0,71 & 0,62 & 0,03 \\
\hline $\mathrm{FeO}$ & 5,18 & 3,11 & 3,03 & 2,81 & 3,16 & 2,95 & 2,69 & 3,60 & 3,14 & 3,55 & 3,64 & 3,87 & 3,95 & 4,36 & 3,72 & 1,84 \\
\hline $\mathrm{MnO}$ & 0,13 & 0,07 & 0,11 & 0,13 & 0,15 & 0,09 & 0,04 & 0,05 & 0,03 & 0,15 & 0,15 & 0,17 & 0,17 & 0,03 & 0,08 & 0,08 \\
\hline $\mathrm{MgO}$ & 18,01 & 17,45 & 17,56 & 17,81 & 17,75 & 17,74 & 17,62 & 18,11 & 17,77 & 17,64 & 17,29 & 17,40 & 17,51 & 17,48 & 17,34 & 17,90 \\
\hline $\mathrm{CaO}$ & 20,57 & 21,51 & 21,16 & 21,67 & 21,58 & 21,32 & 23,96 & 20,78 & 20,57 & 20,70 & 20,88 & 21,16 & 20,87 & 20,75 & 21,02 & 24,86 \\
\hline $\mathrm{Na}_{2} \mathrm{O}$ & 0,80 & 1,07 & 1,03 & 0,98 & 1,01 & 1,10 & 0,58 & 1,45 & 1,44 & 1,25 & 1,35 & 1,35 & 1,31 & 1,26 & 1,63 & 0,44 \\
\hline $\mathrm{K}_{2} \mathrm{O}$ & 0,00 & 0,01 & 0,00 & 0,02 & 0,03 & 0,02 & 0,22 & 0,04 & 0,01 & 0,02 & 0,00 & 0,03 & 0,03 & 0,02 & 0,00 & 0,02 \\
\hline $\mathrm{Cr}_{2} \mathrm{O}_{3}$ & 0,10 & 1,80 & 1,34 & 1,51 & 1,42 & 1,77 & 0,11 & 1,85 & 1,87 & 1,14 & 2,13 & 1,43 & 1,29 & 1,35 & 2,08 & 0,24 \\
\hline $\mathrm{NiO}$ & n.d. & n.d. & n.d. & n.d. & n.d. & n.d. & n.d. & 0,13 & 0,09 & 0,09 & 0,10 & 0,10 & 0,03 & 0,04 & 0,03 & 0,00 \\
\hline Total & 99,80 & 100,65 & 99,80 & 101,16 & 100,96 & 101,08 & 100,74 & 100,32 & 98,91 & 97,27 & 98,85 & 98,85 & 98,42 & 97,94 & 98,18 & 99,79 \\
\hline $\mathrm{TSi}$ & 1,943 & 1,991 & 2,000 & 2,001 & 1,979 & 2,000 & 1,972 & 1,949 & 1,966 & 1,918 & 1,959 & 1,928 & 1,924 & 1,916 & 1,900 & 1,968 \\
\hline $\mathrm{TFe}^{3+}$ & 0,057 & 0,000 & 0,000 & 0,000 & 0,003 & 0,000 & 0,028 & 0,051 & 0,029 & 0,082 & 0,034 & 0,072 & 0,076 & 0,084 & 0,100 & 0,032 \\
\hline TAl & 0,000 & 0,009 & 0,000 & 0,000 & 0,019 & 0,000 & 0,000 & 0,000 & 0,004 & 0,000 & 0,007 & 0,000 & 0,000 & 0,000 & 0,000 & 0,000 \\
\hline $\mathrm{T}$ total & 2,000 & 2,000 & 2,000 & 2,001 & 2,000 & 2,000 & 2,000 & 2,000 & 2,000 & 2,000 & 2,000 & 2,000 & 2,000 & 2,000 & 2,000 & 2,000 \\
\hline M2Al & 0,013 & 0,007 & 0,018 & 0,017 & 0,010 & 0,017 & 0,009 & 0,033 & 0,029 & 0,033 & 0,016 & 0,027 & 0,034 & 0,031 & 0,027 & 0,001 \\
\hline $\mathrm{M} 2 \mathrm{Cr}$ & 0,002 & 0,034 & 0,026 & 0,029 & 0,027 & 0,034 & 0,002 & 0,035 & 0,036 & 0,022 & 0,041 & 0,028 & 0,025 & 0,026 & 0,040 & 0,005 \\
\hline $\mathrm{M} 2 \mathrm{Fe}^{3+}$ & 0,016 & 0,000 & 0,000 & 0,000 & 0,000 & 0,000 & 0,037 & 0,014 & 0,000 & 0,060 & 0,000 & 0,058 & 0,058 & 0,064 & 0,073 & 0,044 \\
\hline M2Ti & 0,040 & 0,009 & 0,007 & 0,005 & 0,008 & 0,005 & 0,014 & 0,009 & 0,008 & 0,012 & 0,009 & 0,007 & 0,008 & 0,007 & 0,008 & 0,003 \\
\hline $\mathrm{M} 2 \mathrm{Ni}$ & 0,000 & 0,000 & 0,000 & 0,000 & 0,000 & 0,000 & 0,000 & 0,004 & 0,003 & 0,003 & 0,003 & 0,003 & 0,001 & 0,001 & 0,001 & 0,000 \\
\hline $\mathrm{M} 2 \mathrm{Fe}^{2+}$ & 0,000 & 0,000 & 0,000 & 0,000 & 0,000 & 0,000 & 0,000 & 0,000 & 0,000 & 0,000 & 0,000 & 0,000 & 0,000 & 0,000 & 0,000 & 0,000 \\
\hline M2Mg & 0,980 & 0,943 & 0,954 & 0,955 & 0,953 & 0,952 & 0,946 & 0,964 & 0,959 & 0,979 & 0,939 & 0,953 & 0,962 & 0,966 & 0,956 & 0,967 \\
\hline M2Mn & 0,000 & 0,002 & 0,000 & 0,000 & 0,002 & 0,000 & 0,000 & 0,000 & 0,000 & 0,000 & 0,000 & 0,000 & 0,000 & 0,000 & 0,000 & 0,000 \\
\hline M2total & 1,000 & 0,995 & 1,000 & 1,000 & 1,000 & 1,000 & 1,000 & 1,000 & 1,000 & 1,000 & 1,000 & 1,000 & 1,000 & 1,000 & 1,000 & 1,020 \\
\hline $\mathrm{XMg}$ & 0,050 & 0,000 & 0,005 & 0,006 & 0,000 & 0,008 & 0,008 & 0,059 & 0,034 & 0,109 & 0,008 & 0,077 & 0,088 & 0,016 & 0,106 & 0,000 \\
\hline $\mathrm{XFe}^{2+}$ & 0,085 & 0,094 & 0,092 & 0,085 & 0,093 & 0,089 & 0,016 & 0,043 & 0,066 & 0,000 & 0,077 & 0,000 & 0,000 & 0,000 & 0,000 & 0,000 \\
\hline $\mathrm{XMn}$ & 0,004 & 0,000 & 0,003 & 0,004 & 0,002 & 0,003 & 0,001 & 0,002 & 0,001 & 0,005 & 0,005 & 0,005 & 0,005 & 0,001 & 0,003 & 0,002 \\
\hline $\mathrm{XCa}$ & 0,804 & 0,835 & 0,826 & 0,835 & 0,833 & 0,823 & 0,924 & 0,795 & 0,798 & 0,826 & 0,815 & 0,833 & 0,824 & 0,824 & 0,833 & 0,966 \\
\hline $\mathrm{XNa}$ & 0,056 & 0,075 & 0,073 & 0,068 & 0,071 & 0,077 & 0,041 & 0,100 & 0,101 & 0,090 & 0,095 & 0,096 & 0,094 & 0,091 & 0,117 & 0,031 \\
\hline Xtotal & 1,000 & 1,004 & 1,000 & 0,998 & 0,999 & 0,999 & 0,990 & 0,998 & 0,999 & 1,030 & 1,000 & 1,001 & 1,011 & 1,012 & 1,059 & 0,999 \\
\hline \#mg & 0,861 & 0,909 & 0,912 & 0,919 & 0,909 & 0,915 & 0,921 & 0,900 & 0,910 & 0,874 & 0,894 & 0,879 & 0,878 & 0,867 & 0,847 & 0,927 \\
\hline $\mathrm{Ca} / \mathrm{Ca}+\mathrm{Al}$ & 0,984 & 0,982 & 0,979 & 0,980 & 0,967 & 0,980 & 0,990 & 0,960 & 0,960 & 0,961 & 0,972 & 0,968 & 0,961 & 0,964 & 0,968 & 0,999 \\
\hline $\mathrm{Cr} \#$ & 0,126 & 0,691 & 0,590 & 0,625 & 0,488 & 0,665 & 0,185 & 0,510 & 0,515 & 0,402 & 0,634 & 0,505 & 0,426 & 0,459 & 0,599 & 0,810 \\
\hline
\end{tabular}


Tabela 45- Composição química de clinopiroxênio secundário em peridotitos dos corpos Indaiá 1 e Limeira 1.

\begin{tabular}{|c|c|c|c|c|c|c|c|c|c|c|c|c|c|c|c|c|}
\hline $\begin{array}{c}\text { Código } \\
\text { da } \\
\text { amostra }\end{array}$ & In1-6-1 & In1-6-2 & In1-6-3 & In1-6-4 & In1-12-1 & In1-12-2 & In1-12-3 & In1-12-4 & In1-12-5 & Lm1-38-11a & Lm1-38-4 & Lm1-22-19b & Lm1-22-16b & Lm1-22-14b & Lm1-22-3 & Lm1-22-4 \\
\hline Tipo & \multicolumn{4}{|c|}{ flogopita ilmenita wehrlito } & \multicolumn{5}{|c|}{ harzburgito com bolsões de clinopiroxênio } & \multicolumn{2}{|c|}{$\begin{array}{l}\text { wehrlito com ilmenita e } \\
\text { flogopita }\end{array}$} & \multicolumn{5}{|c|}{ dunito com flocgopita e clinopiroxênio secundários } \\
\hline $\mathrm{SiO}_{2}$ & 54,21 & 54,44 & 54,34 & 54,20 & 54,44 & 54,27 & 54,41 & 54,54 & 54,11 & 54,23 & 53,82 & 54,54 & 54,39 & 52,71 & 53,79 & 52,93 \\
\hline $\mathrm{TiO}_{2}$ & 0,12 & 0,26 & 0,16 & 0,05 & 0,04 & 0,10 & 0,00 & 0,04 & 0,06 & 0,16 & 0,09 & 0,13 & 0,29 & 0,30 & 0,22 & 0,18 \\
\hline $\mathrm{Al}_{2} \mathrm{O}_{3}$ & 0,29 & 0,22 & 0,29 & 0,28 & 1,08 & 0,94 & 0,68 & 0,58 & 0,27 & 0,32 & 0,17 & 0,42 & 0,00 & 0,05 & 0,48 & 0,31 \\
\hline $\mathrm{FeO}$ & 4,40 & 4,35 & 4,28 & 4,18 & 2,64 & 2,36 & 2,24 & 2,27 & 1,94 & 2,49 & 3,05 & 2,92 & 3,00 & 3,42 & 2,83 & 3,21 \\
\hline $\mathrm{MnO}$ & 0,10 & 0,18 & 0,11 & 0,14 & 0,12 & 0,11 & 0,04 & 0,07 & 0,07 & 0,06 & 0,13 & 0,08 & 0,01 & 0,09 & 0,04 & 0,21 \\
\hline $\mathrm{MgO}$ & 17,16 & 17,13 & 17,31 & 17,29 & 16,44 & 15,85 & 16,00 & 16,62 & 16,67 & 18,27 & 17,68 & 17,61 & 17,68 & 20,34 & 17,54 & 17,67 \\
\hline $\mathrm{CaO}$ & 22,06 & 21,58 & 22,39 & 22,14 & 19,28 & 20,48 & 20,19 & 21,79 & 21,90 & 23,06 & 23,15 & 21,31 & 23,12 & 20,76 & 21,32 & 20,91 \\
\hline $\mathrm{Na}_{2} \mathrm{O}$ & 0,75 & 0,75 & 0,76 & 0,74 & 2,32 & 2,55 & 2,33 & 1,83 & 1,66 & 0,71 & 0,96 & 0,89 & 0,68 & 0,67 & 0,76 & 0,85 \\
\hline $\mathrm{K}_{2} \mathrm{O}$ & 0,04 & 0,04 & 0,01 & 0,01 & 0,00 & 0,00 & 0,02 & 0,08 & 0,01 & 0,01 & 0,00 & 0,02 & 0,19 & 0,09 & 0,01 & 0,03 \\
\hline $\mathrm{Cr}_{2} \mathrm{O}_{3}$ & 0,47 & 0,50 & 0,40 & 0,48 & 2,88 & 3,53 & 3,91 & 2,66 & 2,85 & 0,62 & 1,47 & 1,65 & 0,33 & 0,23 & 1,10 & 0,83 \\
\hline $\mathrm{NiO}$ & n.d. & n.d. & n.d. & n.d. & n.d. & n.d. & n.d. & n.d. & n.d. & 0,05 & 0,00 & 0,00 & 0,00 & 0,04 & 0,08 & 0,13 \\
\hline Total & 99,60 & 99,45 & 100,05 & 99,50 & 99,24 & 100,18 & 99,82 & 100,47 & 99,52 & 99,97 & 100,51 & 99,57 & 99,70 & 98,70 & 98,18 & 97,27 \\
\hline $\mathrm{TSi}$ & 1,983 & 1,996 & 1,977 & 1,982 & 1,994 & 1,975 & 1,993 & 1,976 & 1,982 & 1,962 & 1,948 & 1,995 & 1,978 & 1,916 & 1,991 & 1,974 \\
\hline $\mathrm{TFe}^{3+}$ & 0,017 & 0,004 & 0,023 & 0,018 & 0,000 & 0,014 & 0,000 & 0,024 & 0,001 & 0,038 & 0,052 & 0,000 & 0,022 & 0,084 & 0,000 & 0,026 \\
\hline TAl & 0,000 & 0,000 & 0,000 & 0,000 & 0,006 & 0,011 & 0,007 & 0,000 & 0,012 & 0,000 & 0,000 & 0,005 & 0,000 & 0,000 & 0,009 & 0,000 \\
\hline $\mathrm{T}$ total & 2,000 & 2,000 & 2,000 & 2,000 & 2,000 & 2,000 & 2,000 & 2,000 & 1,995 & 2,000 & 2,000 & 2,000 & 2,000 & 2,000 & 2,000 & 2,000 \\
\hline M2Al & 0,013 & 0,010 & 0,013 & 0,012 & 0,040 & 0,030 & 0,022 & 0,025 & 0,000 & 0,013 & 0,007 & 0,013 & 0,000 & 0,002 & 0,012 & 0,014 \\
\hline $\mathrm{M} 2 \mathrm{Cr}$ & 0,009 & 0,010 & 0,008 & 0,009 & 0,056 & 0,068 & 0,076 & 0,051 & 0,055 & 0,012 & 0,028 & 0,032 & 0,006 & 0,004 & 0,021 & 0,016 \\
\hline $\mathrm{M}^{2} \mathrm{Fe}^{3+}$ & 0,031 & 0,011 & 0,037 & 0,032 & 0,000 & 0,000 & 0,000 & 0,002 & 0,000 & 0,036 & 0,037 & 0,000 & 0,047 & 0,107 & 0,000 & 0,024 \\
\hline M2Ti & 0,003 & 0,007 & 0,004 & 0,001 & 0,001 & 0,003 & 0,000 & 0,001 & 0,002 & 0,004 & 0,002 & 0,004 & 0,008 & 0,008 & 0,006 & 0,005 \\
\hline M2Ni & 0,000 & 0,000 & 0,000 & 0,000 & 0,000 & 0,000 & 0,000 & 0,000 & 0,000 & 0,001 & 0,000 & 0,000 & 0,000 & 0,001 & 0,003 & 0,004 \\
\hline $\mathrm{M} 2 \mathrm{Fe}^{2+}$ & 0,000 & 0,000 & 0,000 & 0,000 & 0,006 & 0,040 & 0,028 & 0,023 & 0,033 & 0,000 & 0,000 & 0,000 & 0,000 & 0,000 & 0,000 & 0,000 \\
\hline $\mathrm{M} 2 \mathrm{Mg}$ & 0,935 & 0,936 & 0,939 & 0,943 & 0,898 & 0,860 & 0,874 & 0,898 & 0,910 & 0,985 & 0,954 & 0,960 & 0,959 & 0,877 & 0,968 & 0,982 \\
\hline M2Mn & 0,003 & 0,005 & 0,000 & 0,002 & 0,000 & 0,000 & 0,000 & 0,000 & 0,000 & 0,000 & 0,000 & 0,000 & 0,000 & 0,000 & 0,000 & 0,000 \\
\hline M2total & 0,994 & 0,979 & 1,000 & 1,000 & 1,000 & 1,000 & 1,000 & 1,000 & 1,000 & 1,000 & 1,000 & 1,000 & 1,000 & 1,000 & 1,000 & 1,000 \\
\hline $\mathrm{XMg}$ & 0,000 & 0,000 & 0,000 & 0,000 & 0,000 & 0,000 & 0,000 & 0,000 & 0,000 & 0,053 & 0,029 & 0,009 & 0,020 & 0,225 & 0,010 & 0,046 \\
\hline $\mathrm{XFe}^{2+}$ & 0,086 & 0,118 & 0,070 & 0,078 & 0,075 & 0,018 & 0,040 & 0,020 & 0,025 & 0,002 & 0,002 & 0,089 & 0,022 & 0,000 & 0,088 & 0,050 \\
\hline XMn & 0,000 & 0,000 & 0,003 & 0,002 & 0,004 & 0,003 & 0,001 & 0,002 & 0,002 & 0,002 & 0,004 & 0,002 & 0,000 & 0,003 & 0,001 & 0,007 \\
\hline $\mathrm{XCa}$ & 0,864 & 0,848 & 0,872 & 0,868 & 0,756 & 0,799 & 0,792 & 0,846 & 0,860 & 0,894 & 0,898 & 0,835 & 0,901 & 0,808 & 0,846 & 0,835 \\
\hline $\mathrm{XNa}$ & 0,053 & 0,053 & 0,054 & 0,052 & 0,165 & 0,180 & 0,165 & 0,128 & 0,118 & 0,050 & 0,067 & 0,063 & 0,048 & 0,047 & 0,055 & 0,062 \\
\hline Xtotal & 1,004 & 1,019 & 0,999 & 1,000 & 1,000 & 1,000 & 0,999 & 0,996 & 1,005 & 1,000 & 1,000 & 0,999 & 0,991 & 1,083 & 0,999 & 0,999 \\
\hline$\# \mathrm{mg}$ & 0,874 & 0,875 & 0,878 & 0,880 & 0,917 & 0,923 & 0,927 & 0,929 & 0,939 & 0,929 & 0,912 & 0,915 & 0,913 & 0,852 & 0,917 & 0,907 \\
\hline $\mathrm{Ca} / \mathrm{ca}+\mathrm{Al}$ & 0,986 & 0,989 & 0,986 & 0,986 & 0,942 & 0,952 & 0,964 & 0,972 & 0,987 & 0,985 & 0,992 & 0,979 & 1,000 & 0,997 & 0,976 & 0,984 \\
\hline $\mathrm{Cr} \#$ & 0,418 & 0,501 & 0,380 & 0,438 & 0,543 & 0,625 & 0,720 & 0,673 & 0,827 & 0,469 & 0,792 & 0,639 & 1,000 & 0,681 & 0,507 & 0,546 \\
\hline
\end{tabular}


Tabela 46- Composição química de clinopiroxênio em xenólitos crustais e em reações com carbonato (nódulos esverdeados) nos corpos Indaiá 1 e Limeira 1 e Forca. Lm1-27-3 In1-20d-7b In1-20d-9c In1-20d-2a In1-20d-6a In1-11-7c Lm1-25-1 Lm1-25-1i Lm1-25-1f Lm1-25-2e Lm1-25-12 Lm1-25-10b Lm1-25-11c

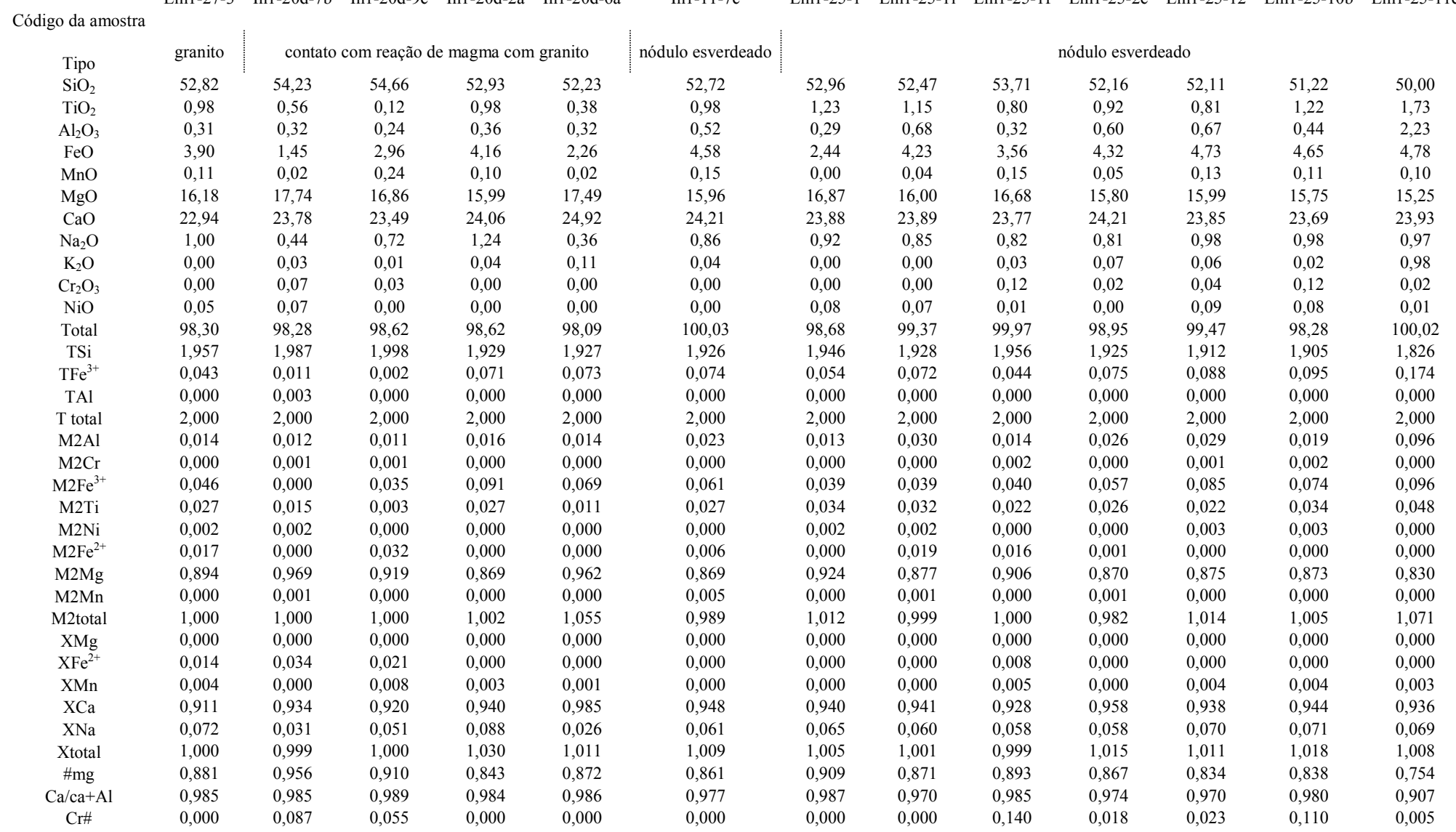


Tabela 47- Composição química de clinopiroxênio em dunitos, piroxenitos e megacristal nos corpos Indaiá 1, Limeira 1 e Forca.

\begin{tabular}{|c|c|c|c|c|c|c|c|c|c|c|c|c|c|c|}
\hline Código da amostra & Fo-3-5 & Fo-3-4 & Fo-3-1 & Lm1-14b & Lm1-14b & Lm1-14-13c & Lm1-14-13d & Lm1-40-10a & Lm1-40-7 & Lm1-41-4b & Lm1-29-3b & In1-33-8b & Lm1-32-2h & In1-20a-8e \\
\hline Tipo & \multicolumn{3}{|c|}{ megacristal } & \multicolumn{4}{|c|}{ piroxenito } & \multicolumn{2}{|c|}{ piroxenito } & dunito & dunito & harzburgito porfiroclástico em mosaico & dunito porfiroclastico & macrocristal \\
\hline $\mathrm{SiO}_{2}$ & 52,97 & 52,40 & 51,91 & 47,93 & 47,60 & 47,93 & 47,60 & 53,66 & 52,93 & 54,22 & 53,71 & 54,00 & 53,35 & 54,25 \\
\hline $\mathrm{TiO}_{2}$ & 0,63 & 0,64 & 0,60 & 1,13 & 1,14 & 1,13 & 1,14 & 0,09 & 0,31 & 0,16 & 0,34 & 0,76 & 0,26 & 0,37 \\
\hline $\mathrm{FeO}$ & 6,42 & 6,52 & 6,38 & 6,24 & 6,25 & 6,24 & 6,25 & 1,27 & 4,52 & 3,19 & 3,87 & 4,58 & 1,79 & 1,30 \\
\hline $\mathrm{MnO}$ & 0,24 & 0,15 & 0,19 & 0,12 & 0,27 & 0,12 & 0,27 & 0,09 & 0,11 & 0,12 & 0,08 & 0,11 & 0,00 & 0,00 \\
\hline $\mathrm{MgO}$ & 18,46 & 18,15 & 18,22 & 12,20 & 12,21 & 12,20 & 12,21 & 18,15 & 16,04 & 17,63 & 16,63 & 18,05 & 18,29 & 17,51 \\
\hline $\mathrm{CaO}$ & 17,34 & 17,20 & 16,85 & 22,88 & 22,67 & 22,88 & 22,67 & 24,25 & 24,17 & 21,45 & 20,41 & 20,34 & 22,17 & 25,39 \\
\hline $\mathrm{Na}_{2} \mathrm{O}$ & 1,40 & 1,35 & 1,25 & 1,13 & 1,36 & 1,13 & 1,36 & 0,30 & 0,59 & 0,74 & 1,73 & 0,89 & 0,72 & 0,35 \\
\hline $\mathrm{Cr}_{2} \mathrm{O}_{3}$ & 0,41 & 0,47 & 0,45 & 0,24 & 0,35 & 0,24 & 0,35 & 0,00 & 0,00 & 0,93 & 1,82 & 0,68 & 0,56 & 0,01 \\
\hline $\mathrm{NiO}$ & 0,00 & 0,00 & 0,03 & 0,00 & 0,02 & 0,00 & 0,02 & 0,00 & 0,00 & 0,09 & 0,18 & 0,08 & 0,04 & 0,04 \\
\hline Total & 98,63 & 97,77 & 97,80 & 100,43 & 100,20 & 100,43 & 100,20 & 97,96 & 98,84 & 98,78 & 99,32 & 98,94 & 97,76 & 99,47 \\
\hline $\mathrm{TSi}$ & 1,916 & 1,915 & 1,922 & 1,756 & 1,746 & 1,756 & 1,746 & 1,975 & 1,957 & 1,996 & 1,934 & 1,968 & 1,951 & 1,974 \\
\hline $\mathrm{TFe}^{3+}$ & 0,084 & 0,085 & 0,078 & 0,130 & 0,166 & 0,130 & 0,166 & 0,025 & 0,043 & 0,000 & 0,050 & 0,032 & 0,049 & 0,026 \\
\hline TAl & 0,000 & 0,000 & 0,000 & 0,115 & 0,089 & 0,115 & 0,089 & 0,000 & 0,000 & 0,004 & 0,015 & 0,000 & 0,000 & 0,000 \\
\hline $\mathrm{T}$ total & 2,000 & 2,000 & 2,000 & 2,000 & 2,000 & 2,000 & 2,000 & 2,000 & 2,000 & 2,000 & 2,000 & 2,000 & 2,000 & 2,000 \\
\hline M2Al & 0,091 & 0,095 & 0,084 & 0,252 & 0,272 & 0,252 & 0,272 & 0,004 & 0,006 & 0,005 & 0,081 & 0,013 & 0,030 & 0,007 \\
\hline $\mathrm{M} 2 \mathrm{Cr}$ & 0,008 & 0,009 & 0,009 & 0,005 & 0,007 & 0,005 & 0,007 & 0,000 & 0,000 & 0,018 & 0,035 & 0,013 & 0,011 & 0,000 \\
\hline $\mathrm{M} 2 \mathrm{Fe}^{3+}$ & 0,037 & 0,029 & 0,028 & 0,000 & 0,000 & 0,000 & 0,000 & 0,040 & 0,063 & 0,000 & 0,000 & 0,008 & 0,056 & 0,028 \\
\hline M2Ti & 0,017 & 0,018 & 0,017 & 0,031 & 0,031 & 0,031 & 0,031 & 0,002 & 0,009 & 0,004 & 0,009 & 0,021 & 0,007 & 0,010 \\
\hline $\mathrm{M} 2 \mathrm{Ni}$ & 0,000 & 0,000 & 0,001 & 0,000 & 0,001 & 0,000 & 0,001 & 0,000 & 0,000 & 0,003 & 0,005 & 0,002 & 0,001 & 0,001 \\
\hline M2Mg & 0,995 & 0,989 & 0,861 & 0,666 & 0,667 & 0,666 & 0,667 & 0,996 & 0,884 & 0,968 & 0,893 & 0,981 & 0,997 & 0,950 \\
\hline M2Mn & 0,000 & 0,000 & 0,000 & 0,000 & 0,000 & 0,000 & 0,000 & 0,000 & 0,003 & 0,002 & 0,000 & 0,000 & 0,000 & 0,000 \\
\hline M2total & 1,000 & 1,000 & 1,000 & 1,000 & 1,000 & 1,000 & 1,000 & 1,000 & 0,999 & 1,000 & 1,000 & 1,000 & 1,000 & 0,996 \\
\hline $\mathrm{XMg}$ & 0,148 & 0,139 & 0,144 & 0,000 & 0,000 & 0,000 & 0,000 & 0,000 & 0,000 & 0,000 & 0,023 & 0,039 & 0,103 & 0,000 \\
\hline $\mathrm{XFe}^{2+}$ & 0,074 & 0,086 & 0,092 & 0,016 & 0,004 & 0,016 & 0,004 & 0,000 & 0,000 & 0,098 & 0,066 & 0,100 & 0,000 & 0,000 \\
\hline XMn & 0,007 & 0,005 & 0,006 & 0,004 & 0,008 & 0,004 & 0,008 & 0,003 & 0,000 & 0,001 & 0,002 & 0,003 & 0,000 & 0,000 \\
\hline $\mathrm{XCa}$ & 0,672 & 0,673 & 0,669 & 0,898 & 0,891 & 0,898 & 0,891 & 0,956 & 0,958 & 0,846 & 0,788 & 0,794 & 0,869 & 0,990 \\
\hline $\mathrm{XNa}$ & 0,098 & 0,095 & 0,089 & 0,080 & 0,097 & 0,080 & 0,097 & 0,022 & 0,042 & 0,053 & 0,121 & 0,063 & 0,051 & 0,025 \\
\hline Xtotal & 0,999 & 0,998 & 1,000 & 0,998 & 1,000 & 0,998 & 1,000 & 1,024 & 1,000 & 0,998 & 1,000 & 0,999 & 1,022 & 1,015 \\
\hline$\# \mathrm{mg}$ & 0,837 & 0,832 & 0,836 & 0,777 & 0,777 & 0,777 & 0,777 & 0,939 & 0,863 & 0,908 & 0,884 & 0,875 & 0,905 & 0,946 \\
\hline $\mathrm{Ca} / \mathrm{ca}+\mathrm{Al}$ & 0,881 & 0,877 & 0,888 & 0,710 & 0,712 & 0,710 & 0,712 & 0,996 & 0,994 & 0,989 & 0,891 & 0,984 & 0,966 & 0,993 \\
\hline $\mathrm{Cr} \#$ & 0,080 & 0,088 & 0,095 & 0,013 & 0,018 & 0,013 & 0,018 & 0,000 & 0,000 & 0,662 & 0,265 & 0,498 & 0,262 & 0,033 \\
\hline
\end{tabular}


Tabela 48- Composição química de clinopiroxênio em nódulos ou na matriz dos corpos Indaiá 2 e Facão.

\begin{tabular}{|c|c|c|c|c|c|c|c|c|c|c|c|c|c|c|c|c|c|c|c|c|c|}
\hline \multirow[t]{2}{*}{ Códiç } & In2-1-9 & In2-1-17 & In2-1-12 & In2-1-31a & In2-1-34 & Fac-1-1 & Fac-2-1 & Fac-2-2 & $\mathrm{Fac}-2-2 \mathrm{~b}$ & Fac-4-1a & Fac-5-6a & Fac-5-6b & Fac-5-6c & Fac-5-10 & Fac-5-510b & Fac-5-50c & Fac-5-12 & Fac-6-5 & Fac-6-618 & Fac-6-20 & \\
\hline & \multicolumn{2}{|c|}{ matriz } & $\begin{array}{c}\text { matriz } \\
\text { próxima a } \\
\text { xenólito de } \\
\text { kalsilitito }\end{array}$ & $\begin{array}{l}\text { borda de } \\
\text { reação }\end{array}$ & $\begin{array}{l}\text { veio de } \\
\text { clinopiroxénio }\end{array}$ & $\begin{array}{c}\text { borda de } \\
\text { xenólito } \\
\text { vifreo }\end{array}$ & & matriz & & $\begin{array}{l}\text { cristais } \\
\text { eudedricos } \\
\text { exnólito em } \\
\text { desequilibrio }\end{array}$ & \multicolumn{7}{|c|}{ flogopita piroxen } & \multicolumn{3}{|c|}{ matriz } & $\begin{array}{c}\text { pequeno } \\
\text { crista lem } \\
\text { intersticio de } \\
\text { dunito }\end{array}$ \\
\hline $\mathrm{SiO}_{2}$ & 53,30 & 53,20 & 53,11 & 53,46 & 53,12 & 54,01 & 52,89 & 52,97 & 53,43 & 52,31 & 54,20 & 51,41 & 53,67 & 52,65 & 54,15 & 50,44 & 52,88 & 51,70 & 52,89 & 54,37 & 50,29 \\
\hline $\mathrm{TiO}_{2}$ & 1,50 & 1,15 & 1,37 & 0,94 & 0,78 & 0,21 & 1,19 & 1,08 & 0,90 & 0,47 & 0,13 & 1,49 & 0,26 & 1,50 & 0,45 & 2,53 & 1,10 & 1,21 & 0,32 & 0,14 & 2,11 \\
\hline $\mathrm{Al}_{2} \mathrm{O}_{3}$ & 0,35 & 0,34 & 0,41 & 0,65 & 0,47 & 0,18 & 0,44 & 0,49 & 0,27 & 0,13 & 0,02 & 0,35 & 0,13 & 0,62 & 0,21 & 2,26 & 0,57 & 0,47 & 0,16 & 0,07 & 1,28 \\
\hline $\mathrm{FeO}$ & 4,11 & 5,02 & 5,38 & 5,74 & 6,22 & 2,69 & 4,45 & 4,50 & 3,50 & 2,68 & 7,11 & 4,38 & 6,12 & 4,11 & 5,00 & 4,65 & 6,60 & 4,03 & 3,30 & 3,24 & 5,41 \\
\hline $\mathrm{MnO}$ & 0,08 & 0,10 & 0,23 & 0,12 & 0,15 & 0,12 & 0,06 & 0,10 & 0,00 & 0,13 & 0,10 & 0,02 & 0,18 & 0,08 & 0,05 & 0,04 & 0,15 & 0,13 & 0,09 & 0,03 & 0,04 \\
\hline $\mathrm{MgO}$ & 15,96 & 15,75 & 15,06 & 15,19 & 14,71 & 16,67 & 16,26 & 15,69 & 16,46 & 16,44 & 14,72 & 15,83 & 15,50 & 16,14 & 15,82 & 15,35 & 15,08 & 16,31 & 17,02 & 17,47 & 15,40 \\
\hline $\mathrm{CaO}$ & 23,33 & 23,38 & 22,62 & 22,66 & 23,20 & 24,43 & 24,24 & 24,25 & 24,79 & 25,04 & 21,69 & 24,85 & 22,08 & 24,12 & 23,83 & 24,24 & 23,39 & 24,58 & 24,43 & 24,14 & 23,47 \\
\hline $\mathrm{Na}_{2} \mathrm{O}$ & 0,96 & 1,10 & 1,51 & 1,40 & 0,67 & 0,55 & 0,42 & 0,56 & 0,38 & 0,65 & 1,59 & 0,89 & 1,36 & 0,80 & 0,56 & 0,28 & 0,90 & 0,37 & 0,77 & 0,60 & 0,64 \\
\hline $\mathrm{K}_{2} \mathrm{O}$ & 0,07 & 0,10 & 0,04 & 0,13 & 0,08 & 0,03 & 0,02 & 0,00 & 0,00 & 0,01 & 0,00 & 1,48 & 0,00 & 0,01 & 0,02 & 0,00 & 0,03 & 0,06 & 0,05 & 0,00 & 0,00 \\
\hline $\mathrm{Cr}_{2} \mathrm{O}_{3}$ & 0,00 & 0,02 & 0,02 & 0,02 & 0,00 & 0,23 & 0,02 & 0,05 & 0,22 & 0,61 & 0,16 & 0,12 & 0,20 & 0,07 & 0,18 & 0,47 & 0,00 & 0,01 & 0,38 & 0,46 & 0,22 \\
\hline $\mathrm{NiO}$ & 0,06 & 0,11 & 0,02 & 0,06 & 0,00 & 0,15 & 0,00 & 0,12 & 0,12 & 0,15 & 0,00 & 0,01 & 0,02 & 0,06 & 0,00 & 0,00 & 0,07 & 0,00 & 0,00 & 0,05 & 0,09 \\
\hline Total & 98,75 & 99,19 & 98,26 & 98,97 & 98,73 & 98,71 & 99,56 & 99,23 & 99,68 & 97,97 & 98,14 & 99,94 & 98,16 & 99,37 & 99,71 & 99,97 & 99,86 & 98,49 & 98,65 & 99,97 & 98,32 \\
\hline $\mathrm{TSi}$ & 1,954 & 1,941 & 1,949 & 1,949 & 1,971 & 1,980 & 1,939 & 1,948 & 1,954 & 1,934 & 1,994 & 1,861 & 1,973 & 1,922 & 1,982 & 1,858 & 1,933 & 1,913 & 1,933 & 1,965 & 1,871 \\
\hline $\mathrm{TFe}^{3+}$ & 0,046 & 0,059 & 0,051 & 0,051 & 0,029 & 0,020 & 0,061 & 0,052 & 0,046 & 0,066 & 0,006 & 0,139 & 0,027 & 0,078 & 0,018 & 0,042 & 0,067 & 0,087 & 0,067 & 0,035 & 0,118 \\
\hline TAl & 0,000 & 0,000 & 0,000 & 0,000 & 0,000 & 0,000 & 0,000 & 0,000 & 0,000 & 0,000 & 0,000 & 0,000 & 0,000 & 0,000 & 0,000 & 0,098 & 0,000 & 0,000 & 0,000 & 0,000 & 0,010 \\
\hline $\mathrm{T}$ total & 2,000 & 2,000 & 2,000 & 2,000 & 2,000 & 2,000 & 2,000 & 2,000 & 2,000 & 2,000 & 2,000 & 2,000 & 2,000 & 2,000 & 2,000 & 1,999 & 2,000 & 2,000 & 2,000 & 2,000 & 2,000 \\
\hline M2Al & 0,015 & 0,015 & 0,018 & 0,028 & 0,020 & 0,008 & 0,019 & 0,021 & 0,011 & 0,005 & 0,001 & 0,015 & 0,006 & 0,027 & 0,009 & 0,000 & 0,024 & 0,020 & 0,007 & 0,003 & 0,046 \\
\hline $\mathrm{M} 2 \mathrm{Cr}$ & 0,000 & 0,000 & 0,000 & 0,000 & 0,000 & 0,004 & 0,000 & 0,001 & 0,004 & 0,012 & 0,003 & 0,002 & 0,004 & 0,001 & 0,003 & 0,009 & 0,000 & 0,000 & 0,007 & 0,009 & 0,004 \\
\hline $\mathrm{M}_{2} \mathrm{Fe}^{3+}$ & 0,020 & 0,063 & 0,066 & 0,075 & 0,016 & 0,030 & 0,006 & 0,009 & 0,001 & 0,052 & 0,103 & 0,168 & 0,094 & 0,022 & 0,016 & 0,000 & 0,047 & 0,029 & 0,082 & 0,044 & 0,000 \\
\hline M2Ti & 0,041 & 0,032 & 0,038 & 0,026 & 0,022 & 0,006 & 0,033 & 0,030 & 0,025 & 0,013 & 0,004 & 0,041 & 0,007 & 0,041 & 0,013 & 0,070 & 0,030 & 0,034 & 0,009 & 0,004 & 0,059 \\
\hline $\mathrm{M} 2 \mathrm{Ni}$ & 0,002 & 0,003 & 0,001 & 0,002 & 0,000 & 0,004 & 0,000 & 0,003 & 0,004 & 0,004 & 0,000 & 0,000 & 0,001 & 0,002 & 0,000 & 0,000 & 0,002 & 0,000 & 0,000 & 0,001 & 0,003 \\
\hline $\mathrm{M} 2 \mathrm{Fe}^{2+}$ & 0,049 & 0,031 & 0,048 & 0,043 & 0,127 & 0,032 & 0,053 & 0,075 & 0,057 & 0,000 & 0,082 & 0,000 & 0,039 & 0,025 & 0,096 & 0,078 & 0,074 & 0,009 & 0,000 & 0,000 & 0,033 \\
\hline $\mathrm{M} 2 \mathrm{Mg}$ & 0,872 & 0,856 & 0,824 & 0,826 & 0,814 & 0,911 & 0,888 & 0,860 & 0,897 & 0,906 & 0,807 & 0,854 & 0,849 & 0,879 & 0,863 & 0,843 & 0,822 & 0,900 & 0,927 & 0,941 & 0,854 \\
\hline M2Mn & 0,000 & 0,000 & 0,006 & 0,000 & 0,000 & 0,004 & 0,000 & 0,000 & 0,000 & 0,004 & 0,000 & 0,000 & 0,000 & 0,003 & 0,000 & 0,000 & 0,000 & 0,004 & 0,000 & 0,000 & 0,000 \\
\hline M2total & 1,000 & 1,000 & 1,000 & 1,000 & 1,000 & 1,000 & 1,000 & 1,000 & 1,000 & 0,997 & 1,000 & 1,080 & 1,000 & 1,000 & 1,000 & 1,000 & 1,000 & 0,996 & 1,000 & 1,003 & 1,000 \\
\hline $\mathrm{XMg}$ & 0,000 & 0,000 & 0,000 & 0,000 & 0,000 & 0,000 & 0,000 & 0,000 & 0,000 & 0,000 & 0,000 & 0,000 & 0,000 & 0,000 & 0,000 & 0,000 & 0,000 & 0,000 & 0,032 & 0,000 & 0,000 \\
\hline $\mathrm{XFe}^{2+}$ & 0,010 & 0,000 & 0,000 & 0,006 & 0,021 & 0,000 & 0,016 & 0,002 & 0,002 & 0,000 & 0,028 & 0,000 & 0,028 & 0,000 & 0,023 & 0,023 & 0,014 & 0,000 & 0,000 & 0,019 & 0,017 \\
\hline XMn & 0,002 & 0,003 & 0,001 & 0,004 & 0,005 & 0,000 & 0,002 & 0,003 & 0,000 & 0,000 & 0,003 & 0,001 & 0,006 & 0,000 & 0,001 & 0,001 & 0,005 & 0,000 & 0,003 & 0,001 & 0,001 \\
\hline $\mathrm{XCa}$ & 0,916 & 0,914 & 0,889 & 0,885 & 0,922 & 0,960 & 0,952 & 0,955 & 0,971 & 0,992 & 0,855 & 0,964 & 0,870 & 0,944 & 0,935 & 0,957 & 0,916 & 0,974 & 0,957 & 0,935 & 0,936 \\
\hline $\mathrm{XNa}$ & 0,068 & 0,078 & 0,108 & 0,099 & 0,048 & 0,039 & 0,030 & 0,040 & 0,027 & 0,047 & 0,113 & 0,062 & 0,097 & 0,056 & 0,040 & 0,020 & 0,064 & 0,027 & 0,055 & 0,042 & 0,046 \\
\hline Xtotal & 0,997 & 0,995 & 0,998 & 0,994 & 0,996 & 0,999 & 0,999 & 1,000 & 1,000 & 1,038 & 1,000 & 1,027 & 1,000 & 1,000 & 0,999 & 1,001 & 0,999 & 1,001 & 1,046 & 0,997 & 1,000 \\
\hline$\# \mathrm{mg}$ & 0,874 & 0,848 & 0,833 & 0,825 & 0,808 & 0,917 & 0,867 & 0,861 & 0,894 & 0,884 & 0,787 & 0,735 & 0,819 & 0,875 & 0,849 & 0,855 & 0,803 & 0,878 & 0,862 & 0,906 & 0,835 \\
\hline $\mathrm{Ca} / \mathrm{ca}^{\mathrm{O}} \mathrm{Al}$ & 0,984 & 0,984 & 0,981 & 0,969 & 0,978 & 0,992 & 0,980 & 0,978 & 0,988 & 0,994 & 0,999 & 0,985 & 0,993 & 0,973 & 0,990 & 0907 & 0,974 & 0,980 & 0,993 & 0,997 & 0,943 \\
\hline $\mathrm{Cr} \#$ & 0,000 & 0,031 & 0,026 & 0,016 & 0,000 & 0,359 & 0,018 & 0,042 & 0,268 & 0,685 & 0,748 & 0,135 & 0,400 & 0,050 & 0,272 & 0,086 & 0,000 & 0,006 & 0,517 & 0,739 & 0,070 \\
\hline
\end{tabular}


Tabela 49- Composição química de espinélio em harzburgitos e lherzolitos com espinélio dos corpos Indaiá 1 e Limeira 1 e Forca.

\begin{tabular}{|c|c|c|c|c|c|c|c|c|c|c|c|c|c|c|c|c|}
\hline \multirow[t]{2}{*}{$\begin{array}{l}\text { Código da } \\
\text { amostra }\end{array}$} & Fo-2- $1^{a}$ & Fo-2-2 $2^{\mathrm{a}}$ & Fo-2-2b & Fo-2-5c & Fo-2-5d & Fo-2-5i & Fo-2-9 & Fo-2-9b & Fo-2-9d & Fo-2-9e & Fo-2-25 & Fo-6-23 & Fo-6-18 & In1-4-2 & In1-4-3 & Lm1-17-13 \\
\hline & \multicolumn{3}{|c|}{$\begin{array}{l}\text { espinélio lherzolito granoblástico } \\
\text { centro do xenólito }\end{array}$} & \multicolumn{8}{|c|}{$\begin{array}{l}\text { espinélio therzolito granoblástico } \\
\text { contato com kimberlito }\end{array}$} & \multicolumn{2}{|c|}{$\begin{array}{l}\text { Harzburgito com } \\
\text { espinélio }\end{array}$} & \multicolumn{2}{|c|}{$\begin{array}{l}\text { lherzolito protogranular } \\
\text { com espinélio }\end{array}$} & $\begin{array}{l}\text { harzburgito } \\
\text { protogranular } \\
\text { com } \\
\text { espinélio }\end{array}$ \\
\hline $\begin{array}{l}\mathrm{rpo}_{2} \\
\mathrm{SiO}_{2}\end{array}$ & 0,01 & 0,02 & 0,55 & 0,05 & 0,30 & 3,42 & 0,01 & 0,00 & 0,00 & 0,01 & 0,00 & 0,52 & 0,08 & 0,00 & 0,05 & 0,00 \\
\hline $\mathrm{TiO}_{2}$ & 0,05 & 1,08 & 0,74 & 17,42 & 9,49 & 8,20 & 5,98 & 9,95 & 11,27 & 10,54 & 0,05 & 0,71 & 0,08 & 0,01 & 0,01 & 0,05 \\
\hline $\mathrm{Al}_{2} \mathrm{O}_{3}$ & 48,94 & 36,85 & 39,37 & 0,49 & 2,33 & 2,24 & 7,51 & 0,81 & 0,71 & 0,93 & 49,00 & 28,08 & 33,17 & 55,44 & 55,80 & 54,14 \\
\hline $\mathrm{Cr}_{2} \mathrm{O}_{3}$ & 19,40 & 19,06 & 17,23 & 4,67 & 0,37 & 0,61 & 43,94 & 33,73 & 28,43 & 30,42 & 18,62 & 34,06 & 36,61 & 12,06 & 12,75 & 14,47 \\
\hline $\mathrm{FeO}$ & 8,32 & 9,43 & 7,57 & 18,44 & 16,61 & 12,79 & 17,89 & 17,33 & 16,18 & 17,57 & 7,79 & 8,08 & 8,06 & 6,25 & 6,70 & 6,03 \\
\hline $\mathrm{Fe}_{2} \mathrm{O}_{3}$ & 6,69 & 15,85 & 16,56 & 40,11 & 53,74 & 50,71 & 12,86 & 23,64 & 26,53 & 24,90 & 6,67 & 9,65 & 4,69 & 7,17 & 6,55 & 5,91 \\
\hline $\mathrm{MnO}$ & 0,05 & 0,12 & 0,12 & 0,87 & 0,83 & 0,82 & 0,05 & 0,79 & 0,69 & 0,84 & 0,05 & 0,15 & 0,04 & 0,07 & 0,01 & 0,07 \\
\hline $\mathrm{MgO}$ & 17,27 & 16,91 & 18,91 & 17,61 & 16,87 & 18,07 & 10,72 & 13,73 & 15,92 & 13,62 & 17,61 & 17,18 & 17,20 & 19,10 & 18,81 & 19,21 \\
\hline $\mathrm{CaO}$ & 0,00 & 0,02 & 0,00 & 0,81 & 0,53 & 0,58 & 0,17 & 0,20 & 0,20 & 0,18 & 0,02 & 0,02 & 0,01 & 0,00 & 0,01 & 0,02 \\
\hline $\mathrm{K}_{2} \mathrm{O}$ & 0,00 & 0,03 & 0,07 & 0,01 & 0,06 & 0,33 & 0,00 & 0,00 & 0,04 & 0,03 & 0,00 & 0,03 & 0,00 & 0,00 & 0,00 & 0,05 \\
\hline $\mathrm{Na}_{2} \mathrm{O}$ & 0,07 & 0,01 & 0,03 & 0,15 & 0,16 & 0,07 & 0,00 & 0,01 & 0,00 & 0,05 & 0,02 & 0,05 & 0,00 & 0,00 & 0,23 & 0,02 \\
\hline $\mathrm{NiO}$ & 0,19 & 0,38 & 0,45 & 0,27 & 0,26 & 0,29 & 0,25 & 0,26 & 0,14 & 0,16 & 0,15 & 0,35 & 0,15 & 0,32 & 0,28 & 0,27 \\
\hline Total & 101,00 & 99,76 & 101,58 & 100,88 & 101,56 & 98,10 & 99,39 & 100,45 & 100,10 & 99,24 & 99,98 & 98,88 & 100,09 & 100,42 & 101,21 & 100,27 \\
\hline YAl & 1,632 & 1,305 & 1,336 & 0,019 & 0,090 & 0,088 & 0,342 & 0,036 & 0,030 & 0,041 & 1,640 & 1,076 & 1,240 & 1,764 & 1,765 & 1,740 \\
\hline $\mathrm{YFe}^{3+}$ & 0,077 & 0,359 & 0,359 & 1,004 & 1,322 & 1,266 & 0,374 & 0,666 & 0,726 & 0,703 & 0,080 & 0,236 & 0,112 & 0,064 & 0,053 & 0,051 \\
\hline $\mathrm{YCr}$ & 0,289 & 0,302 & 0,262 & 0,082 & 0,006 & 0,011 & 0,896 & 0,666 & 0,545 & 0,601 & 0,279 & 0,584 & 0,612 & 0,172 & 0,180 & 0,208 \\
\hline YTi & 0,001 & 0,024 & 0,016 & 0,436 & 0,233 & 0,205 & 0,174 & 0,281 & 0,308 & 0,297 & 0,001 & 0,017 & 0,002 & 0,000 & 0,000 & 0,001 \\
\hline YSi & 0,000 & 0,001 & 0,016 & 0,002 & 0,010 & 0,113 & 0,000 & 0,000 & 0,000 & 0,000 & 0,000 & 0,017 & 0,002 & 0,000 & 0,001 & 0,000 \\
\hline $\mathrm{YFe}^{2+}$ & 0,000 & 0,009 & 0,012 & 0,457 & 0,338 & 0,318 & 0,213 & 0,351 & 0,390 & 0,357 & 0,000 & 0,071 & 0,032 & 0,000 & 0,000 & 0,000 \\
\hline Ytotal & 2,000 & 2,000 & 2,000 & 2,000 & 2,000 & 2,000 & 2,000 & 2,000 & 2,000 & 2,000 & 2,000 & 2,000 & 2,000 & 2,000 & 2,000 & 2,000 \\
\hline $\mathrm{XFe}^{2+}$ & 0,262 & 0,228 & 0,171 & 0,056 & 0,116 & 0,037 & 0,365 & 0,192 & 0,102 & 0,194 & 0,248 & 0,149 & 0,182 & 0,223 & 0,229 & 0,208 \\
\hline $\mathrm{XMg}$ & 0,728 & 0,758 & 0,812 & 0,874 & 0,822 & 0,894 & 0,618 & 0,767 & 0,863 & 0,762 & 0,746 & 0,832 & 0,813 & 0,769 & 0,753 & 0,781 \\
\hline XMn & 0,001 & 0,003 & 0,003 & 0,024 & 0,023 & 0,023 & 0,002 & 0,025 & 0,021 & 0,027 & 0,001 & 0,004 & 0,001 & 0,001 & 0,000 & 0,002 \\
\hline XK & 0,000 & 0,001 & 0,002 & 0,000 & 0,003 & 0,014 & 0,000 & 0,000 & 0,002 & 0,002 & 0,000 & 0,001 & 0,000 & 0,000 & 0,000 & 0,002 \\
\hline $\mathrm{XNa}$ & 0,004 & 0,000 & 0,001 & 0,010 & 0,010 & 0,004 & 0,000 & 0,001 & 0,000 & 0,004 & 0,001 & 0,003 & 0,000 & 0,000 & 0,012 & 0,001 \\
\hline $\mathrm{XCa}$ & 0,000 & 0,001 & 0,000 & 0,029 & 0,019 & 0,020 & 0,007 & 0,008 & 0,008 & 0,007 & 0,001 & 0,001 & 0,000 & 0,000 & 0,000 & 0,001 \\
\hline $\mathrm{XNi}$ & 0,004 & 0,009 & 0,010 & 0,007 & 0,007 & 0,008 & 0,008 & 0,008 & 0,004 & 0,005 & 0,003 & 0,009 & 0,004 & 0,007 & 0,006 & 0,006 \\
\hline Xtotal & 1,000 & 1,000 & 1,000 & 1,000 & 1,000 & 1,000 & 1,000 & 1,000 & 1,000 & 1,000 & 1,000 & 1,000 & 1,000 & 1,000 & 1,000 & 1,000 \\
\hline $\mathrm{Cr} \#$ & 0,151 & 0,188 & 0,164 & 0,809 & 0,067 & 0,108 & 0,724 & 0,949 & 0,947 & 0,936 & 0,145 & 0,352 & 0,330 & 0,089 & 0,093 & 0,107 \\
\hline $\mathrm{Fe} 2 \#$ & 0,265 & 0,238 & 0,183 & 0,370 & 0,356 & 0,284 & 0,484 & 0,415 & 0,363 & 0,420 & 0,249 & 0,209 & 0,208 & 0,225 & 0,233 & 0,210 \\
\hline
\end{tabular}


Tabela 50- Composição química de espinélio em harzburgitos e lherzolitos com espinélio ou Cr-espinélio dos corpos Indaiá 1 e Limeira 1 e Forca.

\begin{tabular}{|c|c|c|c|c|c|c|c|c|c|c|c|c|c|c|c|c|c|c|c|}
\hline \multirow[t]{2}{*}{$\begin{array}{l}\text { Código da } \\
\text { amostra }\end{array}$} & In1-9-1 & In1-9-2 & In1-9-3 & In1-9-4 & \multirow{2}{*}{$\begin{array}{c}\text { In1-13a-2 } \\
\text { lherzolito } \\
\text { protogranular } \\
\text { com } \\
\text { espinélio }\end{array}$} & \multirow{2}{*}{\begin{tabular}{|c} 
In1-14a-2 \\
lherzolito \\
protogranular \\
com \\
espinélio
\end{tabular}} & \multirow{2}{*}{\multicolumn{2}{|c|}{$\begin{array}{c}\text { In1-3-1 In1-3-2 } \\
\text { harzburgito granoblástico } \\
\text { com Cr-espinélio }\end{array}$}} & $\begin{array}{l}\text { In1-14c- } \\
2\end{array}$ & $\begin{array}{l}\text { In1-14c- } \\
6\end{array}$ & $\begin{array}{c}\text { In1-14c- } \\
7\end{array}$ & Lm1-20a-9 & $\begin{array}{l}\text { Lm1-20a- } \\
9 \mathrm{~b}\end{array}$ & $\begin{array}{c}\text { Lm1-20a- } \\
12\end{array}$ & $\begin{array}{c}\text { Lm1-20a- } \\
18\end{array}$ & $\begin{array}{c}\text { Lm1-20a- } \\
\quad 17\end{array}$ & Lm1-20-21 & Lml-20-2n & Lm1-20-2p \\
\hline & \multicolumn{4}{|c|}{ Iherzolito protogranular com espinélio } & & & & & \multicolumn{3}{|c|}{$\begin{array}{l}\text { dunito protogranular com } \\
\text { espinélio }\end{array}$} & \multicolumn{8}{|c|}{ harzburgito granoblástico com Cr-espinélio } \\
\hline $\mathrm{SiO}_{2}$ & 0,00 & 0,02 & 0,00 & 0,02 & 0,03 & 0,02 & 0,02 & 0,03 & 0,00 & 0,00 & 0,00 & 0,10 & 0,11 & 0,17 & 0,18 & 0,25 & 0,00 & 7,80 & 0,10 \\
\hline $\mathrm{TiO}_{2}$ & 0,04 & 0,05 & 0,09 & 0,05 & 0,12 & 0,07 & 0,10 & 0,09 & 0,09 & 0,09 & 0,06 & 0,05 & 0,02 & 0,07 & 0,02 & 0,07 & 4,01 & 3,47 & 9,60 \\
\hline $\mathrm{Al}_{2} \mathrm{O}_{3}$ & 51,71 & 55,10 & 53,41 & 51,23 & 43,37 & 51,67 & 28,31 & 25,81 & 39,90 & 39,83 & 40,08 & 38,56 & 38,95 & 39,92 & 40,13 & 39,73 & 1,40 & 2,48 & 1,31 \\
\hline $\mathrm{Cr}_{2} \mathrm{O}_{3}$ & 15,73 & 12,67 & 13,82 & 15,88 & 26,36 & 15,75 & 40,31 & 41,12 & 29,04 & 28,66 & 28,50 & 28,51 & 28,24 & 28,38 & 27,27 & 28,06 & 51,91 & 3,29 & 0,36 \\
\hline $\mathrm{FeO}$ & 10,16 & 10,21 & 10,27 & 11,12 & 13,25 & 11,29 & 17,12 & 16,21 & 10,09 & 10,36 & 9,99 & 9,47 & 9,90 & 10,03 & 9,44 & 9,64 & 16,46 & 14,42 & 19,37 \\
\hline $\mathrm{Fe}_{2} \mathrm{O}_{3}$ & 2,48 & 1,84 & 2,54 & 1,29 & 0,57 & 1,28 & 1,13 & 2,10 & 6,01 & 6,08 & 6,42 & 5,90 & 5,97 & 5,48 & 5,77 & 6,11 & 14,30 & 50,27 & 53,47 \\
\hline $\mathrm{MnO}$ & 0,07 & 0,10 & 0,10 & 0,07 & 0,13 & 0,11 & 0,20 & 0,20 & 0,16 & 0,10 & 0,17 & 0,09 & 0,04 & 0,11 & 0,07 & 0,00 & 0,60 & 0,80 & 1,19 \\
\hline $\mathrm{MgO}$ & 19,44 & 19,80 & 19,56 & 18,45 & 16,82 & 18,51 & 12,43 & 12,47 & 15,41 & 15,13 & 15,51 & 15,42 & 15,16 & 15,09 & 15,52 & 15,64 & 10,91 & 12,68 & 13,45 \\
\hline $\mathrm{CaO}$ & 0,00 & 0,00 & 0,00 & 0,01 & 0,00 & 0,01 & 0,00 & 0,00 & 0,03 & 0,02 & 0,03 & 0,00 & 0,00 & 0,03 & 0,02 & 0,00 & 0,10 & 3,93 & 0,30 \\
\hline $\mathrm{K}_{2} \mathrm{O}$ & n.d. & n.d. & n.d. & n.d. & n.d. & n.d. & n.d. & n.d. & 0,00 & 0,01 & 0,00 & 0,00 & 0,00 & 0,00 & 0,00 & 0,00 & 0,03 & 0,32 & 0,02 \\
\hline $\mathrm{Na}_{2} \mathrm{O}$ & 0,00 & 0,00 & 0,00 & 0,00 & 0,00 & 0,00 & 0,00 & 0,00 & 0,03 & 0,07 & 0,12 & 0,00 & 0,00 & 0,05 & 0,00 & 0,13 & 0,04 & 0,09 & 0,13 \\
\hline $\mathrm{NiO}$ & 0,26 & 0,31 & 0,31 & 0,25 & 0,17 & 0,29 & 0,03 & 0,03 & 0,12 & 0,07 & 0,14 & 0,08 & 0,00 & 0,08 & 0,07 & 0,13 & 0,24 & 0,11 & 0,19 \\
\hline Total & 99,88 & 100,10 & 100,10 & 98,38 & 100,81 & 99,00 & 99,65 & 98,06 & 100,87 & 100,42 & 101,02 & 98,18 & 98,38 & 99,40 & 98,48 & 99,77 & 100,01 & 99,66 & 99,49 \\
\hline YAl & 1,679 & 1,748 & 1,712 & 1,695 & 1,504 & 1,698 & 1,130 & 1,060 & 1,430 & 1,434 & 1,429 & 1,419 & 1,430 & 1,447 & 1,457 & 1,430 & 0,067 & 0,098 & 0,053 \\
\hline $\mathrm{YFe}^{3+}$ & 0,051 & 0,037 & 0,052 & 0,027 & 0,013 & 0,027 & 0,029 & 0,055 & 0,103 & 0,103 & 0,114 & 0,108 & 0,103 & 0,086 & 0,094 & 0,140 & 0,438 & 1,269 & 1,382 \\
\hline $\mathrm{YCr}$ & 0,228 & 0,180 & 0,198 & 0,235 & 0,409 & 0,232 & 0,719 & 0,755 & 0,465 & 0,461 & 0,455 & 0,469 & 0,464 & 0,460 & 0,443 & 0,420 & 1,113 & 0,058 & 0,006 \\
\hline YTi & 0,001 & 0,001 & 0,002 & 0,001 & 0,003 & 0,001 & 0,003 & 0,002 & 0,002 & 0,002 & 0,001 & 0,001 & 0,000 & 0,002 & 0,001 & 0,002 & 0,123 & 0,088 & 0,248 \\
\hline YSi & 0,000 & 0,001 & 0,000 & 0,001 & 0,001 & 0,000 & 0,001 & 0,001 & 0,000 & 0,000 & 0,000 & 0,003 & 0,003 & 0,005 & 0,005 & 0,008 & 0,000 & 0,262 & 0,003 \\
\hline $\mathrm{YFe}^{2+}$ & 0,040 & 0,033 & 0,036 & 0,041 & 0,071 & 0,042 & 0,119 & 0,127 & 0,000 & 0,000 & 0,000 & 0,000 & 0,000 & 0,000 & 0,000 & 0,000 & 0,259 & 0,225 & 0,307 \\
\hline Ytotal & 2,000 & 2,000 & 2,000 & 2,000 & 2,000 & 2,000 & 2,000 & 2,000 & 2,000 & 2,000 & 2,000 & 2,000 & 2,000 & 2,000 & 2,000 & 2,000 & 2,000 & 2,000 & 2,000 \\
\hline $\mathrm{XFe}^{2+}$ & 0,194 & 0,196 & 0,198 & 0,220 & 0,255 & 0,221 & 0,366 & 0,346 & 0,292 & 0,302 & 0,285 & 0,278 & 0,295 & 0,299 & 0,283 & 0,277 & 0,301 & 0,179 & 0,250 \\
\hline $\mathrm{XMg}$ & 0,798 & 0,795 & 0,793 & 0,772 & 0,738 & 0,769 & 0,628 & 0,648 & 0,699 & 0,689 & 0,700 & 0,718 & 0,704 & 0,692 & 0,713 & 0,712 & 0,662 & 0,634 & 0,689 \\
\hline XMn & 0,002 & 0,002 & 0,002 & 0,002 & 0,003 & 0,003 & 0,006 & 0,006 & 0,004 & 0,003 & 0,004 & 0,002 & 0,001 & 0,003 & 0,002 & 0,000 & 0,021 & 0,023 & 0,035 \\
\hline XK & 0,000 & 0,000 & 0,000 & 0,000 & 0,000 & 0,000 & 0,000 & 0,000 & 0,000 & 0,000 & 0,000 & 0,000 & 0,000 & 0,000 & 0,000 & 0,000 & 0,001 & 0,014 & 0,001 \\
\hline $\mathrm{XNa}$ & 0,000 & 0,000 & 0,000 & 0,000 & 0,000 & 0,000 & 0,000 & 0,000 & 0,002 & 0,004 & 0,007 & 0,000 & 0,000 & 0,003 & 0,000 & 0,007 & 0,003 & 0,006 & 0,008 \\
\hline $\mathrm{XCa}$ & 0,000 & 0,000 & 0,000 & 0,000 & 0,000 & 0,000 & 0,000 & 0,000 & 0,001 & 0,001 & 0,001 & 0,000 & 0,000 & 0,001 & 0,001 & 0,000 & 0,004 & 0,141 & 0,011 \\
\hline $\mathrm{XNi}$ & 0,006 & 0,007 & 0,007 & 0,006 & 0,004 & 0,007 & 0,001 & 0,001 & 0,003 & 0,002 & 0,003 & 0,002 & 0,000 & 0,002 & 0,002 & 0,003 & 0,008 & 0,003 & 0,005 \\
\hline Xtotal & 1,000 & 1,000 & 1,000 & 1,000 & 1,000 & 1,000 & 1,000 & 1,000 & 1,000 & 1,000 & 1,000 & 1,000 & 1,000 & 1,000 & 1,000 & 1,000 & 1,000 & 1,000 & 1,000 \\
\hline $\mathrm{Cr} \#$ & 0,120 & 0,093 & 0,104 & 0,122 & 0,214 & 0,120 & 0,389 & 0,416 & 0,246 & 0,243 & 0,241 & 0,248 & 0,245 & 0,241 & 0,233 & 0,240 & 0,943 & 0,372 & 0,109 \\
\hline $\mathrm{Fe} 2 \#$ & 0,227 & 0,224 & 0,228 & 0,253 & 0,307 & 0,255 & 0,436 & 0,422 & 0,295 & 0,304 & 0,289 & 0,279 & 0,295 & 0,302 & 0,284 & 0,280 & 0,458 & 0,389 & 0,447 \\
\hline
\end{tabular}


Tabela 51- Composição química de espinélio em harzburgitos e lherzolitos com espinélio dos corpos Indaiá 1 e Limeira 1 e Forca.

\begin{tabular}{|c|c|c|c|c|c|c|c|c|c|c|c|c|c|c|c|c|c|}
\hline Código da & \multicolumn{3}{|c|}{ harzburgito com Cr-espinélio } & \multicolumn{5}{|c|}{ harzburgito com Cr-espinélio } & \multicolumn{2}{|c|}{ dunito protograular } & $\begin{array}{l}\text { Lm1-29-12a } \\
\text { dunito } \\
\text { protogranular }\end{array}$ & \multicolumn{4}{|c|}{ dunito granoblástico com Cr-espinélio e pargasita } & \multicolumn{2}{|c|}{$\begin{array}{l}\text { harzburgito com Cr- } \\
\text { espinélio e pargasita }\end{array}$} \\
\hline $\mathrm{SiO}_{2}$ & 0,00 & 0,03 & 0,06 & 0,00 & 0,00 & 0,00 & 0,00 & 0,00 & 0,00 & 0,05 & 0,77 & 0,00 & 0,03 & 0,02 & 0,00 & 0,00 & 0,00 \\
\hline $\mathrm{TiO}_{2}$ & 0,04 & 0,04 & 0,04 & 0,10 & 0,06 & 0,00 & 0,12 & 0,04 & 2,90 & 3,63 & 4,72 & 0,32 & 0,23 & 0,19 & 0,10 & 0,13 & 0,23 \\
\hline $\mathrm{Al}_{2} \mathrm{O}_{3}$ & 35,60 & 35,56 & 37,40 & 22,94 & 23,41 & 23,32 & 22,92 & 23,33 & 3,89 & 3,48 & 1,67 & 25,76 & 26,49 & 26,10 & 26,35 & 24,50 & 25,70 \\
\hline $\mathrm{Cr}_{2} \mathrm{O}_{3}$ & 32,21 & 32,14 & 30,03 & 44,63 & 44,84 & 44,59 & 46,08 & 44,35 & 58,98 & 56,89 & 1,31 & 41,77 & 42,44 & 42,80 & 43,76 & 43,93 & 43,08 \\
\hline $\mathrm{FeO}$ & 11,35 & 11,10 & 10,80 & 13,90 & 13,63 & 13,27 & 12,01 & 13,99 & 14,89 & 13,13 & 20,93 & 18,22 & 17,72 & 17,85 & 17,95 & 14,25 & 13,70 \\
\hline $\mathrm{Fe}_{2} \mathrm{O}_{3}$ & 6,23 & 6,07 & 6,51 & 5,33 & 5,69 & 5,32 & 4,66 & 5,47 & 6,82 & 8,04 & 57,80 & 1,97 & 0,85 & 1,60 & 1,07 & 6,00 & 5,98 \\
\hline $\mathrm{MnO}$ & 0,10 & 0,08 & 0,05 & 0,11 & 0,18 & 0,04 & 0,08 & 0,18 & 0,07 & 0,64 & 0,88 & 0,23 & 0,18 & 0,18 & 0,22 & 0,15 & 0,07 \\
\hline $\mathrm{MgO}$ & 13,90 & 14,12 & 14,39 & 10,93 & 11,51 & 11,62 & 13,04 & 10,80 & 11,76 & 13,46 & 9,71 & 11,50 & 12,02 & 12,03 & 12,01 & 11,18 & 12,03 \\
\hline $\mathrm{CaO}$ & 0,02 & 0,05 & 0,02 & 0,02 & 0,02 & 0,05 & 0,03 & 0,00 & 0,05 & 0,05 & 0,27 & 0,01 & 0,02 & 0,00 & 0,00 & 0,01 & 0,00 \\
\hline $\mathrm{K}_{2} \mathrm{O}$ & 0,00 & 0,02 & 0,00 & 0,00 & 0,02 & 0,05 & 0,00 & 0,00 & 0,04 & 0,00 & 0,02 & n.d. & n.d. & n.d. & n.d. & 0,00 & 0,00 \\
\hline $\mathrm{Na}_{2} \mathrm{O}$ & 0,15 & 0,11 & 0,00 & 0,00 & 0,00 & 0,00 & 0,00 & 0,00 & 0,18 & 0,04 & 0,00 & 0,00 & 0,00 & 0,00 & 0,00 & 0,04 & 0,02 \\
\hline $\mathrm{NiO}$ & 0,10 & 0,05 & 0,20 & 0,09 & 0,06 & 0,11 & 0,08 & 0,09 & 0,20 & 0,15 & 0,20 & 0,07 & 0,04 & 0,07 & 0,04 & 0,05 & 0,05 \\
\hline Total & 99,70 & 99,37 & 99,51 & 98,04 & 99,42 & 98,37 & 99,02 & 98,24 & 99,77 & 99,55 & 98,30 & 99,86 & 100,00 & 100,84 & 101,49 & 100,25 & 100,87 \\
\hline YAl & 1,334 & 1,335 & 1,383 & 0,980 & 0,981 & 0,986 & 0,958 & 0,993 & 0,187 & 0,165 & 0,071 & 1,050 & 1,072 & 1,051 & 1,057 & 1,013 & 1,042 \\
\hline $\mathrm{YFe}^{3+}$ & 0,125 & 0,123 & 0,117 & 0,145 & 0,152 & 0,144 & 0,125 & 0,149 & 0,209 & 0,243 & 1,559 & 0,051 & 0,022 & 0,041 & 0,028 & 0,158 & 0,155 \\
\hline $\mathrm{YCr}$ & 0,540 & 0,539 & 0,497 & 0,853 & 0,840 & 0,843 & 0,862 & 0,845 & 1,267 & 1,203 & 0,025 & 0,761 & 0,768 & 0,771 & 0,785 & 0,813 & 0,781 \\
\hline YTi & 0,001 & 0,001 & 0,001 & 0,003 & 0,002 & 0,000 & 0,003 & 0,001 & 0,089 & 0,110 & 0,127 & 0,008 & 0,006 & 0,005 & 0,003 & 0,004 & 0,006 \\
\hline $\mathrm{YV}$ & 0,000 & 0,000 & 0,000 & 0,000 & 0,000 & 0,000 & 0,000 & 0,000 & 0,000 & 0,000 & 0,000 & 0,000 & 0,000 & 0,000 & 0,000 & 0,000 & 0,000 \\
\hline YSi & 0,000 & 0,001 & 0,002 & 0,000 & 0,000 & 0,000 & 0,000 & 0,000 & 0,000 & 0,002 & 0,028 & 0,000 & 0,001 & 0,001 & 0,000 & 0,000 & 0,000 \\
\hline $\mathrm{YFF}^{2+}$ & 0,000 & 0,000 & 0,000 & 0,019 & 0,025 & 0,028 & 0,052 & 0,012 & 0,249 & 0,277 & 0,190 & 0,129 & 0,131 & 0,131 & 0,128 & 0,012 & 0,016 \\
\hline Ytotal & 2,000 & 2,000 & 2,000 & 2,000 & 2,000 & 2,000 & 2,000 & 2,000 & 2,000 & 2,000 & 2,000 & 2,000 & 2,000 & 2,000 & 2,000 & 2,000 & 2,000 \\
\hline $\mathrm{XFe}^{2+}$ & 0,326 & 0,317 & 0,319 & 0,403 & 0,381 & 0,370 & 0,304 & 0,410 & 0,259 & 0,163 & 0,437 & 0,398 & 0,378 & 0,380 & 0,383 & 0,406 & 0,378 \\
\hline $\mathrm{XMg}$ & 0,659 & 0,670 & 0,673 & 0,591 & 0,610 & 0,621 & 0,690 & 0,582 & 0,714 & 0,805 & 0,519 & 0,593 & 0,615 & 0,613 & 0,609 & 0,585 & 0,617 \\
\hline XMn & 0,003 & 0,002 & 0,001 & 0,003 & 0,005 & 0,001 & 0,003 & 0,005 & 0,002 & 0,022 & 0,027 & 0,007 & 0,005 & 0,005 & 0,006 & 0,005 & 0,002 \\
\hline $\mathrm{XZn}$ & 0,000 & 0,000 & 0,000 & 0,000 & 0,000 & 0,000 & 0,000 & 0,000 & 0,000 & 0,000 & 0,000 & 0,000 & 0,000 & 0,000 & 0,000 & 0,000 & 0,000 \\
\hline XK & 0,000 & 0,001 & 0,000 & 0,000 & 0,001 & 0,002 & 0,000 & 0,000 & 0,002 & 0,000 & 0,001 & 0,000 & 0,000 & 0,000 & 0,000 & 0,000 & 0,000 \\
\hline $\mathrm{XNa}$ & 0,009 & 0,007 & 0,000 & 0,000 & 0,000 & 0,000 & 0,000 & 0,000 & 0,014 & 0,003 & 0,000 & 0,000 & 0,000 & 0,000 & 0,000 & 0,003 & 0,001 \\
\hline $\mathrm{XCa}$ & 0,001 & 0,002 & 0,001 & 0,001 & 0,001 & 0,002 & 0,001 & 0,000 & 0,002 & 0,002 & 0,010 & 0,000 & 0,001 & 0,000 & 0,000 & 0,000 & 0,000 \\
\hline $\mathrm{XNi}$ & 0,002 & 0,001 & 0,005 & 0,003 & 0,002 & 0,003 & 0,002 & 0,003 & 0,007 & 0,005 & 0,006 & 0,002 & 0,001 & 0,002 & 0,001 & 0,002 & 0,002 \\
\hline Xtotal & 1,000 & 1,000 & 1,000 & 1,000 & 1,000 & 1,000 & 1,000 & 1,000 & 1,000 & 1,000 & 1,000 & 1,000 & 1,000 & 1,000 & 1,000 & 1,000 & 1,000 \\
\hline Cr\# & 0,288 & 0,288 & 0,264 & 0,465 & 0,461 & 0,461 & 0,473 & 0,460 & 0,871 & 0,880 & 0,260 & 0,420 & 0,417 & 0,423 & 0,426 & 0,445 & 0,428 \\
\hline Fe2\# & 0,331 & 0,200 & $\begin{array}{l}0,207 \\
0,322\end{array}$ & 0,416 & 0,399 & $\begin{array}{l}0,401 \\
0,390\end{array}$ & 0,341 & 0,421 & 0,415 & 0,354 & $\begin{array}{l}0,547 \\
0,54\end{array}$ & 0,471 & $\begin{array}{l}0,417 \\
0,453\end{array}$ & 0,454 & 0,456 & 0,417 & $\begin{array}{l}0,420 \\
0,390\end{array}$ \\
\hline
\end{tabular}


Tabela 52- Composição química de espinélio em harzburgitos e dunitos com flogopita dos corpos Indaiá 1 e Limeira 1 e Forca.

\begin{tabular}{|c|c|c|c|c|c|c|c|c|c|c|c|c|c|c|c|c|c|c|}
\hline $\begin{array}{l}\text { Código } \\
\text { da } \\
\text { amostra }\end{array}$ & Fo-5-12b & pita dunito & om Cr-espi & Fo-5-12e & Lm1-1-3 & $\begin{array}{l}\text { Lm1-1-3b } \\
\text { urgito com }\end{array}$ & $\begin{array}{l}\text { Lm1-1-5 } \\
\text { oolsões de fl }\end{array}$ & goopita e tit & Lm1-1-5 & $\begin{array}{c}\text { Lm1-15- } \\
16 a\end{array}$ & \multicolumn{3}{|c|}{$\begin{array}{l}\text { Lm1-15-4 Lm1-15-3 Lm1-15-2 } \\
\text { harzburgito com bolsões de flogopita }\end{array}$} & Lm1-15-7 & $\begin{array}{l}\text { Lm1-22- } \\
7 \mathrm{~b} \\
\text { flogopita } \\
\text { dunito } \\
\text { com cpx } \\
\text { secundário }\end{array}$ & \multicolumn{3}{|c|}{ 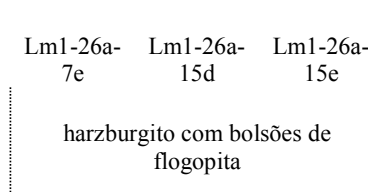 } \\
\hline $\begin{array}{l}\text { Tipo } \\
\mathrm{SiO}_{2}\end{array}$ & 0,00 & 0,01 & 0,00 & 0,02 & 0,00 & 0,00 & 0,00 & 0,00 & 0,00 & 0,00 & 0,00 & 0,00 & 0,00 & 0,47 & & 0,19 & 0,01 & 0,00 \\
\hline $\mathrm{TiO}_{2}$ & 4,00 & 4,07 & 4,21 & 4,13 & 4,90 & 4,91 & 4,84 & 4,80 & 4,95 & 0,88 & 0,76 & 0,66 & 0,73 & 0,54 & 4,43 & 3,54 & 5,35 & 5,27 \\
\hline $\mathrm{Al}_{2} \mathrm{O}_{3}$ & 3,57 & 3,59 & 3,55 & 3,63 & 2,94 & 3,79 & 3,06 & 3,39 & 3,56 & 2,61 & 2,65 & 2,68 & 2,62 & 2,84 & 0,86 & 1,46 & 3,24 & 3,23 \\
\hline $\mathrm{Cr}_{2} \mathrm{O}_{3}$ & 54,72 & 54,55 & 53,38 & 54,33 & 51,63 & 52,21 & 50,91 & 51,40 & 51,74 & 62,10 & 62,83 & 63,83 & 62,64 & 62,65 & 5,10 & 2,42 & 48,31 & 47,18 \\
\hline $\mathrm{FeO}$ & 15,95 & 15,96 & 16,26 & 16,26 & 17,92 & 18,04 & 18,11 & 18,10 & 17,93 & 14,46 & 14,65 & 14,51 & 14,77 & 14,39 & 19,94 & 20,85 & 19,58 & 19,69 \\
\hline $\mathrm{Fe}_{2} \mathrm{O}_{3}$ & 10,29 & 9,66 & 10,81 & 9,89 & 12,30 & 10,89 & 12,12 & 12,30 & 12,07 & 7,11 & 7,03 & 6,65 & 7,00 & 7,36 & 55,16 & 60,01 & 14,93 & 15,34 \\
\hline $\mathrm{MnO}$ & 0,19 & 0,18 & 0,15 & 0,11 & 0,15 & 0,07 & 0,19 & 0,09 & 0,21 & 0,11 & 0,01 & 0,00 & 0,06 & 0,22 & 0,73 & 0,65 & 0,25 & 0,15 \\
\hline $\mathrm{MgO}$ & 11,53 & 11,48 & 11,32 & 11,31 & 10,38 & 10,11 & 9,89 & 10,28 & 10,30 & 11,02 & 10,96 & 11,10 & 10,74 & 11,04 & 10,46 & 10,15 & 9,08 & 8,96 \\
\hline $\mathrm{CaO}$ & 0,00 & 0,00 & 0,01 & 0,05 & 0,02 & 0,09 & 0,02 & 0,01 & 0,00 & 0,02 & 0,12 & 0,03 & 0,05 & 0,05 & 0,26 & 0,11 & 0,03 & 0,01 \\
\hline $\mathrm{K}_{2} \mathrm{O}$ & 0,00 & 0,04 & 0,04 & 0,01 & 0,03 & 0,02 & 0,00 & 0,00 & 0,00 & 0,03 & 0,03 & 0,02 & 0,03 & 0,32 & 0,00 & 0,04 & 0,01 & 0,00 \\
\hline $\mathrm{Na}_{2} \mathrm{O}$ & 0,00 & 0,01 & 0,00 & 0,11 & 0,00 & 0,29 & 0,73 & 0,04 & 0,00 & 0,06 & 0,00 & 0,05 & 0,10 & 0,25 & 0,13 & 0,19 & 0,04 & 0,14 \\
\hline $\mathrm{NiO}$ & 0,40 & 0,18 & 0,32 & 0,21 & 0,18 & 0,26 & 0,10 & 0,13 & 0,37 & 0,07 & 0,12 & 0,21 & 0,06 & 0,02 & 0,11 & 0,19 & 0,35 & 0,17 \\
\hline Total & 100,66 & 99,73 & 100,05 & 100,07 & 100,46 & 100,69 & 99,97 & 100,54 & 101,13 & 98,45 & 99,16 & 99,73 & 98,79 & 100,16 & 98,77 & 99,80 & 101,19 & 100,14 \\
\hline YAl & 0,169 & 0,171 & 0,169 & 0,172 & 0,140 & 0,179 & 0,145 & 0,161 & 0,168 & 0,131 & 0,132 & 0,133 & 0,131 & 0,138 & 0,036 & 0,061 & 0,153 & 0,153 \\
\hline $\mathrm{YFe}^{3+}$ & 0,310 & 0,294 & 0,327 & 0,300 & 0,373 & 0,328 & 0,366 & 0,372 & 0,363 & 0,227 & 0,224 & 0,211 & 0,224 & 0,229 & 1,489 & 1,597 & 0,449 & 0,464 \\
\hline $\mathrm{YCr}$ & 1,157 & 1,163 & 1,132 & 1,153 & 1,097 & 1,101 & 1,077 & 1,088 & 1,089 & 1,390 & 1,400 & 1,416 & 1,402 & 1,368 & 0,096 & 0,045 & 1,017 & 1,001 \\
\hline YTi & 0,121 & 0,124 & 0,128 & 0,125 & 0,149 & 0,148 & 0,146 & 0,145 & 0,149 & 0,028 & 0,024 & 0,021 & 0,023 & 0,017 & 0,120 & 0,094 & 0,161 & 0,160 \\
\hline YSi & 0,000 & 0,001 & 0,000 & 0,001 & 0,000 & 0,000 & 0,000 & 0,000 & 0,000 & 0,000 & 0,000 & 0,000 & 0,000 & 0,020 & 0,057 & 0,007 & 0,000 & 0,000 \\
\hline $\mathrm{YFe}^{2+}$ & 0,243 & 0,247 & 0,244 & 0,249 & 0,241 & 0,245 & 0,267 & 0,234 & 0,232 & 0,224 & 0,220 & 0,220 & 0,220 & 0,228 & 0,202 & 0,196 & 0,220 & 0,222 \\
\hline Ytotal & 2,000 & 2,000 & 2,000 & 2,000 & 2,000 & 2,000 & 2,000 & 2,000 & 2,000 & 2,000 & 2,000 & 2,000 & 2,000 & 2,000 & 2,000 & 2,000 & 2,000 & 2,000 \\
\hline $\mathrm{XFe}^{2+}$ & 0,291 & 0,293 & 0,303 & 0,299 & 0,363 & 0,359 & 0,341 & 0,374 & 0,367 & 0,289 & 0,298 & 0,291 & 0,304 & 0,270 & 0,397 & 0,421 & 0,435 & 0,440 \\
\hline XMg & 0,689 & 0,692 & 0,679 & 0,679 & 0,624 & 0,603 & 0,592 & 0,615 & 0,614 & 0,697 & 0,691 & 0,696 & 0,680 & 0,682 & 0,559 & 0,535 & 0,541 & 0,538 \\
\hline $\mathrm{XMn}$ & 0,006 & 0,006 & 0,005 & 0,004 & 0,005 & 0,002 & 0,006 & 0,003 & 0,007 & 0,004 & 0,000 & 0,000 & 0,002 & 0,008 & 0,022 & 0,019 & 0,008 & 0,005 \\
\hline XK & 0,000 & 0,002 & 0,002 & 0,000 & 0,002 & 0,001 & 0,000 & 0,000 & 0,000 & 0,002 & 0,002 & 0,001 & 0,002 & 0,017 & 0,000 & 0,002 & 0,001 & 0,000 \\
\hline $\mathrm{XNa}$ & 0,000 & 0,000 & 0,000 & 0,009 & 0,000 & 0,023 & 0,057 & 0,003 & 0,000 & 0,005 & 0,000 & 0,004 & 0,008 & 0,020 & 0,009 & 0,013 & 0,003 & 0,011 \\
\hline $\mathrm{XCa}$ & 0,000 & 0,000 & 0,000 & 0,002 & 0,001 & 0,004 & 0,001 & 0,000 & 0,000 & 0,001 & 0,005 & 0,001 & 0,002 & 0,002 & 0,010 & 0,004 & 0,001 & 0,001 \\
\hline $\mathrm{XNi}$ & 0,013 & 0,006 & 0,010 & 0,007 & 0,006 & 0,008 & 0,003 & 0,004 & 0,012 & 0,002 & 0,004 & 0,007 & 0,002 & 0,001 & 0,003 & 0,005 & 0,011 & 0,005 \\
\hline Xtotal & 1,000 & 1,000 & 1,000 & 1,000 & 1,000 & 1,000 & 1,000 & 1,000 & 1,000 & 1,000 & 1,000 & 1,000 & 1,000 & 1,000 & 1,000 & 1,000 & 1,000 & 1,000 \\
\hline $\mathrm{Cr} \#$ & 0,873 & 0,872 & 0,870 & 0,870 & 0,887 & 0,860 & 0,881 & 0,871 & 0,867 & 0,914 & 0,914 & 0,914 & 0,915 & 0,908 & 0,727 & 0,425 & 0,869 & 0,867 \\
\hline $\mathrm{Fe} 2 \#$ & 0,437 & 0,438 & 0,446 & 0,446 & 0,492 & 0,500 & 0,507 & 0,497 & 0,494 & 0,424 & 0,429 & 0,423 & 0,436 & 0,422 & 0,517 & 0,535 & 0,547 & 0,552 \\
\hline
\end{tabular}


Tabela 53-Composição química de espinélio em harzburgitos e dunitos com flogopita, clinopiroxenio secundário e com pouco espinélio dos corpos Indaiá 1 e Limeira 1 e Forca.

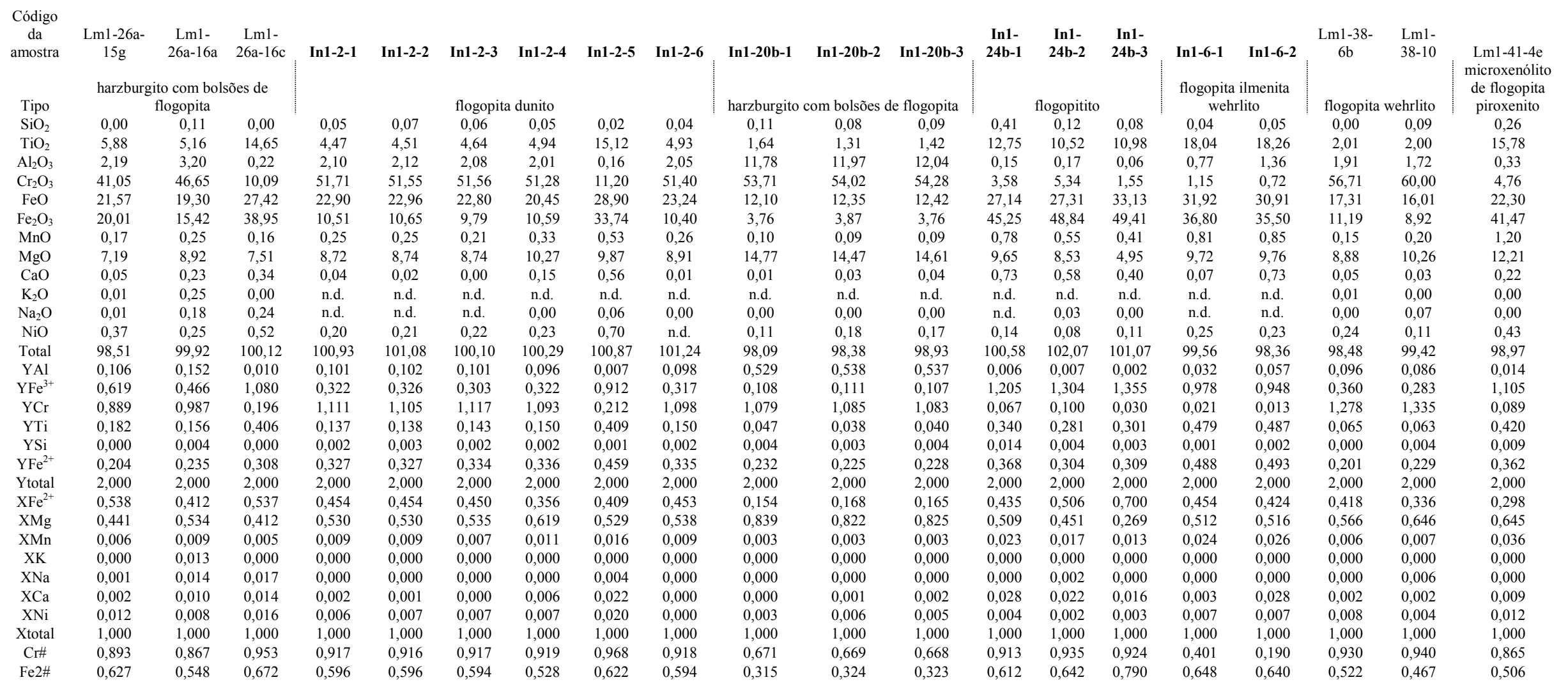


Tabela 54- Composição química de magnetita na matriz dos corpos Indaiá 2 e Facão.

\begin{tabular}{|c|c|c|c|c|c|c|c|c|c|c|c|c|c|}
\hline $\begin{array}{l}\text { Código da } \\
\text { amostra }\end{array}$ & In2-1-14 & In2-1-15 & In2-1-18 & $\begin{array}{l}\text { In2-1-25 } \\
\text { borda de } \\
\text { olivina }\end{array}$ & $\begin{array}{l}\text { In2-1-35 } \\
\begin{array}{c}\text { macrocristal } \\
\text { borda }\end{array}\end{array}$ & $\begin{array}{l}\text { In2-1-35b } \\
\text { macrocristal } \\
\text { centro }\end{array}$ & $\begin{array}{c}\text { macrocristal } \\
\text { borda }\end{array}$ & $\begin{array}{l}\text { Fac-1-10 } \\
\text { macrocristal } \\
\text { centro }\end{array}$ & Fac-2-11b & $\begin{array}{c}\text { Fac-5-13c } \\
\text { inclusão em } \\
\text { macrocristal de } \\
\text { olivina }\end{array}$ & $\begin{array}{c}\text { Fac-6-12 } \\
\text { lamela de } \\
\text { ilmenita inclusa } \\
\text { em macrocristal } \\
\text { de olivina }\end{array}$ & $\begin{array}{c}\text { Fac-6-12' } \\
\text { lamelas em } \\
\text { ilmenita } \\
\text { inclusão em } \\
\text { macrocristal de } \\
\text { olivina }\end{array}$ & $\begin{array}{c}\text { Fac-6-12" } \\
\text { lamelas em } \\
\text { ilmenita } \\
\text { inclusão em } \\
\text { macrocristal de } \\
\text { olivina }\end{array}$ \\
\hline $\mathrm{SiO}_{2}$ & 0,04 & 0,12 & 0,16 & 0,05 & 0,11 & 0,00 & 0,13 & 0,00 & 0,11 & 0,00 & 0,00 & 0,02 & 0,00 \\
\hline $\mathrm{TiO}_{2}$ & 12,73 & 12,89 & 14,09 & 13,26 & 7,43 & 4,29 & 18,86 & 3,57 & 16,56 & 19,38 & 18,29 & 13,58 & 22,07 \\
\hline $\mathrm{Al}_{2} \mathrm{O}_{3}$ & 0,12 & 0,14 & 0,13 & 0,14 & 0,53 & 5,16 & 0,14 & 2,51 & 0,10 & 0,00 & 0,03 & 0,34 & 0,27 \\
\hline $\mathrm{Cr}_{2} \mathrm{O}_{3}$ & 3,12 & 4,22 & 0,21 & 1,13 & 25,67 & 42,87 & 3,17 & 40,85 & 5,27 & 3,34 & 24,55 & 26,23 & 22,38 \\
\hline $\mathrm{FeO}$ & 35,46 & 34,99 & 31,00 & 30,62 & 25,82 & 21,95 & 33,52 & 21,26 & 32,52 & 34,71 & 28,69 & 26,82 & 30,14 \\
\hline $\mathrm{Fe}_{2} \mathrm{O}_{3}$ & 40,99 & 39,99 & 48,07 & 48,41 & 33,31 & 19,01 & 38,46 & 23,30 & 40,34 & 38,81 & 21,09 & 25,74 & 18,11 \\
\hline $\mathrm{MgO}$ & 3,50 & 3,92 & 3,67 & 3,66 & 4,25 & 5,80 & 2,60 & 6,80 & 2,77 & 2,29 & 6,56 & 6,41 & 6,89 \\
\hline $\mathrm{CaO}$ & 0,38 & 0,36 & 0,42 & 0,27 & 0,12 & 0,10 & 0,17 & 0,04 & 0,05 & 0,04 & 0,01 & 0,01 & 0,04 \\
\hline $\mathrm{K}_{2} \mathrm{O}$ & 0,05 & 0,00 & 0,00 & 0,01 & 0,05 & 0,04 & 0,01 & 0,00 & 0,00 & 0,02 & 0,00 & 0,03 & 0,00 \\
\hline $\mathrm{Na}_{2} \mathrm{O}$ & 0,34 & 0,20 & 0,19 & 0,06 & 0,02 & 0,02 & 0,04 & 0,00 & 0,14 & 0,50 & 0,00 & 0,12 & 0,01 \\
\hline $\mathrm{NiO}$ & 0,15 & 0,17 & 0,01 & 0,10 & 0,15 & 0,13 & 0,17 & 0,11 & 0,34 & 0,13 & 0,49 & 0,48 & 0,38 \\
\hline Total & 97,94 & 98,12 & 99,09 & 98,80 & 98,40 & 100,37 & 98,25 & 98,78 & 99,06 & 100,04 & 99,92 & 100,09 & 100,64 \\
\hline YAl & 0,005 & 0,006 & 0,006 & 0,006 & 0,025 & 0,245 & 0,006 & 0,122 & 0,004 & 0,000 & 0,001 & 0,016 & 0,012 \\
\hline $\mathrm{YFe}^{3+}$ & 1,167 & 1,139 & 1,350 & 1,371 & 1,016 & 0,577 & 1,110 & 0,720 & 1,160 & 1,098 & 0,618 & 0,757 & 0,521 \\
\hline $\mathrm{YCr}$ & 0,062 & 0,084 & 0,004 & 0,022 & 0,549 & 0,912 & 0,064 & 0,884 & 0,106 & 0,066 & 0,504 & 0,541 & 0,451 \\
\hline YTi & 0,363 & 0,367 & 0,396 & 0,376 & 0,227 & 0,130 & 0,544 & 0,110 & 0,476 & 0,548 & 0,536 & 0,399 & 0,635 \\
\hline YV & 0,000 & 0,000 & 0,000 & 0,000 & 0,000 & 0,000 & 0,000 & 0,000 & 0,000 & 0,000 & 0,000 & 0,000 & 0,000 \\
\hline $\mathrm{YSi}$ & 0,002 & 0,005 & 0,006 & 0,002 & 0,005 & 0,000 & 0,005 & 0,000 & 0,004 & 0,000 & 0,000 & 0,001 & 0,000 \\
\hline $\mathrm{XFe}^{2+}$ & 0,721 & 0,708 & 0,729 & 0,741 & 0,696 & 0,605 & 0,804 & 0,566 & 0,791 & 0,803 & 0,595 & 0,590 & 0,582 \\
\hline $\mathrm{XMg}$ & 0,197 & 0,221 & 0,204 & 0,205 & 0,257 & 0,349 & 0,149 & 0,416 & 0,158 & 0,128 & 0,381 & 0,373 & 0,393 \\
\hline XMn & 0,034 & 0,036 & 0,037 & 0,035 & 0,032 & 0,033 & 0,032 & 0,012 & 0,028 & 0,026 & 0,008 & 0,010 & 0,011 \\
\hline $\mathrm{XZn}$ & 0,000 & 0,000 & 0,000 & 0,000 & 0,000 & 0,000 & 0,000 & 0,000 & 0,000 & 0,000 & 0,000 & 0,000 & 0,000 \\
\hline XK & 0,003 & 0,000 & 0,000 & 0,001 & 0,003 & 0,002 & 0,001 & 0,000 & 0,000 & 0,001 & 0,000 & 0,002 & 0,000 \\
\hline $\mathrm{XNa}$ & 0,025 & 0,015 & 0,014 & 0,004 & 0,002 & 0,002 & 0,003 & 0,000 & 0,010 & 0,037 & 0,000 & 0,009 & 0,001 \\
\hline $\mathrm{XCa}$ & 0,015 & 0,015 & 0,017 & 0,011 & 0,005 & 0,004 & 0,007 & 0,002 & 0,002 & 0,002 & 0,000 & 0,000 & 0,002 \\
\hline $\mathrm{XNi}$ & 0,004 & 0,005 & 0,000 & 0,003 & 0,005 & 0,004 & 0,005 & 0,004 & 0,010 & 0,004 & 0,015 & 0,015 & 0,012 \\
\hline Xtotal & 1,000 & 1,000 & 1,000 & 1,000 & 1,000 & 1,000 & 1,000 & 1,000 & 1,000 & 1,000 & 1,000 & 1,000 & 1,000 \\
\hline $\mathrm{Cr} \#$ & 0,923 & 0,929 & 0,408 & 0,785 & 0,956 & 0,788 & 0,911 & 0,879 & 0,960 & 0,999 & 0,998 & 0,972 & 0,974 \\
\hline $\mathrm{Fe} 2 \#$ & 0,850 & 0,834 & 0,826 & 0,824 & 0,773 & 0,680 & 0,878 & 0,637 & 0,868 & 0,895 & 0,710 & 0,701 & 0,710 \\
\hline
\end{tabular}


Tabela 55-Composição química de espinélio na matriz e em nódulos dos corpos Indaiá 2 e Facão.

\begin{tabular}{|c|c|c|c|c|c|c|c|c|c|c|c|c|c|c|}
\hline $\begin{array}{c}\text { Código da amostra } \\
\text { Tipo }\end{array}$ & $\begin{array}{c}\text { Fac-6-1 } \\
\text { borda de olivina }\end{array}$ & Fac-6-2 & $\begin{array}{l}\text { Fac-6-14 } \\
\text { matriz }\end{array}$ & Fac-6-1 & $\begin{array}{l}\text { Fac-6-3 } \\
\text { matriz }\end{array}$ & $\begin{array}{c}\text { Fac-6-14 } \\
\text { borda de olivina }\end{array}$ & $\begin{array}{l}\text { Fac-7-4 } \\
\text { macrocristal borda }\end{array}$ & $\begin{array}{c}\text { Fac-7-5 } \\
\text { macrocristal centro }\end{array}$ & $\begin{array}{r}\text { Fac-7- } \\
\mathrm{m}\end{array}$ & $\begin{array}{l}\text { Fac-7- } \\
\text { iz }\end{array}$ & Fo-1-15 & $\begin{array}{l}\text { Fo-1-16c } \\
\text { matriz }\end{array}$ & Fo-1-27 & $\begin{array}{c}\text { Fo-6-22 } \\
\text { matriz }\end{array}$ \\
\hline $\mathrm{SiO}_{2}$ & 0,00 & 0,00 & 0,00 & 0,01 & 0,21 & 0,06 & 0,07 & 0,00 & 0,00 & 0,00 & 0,17 & 0,21 & 0,00 & 0,07 \\
\hline $\mathrm{TiO}_{2}$ & 16,50 & 16,46 & 18,13 & 16,31 & 19,84 & 17,43 & 16,74 & 3,64 & 5,79 & 13,64 & 12,61 & 23,58 & 0,04 & 0,04 \\
\hline $\mathrm{Al}_{2} \mathrm{O}_{3}$ & 0,05 & 0,00 & 0,00 & 0,18 & 0,04 & 0,11 & 0,05 & 1,51 & 4,91 & 0,30 & 1,22 & 0,73 & 16,40 & 38,19 \\
\hline $\mathrm{Cr}_{2} \mathrm{O}_{3}$ & 5,39 & 5,53 & 3,27 & 5,24 & 1,87 & 3,74 & 2,58 & 45,51 & 42,23 & 11,76 & 8,29 & 0,19 & 50,11 & 30,78 \\
\hline $\mathrm{FeO}$ & 32,92 & 32,08 & 33,88 & 32,07 & 35,32 & 33,02 & 32,27 & 22,92 & 21,43 & 30,28 & 16,72 & 22,07 & 13,04 & 10,53 \\
\hline $\mathrm{Fe}_{2} \mathrm{O}_{3}$ & 42,26 & 42,26 & 41,29 & 40,45 & 38,06 & 41,71 & 42,95 & 20,40 & 17,44 & 38,60 & 41,88 & 29,10 & 8,24 & 5,98 \\
\hline $\mathrm{MnO}$ & 0,81 & 0,82 & 0,79 & 0,84 & 0,74 & 0,76 & 0,80 & 0,63 & 0,58 & 0,65 & 0,86 & 0,92 & 0,14 & 0,07 \\
\hline $\mathrm{MgO}$ & 3,39 & 4,14 & 3,00 & 3,29 & 1,41 & 3,43 & 3,61 & 4,91 & 7,10 & 3,80 & 16,78 & 13,66 & 12,67 & 15,05 \\
\hline $\mathrm{CaO}$ & 0,01 & 0,04 & 0,00 & 0,00 & 0,60 & 0,02 & 0,31 & 0,01 & 0,01 & 0,02 & 0,23 & 9,12 & 0,11 & 0,01 \\
\hline $\mathrm{K}_{2} \mathrm{O}$ & 0,01 & 0,00 & 0,01 & 0,00 & 0,00 & 0,03 & 0,03 & 0,02 & 0,00 & 0,00 & 0,06 & 0,04 & 0,02 & 0,00 \\
\hline $\mathrm{Na}_{2} \mathrm{O}$ & 0,15 & 0,00 & 0,58 & 0,00 & 0,05 & 0,03 & 0,17 & 0,05 & 0,01 & 0,05 & 0,00 & 0,31 & 0,02 & 0,09 \\
\hline $\mathrm{NiO}$ & 0,20 & 0,29 & 0,12 & 0,11 & 0,13 & 0,27 & 0,26 & 0,03 & 0,24 & 0,29 & 0,26 & 0,33 & 0,06 & 0,07 \\
\hline Total & 101,69 & 101,61 & 101,08 & 98,49 & 98,28 & 100,62 & 99,84 & 99,63 & 99,75 & 99,39 & 99,08 & 100,25 & 100,86 & 100,89 \\
\hline YAl & 0,002 & 0,000 & 0,000 & 0,008 & 0,002 & 0,005 & 0,002 & 0,075 & 0,232 & 0,013 & 0,049 & 0,028 & 0,706 & 1,387 \\
\hline $\mathrm{YFe}^{3+}$ & 1,180 & 1,177 & 1,149 & 1,167 & 1,103 & 1,172 & 1,207 & 0,648 & 0,527 & 1,121 & 1,084 & 1,109 & 0,227 & 0,111 \\
\hline $\mathrm{YCr}$ & 0,105 & 0,108 & 0,064 & 0,106 & 0,038 & 0,074 & 0,051 & 1,013 & 0,893 & 0,239 & 0,150 & 0,003 & 0,965 & 0,500 \\
\hline YTi & 0,460 & 0,458 & 0,504 & 0,470 & 0,575 & 0,489 & 0,470 & 0,116 & 0,175 & 0,396 & 0,326 & 0,584 & 0,001 & 0,001 \\
\hline YSi & 0,000 & 0,000 & 0,000 & 0,001 & 0,008 & 0,002 & 0,003 & 0,000 & 0,000 & 0,000 & 0,006 & 0,007 & 0,000 & 0,002 \\
\hline $\mathrm{YFe}^{2+}$ & 0,252 & 0,257 & 0,283 & 0,248 & 0,275 & 0,258 & 0,267 & 0,148 & 0,173 & 0,231 & 0,385 & 0,608 & 0,101 & 0,000 \\
\hline Ytotal & 2,000 & 2,000 & 2,000 & 2,000 & 2,000 & 2,000 & 2,000 & 2,000 & 2,000 & 2,000 & 2,000 & 2,000 & 2,000 & 2,000 \\
\hline $\mathrm{XFe}^{2+}$ & 0,769 & 0,736 & 0,764 & 0,781 & 0,862 & 0,772 & 0,740 & 0,661 & 0,546 & $\begin{array}{l}2,000 \\
0,746\end{array}$ & 0,096 & 0,000 & 0,297 & 0,299 \\
\hline $\mathrm{XMg}$ & 0,188 & 0,228 & 0,165 & 0,188 & 0,081 & 0,191 & 0,201 & 0,309 & 0,425 & 0,219 & 0,860 & 0,671 & 0,690 & 0,691 \\
\hline $\mathrm{XMn}$ & 0,026 & 0,026 & 0,025 & 0,027 & 0,024 & 0,024 & 0,025 & 0,023 & 0,020 & 0,021 & 0,025 & 0,026 & 0,004 & 0,002 \\
\hline XK & 0,001 & 0,000 & 0,001 & 0,000 & 0,000 & 0,002 & 0,002 & 0,001 & 0,000 & 0,000 & 0,003 & 0,002 & 0,001 & 0,000 \\
\hline $\mathrm{XNa}$ & 0,011 & 0,000 & 0,041 & 0,000 & 0,004 & 0,002 & 0,012 & 0,004 & 0,001 & 0,004 & 0,000 & 0,020 & 0,001 & 0,006 \\
\hline $\mathrm{XCa}$ & 0,001 & 0,001 & 0,000 & 0,000 & 0,025 & 0,001 & 0,012 & 0,001 & 0,001 & 0,001 & 0,008 & 0,322 & 0,004 & 0,000 \\
\hline $\mathrm{XNi}$ & 0,006 & 0,009 & 0,004 & 0,003 & 0,004 & 0,008 & 0,008 & 0,001 & 0,008 & 0,009 & 0,007 & 0,009 & 0,002 & 0,002 \\
\hline Xtotal & 1,000 & 1,000 & 1,000 & 1,000 & 1,000 & 1,000 & 1,000 & 1,000 & 1,000 & 1,000 & 1,000 & 1,000 & 1,000 & 1,000 \\
\hline $\mathrm{Cr} \#$ & 0,979 & 1,000 & 1,000 & 0,929 & 0,950 & 0,939 & 0,955 & 0,931 & 0,794 & 0,947 & 0,753 & 0,107 & 0,578 & 0,265 \\
\hline $\mathrm{Fe} 2 \#(\mathrm{Fe} / \mathrm{Fe} 2+\mathrm{Mg}$ & 0,845 & 0,813 & 0,864 & 0,845 & 0,934 & 0,844 & 0,834 & 0,724 & 0,629 & 0,817 & 0,358 & 0,475 & 0,366 & 0,302 \\
\hline
\end{tabular}


Tabela 56- Composição química de espinélio na matriz e em nódulos dos corpos Indaiá 2 e Facão.

\begin{tabular}{|c|c|c|c|c|c|c|c|c|c|c|c|}
\hline \multirow[t]{2}{*}{ Código da amostra } & \multirow{2}{*}{\multicolumn{2}{|c|}{$\begin{array}{l}\text { Fac-5-9b Fac-5-9d } \\
\text { associado a perovskita em flogopita } \\
\text { piroxenito }\end{array}$}} & \multirow{2}{*}{ flogopita piroxenito } & \multirow{2}{*}{$\begin{array}{c}\text { Fac-6-29 } \\
\text { xenólito máfico em } \\
\text { desequilibrio textural }\end{array}$} & \multirow{2}{*}{\begin{tabular}{|l|} 
Fac-7-7 \\
cristais pequenos em \\
interstício de \\
wehrlito
\end{tabular}} & \multicolumn{2}{|r|}{ Lm1-25-1e } & \multicolumn{2}{|c|}{ In1-36-2d } & \multirow{2}{*}{$\begin{array}{c}\text { Fac-8-4 } \\
\text { lamela de } \\
\text { ilmenita inclusa } \\
\text { em olivina de } \\
\text { dunito }\end{array}$} & \multirow{2}{*}{$\begin{array}{c}\text { Fac-8-9 } \\
\text { cristal em interstício } \\
\text { de dunito }\end{array}$} \\
\hline & & & & & & nódu & rdeado & & & & \\
\hline $\begin{array}{l}\text { Tipo } \\
\mathrm{SiO}_{2}\end{array}$ & 0,00 & 0,06 & 0,00 & 0,02 & 0,16 & 0,00 & 0,00 & 0,02 & 0,00 & 0,05 & 0,29 \\
\hline $\mathrm{TiO}_{2}$ & 20,12 & 19,35 & 20,71 & 3,74 & 14,44 & 4,49 & 3,98 & 18,86 & 0,09 & 12,49 & 17,43 \\
\hline $\mathrm{Al}_{2} \mathrm{O}_{3}$ & 0,00 & 0,11 & 0,06 & 0,90 & 0,31 & 6,27 & 5,28 & 0,84 & 16,20 & 0,54 & 0,05 \\
\hline $\mathrm{Cr}_{2} \mathrm{O}_{3}$ & 1,52 & 1,70 & 0,99 & 48,13 & 22,81 & 41,66 & 45,98 & 4,23 & 47,19 & 26,77 & 3,22 \\
\hline $\mathrm{FeO}$ & 35,12 & 34,75 & 33,35 & 24,03 & 27,98 & 16,49 & 18,85 & 25,36 & 12,83 & 25,56 & 32,77 \\
\hline $\mathrm{Fe}_{2} \mathrm{O}_{3}$ & 38,37 & 40,18 & 37,77 & 19,45 & 26,24 & 19,78 & 15,87 & 38,63 & 10,88 & 25,37 & 40,32 \\
\hline $\mathrm{MnO}$ & 0,57 & 0,82 & 0,80 & 0,37 & 0,32 & 0,24 & 0,66 & 1,18 & 0,05 & 0,29 & 0,94 \\
\hline $\mathrm{MgO}$ & 2,07 & 2,26 & 3,70 & 4,22 & 5,10 & 12,42 & 8,58 & 11,29 & 13,06 & 6,79 & 2,66 \\
\hline $\mathrm{CaO}$ & 0,30 & 0,25 & 0,07 & 0,12 & 0,11 & 0,08 & 0,40 & 0,56 & 0,02 & 0,03 & 0,05 \\
\hline $\mathrm{K}_{2} \mathrm{O}$ & 0,00 & 0,02 & 0,01 & 0,00 & 0,01 & 0,00 & 0,02 & 0,00 & 0,02 & 0,00 & 0,05 \\
\hline $\mathrm{Na}_{2} \mathrm{O}$ & 0,19 & 0,09 & 0,77 & 0,00 & 0,13 & 0,03 & 0,02 & 0,10 & 0,03 & 0,02 & 0,14 \\
\hline $\mathrm{NiO}$ & 0,13 & 0,20 & 0,20 & 0,21 & 0,55 & 0,22 & 0,12 & 0,10 & 0,17 & 0,37 & 0,29 \\
\hline Total & 98,40 & 99,78 & 98,44 & 101,20 & 98,16 & 101,68 & 99,78 & 101,16 & 100,53 & 98,30 & 98,20 \\
\hline YAl & 0,000 & 0,005 & 0,003 & 0,045 & 0,015 & 0,275 & 0,249 & 0,034 & 0,693 & 0,025 & 0,002 \\
\hline $\mathrm{YFe}^{3+}$ & 1,103 & 1,139 & 1,060 & 0,619 & 0,787 & 0,555 & 0,477 & 1,009 & 0,297 & 0,759 & 1,163 \\
\hline $\mathrm{YCr}$ & 0,031 & 0,034 & 0,019 & 1,073 & 0,479 & 0,819 & 0,968 & 0,077 & 0,902 & 0,561 & 0,065 \\
\hline $\mathrm{YTi}$ & 0,578 & 0,548 & 0,581 & 0,119 & 0,433 & 0,126 & 0,120 & 0,493 & 0,002 & 0,374 & 0,503 \\
\hline YSi & 0,000 & 0,002 & 0,000 & 0,001 & 0,006 & 0,000 & 0,000 & 0,001 & 0,000 & 0,002 & 0,011 \\
\hline $\mathrm{YFe}^{2+}$ & 0,289 & 0,272 & 0,336 & 0,143 & 0,280 & 0,224 & 0,187 & 0,386 & 0,106 & 0,278 & 0,256 \\
\hline Ytotal & 2,000 & 2,000 & 2,000 & 2,000 & 2,000 & 2,000 & 2,000 & 2,000 & 2,000 & 2,000 & 2,000 \\
\hline $\mathrm{XFe}^{2+}$ & 0,833 & 0,823 & 0,704 & 0,708 & 0,653 & 0,290 & 0,443 & 0,351 & 0,284 & 0,572 & 0,794 \\
\hline $\mathrm{XMg}$ & 0,118 & 0,127 & 0,206 & 0,266 & 0,303 & 0,691 & 0,511 & 0,584 & 0,706 & 0,403 & 0,152 \\
\hline XMn & 0,019 & 0,026 & 0,025 & 0,013 & 0,011 & 0,007 & 0,022 & 0,035 & 0,002 & 0,010 & 0,030 \\
\hline XK & 0,000 & 0,001 & 0,000 & 0,000 & 0,001 & 0,000 & 0,001 & 0,000 & 0,001 & 0,000 & 0,002 \\
\hline $\mathrm{XNa}$ & 0,014 & 0,007 & 0,056 & 0,000 & 0,010 & 0,002 & 0,001 & 0,007 & 0,002 & 0,002 & 0,010 \\
\hline $\mathrm{XCa}$ & 0,012 & 0,010 & 0,003 & 0,006 & 0,005 & 0,003 & 0,017 & 0,021 & 0,001 & 0,001 & 0,002 \\
\hline $\mathrm{XNi}$ & 0,004 & 0,006 & 0,006 & 0,007 & 0,018 & 0,007 & 0,004 & 0,003 & 0,005 & 0,012 & 0,009 \\
\hline Xtotal & 1,000 & 1,000 & 1,000 & 1,000 & 1,000 & 1,000 & 1,000 & 1,000 & 1,000 & 1,000 & 1,000 \\
\hline $\mathrm{Cr} \#$ & 0,997 & 0,869 & 0,873 & 0,960 & 0,970 & 0,748 & 0,796 & 0,693 & 0,566 & 0,957 & 0,969 \\
\hline $\mathrm{Fe} 2 \#(\mathrm{Fe} / \mathrm{Fe} 2+\mathrm{Mg}$ & 0,905 & 0,896 & 0,835 & 0,762 & 0,755 & 0,427 & 0,552 & 0,558 & 0,355 & 0,679 & 0,874 \\
\hline
\end{tabular}


Tabela 57- Composição química de anfibólio em xenólitos de peridotitos com Cr-espinélio do kimberlito Indaiá 1 e na matriz e em autólitos dos corpos Indaiá 2 e Facão.

\begin{tabular}{|c|c|c|c|c|c|c|c|c|c|c|c|c|c|c|c|}
\hline \multirow[t]{2}{*}{$\begin{array}{l}\text { Código } \\
\text { da } \\
\text { amostra }\end{array}$} & \multirow{2}{*}{\multicolumn{4}{|c|}{$\begin{array}{lccr}\text { In1-24a-1 } & 2 & 3 & 4 \\
\text { dunito granoblástico com } & \text { Cr-espinélio e } \\
\text { pargasita }\end{array}$}} & \multirow{2}{*}{\multicolumn{2}{|c|}{$\begin{array}{l}\text { In1-50-5' In-50-8' } \\
\text { harzburgito com Cr- } \\
\text { espinélio e pargasita }\end{array}$}} & \multirow{2}{*}{\multicolumn{2}{|c|}{$\begin{array}{l}\text { In2-1- In2-1- } \\
46 \quad 46 \mathrm{~b} \\
\\
\text { reação com } \\
\text { xenólito crustal }\end{array}$}} & \multirow{2}{*}{$\begin{array}{l}\text { Fac-1-5 } \\
\text { cristal } \\
\text { euédrico } \\
\text { dentro } \\
\text { de vidro }\end{array}$} & \multirow[t]{2}{*}{$\begin{array}{l}\text { Fac-6- } \\
15\end{array}$} & \multirow[t]{2}{*}{$\begin{array}{c}\text { Fac-6- } \\
19\end{array}$} & \multirow{2}{*}{$\begin{array}{l}\text { Fac-6- } \\
19 " \\
\text { autólito }\end{array}$} & \multirow[t]{2}{*}{$\begin{array}{l}\text { Fac-6- } \\
24 \mathrm{~b}\end{array}$} & \multirow[t]{2}{*}{$\begin{array}{c}\text { Fac-6- } \\
24 a\end{array}$} & \multirow{2}{*}{$\begin{array}{l}\text { Fac-4-5 } \\
\text { autólito }\end{array}$} \\
\hline & & & & & & & & & & & & & & & \\
\hline $\mathrm{SiO}_{2}$ & 44,14 & 43,75 & 43,92 & 44,00 & 42,76 & 42,64 & 57,05 & 56,82 & 54,86 & 52,05 & 53,72 & 53,88 & 51,41 & 52,62 & 52,04 \\
\hline $\mathrm{TiO}_{2}$ & 2,18 & 2,15 & 1,96 & 2,19 & 2,22 & 2,19 & 0,68 & 0,74 & 3,67 & 0,98 & 1,81 & 1,56 & 0,74 & 0,72 & 4,42 \\
\hline $\mathrm{Al}_{2} \mathrm{O}_{3}$ & 12,35 & 12,36 & 12,26 & 12,31 & 12,45 & 12,47 & 0,10 & 0,08 & 0,73 & 1,13 & 1,04 & 1,06 & 1,13 & 1,04 & 0,23 \\
\hline $\mathrm{FeO}$ & 2,36 & 2,51 & 2,52 & 2,49 & 2,71 & 2,50 & 2,64 & 2,62 & 3,25 & 3,30 & 5,65 & 4,79 & 3,06 & 3,01 & 3,52 \\
\hline $\mathrm{MnO}$ & 0,04 & 0,03 & 0,00 & 0,07 & 0,01 & 0,10 & 0,07 & 0,12 & 0,08 & 0,00 & 0,08 & 0,03 & 0,03 & 0,00 & 0,02 \\
\hline $\mathrm{MgO}$ & 18,26 & 18,41 & 18,16 & 18,33 & 18,16 & 17,98 & 22,14 & 22,33 & 19,73 & 21,88 & 20,20 & 20,58 & 21,76 & 21,46 & 18,32 \\
\hline $\mathrm{CaO}$ & 11,37 & 11,30 & 11,60 & 11,40 & 11,36 & 11,61 & 6,25 & 6,27 & 4,83 & 7,16 & 5,39 & 6,21 & 7,19 & 6,90 & 3,19 \\
\hline $\mathrm{Na}_{2} \mathrm{O}$ & 3,48 & 3,54 & 3,47 & 3,54 & 3,82 & 4,00 & 4,96 & 4,80 & 5,41 & 4,90 & 5,91 & 5,16 & 4,70 & 4,87 & 7,59 \\
\hline $\mathrm{K}_{2} \mathrm{O}$ & 0,92 & 1,06 & 1,17 & 1,16 & 1,24 & 1,24 & 4,16 & 4,11 & 4,58 & 4,29 & 4,35 & 4,51 & 4,39 & 4,42 & 4,75 \\
\hline $\mathrm{Cr}_{2} \mathrm{O}_{3}$ & n.d. & n.d. & n.d. & n.d. & 2,30 & 2,34 & 0,30 & 0,20 & 0,01 & 0,14 & 0,05 & 0,05 & 0,31 & 0,72 & 0,02 \\
\hline $\mathrm{NiO}$ & n.d. & n.d. & n.d. & n.d. & 0,18 & 0,15 & 0,06 & 0,00 & 0,08 & 0,13 & 0,14 & 0,02 & 0,06 & 0,00 & 0,05 \\
\hline Total & 95,09 & 95,09 & 95,06 & 95,48 & 97,20 & 97,23 & 98,41 & 98,08 & 97,25 & 95,94 & 98,34 & 97,84 & 94,78 & 95,74 & 94,16 \\
\hline $\mathrm{TSi}$ & 6,44 & 6,37 & 6,41 & 6,39 & 6,17 & 6,14 & 7,95 & 7,94 & 7,82 & 7,42 & 7,53 & 7,60 & 7,41 & 7,54 & 7,56 \\
\hline TAl & 1,56 & 1,63 & 1,59 & 1,61 & 1,83 & 1,86 & 0,02 & 0,01 & 0,12 & 0,48 & 0,28 & 0,24 & 0,27 & 0,20 & 0,04 \\
\hline $\mathrm{TFe}^{3}$ & 0,00 & 0,00 & 0,00 & 0,00 & 0,00 & 0,00 & 0,00 & 0,00 & 0,00 & 0,00 & 0,00 & 0,00 & 0,00 & 0,00 & 0,00 \\
\hline TTi & 0,00 & 0,00 & 0,00 & 0,00 & 0,00 & 0,00 & 0,03 & 0,04 & 0,06 & 0,10 & 0,19 & 0,17 & 0,08 & 0,08 & 0,40 \\
\hline Ttotal & 8,00 & 8,00 & 8,00 & 8,00 & 8,00 & 8,00 & 8,00 & 8,00 & 8,00 & 8,00 & 8,00 & 8,00 & 8,00 & 8,00 & 8,00 \\
\hline $\mathrm{Cal}$ & 0,22 & 0,14 & 0,22 & 0,16 & 0,00 & 0,00 & 0,92 & 0,93 & 0,61 & 0,61 & 0,53 & 0,72 & 0,84 & 0,86 & 0,46 \\
\hline $\mathrm{CTi}$ & 0,24 & 0,24 & 0,21 & 0,24 & 0,24 & 0,24 & 0,04 & 0,04 & 0,33 & 0,00 & 0,00 & 0,00 & 0,00 & 0,00 & 0,08 \\
\hline $\mathrm{CFe}^{2}$ & 0,29 & 0,31 & 0,31 & 0,30 & 0,33 & 0,30 & 0,31 & 0,31 & 0,39 & 0,39 & 0,66 & 0,57 & 0,37 & 0,36 & 0,43 \\
\hline $\mathrm{CFe}^{3}$ & 0,00 & 0,00 & 0,00 & 0,00 & 0,00 & 0,00 & 0,00 & 0,00 & 0,00 & 0,00 & 0,00 & 0,00 & 0,00 & 0,00 & 0,00 \\
\hline $\mathrm{CMn}$ & 0,00 & 0,00 & 0,00 & 0,01 & 0,00 & 0,01 & 0,01 & 0,01 & 0,01 & 0,00 & 0,01 & 0,00 & 0,00 & 0,00 & 0,00 \\
\hline $\mathrm{CMg}$ & 3,97 & 4,00 & 3,95 & 3,97 & 3,90 & 3,86 & 4,60 & 4,65 & 4,19 & 4,65 & 4,22 & 4,33 & 4,68 & 4,58 & 3,97 \\
\hline $\mathrm{CCr}$ & 0,00 & 0,00 & 0,00 & 0,00 & 0,17 & 0,18 & 0,02 & 0,01 & 0,00 & 0,01 & 0,00 & 0,00 & 0,02 & 0,05 & 0,00 \\
\hline Total C & 4,72 & 4,68 & 4,69 & 4,68 & 4,65 & 4,5 & 5,90 & 5,95 & 5,54 & 5,66 & 5,43 & 5,62 & 5,91 & 5,85 & 4,94 \\
\hline $\mathrm{BCa}$ & 1,78 & 1,76 & 1,81 & 1,77 & 1,75 & 1,79 & 0,93 & 0,94 & 0,74 & 1,09 & 0,81 & 0,94 & 1,11 & 1,06 & 0,50 \\
\hline $\mathrm{BNa}$ & 0,22 & 0,24 & 0,19 & 0,23 & 0,25 & 0,21 & 1,07 & 1,06 & 1,26 & 0,91 & 1,19 & 1,06 & 0,89 & 0,94 & 1,50 \\
\hline Total B & 2,00 & 2,00 & 2,00 & 2,00 & 2,00 & 2,00 & 2,00 & 2,00 & 2,00 & 2,00 & 2,00 & 2,00 & 2,00 & 2,00 & 2,00 \\
\hline $\mathrm{A} \mathrm{Na}$ & 0,76 & 0,76 & 0,79 & 0,77 & 0,82 & 0,91 & 0,28 & 0,24 & 0,23 & 0,45 & 0,42 & 0,35 & 0,43 & 0,41 & 0,63 \\
\hline A K & 0,17 & 0,20 & 0,22 & 0,21 & 0,23 & 0,23 & 0,74 & 0,73 & 0,83 & 0,78 & 0,78 & 0,81 & 0,81 & 0,81 & 0,88 \\
\hline Total A & 0,94 & 0,96 & 1,01 & 0,99 & 1,05 & 1,14 & 1,01 & 0,98 & 1,07 & 1,22 & 1,19 & 1,16 & 1,23 & 1,22 & 1,51 \\
\hline \#mg & 0,93 & 0,93 & 0,93 & 0,93 & 0,92 & 0,93 & 0,94 & 0,94 & 0,92 & 0,92 & 0,86 & 0,88 & 0,93 & 0,93 & 0,90 \\
\hline
\end{tabular}


Tabela 58- Composição química de ilmenita em xenólitos dos corpos Facão, Indaiá 1 e Limeira 1.

\begin{tabular}{|c|c|c|c|c|c|c|c|c|c|c|c|c|c|c|c|c|}
\hline $\begin{array}{l}\text { Código da } \\
\text { amostra }\end{array}$ & In1-2-1 & In1-2-2 & In1-6-1 & In1-6-2 & In1-6-3 & In1-6-4 & In1-6-5 & In1-6-7 & In1-24b-1 & In1-24b-2 & In1-24b-4 & Lm1-22-8b & Fac-5-14 & In1-36-6 & $\begin{array}{l}\text { In1- } \\
36-8\end{array}$ & $\begin{array}{l}\text { In1- } \\
36- \\
10 \mathrm{a}\end{array}$ \\
\hline Tipo & flogopi & dunito & & & flogopita $\mathrm{i}$ & piroxenito & & & & flogopitito & & $\begin{array}{c}\text { flogopita } \\
\text { clinopiroxenio } \\
\text { dunito }\end{array}$ & $\begin{array}{c}\text { xenólito } \\
\text { piroxenítico }\end{array}$ & \multicolumn{3}{|c|}{ megacristal } \\
\hline $\mathrm{SiO}_{2}$ & 0,02 & 0,00 & 0,03 & 0,02 & 0,01 & 0,03 & 0,00 & 0,02 & 0,04 & 0,01 & 0,01 & 0,00 & 0,00 & 0,03 & 0,05 & 0,12 \\
\hline $\mathrm{TiO}_{2}$ & 47,45 & 47,88 & 51,48 & 50,29 & 48,06 & 50,77 & 51,54 & 50,55 & 49,47 & 49,37 & 51,40 & 50,73 & 51,05 & 48,86 & 46,41 & 48,64 \\
\hline $\mathrm{Al}_{2} \mathrm{O}_{3}$ & 0,12 & 0,14 & 0,11 & 0,06 & 0,08 & 0,14 & 0,10 & 0,08 & 0,16 & 0,20 & 0,21 & 0,10 & 0,00 & 0,12 & 0,16 & 0,04 \\
\hline $\mathrm{Cr}_{2} \mathrm{O}_{3}$ & 7,52 & 7,58 & 1,65 & 1,57 & 1,53 & 1,52 & 1,51 & 1,58 & 2,12 & 1,98 & 1,84 & 3,56 & 0,08 & 1,60 & 1,86 & 1,10 \\
\hline $\mathrm{MgO}$ & 11,87 & 12,12 & 10,87 & 9,40 & 9,37 & 9,43 & 9,97 & 9,57 & 10,07 & 9,92 & 9,79 & 10,10 & 7,90 & 8,91 & 8,62 & 7,07 \\
\hline $\mathrm{CaO}$ & 0,06 & 0,02 & 0,01 & 0,05 & 0,01 & 0,00 & 0,03 & 0,02 & 0,03 & 0,01 & 0,00 & 0,04 & 0,02 & 0,04 & 0,02 & 0,00 \\
\hline $\mathrm{MnO}$ & 0,31 & 0,29 & 0,44 & 0,31 & 0,35 & 0,35 & 0,41 & 0,36 & 0,30 & 0,32 & 0,28 & 0,85 & 0,85 & 0,45 & 0,47 & 0,23 \\
\hline $\mathrm{FeO}$ & 31,56 & 31,97 & 36,37 & 38,20 & 38,83 & 38,01 & 37,34 & 37,49 & 37,67 & 38,02 & 36,90 & 33,26 & 38,33 & 40,78 & 41,32 & 42,20 \\
\hline $\mathrm{Na}_{2} \mathrm{O}$ & n.d. & n.d. & n.d. & n.d. & n.d. & n.d. & n.d. & n.d. & n.d. & n.d. & n.d. & 0,36 & 0,30 & 0,18 & 0,12 & 0,25 \\
\hline $\mathrm{K}_{2} \mathrm{O}$ & n.d. & n.d. & n.d. & n.d. & n.d. & n.d. & n.d. & n.d. & n.d. & n.d. & n.d. & 0,04 & 0,01 & 0,00 & 0,02 & 0,00 \\
\hline $\mathrm{NiO}$ & n.d. & n.d. & n.d. & n.d. & n.d. & n.d. & n.d. & n.d. & n.d. & n.d. & n.d. & 0,14 & 0,01 & 0,17 & 0,15 & 0,16 \\
\hline Total & 98,91 & 100,00 & 100,96 & 99,90 & 98,24 & 100,24 & 100,90 & 99,67 & 99,86 & 99,84 & 100,43 & 99,17 & 98,55 & 101,14 & 99,20 & 99,80 \\
\hline YTi & 0,848 & 0,845 & 0,893 & 0,890 & 0,863 & 0,895 & 0,900 & 0,896 & 0,872 & 0,871 & 0,904 & 0,902 & 0,918 & 0,854 & 0,828 & 0,872 \\
\hline $\mathrm{YFe}^{3+}$ & 0,152 & 0,155 & 0,107 & 0,110 & 0,137 & 0,105 & 0,100 & 0,104 & 0,128 & 0,129 & 0,096 & 0,098 & 0,082 & 0,146 & 0,172 & 0,128 \\
\hline $\mathrm{Y}$ total & 1,000 & 1,000 & 1,000 & 1,000 & 1,000 & 1,000 & 1,000 & 1,000 & 1,000 & 1,000 & 1,000 & 1,000 & 1,000 & 1,000 & 1,000 & 1,000 \\
\hline $\mathrm{XFe}^{3+}$ & 0,000 & 0,000 & 0,053 & 0,059 & 0,087 & 0,053 & 0,051 & 0,052 & 0,056 & 0,062 & 0,034 & 0,002 & 0,093 & 0,100 & 0,113 & 0,098 \\
\hline $\mathrm{XFe}^{2+}$ & 0,474 & 0,472 & 0,541 & 0,583 & 0,551 & 0,587 & 0,574 & 0,582 & 0,554 & 0,554 & 0,591 & 0,557 & 0,592 & 0,546 & 0,534 & 0,614 \\
\hline $\mathrm{XMg}$ & 0,420 & 0,424 & 0,374 & 0,330 & 0,333 & 0,330 & 0,345 & 0,336 & 0,352 & 0,347 & 0,341 & 0,356 & 0,282 & 0,309 & 0,305 & 0,251 \\
\hline $\mathrm{XCr}$ & 0,094 & 0,094 & 0,020 & 0,020 & 0,019 & 0,019 & 0,018 & 0,020 & 0,026 & 0,024 & 0,023 & 0,044 & 0,001 & 0,020 & 0,023 & 0,014 \\
\hline $\mathrm{XMn}$ & 0,006 & 0,006 & 0,009 & 0,006 & 0,007 & 0,007 & 0,008 & 0,007 & 0,006 & 0,006 & 0,006 & 0,017 & 0,017 & 0,009 & 0,009 & 0,005 \\
\hline XAl & 0,003 & 0,004 & 0,003 & 0,002 & 0,002 & 0,004 & 0,003 & 0,002 & 0,004 & 0,006 & 0,006 & 0,003 & 0,000 & 0,003 & 0,004 & 0,001 \\
\hline $\mathrm{XNa}$ & 0,000 & 0,000 & 0,000 & 0,000 & 0,000 & 0,000 & 0,000 & 0,000 & 0,000 & 0,000 & 0,000 & 0,016 & 0,014 & 0,008 & 0,005 & 0,011 \\
\hline XK & 0,000 & 0,000 & 0,000 & 0,000 & 0,000 & 0,000 & 0,000 & 0,000 & 0,000 & 0,000 & 0,000 & 0,001 & 0,000 & 0,000 & 0,001 & 0,000 \\
\hline $\mathrm{XNi}$ & 0,000 & 0,000 & 0,000 & 0,000 & 0,000 & 0,000 & 0,000 & 0,000 & 0,000 & 0,000 & 0,000 & 0,003 & 0,000 & 0,003 & 0,003 & 0,003 \\
\hline $\mathrm{XCa}$ & 0,001 & 0,001 & 0,000 & 0,001 & 0,000 & 0,000 & 0,001 & 0,001 & 0,001 & 0,000 & 0,000 & 0,001 & 0,001 & 0,001 & 0,001 & 0,000 \\
\hline Xtotal & 1,000 & 1,000 & 0,999 & 0,999 & 1,000 & 0,999 & 1,000 & 1,000 & 0,999 & 1,000 & 1,000 & 1,000 & 1,000 & 0,999 & 0,999 & 0,997 \\
\hline FE3/FE2+FE3 & 0,243 & 0,247 & 0,228 & 0,224 & 0,289 & 0,211 & 0,208 & 0,212 & 0,250 & 0,257 & 0,181 & 0,152 & 0,228 & 0,311 & 0,348 & 0,270 \\
\hline \#mg & 0,428 & 0,433 & 0,408 & 0,361 & 0,377 & 0,359 & 0,375 & 0,366 & 0,388 & 0,385 & 0,366 & 0,390 & 0,322 & 0,361 & 0,363 & 0,290 \\
\hline $\mathrm{Fe}_{2} \mathrm{O}_{3}$ & 8,515 & 8,776 & 9,224 & 9,530 & 12,461 & 8,932 & 8,640 & 8,835 & 10,450 & 10,839 & 7,410 & 5,635 & 9,726 & 14,081 & 15,980 & 12,654 \\
\hline
\end{tabular}


Tabela 59- Composição química de ilmenita na matriz dos corpos Facão, Indaiá1 e Limeira 1 e Forca.

\begin{tabular}{|c|c|c|c|c|c|c|c|c|c|c|c|c|c|c|c|c|c|c|c|}
\hline $\begin{array}{l}\text { Código da } \\
\text { amostra }\end{array}$ & $\begin{array}{r}\text { Fac-6-11 } \\
\begin{array}{r}\text { ilmenita cc } \\
\text { macr }\end{array}\end{array}$ & $\begin{array}{l}\text { Fac-6- } \\
11^{\prime}\end{array}$ & $\begin{array}{l}\text { Inclusão em } \\
\text { livina }\end{array}$ & $\begin{array}{l}\text { Fo-2- } \\
10 \mathrm{~b}^{\prime \prime}\end{array}$ & Fo-3-12a & Fo-3-13 & $\begin{array}{l}\text { Fo-1- } \\
16 \mathrm{a}\end{array}$ & $\begin{array}{l}\text { Fo-1- } \\
16 \mathrm{e}\end{array}$ & $\begin{array}{l}\text { Fo-1- } \\
16 \mathrm{e}^{\prime \prime}\end{array}$ & $\begin{array}{l}\text { Fo-1-23b } \\
\text { borda de } \\
\text { xenólito }\end{array}$ & macrocristal & centro de macrocristal & Fo-6-6b & $\begin{array}{l}\text { Lm1-25-3 } \\
\text { macrocristal }\end{array}$ & $\begin{array}{c}\text { Lm1-32-4b } \\
\text { inclusão em } \\
\text { macrocristal } \\
\text { de olivina }\end{array}$ & In1-11-1a & In1-36-2a' & $\begin{array}{l}\text { In1-36- } \\
2 c^{\prime}\end{array}$ & $\begin{array}{c}\text { In1-36- } \\
9 \mathrm{~b}\end{array}$ \\
\hline $\mathrm{SiO}_{2}$ & 0,00 & 0,02 & 0,00 & 0,04 & 0,04 & 0,00 & 0,04 & 0,05 & 0,02 & 0,06 & 0,03 & 0,02 & 0,01 & 0,00 & 0,01 & 0,14 & 0,11 & 0,02 & 0,12 \\
\hline $\mathrm{TiO}_{2}$ & 55,22 & 55,90 & 55,10 & 50,56 & 50,16 & 51,65 & 53,13 & 54,98 & 54,42 & 52,83 & 50,92 & 48,34 & 50,74 & 51,07 & 51,02 & 51,12 & 55,73 & 56,16 & 53,27 \\
\hline $\mathrm{Al}_{2} \mathrm{O}_{3}$ & 0,00 & 0,01 & 0,00 & 0,39 & 0,41 & 0,20 & 0,61 & 0,22 & 0,41 & 1,11 & 0,38 & 0,32 & 0,58 & 0,06 & 0,11 & 0,00 & 0,09 & 0,07 & 0,14 \\
\hline $\mathrm{Cr}_{2} \mathrm{O}_{3}$ & 0,51 & 0,90 & 1,00 & 0,07 & 0,06 & 0,95 & 0,23 & 0,41 & 0,21 & 1,81 & 0,16 & 2,40 & 0,63 & 3,23 & 3,46 & 1,23 & 1,77 & 1,61 & 1,45 \\
\hline $\mathrm{MgO}$ & 11,62 & 11,97 & 11,98 & 8,38 & 8,80 & 9,15 & 12,80 & 20,23 & 17,38 & 20,41 & 8,40 & 8,35 & 9,42 & 12,33 & 12,39 & 12,27 & 15,76 & 15,00 & 9,89 \\
\hline $\mathrm{CaO}$ & 0,00 & 0,03 & 0,00 & 0,07 & 0,01 & 0,00 & 0,06 & 0,67 & 0,80 & 0,26 & 0,04 & 0,04 & 0,04 & 0,01 & 0,00 & 0,06 & 0,18 & 0,17 & 0,01 \\
\hline $\mathrm{MnO}$ & 0,21 & 0,39 & 0,32 & 0,31 & 0,37 & 0,33 & 0,49 & 0,79 & 0,77 & 0,85 & 0,27 & 0,27 & 0,29 & 0,57 & 0,47 & 0,66 & 1,20 & 0,91 & 0,35 \\
\hline $\mathrm{FeO}$ & 31,13 & 31,33 & 30,36 & 38,87 & 38,41 & 36,58 & 32,98 & 23,43 & 26,39 & 23,37 & 39,27 & 38,98 & 38,20 & 30,71 & 31,50 & 33,69 & 25,41 & 26,71 & 36,18 \\
\hline $\mathrm{Na}_{2} \mathrm{O}$ & 0,00 & 0,05 & 0,04 & 0,03 & 0,00 & 0,18 & 0,09 & 0,05 & 0,08 & 0,19 & 0,04 & 0,11 & 0,19 & 0,09 & 0,16 & 0,52 & 0,09 & 0,23 & 0,19 \\
\hline $\mathrm{K}_{2} \mathrm{O}$ & 0,00 & 0,01 & 0,04 & 0,03 & 0,00 & 0,01 & 0,00 & 0,00 & 0,00 & 0,05 & 0,00 & 0,01 & 0,00 & 0,05 & 0,06 & 0,00 & 0,05 & 0,02 & 0,03 \\
\hline $\mathrm{NiO}$ & 0,14 & 0,33 & 0,12 & 0,00 & 0,08 & 0,20 & 0,02 & 0,03 & 0,02 & 0,15 & 0,00 & 0,21 & 0,07 & 0,19 & 0,16 & 0,06 & 0,06 & 0,00 & 0,16 \\
\hline Total & 98,84 & 100,94 & 98,94 & 98,73 & 98,35 & 99,26 & 100,44 & 100,86 & 100,50 & 101,09 & 99,50 & 99,04 & 100,17 & 98,28 & 99,33 & 99,75 & 100,43 & 100,89 & 101,81 \\
\hline YTi & 0,972 & 0,963 & 0,967 & 0,906 & 0,899 & 0,918 & 0,907 & 0,888 & 0,898 & 0,849 & 0,906 & 0,869 & 0,889 & 0,903 & 0,892 & 0,880 & 0,939 & 0,946 & 0,921 \\
\hline $\mathrm{YFe}^{3+}$ & 0,028 & 0,037 & 0,033 & 0,094 & 0,101 & 0,082 & 0,093 & 0,112 & 0,102 & 0,151 & 0,094 & 0,131 & 0,111 & 0,097 & 0,108 & 0,120 & 0,061 & 0,054 & 0,079 \\
\hline $\mathrm{Y}$ total & 1,000 & 1,000 & 1,000 & 1,000 & 1,000 & 1,000 & 1,000 & 1,000 & 1,000 & 1,000 & 1,000 & 1,000 & 1,000 & 1,000 & 1,000 & 1,000 & 1,000 & 1,000 & 1,000 \\
\hline $\mathrm{XFe}^{3+}$ & 0,012 & 0,011 & 0,005 & 0,081 & 0,085 & 0,055 & 0,072 & 0,095 & 0,088 & 0,079 & 0,079 & 0,052 & 0,084 & 0,001 & 0,007 & 0,099 & 0,007 & 0,014 & 0,035 \\
\hline $\mathrm{XFe}^{2+}$ & 0,569 & 0,552 & 0,555 & 0,598 & 0,580 & 0,586 & 0,460 & 0,214 & 0,293 & 0,188 & 0,603 & 0,595 & 0,548 & 0,505 & 0,497 & 0,426 & 0,408 & 0,432 & 0,582 \\
\hline XMg & 0,405 & 0,409 & 0,417 & 0,297 & 0,313 & 0,322 & 0,433 & 0,647 & 0,568 & 0,650 & 0,296 & 0,297 & 0,327 & 0,432 & 0,429 & 0,419 & 0,526 & 0,501 & 0,339 \\
\hline $\mathrm{XCr}$ & 0,006 & 0,011 & 0,012 & 0,001 & 0,001 & 0,012 & 0,003 & 0,005 & 0,002 & 0,020 & 0,002 & 0,030 & 0,008 & 0,040 & 0,042 & 0,015 & 0,021 & 0,019 & 0,018 \\
\hline XMn & 0,004 & 0,008 & 0,006 & 0,006 & 0,007 & 0,007 & 0,009 & 0,014 & 0,014 & 0,015 & 0,005 & 0,006 & 0,006 & 0,011 & 0,009 & 0,013 & 0,023 & 0,017 & 0,007 \\
\hline XAl & 0,000 & 0,000 & 0,000 & 0,011 & 0,012 & 0,006 & 0,016 & 0,006 & 0,011 & 0,028 & 0,010 & 0,009 & 0,016 & 0,002 & 0,003 & 0,000 & 0,002 & 0,002 & 0,004 \\
\hline $\mathrm{XNa}$ & 0,000 & 0,002 & 0,002 & 0,001 & 0,000 & 0,008 & 0,004 & 0,002 & 0,003 & 0,008 & 0,002 & 0,005 & 0,009 & 0,004 & 0,007 & 0,023 & 0,004 & 0,010 & 0,009 \\
\hline XK & 0,000 & 0,000 & 0,001 & 0,001 & 0,000 & 0,000 & 0,000 & 0,000 & 0,000 & 0,001 & 0,000 & 0,000 & 0,000 & 0,001 & 0,002 & 0,000 & 0,001 & 0,000 & 0,001 \\
\hline $\mathrm{XNi}$ & 0,003 & 0,006 & 0,002 & 0,000 & 0,002 & 0,004 & 0,000 & 0,001 & 0,000 & 0,003 & 0,000 & 0,004 & 0,001 & 0,004 & 0,003 & 0,001 & 0,001 & 0,000 & 0,003 \\
\hline $\mathrm{XCa}$ & 0,000 & 0,001 & 0,000 & 0,002 & 0,000 & 0,000 & 0,001 & 0,015 & 0,019 & 0,006 & 0,001 & 0,001 & 0,001 & 0,000 & 0,000 & 0,002 & 0,004 & 0,004 & 0,000 \\
\hline Xtotal & 1,000 & 0,999 & 1,000 & 0,999 & 0,999 & 1,000 & 0,999 & 0,999 & 0,999 & 0,999 & 0,999 & 1,000 & 1,000 & 1,000 & 1,000 & 0,997 & 0,998 & 0,999 & 0,997 \\
\hline FE3/FE2+FE3 & 0,065 & 0,080 & 0,064 & 0,227 & 0,243 & 0,189 & 0,265 & 0,492 & 0,394 & 0,549 & 0,223 & 0,235 & 0,263 & 0,163 & 0,189 & 0,339 & 0,143 & 0,136 & 0,163 \\
\hline$\# \mathrm{mg}$ & 0,416 & 0,425 & 0,429 & 0,332 & 0,350 & 0,355 & 0,485 & 0,752 & 0,659 & 0,775 & 0,329 & 0,333 & 0,374 & 0,461 & 0,464 & 0,496 & 0,563 & 0,537 & 0,368 \\
\hline $\mathrm{Fe} 2 \mathrm{O} 3$ & 2,266 & 2,779 & 2,150 & 9,803 & 10,364 & 7,692 & 9,709 & 12,810 & 11,544 & 14,259 & 9,745 & 10,187 & 11,171 & 5,563 & 6,607 & 12,705 & 4,031 & 4,026 & 6,543 \\
\hline
\end{tabular}


Tabela 60- Composição química de flogopita de xenólitos dos corpos Indaiá 1 e Limeira 1.

\begin{tabular}{|c|c|c|c|c|c|c|c|c|c|c|c|c|c|c|c|c|c|c|c|}
\hline $\begin{array}{l}\text { Código da } \\
\text { amostra }\end{array}$ & Fac-5-2 & & Lm1-1-4 & $\begin{array}{l}\text { Lm1-1- } \\
4 \mathrm{~b}\end{array}$ & Lm1-1-8 & Lm1-15-6' & $\begin{array}{c}\mathrm{Lm} 1-15- \\
13\end{array}$ & $\begin{array}{l}\text { Lm1-15- } \\
\quad 15\end{array}$ & Lm1-22-18 & Lm1-22-6 & Lm1-22-5 & In1-1-1 & $\begin{array}{l}\text { In1- } \\
1-2\end{array}$ & In1-2-1 & $\underset{2}{\text { In1-2- }}$ & $\underset{3}{\text { In1-2- }}$ & $\underset{4}{\text { In1-2- }}$ & $\begin{array}{l}\text { In1-2- } \\
5\end{array}$ & $\begin{array}{c}\text { In1-2- } \\
6\end{array}$ \\
\hline Tipo & $\begin{array}{c}\text { flogopita } \\
\text { piroxenito }\end{array}$ & $\begin{array}{c}\text { flogopita } \\
\text { dunito com } \\
\text { Cr-espinélio }\end{array}$ & \multicolumn{3}{|c|}{$\begin{array}{l}\text { harzburgito com bolsões de } \\
\text { flogopita e titanato }\end{array}$} & \multicolumn{3}{|c|}{$\begin{array}{l}\text { harzburgito com bolsões de } \\
\text { flogopita }\end{array}$} & flogopita $\mathrm{d} \mathrm{t}$ & com clinopirc & secundário & \multicolumn{2}{|c|}{$\begin{array}{l}\text { harzburgito } \\
\text { porfiroclástico }\end{array}$} & \multicolumn{6}{|c|}{ flogopita dunito } \\
\hline $\mathrm{SiO}_{2}$ & 39,98 & 40,06 & 41,09 & 41,81 & 39,81 & 41,44 & 42,47 & 43,21 & 41,92 & 41,54 & 41,54 & 40,84 & 39,89 & 40,86 & 40,72 & 40,51 & 40,34 & 40,75 & 40,41 \\
\hline $\mathrm{TiO}_{2}$ & 5,54 & 2,43 & 2,75 & 2,76 & 2,81 & 0,71 & 0,47 & 0,87 & 1,74 & 1,65 & 1,73 & 5,53 & 5,37 & 2,01 & 1,97 & 1,72 & 2,19 & 1,97 & 2,13 \\
\hline $\mathrm{Al}_{2} \mathrm{O}_{3}$ & 10,50 & 12,53 & 12,57 & 12,80 & 12,57 & 12,65 & 11,90 & 12,28 & 12,07 & 11,86 & 12,07 & 10,78 & 12,35 & 11,49 & 11,59 & 11,60 & 11,61 & 11,62 & 11,55 \\
\hline $\mathrm{FeO}$ & 6,12 & 3,84 & 4,63 & 4,71 & 4,47 & 3,18 & 3,24 & 3,12 & 4,79 & 4,61 & 4,37 & 5,99 & 6,64 & 4,38 & 4,35 & 4,64 & 4,42 & 4,43 & 4,75 \\
\hline $\mathrm{MnO}$ & 0,05 & 0,00 & 0,00 & 0,04 & 0,09 & 0,01 & 0,05 & 0,03 & 0,01 & 0,05 & 0,00 & 0,02 & 0,03 & 0,02 & 0,04 & 0,02 & 0,05 & 0,01 & 0,01 \\
\hline $\mathrm{MgO}$ & 21,33 & 22,57 & 22,69 & 22,56 & 23,25 & 24,95 & 25,50 & 24,29 & 23,78 & 23,79 & 23,42 & 22,02 & 20,57 & 24,06 & 24,19 & 24,04 & 24,09 & 24,05 & 24,11 \\
\hline $\mathrm{CaO}$ & 0,03 & 0,00 & 0,00 & 0,00 & 0,06 & 0,00 & 0,02 & 0,00 & 0,00 & 0,00 & 0,00 & 0,00 & 0,07 & 0,03 & 0,07 & 0,02 & 0,02 & 0,00 & 0,01 \\
\hline $\mathrm{Na}_{2} \mathrm{O}$ & 0,46 & 0,18 & 0,07 & 0,03 & 0,02 & 0,37 & 0,27 & 0,15 & 0,00 & 0,00 & 0,05 & 0,38 & 0,24 & 0,15 & 0,05 & 0,09 & 0,12 & 0,04 & 0,07 \\
\hline $\mathrm{K}_{2} \mathrm{O}$ & 10,12 & 10,81 & 10,92 & 9,63 & 11,07 & 10,30 & 9,98 & 8,61 & 8,80 & 10,89 & 9,44 & 10,42 & 10,62 & 10,98 & 10,75 & 10,67 & 10,60 & 10,71 & 10,88 \\
\hline $\mathrm{BaO}$ & n.d. & n.d. & n.d. & n.d. & n.d. & n.d. & n.d. & n.d. & n.d. & n.d. & n.d. & n.d. & n.d. & n.d. & n.d. & n.d. & n.d. & n.d. & n.d. \\
\hline $\mathrm{Cr}_{2} \mathrm{O}_{3}$ & 0,02 & 1,46 & 1,40 & 1,25 & 1,16 & 1,05 & 1,09 & 1,19 & 0,69 & 0,71 & 0,74 & n.d. & n.d. & n.d. & n.d. & n.d. & n.d. & n.d. & n.d. \\
\hline $\mathrm{NiO}$ & 0,12 & 0,18 & 0,22 & 0,24 & 0,18 & 0,30 & 0,26 & 0,21 & 0,20 & 0,20 & 0,28 & n.d. & n.d. & n.d. & n.d. & n.d. & n.d. & n.d. & n.d. \\
\hline Total & 94,26 & 94,05 & 96,34 & 95,84 & 95,51 & 94,96 & 95,24 & 93,97 & 93,99 & 95,30 & 93,64 & 95,97 & 95,77 & 93,97 & 93,74 & 93,31 & 93,43 & 93,57 & 93,92 \\
\hline $\mathrm{TSi}$ & 5,956 & 5,904 & 5,942 & 6,094 & 5,779 & 5,952 & 6,085 & 6,328 & 6,172 & 6,012 & 6,132 & 5,963 & 5,865 & 5,955 & 5,950 & 5,945 & 5,916 & 5,969 & 5,900 \\
\hline TAl & 1,843 & 2,096 & 2,058 & 1,906 & 2,151 & 2,048 & 1,915 & 1,672 & 1,828 & 1,988 & 1,868 & 1,856 & 2,135 & 1,973 & 1,996 & 2,007 & 2,006 & 2,005 & 1,988 \\
\hline $\mathrm{TFe}^{3+}$ & 0,201 & 0,000 & 0,000 & 0,000 & 0,070 & 0,000 & 0,000 & 0,000 & 0,000 & 0,000 & 0,000 & 0,181 & 0,000 & 0,072 & 0,054 & 0,048 & 0,078 & 0,026 & 0,113 \\
\hline Ttotal & 8,000 & 8,000 & 8,000 & 8,000 & 8,000 & 8,000 & 8,000 & 8,000 & 8,000 & 8,000 & 8,000 & 8,000 & 8,000 & 8,000 & 8,000 & 8,000 & 8,000 & 8,000 & 8,000 \\
\hline MAl & 0,000 & 0,080 & 0,083 & 0,293 & 0,000 & 0,093 & 0,095 & 0,447 & 0,268 & 0,036 & 0,232 & 0,000 & 0,006 & 0,000 & 0,000 & 0,000 & 0,000 & 0,000 & 0,000 \\
\hline $\mathrm{MMg}$ & 4,735 & 4,959 & 4,890 & 4,902 & 5,032 & 5,343 & 5,447 & 5,303 & 5,220 & 5,133 & 5,153 & 4,792 & 4,509 & 5,228 & 5,270 & 5,259 & 5,268 & 5,253 & 5,248 \\
\hline $\mathrm{MFe}^{2+}$ & 0,561 & 0,473 & 0,560 & 0,574 & 0,473 & 0,382 & 0,388 & 0,382 & 0,590 & 0,558 & 0,540 & 0,550 & 0,817 & 0,461 & 0,478 & 0,522 & 0,465 & 0,517 & 0,467 \\
\hline $\mathrm{MFe}^{3+}$ & 0,000 & 0,000 & 0,000 & 0,000 & 0,000 & 0,000 & 0,000 & 0,000 & 0,000 & 0,000 & 0,000 & 0,000 & 0,000 & 0,000 & 0,000 & 0,000 & 0,000 & 0,000 & 0,000 \\
\hline MTi & 0,621 & 0,269 & 0,300 & 0,303 & 0,307 & 0,076 & 0,050 & 0,095 & 0,193 & 0,180 & 0,192 & 0,607 & 0,594 & 0,220 & 0,216 & 0,190 & 0,241 & 0,217 & 0,234 \\
\hline MMn & 0,006 & 0,000 & 0,000 & 0,005 & 0,011 & 0,001 & 0,005 & 0,004 & 0,001 & 0,006 & 0,000 & 0,003 & 0,004 & 0,003 & 0,005 & 0,002 & 0,007 & 0,001 & 0,001 \\
\hline $\mathrm{MCr}$ & 0,001 & 0,113 & 0,107 & 0,096 & 0,089 & 0,080 & 0,082 & 0,092 & 0,053 & 0,054 & 0,057 & 0,000 & 0,000 & 0,000 & 0,000 & 0,000 & 0,000 & 0,000 & 0,000 \\
\hline Mtotal & 5,926 & 5,895 & 5,940 & 6,174 & 5,912 & 5,975 & 6,068 & 6,323 & 6,324 & 5,966 & 6,174 & 5,953 & 5,930 & 5,911 & 5,969 & 5,974 & 5,981 & 5,988 & 5,950 \\
\hline IK & 1,923 & 2,032 & 2,014 & 1,790 & 2,050 & 1,887 & 1,825 & 1,609 & 1,652 & 2,010 & 1,778 & 1,941 & 1,993 & 2,042 & 2,005 & 1,998 & 1,983 & 2,001 & 2,027 \\
\hline INa & 0,133 & 0,052 & 0,020 & 0,008 & 0,007 & 0,103 & 0,074 & 0,043 & 0,000 & 0,000 & 0,014 & 0,106 & 0,067 & 0,041 & 0,015 & 0,024 & 0,033 & 0,012 & 0,020 \\
\hline $\mathrm{ICa}$ & 0,005 & 0,000 & 0,000 & 0,000 & 0,010 & 0,000 & 0,004 & 0,000 & 0,000 & 0,000 & 0,000 & 0,000 & 0,010 & 0,005 & 0,011 & 0,003 & 0,003 & 0,000 & 0,002 \\
\hline IBa & 0,000 & 0,000 & 0,000 & 0,000 & 0,000 & 0,000 & 0,000 & 0,000 & 0,000 & 0,000 & 0,000 & 0,000 & 0,000 & 0,000 & 0,000 & 0,000 & 0,000 & 0,000 & 0,000 \\
\hline Itotal & 2,061 & 2,084 & 2,034 & 1,798 & 2,067 & 1,990 & 1,902 & 1,651 & 1,652 & 2,010 & 1,792 & 2,047 & 2,070 & 2,089 & 2,031 & 2,026 & 2,019 & 2,012 & 2,050 \\
\hline$\# \mathrm{Mg}$ & 0,861 & 0,913 & 0,897 & 0,895 & 0,903 & 0,933 & 0,933 & 0,933 & 0,898 & 0,902 & 0,905 & 0,868 & 0,847 & 0,907 & 0,908 & 0,902 & 0,907 & 0,906 & 0,901 \\
\hline $\mathrm{Al} /(\mathrm{Al}+\mathrm{Cr})$ & 0,999 & 0,951 & 0,953 & 0,958 & 0,960 & 0,964 & 0,961 & 0,959 & 0,975 & 0,974 & 0,973 & 1,000 & 1,000 & 1,000 & 1,000 & 1,000 & 1,000 & 1,000 & 1,000 \\
\hline $\mathrm{FeOt}$ & 6,120 & 3,841 & 4,630 & 4,713 & 4,474 & 3,184 & 3,239 & 3,121 & 4,789 & 4,609 & 4,371 & 5,991 & 6,641 & 4,375 & 4,353 & 4,641 & 4,422 & 4,427 & 4,746 \\
\hline
\end{tabular}


Tabela 61- Composição química de flogopita de xenólitos dos corpos Indaiá 1.

\begin{tabular}{|c|c|c|c|c|c|c|c|c|c|c|c|c|c|c|}
\hline $\begin{array}{l}\text { Código da } \\
\text { amostra }\end{array}$ & $\begin{array}{c}\text { In1-20b-4 } \\
\text { harzburg }\end{array}$ & $\begin{array}{l}\text { In1-20b-5 } \\
\text { com bolsões }\end{array}$ & $\begin{array}{l}\text { In1-20b-6 } \\
\text { flogopita }\end{array}$ & In1-24b-1 & In1-24b-2 & $\begin{array}{r}\text { In1-24b-3 } \\
\text { flo }\end{array}$ & $\begin{array}{l}\text { In1-24b-4 } \\
\text { tito }\end{array}$ & In1-24b-5 & In1-24b-6 & Lm1-26a-4a & $\begin{array}{l}\text { Lm1-26a-11a } \\
\text { rzburgito com b }\end{array}$ & $\begin{array}{c}\text { Lm1-26a- } \\
11 \mathrm{~b} \\
\text { sões de flog }\end{array}$ & Lm1-26a-11c & $\begin{array}{l}\text { Lm1-28-1e } \\
\text { dunito com } \\
\text { bolsões de }\end{array}$ \\
\hline Tipo & \multicolumn{3}{|c|}{ harzburgito com bolsões de flogopita } & \multicolumn{6}{|c|}{ flogopitito } & \multicolumn{4}{|c|}{ harzburgito com bolsões de flogopita } & flogopita \\
\hline $\begin{array}{l}\mathrm{SiO}_{2} \\
\mathrm{TiO}_{2}\end{array}$ & $\begin{array}{c}39,68 \\
2,34\end{array}$ & $\begin{array}{c}39,22 \\
2,01\end{array}$ & $\begin{array}{c}38,05 \\
2,35\end{array}$ & $\begin{array}{c}40,37 \\
3,24\end{array}$ & $\begin{array}{c}39,86 \\
3,25\end{array}$ & $\begin{array}{c}41,09 \\
3,08\end{array}$ & $\begin{array}{c}40,87 \\
3,17\end{array}$ & $\begin{array}{c}40,53 \\
3,14\end{array}$ & $\begin{array}{c}40,89 \\
3,08\end{array}$ & $\begin{array}{l}39,14 \\
2,77\end{array}$ & $\begin{array}{c}40,51 \\
2,67\end{array}$ & $\begin{array}{c}41,25 \\
2,68\end{array}$ & $\begin{array}{c}39,59 \\
2,75\end{array}$ & $\begin{array}{c}43,32 \\
0,54\end{array}$ \\
\hline $\begin{array}{c}\mathrm{TiO}_{2} \\
\mathrm{Al}_{2} \mathrm{O}_{3}\end{array}$ & 14,26 & 13,97 & 13,66 & 11,94 & 12,13 & 11,91 & 12,17 & $\begin{array}{r}3,14 \\
12,14\end{array}$ & $\begin{array}{r}3,08 \\
12,32\end{array}$ & $\begin{array}{c}2,77 \\
12,35\end{array}$ & $\begin{array}{l}2,6 / 1 \\
12,17\end{array}$ & 12,30 & $\begin{array}{c}2,75 \\
12,36\end{array}$ & $\begin{array}{l}0,54 \\
9,21\end{array}$ \\
\hline $\mathrm{FeO}$ & 2,91 & 2,77 & 2,98 & 5,93 & 5,75 & 5,91 & 5,73 & 5,83 & 5,61 & 5,25 & 5,33 & 5,43 & 5,19 & 4,57 \\
\hline $\mathrm{MnO}$ & 0,05 & 0,01 & 0,01 & 0,05 & 0,00 & 0,03 & 0,01 & 0,02 & 0,04 & 0,07 & 0,09 & 0,02 & 0,01 & 0,00 \\
\hline $\mathrm{MgO}$ & 23,11 & 23,28 & 23,02 & 22,52 & 22,81 & 23,18 & 22,91 & 22,89 & 22,98 & 21,61 & 22,77 & 22,57 & 22,66 & 24,67 \\
\hline $\mathrm{CaO}$ & 0,01 & 0,01 & 0,03 & 0,02 & 0,06 & 0,00 & 0,00 & 0,01 & 0,02 & 0,01 & 0,00 & 0,00 & 0,01 & 0,06 \\
\hline $\mathrm{Na}_{2} \mathrm{O}$ & 0,21 & 0,22 & 0,23 & 0,07 & 0,08 & 0,03 & 0,04 & 0,12 & 0,09 & 0,16 & 0,04 & 0,10 & 0,21 & 0,35 \\
\hline $\mathrm{K}_{2} \mathrm{O}$ & 10,52 & 10,14 & 10,52 & 10,59 & 10,64 & 10,70 & 10,62 & 10,72 & 10,61 & 10,07 & 11,13 & 10,82 & 11,03 & 10,43 \\
\hline $\mathrm{BaO}$ & n.d. & n.d. & n.d. & n.d. & n.d. & n.d. & n.d. & n.d. & n.d. & n.d. & n.d. & n.d. & n.d. & n.d. \\
\hline $\mathrm{Cr}_{2} \mathrm{O}_{3}$ & 2,09 & 2,05 & 2,19 & 0,44 & 0,39 & 0,33 & 0,36 & 0,42 & 0,47 & 1,25 & 1,06 & 1,02 & 1,11 & 0,40 \\
\hline $\mathrm{NiO}$ & n.d. & n.d. & n.d. & n.d. & n.d. & n.d. & n.d. & n.d. & n.d. & 0,30 & 0,21 & 0,22 & 0,43 & 0,22 \\
\hline Total & 95,18 & 93,68 & 93,05 & 95,16 & 94,98 & 96,26 & 95,87 & 95,81 & 96,10 & 92,97 & 95,99 & 96,40 & 95,35 & 93,78 \\
\hline $\mathrm{TSi}$ & 5,766 & 5,774 & 5,648 & 5,907 & 5,828 & 5,931 & 5,925 & 5,877 & 5,911 & 5,880 & 5,874 & 5,964 & 5,770 & 6,323 \\
\hline TAl & 2,234 & 2,226 & 2,352 & 2,060 & 2,090 & 2,026 & 2,075 & 2,074 & 2,089 & 2,120 & 2,080 & 2,036 & 2,123 & 1,584 \\
\hline $\mathrm{TFe}^{3+}$ & 0,000 & 0,000 & 0,000 & 0,033 & 0,081 & 0,044 & 0,000 & 0,049 & 0,000 & 0,000 & 0,046 & 0,000 & 0,108 & 0,093 \\
\hline Ttotal & 8,000 & 8,000 & 8,000 & 8,000 & 8,000 & 8,000 & 8,000 & 8,000 & 8,000 & 8,000 & 8,000 & 8,000 & 8,000 & 8,000 \\
\hline Mal & 0,209 & 0,197 & 0,037 & 0,000 & 0,000 & 0,000 & 0,004 & 0,000 & 0,009 & 0,067 & 0,000 & 0,059 & 0,000 & 0,000 \\
\hline $\mathrm{MMg}$ & 5,005 & 5,110 & 5,094 & 4,913 & 4,972 & 4,987 & 4,951 & 4,948 & 4,951 & 4,840 & 4,922 & 4,864 & 4,924 & 5,366 \\
\hline $\mathrm{MFe}^{2+}$ & 0,354 & 0,341 & 0,370 & 0,693 & 0,622 & 0,670 & 0,694 & 0,657 & 0,678 & 0,660 & 0,600 & 0,656 & 0,525 & 0,466 \\
\hline $\mathrm{MFe}^{3+}$ & 0,000 & 0,000 & 0,000 & 0,000 & 0,000 & 0,000 & 0,000 & 0,000 & 0,000 & 0,000 & 0,000 & 0,000 & 0,000 & 0,000 \\
\hline MTi & 0,256 & 0,223 & 0,262 & 0,356 & 0,357 & 0,334 & 0,345 & 0,342 & 0,334 & 0,313 & 0,292 & 0,292 & 0,302 & 0,059 \\
\hline MMn & 0,006 & 0,001 & 0,002 & 0,006 & 0,000 & 0,004 & 0,002 & 0,003 & 0,005 & 0,009 & 0,011 & 0,002 & 0,001 & 0,000 \\
\hline $\mathrm{MCr}$ & 0,160 & 0,159 & 0,171 & 0,034 & 0,030 & 0,025 & 0,027 & 0,032 & 0,036 & 0,099 & 0,081 & 0,077 & 0,086 & 0,031 \\
\hline Mtotal & 5,991 & 6,031 & 5,936 & 6,001 & 5,982 & 6,020 & 6,024 & 5,982 & 6,014 & 5,987 & 5,905 & 5,951 & 5,837 & 5,922 \\
\hline IK & 1,949 & 1,905 & 1,992 & 1,976 & 1,985 & 1,970 & 1,964 & 1,983 & 1,956 & 1,929 & 2,059 & 1,995 & 2,052 & 1,943 \\
\hline INa & 0,058 & 0,063 & 0,066 & 0,020 & 0,024 & 0,010 & 0,012 & 0,034 & 0,026 & 0,046 & 0,011 & 0,029 & 0,059 & 0,100 \\
\hline $\mathrm{ICa}$ & 0,002 & 0,001 & 0,005 & 0,003 & 0,010 & 0,000 & 0,000 & 0,002 & 0,004 & 0,002 & 0,000 & 0,000 & 0,002 & 0,010 \\
\hline $\mathrm{IBa}$ & 0,000 & 0,000 & 0,000 & 0,000 & 0,000 & 0,000 & 0,000 & 0,000 & 0,000 & 0,000 & 0,000 & 0,000 & 0,000 & 0,000 \\
\hline Itotal & 2,009 & 1,969 & 2,064 & 1,999 & 2,018 & 1,980 & 1,976 & 2,018 & 1,986 & 1,977 & 2,070 & 2,024 & 2,113 & 2,052 \\
\hline$\# \mathrm{Mg}$ & 0,934 & 0,937 & 0,932 & 0,871 & 0,876 & 0,875 & 0,877 & 0,875 & 0,880 & 0,880 & 0,884 & 0,881 & 0,886 & 0,906 \\
\hline $\mathrm{Al} /(\mathrm{Al}+\mathrm{Cr})$ & 0,938 & 0,938 & 0,933 & 0,984 & 0,986 & 0,988 & 0,987 & 0,985 & 0,983 & 0,957 & 0,963 & 0,964 & 0,961 & 0,981 \\
\hline
\end{tabular}


Tabela 62- Composição química de flogopita de xenólitos dos corpos Indaiá1 e Limeira 1.

\begin{tabular}{|c|c|c|c|c|c|c|c|c|c|c|c|c|c|c|}
\hline $\begin{array}{l}\text { Código da } \\
\text { amostra }\end{array}$ & In1-6-1 & In1-6-2 & In1-6-3 & $\begin{array}{r}\text { In1-6-4 } \\
\text { flogopita }\end{array}$ & $\begin{array}{l}\text { In1-6-5 } \\
\text { ta wehrlito }\end{array}$ & In1-6-6 & In1-6-7 & In1-6-8 & Lm1-38-6a & $\begin{array}{l}\text { Lm1-38-11b } \\
\text { logopita wehrli }\end{array}$ & Lm1-38-4f & \multirow{3}{*}{$\begin{array}{c}\text { Lm1-41-4a } \\
\text { flogopita } \\
\text { piroxenito } \\
42,20\end{array}$} & \multirow{3}{*}{$\begin{array}{c}\text { Lm1-14-4c' } \\
\text { dunito } \\
\text { protogranular } \\
40,54\end{array}$} & \multirow{3}{*}{$\begin{array}{c}\text { Lm1-32-2g } \\
\text { dunito } \\
\text { porfiroclástico } \\
40,29\end{array}$} \\
\hline $\begin{array}{l}\text { Tipo } \\
\mathrm{SiO}_{2}\end{array}$ & \multicolumn{8}{|c|}{ flogopita ilmenita wehrlito } & \multicolumn{3}{|c|}{ flogopita wehrlito } & & & \\
\hline $\mathrm{SiO}_{2}$ & $\begin{array}{l}41,00 \\
1,81\end{array}$ & $\begin{array}{l}41,31 \\
1,42\end{array}$ & $\begin{array}{c}41,58 \\
1,51\end{array}$ & $\begin{array}{c}41,42 \\
1,37\end{array}$ & 1,51 & 1,52 & $\begin{array}{l}4,24 \\
1,44\end{array}$ & $\begin{array}{l}41,31 \\
1,40\end{array}$ & $\begin{array}{r}40,81 \\
124\end{array}$ & $\begin{array}{r}41,20 \\
1.26\end{array}$ & $\begin{array}{l}40,91 \\
124\end{array}$ & & & \\
\hline $\begin{array}{c}\mathrm{TiO}_{2} \\
\mathrm{Al}_{2} \mathrm{O}_{3}\end{array}$ & $\begin{array}{c}1,81 \\
11,06\end{array}$ & $\begin{array}{c}1,42 \\
10,98\end{array}$ & $\begin{array}{c}1,51 \\
11,18\end{array}$ & $\begin{array}{c}1,37 \\
10,96\end{array}$ & 11,03 & $\begin{array}{l}1,32 \\
11,07\end{array}$ & $\begin{array}{l}1,44 \\
10,75\end{array}$ & $\begin{array}{c}1,40 \\
11,11\end{array}$ & $\begin{array}{c}1,24 \\
11,51\end{array}$ & $\begin{array}{c}1,26 \\
11,65\end{array}$ & $\begin{array}{c}1,24 \\
11,50\end{array}$ & $\begin{array}{c}1,66 \\
11,44\end{array}$ & $\begin{array}{c}2,39 \\
12,75\end{array}$ & $\begin{array}{c}4,43 \\
13,27\end{array}$ \\
\hline $\begin{array}{l}\mathrm{Al}_{2} \mathrm{O}_{3} \\
\mathrm{FeO}\end{array}$ & 6,36 & 6,41 & 6,48 & 6,60 & 6,51 & 6,31 & 6,29 & 6,01 & 4,26 & 3,87 & $\begin{array}{l}1,50 \\
3,60\end{array}$ & $\begin{array}{l}1,01 \\
5,01\end{array}$ & $\begin{array}{c}12,75 \\
3,11\end{array}$ & $\begin{array}{c}13,27 \\
5,57\end{array}$ \\
\hline $\mathrm{MnO}$ & 0,02 & 0,05 & 0,01 & 0,03 & 0,03 & 0,05 & 0,03 & 0,02 & 0,00 & 0,02 & 0,01 & 0,00 & 0,02 & 0,09 \\
\hline $\mathrm{MgO}$ & 24,32 & 24,23 & 24,63 & 24,36 & 24,44 & 24,07 & 24,54 & 24,21 & 23,74 & 24,53 & 24,05 & 23,78 & 24,27 & 21,39 \\
\hline $\mathrm{CaO}$ & 0,05 & 0,03 & 0,05 & 0,03 & 0,00 & 0,00 & 0,02 & 0,02 & 0,00 & 0,00 & 1,00 & 0,04 & 0,00 & 0,02 \\
\hline $\mathrm{Na}_{2} \mathrm{O}$ & 0,22 & 0,22 & 0,10 & 0,20 & 0,09 & 0,10 & 0,08 & 0,16 & 0,05 & 0,22 & 0,17 & 0,36 & 0,15 & 0,04 \\
\hline $\mathrm{K}_{2} \mathrm{O}$ & 10,61 & 10,80 & 10,78 & 10,85 & 10,81 & 10,87 & 10,78 & 10,67 & 10,70 & 10,24 & 10,54 & 11,10 & 11,11 & 10,39 \\
\hline $\mathrm{BaO}$ & n.d. & n.d. & n.d. & n.d. & n.d. & n.d. & n.d. & n.d. & n.d. & n.d. & n..d. & n.d. & n.d. & n.d. \\
\hline $\mathrm{Cr}_{2} \mathrm{O}_{3}$ & 0,17 & 0,18 & 0,21 & 0,13 & 0,21 & 0,20 & 0,19 & 0,19 & 0,93 & 0,70 & 0,85 & 0,30 & 1,31 & 0,98 \\
\hline $\mathrm{NiO}$ & n.d. & n.d. & n.d. & n.d. & n.d. & n.d. & n.d. & n.d. & 0,28 & 0,25 & 0,27 & 0,14 & 0,23 & 0,11 \\
\hline Total & 95,99 & 95,69 & 96,53 & 95,94 & 96,37 & 95,43 & 95,34 & 95,35 & 93,52 & 93,94 & 94,13 & 96,02 & 95,89 & 96,59 \\
\hline $\mathrm{TSi}$ & 5,939 & 5,951 & 5,933 & 5,941 & 5,970 & 5,957 & 5,951 & 5,998 & 6,006 & 6,006 & 5,963 & 6,042 & 5,817 & 5,869 \\
\hline TAl & 1,871 & 1,861 & 1,880 & 1,853 & 1,860 & 1,883 & 1,828 & 1,889 & 1,994 & 1,994 & 1,975 & 1,931 & 2,156 & 2,131 \\
\hline $\mathrm{TFe}^{3+}$ & 0,190 & 0,189 & 0,187 & 0,207 & 0,170 & 0,160 & 0,221 & 0,113 & 0,000 & 0,000 & 0,062 & 0,027 & 0,026 & 0,000 \\
\hline Ttotal & 8,000 & 8,000 & 8,000 & 8,000 & 8,000 & 8,000 & 8,000 & 8,000 & 8,000 & 8,000 & 8,000 & 8,000 & 8,000 & 8,000 \\
\hline Mal & 0,000 & 0,000 & 0,000 & 0,000 & 0,000 & 0,000 & 0,000 & 0,000 & 0,003 & 0,008 & 0,000 & 0,000 & 0,000 & 0,147 \\
\hline MMg & 5,205 & 5,196 & 5,238 & 5,210 & 5,211 & 5,181 & 5,279 & 5,208 & 5,209 & 5,329 & 5,225 & 5,076 & 5,190 & 4,645 \\
\hline $\mathrm{MFe}^{2+}$ & 0,574 & 0,583 & 0,586 & 0,585 & 0,609 & 0,601 & 0,538 & 0,611 & 0,524 & 0,472 & 0,377 & 0,572 & 0,347 & 0,679 \\
\hline $\mathrm{MFe}^{3+}$ & 0,000 & 0,000 & 0,000 & 0,000 & 0,000 & 0,000 & 0,000 & 0,000 & 0,000 & 0,000 & 0,000 & 0,000 & 0,000 & 0,000 \\
\hline $\mathrm{MCr}$ & 0,013 & 0,013 & 0,016 & 0,010 & 0,016 & 0,015 & 0,014 & 0,014 & 0,072 & 0,054 & 0,065 & 0,022 & 0,099 & 0,075 \\
\hline Mtotal & 5,989 & 5,952 & 6,004 & 5,955 & 6,002 & 5,969 & 5,990 & 5,989 & 5,945 & 6,003 & 5,804 & 5,850 & 5,897 & 6,043 \\
\hline IK & 1,943 & 1,982 & 1,962 & 1,986 & 1,973 & 2,003 & 1,984 & 1,964 & 2,009 & 1,904 & 1,960 & 2,028 & 2,034 & 1,930 \\
\hline $\mathrm{INa}$ & 0,061 & 0,062 & 0,026 & 0,055 & 0,024 & 0,027 & 0,023 & 0,044 & 0,013 & 0,063 & 0,048 & 0,099 & 0,043 & 0,011 \\
\hline $\mathrm{ICa}$ & 0,007 & 0,004 & 0,008 & 0,004 & 0,000 & 0,000 & 0,004 & 0,003 & 0,000 & 0,000 & 0,156 & 0,007 & 0,000 & 0,003 \\
\hline IBa & 0,000 & 0,000 & 0,000 & 0,000 & 0,000 & 0,000 & 0,000 & 0,000 & 0,000 & 0,000 & 0,000 & 0,000 & 0,000 & 0,000 \\
\hline Itotal & 2,011 & 2,048 & 1,996 & 2,045 & 1,998 & 2,031 & 2,010 & 2,011 & 2,022 & 1,968 & 2,165 & 2,134 & 2,077 & 1,945 \\
\hline \#Mg & 0,872 & 0,871 & 0,871 & 0,868 & 0,870 & 0,872 & 0,874 & 0,878 & 0,909 & 0,919 & 0,922 & 0,894 & 0,933 & 0,872 \\
\hline $\mathrm{Al} /(\mathrm{Al}+\mathrm{Cr})$ & 0,993 & 0,993 & 0,992 & 0,995 & 0,992 & 0,992 & 0,992 & 0,993 & 0,965 & 0,974 & 0,968 & 0,989 & 0,956 & 0,968 \\
\hline
\end{tabular}


Tabela 63- Composição química de flogopita da macrocristais e megacristais da matriz dos corpos Indaiál e Limeira 1.

\begin{tabular}{|c|c|c|c|c|c|c|c|c|c|c|c|c|c|c|}
\hline $\begin{array}{l}\text { Código da } \\
\text { amostra }\end{array}$ & Lm1-40-1 & Lm1-41-3 & In1-20d-9f & In1-11-7a & In1-11-12a & In1-36-4 & In1-36-5 & In1-36-3 & In1-36a-5 & In1-36a-6 & In1-36a-7 & In1-36a-8 & \multirow{2}{*}{$\begin{array}{l}\text { Lm1-38-1 } \\
\text { nódulo } \\
\text { esverdeado }\end{array}$} & \multirow{2}{*}{$\begin{array}{l}\text { Lm1-25-5 } \\
\text { nódulo } \\
\text { esverdeado }\end{array}$} \\
\hline Tipo & macrocristal & macrocristal & macrocristal & \multicolumn{2}{|c|}{$\begin{array}{l}\text { macrocristal em nódulo } \\
\text { esverdeado }\end{array}$} & \multicolumn{7}{|c|}{ megacristal de flogopita } & & \\
\hline $\mathrm{SiO}_{2}$ & 40,68 & 41,05 & 42,91 & 41,91 & 41,63 & 42,73 & 40,72 & 41,65 & 40,15 & 41,31 & 38,87 & 40,80 & 36,87 & 41,21 \\
\hline $\begin{array}{l}\mathrm{SlO}_{2} \\
\mathrm{TiO}_{2}\end{array}$ & 1,22 & 1,80 & 0,04 & 1,37 & 1,35 & 0,28 & 0,29 & 0,31 & 1,72 & 0,29 & 0,44 & 0,19 & $\begin{array}{l}1,78 \\
1,8\end{array}$ & 1,35 \\
\hline $\mathrm{Al}_{2} \mathrm{O}_{3}$ & 11,75 & 11,68 & 5,27 & 8,28 & 9,49 & 11,65 & 12,03 & 11,98 & 11,00 & 11,20 & 11,12 & 10,93 & 9,86 & 8,40 \\
\hline $\mathrm{FeO}$ & 5,44 & 4,36 & 10,10 & 7,24 & 6,07 & 5,17 & 5,46 & 5,51 & 4,85 & 5,24 & 4,91 & 5,76 & 10,18 & 7,74 \\
\hline $\mathrm{MnO}$ & 0,00 & 0,01 & 0,18 & 0,13 & 0,04 & 0,07 & 0,02 & 0,04 & 0,00 & 0,03 & 0,02 & 0,02 & 0,33 & 0,04 \\
\hline $\mathrm{MgO}$ & 22,54 & $\begin{array}{l}23,58 \\
238\end{array}$ & 29,21 & 24,43 & 24,81 & 24,19 & 24,74 & 24,57 & 23,70 & 24,29 & $\begin{array}{r}24,33 \\
24,\end{array}$ & $\begin{array}{l}25,35 \\
25,35\end{array}$ & 25,96 & $\begin{array}{l}24,07 \\
24, \quad-10\end{array}$ \\
\hline $\mathrm{CaO}$ & 0,06 & 0,03 & 0,27 & 0,20 & 0,24 & 0,03 & 0,00 & 0,08 & 0,02 & 0,00 & 0,00 & 0,00 & 1,74 & 0,01 \\
\hline $\mathrm{Na}_{2} \mathrm{O}$ & 0,42 & 0,27 & 0,50 & 0,13 & 0,07 & 0,22 & 0,16 & 0,20 & 0,15 & 0,13 & 0,25 & 0,27 & 0,39 & 0,02 \\
\hline $\mathrm{BaO}$ & $\begin{array}{l}\text { n.d. } \\
\text { n.d. }\end{array}$ & $\begin{array}{l}\text { n.d. } \\
\text { n.d }\end{array}$ & $\begin{array}{l}\text { n.d. } \\
\text { n.d. }\end{array}$ & $\begin{array}{l}\text { n.d. } \\
\text { nos }\end{array}$ & $\begin{array}{l}\text { n.d. } \\
\text { not }\end{array}$ & $\begin{array}{l}\text { n.d. } \\
\text { nots }\end{array}$ & $\begin{array}{l}\text { n.d. } \\
\text { nos }\end{array}$ & $\begin{array}{l}\text { n.d. } \\
\text { nos }\end{array}$ & 0,33 & 0,02 & 0,00 & 0,19 & $\begin{array}{l}\text { n.d. } \\
\text { no }\end{array}$ & $\begin{array}{l}\text { n.d. } \\
\text { no }\end{array}$ \\
\hline $\mathrm{Cr}_{2} \mathrm{O}_{3}$ & 0,67 & 0,46 & 0,02 & 0,05 & 0,04 & 0,12 & 0,26 & 0,01 & 0,35 & 0,24 & 0,10 & 0,04 & 0,00 & 0,00 \\
\hline $\mathrm{NiO}$ & 0,15 & 0,15 & 0,07 & 0,00 & 0,00 & 0,15 & 0,11 & 0,12 & 0,23 & 0,21 & 0,15 & 0,07 & 0,02 & 0,00 \\
\hline Total & 92,76 & 94,26 & 92,93 & 94,31 & 94,35 & 95,12 & 94,42 & 94,81 & 92,89 & 92,84 & 90,61 & 94,20 & 92,15 & 92,86 \\
\hline $\mathrm{TSi}$ & 6,055 & 5,984 & 6,346 & 6,137 & 6,062 & 6,150 & 5,886 & 6,001 & 5,956 & 6,092 & 5,831 & 5,900 & 5,546 & 6,142 \\
\hline TAl & 1,945 & 2,006 & 0,918 & 1,428 & 1,628 & 1,850 & 2,050 & 1,999 & 1,924 & 1,908 & 1,966 & 1,862 & 1,747 & 1,475 \\
\hline $\mathrm{TFe}^{3+}$ & 0,000 & 0,010 & 0,736 & 0,435 & 0,310 & 0,000 & 0,064 & 0,000 & 0,121 & 0,000 & 0,203 & 0,237 & 0,706 & 0,383 \\
\hline Ttotal & 8,000 & 8,000 & 8,000 & 8,000 & 8,000 & 8,000 & 8,000 & 8,000 & 8,000 & 8,000 & 8,000 & 8,000 & 8,000 & 8,000 \\
\hline MAl & 0,116 & 0,000 & 0,000 & 0,000 & 0,000 & 0,127 & 0,000 & 0,035 & 0,000 & 0,039 & 0,000 & 0,000 & 0,000 & 0,000 \\
\hline $\mathrm{MMg}$ & 5,001 & 5,124 & 6,441 & 5,332 & 5,386 & 5,191 & 5,332 & 5,279 & 5,241 & 5,341 & 5,442 & 5,466 & 5,822 & 5,348 \\
\hline $\mathrm{MFF}^{2+}$ & 0,677 & 0,522 & 0,514 & 0,451 & 0,429 & 0,622 & 0,597 & 0,664 & 0,480 & 0,647 & 0,413 & 0,459 & 0,574 & 0,582 \\
\hline $\mathrm{MFe}^{3+}$ & 0,000 & 0,000 & 0,000 & 0,000 & 0,000 & 0,000 & 0,000 & 0,000 & 0,000 & $\begin{array}{l}0,000 \\
0,000\end{array}$ & 0,000 & 0,000 & 0,000 & 0,000 \\
\hline MMn & 0,000 & 0,001 & 0,023 & 0,016 & 0,005 & 0,009 & 0,002 & 0,005 & 0,000 & 0,004 & 0,003 & 0,002 & 0,041 & 0,005 \\
\hline $\mathrm{MCr}$ & 0,053 & 0,036 & 0,002 & 0,004 & 0,003 & 0,009 & 0,020 & 0,000 & 0,027 & 0,018 & 0,008 & 0,003 & 0,000 & 0,000 \\
\hline Mtotal & 5,984 & 5,880 & 6,984 & $\begin{array}{l}5,954 \\
5,94\end{array}$ & 5,971 & 5,988 & 5,982 & 6,018 & 5,941 & $\begin{array}{l}6,080 \\
6,080\end{array}$ & 5,915 & 5,951 & 6,639 & 6,086 \\
\hline IK & 1,867 & 2,020 & 0,822 & 1,979 & 1,970 & 1,927 & 1,961 & 1,899 & 1,964 & 1,856 & 1,994 & 1,954 & 0,965 & 1,907 \\
\hline INa & 0,123 & 0,077 & 0,142 & 0,036 & 0,021 & 0,062 & 0,045 & 0,057 & 0,045 & 0,037 & 0,073 & 0,076 & 0,113 & 0,005 \\
\hline ICa & 0,009 & 0,005 & 0,043 & 0,031 & 0,038 & 0,005 & 0,000 & 0,012 & 0,003 & 0,000 & 0,000 & 0,000 & 0,280 & 0,001 \\
\hline $\mathrm{IBa}$ & 0,000 & 0,000 & 0,000 & 0,000 & 0,000 & 0,000 & 0,000 & 0,000 & 0,019 & 0,001 & 0,000 & 0,011 & 0,000 & 0,000 \\
\hline Itotal & 1,998 & 2,102 & 1,008 & 2,046 & 2,029 & 1,994 & 2,005 & 1,968 & 2,031 & 1,894 & 2,067 & 2,041 & 1,358 & 1,914 \\
\hline$\# \mathrm{Mg}$ & 0,881 & 0,906 & 0,837 & 0,857 & 0,879 & 0,893 & 0,890 & 0,888 & 0,897 & 0,892 & 0,898 & 0,887 & 0,820 & 0,847 \\
\hline $\mathrm{Al} /(\mathrm{Al}+\mathrm{Cr})$ & 0,975 & 0,983 & 0,998 & 0,997 & 0,998 & 0,995 & 0,990 & 1,000 & 0,986 & 0,991 & 0,996 & 0,998 & 1,000 & 1,000 \\
\hline
\end{tabular}


Tabela 64- Composição química de flogopita da macrocristais e megacristais da matriz dos corpos Indaiá 2 e Facão.

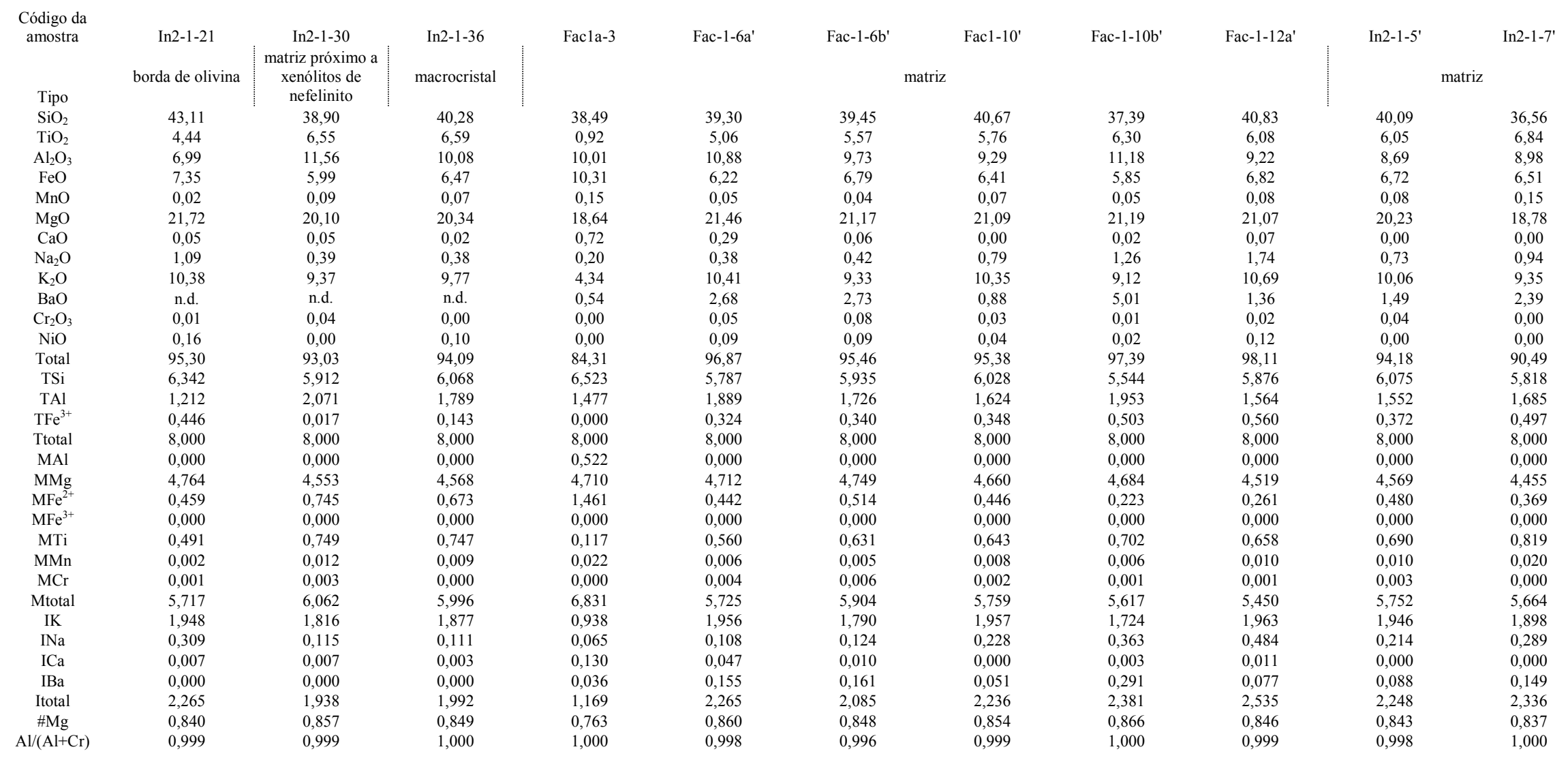


Tabela 65-Composição química de titanatos de xenólitos e macrocristais corpos Indaiá 1 e Limeira 1.

\begin{tabular}{|c|c|c|c|c|c|c|c|c|}
\hline \multirow[t]{2}{*}{$\begin{array}{l}\text { Código da } \\
\text { amostra }\end{array}$} & Lm1-1-2a & Lm1-1-2b & Lm1-1-13c & Lm1-1-2c & Fo-3 13b & In1-36-2a & In1-36-2b & In1-36-2b' \\
\hline & \multicolumn{4}{|c|}{ harzburgito com bolsões de flogopita e titanato } & $\begin{array}{l}\text { macrocristal } \\
\text { de ilmenita }\end{array}$ & \multicolumn{3}{|c|}{ macrocristal de ilmenita } \\
\hline $\mathrm{SiO}_{2}$ & 0,00 & 0,00 & 0,00 & 0,00 & 0,05 & 0,04 & 0,00 & 0,00 \\
\hline $\mathrm{TiO}_{2}$ & 56,00 & 64,25 & 5,05 & 59,36 & 45,03 & 90,19 & 82,54 & 73,13 \\
\hline $\mathrm{Al}_{2} \mathrm{O}_{3}$ & 0,58 & 0,82 & 3,52 & 0,82 & 0,32 & 0,00 & 0,10 & 0,10 \\
\hline $\mathrm{FeO}$ & 7,29 & 10,38 & 28,92 & 10,52 & 31,51 & 0,72 & 4,43 & 7,28 \\
\hline $\mathrm{MnO}$ & 0,00 & 0,01 & 0,24 & 0,05 & 1,85 & 0,00 & 0,06 & 0,00 \\
\hline $\mathrm{MgO}$ & 2,34 & 3,57 & 9,94 & 3,57 & 7,23 & 0,81 & 1,17 & 1,76 \\
\hline $\mathrm{CaO}$ & 1,65 & 1,48 & 0,05 & 1,58 & 0,24 & 0,08 & 0,24 & 1,25 \\
\hline $\mathrm{Na}_{2} \mathrm{O}$ & 0,33 & 0,16 & 0,00 & 0,11 & 0,53 & 0,24 & 0,18 & 0,60 \\
\hline $\mathrm{K}_{2} \mathrm{O}$ & 7,90 & 1,02 & 0,00 & 0,89 & 1,95 & 2,44 & 8,52 & 10,57 \\
\hline $\mathrm{Cr}_{2} \mathrm{O}_{3}$ & 14,91 & 14,74 & 51,82 & 14,66 & 1,76 & 2,36 & 1,78 & 1,55 \\
\hline $\mathrm{NiO}$ & 0,13 & 0,09 & 0,27 & 0,13 & 0,13 & 0,00 & 0,00 & 0,06 \\
\hline Total & 91,14 & 96,53 & 99,81 & 91,69 & 90,60 & 96,89 & 99,02 & 96,30 \\
\hline
\end{tabular}


Tabela 66- Composição química de perovskita da macrocristais e megacristais da matriz dos corpos Indaiá 2, Facão, Forca 1.

\begin{tabular}{|c|c|c|c|c|c|c|c|c|c|c|c|c|c|c|c|c|c|c|}
\hline $\begin{array}{l}\text { Código da } \\
\text { amostra }\end{array}$ & In2-1-13 & In2-1-22 & In2-1-23 & Fac-5-9 & Fac-6-3 & Fac-6-3' & Fac-8-6 & Fo-2-5a & Fo-2-5b & Fo-2-5f & Fo-2-5h & Fo-2-13 & Fo-2-34 & Fo-3-12b & Fo-1-9 & Fo-1-13a & Fo-1-13b & Fo-1-15d \\
\hline Tipo & & matriz & & matriz & & & matriz & \multicolumn{6}{|c|}{ matriz } & matriz & \multicolumn{4}{|c|}{ matriz } \\
\hline $\mathrm{SiO}_{2}$ & 0,00 & 0,00 & 0,03 & 0,00 & 0,00 & 0,07 & 0,73 & 0,08 & 0,00 & 0,23 & 0,01 & 2,07 & 3,17 & 0,00 & 0,25 & 0,12 & 0,14 & 0,06 \\
\hline $\mathrm{TiO}_{2}$ & 53,49 & 53,47 & 52,60 & 55,86 & 54,46 & 54,89 & 55,32 & 56,56 & 55,73 & 58,43 & 57,06 & 37,37 & 47,84 & 40,67 & 55,39 & 53,47 & 53,07 & 58,28 \\
\hline $\mathrm{Al}_{2} \mathrm{O}_{3}$ & 0,28 & 0,25 & 0,26 & 0,07 & 0,00 & 0,10 & 0,12 & 0,08 & 0,05 & 0,14 & 0,02 & 0,25 & 0,19 & 0,35 & 0,10 & 0,08 & 0,10 & 0,02 \\
\hline $\mathrm{FeO}$ & 2,12 & 2,07 & 2,28 & 0,74 & 1,23 & 1,03 & 1,47 & 1,15 & 1,31 & 1,76 & 1,44 & 22,72 & 9,16 & 22,27 & 1,74 & 1,64 & 2,10 & 1,54 \\
\hline $\mathrm{MnO}$ & 0,00 & 0,00 & 0,03 & 0,05 & 0,00 & 0,00 & 0,12 & 0,10 & 0,03 & 0,00 & 0,04 & 0,39 & 0,33 & 0,20 & 0,00 & 0,02 & 0,01 & 0,00 \\
\hline $\mathrm{MgO}$ & 0,10 & 0,00 & 0,07 & 0,11 & 0,31 & 0,06 & 0,14 & 0,14 & 0,02 & 0,18 & 0,06 & 5,62 & 6,12 & 3,82 & 0,30 & 0,14 & 0,22 & 0,07 \\
\hline $\mathrm{CaO}$ & 36,62 & 36,65 & 36,69 & 39,01 & 37,26 & 38,41 & 36,96 & 39,28 & 37,88 & 37,42 & 36,36 & 20,18 & 23,15 & 21,66 & 32,74 & 32,83 & 36,07 & 33,54 \\
\hline $\mathrm{Na}_{2} \mathrm{O}$ & 0,35 & 0,25 & 0,27 & 0,24 & 0,30 & 0,44 & 0,85 & 0,44 & 0,63 & 0,66 & 0,98 & 0,55 & 1,24 & 0,87 & 1,30 & 1,34 & 1,22 & 1,33 \\
\hline $\mathrm{K}_{2} \mathrm{O}$ & 0,09 & 0,07 & 0,03 & 0,08 & 0,15 & 0,14 & 0,19 & 0,00 & 0,00 & 0,12 & 0,06 & 0,11 & 0,24 & 0,08 & 0,12 & 0,11 & 0,11 & 0,04 \\
\hline $\mathrm{Cr}_{2} \mathrm{O}_{3}$ & 0,00 & 0,10 & 0,00 & 0,01 & 0,04 & 0,18 & 0,12 & 1,03 & 0,62 & 0,03 & 0,47 & 0,97 & 0,04 & 0,08 & 0,37 & 0,42 & 0,04 & 0,42 \\
\hline $\mathrm{NiO}$ & 0,13 & 0,13 & 0,08 & 0,00 & 0,00 & 0,03 & 0,06 & 0,00 & 0,08 & 0,02 & 0,00 & 0,13 & 0,01 & 0,02 & 0,05 & 0,00 & 0,00 & 0,00 \\
\hline Total & 93,19 & 92,99 & 92,35 & 96,19 & 93,74 & 95,35 & 96,08 & 98,86 & 96,35 & 98,98 & 96,48 & 90,36 & 91,49 & 90,01 & 92,36 & 90,18 & 93,10 & 95,29 \\
\hline BTi & 0,974 & 0,978 & 0,967 & 0,985 & 0,985 & 0,975 & 0,972 & 0,973 & 0,983 & 1,000 & 1,000 & 0,689 & 0,857 & 0,760 & 1,000 & 1,000 & 0,957 & 1,000 \\
\hline $\mathrm{BFe}^{3+}$ & 0,026 & 0,021 & 0,033 & 0,015 & 0,014 & 0,021 & 0,009 & 0,013 & 0,010 & 0,000 & 0,000 & 0,248 & 0,067 & 0,239 & 0,000 & 0,000 & 0,039 & 0,000 \\
\hline $\mathrm{Bl}$ & 0,000 & 0,000 & 0,001 & 0,000 & 0,000 & 0,002 & 0,017 & 0,002 & 0,000 & 0,005 & 0,000 & 0,051 & 0,075 & 0,000 & 0,006 & 0,003 & 0,003 & 0,002 \\
\hline Ttotal & 1,000 & 0,999 & 1,000 & 1,000 & 0,999 & 0,998 & 0,999 & 0,988 & 0,992 & 1,005 & 1,000 & 0,988 & 0,999 & 0,999 & 1,006 & 1,003 & 0,999 & 1,002 \\
\hline $\mathrm{AFe}^{3+}$ & 0,017 & 0,022 & 0,014 & 0,000 & 0,010 & 0,000 & 0,019 & 0,009 & 0,016 & 0,033 & 0,028 & 0,218 & 0,115 & 0,223 & 0,036 & 0,034 & 0,003 & 0,000 \\
\hline AAl & 0,000 & 0,000 & 0,000 & 0,000 & 0,000 & 0,000 & 0,000 & 0,000 & 0,000 & 0,000 & 0,000 & 0,000 & 0,000 & 0,000 & 0,000 & 0,000 & 0,000 & 0,031 \\
\hline $\mathrm{AMg}$ & 0,004 & 0,000 & 0,002 & 0,004 & 0,011 & 0,002 & 0,005 & 0,005 & 0,001 & 0,006 & 0,002 & 0,205 & 0,217 & 0,141 & 0,011 & 0,005 & 0,008 & 0,002 \\
\hline $\mathrm{AFe}^{2+}$ & 0,000 & 0,001 & 0,000 & 0,000 & 0,001 & 0,002 & 0,001 & 0,012 & 0,008 & 0,000 & 0,006 & 0,012 & 0,001 & 0,001 & 0,005 & 0,005 & 0,001 & 0,005 \\
\hline $\mathrm{AK}$ & 0,000 & 0,000 & 0,001 & 0,001 & 0,000 & 0,000 & 0,002 & 0,002 & 0,001 & 0,000 & 0,001 & 0,008 & 0,007 & 0,004 & 0,000 & 0,001 & 0,000 & 0,000 \\
\hline $\mathrm{ANi}$ & 0,008 & 0,007 & 0,008 & 0,002 & 0,000 & 0,003 & 0,003 & 0,002 & 0,001 & 0,004 & 0,001 & 0,007 & 0,005 & 0,010 & 0,003 & 0,002 & 0,003 & 0,001 \\
\hline $\mathrm{ACr}$ & 0,016 & 0,012 & 0,013 & 0,011 & 0,014 & 0,020 & 0,038 & 0,019 & 0,029 & 0,029 & 0,045 & 0,026 & 0,057 & 0,042 & 0,061 & 0,065 & 0,057 & 0,061 \\
\hline AMn & 0,000 & 0,000 & 0,000 & 0,000 & 0,000 & 0,000 & 0,000 & 0,000 & 0,000 & 0,000 & 0,000 & 0,000 & 0,000 & 0,000 & 0,000 & 0,000 & 0,000 & 0,000 \\
\hline ATi & 0,003 & 0,002 & 0,001 & 0,002 & 0,005 & 0,004 & 0,006 & 0,000 & 0,000 & 0,003 & 0,002 & 0,004 & 0,007 & 0,002 & 0,004 & 0,004 & 0,003 & 0,001 \\
\hline $\mathrm{ACa}$ & 0,003 & 0,003 & 0,002 & 0,000 & 0,000 & 0,001 & 0,001 & 0,000 & 0,002 & 0,000 & 0,000 & 0,003 & 0,000 & 0,000 & 0,001 & 0,000 & 0,000 & 0,000 \\
\hline ATotal & 0,950 & 0,955 & 0,960 & 0,980 & 0,960 & 0,971 & 0,925 & 0,962 & 0,951 & 0,915 & 0,912 & 0,530 & 0,591 & 0,576 & 0,856 & 0,877 & 0,926 & 0,855 \\
\hline
\end{tabular}


Tabela 67- Composição química de perovskita da matriz dos corpos Forca 1, Indaiá 1 e Limeira 1.

\begin{tabular}{|c|c|c|c|c|c|c|c|c|c|c|c|c|c|c|c|c|c|c|c|}
\hline $\begin{array}{l}\text { Código da } \\
\text { amostra }\end{array}$ & Fo-1-16b & Fo-1-16d & Fo-1-23e & Fo-6-21b & Fo-6-21c & Lm1-1-12 & $\begin{array}{c}\text { Lm1-1- } \\
12 \mathrm{a}\end{array}$ & $\begin{array}{c}\mathrm{Lm} 1-25- \\
1 \mathrm{j}\end{array}$ & $\begin{array}{c}\mathrm{Lm} 1-20- \\
2 \mathrm{e}\end{array}$ & $\begin{array}{c}\text { Lm1-38- } \\
1 \mathrm{~b}\end{array}$ & In1-6-1 & In1-2-1 & In1-24b-1 & $\begin{array}{c}\text { In1 -11- } \\
14 \mathrm{~b}\end{array}$ & $\begin{array}{c}\text { In1-25a- } \\
6 \mathrm{~b}\end{array}$ & $\begin{array}{c}\text { In1-25a- } \\
6 \mathrm{~b}\end{array}$ & In1-36-1 & In1-36-2e & In1-36-2f \\
\hline Tipo & & matriz & & \multicolumn{2}{|c|}{ matriz } & \multicolumn{2}{|c|}{ matriz } & Matriz & matriz & matriz & matriz & matriz & matriz & matriz & \multicolumn{2}{|c|}{ matriz } & \multirow{2}{*}{\multicolumn{3}{|c|}{$\begin{array}{c}\text { matriz } \\
0,03\end{array}$}} \\
\hline $\mathrm{SiO}_{2}$ & 0,00 & 0,04 & 0,00 & 0,00 & 0,00 & 0,00 & 0,06 & 0,19 & 0,00 & 0,11 & 0,08 & 2,94 & 7,47 & 0,17 & 6,57 & 3,63 & & & \\
\hline $\mathrm{TiO}_{2}$ & 50,39 & 55,82 & 56,59 & 45,57 & 55,83 & 51,80 & 56,07 & 57,96 & 54,73 & 53,08 & 57,87 & 50,68 & 35,97 & 50,37 & 53,85 & 56,91 & 54,68 & 53,64 & 51,24 \\
\hline $\mathrm{Al}_{2} \mathrm{O}_{3}$ & 0,07 & 0,04 & 0,06 & 0,16 & 0,11 & 0,00 & 0,04 & 0,12 & 0,11 & 0,19 & n.d. & n.d. & n.d. & 0,19 & 0,00 & 0,00 & 0,16 & 0,11 & 0,13 \\
\hline $\mathrm{FeO}$ & 8,67 & 1,28 & 1,50 & 13,96 & 1,08 & 1,65 & 1,24 & 1,48 & 1,52 & 1,99 & 1,54 & 2,27 & 12,03 & 2,06 & 2,78 & 2,29 & 1,67 & 2,15 & 3,41 \\
\hline $\mathrm{MnO}$ & 0,25 & 0,05 & 0,05 & 0,15 & 0,04 & 0,03 & 0,00 & 0,02 & 0,07 & 0,00 & n.d. & n.d. & n.d. & 0,03 & 0,00 & 0,07 & 0,07 & 0,04 & 0,01 \\
\hline $\mathrm{MgO}$ & 1,50 & 0,06 & 0,06 & 2,38 & 0,05 & 0,08 & 0,10 & 0,04 & 0,07 & 0,11 & 0,06 & 0,66 & 2,48 & 0,00 & 1,75 & 0,71 & 0,00 & 0,11 & 1,02 \\
\hline $\mathrm{CaO}$ & 27,39 & 36,83 & 36,19 & 26,85 & 39,22 & 36,05 & 38,11 & 37,96 & 37,64 & 38,08 & 39,18 & 33,99 & 32,64 & 37,79 & 27,58 & 29,38 & 32,77 & 34,72 & 28,12 \\
\hline $\mathrm{Na}_{2} \mathrm{O}$ & 1,46 & 0,91 & 1,04 & 1,18 & 0,83 & 0,43 & 0,57 & 1,07 & 0,59 & 0,24 & 0,36 & 1,37 & 0,34 & 0,18 & 3,44 & 2,86 & 1,07 & 0,98 & 0,10 \\
\hline $\mathrm{K}_{2} \mathrm{O}$ & 0,12 & 0,05 & 0,07 & 0,06 & 0,03 & 0,05 & 0,06 & 0,09 & 0,07 & 0,01 & n.d. & n.d. & n.d. & 0,03 & 0,64 & 0,47 & 0,05 & 0,04 & 0,37 \\
\hline $\mathrm{Cr}_{2} \mathrm{O}_{3}$ & 0,09 & 0,11 & 0,37 & 0,23 & 0,16 & 0,73 & 0,65 & 0,08 & 0,72 & 0,04 & 0,47 & 0,78 & 0,23 & 0,00 & 0,14 & 0,18 & 0,00 & 0,03 & 1,58 \\
\hline $\mathrm{NiO}$ & 0,11 & 0,00 & 0,00 & 0,09 & 0,00 & 0,00 & 0,00 & 0,00 & 0,11 & 0,00 & n.d. & n.d. & n.d. & 0,03 & 0,00 & 0,00 & 0,00 & 0,00 & 0,00 \\
\hline Total & 90,07 & 95,20 & 95,94 & 90,63 & 97,35 & 90,81 & 96,91 & 99,01 & 95,64 & 93,86 & 99,55 & 92,68 & 91,15 & 90,85 & 96,76 & 96,50 & 90,48 & 91,85 & 93,10 \\
\hline BTi & 0,946 & 0,992 & 1,000 & 0,845 & 0,967 & 0,970 & 0,983 & 0,989 & 0,971 & 0,958 & 0,990 & 0,914 & 0,644 & 0,936 & 0,909 & 0,982 & 1,000 & 0,988 & 0,942 \\
\hline $\mathrm{BFe}^{3+}$ & 0,053 & 0,006 & 0,000 & 0,152 & 0,031 & 0,021 & 0,008 & 0,005 & 0,020 & 0,039 & 0,002 & 0,006 & 0,175 & 0,059 & 0,000 & 0,000 & 0,000 & 0,011 & 0,000 \\
\hline BAl & 0,000 & 0,001 & 0,000 & 0,000 & 0,000 & 0,000 & 0,001 & 0,004 & 0,000 & 0,003 & 0,002 & 0,070 & 0,178 & 0,004 & 0,147 & 0,083 & 0,000 & 0,001 & 0,174 \\
\hline Ttotal & 0,999 & 0,999 & 1,000 & 0,997 & 0,998 & 0,990 & 0,992 & 0,999 & 0,991 & 0,999 & 0,994 & 0,990 & 0,997 & 1,000 & 1,057 & 1,065 & 1,000 & 1,000 & 1,116 \\
\hline $\mathrm{AFe}^{3+}$ & 0,128 & 0,020 & 0,030 & 0,135 & 0,000 & 0,013 & 0,016 & 0,023 & 0,010 & 0,001 & 0,027 & 0,040 & 0,064 & 0,000 & 0,052 & 0,044 & 0,000 & 0,033 & 0,000 \\
\hline AAl & 0,000 & 0,000 & 0,000 & 0,000 & 0,000 & 0,000 & 0,000 & 0,000 & 0,000 & 0,000 & 0,000 & 0,000 & 0,000 & 0,000 & 0,000 & 0,000 & 0,035 & 0,000 & 0,070 \\
\hline $\mathrm{AMg}$ & 0,056 & 0,002 & 0,002 & 0,088 & 0,002 & 0,003 & 0,004 & 0,001 & 0,003 & 0,004 & 0,002 & 0,024 & 0,088 & 0,000 & 0,059 & 0,024 & 0,000 & 0,004 & 0,037 \\
\hline $\mathrm{AFe}^{2+}$ & 0,001 & 0,001 & 0,005 & 0,003 & 0,002 & 0,010 & 0,008 & 0,001 & 0,009 & 0,001 & 0,006 & 0,010 & 0,003 & 0,000 & 0,002 & 0,002 & 0,000 & 0,000 & 0,020 \\
\hline AK & 0,005 & 0,001 & 0,001 & 0,003 & 0,001 & 0,001 & 0,000 & 0,000 & 0,001 & 0,000 & 0,000 & 0,000 & 0,000 & 0,001 & 0,000 & 0,001 & 0,002 & 0,001 & 0,000 \\
\hline $\mathrm{ANi}$ & 0,002 & 0,001 & 0,002 & 0,005 & 0,003 & 0,000 & 0,001 & 0,003 & 0,003 & 0,005 & 0,000 & 0,000 & 0,000 & 0,005 & 0,000 & 0,000 & 0,005 & 0,003 & 0,004 \\
\hline $\mathrm{ACr}$ & 0,071 & 0,042 & 0,047 & 0,057 & 0,037 & 0,021 & 0,026 & 0,047 & 0,027 & 0,011 & 0,016 & 0,064 & 0,016 & 0,009 & 0,150 & 0,127 & 0,052 & 0,047 & 0,005 \\
\hline AMn & 0,000 & 0,000 & 0,000 & 0,000 & 0,000 & 0,000 & 0,000 & 0,000 & 0,000 & 0,000 & 0,000 & 0,000 & 0,000 & 0,000 & 0,000 & 0,000 & 0,000 & 0,000 & 0,000 \\
\hline $\mathrm{ATi}$ & 0,004 & 0,002 & 0,002 & 0,002 & 0,001 & 0,002 & 0,002 & 0,003 & 0,002 & 0,000 & 0,000 & 0,000 & 0,000 & 0,001 & 0,018 & 0,014 & 0,002 & 0,001 & 0,012 \\
\hline Aca & 0,002 & 0,000 & 0,000 & 0,002 & 0,000 & 0,000 & 0,000 & 0,000 & 0,002 & 0,00 & 0,000 & 0,000 & 0,0 & 0,001 & 0,000 & 0,000 & 0,000 & 0,000 & 0,000 \\
\hline ATotal & 0,732 & 0,932 & 0,911 & 0,709 & 0,967 & 0,961 & 0,951 & 0,923 & 0,951 & 0,978 & 0,955 & 0,873 & 0,832 & 1,000 & 0,663 & 0,722 & 0,877 & 0,911 & 0,736 \\
\hline
\end{tabular}


Tabela 68- Composição química de monticellita instersticial em xenólitos, piroxenito e na matriz do corpo Limeira 1.

\begin{tabular}{|c|c|c|c|c|c|c|c|c|c|c|c|c|}
\hline \multirow[t]{2}{*}{$\begin{array}{l}\text { Código da } \\
\text { amostra }\end{array}$} & \multirow{2}{*}{$\begin{array}{c}\text { Lm1-1-11 } \\
\text { intersticial } \\
\text { em dunito } \\
\text { com } \\
\text { flogopita }\end{array}$} & \multirow[t]{2}{*}{ Lm1-14-13b } & \multirow{2}{*}{$\begin{array}{l}\text { Lm1-14-15b } \\
\text { intersticial piroxenito }\end{array}$} & \multirow[t]{2}{*}{ Lm1-14-16 } & \multirow[t]{2}{*}{ Lm1-20-2g } & \multirow{2}{*}{\multicolumn{2}{|c|}{$\begin{array}{cc}\text { Lm1-20- } & \text { Lm1-20- } \\
2 \mathrm{~h} & 2 \mathrm{k} \\
& \\
\text { macrocristal de olivina }\end{array}$}} & \multirow[t]{2}{*}{$\begin{array}{l}\text { Lm1-20- } \\
25\end{array}$} & \multirow{2}{*}{\multicolumn{2}{|c|}{$\begin{array}{l}\text { Lm1-22-14e } \\
\text { borda de reação com flogopita dunito com bolsões de cpx }\end{array}$}} & \multirow{2}{*}{$\begin{array}{l}\text { Lm1-25- } \\
\quad 1 \mathrm{c} \\
\text { borda de } \\
\text { nódulo } \\
\text { verde }\end{array}$} & \multirow{2}{*}{$\begin{array}{c}\text { Lm1-32-2c } \\
\text { intersticial em } \\
\text { olivina } \\
\text { porfiroclástica }\end{array}$} \\
\hline & & & & & & & & & & & & \\
\hline $\mathrm{SiO}_{2}$ & 36,42 & 34,92 & 35,36 & 35,25 & 36,24 & 37,40 & 38,10 & 37,54 & 36,91 & 37,23 & 36,41 & 36,91 \\
\hline $\mathrm{TiO}_{2}$ & 0,00 & 1,12 & 0,02 & 0,10 & 0,11 & 0,05 & 0,09 & 0,00 & 0,16 & 0,12 & 0,00 & 0,02 \\
\hline $\mathrm{Al}_{2} \mathrm{O}_{3}$ & 0,00 & 0,00 & 0,10 & 0,03 & 0,00 & 0,08 & 0,06 & 0,03 & 0,11 & 0,00 & 0,00 & 0,01 \\
\hline $\mathrm{FeO}$ & 4,22 & 4,35 & 4,12 & 9,05 & 9,38 & 3,14 & 3,27 & 4,09 & 4,77 & 4,22 & 9,94 & 5,83 \\
\hline $\mathrm{MnO}$ & 0,21 & 0,21 & 0,27 & 0,40 & 0,54 & 0,43 & 0,54 & 0,27 & 0,23 & 0,35 & 0,53 & 0,22 \\
\hline $\mathrm{MgO}$ & 22,90 & 22,56 & 23,42 & 20,59 & 20,28 & 24,81 & 25,32 & 23,70 & 22,56 & 23,20 & 19,59 & 22,95 \\
\hline $\mathrm{CaO}$ & 34,76 & 35,01 & 35,07 & 33,44 & 32,68 & 33,81 & 34,18 & 35,75 & 34,88 & 36,84 & 33,21 & 35,28 \\
\hline $\mathrm{Na}_{2} \mathrm{O}$ & 0,00 & 0,46 & 0,27 & 0,00 & 0,08 & 0,00 & 0,06 & 0,04 & 0,19 & 0,06 & 0,13 & 0,00 \\
\hline $\mathrm{K}_{2} \mathrm{O}$ & 0,04 & 0,00 & 0,02 & 0,03 & 0,00 & 0,03 & 0,08 & 0,00 & 0,07 & 0,00 & 0,02 & 0,10 \\
\hline $\mathrm{Cr}_{2} \mathrm{O}_{3}$ & 0,00 & 0,06 & 0,01 & 0,00 & 0,00 & 0,01 & 0,06 & 0,00 & 0,11 & 0,03 & 0,02 & 0,02 \\
\hline $\mathrm{NiO}$ & 0,06 & 0,07 & 0,10 & 0,03 & 0,00 & 0,03 & 0,00 & 0,09 & 0,13 & 0,00 & 0,00 & 0,16 \\
\hline Total & 98,61 & 98,76 & 98,77 & 98,92 & 99,31 & 99,81 & 101,77 & 101,52 & 100,11 & 102,04 & 99,85 & 101,50 \\
\hline $\mathrm{TSi}$ & 0,979 & 0,938 & 0,945 & 0,963 & 0,988 & 0,986 & 0,985 & 0,979 & 0,980 & 0,969 & 0,991 & 0,969 \\
\hline $\mathrm{TFe}^{3+}$ & 0,021 & 0,062 & 0,055 & 0,037 & 0,012 & 0,014 & 0,015 & 0,021 & 0,020 & 0,031 & 0,009 & 0,031 \\
\hline TAl & 0,000 & 0,000 & 0,000 & 0,000 & 0,000 & 0,000 & 0,000 & 0,000 & 0,000 & 0,000 & 0,000 & 0,000 \\
\hline Ttotal & 1,000 & 1,000 & 1,000 & 1,000 & 1,000 & 1,000 & 1,000 & 1,000 & 1,000 & 1,000 & 1,000 & 1,000 \\
\hline${\mathrm{M} 1 F e^{3+}}^{3+}$ & 0,022 & 0,039 & 0,066 & 0,033 & 0,011 & 0,011 & 0,013 & 0,022 & 0,018 & 0,029 & 0,016 & 0,032 \\
\hline M1Al & 0,000 & 0,000 & 0,003 & 0,001 & 0,000 & 0,002 & 0,002 & 0,001 & 0,003 & 0,000 & 0,000 & 0,000 \\
\hline $\mathrm{M} 1 \mathrm{Mg}$ & 0,918 & 0,903 & 0,933 & 0,838 & 0,824 & 0,975 & 0,976 & 0,922 & 0,893 & 0,900 & 0,795 & 0,898 \\
\hline${\mathrm{M} 1 \mathrm{Fe}^{2+}}^{2+}$ & 0,051 & 0,000 & 0,000 & 0,136 & 0,191 & 0,045 & 0,042 & 0,046 & 0,068 & 0,032 & 0,202 & 0,065 \\
\hline M1K & 0,001 & 0,000 & 0,001 & 0,001 & 0,000 & 0,001 & 0,003 & 0,000 & 0,002 & 0,000 & 0,001 & 0,003 \\
\hline $\mathrm{M} 1 \mathrm{Ni}$ & 0,001 & 0,002 & 0,002 & 0,001 & 0,000 & 0,001 & 0,000 & 0,002 & 0,003 & 0,000 & 0,000 & 0,003 \\
\hline $\mathrm{M} 1 \mathrm{Cr}$ & 0,000 & 0,001 & 0,000 & 0,000 & 0,000 & 0,000 & 0,001 & 0,000 & 0,002 & 0,000 & 0,000 & 0,000 \\
\hline M1Mn & 0,005 & 0,005 & 0,006 & 0,009 & 0,012 & 0,010 & 0,012 & 0,006 & 0,005 & 0,008 & 0,012 & 0,005 \\
\hline M1Ti & 0,000 & 0,023 & 0,000 & 0,002 & 0,002 & 0,001 & 0,002 & 0,000 & 0,003 & 0,002 & 0,000 & 0,000 \\
\hline $\mathrm{M} 1 \mathrm{Ca}$ & 1,001 & 1,007 & 1,004 & 0,978 & 0,955 & 0,955 & 0,947 & 0,999 & 0,992 & 1,027 & 0,968 & 0,992 \\
\hline M1Total & 2,000 & 1,979 & 2,015 & 2,000 & 1,996 & 2,000 & 1,997 & 1,998 & 1,990 & 1,997 & 1,993 & 2,000 \\
\hline$\# \mathrm{Mg}$ & 0,947 & 1,000 & 1,000 & 0,860 & 0,812 & 0,956 & 0,958 & 0,952 & 0,930 & 0,966 & 0,798 & 0,933 \\
\hline \#Fe3 & 0,457 & 1,000 & 1,000 & 0,342 & 0,109 & 0,357 & 0,402 & 0,480 & 0,361 & 0,656 & 0,109 & 0,493 \\
\hline \#Mg(total) & 0,906 & 0,900 & 0,885 & 0,802 & 0,794 & 0,934 & 0,932 & 0,912 & 0,894 & 0,907 & 0,778 & 0,875 \\
\hline
\end{tabular}


Tabela 69- Composição química de monticellita da macrocristais e megacristais da matriz dos corpos Indaiá1 e Limeira 1.

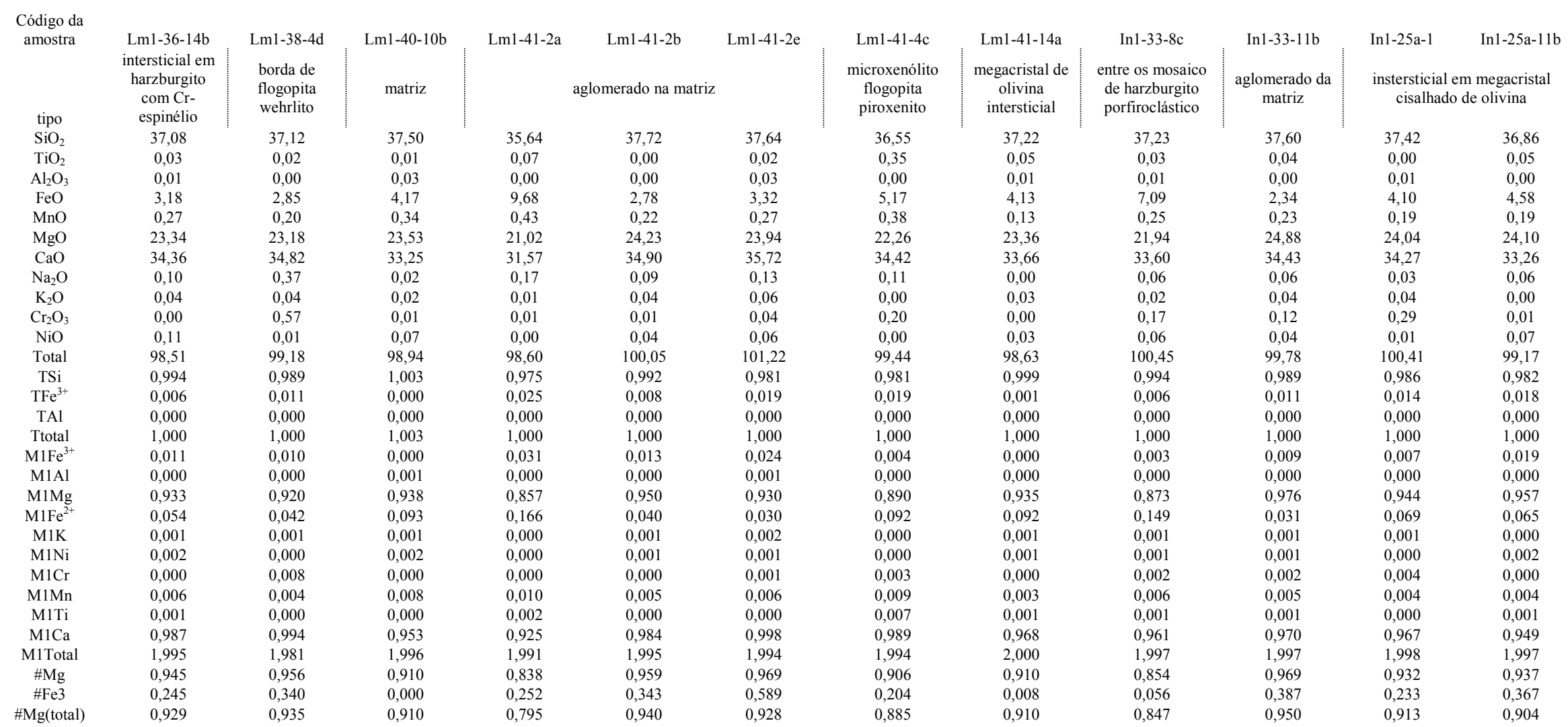


Tabela 71- Composição química de harmotoma (zeólita) e saponita de autólitos e da matriz dos corpos Facão e Indaiá 2.

\begin{tabular}{|c|c|c|c|c|c|c|c|c|c|c|c|c|c|}
\hline & Fac-1-1 & Fac-1-2 & Fac-1-9 & Fac-1-11b & Fac-1-12b & & Fac-1a-3 & Fac-1a-7 & Fac-1a-7a & Fac-1a-8 & Fac-1a-9 & In2-1-a1 & In1-2-a7 \\
\hline $\mathrm{Na}_{2} \mathrm{O}$ & 0,6395 & 0,3517 & 0,5187 & 0,4631 & 0,2198 & $\mathrm{Na} 2 \mathrm{O}$ & 0,1979 & 0 & 0,116 & 0,7776 & 0,1342 & 0,42 & 0,9365 \\
\hline $\mathrm{MgO}$ & 1,3804 & 0,0593 & 1,8793 & 0,5583 & 0,3928 & $\mathrm{MgO}$ & 18,6442 & 18,767 & 23,6478 & 25,0324 & 23,9007 & 18,9644 & 18,7783 \\
\hline $\mathrm{Al}_{2} \mathrm{O}_{3}$ & 20,0988 & 23,7248 & 19,7572 & 20,0845 & 21,169 & $\mathrm{Al}_{2} \mathrm{O}$ & 10,0083 & 9,1924 & 9,8584 & 10,2431 & 9,5768 & 15,2457 & 8,9822 \\
\hline $\mathrm{SiO}_{2}$ & 41,0028 & 39,9021 & 41,1373 & 44,7656 & 46,5311 & $\mathrm{SiO}_{2}$ & 38,4918 & 41,945 & 43,0416 & 43,2642 & 42,6488 & 39,4585 & 36,5559 \\
\hline $\mathrm{K}_{2} \mathrm{O}$ & 0,9311 & 0,6641 & 1,1956 & 0,7457 & 0,7711 & $\mathrm{~K}_{2} \mathrm{O}$ & 4,3404 & 2,887 & 3,3995 & 3,2572 & 3,306 & 3,2314 & 9,3496 \\
\hline $\mathrm{CaO}$ & 1,6959 & 2,964 & 1,5564 & 1,6558 & 1,6888 & $\mathrm{CaO}$ & 0,7157 & 0,5673 & 0,5479 & 0,6598 & 0,495 & 0,5661 & 0,0018 \\
\hline $\mathrm{TiO}_{2}$ & 0,2994 & 0,0823 & 0,0643 & 0,2481 & 0,2324 & $\mathrm{TiO}_{2}$ & 0,9163 & 0,6683 & 0,9699 & 0,5434 & 0,6122 & 1,0335 & 6,8427 \\
\hline $\mathrm{Cr}_{2} \mathrm{O}_{3}$ & 0 & 0,0921 & 0 & 0,0289 & 0,0058 & $\mathrm{Cr}_{2} \mathrm{O}_{3}$ & 0 & 0,0296 & 0 & 0 & 0,0358 & 0 & 0 \\
\hline $\mathrm{MnO}$ & 0 & 0 & 0 & 0 & 0 & $\mathrm{MnO}$ & 0,1515 & 0,1537 & 0,2823 & 0,2875 & 0,1799 & 0,1367 & 0,1457 \\
\hline $\mathrm{FeO}$ & 0,107 & 0,1392 & 0,1534 & 0,8584 & 0,9484 & $\mathrm{FeO}$ & 10,3098 & 8,2491 & 7,9436 & 8,2342 & 7,4146 & 6,9671 & 6,5065 \\
\hline $\mathrm{NiO}$ & 0 & 0,0901 & 0,1086 & 0,0317 & 0,0642 & $\mathrm{NiO}$ & 0 & 0,0726 & 0,0097 & 0,0339 & 0 & 0,0286 & 0 \\
\hline $\mathrm{BaO}$ & 22,6877 & 22,7673 & 22,3991 & 22,9703 & 19,3142 & $\mathrm{BaO}$ & 0,538 & 0,252 & 0,3785 & 0,1893 & 0,4214 & 0,5394 & 2,3863 \\
\hline Total & 88,8426 & 90,837 & 88,7699 & 92,4104 & 91,3376 & Total & 84,3139 & 82,784 & 90,1952 & 92,5226 & 88,7254 & 86,5914 & 90,4855 \\
\hline
\end{tabular}

Tabela 72-Composição química de nefelina de xenólito do corpo Indaiá 2.

$\begin{array}{lccc} & \text { In2-1-3 } & \text { In2-1-4 } & \text { In2-1-8 } \\ \mathrm{Na}_{2} \mathrm{O} & 14,5839 & 14,8137 & 13,911 \\ \mathrm{MgO} & 0,398 & 0,3744 & 0,4077 \\ \mathrm{Al}_{2} \mathrm{O}_{3} & 31,4004 & 31,2506 & 31,1384 \\ \mathrm{SiO}_{2} & 41,39 & 41,6251 & 42,1053 \\ \mathrm{~K}_{2} \mathrm{O} & 9,3983 & 9,4069 & 9,2192 \\ \mathrm{CaO} & 0,0564 & 0,0102 & 0,3019 \\ \mathrm{TiO} & 0,085 & 0 & 0,1061 \\ \mathrm{Cr}_{2} \mathrm{O}_{3} & 0 & 0,0421 & 0 \\ \mathrm{MnO} & 0 & 0 & 0,0151 \\ \mathrm{FeO} & 3,6565 & 3,6026 & 3,2778 \\ \mathrm{NiO} & 0 & 0 & 0 \\ \mathrm{Total} & 100,9685 & 101,1256 & 100,4825\end{array}$




\section{ANEXO D}

Tabelas com a composição de elementos traço em minerais de xenólitos e rochas hospedeiras, com a seguinte ordem:

\section{Olivina}

Ortopiroxênio

Clinopiroxênio

Minerais do grupo do espinélio

Anfibólio

Ilmenita

Flogopita

Titanatos

Apatita

Perovskita 
Tabela 73- Elementos traço analisados por LA-ICP-MS em olivina de peridotitos com espinélio (em ppm).

\begin{tabular}{|c|c|}
\hline OL-1 & \\
\hline 1.68 & 150 \\
\hline $\begin{array}{l}2,42 \\
2,42\end{array}$ & 2,13 \\
\hline n.d. & n.d. \\
\hline 1,98 & 6,24 \\
\hline 226654 & 204163 \\
\hline 30,63 & 22,55 \\
\hline$<66,58$ & $<59,75$ \\
\hline 2,90 & 2,78 \\
\hline 4,21 & 8,59 \\
\hline 0,42 & 0,41 \\
\hline 2,43 & 3,03 \\
\hline 1199,95 & 1103,13 \\
\hline 157,15 & 141,38 \\
\hline 3239,73 & 2991,36 \\
\hline n.d. & n.d. \\
\hline 19,44 & 15,18 \\
\hline$<0,0190$ & $<0,0181$ \\
\hline$<0,0047$ & 0,01 \\
\hline 0,00 & $<0,0035$ \\
\hline$<0,0077$ & $<0,0069$ \\
\hline$<0,0046$ & $<0,0041$ \\
\hline$<0,0091$ & $<0,0111$ \\
\hline$<0,031$ & $<0,028$ \\
\hline 0,00 & $<0,0029$ \\
\hline$<0,0029$ & 0,00 \\
\hline 0,00 & $<0,0024$ \\
\hline 0,01 & $<0,0208$ \\
\hline$<0,0217$ & 0,01 \\
\hline$<0,050$ & $<0,0228$ \\
\hline$<0,0061$ & $<0,0055$ \\
\hline$<0,0037$ & $<0,0033$ \\
\hline$<0,0180$ & 0,02 \\
\hline$<0,0037$ & $<0,0033$ \\
\hline$<0,0155$ & $<0,0099$ \\
\hline 0,00 & $<0,0033$ \\
\hline$<0,022$ & $<0,0283$ \\
\hline$<0,00$ & $<0,0033$ \\
\hline 0,00 & $<0,0108$ \\
\hline$<0,0035$ & 0,00 \\
\hline 0,02 & 0,04 \\
\hline$<0,0036$ & $<0,00$ \\
\hline 0,00 & $<0,0026$ \\
\hline
\end{tabular}

OL-1a
1,65
10,52
309996
8,50
213941
21,66
$<61,79$
2,17
14,29
0,58
3,55
1142,67
148,02
3549,10
n.d.
18,91
0,04
0,54
0,01
0,02
0,01
$<0,0122$
2,73
0,02
$<0,0054$
$<0,0033$
$<0,00$
0,02
0,01
$<0,0079$
0,00
$<0,035$
$<0,0049$
0,01
$<0,0049$
0,01
$<0,0095$
0,01
0,01
0,68
0,00
$<0,0034$

In1-14a

OL- 2
1,25
1,13
309996
4,65
191803
20,31
$<61,86$

$<61,86$
2,06

2,06
10,26
0,47

3,41

1229,66

2951,12

n.d.

21,59
$<0,028$

$<0,028$
0,02
$<0,0050$

$<0,0050$
0,02

$<0,0055$

$<0,0055$

$<, 12$
$<0,0039$

0,00

$<0,00296$

$<0,00$
$<0,025$

$<0,031$

$<0,0070$
$<0,0043$

$<0,022$

$<0,0044$

$<0,0133$

0,00

$<0,025$
0,01

$<0,0142$

0,00
1,03

0,00

$<0,0043$

OL-3-9
1,27
0,90
305473
1,99
189429
$<3,12$
$<28,59$
2,25
0,43
0,32
2,82
1188,55
140,15
3740,32
1,38
18,00
$<0,0115$
$<0,0056$
$<0,0080$
$<0,0094$
$<0,0058$
n.d.
0,02
$<0,0037$
$<0,0032$
$<0,0032$
$<0,025$
$<0,022$
$<0,0062$
$<0,019$
$<0,0030$
$<0,0114$
$<0,0043$
$<0,0134$
$<0,0040$
$<0,021$
$<0,0041$
$<0,032$
$<0,0057$
0,03
0,01
$<0,0044$

\begin{tabular}{cc} 
Lm1-17 & \\
OL-3-9b65um & OL-10-865um \\
1,34 & 1,31 \\
10,78 & 1,42 \\
305473 & 305593 \\
2,81 & 8,56 \\
187273 & 217925 \\
$<5,05$ & $<5,42$ \\
$<44,59$ & $<46,69$ \\
2,47 & 2,36 \\
1,01 & 0,88 \\
0,32 & 0,25 \\
2,26 & 3,06 \\
964,94 & 1015,65 \\
150,20 & 131,45 \\
2995,55 & 3100,77 \\
1,19 & 1,15 \\
17,03 & 13,48 \\
$<0,0133$ & $<0,0168$ \\
$<0,0118$ & 0,01 \\
0,01 & 0,01 \\
$<0,0196$ & 0,02 \\
$<0,0129$ & $<0,0145$ \\
n.d. & n.d. \\
0,06 & 0,06 \\
$<0,0043$ & $<0,0060$ \\
0,01 & $<0,0067$ \\
$<0,0040$ & $<0,0045$ \\
$<0,044$ & $<0,043$ \\
$<0,032$ & $<0,028$ \\
$<0,0083$ & $<0,0125$ \\
$<0,042$ & $<0,022$ \\
$<0,0060$ & $<0,0044$ \\
$<0,025$ & 0,02 \\
$<0,0042$ & $<0,0063$ \\
$<0,0214$ & 0,03 \\
$<0,0056$ & $<0,0069$ \\
$<0,044$ & 0,05 \\
$<0,0065$ & 0,01 \\
$<0,052$ & $<0,065$ \\
$<0,0090$ & $<0,0105$ \\
0,03 & 0,03 \\
$<0,0070$ & 0,07 \\
$<0,0086$ & $<0,0114$ \\
& \\
\hline &
\end{tabular}


Tabela 74- Elementos traço analisados por LA-ICP-MS em olivina de peridotitos com Cr- espinélio (em ppm).

\begin{tabular}{|c|c|c|c|c|c|c|c|c|c|}
\hline \multicolumn{3}{|c|}{ Lm1-20a } & \multicolumn{3}{|c|}{ In1-3 } & \multicolumn{2}{|c|}{ In1-24a } & \multicolumn{2}{|c|}{ In1-50 } \\
\hline${ }_{7} \mathrm{Li}$ & OL-1-1 & OL-2-3 & OL-1 & OL-2 & OL-3 & OL-1 & OL-2 & OL12-7 & OL10-8 \\
\hline${ }_{23} \mathrm{Na}$ & 1,36 & 1,18 & 1,79 & 1,45 & 1,57 & 1,74 & 1,73 & 1,34 & 1,80 \\
\hline${ }_{25} \mathrm{Mg}$ & 1,19 & 1,05 & 3,85 & 1,01 & 1,89 & 2,43 & 2,99 & 1,91 & 7,14 \\
\hline${ }_{27} \mathrm{Al}$ & 307041 & 305774 & 306377 & 306377 & 306377 & 312408 & 312408 & 311685 & 312951 \\
\hline${ }_{29} \mathrm{Si}$ & 1,41 & 1,44 & 0,94 & 0,74 & $<0,86$ & 1,42 & 1,86 & 2,00 & 17,38 \\
\hline${ }_{31} \mathrm{P}$ & 186991 & 214317 & 174326 & 195661 & 164507 & 197671 & 202636 & 224106 & 256973 \\
\hline${ }_{42} \mathrm{Ca}$ & 5,34 & $<5,61$ & $<21,60$ & $<23,90$ & $<23,48$ & 23,73 & 70,78 & 36,05 & 36,45 \\
\hline${ }_{45} \mathrm{Sc}$ & $<37,97$ & $<40,52$ & $<135,74$ & $<145,37$ & 186,59 & $<125,33$ & $<174,93$ & $<38,99$ & $<41,47$ \\
\hline${ }_{49} \mathrm{Ti}$ & 1,89 & 2,03 & 2,62 & 3,39 & 2,31 & 2,24 & 2,83 & 2,09 & 2,22 \\
\hline${ }_{51} \mathrm{~V}$ & 1,48 & 1,59 & 4,00 & 1,38 & 2,17 & 3,70 & 2,22 & 4,13 & 4,74 \\
\hline${ }_{52} \mathrm{Cr}$ & 0,45 & 0,50 & 0,15 & 0,24 & 0,28 & 0,17 & 0,19 & 0,20 & 0,13 \\
\hline${ }_{55} \mathrm{Mn}$ & 3,03 & 2,59 & 2,92 & 4,56 & 3,47 & 3,96 & 2,22 & 1,79 & 2,27 \\
\hline${ }_{59} \mathrm{Co}$ & 969,32 & 1002,90 & 910,98 & 888,77 & 938,42 & 956,19 & 835,43 & 860,02 & 880,27 \\
\hline${ }_{62} \mathrm{Ni}$ & 140,27 & 144,40 & 129,21 & 123,75 & 128,63 & 130,51 & 113,89 & 134,79 & 152,73 \\
\hline${ }_{63} \mathrm{Cu}$ & 3095,23 & 2897,92 & 2926,25 & 2813,89 & 2991,29 & 2668,83 & 2470,02 & 3255,16 & 3900,28 \\
\hline${ }_{66} \mathrm{Zn}$ & 0,18 & $<0,069$ & n.d. & n.d. & n.d. & n.d. & n.d. & $<0,070$ & $<0,083$ \\
\hline${ }_{85} \mathrm{Rb}$ & 19,70 & 23,63 & 21,66 & 18,42 & 27,50 & 25,14 & 29,89 & 27,99 & 30,44 \\
\hline${ }_{88} \mathrm{Sr}$ & $<0,0162$ & $<0,0147$ & $<0,054$ & $<0,053$ & $<0,053$ & $<0,062$ & $<0,080$ & $<0,0192$ & $<0,0202$ \\
\hline${ }_{89} \mathrm{Y}$ & 0,01 & 0,02 & $<0,0116$ & $<0,0189$ & $<0,0093$ & $<0,0158$ & $<0,0213$ & $<0,0123$ & 0,06 \\
\hline${ }_{90} \mathrm{Zr}$ & $<0,0119$ & 0,01 & 0,00 & 0,01 & $<0,0122$ & $<0,00$ & $<0,0177$ & 0,01 & 0,02 \\
\hline${ }_{93} \mathrm{Nb}$ & $<0,0198$ & $<0,0251$ & 0,01 & 0,01 & $<0,00$ & 0,01 & $<0,049$ & 0,04 & 0,09 \\
\hline${ }_{133} \mathrm{Cs}$ & $<0,0115$ & $<0,0107$ & $<0,0113$ & 0,01 & 0,01 & $<0,027$ & $<0,00$ & $<0,0136$ & $<0,0139$ \\
\hline${ }_{137} \mathrm{Ba}$ & n.d. & n.d. & $<0,025$ & $<0,029$ & 0,02 & $<0,0197$ & $<0,0205$ & n.d. & n.d. \\
\hline${ }_{139} \mathrm{La}$ & $<0,041$ & 0,08 & $<0,058$ & $<0,117$ & $<0,066$ & $<0,089$ & 0,09 & $<0,054$ & 0,14 \\
\hline${ }_{140} \mathrm{Ce}$ & $<0,0068$ & $<0,0056$ & $<0,00$ & $<0,0099$ & 0,00 & 0,00 & 0,01 & 0,01 & 0,01 \\
\hline${ }_{141} \mathrm{Pr}$ & $<0,0051$ & $<0,0057$ & 0,00 & $<0,00$ & $<0,0082$ & $<0,0083$ & $<0,0112$ & 0,01 & 0,04 \\
\hline${ }_{146} \mathrm{Nd}$ & $<0,0040$ & $<0,0045$ & $<0,0091$ & $<0,0128$ & $<0,0073$ & $<0,00$ & $<0,0145$ & $<0,0061$ & $<0,0057$ \\
\hline${ }_{149} \mathrm{Sm}$ & $<0,046$ & $<0,043$ & $<0,00$ & 0,01 & $<0,00$ & $<0,00$ & 0,05 & $<0,054$ & $<0,060$ \\
\hline${ }_{151} \mathrm{Eu}$ & 0,04 & $<0,043$ & 0,08 & 0,03 & $<0,114$ & $<0,086$ & $<0,116$ & $<0,042$ & $<0,045$ \\
\hline${ }_{157} \mathrm{Gd}$ & $<0,0118$ & $<0,0120$ & $<0,00$ & $<0,083$ & 0,02 & 0,02 & $<0,106$ & $<0,0124$ & $<0,0177$ \\
\hline${ }_{159} \mathrm{~Tb}$ & $<0,033$ & $<0,037$ & 0,01 & $<0,0175$ & $<0,0172$ & 0,00 & $<0,0224$ & $<0,049$ & $<0,055$ \\
\hline${ }_{161} \mathrm{Dy}$ & $<0,0067$ & $<0,0057$ & $<0,0128$ & $<0,0148$ & $<0,00$ & 0,01 & $<0,0208$ & $<0,0101$ & $<0,0067$ \\
\hline${ }_{165} \mathrm{Ho}$ & $<0,020$ & $<0,0225$ & $<0,046$ & $<0,053$ & 0,05 & $<0,00$ & $<0,114$ & 0,03 & $<0,038$ \\
\hline${ }_{166} \mathrm{Er}$ & $<0,0076$ & $<0,0073$ & $<0,0096$ & $<0,0111$ & $<0,0189$ & 0,00 & $<0,0169$ & $<0,0075$ & $<0,0089$ \\
\hline${ }_{169} \mathrm{Tm}$ & $<0,0200$ & $<0,0184$ & $<0,040$ & $<0,046$ & 0,01 & $<0,055$ & 0,01 & $<0,0195$ & 0,03 \\
\hline${ }_{172} \mathrm{Yb}$ & 0,01 & $<0,0054$ & $<0,0204$ & $<0,00$ & 0,00 & 0,01 & $<0,0218$ & $<0,0075$ & $<0,0090$ \\
\hline${ }_{175} \mathrm{Lu}$ & $<0,030$ & $<0,038$ & $<0,064$ & 0,03 & $<0,051$ & $<0,087$ & $<0,068$ & $<0,048$ & $<0,067$ \\
\hline${ }_{178} \mathrm{Hf}$ & $<0,0056$ & $<0,0080$ & $<0,0122$ & $<0,0200$ & 0,00 & $<0,0119$ & $<0,00$ & $<0,0079$ & $<0,0071$ \\
\hline${ }_{181} \mathrm{Ta}$ & 0,04 & $<0,043$ & $<0,00$ & 0,01 & $<0,036$ & $<0,037$ & $<0,050$ & $<0,061$ & $<0,077$ \\
\hline${ }_{208} \mathrm{~Pb}$ & $<0,0115$ & $<0,0088$ & $<0,00$ & $<0,00$ & $<0,00$ & $<0,0155$ & 0,00 & $<0,0092$ & $<0,0124$ \\
\hline${ }_{232} \mathrm{Th}$ & 0,02 & 0,05 & 0,02 & 0,03 & 0,03 & 0,04 & 0,08 & 0,05 & 0,04 \\
\hline${ }_{238} \mathrm{U}$ & $<0,0076$ & $<0,0107$ & $<0,0088$ & $<0,0144$ & $<0,0100$ & $<0,0102$ & $<0,0194$ & 0,03 & 0,03 \\
\hline & 0,01 & $<0,0093$ & $<0,0068$ & $<0,0112$ & $<0,0078$ & $<0,0106$ & $<0,0101$ & $<0,0113$ & $<0,0107$ \\
\hline
\end{tabular}


Tabela 75- Elementos traço analisados por LA-ICP-MS em olivina de harburgitos com textura porfiroclática em mosaico (em ppm).

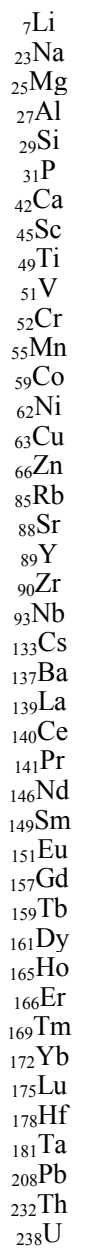

OL6-1
2,67
178,10
292144
138,37
245288
92,20
661,33
2,09
114,75
6,76
461,50
1050,33
181,15
3377,96
7,79
83,94
$<0,0198$
0,02
0,04
0,19
$<0,0113$
.d.
0,06
$<0,0052$
$<0,0072$
$<0,0055$
$<0,039$
$<0,023$
$<0,0073$
$<0,038$
$<0,0055$
$<0,0220$
0,01
$<0,0164$
$<0,0063$
$<0,046$
$<0,0076$
$<0,045$
$<0,0082$
0,06
$<0,0081$
$<0,0088$

In1-33
OL7-4
3,48
172,76
288887
177,61
235883
81,39
742,82
2,37
118,54
16,62
510,66
1046,86
172,24
3099,86
7,71
93,90
0,72
0,84
0,06
0,42
0,09
n.d.
1,54
0,09
0,16
0,01
0,05
$<0,048$
0,02
$<0,043$
$<0,0041$
$<0,026$
$<0,0078$
$<0,022$
0,01
$<0,047$
$<0,0097$
$<0,055$
$<0,0092$
0,22
$<0,0112$
0,03

OL8-5
3,69
162,79
288284
188,03
221626
94,79
1537,99
2,77
161,87
19,99
468,84
864,18
140,02
2733,36
5,47
92,14
0,87
3,11
0,14
1,28
0,15
n.d.
1,77
0,20
0,45
0,04
0,09
$<0,038$
$<0,0096$
$<0,036$
0,01
0,03
$<0,0085$
$<0,021$
$<0,0070$
$<0,056$
$<0,0106$
$<0,089$
$<0,0110$
0,18
0,04
0,01

oliv- $1^{\text {a }}$
2,28
178,27
304568
192,77
207965
71,28
677,86
3,74
132,74
7,00
714,41
1018,78
156,84
3009,76
n.d.
73,19
$<0,073$
0,09
0,07
0,22
$<0,024$
$<0,053$
0,27
0,00
0,00
$<0,0094$
$<0,047$
0,07
$<0,00$
$<0,0166$
$<0,00$
$<0,00$
$<0,00$
0,02
$<0,0188$
$<0,083$
$<0,0129$
$<0,055$
0,00
0,55
$<0,00$
$<0,0097$

In1-1
oliv-2spot
2,83
200,94
304568
102,66
197194
108,87
309,63
3,81
115,34
6,43
744,19
1127,10
195,37
2847,72
n.d.
74,43
$<0,074$
0,07
0,10
0,13
$<0,0179$
$<0,056$
0,16
$<0,0133$
$<0,0080$
$<0,0120$
0,08
$<0,00$
$<0,124$
$<0,00$
$<0,0123$
$<0,064$
$<0,0184$
0,05
$<0,0139$
$<0,00$
$<0,00$
$<0,057$
$<0,0120$
0,04
$<0,00$
$<0,0071$

oliv-3 212,09 304568 218884 $<37,13$
569,62 4,60 132,58
9,05 1087,76 963,85 158,29
3527,94 3527,94 n.d. $<0,091$ 0,13 0,04 0,22 $<0,053$ 0,31 0,00
$<0,0085$ $<0,00$ $<0,052$ $<0,155$ 0,03 $<0,0176$ $<0,0129$ $<0,0138$ $<0,00$ $<0,0214$ $<0,095$ $<0,0136$ $<0,075$ 0,00 0,48
$<0,0116$ $<0,0075$ 
Tabela 76- Elementos traço analisados por LA-ICP-MS em olivina de peridotitos metassomatisados e em pirooxenito (em ppm).

\begin{tabular}{|c|c|c|c|c|c|c|c|c|c|c|c|c|}
\hline & & & & Lm1-1 & & & & & & & & Fac-5 \\
\hline & OL1-8 & OL2-9 & OL1-7 & OL1d-8 & OL1-7b80\% & Ol-1a & Ol-1b & OL-1 & OL-2 & OL-1-3 & OL-2-4 & OL-1-1 \\
\hline${ }_{7} \mathrm{Li}$ & 2,35 & 1,57 & 3,33 & 2,54 & 1,70 & 3,16 & 1,58 & 1,30 & 1,22 & 1,58 & 1,47 & 9,97 \\
\hline${ }_{23} \mathrm{Na}$ & 57,99 & 46,48 & 106,48 & 77,93 & 86,55 & 59,54 & 62,64 & 15,30 & 14,55 & 183,20 & 98,27 & 199,75 \\
\hline${ }_{25} \mathrm{Mg}$ & 297994 & 296667 & 290033 & 292928 & 290033 & 272000 & 272000 & 311202 & 311202 & 311202 & 312951 & 284183 \\
\hline${ }_{27} \mathrm{Al}$ & 7,87 & 6,67 & 27,72 & 24,72 & 17,57 & 6,22 & 7,34 & 1,35 & 1,23 & 79,02 & 89,60 & 169,96 \\
\hline${ }_{29} \mathrm{Si}$ & 207330 & 219555 & 221046 & 171352 & 180035 & 206603 & 239905 & 201561 & 197622 & 236896 & 227041 & 197664 \\
\hline${ }_{31} \mathrm{P}$ & 110,37 & 9,99 & 55,82 & $<4,22$ & 66,84 & 190,90 & 175,52 & $<25,50$ & $<22,60$ & 13,64 & 6,80 & 70,21 \\
\hline${ }_{42} \mathrm{Ca}$ & 148,00 & 139,40 & 347,87 & 336,58 & 219,29 & 280,18 & 261,06 & $<138,74$ & $<119,89$ & 326,82 & 325,38 & 897,69 \\
\hline${ }_{45}^{42} \mathrm{Sc}$ & 1,78 & 1,81 & 3,28 & 3,54 & 2,13 & 3,76 & 3,19 & 2,44 & 2,75 & 4,58 & 4,54 & 2,59 \\
\hline${ }_{49} \mathrm{Ti}$ & 102,46 & 9,83 & 174,32 & 159,81 & 147,28 & 100,94 & 88,01 & 12,35 & 2,65 & 57,42 & 71,77 & 128,79 \\
\hline${ }_{51} \mathrm{~V}$ & 4,33 & 4,08 & 6,42 & 5,23 & 5,49 & 3,63 & 4,36 & 1,41 & 1,24 & 5,50 & 5,62 & 6,31 \\
\hline${ }_{52} \mathrm{Cr}$ & 134,94 & 115,20 & 285,32 & 200,95 & 200,38 & 32,78 & 43,26 & 31,59 & 30,78 & 353,68 & 316,69 & 550,42 \\
\hline${ }_{55} \mathrm{Mn}$ & 1265,44 & 1184,99 & 1694,53 & 1049,76 & 1210,36 & 1399,14 & 1619,76 & 818,20 & 815,68 & 852,10 & 805,47 & 1110,06 \\
\hline${ }_{59} \mathrm{Co}$ & 142,42 & 135,63 & 149,82 & 117,34 & 165,72 & 146,66 & 178,18 & 120,79 & 124,57 & 129,63 & 131,21 & 177,21 \\
\hline${ }_{6} \mathrm{Ni}$ & 2877,78 & 2887,26 & 3658,09 & 2911,09 & 3007,38 & 1383,47 & 1590,55 & 2980,72 & 2925,21 & 852,1 & 805,47 & 2884,64 \\
\hline${ }_{63} \mathrm{Cu}$ & 1,13 & 1,05 & 2,53 & 2,39 & 2,04 & n.d. & n.d. & n.d. & n.d. & 1,83 & 1,62 & 3,47 \\
\hline${ }_{66} \mathrm{Zn}$ & 96,71 & 95,93 & 99,06 & 96,59 & 89,48 & 127,27 & 128,31 & 44,49 & 42,08 & 47,44 & 41,28 & 83,69 \\
\hline${ }_{85} \mathrm{Rb}$ & $<0,0180$ & $<0,0204$ & 0,11 & $<0,0197$ & 0,04 & $<0,090$ & $<0,085$ & $<0,056$ & $<0,061$ & 0,11 & $<0,0194$ & $<0,0163$ \\
\hline${ }_{88} \mathrm{Sr}$ & 0,02 & $<0,0140$ & 0,36 & $<0,0117$ & 0,43 & 0,01 & 0,03 & $<0,0180$ & $<0,0167$ & 0,06 & $<0,0118$ & 0,05 \\
\hline${ }_{89}^{80 \mathrm{Y}}$ & $<0,0112$ & $<0,0155$ & $<0,016$ & 0,02 & 0,03 & $<0,026$ & $<0,021$ & $<0,0181$ & 0,01 & 0,04 & 0,04 & 0,04 \\
\hline${ }_{90}^{8} \mathrm{Zr}$ & 0,38 & 0,31 & 1,26 & 1,20 & 1,07 & 0,40 & 0,38 & 0,11 & $<0,053$ & 1,73 & 1,84 & 0,16 \\
\hline${ }_{93} \mathrm{Nb}$ & 0,09 & 0,23 & 0,02 & 0,05 & 0,03 & 0,15 & 0,14 & 2,81 & 0,90 & 0,02 & 0,03 & $<0,0140$ \\
\hline${ }_{133} \mathrm{Cs}$ & n.d. & n.d. & n.d. & n.d. & n.d. & $<0,040$ & $<0,035$ & $<0,0184$ & $<0,0170$ & n.d. & n.d. & n.d. \\
\hline${ }_{137} \mathrm{Ba}$ & $<0,058$ & 0,05 & 3,18 & $<0,045$ & 1,02 & $<0,068$ & $<0,147$ & 0,08 & 0,08 & 0,34 & $<0,043$ & 0,06 \\
\hline${ }_{139} \mathrm{La}$ & $<0,0064$ & $<0,0074$ & 0,02 & $<0,0084$ & 0,02 & $<0,0117$ & $<0,0096$ & $<0,0143$ & 0,01 & $<0,0078$ & $<0,0062$ & $<0,0065$ \\
\hline${ }_{140} \mathrm{Ce}$ & $<0,0063$ & $<0,0095$ & 0,03 & $<0,0064$ & 0,15 & $<0,0092$ & $<0,0107$ & $<0,0124$ & $<0,0115$ & 0,01 & $<0,0055$ & 0,02 \\
\hline${ }_{141} \mathrm{Pr}$ & $<0,0052$ & $<0,0060$ & 0,01 & $<0,0068$ & 0,01 & 0,01 & $<0,0075$ & 0,00 & 0,00 & $<0,0049$ & $<0,0057$ & $<0,0067$ \\
\hline${ }_{146} \mathrm{Nd}$ & $<0,048$ & $<0,047$ & $<0,058$ & $<0,049$ & 0,33 & 0,04 & $<0,00$ & 0,03 & $<0,044$ & $<0,066$ & $<0,049$ & 0,04 \\
\hline${ }_{149} \mathrm{Sm}$ & $<0,041$ & $<0,042$ & $<0,042$ & $<0,037$ & 0,09 & 0,06 & $<0,074$ & $<0,118$ & $<0,134$ & $<0,047$ & $<0,046$ & $<0,033$ \\
\hline${ }_{151} \mathrm{Eu}$ & $<0,0088$ & $<0,0094$ & 0,02 & $<0,0121$ & $<0,0120$ & $<0,115$ & 0,05 & $<0,112$ & $<0,073$ & $<0,0124$ & $<0,0102$ & 0,01 \\
\hline${ }_{157} \mathrm{Gd}$ & $<0,032$ & $<0,045$ & $<0,041$ & $<0,039$ & $<0,039$ & $<0,00$ & $<0,0154$ & $<0,00$ & $<0,0151$ & $<0,029$ & $<0,043$ & $<0,035$ \\
\hline${ }_{159} \mathrm{~Tb}$ & $<0,0071$ & $<0,0063$ & $<0,0068$ & $<0,0065$ & $<0,0081$ & $<0,0209$ & $<0,0121$ & 0,00 & $<0,0102$ & $<0,0094$ & $<0,0064$ & $<0,0052$ \\
\hline${ }_{161} \mathrm{Dy}$ & $<0,025$ & $<0,032$ & $<0,037$ & $<0,030$ & $<0,0250$ & $<0,140$ & $<0,094$ & $<0,105$ & $<0,080$ & $<0,033$ & $<0,033$ & $<0,022$ \\
\hline${ }_{165} \mathrm{Ho}$ & $<0,0059$ & $<0,0083$ & $<0,0079$ & $<0,0084$ & $<0,0066$ & $<0,0165$ & 0,00 & 0,00 & $<0,0137$ & $<0,0069$ & $<0,0115$ & $<0,0090$ \\
\hline${ }_{166} \mathrm{Er}$ & $<0,0204$ & 0,02 & $<0,031$ & $<0,024$ & $<0,022$ & 0,03 & 0,01 & $<0,031$ & $<0,028$ & $<0,023$ & 0,03 & $<0,025$ \\
\hline${ }_{166} \mathrm{Tm}$ & $<0,0067$ & $<0,0048$ & $<0,0099$ & $<0,0084$ & 0,01 & $<0,0155$ & $<0,0127$ & $<0,00$ & $<0,0100$ & $<0,0105$ & $<0,0109$ & $<0,0058$ \\
\hline${ }_{172} \mathrm{Yb}$ & $<0,041$ & $<0,042$ & $<0,060$ & $<0,057$ & $<0,047$ & $<0,00$ & 0,02 & $<0,070$ & $<0,046$ & $<0,064$ & $<0,056$ & $<0,033$ \\
\hline${ }_{175} \mathrm{Lu}$ & $<0,0116$ & $<0,0098$ & 0,01 & $<0,0110$ & 0,01 & $<0,00$ & $<0,0208$ & $<0,0147$ & 0,00 & $<0,0109$ & $<0,0069$ & $<0,0083$ \\
\hline${ }_{178} \mathrm{Hf}$ & $<0,053$ & $<0,058$ & $<0,074$ & 0,08 & $<0,068$ & $<0,056$ & 0,05 & $<0,048$ & $<0,044$ & 0,12 & $<0,092$ & $<0,051$ \\
\hline${ }_{181} \mathrm{Ta}$ & $<0,0105$ & 0,02 & $<0,0126$ & $<0,0081$ & $<0,0071$ & $<0,00$ & 0,01 & 0,05 & $<0,0177$ & $<0,0113$ & $<0,0119$ & $<0,0064$ \\
\hline${ }_{208} \mathrm{~Pb}$ & 0,10 & 0,04 & 0,03 & 0,07 & 0,07 & $<0,035$ & 0,05 & 0,06 & 0,03 & 0,11 & 0,03 & $<0,022$ \\
\hline${ }_{232} \mathrm{Th}$ & $<0,0098$ & $<0,0081$ & 0,01 & 0,01 & $<0,0087$ & $<0,0144$ & $<0,0118$ & 0,01 & $<0,0136$ & $<0,0102$ & 20,53 & $<0,0108$ \\
\hline${ }_{238}^{232} \mathrm{U}$ & $<0,0065$ & $<0,0090$ & 0,01 & 0,01 & $<0,0068$ & $<0,0088$ & 0,01 & 0,00 & 0,00 & $<0,0096$ & $<0,0081$ & $<0,0065$ \\
\hline
\end{tabular}


Tabela 77- Elementos traço analisados por LA-ICP-MS em ortopiroxênio de peridotitos com espinélio (em ppm).

\begin{tabular}{|c|c|c|c|c|c|c|c|c|c|c|c|}
\hline \multirow[b]{3}{*}{${ }_{7} \mathrm{Li}$} & \multicolumn{4}{|c|}{ In1-4 } & & \multicolumn{2}{|c|}{ In1-14a } & \multirow[b]{2}{*}{ OPX-3 } & \multicolumn{2}{|c|}{ Lm1-17 } \\
\hline & OPX-1 & OPX-1b & OPX-1c & OPX-2 & OPX-3 & OPX-1 & PX-1b & OPX-2 & & opx-6a-5 & opx $-5-6$ \\
\hline & 1,41 & 1,10 & 1,12 & 1,29 & 1,45 & 1,25 & 0,90 & 0,83 & 1,54 & 1,57 & 1,52 \\
\hline${ }_{23} \mathrm{Na}$ & 474,26 & 289,38 & 522,69 & 202,53 & 389,58 & 99,33 & 110,69 & 157,54 & 169,63 & 399,34 & 401,59 \\
\hline${ }_{25} \mathrm{Mg}$ & n.d. & n.d. & n.d. & n.d. & n.d. & 200833,9 & 200833,9 & 215549,7 & 200833,9 & 205477,8 & 199265,8 \\
\hline${ }_{27} \mathrm{Al}$ & 28608,13 & 23613,38 & 28145,58 & 21964,97 & 22342,32 & 15850,08 & 14232,56 & 18024,46 & 17664,77 & 22671,12 & 24992,04 \\
\hline${ }_{29} \mathrm{Si}$ & 289955,7 & 279572,4 & 264510,5 & 250954,2 & 199199,9 & 237762,0 & 262524,0 & 276801,9 & 263141,9 & 266155,4 & 195165,4 \\
\hline${ }_{31} \mathrm{P}$ & $<28,97$ & $<25,90$ & $<28,35$ & $<27,83$ & $<28,16$ & $<25,09$ & $<18,97$ & $<24,24$ & $<31,19$ & $<5,02$ & $<5,09$ \\
\hline${ }_{42} \mathrm{Ca}$ & 3560,77 & 2577,29 & 5623,94 & 1782,02 & 3833,35 & 835,48 & 871,04 & 1936,50 & 1636,77 & 5835,52 & 4876,57 \\
\hline${ }_{45} \mathrm{Sc}$ & 21,40 & 21,21 & 24,23 & 17,27 & 19,08 & 17,64 & 11,87 & 15,79 & 17,05 & 23,79 & 25,33 \\
\hline${ }_{49} \mathrm{Ti}$ & 479,78 & 451,36 & 508,52 & 394,62 & 415,42 & 198,22 & 182,98 & 266,47 & 222,24 & 74,19 & 68,74 \\
\hline${ }_{51} \mathrm{~V}$ & 115,18 & 114,65 & 105,96 & 107,76 & 98,21 & 91,55 & 84,01 & 79,86 & 93,49 & 110,86 & 93,92 \\
\hline${ }_{52} \mathrm{Cr}$ & 3826,78 & 3089,43 & 3731,91 & 2820,55 & 2998,55 & 2608,30 & 2700,12 & 2624,08 & 3170,41 & 3956,74 & 3184,36 \\
\hline${ }_{55} \mathrm{Mn}$ & 1311,15 & 1499,18 & 1204,37 & 1478,19 & 1242,19 & 958,30 & 989,18 & 1002,96 & 1044,95 & 1082,34 & 1075,00 \\
\hline${ }_{59} \mathrm{Co}$ & 50,37 & 50,27 & 53,27 & 50,66 & 53,56 & 47,56 & 49,94 & 51,21 & 50 & 53,25 & 48,71 \\
\hline${ }_{6} \mathrm{Ni}$ & 820,28 & 687,80 & 640,72 & 657,90 & 646,46 & 601,08 & 577,29 & 525 & & 672,35 & 696,60 \\
\hline${ }_{63} \mathrm{Cu}$ & n.d. & n.d. & n.d. & n.d. & n.d. & n. & n.d. & n. & & 1,56 & 1,40 \\
\hline${ }_{66} \mathrm{Zn}$ & 23,0 & 17 & 21 , & & & & 21 , & & & 21,69 & 19,56 \\
\hline${ }_{85} \mathrm{Rb}$ & $<0,092$ & $<0,072$ & $<0,082$ & $<0,086$ & $<0,086$ & $<0,064$ & $<0,052$ & $<0,075$ & $<0,078$ & $<0,0182$ & 0,13 \\
\hline${ }_{88} \mathrm{Sr}$ & 0,02 & 0,38 & 0,02 & $<0,0162$ & $<0,017$ & 0 & 0,41 & 0,67 & & 0,02 & 0,30 \\
\hline${ }_{89}^{80 \mathrm{Y}}$ & 0 & 0 , & 0,9 & 0,3 & 0,69 & 0 , & 0 , & 0 , & & 0,6 & 0,67 \\
\hline${ }_{90} \mathrm{Zr}$ & 0,11 & 0, & 0,12 & 0,0 & & 0,2 & 0,2 & 0,6 & & $<0,0157$ & 0,02 \\
\hline${ }_{93} \mathrm{Nb}$ & 0,00 & $0, \mathrm{C}$ & $<0,0160$ & 0,0 & $<0,0171$ & 0,0 & 0,0 & 0,0 & $<0,018$ & $<0,0098$ & $<0,0102$ \\
\hline${ }_{133} \mathrm{Cs}$ & n.d & n. & n.d. & n. & n.d. & & n. & n. & & n.d. & n.d. \\
\hline 153 & $<0,074$ & & $<0$, & $<0$, & & & & & & & 0,10 \\
\hline${ }_{139} \mathrm{La}$ & 0,01 & 0,03 & $<0,01$ & 0,0 & $<0,0$ & 0 , & 0, & 0, & & $<0,0050$ & $<0,0051$ \\
\hline${ }_{140} \mathrm{Ce}$ & $<0,0097$ & $<0,0087$ & $<0,00$ & 0, & $<0,0147$ & $<0$, & 0, & 0 , & & $<0,0050$ & 0,01 \\
\hline${ }_{141}^{140} \mathrm{P}$ & & & $<0$ & & & & 0 , & & & $<0$ & $<0,0054$ \\
\hline${ }_{146}^{14 \mathrm{Nd}}$ & $<0,071$ & $<0,07$ & $<0,050$ & $<0,050$ & $<0,055$ & $<0$, & 0,0 & $<0,049$ & $<0,00$ & $<0,043$ & $<0,038$ \\
\hline m & $<0,10$ & $<0$ & $<0, \mathrm{C}$ & $<0$ & $<0$ & & $<0$ & 0, & & & $<0,038$ \\
\hline & $<0,0$ & $<0,0$ & $<0$ & $<0,0$ & $<0$ & $<0$, & $<0$ & & & $<0,0081$ & $<0,0120$ \\
\hline${ }_{157}^{15 \mathrm{G}}$ & $<0,11$ & $<0,074$ & $<0,0$ & $<0,0$ & $<0$, & 0 & $<0$ & $<0$ & $<0$ & 0,03 & $<0,040$ \\
\hline 137 & $<0,01$ & & $<0,0$ & $<0, \mathrm{C}$ & & & & $<0$ & & 0, & 0,01 \\
\hline & 0,0 & $<0$, & $<0,0$ & 0 , & & $<0$, & $<0$, & $<0$ & & 0, & 0,07 \\
\hline & $<0,01$ & & & & & & 0, & 0, & & 0, & 0,02 \\
\hline 166 & 0,0 & & 0 , & $<0,0$ & 0 & 0 , & 0, & $<0$, & & 0, & 0,09 \\
\hline & 0 , & & & $<0,0$ & & $<0, \mathrm{C}$ & $<0,0$ & & & 0 & 0,03 \\
\hline & 0,2 & & & & & 0 , & 0 , & & & 0 & 0,24 \\
\hline & 0,0 & 0,0 & 0, & 0 , & & 0 & $<0,0122$ & 0,0 & $<0,021$ & 0,0 & 0,05 \\
\hline & 0, & & & & & & 0,0 & $<0,067$ & $<0,00$ & $<0$ & $<0,059$ \\
\hline & $<0,0123$ & $<0,0154$ & $<0,0120$ & 0, & 0, & 0,0 & $<0,0079$ & $0, \mathrm{C}$ & $<0,00$ & $<0,0095$ & $<0,0085$ \\
\hline & $<0,0$ & 0 , & $<0,0$ & $<0$ & & & 0 , & & & 0, & 0,03 \\
\hline & 0,0 & $<0,01$ & $<0$ & 0, & $<0,0$ & $<0,0$ & 0,0 & $<0,0106$ & & 0,01 & 0,01 \\
\hline${ }_{238} 23 \mathrm{U}$ & 0,00 & $<0,0121$ & $<0,00$ & 0,01 & $<0,0095$ & $<0,0085$ & $<0,0059$ & 0,00 & $<0,00$ & $<0,0078$ & $<0,0081$ \\
\hline
\end{tabular}


Tabela 78- Elementos traço analisados por LA-ICP-MS ortopiroxênio de peridotitos com Cr- espinélio (em ppm).

\begin{tabular}{|c|c|c|c|c|c|c|c|c|c|c|c|}
\hline & \multirow{2}{*}{$\begin{array}{l}\text { Lm1-20a } \\
\text { opx11b-4 }\end{array}$} & \multicolumn{6}{|c|}{ In1-3 } & \multicolumn{2}{|c|}{ In1-24a } & \multicolumn{2}{|c|}{ In1-50 } \\
\hline & & OPX-1 & OPX-2 & OPX-3 & OPX-3b & OPX-4 & OPX-5 & OPX-1 & OPX-2 & opх7-9 & орх2-10 \\
\hline${ }_{7} \mathrm{Li}$ & 1,56 & 1,91 & 1,52 & 1,67 & 1,21 & 1,49 & 1,75 & 0,52 & $<0,39$ & 0,40 & 1,56 \\
\hline${ }_{23} \mathrm{Na}$ & 258,80 & 244,32 & 190,72 & 1086,31 & 281,57 & 173,37 & 206,66 & 202,16 & 365,27 & 392,99 & 509,86 \\
\hline${ }_{25} \mathrm{Mg}$ & 262300,00 & 218806,39 & 218806,39 & 218806,39 & 218806,39 & 218806,42 & 218806,42 & 214343,47 & 211086,70 & 215368,75 & 213318,17 \\
\hline${ }_{27} \mathrm{Al}$ & 15717,24 & 9967,44 & 8927,06 & 10698,60 & 10081,81 & 9741,72 & 8431,22 & 9431,08 & 8749,52 & 9272,98 & 7724,48 \\
\hline${ }_{29} \mathrm{Si}$ & 293849,47 & 300047,53 & 251719,86 & 307243,13 & 299730,00 & 381779,25 & 319674,41 & 296540,94 & 294907,13 & 265004,63 & 239069,02 \\
\hline${ }_{31} \mathrm{P}$ & 5,55 & $<30,60$ & $<29,90$ & $<45,63$ & $<37,55$ & $<41,38$ & $<37,59$ & $<41,48$ & 41,75 & $<5,47$ & 22,81 \\
\hline${ }_{42} \mathrm{Ca}$ & 3075,87 & 4728,45 & 3172,42 & 19058,48 & 3697,48 & 2991,50 & 2926,21 & 2115,88 & 3158,04 & 3281,80 & 2843,35 \\
\hline${ }_{45} \mathrm{Sc}$ & 28,25 & 25,56 & 23,57 & 38,20 & 26,03 & 29,24 & 21,93 & 18,76 & 26,47 & 22,71 & 23,59 \\
\hline${ }_{49} \mathrm{Ti}$ & 96,09 & 176,69 & 156,21 & 219,95 & 153,54 & 204,34 & 141,67 & 658,42 & 778,73 & 705,72 & 741,72 \\
\hline${ }_{51} \mathrm{~V}$ & 114,51 & 70,76 & 71,81 & 93,70 & 67,53 & 83,75 & 62,03 & 57,47 & 70,73 & 62,92 & 76,66 \\
\hline${ }_{52} \mathrm{Cr}$ & 4209,96 & 3801,90 & 2626,24 & 4182,98 & 3712,06 & 3867,07 & 3052,55 & 3011,05 & 3253,25 & 3544,99 & 3437,87 \\
\hline${ }_{55} \mathrm{Mn}$ & 1307,35 & 1028,94 & 1003,90 & 1075,28 & 885,22 & 1247,47 & 1108,15 & 944,67 & 1030,98 & 1103,34 & 1145,92 \\
\hline${ }_{59} \mathrm{Co}$ & 57,23 & 54,06 & 47,99 & 57,44 & 48,80 & 53,90 & 48,68 & 46,53 & 48,33 & 49,68 & 51,04 \\
\hline${ }_{6} \mathrm{Ni}$ & 627,90 & 723,09 & 672,85 & 818,23 & 615,82 & 625,29 & 649,68 & 577,64 & 524,94 & 558,90 & 666,33 \\
\hline${ }_{63} \mathrm{Cu}$ & 0,75 & n.d. & n.d. & n.d. & n.d. & n.d. & n.d. & n.d. & n.d. & $<0,077$ & 0,37 \\
\hline${ }_{66} \mathrm{Zn}$ & 26,42 & 24,73 & 24,90 & 32,62 & 27,25 & 24,72 & 24,78 & 22,79 & 23,68 & 23,91 & 25,46 \\
\hline${ }_{85} \mathrm{Rb}$ & $<0,0035$ & $<0,072$ & $<0,079$ & $<0,091$ & 0,08 & $<0,089$ & $<0,072$ & $<0,081$ & 0,95 & $<0,0180$ & 10,55 \\
\hline${ }_{88} \mathrm{Sr}$ & 0,02 & $<0,021$ & 0,02 & 0,93 & 0,11 & 0,02 & $<0,0145$ & 0,09 & 1,71 & 0,33 & 21,73 \\
\hline${ }_{89}^{80 \mathrm{Y}}$ & 0,16 & 0,25 & 0,23 & 1,06 & 0,27 & 0,19 & 0,25 & 0,26 & 0,38 & 0,36 & 0,41 \\
\hline${ }_{90} \mathrm{Zr}$ & $<0,0040$ & 0,21 & 0,17 & 0,65 & 0,25 & 0,16 & 0,08 & 2,98 & 4,29 & 3,59 & 3,70 \\
\hline${ }_{93} \mathrm{Nb}$ & 0,02 & $<0,0163$ & 0,01 & 0,01 & $<0,034$ & $<0,029$ & 0,01 & $<0,036$ & 0,03 & 0,03 & 0,06 \\
\hline${ }_{133} \mathrm{Cs}$ & 0,00 & n.d. & n.d. & n.d. & n.d. & n.d. & n.d. & n.d. & n.d. & n.d. & n.d. \\
\hline${ }_{137} \mathrm{Ba}$ & $<0,0071$ & $<0,133$ & 0,10 & $<0,164$ & $<0,095$ & $<0,00$ & $<0,092$ & $<0,145$ & 1,62 & 0,08 & 33,52 \\
\hline${ }_{139} \mathrm{La}$ & $<0,0013$ & 0,01 & $<0,0167$ & 0,02 & 0,00 & $<0,00$ & $<0,00$ & $<0,0144$ & $<0,019$ & $<0,0078$ & 0,27 \\
\hline${ }_{140} \mathrm{Ce}$ & $<0,00099$ & 0,01 & $<0,0116$ & 0,02 & 0,02 & $<0,0146$ & $<0,0130$ & $<0,0187$ & 0,10 & 0,02 & 0,47 \\
\hline${ }_{141} \mathrm{Pr}$ & $<0,00082$ & $<0,0093$ & $<0,00$ & $<0,0137$ & $<0,0195$ & $<0,00$ & 0,01 & $<0,0111$ & $<0,0180$ & $<0,0064$ & 0,03 \\
\hline${ }_{146} \mathrm{Nd}$ & $<0,0075$ & $<0,00$ & $<0,055$ & $<0,00$ & $<0,066$ & $<0,099$ & 0,02 & $<0,071$ & 0,13 & $<0,052$ & 0,08 \\
\hline${ }_{149} \mathrm{Sm}$ & $<0,0057$ & $<0,117$ & $<0,097$ & 0,11 & $<0,083$ & $<0,087$ & $<0,136$ & $<0,155$ & $<0,119$ & $<0,037$ & 0,05 \\
\hline${ }_{151} \mathrm{Eu}$ & 0,01 & 0,02 & $<0,00$ & 0,01 & $<0,0242$ & $<0,036$ & $<0,033$ & $<0,050$ & $<0,032$ & 0,02 & $<0,0128$ \\
\hline${ }_{157} \mathrm{Gd}$ & $<0,0065$ & $<0,156$ & $<0,128$ & 0,18 & 0,07 & $<0,162$ & $<0,102$ & $<0,162$ & $<0,107$ & $<0,043$ & $<0,044$ \\
\hline${ }_{159} \mathrm{~Tb}$ & $<0,00114$ & 0,02 & $<0,018$ & $<0,019$ & 0,01 & $<0,0161$ & $<0,0144$ & $<0,0170$ & 0,00 & 0,01 & $<0,0068$ \\
\hline${ }_{161} \mathrm{Dy}$ & $<0,0048$ & $<0,066$ & $<0,067$ & 0,19 & $<0,080$ & $<0,085$ & 0,03 & $<0,077$ & 0,14 & 0,07 & 0,04 \\
\hline${ }_{165} \mathrm{Ho}$ & 0,01 & 0,02 & $<0,0176$ & 0,02 & 0,02 & 0,01 & $<0,0144$ & $<0,0236$ & $<0,027$ & $<0,0111$ & 0,01 \\
\hline${ }_{166} \mathrm{Er}$ & $<0,0033$ & 0,05 & $<0,043$ & 0,11 & 0,08 & 0,09 & $<0,048$ & $<0,088$ & 0,08 & 0,05 & 0,06 \\
\hline $\begin{array}{l}{ }_{169} \mathrm{Tm} \\
\text { Tm }\end{array}$ & $<0,0013$ & $<0,00$ & $<0,0182$ & 0,03 & $<0,00$ & $<0,00$ & $<0,0147$ & 0,00 & 0,02 & $<0,0084$ & $<0,0093$ \\
\hline${ }_{172} \mathrm{Yb}$ & 0,11 & $<0,075$ & $<0,054$ & 0,11 & 0,08 & $<0,071$ & 0,11 & $<0,080$ & 0,10 & $<0,066$ & $<0,053$ \\
\hline${ }_{175} \mathrm{Lu}$ & 0,02 & 0,03 & $<0,017$ & 0,02 & 0,03 & $<0,015$ & $<0,0139$ & 0,00 & $<0,0148$ & $<0,0093$ & $<0,0114$ \\
\hline${ }_{178} \mathrm{Hf}$ & $<0,0064$ & $<0,040$ & $<0,00$ & 0,03 & 0,05 & $<0,051$ & $<0,00$ & 0,15 & 0,24 & 0,20 & 0,24 \\
\hline${ }_{181} \mathrm{Ta}$ & $<0,0016$ & $<0,0176$ & $<0,0179$ & 0,01 & $<0,0269$ & 0,02 & $<0,0211$ & 0,01 & $<0,023$ & $<0,0109$ & $<0,0125$ \\
\hline${ }_{208} \mathrm{~Pb}$ & 0,06 & $<0,024$ & $<0,024$ & 0,05 & $<0,029$ & $<0,037$ & $<0,033$ & 0,78 & 0,05 & $<0,022$ & 0,14 \\
\hline${ }_{232} \mathrm{Th}$ & 0,04 & 0,01 & 0,01 & $<0,0195$ & $<0,0160$ & $<0,0169$ & $<0,021$ & $<0,0154$ & 0,04 & 0,02 & 0,01 \\
\hline${ }_{238} \mathrm{U}$ & $<0,00166$ & $<0,0091$ & $<0,0131$ & $<0,0137$ & 0,01 & $<0,00$ & 0,01 & $<0,0172$ & $<0,0113$ & $<0,0089$ & 0,02 \\
\hline
\end{tabular}


Tabela 79- Elementos traço analisados por LA-ICP-MS em ortopiroxênio de harzburgitos com textura porfiroclática em mosaico e em peridotitos metassomatisados (em ppm).

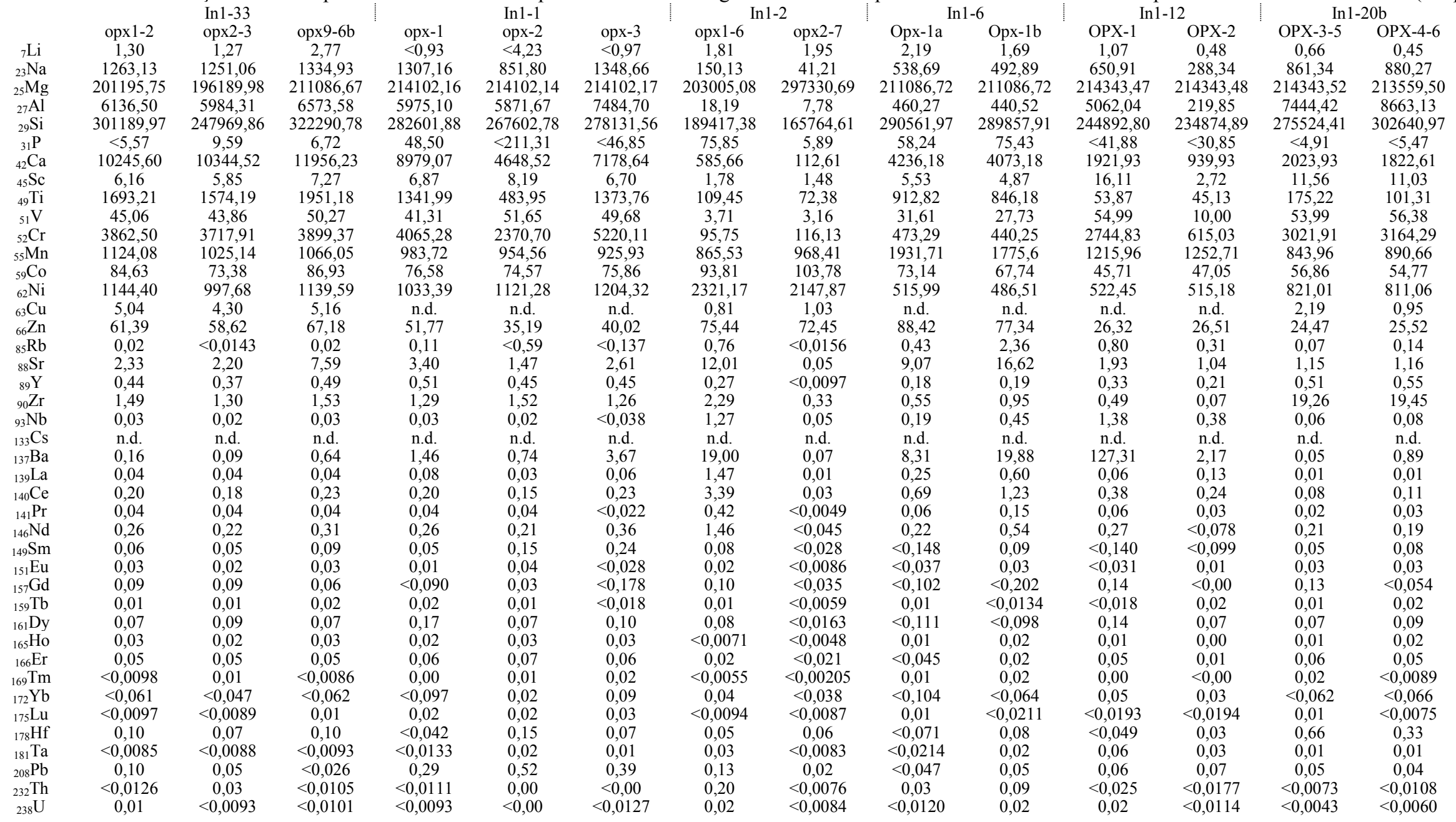


Tabela 80- Elementos traço analisados por LA-ICP-MS em cristais de clinopiroxênio de harzburgitos e lherzolitos com espinélio (em ppm).

\begin{tabular}{|c|c|c|c|c|c|c|c|c|c|c|c|c|}
\hline \multirow{3}{*}{${ }_{7} \mathrm{Li}$} & & & & & & & \multicolumn{2}{|c|}{ In1-1 } & \\
\hline & $\mathrm{p} 2$ & p3 & p3b & $\mathrm{p} 4$ & $\mathrm{p} 4 \mathrm{~b}$ & plb & cpx-pt-2 & cpx-pt-3 & $\mathrm{cp} \times 1-\mathrm{c}-1$ & cpx1-b-2 & cpx11-3 & cp $\times 12-4$ \\
\hline & n.d. & n.d. & n.d. & n.d. & n.d. & n.d. & n.d. & n.d. & 3,56 & 2,93 & 1,93 & 2,07 \\
\hline${ }_{23} \mathrm{Na}$ & n.d. & n.d. & n.d. & n.d. & n.d. & n.d. & n.d. & n.d. & 6480,99 & 5913,41 & 6127,36 & 5826,04 \\
\hline${ }_{25} \mathrm{Mg}$ & 124389 & 138646 & 138773 & 121686 & 133318 & 138388 & 124336 & 156196 & 104412 & 99404 & 111768 & 101439 \\
\hline${ }_{27} \mathrm{Al}$ & n.d. & n.d. & n.d. & n.d. & n.d. & n.d. & n.d. & n.d. & 28385 & 26667 & 28340 & 28478 \\
\hline${ }_{29} \mathrm{Si}$ & 212243 & 245150 & 265678 & 227360 & 248396 & 252749 & 249695 & 275124 & 224686 & 174589 & 183061 & 201858 \\
\hline${ }_{31} \mathrm{P}$ & 17,05 & $<9,22$ & $<10,74$ & 25,20 & 18,20 & 22,62 & 20,84 & 30,41 & $<10,77$ & 13,59 & $<9,00$ & $<9,67$ \\
\hline${ }_{42} \mathrm{Ca}$ & 157234 & 157234 & 157234 & 157234 & 157234 & 157234 & 164596 & 161737 & 157234 & 157234 & 150659 & 159450 \\
\hline${ }_{45} \mathrm{Sc}$ & 57,74 & 63,90 & 63,63 & 56,98 & 58,05 & 50,52 & 78,87 & 59,06 & 53,15 & 64,89 & 69,76 & 72,49 \\
\hline${ }_{49} \mathrm{Ti}$ & 1732,32 & 1954,86 & 1870,86 & 1889,24 & 2045,98 & 1660,21 & 1857,67 & 1658,57 & 242,33 & 273,38 & 214,97 & 257,85 \\
\hline${ }_{51}^{49} \mathrm{~V}$ & 189,32 & 234,68 & 230,84 & 220,47 & 233,17 & 203,15 & 276,07 & 272,41 & 176,96 & 187,18 & 177,12 & 175,66 \\
\hline${ }_{52} \mathrm{Cr}$ & 4551,16 & 5334,27 & 5696,62 & 5512,96 & 5097,45 & 5099,29 & 5250,02 & 6678,89 & 6340,98 & 6473,69 & 5808,67 & 5828,05 \\
\hline${ }_{55} \mathrm{Mn}$ & 647,50 & 730,50 & 727,68 & 643,09 & 636,89 & 667,17 & 580,91 & 565,67 & 558,19 & 543,85 & 607,30 & 514,39 \\
\hline${ }_{59} \mathrm{Co}$ & 13,86 & 14,96 & 19,59 & 15,34 & 14,20 & 15,46 & 16,33 & 25,61 & 14,72 & 15,02 & 15,05 & 13,28 \\
\hline${ }_{6} \mathrm{Ni}$ & 191,91 & 246,88 & 245,46 & 234,95 & 211,20 & 226,84 & 261,45 & 292,68 & 284,52 & 279,58 & 233,49 & 236,29 \\
\hline${ }_{6} \mathrm{Cu}$ & 0,21 & 0,45 & 0,30 & 0,23 & 0,16 & 0,22 & 0,14 & 0,21 & 5,63 & 4,69 & 2,98 & 2,14 \\
\hline${ }_{66} \mathrm{Zn}$ & 2,48 & 4,43 & 6,57 & 4,98 & 2,99 & 4,32 & 11,75 & 49,63 & 6,03 & 5,73 & 6,82 & 5,08 \\
\hline${ }_{85} \mathrm{Rb}$ & $<0,0102$ & 0,18 & $<0,0143$ & 0,49 & 0,11 & 1,12 & 0,01 & $<0,0112$ & $<0,044$ & $<0,033$ & $<0,040$ & $<0,036$ \\
\hline${ }_{88} \mathrm{Sr}$ & 1,63 & 2,19 & 1,83 & 1,69 & 1,73 & 2,24 & 76,28 & 73,58 & 0,03 & $<0,026$ & 0,05 & 0,04 \\
\hline${ }_{89} \mathrm{Y}$ & 11,34 & 13,05 & 11,44 & 11,02 & 11,08 & 9,42 & 11,30 & 9,75 & 8,53 & 8,18 & 8,71 & 9,94 \\
\hline${ }_{90} \mathrm{Zr}$ & 1,24 & 1,74 & 1,51 & 1,48 & 1,23 & 1,42 & 10,56 & 9,58 & 0,06 & $<0,039$ & 0,08 & $<0,041$ \\
\hline${ }_{93} \mathrm{Nb}$ & 0,03 & 0,01 & 0,01 & 0,01 & 0,03 & 0,02 & 0,05 & $<0,019$ & $<0,027$ & $<0,0173$ & $<0,0189$ & $<0,022$ \\
\hline${ }_{133} \mathrm{Cs}$ & $<0,0049$ & 0,00 & $<0,0056$ & 0,10 & 0,04 & 0,01 & 0,01 & $<0,0067$ & $<0,0113$ & $<0,0120$ & 0,02 & $<0,0138$ \\
\hline${ }_{137} \mathrm{Ba}$ & 0,06 & 7,11 & 0,02 & 0,19 & 0,06 & 2,11 & 0,11 & 0,06 & $<0,108$ & $<0,087$ & 0,09 & $<0,105$ \\
\hline${ }_{139} \mathrm{La}$ & $<0,00$ & 0,01 & 0,00 & 0,01 & $<0,0069$ & 0,01 & 0,96 & 0,81 & $<0,0155$ & $<0,0108$ & $<0,0113$ & $<0,0122$ \\
\hline${ }_{140} \mathrm{Ce}$ & 0,02 & 0,04 & 0,03 & 0,03 & 0,03 & 0,04 & 5,22 & 5,21 & $<0,0090$ & $<0,0099$ & $<0,0117$ & $<0,0127$ \\
\hline${ }_{141} \mathrm{Pr}$ & 0,02 & 0,03 & 0,02 & 0,04 & 0,02 & 0,03 & 1,00 & 0,97 & $<0,0099$ & $<0,0088$ & $<0,0091$ & 0,01 \\
\hline${ }_{146} \mathrm{Nd}$ & 0,56 & 0,50 & 0,46 & 0,53 & 0,57 & 0,53 & 4,47 & 5,58 & 0,06 & $<0,047$ & $<0,071$ & $<0,050$ \\
\hline${ }_{1449} \mathrm{Sm}$ & 0,65 & 0,64 & 0,67 & 0,51 & 0,64 & 0,64 & 1,34 & 1,18 & $<0,104$ & $<0,072$ & $<0,079$ & $<0,110$ \\
\hline${ }_{151} \mathrm{Eu}$ & 0,29 & 0,33 & 0,28 & 0,33 & 0,34 & 0,29 & 0,51 & 0,43 & 0,08 & 0,02 & 0,05 & $<0,019$ \\
\hline${ }_{157} \mathrm{Gd}$ & 1,05 & 0,86 & 1,02 & 0,88 & 1,01 & 0,91 & 1,11 & 1,21 & 0,38 & 0,27 & 0,34 & 0,39 \\
\hline${ }_{159} \mathrm{~Tb}$ & 0,25 & 0,29 & 0,25 & 0,24 & 0,23 & 0,23 & 0,27 & 0,20 & 0,12 & 0,12 & 0,10 & 0,09 \\
\hline${ }_{161} \mathrm{Dy}$ & 1,95 & 2,17 & 2,54 & 1,91 & 1,79 & 1,86 & 1,83 & 1,76 & 1,19 & 0,93 & 0,98 & 1,17 \\
\hline${ }_{165} \mathrm{Ho}$ & 0,41 & 0,43 & 0,54 & 0,39 & 0,40 & 0,42 & 0,40 & 0,39 & 0,34 & 0,31 & 0,33 & 0,34 \\
\hline${ }_{166} \mathrm{Er}$ & 1,49 & 1,42 & 1,31 & 1,40 & 1,36 & 1,33 & 1,58 & 1,22 & 1,30 & 0,86 & 1,17 & 1,16 \\
\hline${ }_{169} \mathrm{Tm}$ & 0,20 & 0,18 & 0,22 & 0,16 & 0,20 & 0,20 & 0,19 & 0,16 & 0,20 & 0,19 & 0,19 & 0,21 \\
\hline${ }_{172} \mathrm{Yb}$ & 1,50 & 1,69 & 1,81 & 1,27 & 1,58 & 1,36 & 1,60 & 1,29 & 1,38 & 1,36 & 1,27 & 1,50 \\
\hline${ }_{175} \mathrm{Lu}$ & 0,18 & 0,23 & 0,22 & 0,18 & 0,18 & 0,17 & 0,22 & 0,17 & 0,23 & 0,24 & 0,21 & 0,23 \\
\hline${ }_{178} \mathrm{Hf}$ & 0,24 & 0,23 & 0,11 & 0,17 & 0,15 & 0,15 & 0,35 & 0,33 & $<0,062$ & 0,05 & $<0,047$ & $<0,047$ \\
\hline${ }_{181} \mathrm{Ta}$ & n.d. & 0,00 & 0,00 & 0,00 & n.d. & n.d. & 0,02 & 0,03 & $<0,021$ & $<0,0164$ & $<0,0133$ & $<0,0231$ \\
\hline${ }_{208} \mathrm{~Pb}$ & $<0,0228$ & $<0,023$ & 0,04 & 0,15 & 0,10 & 0,03 & 0,34 & 0,34 & $<0,051$ & $<0,041$ & 0,06 & 0,08 \\
\hline${ }_{232} \mathrm{Th}$ & 0,00 & $<0,00$ & 0,00 & $<0,00$ & $<0,00$ & 0,00 & $<0,0105$ & 0,01 & $<0,025$ & $<0,020$ & $<0,0204$ & $<0,023$ \\
\hline${ }_{238} \mathrm{U}$ & $<0,00$ & $<0,00$ & $<0,0061$ & $<0,0048$ & 0,00 & 0,00 & $<0,00$ & 0,00 & $<0,024$ & $<0,018$ & $<0,0169$ & $<0,017$ \\
\hline
\end{tabular}


Tabela 81- Elementos traço analisados por LA-ICP-MS em cristais de clinopiroxênio de harzburgitos e dunitos com espinélio (em ppm).

\begin{tabular}{|c|c|c|c|c|c|c|c|c|c|c|c|}
\hline & & $\mathrm{Lm}$ & & & & & & & & $\operatorname{mi-su}$ & \\
\hline & cpx13-6 & cpx13-6b & cpx8-7 & cpx8-7b & pontol & ponto2 & ponto3 & ponto4 & срх-6-1 & cpx-6-2 & cpx-6-4 \\
\hline${ }_{7} \mathrm{Li}$ & 3,16 & 2,80 & 3,03 & 3,37 & n.d. & n.d. & n.d. & n.d. & 0,71 & 0,69 & 0,73 \\
\hline${ }_{23} \mathrm{Na}$ & 6300,60 & 5919,39 & 6242,99 & 5900,03 & n.d. & n.d. & n.d. & n.d. & 10548,79 & 8946,05 & 9273,18 \\
\hline${ }_{25} \mathrm{Mg}$ & 108863 & 101212 & 124631 & 93784 & 144607 & 141309 & 152047 & 155419 & 127999 & 110822 & 110735 \\
\hline${ }_{27} \mathrm{Al}$ & 17203 & 17661 & 16423 & 14733 & n.d. & n.d. & n.d. & n.d. & 26617 & 23944 & 25377 \\
\hline${ }_{29} \mathrm{Si}$ & 202280 & 208526 & 214881 & 201505 & 240447 & 240125 & 279835 & 245759 & 218203 & 204398 & 199393 \\
\hline${ }_{31} \mathrm{P}$ & $<9,90$ & 8,12 & 20,18 & $<9,05$ & 29,02 & 12,66 & 10,72 & 6,95 & 13,54 & $<8,18$ & 16,36 \\
\hline${ }_{42} \mathrm{Ca}$ & 161451 & 161451 & 160307 & 160808 & 158235 & 155305 & 160236 & 164739 & 155948 & 155948 & 155948 \\
\hline${ }_{45} \mathrm{Sc}$ & 86,46 & 83,31 & 102,61 & 95,43 & 70,71 & 76,59 & 65,83 & 88,00 & 173,06 & 144,26 & 165,74 \\
\hline${ }_{49} \mathrm{Ti}$ & 324,73 & 298,36 & 355,36 & 324,26 & 306,22 & 287,80 & 281,40 & 291,78 & 3647,26 & 2813,72 & 3559,06 \\
\hline${ }_{51} \mathrm{~V}$ & 184,42 & 184,99 & 202,51 & 203,67 & 170,31 & 175,02 & 226,54 & 168,68 & 279,14 & 223,17 & 250,54 \\
\hline${ }_{52} \mathrm{Cr}$ & 5761,98 & 6148,26 & 6289,34 & 5862,36 & 6822,29 & 5043,28 & 7611,29 & 5589,75 & 10895,73 & 9980,71 & 9976,44 \\
\hline${ }_{55} \mathrm{Mn}$ & 423,70 & 421,00 & 504,34 & 441,71 & 607,15 & 550,29 & 688,20 & 545,55 & 440,05 & 385,82 & 397,25 \\
\hline${ }_{59} \mathrm{Co}$ & 12,54 & 12,40 & 12,33 & 11,84 & 17,57 & 17,16 & 21,43 & 18,62 & 12,69 & 11,40 & 11,45 \\
\hline${ }_{62} \mathrm{Ni}$ & 236,77 & 243,41 & 183,21 & 199,11 & 254,70 & 236,59 & 279,31 & 230,51 & 187,01 & 160,77 & 195,61 \\
\hline${ }_{63} \mathrm{Cu}$ & 0,23 & 0,08 & 0,56 & 0,49 & 0,31 & 0,17 & 0,21 & 0,16 & $<0,169$ & 0,20 & 0,20 \\
\hline${ }_{66} \mathrm{Zn}$ & 4,61 & 4,28 & 5,24 & 3,83 & 4,90 & 5,55 & 6,90 & 6,16 & 4,97 & 3,88 & 4,96 \\
\hline${ }_{85} \mathrm{Rb}$ & 0,53 & $<0,030$ & 0,85 & 1,71 & 0,05 & 4,51 & 1,26 & $<0,0108$ & $<0,058$ & $<0,042$ & $<0,052$ \\
\hline${ }_{88} \mathrm{Sr}$ & 27,61 & 38,27 & 76,37 & 34,22 & 16,94 & 13,69 & 15,63 & 13,00 & 429,22 & 293,80 & 364,77 \\
\hline${ }_{89}^{80} \mathrm{Y}$ & 2,88 & 2,78 & 2,96 & 2,38 & 3,03 & 2,85 & 2,38 & 3,30 & 21,50 & 18,45 & 21,36 \\
\hline${ }_{90} \mathrm{Zr}$ & 0,22 & 0,25 & 0,45 & 0,18 & 2,82 & 2,66 & 2,03 & 2,96 & 481,57 & 463,60 & 512,58 \\
\hline${ }_{93} \mathrm{Nb}$ & 1,05 & 1,07 & 0,99 & 0,94 & 0,04 & 0,06 & 0,07 & 0,05 & 2,31 & 1,45 & 2,15 \\
\hline${ }_{133} \mathrm{Cs}$ & $<0,0132$ & $<0,0080$ & 0,01 & 0,03 & $<0,0067$ & 0,02 & 0,01 & $<0,00$ & $<0,0167$ & $<0,0142$ & $<0,0142$ \\
\hline${ }_{137} \mathrm{Ba}$ & 11,75 & 2,65 & 26,00 & 19,74 & 1,80 & 3,03 & 1,10 & $<0,044$ & 0,19 & 0,12 & 0,20 \\
\hline${ }_{139} \mathrm{La}$ & 1,40 & 1,51 & 1,42 & 1,37 & 0,19 & 0,15 & 0,21 & 0,16 & 24,88 & 18,86 & 21,75 \\
\hline${ }_{140} \mathrm{Ce}$ & 1,21 & 1,28 & 1,27 & 1,09 & 0,75 & 0,70 & 1,06 & 0,67 & 52,16 & 28,10 & 48,95 \\
\hline${ }_{141} \mathrm{Pr}$ & 0,10 & 0,11 & 0,11 & 0,09 & 0,18 & 0,15 & 0,20 & 0,15 & 9,59 & 6,20 & 9,51 \\
\hline${ }_{146} \mathrm{Nd}$ & 0,19 & 0,25 & 0,32 & 0,20 & 0,96 & 0,89 & 0,98 & 0,97 & 53,16 & 42,52 & 55,12 \\
\hline${ }_{144} \mathrm{Sm}$ & $<0,089$ & $<0,077$ & $<0,072$ & $<0,105$ & 0,45 & 0,37 & 0,57 & 0,51 & 14,47 & 9,72 & 14,36 \\
\hline${ }_{151} \mathrm{Eu}$ & $<0,028$ & $<0,024$ & 0,02 & 0,02 & 0,21 & 0,15 & 0,20 & 0,19 & 3,56 & 2,77 & 3,05 \\
\hline${ }_{157} \mathrm{Gd}$ & $<0,054$ & 0,08 & $<0,067$ & $<0,077$ & 0,41 & 0,51 & 0,53 & 0,59 & 11,74 & 11,92 & 11,54 \\
\hline${ }_{159} \mathrm{~Tb}$ & 0,02 & 0,03 & 0,03 & 0,02 & 0,11 & 0,11 & 0,08 & 0,09 & 1,26 & 1,11 & 1,24 \\
\hline${ }_{161} \mathrm{Dy}$ & 0,25 & 0,31 & 0,31 & 0,26 & 0,56 & 0,46 & 0,69 & 0,67 & 6,70 & 5,69 & 5,78 \\
\hline${ }_{165} \mathrm{Ho}$ & 0,12 & 0,08 & 0,09 & 0,08 & 0,12 & 0,12 & 0,10 & 0,12 & 0,92 & 0,90 & 0,74 \\
\hline${ }_{166} \mathrm{Er}$ & 0,41 & 0,36 & 0,31 & 0,34 & 0,32 & 0,31 & 0,36 & 0,30 & 2,11 & 1,68 & 1,59 \\
\hline $\begin{array}{l}{ }_{169} \mathrm{Tm} \\
\text { Tm }\end{array}$ & 0,07 & 0,06 & 0,07 & 0,07 & 0,03 & 0,02 & 0,04 & 0,04 & 0,19 & 0,11 & 0,17 \\
\hline${ }_{172} \mathrm{Yb}$ & 0,53 & 0,50 & 0,61 & 0,60 & 0,27 & 0,29 & 0,20 & 0,38 & 0,83 & 1,03 & 0,81 \\
\hline${ }_{175} \mathrm{Lu}$ & 0,08 & 0,10 & 0,11 & 0,10 & 0,04 & 0,03 & 0,02 & 0,05 & 0,12 & 0,04 & 0,11 \\
\hline${ }_{178} \mathrm{Hf}$ & $<0,043$ & $<0,044$ & $<0,040$ & $<0,050$ & 0,11 & 0,07 & 0,09 & 0,09 & 16,68 & 13,62 & 18,24 \\
\hline${ }_{181} \mathrm{Ta}$ & $<0,0214$ & 0,02 & 0,02 & 0,04 & 0,03 & n.d. & 0,01 & 0,01 & 0,96 & 0,72 & 0,84 \\
\hline${ }_{208} \mathrm{~Pb}$ & 0,24 & 0,14 & 0,54 & 0,25 & 0,22 & 0,06 & 0,12 & 0,05 & 0,28 & 0,52 & 0,30 \\
\hline${ }_{232} \mathrm{Th}$ & 12,87 & 0,14 & 0,07 & 0,08 & $<0,0156$ & 0,00 & 0,01 & $<0,00$ & 1,34 & 3,19 & 1,46 \\
\hline${ }_{238} \mathrm{U}$ & 0,05 & 0,06 & 0,06 & 0,04 & $<0,00$ & 0,02 & 0,00 & $<0,00$ & 0,23 & 0,19 & 0,28 \\
\hline
\end{tabular}


Tabela 82- Elementos traço analisados por LA-ICP-MS em cristais de clinopiroxênio e peridotitos metassomatisados (em ppm).

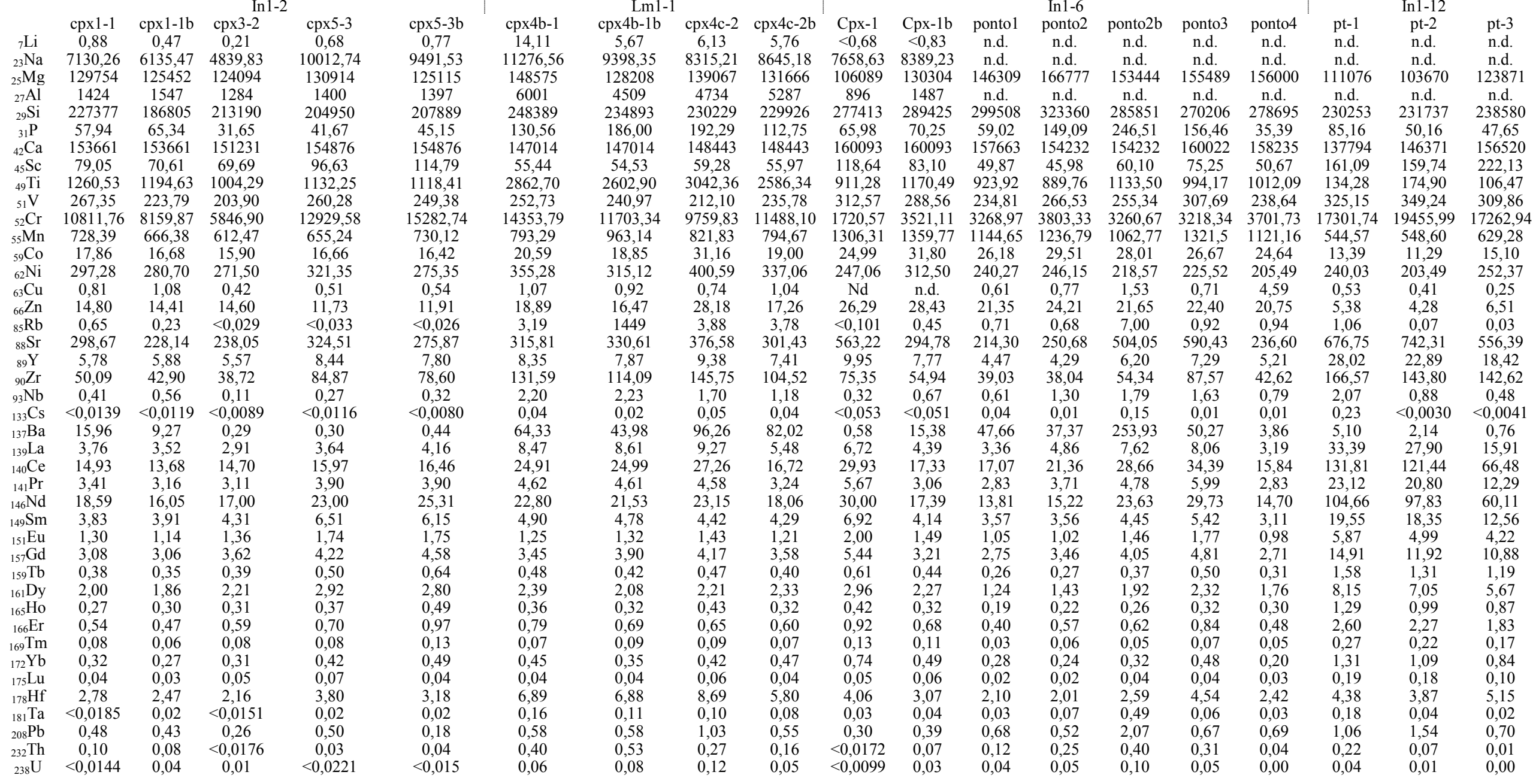


Tabela 83- Elementos traço analisados por LA-ICP-MS em cristais de clinopiroxênio em piroxenitos e megacristal (em ppm).

\begin{tabular}{|c|c|c|c|c|c|c|c|c|c|c|c|c|}
\hline & \multicolumn{4}{|c|}{ Lm1-14 } & \multicolumn{4}{|c|}{ Fo-03 } & \multicolumn{4}{|c|}{ Fac-5 } \\
\hline & сpx13-c-1 & $\mathrm{cpx} 13-\mathrm{c}-1 \mathrm{~b}$ & cpx $13-d-2$ & $\mathrm{cpx} 13-\mathrm{d}-2 \mathrm{~b}$ & cpx2-1 & сpx4-2 & $\operatorname{cpx} 5-3$ & сpх6-4 & $\operatorname{cpx} 1-1$ & $\mathrm{cp} \times 1-1 \mathrm{~b}$ & срх6-2 & cpx6-2b \\
\hline${ }_{7} \mathrm{Li}$ & 2,06 & 2,29 & 1,93 & 4,56 & 0,95 & 0,97 & 1,23 & 1,12 & $<0,136$ & $<0,28$ & 0,28 & $<0,13$ \\
\hline${ }_{23} \mathrm{Na}$ & 5339,44 & 5814,47 & 5556,63 & 5341,52 & 7482,98 & 8230,03 & 7545,22 & 6929,58 & 2839,67 & 3493,06 & 4335,92 & 3645,35 \\
\hline${ }_{25} \mathrm{Mg}$ & 70903 & 81297 & 78848 & 77568 & 132098 & 130401 & 123441 & 111173 & 100473 & 113532 & 106020 & 113131 \\
\hline${ }_{27} \mathrm{Al}$ & 41784 & 44440 & 45653 & 41051 & 10735 & 12061 & 11152 & 12129 & 2620 & 2106 & 1003 & 1667 \\
\hline${ }_{29} \mathrm{Si}$ & 199041 & 191731 & 182423 & 163668 & 240796 & 241767 & 242245 & 216462 & 196115 & 258432 & 215550 & 211133 \\
\hline${ }_{31} \mathrm{P}$ & 46,09 & 41,47 & 38,76 & 38,65 & 15,12 & 21,38 & 27,15 & 10,97 & $<6,62$ & 11,63 & 13,73 & 7,33 \\
\hline${ }_{42} \mathrm{Ca}$ & 146514 & 146514 & 146514 & 146514 & 120784 & 122857 & 123929 & 122714 & 167597 & 167597 & 157234 & 157234 \\
\hline${ }_{45} \mathrm{Sc}$ & 59,59 & 74,41 & 78,56 & 53,06 & 27,65 & 32,86 & 28,70 & 28,76 & 84,07 & 72,63 & 53,69 & 76,93 \\
\hline${ }_{49} \mathrm{Ti}$ & 6953,9 & 8434,45 & 7741,15 & 7338,98 & 4028,65 & 4680,76 & 4342,69 & 4364,01 & 7968,33 & 7100,76 & 3761,93 & 6152,35 \\
\hline${ }_{51} \mathrm{~V}$ & 318,13 & 414,38 & 373,88 & 403,94 & 188,49 & 194,97 & 197,62 & 187,71 & 94,46 & 108,19 & 104,31 & 122,79 \\
\hline${ }_{52} \mathrm{Cr}$ & 1365,02 & 1497,51 & 1513,62 & 1569,93 & 2801,26 & 3040,43 & 3059,13 & 2750,11 & 397,12 & 491,98 & 224,06 & 672,27 \\
\hline${ }_{55} \mathrm{Mn}$ & 763,13 & 979,20 & 929,13 & 868,22 & 1237,16 & 1110,7 & 1183,06 & 903,56 & 412,57 & 563,84 & 816,28 & 631,82 \\
\hline${ }_{59} \mathrm{Co}$ & 26,59 & 29,01 & 28,28 & 26,79 & 36,30 & 36,93 & 38,24 & 32,84 & 17,33 & 22,06 & 26,27 & 21,86 \\
\hline${ }_{62} \mathrm{Ni}$ & 162,13 & 153,52 & 146,43 & 136,10 & 284,78 & 287,71 & 271,24 & 254,88 & 80,94 & 113,42 & 111,74 & 83,17 \\
\hline${ }_{63} \mathrm{Cu}$ & 0,37 & 0,29 & 0,14 & 1,68 & 3,96 & 3,68 & 3,38 & 3,72 & 0,24 & 0,70 & 1,69 & 0,32 \\
\hline${ }_{66} \mathrm{Zn}$ & 17,38 & 23,09 & 18,87 & 27,18 & 30,93 & 29,18 & 31,85 & 26,00 & 14,48 & 20,00 & 20,03 & 17,62 \\
\hline${ }_{85} \mathrm{Rb}$ & 0,10 & $<0,028$ & 0,06 & 0,70 & $<0,030$ & $<0,036$ & $<0,036$ & $<0,031$ & 0,04 & 0,11 & 0,14 & 0,14 \\
\hline${ }_{88} \mathrm{Sr}$ & 67,07 & 615,93 & 151,42 & 500,56 & 129,49 & 160,40 & 148,11 & 136,99 & 728,15 & 942,29 & 359,99 & 500,22 \\
\hline${ }_{89}^{6} \mathrm{Y}$ & 17,56 & 20,63 & 22,73 & 19,90 & 3,42 & 4,43 & 4,36 & 4,28 & 2,99 & 3,27 & 5,10 & 2,97 \\
\hline${ }_{90} \mathrm{Zr}$ & 22,53 & 26,24 & 26,39 & 26,01 & 14,43 & 20,18 & 18,80 & 19,19 & 104,79 & 103,47 & 47,38 & 99,10 \\
\hline${ }_{93} \mathrm{Nb}$ & 0,37 & 0,37 & 0,31 & 0,48 & 0,16 & 0,19 & 0,16 & 0,17 & 0,18 & 0,19 & 0,71 & 0,16 \\
\hline${ }_{133} \mathrm{Cs}$ & $<0,0095$ & $<0,0113$ & $<0,0121$ & 0,02 & $<0,0129$ & $<0,0103$ & $<0,0133$ & $<0,0106$ & $<0,0062$ & $<0,0146$ & $<0,0121$ & $<0,0078$ \\
\hline${ }_{137} \mathrm{Ba}$ & 0,27 & 2,68 & 0,25 & 2,34 & 0,20 & 0,32 & 0,63 & 0,41 & 1,90 & 3,91 & 7,45 & 3,35 \\
\hline${ }_{139} \mathrm{La}$ & 0,93 & 1,01 & 1,01 & 1,06 & 2,84 & 3,36 & 3,53 & 3,61 & 1,61 & 2,63 & 7,76 & 1,90 \\
\hline${ }_{140} \mathrm{Ce}$ & 3,62 & 3,65 & 3,95 & 4,45 & 10,02 & 11,25 & 11,87 & 11,08 & 3,94 & 8,33 & 25,45 & 7,48 \\
\hline${ }_{141} \mathrm{Pr}$ & 0,97 & 0,90 & 0,94 & 1,18 & 1,55 & 2,13 & 2,16 & 2,00 & 0,76 & 1,38 & 4,77 & 1,59 \\
\hline${ }_{146} \mathrm{Nd}$ & 5,70 & 5,66 & 6,17 & 5,49 & 9,20 & 10,71 & 11,50 & 10,48 & 3,13 & 5,47 & 23,19 & 7,62 \\
\hline${ }_{149} \mathrm{Sm}$ & 2,38 & 2,35 & 2,49 & 2,69 & 2,24 & 2,51 & 2,58 & 2,63 & 0,71 & 1,27 & 4,64 & 0,94 \\
\hline${ }_{151} \mathrm{Eu}$ & 0,97 & 1,02 & 1,04 & 0,92 & 0,72 & 0,86 & 0,84 & 0,77 & 0,26 & 0,38 & 1,34 & 0,35 \\
\hline${ }_{157} \mathrm{Gd}$ & 3,25 & 3,34 & 3,91 & 3,11 & 1,91 & 2,00 & 1,90 & 1,94 & 0,97 & 0,87 & 2,91 & 1,32 \\
\hline${ }_{159} \mathrm{~Tb}$ & 0,53 & 0,62 & 0,69 & 0,59 & 0,18 & 0,25 & 0,25 & 0,21 & 0,11 & 0,11 & 0,34 & 0,19 \\
\hline${ }_{161} \mathrm{Dy}$ & 3,89 & 4,04 & 4,65 & 4,29 & 1,00 & 1,12 & 1,17 & 1,26 & 0,68 & 0,64 & 1,73 & 0,81 \\
\hline${ }_{165} \mathrm{Ho}$ & 0,77 & 0,74 & 1,02 & 0,83 & 0,16 & 0,21 & 0,16 & 0,19 & 0,13 & 0,11 & 0,26 & 0,15 \\
\hline${ }_{166} \mathrm{Er}$ & 2,24 & 2,22 & 2,67 & 2,07 & 0,35 & 0,54 & 0,44 & 0,38 & 0,35 & 0,32 & 0,58 & 0,32 \\
\hline${ }_{169} \mathrm{Tm}$ & 0,29 & 0,32 & 0,33 & 0,39 & 0,03 & 0,05 & 0,06 & 0,04 & 0,03 & 0,03 & 0,05 & 0,05 \\
\hline${ }_{172} \mathrm{Yb}$ & 1,90 & 2,27 & 2,17 & 2,09 & 0,24 & 0,31 & 0,26 & 0,23 & 0,34 & 0,20 & 0,24 & 0,24 \\
\hline${ }_{175} \mathrm{Lu}$ & 0,29 & 0,31 & 0,28 & 0,34 & $<0,0170$ & $<0,0186$ & 0,03 & 0,04 & 0,07 & 0,08 & 0,04 & 0,06 \\
\hline${ }_{178} \mathrm{Hf}$ & 0,95 & 1,25 & 1,22 & 1,08 & 0,96 & 1,05 & 1,11 & 1,04 & 5,11 & 5,10 & 2,21 & 3,43 \\
\hline${ }_{181} \mathrm{Ta}$ & 0,04 & $<0,023$ & 0,02 & 0,05 & $<0,0175$ & $<0,021$ & $<0,021$ & $<0,0204$ & $<0,0150$ & 0,04 & $<0,019$ & $<0,013$ \\
\hline${ }_{208} \mathrm{~Pb}$ & 0,04 & 0,08 & 0,07 & 0,12 & 0,20 & 0,21 & 0,19 & 0,16 & 0,17 & 0,22 & 0,23 & 0,22 \\
\hline${ }_{232} \mathrm{Th}$ & 0,03 & 0,02 & $<0,0205$ & 0,04 & 0,02 & 0,02 & $<0,0219$ & 0,04 & 0,02 & 0,03 & 0,25 & $<0,012$ \\
\hline${ }_{238} \mathrm{U}$ & $<0,0161$ & $<0,0173$ & 0,02 & $<0,017$ & 0,02 & $<0,0166$ & $<0,0167$ & $<0,0198$ & $<0,0108$ & $<0,020$ & 0,07 & $<0,0106$ \\
\hline
\end{tabular}


Tabela 84- Elementos traço analisados por LA-ICP-MS em óxidos do grupo do espinélio de peridotitos com espinélio e Cr- espinélio (em ppm).

\begin{tabular}{|c|c|c|c|c|c|c|c|c|c|c|c|c|}
\hline \multirow[t]{2}{*}{ In $1-4$} & \multirow{2}{*}{\multicolumn{2}{|c|}{ In1-14a }} & \multicolumn{2}{|c|}{ Lm1-17 } & \multirow{2}{*}{\multicolumn{2}{|c|}{ Lm1-20a }} & \multirow{2}{*}{\multicolumn{2}{|c|}{ In1-3 }} & \multirow{2}{*}{\multicolumn{2}{|c|}{$\begin{array}{l}\text { In } 1-24 \mathrm{a} \\
\mathrm{sp} 1\end{array}$}} & \multirow{2}{*}{\multicolumn{2}{|c|}{$\begin{array}{l}\operatorname{In} 1-50 \\
\text { sp17-5 }\end{array}$}} \\
\hline & & & sp2-11 & & & & & & & & & \\
\hline 1,16 & 1,45 & $<0,64$ & 1,84 & 1,03 & 0,86 & 1,1 & $<0,62$ & $<0,59$ & $<0,40$ & $<0,43$ & $<0,24$ & $<0,26$ \\
\hline$<1,32$ & 13,91 & 5,30 & 3,66 & 1,11 & 4,83 & $<0,29$ & 4,18 & 3,64 & $<1,36$ & 1,77 & 2,95 & 1,64 \\
\hline & 113082,17 & 113142,48 & 113746 & 60310,5 & 93541,6 & 90948,2 & 73578,78 & 73578,78 & 71467,92 & 71467,92 & 72553,52 & 60310,5 \\
\hline 293872,75 & 260295,19 & 250641,92 & 298409 & 160843 & 206203 & 225942 & 140490,09 & 145537,53 & 139335,61 & 139958,33 & 153078,34 & 130227 \\
\hline 1054,48 & 1278,90 & $<363,81$ & 571,09 & 97,34 & 2663,9 & $<101,57$ & $<382,13$ & $<415,90$ & 534,71 & $<290,49$ & 595,47 & $<146,78$ \\
\hline$<34,16$ & 36,86 & 45,41 & $<9,34$ & $<4,73$ & 10,89 & $<8,05$ & $<45,79$ & $<47,51$ & $<44,13$ & $<40,08$ & $<8,55$ & $<12,68$ \\
\hline$<239,19$ & $<211,08$ & $<243,71$ & $<75,35$ & 41,2 & $<50,07$ & $<62,16$ & $<252,78$ & $<258,35$ & $<219,86$ & $<202,00$ & 213,4 & 144,27 \\
\hline$<0,40$ & 0,58 & 0,57 & 0,453 & 0,125 & 0,356 & 0,414 & 1,55 & 1,15 & 1,51 & 1,98 & 1,78 & 1,68 \\
\hline 219,08 & 248,89 & 196,47 & 62,52 & 23,45 & 118,95 & 146,86 & 557,77 & 563,11 & 1470,35 & 1327,38 & 1424,68 & 699,25 \\
\hline 525,86 & 637,19 & 612,53 & 461,23 & 289,66 & 828,5 & 929,85 & 1296,94 & 1296,41 & 1140,32 & 1101,46 & 1149,66 & 1019,9 \\
\hline 72260,84 & 93964,70 & 80519,96 & 84258,9 & 42628,7 & 174053 & 186429 & 317897,03 & 315658,91 & 270465,44 & 255194,59 & 296474,94 & 267875 \\
\hline 976,37 & 922,29 & 851,83 & 855,29 & 454,9 & 1232,99 & 1306,64 & 2173,42 & 2139,12 & 1916,58 & 1764,81 & 1835,22 & 1790,15 \\
\hline 428,08 & 409,91 & 411,42 & 400,53 & 236,92 & 539,07 & 573,13 & 647,02 & 747,32 & 617,08 & 561,81 & 585,16 & 614,53 \\
\hline 2146,30 & 1825,86 & 2010,67 & 2137,04 & 1016,4 & 895,86 & 814,11 & 525,53 & 439,00 & 525,25 & 422,13 & 442,91 & 342,3 \\
\hline n.d. & n.d. & n.d. & 14,49 & 5,01 & 1,07 & 0,349 & n.d. & n.d. & n.d. & n.d. & 0,451 & $<0,16$ \\
\hline 1580,52 & 1488,02 & 1710,29 & 1372,76 & 919,6 & 2546,59 & 2285,79 & 2090,94 & 2389,39 & 2364,61 & 2102,40 & 2539,73 & 3326,48 \\
\hline 0,30 & 0,21 & 0,11 & 0,03 & 0,055 & 0,056 & 0,267 & 0,62 & 0,63 & 0,58 & 0,61 & 0,434 & 0,73 \\
\hline 0,11 & 0,74 & 2,28 & 0,022 & 0,0223 & 0,458 & $<0,0140$ & $<0,027$ & $<0,0207$ & $<0,023$ & $<0,0148$ & 1,34 & 0,089 \\
\hline$<0,024$ & 0,05 & 0,03 & $<0,0170$ & $<0,0095$ & $<0,0142$ & $<0,0156$ & 0,01 & $<0,033$ & $<0,029$ & $<0,019$ & $<0,0179$ & $<0,038$ \\
\hline 0,21 & 0,83 & 0,11 & 0,067 & 0,046 & 0,099 & 0,083 & 0,11 & 0,09 & 0,13 & 0,25 & 0,7 & 0,41 \\
\hline 0,03 & 0,06 & 0,22 & 0,061 & 0,0293 & 0,063 & 0,079 & 0,19 & 0,13 & 0,12 & 0,11 & 0,165 & 0,169 \\
\hline n.d. & n.d. & n.d. & n.d. & n.d. & n.d. & n.d. & n.d. & n.d. & n.d. & n.d. & n.d. & n.d. \\
\hline 0,14 & 0,89 & 1,01 & $<0,067$ & 0,05 & 0,142 & 0,096 & $<0,00$ & $<0,19$ & 0,06 & $<0,102$ & 0,354 & 0,46 \\
\hline$<0,0190$ & 0,15 & 0,27 & $<0,0121$ & $<0,0048$ & $<0,0070$ & $<0,0097$ & $<0,0171$ & $<0,0186$ & 0,01 & $<0,0144$ & $<0,0132$ & $<0,0167$ \\
\hline 0,01 & 0,27 & 0,55 & $<0,0070$ & $<0,0051$ & 0,0155 & $<0,0091$ & $<0,0232$ & 0,01 & $<0,00$ & $<0,0193$ & 0,0105 & $<0,011$ \\
\hline$<0,0235$ & 0,02 & 0,06 & $<0,0066$ & $<0,0038$ & $<0,0046$ & $<0,0098$ & $<0,00$ & 0,00 & $<0,0125$ & $<0,0163$ & $<0,0088$ & $<0,0130$ \\
\hline$<0,070$ & $<0,102$ & 0,27 & $<0,081$ & $<0,035$ & $<0,043$ & $<0,055$ & $<0,079$ & $<0,150$ & 0,04 & $<0,102$ & $<0,076$ & $<0,089$ \\
\hline$<0,086$ & $<0,189$ & 0,03 & $<0,070$ & $<0,027$ & $<0,057$ & $<0,046$ & $<0,100$ & $<0,00$ & $<0,144$ & $<0,094$ & $<0,056$ & $<0,087$ \\
\hline$<0,00$ & 0,01 & 0,01 & $<0,0145$ & $<0,0109$ & $<0,0129$ & $<0,0194$ & 0,02 & $<0,00$ & $<0,00$ & $<0,024$ & $<0,0150$ & $<0,031$ \\
\hline$<0,00$ & $<0,00$ & 0,04 & $<0,069$ & $<0,030$ & $<0,051$ & $<0,057$ & 0,04 & $<0,141$ & 0,07 & $<0,115$ & $<0,044$ & $<0,084$ \\
\hline$<0,0159$ & $<0,00$ & 0,01 & $<0,0091$ & $<0,0057$ & $<0,0079$ & $<0,0084$ & 0,02 & $<0,0195$ & 0,01 & 0,00 & $<0,0118$ & $<0,0130$ \\
\hline$<0,00$ & $<0,118$ & 0,03 & $<0,041$ & $<0,026$ & $<0,030$ & $<0,035$ & $<0,00$ & 0,03 & $<0,123$ & $<0,00$ & $<0,060$ & $<0,077$ \\
\hline 0,01 & 0,01 & $<0,037$ & $<0,0084$ & $<0,0058$ & $<0,0081$ & $<0,0109$ & 0,01 & $<0,020$ & $<0,018$ & $<0,017$ & $<0,0121$ & $<0,019$ \\
\hline$<0,00$ & $<0,054$ & $<0,063$ & $<0,032$ & $<0,0100$ & $<0,021$ & $<0,037$ & 0,02 & $<0,065$ & $<0,056$ & 0,06 & $<0,038$ & $<0,053$ \\
\hline$<0,0208$ & $<0,00$ & $<0,00$ & $<0,0127$ & $<0,0062$ & $<0,0067$ & 0,0125 & $<0,0266$ & 0,02 & $<0,0167$ & 0,01 & $<0,0113$ & $<0,024$ \\
\hline$<0,00$ & 0,02 & $<0,00$ & $<0,098$ & $<0,041$ & $<0,050$ & $<0,065$ & $<0,085$ & 0,03 & $<0,118$ & $<0,129$ & $<0,071$ & $<0,12$ \\
\hline$<0,0143$ & $<0,0177$ & $<0,021$ & $<0,0096$ & $<0,0054$ & $<0,0119$ & $<0,0093$ & $<0,0254$ & 0,01 & $<0,030$ & $<0,00$ & $<0,0114$ & $<0,024$ \\
\hline 0,03 & $<0,059$ & $<0,068$ & $<0,085$ & $<0,057$ & $<0,097$ & $<0,111$ & $<0,058$ & 0,06 & $<0,059$ & $<0,054$ & $<0,082$ & $<0,22$ \\
\hline 0,00 & 0,01 & $<0,00$ & $<0,0174$ & $<0,0089$ & $<0,0087$ & $<0,0148$ & $<0,020$ & $<0,0215$ & $<0,00$ & $<0,025$ & $<0,0142$ & $<0,030$ \\
\hline 0,06 & 0,22 & 0,26 & $<0,047$ & $<0,022$ & $<0,026$ & $<0,032$ & $<0,025$ & $<0,047$ & 0,03 & 0,04 & 0,054 & 0,09 \\
\hline$<0,0154$ & $<0,022$ & $<0,018$ & $<0,0156$ & $<0,0071$ & $<0,0113$ & 0,0148 & 0,01 & $<0,0295$ & $<0,0241$ & $<0,0156$ & 0,0175 & 0,089 \\
\hline$<0,0108$ & 0,02 & $<0,0126$ & $<0,0128$ & $<0,0065$ & $<0,0094$ & $<0,0119$ & 0,02 & $<0,0156$ & $<0,0132$ & $<0,0120$ & $<0,0135$ & 0,03 \\
\hline
\end{tabular}


Tabela 85- Elementos traço analisados por LA-ICP-MS em óxidos do grupo do espinélio de peridotitos metassomatisados (em ppm).

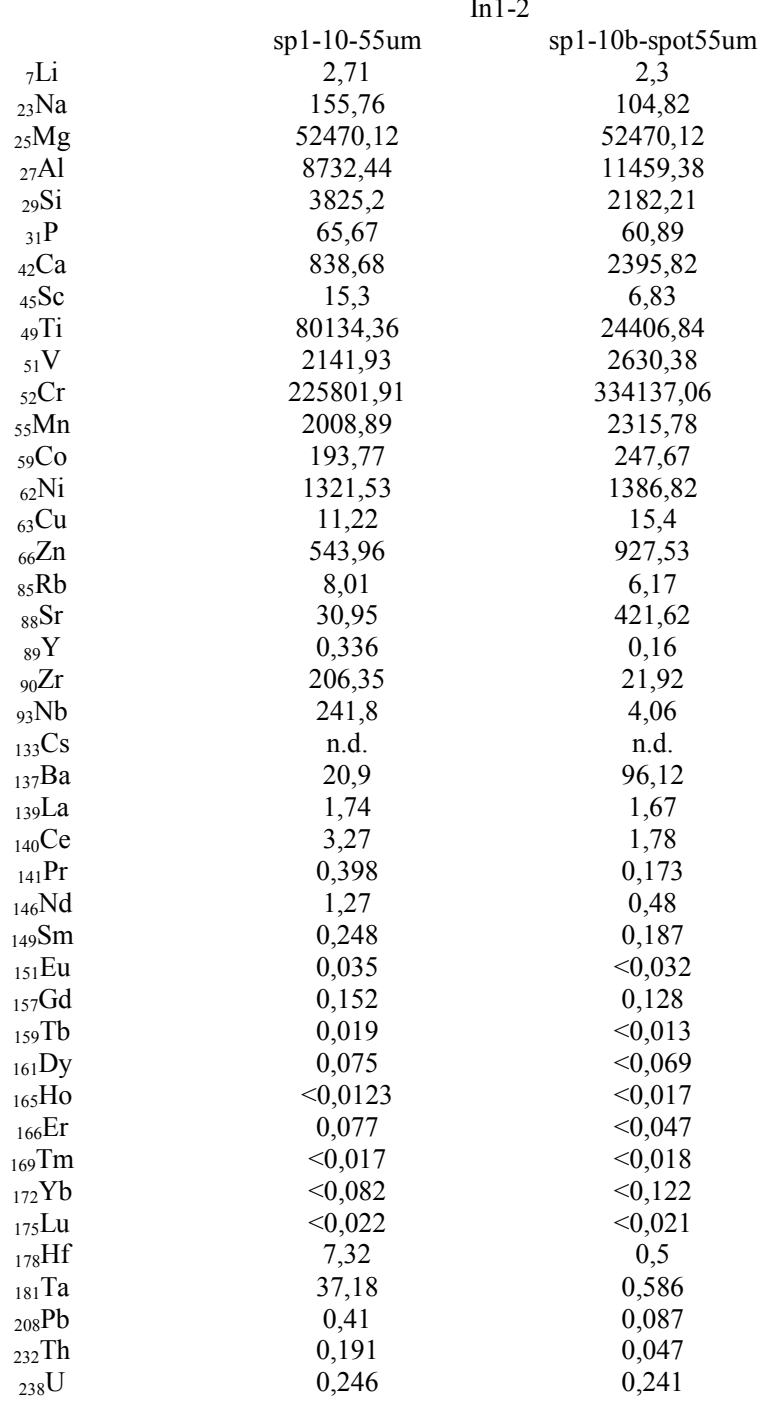

sp1-1spot65um
0,55
39,03
89018,3
66941,9
1704,49
$<4,78$
68,96
6,36
7625,83
985,52
331924
1176,09
186,6
1079,51
6,52
338,37
2,23
0,262
$<0,0173$
38,76
1,04
n.d.
13,07
0,0086
$<0,0057$
$<0,0043$
$<0,051$
$<0,037$
$<0,0114$
$<0,036$
$<0,0049$
$<0,031$
$<0,0094$
$<0,024$
$<0,0061$
$<0,036$
$<0,009$
1,94
0,17
0,037
0,019
$<0,009$

sp2-2spot65um
0,93
40,01
87209
70134,6
3718,13
11,78
100,9
7,63
9053,2
1218,66
320949
1270,85
203,87
1349,2
10,5
381,59
3,02
3,64
1,18
46,57
0,74
n.d.
5,18
0,09
0,268
0,0077
0,122
0,042
$<0,0119$
$<0,055$
0,021
0,13
0,056
0,13
0,031
$<0,042$
$<0,013$
2,54
0,17
0,77
$<0,016$
0,18

$$
\begin{gathered}
\text { Lm1-1 } \\
\text { chr-1-6 } \\
7,54 \\
568,45 \\
66582 \\
22504,9 \\
5346,54 \\
91,93 \\
3467,93 \\
7,37 \\
29894,8 \\
2396,92 \\
348879 \\
2215,06 \\
268,67 \\
2157,9 \\
25,41 \\
836,81 \\
1,95 \\
27,15 \\
0,47 \\
46,21 \\
2,65 \\
\text { n.d. } \\
30,69 \\
2,97 \\
5,01 \\
0,682 \\
2,41 \\
<0,78 \\
<0,212 \\
<0,61 \\
<0,103 \\
0,81 \\
<0,103 \\
<0,27 \\
<0,104 \\
0,51 \\
<0,127 \\
2,29 \\
0,214 \\
1,01 \\
0,48 \\
<0,203 \\
\\
\hline
\end{gathered}
$$


Tabela 86- Elementos traço analisados por LA-ICP-MS em pargasita de peridotitos com Cr- espinélio (em ppm).

\begin{tabular}{|c|c|c|c|c|c|c|}
\hline & & In1-24a & & & In1-50 & \\
\hline & Anf-1 & Anf-2 & Anf-3 & anf-5-2 & anf-5-3 & anf-8-3 \\
\hline${ }_{7} \mathrm{Li}$ & 12,49 & 8,15 & 10,82 & 14,97 & 9,39 & 3,78 \\
\hline${ }_{23} \mathrm{Na}$ & 32554,76 & 35514,02 & 27414,90 & 18212,1 & 19362,25 & 19924,73 \\
\hline${ }_{25} \mathrm{Mg}$ & 113936,09 & 135546,92 & 106638,07 & 110938 & 120686,93 & 121018,48 \\
\hline${ }_{27} \mathrm{Al}$ & 63814,05 & 68039,53 & 61912,82 & 74826,9 & 71153,16 & 71580,66 \\
\hline${ }_{29} \mathrm{Si}$ & 230819,17 & 244699,95 & 160426,55 & 152659 & 144637,8 & 148359,41 \\
\hline${ }_{31} \mathrm{P}$ & 142,09 & 138,34 & 97,90 & 68,01 & 75,71 & 77,8 \\
\hline${ }_{42} \mathrm{Ca}$ & 81618,86 & 81618,86 & 81618,86 & 81118,5 & 81118,53 & 82976,76 \\
\hline${ }_{45} \mathrm{Sc}$ & 172,16 & 251,38 & 158,74 & 149,77 & 147,83 & 159,02 \\
\hline${ }_{49} \mathrm{Ti}$ & 13320,24 & 12155,03 & 14925,64 & 15216,1 & 15982,13 & 15642,7 \\
\hline${ }_{51} \mathrm{~V}$ & 456,45 & 535,93 & 460,91 & 388,73 & 386,72 & 358,35 \\
\hline${ }_{52} \mathrm{Cr}$ & 14000,43 & 15139,84 & 18364,45 & 11742,3 & 14915,95 & 13004,93 \\
\hline${ }_{55} \mathrm{Mn}$ & 345,17 & 372,77 & 328,45 & 241,27 & 278,11 & 263,03 \\
\hline${ }_{59} \mathrm{Co}$ & 31,19 & 35,59 & 31,66 & 24,51 & 25,93 & 25,04 \\
\hline${ }_{62} \mathrm{Ni}$ & 862,98 & 921,48 & 813,27 & 614,26 & 611,5 & 620,97 \\
\hline${ }_{63} \mathrm{Cu}$ & n.d. & n.d. & n.d. & 0,76 & 0,865 & 0,553 \\
\hline${ }_{66} \mathrm{Zn}$ & 9,67 & 12,65 & 10,90 & 6,48 & 8,33 & 9,68 \\
\hline${ }_{85} \mathrm{Rb}$ & 10,03 & 16,03 & 12,09 & 5,63 & 6,88 & 6,47 \\
\hline${ }_{88} \mathrm{Sr}$ & 401,61 & 174,23 & 548,35 & 269,68 & 692,77 & 637,82 \\
\hline${ }_{89} \mathrm{Y}$ & 24,03 & 26,49 & 26,97 & 21,67 & 26,12 & 24,01 \\
\hline${ }_{90} \mathrm{Zr}$ & 430,61 & 393,46 & 495,29 & 353,84 & 425,35 & 409,71 \\
\hline${ }_{93} \mathrm{Nb}$ & 233,61 & 112,97 & 463,87 & 181,75 & 545,13 & 517,71 \\
\hline${ }_{133} \mathrm{Cs}$ & 0,02 & 0,42 & 0,07 & $<0,0132$ & $<0,0110$ & 0,0127 \\
\hline${ }_{137} \mathrm{Ba}$ & 280,91 & 282,95 & 286,94 & 235,11 & 282,01 & 263,22 \\
\hline${ }_{139} \mathrm{La}$ & 24,39 & 16,16 & 38,34 & 18,22 & 41,64 & 42,89 \\
\hline${ }_{140} \mathrm{Ce}$ & 48,39 & 40,03 & 99,97 & 32,7 & 80,3 & 90,57 \\
\hline${ }_{141} \mathrm{Pr}$ & 7,30 & 6,34 & 15,17 & 4,62 & 12,78 & 14,94 \\
\hline${ }_{146} \mathrm{Nd}$ & 39,77 & 30,04 & 68,40 & 22,64 & 71,76 & 76,57 \\
\hline${ }_{149} \mathrm{Sm}$ & 10,71 & 9,71 & 17,43 & 7,16 & 16,96 & 16,77 \\
\hline${ }_{151} \mathrm{Eu}$ & 2,38 & 2,27 & 4,05 & 2,12 & 4,46 & 4,3 \\
\hline${ }_{157} \mathrm{Gd}$ & 8,39 & 7,45 & 11,94 & 7,14 & 12,7 & 12,79 \\
\hline${ }_{159} \mathrm{~Tb}$ & 1,21 & 1,25 & 1,40 & 1,02 & 1,42 & 1,45 \\
\hline${ }_{161} \mathrm{Dy}$ & 6,38 & 5,02 & 6,39 & 5,95 & 7,25 & 7,05 \\
\hline${ }_{165} \mathrm{Ho}$ & 1,00 & 1,04 & 1,01 & 0,893 & 0,895 & 0,953 \\
\hline${ }_{166} \mathrm{Er}$ & 2,02 & 2,36 & 2,08 & 2,26 & 1,97 & 2,05 \\
\hline${ }_{169} \mathrm{Tm}$ & 0,25 & 0,20 & 0,16 & 0,212 & 0,201 & 0,188 \\
\hline${ }_{172} \mathrm{Yb}$ & 1,29 & 1,57 & 1,13 & 1,03 & 1,14 & 1,12 \\
\hline${ }_{175} \mathrm{Lu}$ & 0,11 & 0,20 & 0,10 & 0,169 & 0,148 & 0,125 \\
\hline${ }_{178} \mathrm{Hf}$ & 11,73 & 9,77 & 13,15 & 9,23 & 14,55 & 12,81 \\
\hline${ }_{181} \mathrm{Ta}$ & 7,76 & 3,13 & 33,38 & 5,32 & 38,29 & 35,18 \\
\hline${ }_{208} \mathrm{~Pb}$ & 0,77 & 1,46 & 1,14 & 0,656 & 0,792 & 0,72 \\
\hline${ }_{232} \mathrm{Th}$ & 1,86 & 1,36 & 2,53 & 1,3 & 2,52 & 2,69 \\
\hline${ }_{238} \mathrm{U}$ & 0,35 & 0,17 & 0,42 & 0,209 & 0,311 & 0,393 \\
\hline
\end{tabular}


Tabela 87- Elementos traço em ilmenita de flogopita ilmenita wherlito e de piroxenito; e composição de cristais de titanatos em peridotito metassomatisado (em ppm).

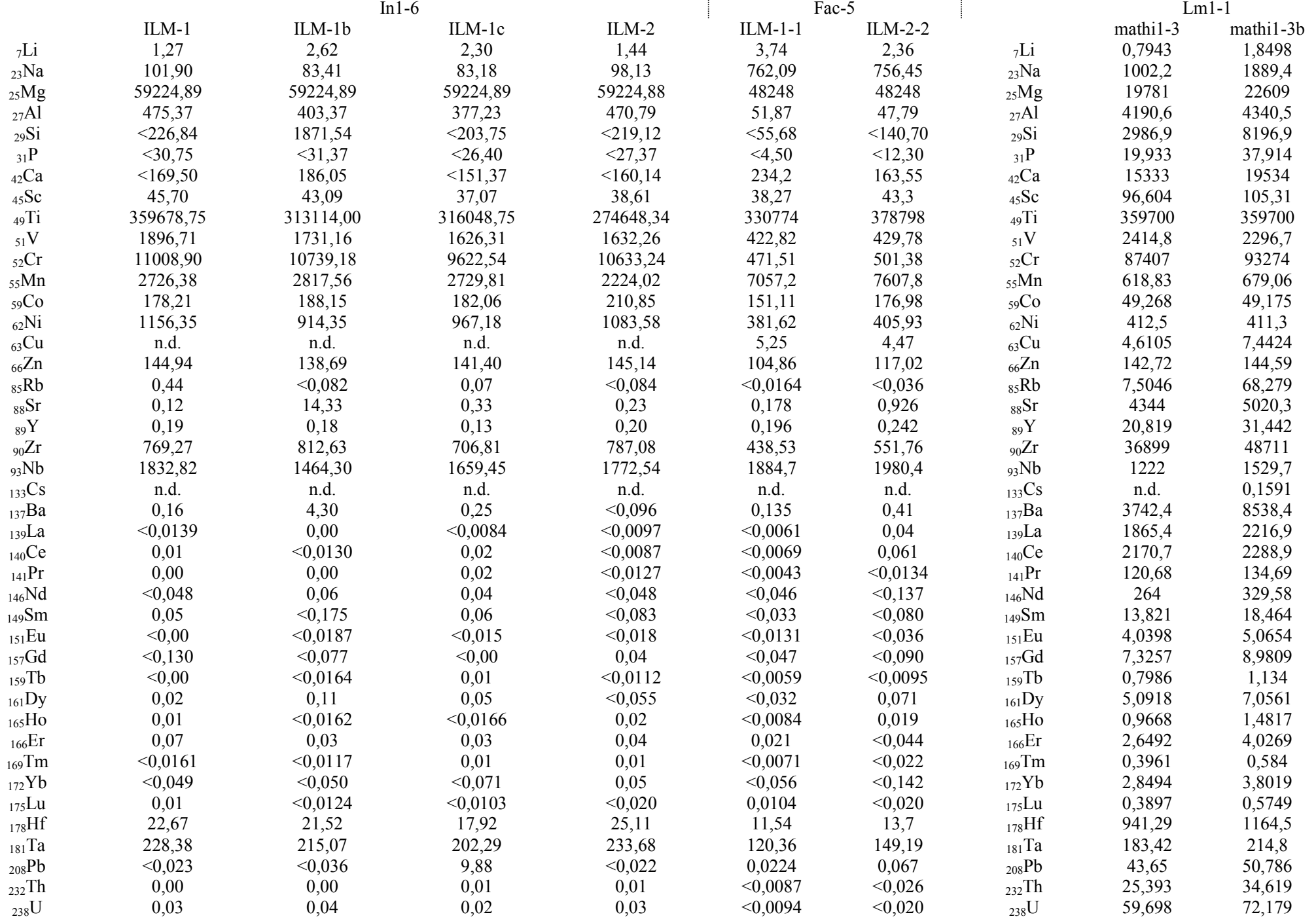




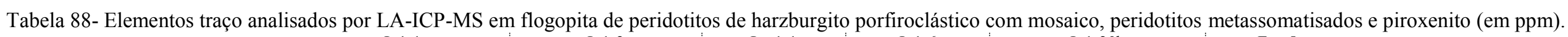

$$
\text { In1-1 In1-2 }
$$

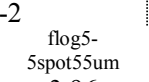

Lm1-1

$$
\text { In1-6 }
$$

$$
\text { In } 1-20 \mathrm{~b}
$$

\begin{tabular}{|c|c|c|c|c|c|c|c|c|c|c|c|c|c|c|}
\hline & Flog-1 & Flog-1b & Flog-1c & $\begin{array}{l}\text { flog3- } \\
\text { 455umraster }\end{array}$ & $\begin{array}{c}\text { flog5- } \\
\text { 5spot55um }\end{array}$ & phl4-4 & phl4b-5 & Flog-1 & $-\sigma^{2}$ & PHL-1-8 & PHL-2-9 & PHL-2-9b & FLOG-2-2 & FLOG-1-1 \\
\hline${ }_{7} \mathrm{Li}$ & 21,62 & $\begin{array}{l}7,89 \\
1295\end{array}$ & 11,11 & 5,95 & 3,96 & 15,33 & 10,78 & 33,68 & $\begin{array}{l}23,59 \\
1803\end{array}$ & 37,39 & $\begin{array}{l}35,75 \\
1874\end{array}$ & 37,46 & 37,77 & $\begin{array}{l}49,78 \\
2962\end{array}$ \\
\hline & $\begin{array}{c}2054 \\
128160\end{array}$ & $\begin{array}{c}1295 \\
128160\end{array}$ & $\begin{array}{c}1301 \\
128160\end{array}$ & $\begin{array}{c}462 \\
144986\end{array}$ & $\begin{array}{c}353 \\
90466\end{array}$ & $\begin{array}{c}448 \\
136784\end{array}$ & $\begin{array}{c}246 \\
90466\end{array}$ & $\begin{array}{c}2973 \\
146796\end{array}$ & $\begin{array}{c}1893 \\
146796\end{array}$ & $\begin{array}{c}2270 \\
\end{array}$ & $\begin{array}{c}1874 \\
130619\end{array}$ & $\begin{array}{c}1589 \\
13061\end{array}$ & $\begin{array}{l}3010 \\
30582\end{array}$ & $\begin{array}{l}2962 \\
28582\end{array}$ \\
\hline${ }_{27}^{5 \mathrm{Ml}}$ & 79566 & 76881 & 65186 & $\begin{array}{l}144900 \\
58018\end{array}$ & 35981 & 130184 & $\begin{array}{l}90400 \\
52984\end{array}$ & $\begin{array}{c}69850 \\
\end{array}$ & $\begin{array}{c}146 / 96 \\
54753\end{array}$ & $\begin{array}{l}139619 \\
80551\end{array}$ & $\begin{array}{l}139619 \\
73916\end{array}$ & $\begin{array}{c}139619 \\
75746\end{array}$ & $\begin{array}{l}128582 \\
47161\end{array}$ & $\begin{array}{l}128582 \\
65303\end{array}$ \\
\hline${ }_{29} \mathrm{Si}$ & 260606 & 239906 & 224289 & 200079 & 99799 & 170984 & 106845 & 215909 & 194628 & 238122 & 198176 & 238947 & 166116 & 219153 \\
\hline${ }_{31} \mathrm{P}$ & 39,42 & $<30,78$ & $<38,60$ & 39,05 & 11,98 & $<9,09$ & $<5,14$ & $<39,53$ & $<37,75$ & 19,78 & 6,81 & 6,65 & $<8,89$ & $<8,33$ \\
\hline${ }_{42} \mathrm{Ca}$ & 323,80 & $<171,64$ & 1471,04 & $<96,18$ & 266,95 & $<85,09$ & 61,4 & 1059,86 & $<194,88$ & 61,95 & 127,92 & 72 & 176,8 & $<56,53$ \\
\hline${ }_{45}^{4} \mathrm{Sc}$ & 5,22 & 4,60 & 5,04 & 1,85 & 1,39 & 4,45 & 3,49 & 3,03 & 3,14 & 6,64 & 7,09 & 6,52 & 0,732 & 0,59 \\
\hline${ }_{49} \mathrm{Ti}$ & 35195 & 41288 & 35799 & 104 & & 164 & 10424 & 11832 & 10504 & 16013 & 14942 & 147 & 30220 & 38098 \\
\hline${ }_{51} \mathrm{~V}$ & 274,48 & 291,20 & 283,41 & 131 & 10 & 153 & 103,59 & 157,2 & 137,97 & 22 & & 222 & & 145,44 \\
\hline${ }_{52} \mathrm{Cr}$ & 6589,31 & 3332,16 & 4078,80 & 5 & 311 & 7473,69 & 4560,59 & 1660,12 & 1516,55 & 15931 & & & & 749,31 \\
\hline $\mathrm{Mn}$ & 293,49 & 279,73 & 274,14 & & 122 & 195,4 & 132,26 & 244 & & 18 & & & & 789,43 \\
\hline${ }_{59} \mathrm{Co}$ & 0 & 75,08 & 97,0 & 45 & 31, & 51, & 43,42 & 70,46 & 78 & 57 & 50 & 50 & & 70,68 \\
\hline${ }_{62} \mathrm{Ni}$ & 1368,68 & 1444,01 & 1447,09 & 1340,8 & 967,02 & 1451,91 & 1057,89 & 1107,91 & 1206,11 & 1817,7 & 16 & 1756,1 & 424,47 & 528,92 \\
\hline${ }^{2} \mathrm{C}$ & n.d. & n.d & n.d. & 0 , & 0,49 & 2, & 1,87 & $n$ & & 1,02 & 7 & 1 , & 3 & 0,91 \\
\hline 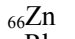 & & & & & & & & & & & & & & 73,49 \\
\hline${ }_{85} \mathrm{Rb}$ & 738,32 & 673,09 & 570 & 45 & 3 & 41 & 249,27 & 721 & 701,12 & 287,41 & 27 & 258 & 444,72 & 499,65 \\
\hline${ }_{88} \mathrm{Sr}$ & 42,3 & 31 & & & & & & 5 & & & & & & 30,74 \\
\hline $\begin{array}{l}8 x^{8 x} \\
89\end{array}$ & 0 & $<0,0$ & & & & & & 0, & $<0$, & & & & & 01 \\
\hline${ }_{90} \mathrm{Z}$ & 12 & 12,6 & 15 & & 6 & 57,76 & 102,48 & 7, & 8 & 129 & 12 & 11 & 6 , & 8,24 \\
\hline${ }_{93} \mathrm{Nb}$ & 14,66 & 12 & 12, & 14 & 9,0 & 7 & 5 & 19, & & 36,52 & 31 & & 12,23 & 14,97 \\
\hline & & 3 , & 4, & & n. & n. & & & & & & & & \\
\hline & 1458,72 & 1183,03 & 101 & & & & & 22 & & & & & & \\
\hline L & & 0,01 & & & 0 , & 73 & 0,0 & 0 & $<0$, & 0,0 & 0,0099 & 0, & 0,0 & $<0,0081$ \\
\hline & & & & & & & & & & & & & & \\
\hline & & & & & & & $<0$, & & & & & & & \\
\hline 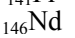 & $<0,0$ & $<0,0$ & $<0$, & & & & $<0$, & $<0$, & & & & $<0$ & $<0,083$ & $<0,054$ \\
\hline & $<0,1$ & & $<0$ & & & & & & & & & & & $<0,063$ \\
\hline & & & & & & & & $<0$ & & & & & & \\
\hline & 0 , & $<0$ & & & & & & & & & & & & \\
\hline & & & & & & & & & & & & & & $<0$ \\
\hline & $<0,00$ & $<0,0$ & & $<$ & & $<$ & $<0$, & $<0$, & $<0$ & & & $<0$ & & 0,057 \\
\hline & & $<0,0$ & & & & & & $<0,0$ & & $<0$ & $<0$, & $<0$ & & $<0,013$ \\
\hline & $<0,065$ & $<0,0$ & $<0$, & & & & & & & & & & & $<0,029$ \\
\hline & $<0,0204$ & & & & & & & & & & & & & \\
\hline & & & $<0,0$ & $<0,1$ & & & & & & & & & & $<0,076$ \\
\hline & 0,0 & $<0,0$ & 0 & $<0$, & $<0,0$ & $<0,0$ & & $<0,0$ & $<0$ & $<0$ & $<0$ & $<0$, & & $<0,0132$ \\
\hline & & & & & & & & & & & & & & 0,49 \\
\hline & & & 1,1 & 1,2 & 0 & 0,8 & 0,4 & 1 , & 1,52 & 4, & 4,19 & 4, & 0 , & 0,87 \\
\hline & & & 0,4 & 0,0 & & & & & $<0,044$ & 0, & 1 & & 0,093 & 0,085 \\
\hline & 0, & $<0,0114$ & $<0,020$ & 0,0 & 0,024 & $<0,023$ & $<0,0121$ & 0,03 & $<0,0209$ & 0,015 & $<0,010$ & $<0,015$ & $<0,0187$ & $<0,020$ \\
\hline & & & & & & & 0012 & & & & onc & & & \\
\hline
\end{tabular}

$$
\text { Fac-5 }
$$

$\begin{array}{cccccccccc}0,024 & <0,023 & <0,0121 & 0,03 & <0,0209 & 0,015 & <0,010 & <0,015 & <0,0187 & <0,020 \\ 0,021 & <0,0157 & 0,012 & 0,02 & 0,01 & 0,02 & <0,0061 & <0,0078 & <0,0173 & <0,015\end{array}$ 
Tabela 89- Elementos traço analisados por LA-ICP-MS em apatita e perovskita da matriz do kimberlito Indaiá (em ppm).

\begin{tabular}{|c|c|c|c|}
\hline & & In1-14a \\
\hline & pv-1 & ap-1 & pv-1 \\
\hline${ }_{7} \mathrm{Li}$ & $<0,47$ & 32,75 & 0,18 \\
\hline${ }_{23} \mathrm{Na}$ & 942,83 & 5378,97 & 652,22 \\
\hline${ }_{25} \mathrm{Mg}$ & 1604,58 & 513584,03 & 1331,28 \\
\hline${ }_{27} \mathrm{Al}$ & 366,41 & 59382,91 & 170,96 \\
\hline${ }_{29} \mathrm{Si}$ & 1854,18 & 472850,03 & 988,44 \\
\hline${ }_{11} \mathrm{P}$ & 75,44 & 112637,13 & 37,65 \\
\hline${ }_{42} \mathrm{Ca}$ & 25207,51 & 393085,56 & 21441,0 \\
\hline${ }_{45} \mathrm{Sc}$ & 1,28 & 162,9 & 1,57 \\
\hline${ }_{49} \mathrm{Ti}$ & 36036,65 & 34333,36 & 26212,30 \\
\hline${ }_{51} \mathrm{~V}$ & 22,35 & 1227,39 & 15, \\
\hline${ }_{52} \mathrm{Cr}$ & 105,41 & 5819,94 & 98,49 \\
\hline${ }_{55} \mathrm{Mn}$ & 35,68 & 7253 & 43,84 \\
\hline $\mathrm{Co}$ & 0,48 & 128, & 0,71 \\
\hline${ }_{2} \mathrm{Ni}$ & 31,14 & 845,77 & 16,74 \\
\hline${ }_{3} \mathrm{Cu}$ & n.d. & n.d. & \\
\hline${ }_{6} \mathrm{Zn}$ & 7,90 & 312,40 & 3 , \\
\hline${ }_{85} \mathrm{Rb}$ & 1,76 & 418 & 1,10 \\
\hline${ }_{8} \mathrm{Sr}$ & 495,30 & 11751,63 & 338,21 \\
\hline${ }_{89}^{80} \mathrm{Y}$ & 46,43 & 310 & 37,37 \\
\hline${ }_{90} \mathrm{Zr}$ & 205,41 & 10645,24 & 169,11 \\
\hline${ }_{93} \mathrm{Nb}$ & 1498,84 & 345,84 & 1014,08 \\
\hline . & 0,01 & 5,0 & 0,02 \\
\hline${ }_{7} \mathrm{Ba}$ & 107,20 & 4906 & 9, \\
\hline${ }_{9} \mathrm{La}$ & 1874, & 101 & 133 \\
\hline${ }_{140} \mathrm{C}$ & 4993 & 236 & 333 \\
\hline 1411 & 655 & 194 & 390 \\
\hline & 230 & 686 & 138 \\
\hline${ }_{\mathrm{Sm}} \mathrm{Sm}$ & 222,20 & 116 & 153 \\
\hline${ }_{51} \mathrm{E}$ & 45,52 & 33 & 35 \\
\hline & 88, & 94 & 66,47 \\
\hline 59$]$ & 8,59 & 13, & 6,38 \\
\hline $\mathrm{J}$ & 29 , & 58 & 21, \\
\hline & 3, & 11 & \\
\hline & 5 , & 22, & 4,27 \\
\hline & 0,35 & 2,27 & 0,32 \\
\hline & 1 , & 10. & \\
\hline & 0,13 & & \\
\hline & 10,82 & 149,97 & 10,31 \\
\hline & 86,5 & 13 , & 48, \\
\hline & 3,42 & 4,60 & 2,43 \\
\hline & 341,67 & 101,35 & 141,50 \\
\hline & 20,79 & 45,45 & 12,76 \\
\hline
\end{tabular}

